\title{
The Substance of
} Psalm 24

\section{An Attempt to Read Scripture after Brevard S. Childs}

Philip E. Sumpter

A thesis submitted to the University of Gloucestershire in accordance with the requirements of the degree Doctor of Philosophy in the Faculty of Education, Humanities and Science

October 2011 
This thesis seeks to contribute to the theory and practice of theological interpretation by explicating the inner coherence of B.S. Childs" "canonical approach" and by exemplifying that approach in an interpretation of Psalm 24.

Part 1 concerns the theory. In this section I argue that Childs' approach rests upon a particular understanding of the nature of the Biblical text. In short, it has a twofold function, that of witnessing to the reality of God and that of shaping the community of faith in light of that reality. The God to whom it witnesses is himself involved in this witnessing activity in that he both evokes and infuses the tradition with his Spirit so that he may be known. The hermeneutical implication is that interpretation must attempt to grasp the reality "behind" the text while respecting the particular form in which that reality has been rendered. The result is a multi-level approach to interpretation involving a continuous dialectic between the witness (verbum) and its content (res). The affirmation of the nature of Scripture as an ongoing vehicle of revelation also implies the significance of the history of faithful Christian interpretation.

Part 2 seeks to exemplify this approach by showing how such a multi-level interpretation of Psalm 24 is both possible and fruitful for our understanding of the reality to which it witnesses. I achieve this by moving through several stages. After reviewing contemporary methodology, I first provide a poetic analysis of the Psalm and conclude that it witnesses to the economy of God in a bid to call Israel to realize its true identity. I then provide a hypothesis of how the final form of the psalm is a result of a tradition historical process with its roots in the pre-exilic temple liturgy. This historical perspective not only clarifies the poetic shape of the psalm, it provides a bridge to discussing the question of the nature of the reality experienced within Israel's cult. I conclude that there is a parallel between the structure of this reality and the shape of Ps 24. I then both confirm and attempt to deepen our understanding of this reality by following canonical pointers internal to the psalm to three other bodies of text: Samuel, the Psalter, and Isaiah. Key to this broader context is the agency of the David found in Ps 24's superscription. I conclude my analysis by suggesting how a better grasp of the divine economy in the light of Christ may help us better understand the inner unity of Ps 24 itself. 


\section{AUTHOR'S DECLARATION}

I declare that the work in this thesis was carried out in accordance with the regulations of the University of Gloucestershire and is original except where indicated by specific reference in the text. No part of the thesis has been submitted as part of any other academic award. The thesis has not been presented to any other education institution in the United Kingdom or overseas.

Any views expressed in the thesis are those of the author and in no way represent those of the University.

Signed Date $10 \cdot 1 \cdot 2.1 .12$ 


\section{Contents}

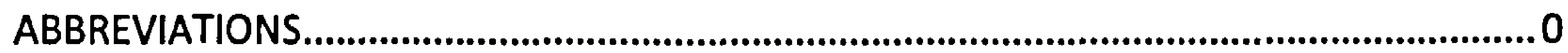

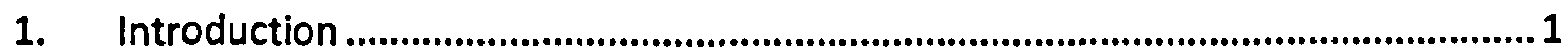

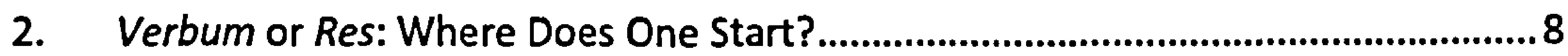

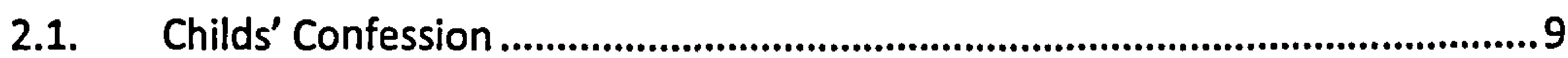

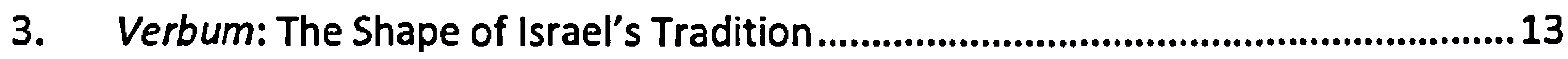

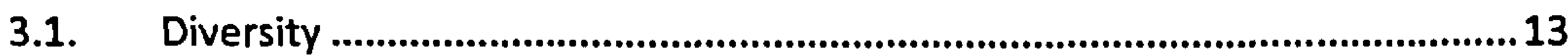

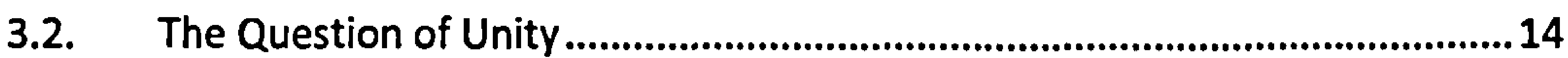

3.3. Form, Function, Context, and Content ....................................................17

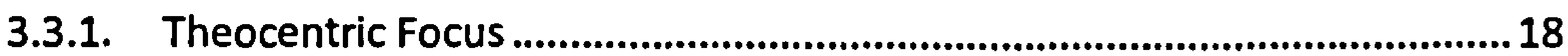

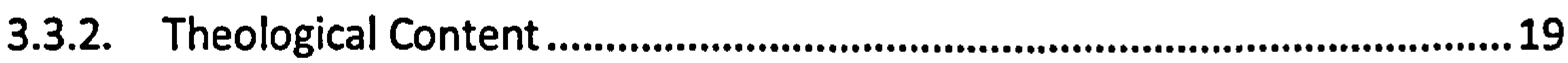

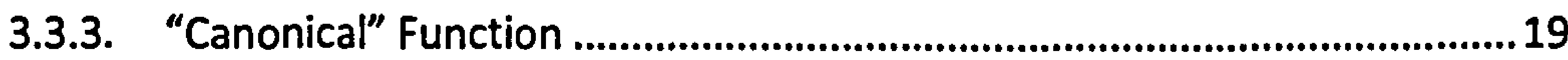

3.3.4. Summary: Continuity within Diversity ...................................................21

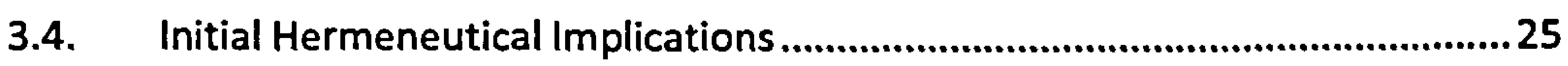

3.5. Excursus: Barth on the Stance of Theology...................................................28

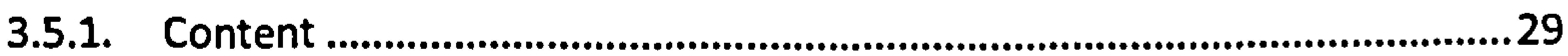

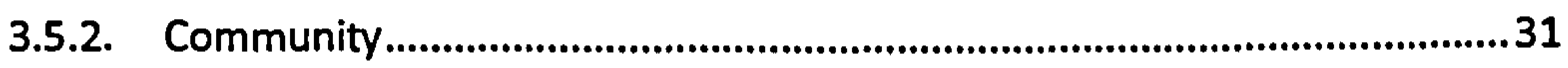

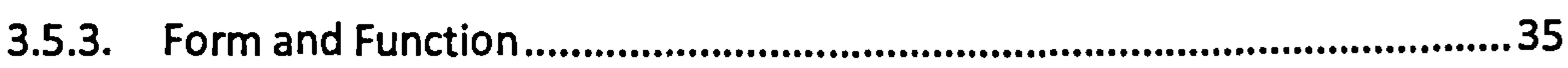

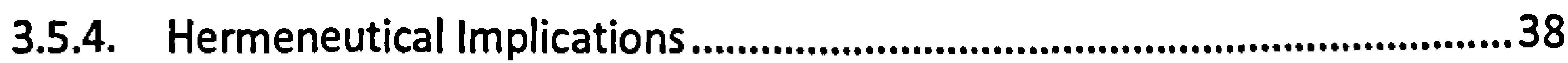

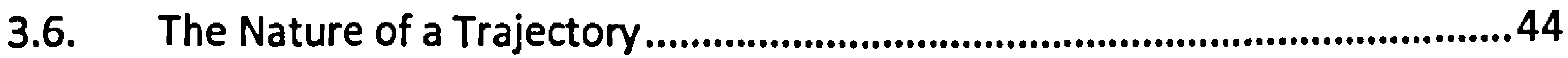

3.6.1. The Challenge of Diachronic Diversity .......................................................44

3.6.2. Israel's Perspective: Economy and Ontology ...........................................46

3.6.3. Childs' Perspective: Dialectic and Growth ................................................47

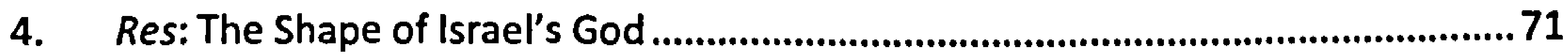

4.1. The Hermeneutical Significance of the Res: Bultmann's Contribution...........72

4.2. Verbum, Res, and Spiritus: Barth's contribution ...........................................78

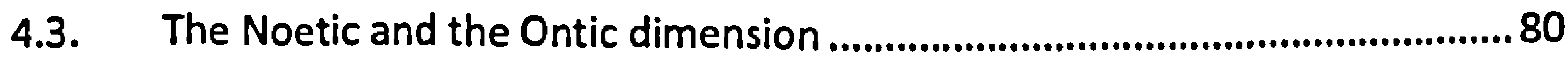

4.4. Res and Form Criticism (Childs and Gerstenberger) ..................................86 


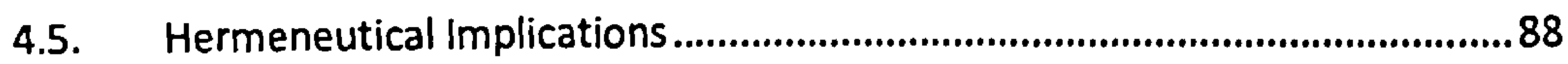

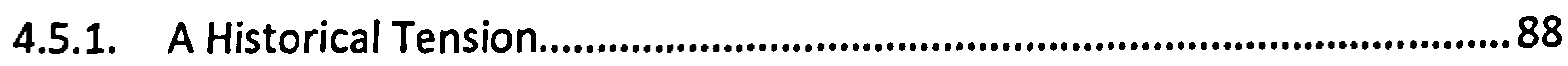

4.5.2. A Multiple-Level Approach to Scripture.................................................92

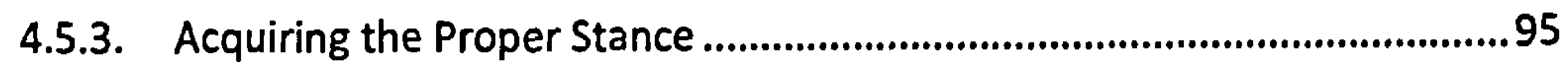

5. Testing the Validity of Childs' Canonical Thesis .......................................................96

6. A Canonical Approach to Psalm 24 ................................................................99

6.1. The Nature of the Task.............................................................................99

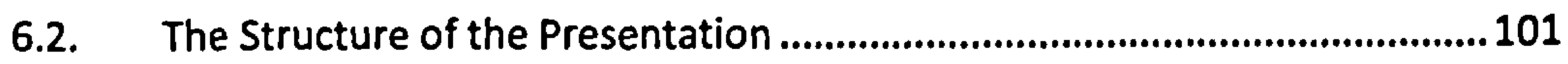

7. Verbum 1: Form, Content, Context, Function........................................................102

7.1. Methodological Considerations ................................................................ 102

7.1.1. Contemporary "Form Criticism" ...........................................................103

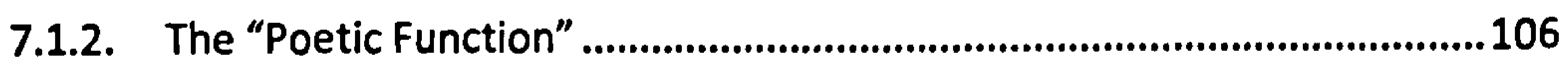

7.1.3. Structure of Presentation...............................................................112

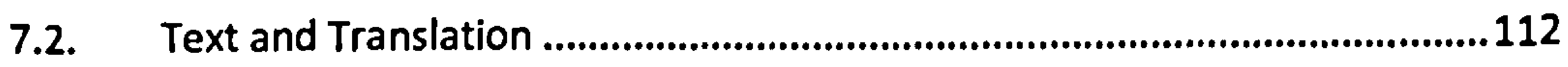

7.2.1. Translation and Poetic Structure ........................................................112

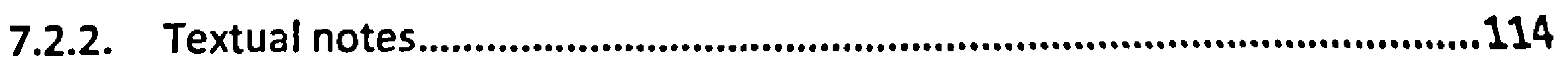

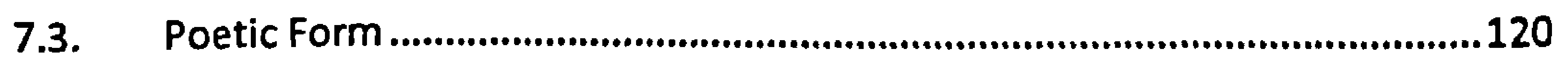

7.3.1. Structure and Proportion ........................................................................120

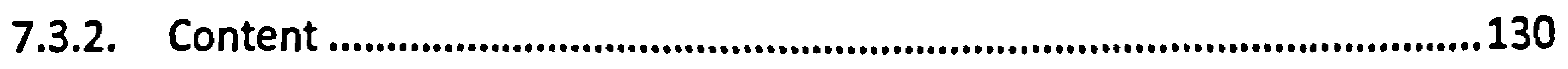

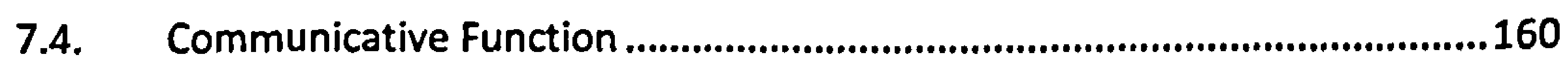

7.4.1. Structure of Presentation...................................................................160

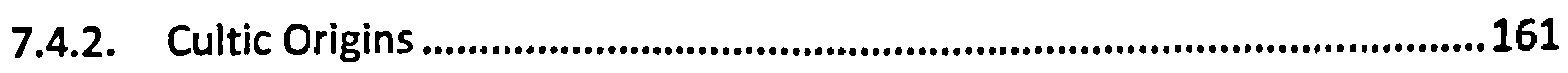

7.4.3. Outline of a Possible Tradition History ..............................................173

7.4.4. The Forces at Work in the Canonical Process ...........................................177

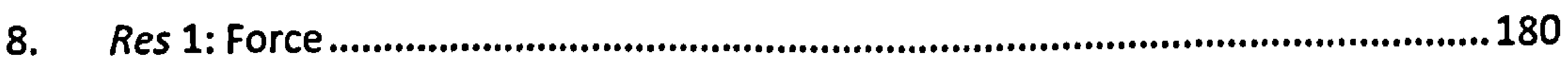

8.1. The Location of Heaven ........................................................................180

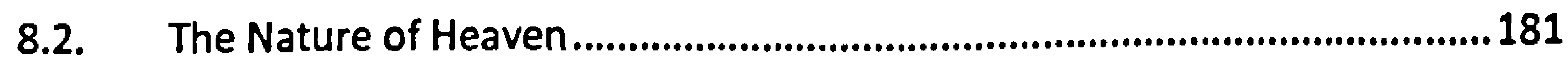

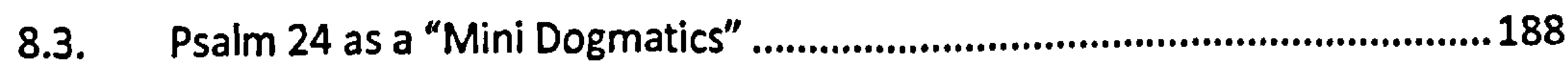


9. Verbum 2: The Broader Literary Context .190

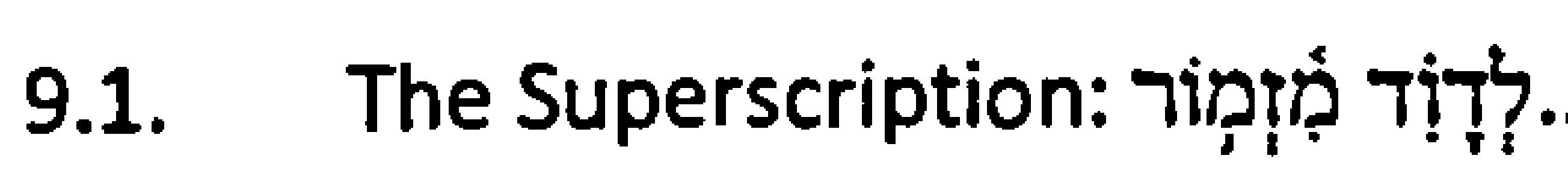

9.1.1. The Complexity of לְִִּ

9.1.2. Canonical Pointers 192

9.1.3. The David of the Books of Samuel. 196

9.1.4. Summary: David in the Context of Psalm 24 207

9.2. The Sub-Collection of Psalms 15-24 .....................................................208

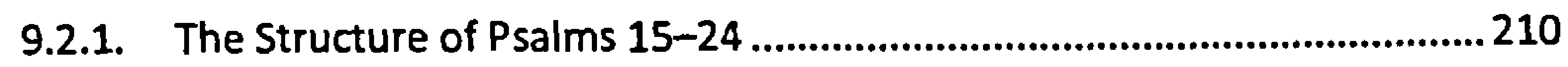

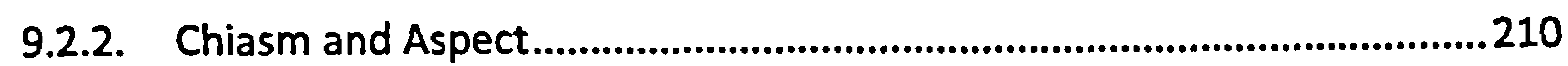

9.2.3. The Dialectic of Divine and Human History ............................................2212

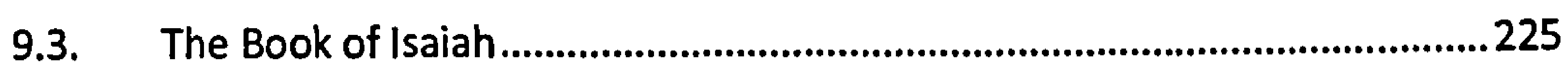

9.3.1. Isaiah and the Psalms/Psalter .........................................................225

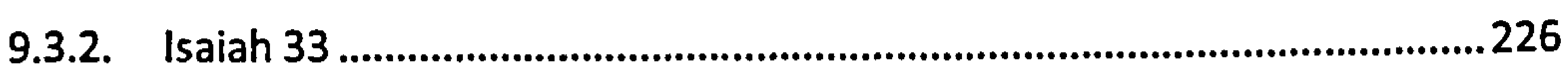

9.3.3. The Servant and the Servants ............................................................ 230

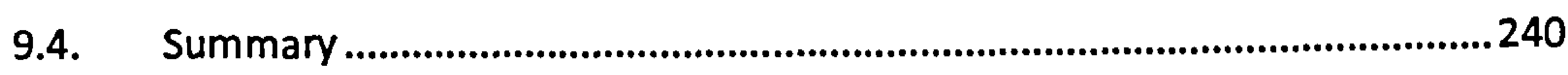

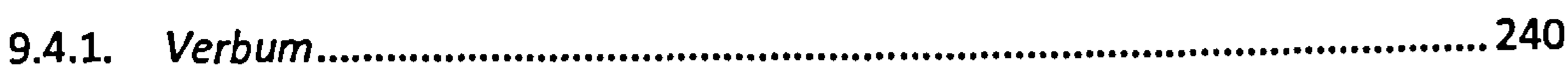

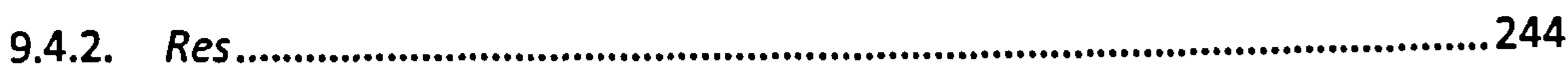

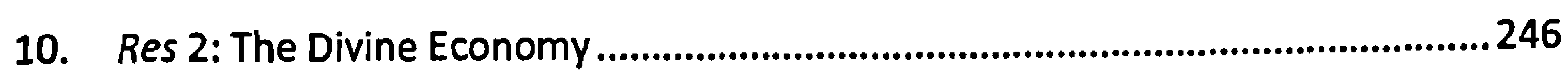

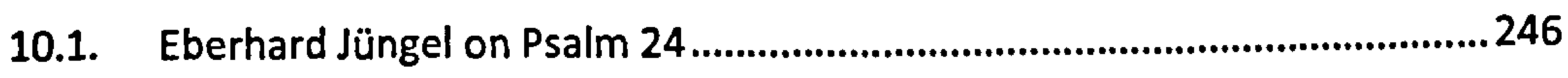

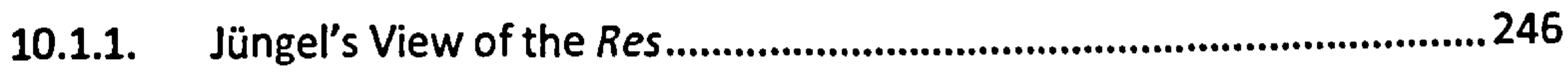

10.1.2. Jüngel's Sermon on Psalm 24 ........................................................247

10.1.3. Response to Jüngel's Actualization of Psalm 24 ...............................2250

10.2. The Church Fathers on Psalm 24..........................................................252

10.2.1. The Fathers' View of the Res..........................................................2252

10.2.2. Patristic Interpretation of Psalm 24 ...............................................2253

10.2.3. Response to Patristic Interpretation of Psalm 24 ..............................2256

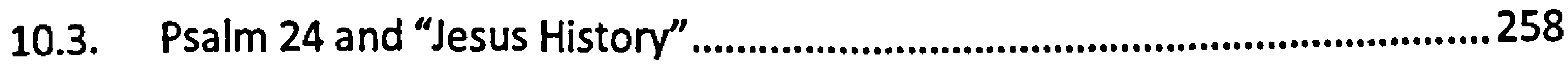




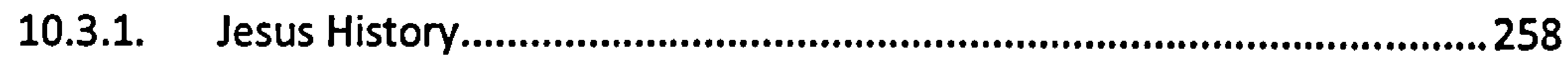

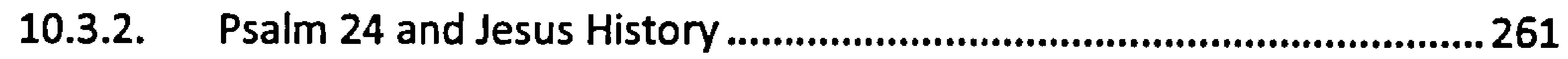

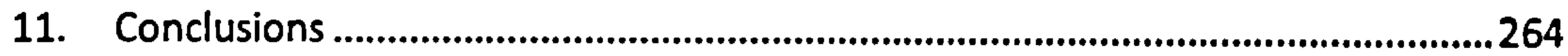

Appendix: Analysis of Childs' Exodus and Isaiah Commentaries .................................270

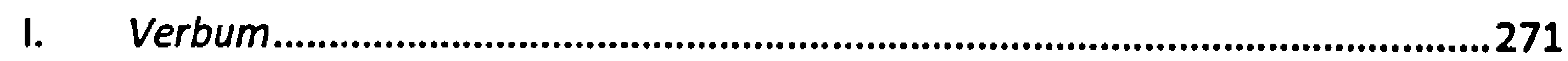

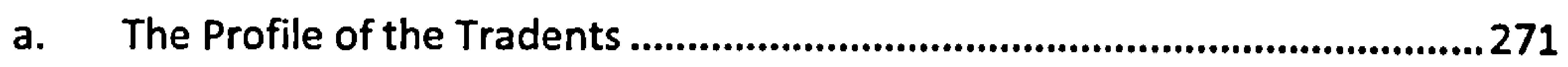

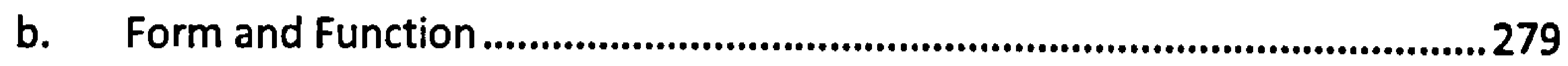

c. The "Effect" on the Final Form.................................................................283

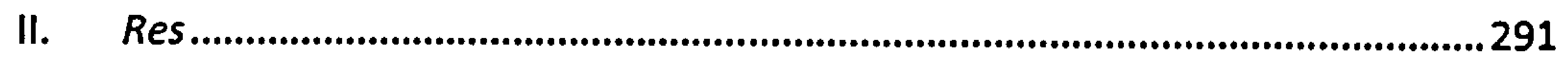

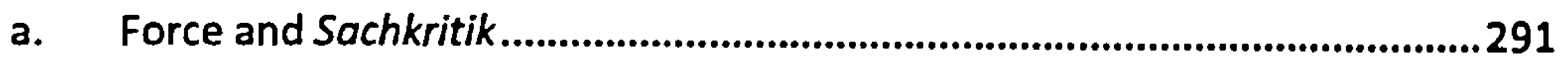

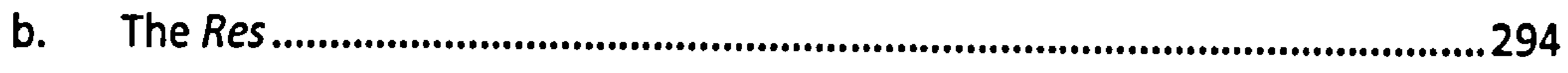

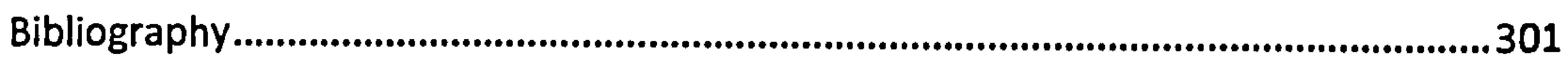




\section{ABBREVIATIONS}

AFPMA The Hebrew Bible: Andersen-Forbes Phrase Marker Analysis. (Andersen, Francis I., and Dean I. Forbes ; Logos Research Systems, Inc. 2005).

ATSHB Ancient Texts for the Study of the Hebrew Bible: A Guide to the Background Literature. (Sparks, Kenton L.; Peabody: Hendrickson Publishers, 2005).

$C D$ Church Dogmatics I/1-IV/4 (Barth, Karl; Edinburgh: T\&T Clark, 1936-1969).

COS:1 The Context of Scripture. Vol. 1. (Hallo, William W., and K. Lawson Younger; Leiden; New York: Brill, 1997-).

DCH The Dictionary of Classical Hebrew. 5 vols. (ed. Clines, David; Sheffield: Sheffield Academic Press, 1993-2001).

DOT:HB Dictionary of the Old Testament: Historical Books. (eds. Arnold, Bill T., and H.G.M. Williamson; Downers Grove, IL: InterVarsity Press, 2005).

DOT:P Dictionary of the Old Testament: Pentateuch. (eds. Alexander, T. Desmond, and David W. Baker; Downer's Grove, IL.: InterVarsity Press, 2003).

DTIB Dictionary for the Theological Interpretation of the Bible (eds. Kevin J. Vanhoozer, Craig G. Bartholomew, Daniel J. Treier and N. T. Wright; London: SPCK, 2005).

FOTL The Forms of the Old Testament Literature. 24 vols. (eds. Knierim, Rolf and Gene M. Tucker; Grand Rapids, MI: William B. Eerdmans Publishing Company, 1988).

GD The Göttingen Dogmatics. (Barth, Karl; translated by Geoffrey W. Bromiley; Grand Rapids: Wm. B. Eerdmans Publishing Company, 1991).

IBHS An Introduction to Biblical Hebrew Syntax. (Waltke, Bruce K.; O'Connor, M.P.; Winona Lak, Ind.: Eisenbrauns, 1990).

KD Die Kirchliche Dogmatik. Volumes I and III (Karl Barth; Zürich: Theologischer Verlag Zürich, 1980).

NIDOTTE New International Dictionary of Old Testament Theology and Exegesis. 5 vols. (ed. VanGemeren, Wilem; Carlisle: Paternoster Publishing, 1996).

NIV The Holy Bible: New International Version. (Grand Rapids, Ml: Zondervan, 1996).

TWAT Theologisches Wörterbuch zum Alten Testament. 8 vols. (eds. Botterwerk, G. Johannes, Helmer Ringgren, and Heinz-Josef Fabry; Stuttgart: W. Kohlhammer, 1970-1994).

YABD The Anchor Yale Bible Dictionary. 6 vols. (ed. Freedman, David Noel; New York: Doubleday, 1992). 


\section{Introduction}

In the introductory essay to the first edition of The Journal of Theological Interpretation, Joel Green notes that there is "a widespread dissatisfaction with the status quo of academic biblical studies." ${ }^{11}$ The reasons for this are threefold: The standard critical methodologies "do not exhaust the subject matter of the Bible or the way in which the biblical materials might be engaged critically or the role of Scripture among God's people." If I may put this into my own words, Biblical studies is still struggling to come to terms with the content, form, and context of the Biblical text. If it is the case that standard critical methodology only scratches the surface of that which the Bible is about, struggles to come to terms with what the Bible is, and cannot enable the Bible to fulfil its intrinsic function, then what is the way forward? Green goes on to note an explosion of activity in recent years that goes under the rubric of "theological interpretation," a mode of reading that attempts to "tune our ears to the voice of God" ${ }^{2}$ for the sake of the church and thereby recover precisely the true nature and content of the Bible itself. This movement, however, is not a unified front, and there are many questions of a theoretical nature that still need to be wrestled with. ${ }^{3}$ Green's general account of the phenomenon is then followed by an article by $R$. Hays, which is programmatic in nature. Hays sets out to delineate that which a theological hermeneutic must contain ${ }^{4}$ and then proceeds to illustrate the theory with a concrete piece of New Testament exegesis. ${ }^{5}$

${ }^{1}$ Green, "(Re-) Turn," 3.

${ }^{2}$ Green, "(Re-) Turn," 2.

${ }^{3}$ The following are listed by Green on p. 3:

"- What is the status of the theological tradition, including the tradition of biblical interpretation, in theological interpretation today?

- What is the role of history and historical criticism in theological interpretation?

- What is the status and role of the OT in the two-testament canonical Scriptures?

- What is the place of exegesis in theological method?

- What is the nature of the 'unity' of Scripture?

- What is the role of the canon in theological interpretation?

- Does theological interpretation extract theological claims or principles from the Bible?"

All of these issues are treated throughout the following thesis.

"Theological exegesis is a practice of and for the church; it is self-involving discourse; it requires historical study; it attends to the literary wholeness of the individual scriptural witnesses; it always presses forward to the synthetic question of canonical coherence; it focuses on the texts as testimony; it is intratextual in character; it finds itself drawn into the complex web of intertextuality; it is committed to the discovery oand exposition of multiple senses in Biblical texts; it receives its training from the Christian tradition; it will produce fresh readings; finally, it ought to be a product of the power of God working through the text in order to reshape us. Childs would agree with all of these axioms, though he would strongly nuance the third (regarding historical study). He is also critical of the dominant position given the NT within Hays' construal (see his critique in Biblical 
What are the criteria that should be fulfilled in order for a theological hermeneutic to gain credibility amongst confessionally Christian Biblical scholars? Luke 24:25-27 offers a portrait of the resurrected Jesus himself engaged in act of "theological exegesis." With his identity veiled to his despairing disciples as they make their way to Emmaus, we are told that Jesus, "beginning with Moses and all the prophets ... interpreted ... the things about himself in all the scriptures" (v. 27). We are not provided with further details concerning the content of this exposition, but Moberly's interpretation of the basic principle involved provides us with coordinates that may help us establish the parameters for answering such a question. According to Moberly, this act of theological exegesis involves a "two-way dialectic between Jesus and Israel's Scriptures." ${ }^{16}$ On the one hand

the logic of Jesus' expounding the Scriptures to his puzzled disciples is that these Scriptures provide a context and a content for making sense of Jesus, when all that the disciples know about him already somehow has not "clicked"; Israel's Scriptures help one make sense of Jesus. Yet these disciples are Jews who are already thoroughly familiar with these Scriptures ... .So presumably a further part of the logic of Jesus' exposition is that the disciples need to be able to read these Scriptures in a new way, in the light of all that had happened surrounding Jesus, so that they can see in these Scriptures what they had not seen before; Jesus helps one make sense of Israel's Scriptures.'

Moberly's two poles of this dialectic, Scripture and Jesus, can be correlated to the broader categories of "witness" and "reality," "form" and "content," "verbum" and "res." Scripture is about something which it functions to point to, yet knowledge of that something also provides a framework for a profounder understanding of Scripture itself. There is a circular movement as one moves from signifier to signified and then back again. A successful theological hermeneutic, then, must provide an adequate account of both the nature of these two dimensions of the text as well as the manner of their interrelation.

The logic of the kind of dialectic exemplified in Luke 24 is similar to the general interpretive theory of the "hermeneutical spiral," in which successful reading proceeds along a "progressive dialectic" between "understanding of the 'parts' of the text and understanding it as a "whole", or, in another version, "between the two poles of a 'preliminary' understanding ... (Vorverständnis), and a fuller understanding (Verstehen), for

Theology, 84). In what follows I will present Childs' own construal of these principles and provide them with a more thorough theoretical grounding.

\footnotetext{
${ }^{5}$ Hays, "Reading."

"Moberly, "Christ," 80.

7 Moberly, "Christ," 80 (emphasis mine).
} 
which this beginning can pave the way. ${ }^{8}$ Reading is never linear, regardless of the type of material or its specific content, so that Jesus' act of explication on the road to Emmaus does not imply that theological interpretation must be an esoteric activity. After all, Jesus was often surprised at the disciples' inability to understand either himself or the Scriptures. It follows that the kind of questions a theological exegete needs to ask concerning the proper manner by which to proceed are not different in kind to what passes for typical Biblical interpretation within the scholarly guild in general. For example, when John Barton, a proponent of the kind of critical methodology that Green and others deem to be insufficient, poses the basic hermeneutical question, "How should we read the Old Testament?" ${ }^{\prime 9}$ his answer mirrors the same dialectical structure: "[N]o method can be used until there is some prior understanding of the text, even though this prior understanding is corrected as the methodological reading proceeds. ${ }^{10}$ Regarding form-critical interpretation of the Psalms, for example, the interpreter moves from an initial analysis of the structure and content of the psalm and then proposes a hypothetical sociological context within which it may have functioned. This context illuminates the meaning of the psalm, which in turn provides information about the context within which other psalms may have functioned. ${ }^{11}$ As Gerstenberger puts it, "Text without reality does not exist."12 The major difference between Jesus' act of reading and Barton's, therefore, concerns their definition of the nature of the broader "reality" that helps the texts make sense. Yet regardless of whether the form is liturgical or final, or whether the content is cultic or Christological, circularity is an inevitable part of the act of reading. Any Biblical hermeneutic, therefore, whether confessional or not, must submit to the same criterion of truth: Does it do justice to the form, function, content, and context of the material at hand? ${ }^{13}$

We thus see a point of contact between "general" and "special" hermeneutics. On the one hand, the circularity of reading is a general human phenomenon within which even "theological" hermeneutics must participate. On the other hand, the particular poles of the dialectic must always be oriented to the concrete phenomenon at hand. The criterion for

${ }^{8}$ Thiselton, "Hermeneutical Circle," 281. See also 4.1. below.

${ }^{9}$ Barton, Reading, 8.

${ }^{10}$ Barton, Reading, 5. The phrase "hermeneutical circle" occurs repeatedly throughout Barton's book on methodology, e.g. pp. 18, 21, 25, 37, 53, 66, 82, 125, 126.

11 Barton, Reading, 37.

${ }^{12}$ Gerstenberger, "Canon," 30.

${ }^{13}$ On the issue of the relation between general and special hermeneutics, see Treier, "Hermeneutics." 
the adequacy of a "theological" hermeneutic is whether it is Biblical or not, whether it succeeds in allowing this particular form and content to be the law for its own understanding. The construction of a Biblical hermeneutic-whether theological or notmust therefore always involve a description of the material itself. In the hope that the circle is not "vicious," 14 the exegete proceeds through a "progressive dialectic" of trial and error, hypothesis and verification, towards growth in "reader competence." 15

These considerations bring me to the topic of this study: that particular constellation of literary, historical, and theological theses developed by the late Brevard Childs and known as the "canonical approach." ${ }^{16}$ At present, this approach is only one "species" of theological interpretation among many. ${ }^{17}$ Its reception within the guild of Biblical studies at large has been largely negative, yet even within circles interested in theological interpretation it meets with resistance. ${ }^{18}$ The reasons for this go beyond the scope of this study, not only because they have been treated elsewhere, ${ }^{19}$ but because it would appear that a major obstacle to its reception is a limited understanding of its true content. Driver's recent analysis of Childs' reception history concludes that the Childs of the secondary literature "is largely a work of fiction, a Frankenstein hatched in an unhappy dream that lingers in daylight much longer than it should. ${ }^{20}$ I will refrain from judging the degree and the extent to which this hard statement is fair, but it does set up the context for my own proposal, for I am not aware of any holistic presentation of Childs' approach that is similar to the one that will be unfolded in the following chapters and that accords in its substance with the basic insights of Driver as well as Seitz. ${ }^{21}$ The key element that is either missing or has not been given its proper due in presentations of Childs' approach by both his supporters as well as his detractors is that pole of the dialectic I have labelled the "content" or the "res"

${ }^{14}$ Barton, Reading, 6.

${ }^{15}$ Barton, Reading, 11.

${ }^{16}$ Childs' magnum opus is his Biblical Theology.

${ }^{17}$ The phrase is from Seitz, "Canonical Approach," 100.

${ }^{18}$ Childs' reception history is the subject of Driver's helpful book, Childs; for resistance to Childs' approach see Treier, "Hermeneutics," 789; Seitz, Word, 102-112.

${ }^{19}$ See especially Driver, Childs, and Seitz, "Theological Interpretation."

${ }^{20}$ Driver, Childs, 58.

${ }^{21}$ I discovered that Driver was writing his PhD on this topic after I had already finished the bulk of my own analysis. His own work has a different focus to this one, interacting far more with Childs' reception within a German and Anglo-Saxon context while making less an attempt to systematize Childs' thought as I do. It was satisfying to see that his results are consistent with mine. I am grateful to Driver for providing me with a draft of his PhD before its publication as well as pdf files of various unpublished documents by Childs. 
of Scripture. Driver himself highlights the centrality of the concept for Childs' thought, ${ }^{22}$ yet apart from stating that it is important, that it is overlooked by his critics, and that it is foundational to his concept of Biblical referentiality, he does not provide us with a systematic overview of the manner in which Childs' concept of "reality" integrates with the material dimension of the form of Scripture itself. Even Seitz, a great interpreter of Childs' work and faithful practitioner of his approach, has not presented this approach in terms of a dialectic between verbum and res. ${ }^{23}$

We thereby come to the purpose of this study. I hope to contribute to the ongoing discussion about "theological" hermeneutics by presenting a coherent account of Childs' canonical thesis in terms of its understanding of those two criteria that should guide the interpretation of any text: the Bible's form and content, its verbum and its res. The format of the theoretical part of the study (Part I) is descriptive and systematic, it does not intend to make any judgement concerning the veracity of Childs' thesis beyond a claim for its internal logical coherence. Evaluating Childs' proposal would require setting up an independent vision of reality equally comprehensive in scope and then judging Childs' proposal in light of it. Not only would such an enterprise tax my current abilities, to say the least, ${ }^{24}$ it would also practically double the size of a study that is already dense enough as it is. My intention is simply to map out the co-ordinates that structure Childs' multidimensional vision, in the hope that future research will wrestle with him in terms of the same global horizon that he himself struggled to comprehend.

The question of the adequacy of Childs' thesis will be tested in practice rather than in theory; this is the subject of Part II. The dry bones of the theory will be clothed with flesh as I seek to set a difficult but theologically important text, Psalm 24, within the dialectic of Childs' particular construal of the Bible's verbum and res that is outlined in Part $I$. Consonant with the general theory of the hermeneutical circle, I will assume the adequacy of Childs' constellation of theses as a working hypothesis and seek to interpret the psalm within that framework. The adequacy of the theory can be measured on two levels: First,

${ }^{22}$ See chapter 5.

${ }^{23}$ Cf. Seitz, Word, 102-112; "Canonical Approach," 100-102. O'Brien in fact laments that Seitz himself does not make his own doctrinal position clear enough when articulating his literary and hermeneutical theses ("Review"). I hope to clarify Childs' ambiguity on this issue in his own work in what follows.

${ }^{24} \mathrm{C}$. B. Hays, rightly notes the extraordinary scope of Childs' work and concludes that canonical interpretation cannot be something for "young scholars." ("Bard," 151). 
according to whether it is workable when confronted with the objective reality ${ }^{25}$ of Scripture's form and content; second, whether it is effective in producing genuine exegetical insight, and thus in mitigating some of the felt deficit generated by traditional academic Biblical studies.

${ }^{25}$ It should be stated that talk of "objective reality" does not imply the adoption of a positivist epistemology. Even post-modernism affirms the existence of "empirical transcendentals" that function as "phenomenological criteria" that stand before our interpretation and are binding on every construal. Cf. Smith, Fall. 


\section{Part I}

Verbum and Res: Establishing the Context 


\section{Verbum or Res: Where Does One Start?}

I have claimed that all interpretation has a certain circularity to it in that one starts with a hypothesis and then moves to affirm or critique that hypothesis in the process of reading. Childs is no different, as can be seen in his statement that the goal of exegesis is "to penetrate [the] texts of Scripture and grapple with the reality which called ... them forth. ${ }^{\prime 26}$ How does he know that this is an adequate hermeneutical procedure? Does he start with a dogmatic presupposition about the content of the text, its res, and then assume that the text must be inspired, or does he start with a literary analysis of the text itself, the verbum, and conclude that it claims to be inspired? And what is the significance of the language of "penetration" and "being called forth"? Can this hermeneutical principle do justice to both dimensions of the text, its form and its content?

I am not aware that Childs consciously attempted to analyse the form of Scripture in isolation from his assumptions concerning the nature of its particular theological content. Yet unless statements like the one above are not to sound fideistic, as has been claimed, ${ }^{27}$ it will aid understanding to first separate them in order to see how they then come together. This is the procedure that will be followed here: I will first look at Childs' account of the nature of Scripture itself in chapter $\underline{3}$. (Verbum) and will then attempt to relate this understanding to Childs' more dogmatic assumptions about the nature of reality itself in chapter $\underline{4}$. (Res).

Before I execute this unnatural separation, however, it will be helpful to start our inquiry with an analysis of a text where verbum and res come together for Childs in a particularly dense manner: his "confession" 28 of his personal experience of God in the context of his profession as a Biblical scholar. My analysis of this confession will not only provide a starting point by which to move into an analysis of his canonical thesis, it will also provide us with a vantage point from which to perceive the basic theological structure I will claim undergirds the whole.

${ }^{26}$ Childs, "Psalm 8," 20 (emphasis mine).

${ }^{27}$ Sweeney notes that Childs is often accused of reading the Bible as a proof text for Barthian theology ("Canonical Criticism," 47).

${ }^{28}$ One may argue that what follows is not strictly speaking a confession but rather a rhetorical moment within a broader piece of theological argumentation. Nevertheless, in the quote that follows (2.1.) the tone is confessional (he even uses the term) and its logical function within its context is to ground an approach to the Old Testament that starts within the framework of the faith thereby explicated. Whether Childs' language is a reflection of his actual experience or not, I take the logic of his statements to be indicative and illuminative of his basic approach in general, and thereby a helpful starting point for my analysis. 


\subsection{Childs' Confession}

The context which elicits Childs' confession of faith is hermeneutical. In his Old Testament Theology, he presents the situation as follows: "I would like to start talking about God in the Old Testament, but how do I do this?"29 Rather than naming a particular method, he provides a description of context:

I do not come to the Old Testament to learn about someone else's God, but about the God we confess, who made himself known to Israel, to Abraham, Isaac and to Jacob. ... The Old Testament bears witness that God revealed himself to Abraham, and we confess that he has also broken into our lives. ... In the context of the church's scripture I seek to be pointed to our God who has made himself known, is making himself known, and will make himself known. ... We live our lives in the midst of confessing, celebrating and hoping. Thus I cannot act as if I were living at the beginning of Israel's history, but as one who already knows the story, and who has entered into the middle of an activity of faith long in progress." ${ }^{30}$

Within this confession we catch a glimpse of the way in which the eternal and the temporal are felt to intersect and the role of Scripture within that conjunction. There are three key elements that structure this description. I underline these elements below and associate with them in bold key terms taken from Childs' broader vocabulary: ${ }^{31}$

1. The divine subject: Before Scripture comes into play, Childs already experiences God. "God has [already] made himself known," and it is God alone who initiates this experience. This act of self-revelation has an almost violent impact on Childs ("he has ... broken into our lives") and is one of a repeated series of such acts spanning Childs' past, present, and future. In every event, God remains the agent of revelation. Childs can only "seek to be pointed to our God," he cannot control the moment itself. Key terms: salvific event, force, coercion, evoke, illumination, infusion, Spirit.

2. The divine object: God "has made himself" known, and is thus both the subject and the object of revelation. In response to being objectified by God's knowledge, Childs becomes a subject by knowing, worshipping, and seeking God. God desires for knowledge of himself to increase ("he will make himself known") and Childs evidently shares this desire, for he "seeks" God in the hope

${ }^{29}$ Childs, Old Testament, 28.

${ }^{30}$ Old Testament, 28-29.

${ }^{31}$ By placing these key terms wihtin this threefold structure 1 intend to provide the reader with a hermeneutical key for interpreting Childs' work. These terms will appear repeatedly in what follows. 
of further illumination. Key terms: theocentric, thematic, ontic/divine reality, res, substance, content, subject matter, Sache, Christ, God.

3. The communal context: This mutual process of knowing and being known takes place in the context of human community. Childs' "l" consistently switches to a "we," which shares his experience of both being known ("broken into our lives") and seeking to know ("activity of faith long in progress"). This community, however, does not merely stand beside Childs, related to him only by the analogous nature of its experience and the identity of the divine partner; it is the context within which God acts and Childs responds. It is the Sitz for his Leben, whose "activity of faith" he must "enter into" if he wishes to know God more fully. Moreover, this activity, the context for the reception of further illumination, is "long in progress," indeed rooted in the historically and culturally remote world of the succeeding generations of "Abraham, Isaac, and Jacob" and yet continuing to embrace Childs' modern American context. The bridge from Palestine to the States, however, is not cultural, ethnic, or religious. It consists solely in the one "substance" of the single deity who has continually evoked diverse human response to his unchanging self. Thus "Abraham, Isaac, and Jacob's" diverse testimonies to God cohere as the one "story of Israel," grounded in nothing other than the God who evoked it. In light of this context, Childs finds himself suspended in a hermeneutical circle revolving around a divine fulcrum: He comes to the partial testimony of Abraham, but he "already knows the story" of Israel. If God is the object of study land not culture or Israelite theology), part informs whole and the whole informs the part. Key terms: community of faith, prophets and apostles, form, function, witness, testimony, kerygmatic, Word, proclamation, confesslonal, canonlcal, cult, struggle, Israel.

We can summarize Childs' experience in terms of its ontic and its noetic dimension. Ontically, God is the context for Childs' entire being, the beginning and end of his experience, the very reason for his becoming a Biblical scholar in the first place and the goal of that activity. Upon closer analysis, this experience appears to betray a Trinitarian structure, for Childs finds himself with a total embrace. ${ }^{32}$ The one who is known by Childs is

${ }^{32}$ For Childs' endorsement of both the economic and immanent Trinity, see Biblical Theology, 82; 375-383. 
the one who enters into Childs' history in order to make that knowledge possible in the first place. In addition to this, there is a medium of knowledge: the community of faith and their treasured testimony. In other words, God operates according to a certain "economy," for he locates Childs in a context and points him towards a text that functions as the particular locus for this moment of revelation. I have indicated this potential Trinitarian structure by underlining the key terms "God," "Israel," and "Spirit" in the analysis. We will return to this matter in more detail later, however (cf. $\underline{4}$.), for the pattern of this divine economy of selfrevelation reveals a particular "noetic structure" ${ }^{\text {"33 }}$ by which it occurs.

Noetically, God utilizes a "vehicle" by which to reveal himself, and this is a thoroughly human community. ${ }^{34}$ God revealed himself to Abraham and his progeny and it is to their historical testimony that he expects us to go if we are to grow in knowledge of him. As Hägglund puts it in an article that deeply influenced Childs, ${ }^{35}$ revelation is "verbally mediated" (durch das Wort vermittelte Offenbarung), and so all talk of God is bound (gebunden) to the historically particular witness of "the prophets and apostles." ${ }^{36}$ This has consequences for theological method:

The word "revelation" means ... that we are concerned with matters which on our own terms we are not able to perceive or generate. We are dependent on the witness of others, on that which "we have heard," what others have related to us. It is for this reason that the "process of passing on" ["das Tradieren"] is accorded such significance. ${ }^{37}$

Given the central significance of this human medium within the structure of Childs' spiritual experience, it is important to pay closer attention to his understanding of its nature. The focus on personal names ("Abraham") and communal functions ("prophets") as well as the very human activity of "passing on" (the etymological root of the word "tradition") of revelation keeps the "textuality" of Scripture grounded in some account of human intentionality and the social context within which communicative acts were executed. Scripture preserves the testimony of the prophets and apostles, it does not

\footnotetext{
${ }^{33}$ The phrase is from Guretzki, Filioque, 98.

${ }^{34}$ Cf. Childs, "Speech-act," 380: "The most fundamental flaw in the new hermeneutical theory [i.e. Wolterstorff's "divine discourse"] arises from the failure to understand the role of the church in collecting, shaping and interpreting the Bible, which is the issue of canon."

${ }^{35}$ B. Hägglund, "Bedeutung." Cf. Driver, Childs, 251: "Apart from Seeligmann's essay on midrash, I suspect that no other single article had more impact on Childs early on than Hägglund's."

${ }^{36}$ Hägglund, "Bedeutung," 41 (translation mine). See also C. Seitz, Word, 102-112.

${ }^{37}$ Hägglund, "Bedeutung," 41 (translation mine).
} 
replace it with its own, secondary, self-referential form of discourse. ${ }^{38}$ It remains imperative for Childs that, however one characterize the nature of Scripture, our thought needs to move from a critical appreciation of the communicative function of its human "tradents" to the form of the literature thereby produced. He stated this early on in his career in his work as a form critic with the following words: "That which is ultimate in the Old Testament has been inextricably tied to the forms of Israel's daily life, including her history, tradition, institutions, thought-patterns, and language. ${ }^{\prime 39} \mathrm{He}$ also stated this long after he had developed a canonical approach, when he argued for the superiority of a form of speech-act theory that limited itself to discerning human discourse rather than a disconnected form of divine discourse. The theological legitimation is that God has "communicated his will to Israel and the church by means of the witness of human agents." ${ }^{40}$ As such, the "prophetic and apostolic" nature of Christian truth means that Sitz im Buch never replaces Sitz im Leben. ${ }^{41}$

Childs' understanding of the medium of revelation sets the proper context for his understanding of the term "canon," an understanding which stands in continuity with the Patristic use of the term. Rather than simply being a synonym for "synchronic," its original Patristic sense was "rule" (kavwv; regula) and could be applied to both Scripture as well as certain creedal formulations. Hägglund has shown that the designation of Scripture and creed as "canonical" was itself derivative of a more fundamental assumption about the functions of these two deposits of tradition. The real "canon" or "rule" was the eternal, unchanging, and salvific reality that Scripture and creed witness to, i.e. their "content." God himself is the measure or "rule" of truth (hence the full term "rule of truth" or "faith";

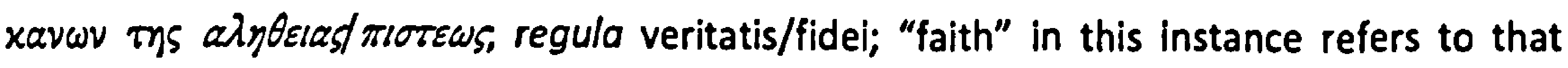
which one believes in rather than the subjective act of believing itself) and its human witnesses are "canonical" only by virtue of their capacity to mediate that reality.

We thus see that Childs' experience commits him to two kinds of inquiry, an inquiry into dogma and a historical-critical analysis of the Bible. On the one hand, Childs wishes to

\footnotetext{
${ }^{38}$ See, e.g., Childs, "Speech-act."

${ }^{39}$ Childs, Myth, 98. See also Childs, Struggle, 309; "Speech-act," 379.

${ }^{40}$ Childs, "Speech-act," 378.

${ }^{41}$ For a detailed theological account of the intellectual freedom of the historical critic see Childs, "Interpretation."

${ }^{42}$ Cf. Childs, Biblical Theology, 32. Similar statements are made by Barth in KD, 1.2, 524; CD, 1.2, 473, cited by Childs in Crisis, 105, fn. 7 (Cf. Driver, Childs, 90, for the reference and the citation; Driver also cites von Campenhausen as a significant impetus for this view, on $p$. 250). For a recent interpretation of Patristic usage, see K. Greene-McCreight, "Rule of Faith," in DTIB, 703-704.
} 
know about God; on the other hand, he can only do so through the vehicle of a human testimony anchored to a human community. Whatever Childs says about the one cannot be said at the expense of the other. In order to attempt to do justice to Childs' struggle on this score, the structure of Part I of this study will echo that of the structure of revelation itself. We will begin with the human "word," the visible, human form of revelation, the verbum, and move to the "Word," the content of revelation, which is the res. Whatever is said about the latter must be given in terms of the former.

\section{Verbum: The Shape of Israel's Tradition}

\subsection{Diversity}

A basic contribution of historical-critical analysis to Biblical exegesis is its uncovering of the breadth and depth of the historical, cultural and theological diversity that characterizes the entity commonly known as "Israel." ${ }^{43}$ Childs fully affirms the reality of this diversity in ancient Israel, present on both diachronic as well as synchronic levels. Across time, for example, Childs affirms that there are shifts in various modes of social organization and economics and thus the attendant forms of religiosity that shaped the traditions out of which "Scripture" grew. Nomadic traditions were combined with Canaanite festivals, Jerusalemite influences worked their way into a new temple-centred spirituality, wisdom influences reshaped patriarchal narrative and the exile precipitated a massive existential crisis that led to new modes of existence, hope, and self-perception. Oral tradition, cultic liturgy, isolated literary documents and intertextually interwoven prophecy characterize some of the modes of religious, political, and sociological expression that have all fed over the centuries into the composite phenomenon that came to be called "Scripture." Again, across space there is also diversity and fluctuation: Royal court, northern sanctuary, various wisdom centres and prophetic dissidence represent just some of the groups of "tradents" 44 that mediated the material that was to become our "Scripture." In short, there is such a thing as a "history of Israelite religion," one which does not necessarily correspond to the narrative portrayal found in the final form of the Bible. This diversity is part of Scripture itself and as such is a datum to be considered when formulating an appropriate

${ }^{43}$ Contemporary cultural theory has problematized concepts of "ethnicity" and the homogeneity of cultures. For the broader issue, see Carrithers, Cultures.

${ }^{44}$ I am aware that this term of Childs' is unusual. I retain it because of its connotation of "tradieren," passing on. See the Hägglund quote above. As we will see, the critical question is: "what is passed on and how?" 
hermeneutic of "Scripture." ${ }^{45}$ In this basic assumption, there is little to distinguish Childs from the majority of mainstream Biblical analysis in the modern period.

\subsection{The Question of Unity}

Yet the simple description of diversity does not do justice to the historical-critical task of analysing the nature of Israelite tradition. Another characteristic of such analysis is its attempt-sometimes explicit and sometimes not-to integrate this account of diversity into an overarching theory of unity, with the implication that this unity is as much a constitutive element of those traditions as their apparent diversity. Whether this unity consists in a philosophical account of the nature of "history," (e.g. Wellhausen's Hegelianism, perhaps) ${ }^{46}$ a sociological account of universal class conflict (e.g. N. Gottwald), an existential account of the basic human need for a coherent identity (e.g. J. Sanders), a political account of the human drive for power (the so-called "Copenhagen school"), or a theological account of divine intervention and sustenance (e.g. G. von Rad), the need to make this move seems motivated by the recognition that Israel itself does not exist in a bubble; it is grounded in some kind of "anterior reality." This is not to say that Biblical scholars are necessarily reductionistic in their accounts of the matrix that generates Israel's traditions. The scholars briefly cited above are nuanced enough to see a diversity of factors at work in Israel's tradition history. Nevertheless, these examples also indicate that one particular factor tends to be emphasized as the primary driving force.

Childs, too, is aware that Israel's traditions are not "a hermetically sealed system, "17 which may surprise those who claim that his canonical approach has its roots in French literary structuralism and a form of literary criticism which is exclusively interested in the "story world" generated by Scripture's self-referential narrative. ${ }^{48}$ In fact, as we will see, the "ontological" question of the presence and nature of an "anterior reality" grounding

${ }^{45}$ See, for example, Childs, Introduction; Childs, Struggle, 321.

${ }^{46}$ Cf. Bartholomew, "Waters," 15; B. Levinson, while not referring to Hegel, does make an interesting case for the kind of Marcionite, dualistic theology of history that undergirds the history of research into Exod 34 ("Goethe").

${ }^{47}$ Childs, Biblical Theology, 100.

${ }^{48}$ E.g. Barton, Reading, 77-88. One only needs to look at the way Childs structures each chapter of his Biblical Theology (written after the aforementioned volume) to see that this is not the case. Rather than moving from Old Testament to New, Childs often introduces a chapter on early Judaism; when treating a subject within the New Testament he usually starts with Paul rather than the gospels, even there distinguishing the synoptics from John. When treating the "law" he chooses an explicitly traditio-historical framework for his presentation. In his treatment of Gen 22 (\$V.1) he starts with Gunkel and moves from there towards the final form. 
Israel's tradition is of vital importance to Childs' entire conception of the nature of the traditio-historical development of Israel's traditions. Without it the canonical approach falls apart. We thus find that Childs is still within the bounds of acceptable academic historical procedure when his thinking about Israel's traditions integrates categories that go beyond simple cultural description.

What constitutes the context of Israel's traditions and thus the element of coherence behind their diversity? This is, of course, a highly complex question and Childs himself provides no absolute answer. He does, however, stake out a set of parameters which he believes do justice to both what criticism has told us about the diversity of Israel's tradition as well as what his experience tells him about the basic fabric of reality. His own particular approach to the issue can be understood in light of his confessional standpoint outlined above.

As we have seen, Childs exists within a dialectical tension between two dimensions of reality. On the one hand, his confession has the flavour of a "theophany," in which a radically different dimension of reality "breaks into" into his world. On the other hand, this experience of the radically new is "punctiliar," in that it does not transform Childs' "old world" into the new, although his experience certainly shakes his interpretation of the old. The "new" is experienced proleptically, such that Childs must seek it afresh within the framework of his old order of existence. Significantly, the very place he must go to seek this alternative dimension of reality is the human testimony of his forebears in the faith, a testimony that fully participates in the old order. In Childs' own words, "The heart of Christian theology is the confession that God has brought into being a new reality which is different in kind from all immanental forces at work in the world (Isa 65.17; Rom. 4.17); ${ }^{\prime 49}$ yet, "no theological formulation stands apart from its time-conditioned quality." However one handles the tension, Childs insists that "the theological dimensions of the biblical tradition ... can never be either separated from or identified with the life of empirical Israel." $" 51$

\footnotetext{
${ }^{49}$ Childs, Old Testament, 25.

${ }^{50}$ Childs, Old Testament, 25.

${ }^{51}$ Childs, Old Testament, 25.
} 
Given this experience of the "qualitatively new," it is understandable that Childs is suspicious of methodologies which claim to "know better"52 than Israel Itself about the reality that constitutes its true context. ${ }^{53}$ In other words, Israel has its own perspective on this matter and it needs to be taken seriously. For Childs, this is a genuinely "ontological" issue and not just a matter of personal piety. If it is the case that one does not assume Israel's basic "truth telling" stance, ${ }^{54}$ thereby assigning "no privileged status to Israel's record," 55 one will inevitably have an "oblique angle of reading" ${ }^{156}$ of that record and thus risk misconstruing it. ${ }^{57}$ The issue at stake here is not the validity of church dogma but the capacity of our theoretical construals to do justice to the actual nature of Israel's tradition. This is the level of his critique of the approaches of J. J. Collins, J. Blenkinsopp, and P. Davies when he asks whether their sociological categories "will prove more objective and unbiased than the theological ones being replaced. ${ }^{458}$ His concern is whether such an "oblique angle of reading" can "generate enough empathy for interpreting religious texts where the perspective is often radically alien to the entire Western mentality. ${ }^{\text {"59 }}$

Childs' own approach to the issue is to try and hold an etic (outsider) and an emic (insider) perspective in dialectical tension, ${ }^{60}$ assuming all the while, however, the basic "truth telling stance" of the tradition..$^{61}$ In this sense, though his modern critical training provides him with categories and tools for interpreting Israel's own statements of faith, those statements in turn influence his "outsider perspective," as a modern critical scholar attempting to account for the totality of a tradition that is greater than the sum of the tradents who mediated it. Despite the dialectical "starting point" (if one can say that), the

52 Childs, Biblical Theology, 98. For an explicit example of modern cosmology as critical interpretive norm, see Bultmann, Mythology, 35-36. This contrasts with Barth's approach; cf. 3.5. below.

${ }^{53}$ Note Steuernagel's concern about the replacement of "dogmaticism" in Biblical research with "historicism": "Wenn es damals notwendig war, die biblische Theologle aus den fesseln der Dogmatik zu befreien, so gilt es heute, wie mir scheint, die alttestamentliche Theologle von den Fesseln der alttestamentlichen Religionsgeschichte zu befreien, in denen sle völlig zu verkümmern droht" (cited in Zimmerli, "Biblische Theologie," 440).

${ }^{54}$ Childs, "Speech-act," 391.

${ }^{55}$ Childs, Biblical Theology, 98.

${ }^{56}$ Childs, "Biblical Studies," 38.

${ }^{57}$ Childs, Biblical Theology, 98. See his critique of N. Gottwald in Old Testament, 25.

${ }^{58}$ Childs, "Biblical Studies," 38.

${ }^{59}$ Childs, "The Canon," 38.

${ }^{60}$ Childs, Biblical Theology, 417.

${ }^{61}$ Cf. Childs, "Speech-act." 
basic thrust of his approach is to move through Israel's emic perspective in order to enrich his own inevitably etic perspective. ${ }^{62}$

Having moved from an account of historical diversity to the question of its underlying "ontological" unity, we find ourselves having to return again to concrete exegesis in order to identify the nature of the reality behind the text. The dialectic continues.

\subsection{Form, Function, Context, and Content}

Childs' early career was spent as a form critic and it is remarkable how consistently the vocabulary of "form," "function," and "community" accompanies his thought throughout his career, ${ }^{63}$ even as these terms are used in ways that go beyond their original intention. ${ }^{64}$ For example, the task of his Introduction is "to describe the form and function of the Hebrew Bible in its role as sacred scripture for ||$_{\text {srael; }}$ "65 his use of the cipher "canon" is meant to emphasize Scripture's "function as the Word of God in the context of the community of faith;" ${ }^{67}$ grasping this involves "establishing the initial setting of a witness within the history of Israel" and then "following a trajectory of its use and application within Israel's history." ${ }^{68}$ of particular importance for Childs is the term "function." Regardless of the form of the tradition under discussion-final form or not-its meaning is determined by its function within a concrete community of faith. ${ }^{69}$ These "etic" categories, then, will provide us with a framework for understanding Childs' construal of Israel's "emic" perspective along with the consequences he drew from that for his own "etic" proposals.

What does a "straightforward" angle of reading look like in contrast to a more "oblique" angle? Childs refers to Deut 31:9-13 as an expression of a more fundamental pattern that can in fact be generalized to apply to all of Israel's traditions, both diachronically as well as

\footnotetext{
${ }^{62}$ This is "faith seeking understanding" applied to historical-critical reconstruction. For Childs" own statement on this principle, see, e.g. Biblical Theology, 86. McGlasson (to whom Biblical Theology was partly dedicated) links this move to Barth (Invitation, 91).

${ }^{63}$ In light of what we have seen about the nature of "canon" as a communal "rule of faith" grounded in the testimony of "prophets and apostles," perhaps this is not surprising. Cf. Klaus Koch's characterization of the method in Formgeschichte, xiii.

${ }^{64} \mathrm{Cf}$. the discussion in Driver, Childs, 125-236; especially p. 134.

${ }^{65}$ Childs, Introduction, 16.

${ }^{66}$ Childs, Biblical Theology, 70.

${ }^{67}$ Childs, "Canonical Shape," 52.

${ }^{68}$ Childs, Biblical Theology, 98. This assumes that a "form" can change when its use has changed. Childs was no "generic realist." Cf. Sparks, ATSHB, 6, for a definition.

${ }^{69} \mathrm{Cf}$. Childs, "Midrash," 51: "One of the fundamental postulates of the form-critical method is the insistence that the form and function of a genre must be held together."
} 
synchronically, whether patriarchal or post-exilic, oral, liturgical, or scriptural. ${ }^{70} \mathrm{Childs}^{\circ}$ basic thesis is that Israel's tradition, despite the aforementioned diversity, is "theocentric in orientation. It identified the will of God for successive generations so that they might live in accordance with the enduring commands of God ... . It is not simply a flexible paradigm without an established content." "71 This statement covers both the "ontological ground" of Israel's tradition as well as the nature of Israel's response, ${ }^{72}$ and requires unpacking.

\subsubsection{Theocentric Focus}

For a start, we see at the outset that the question of "external reality" is in fact a central concern of Israel itself. Regardless of genre and age, Israel's traditions were always oriented to a single referent: the reality of God and his will. For Childs, this is a statement of historical intentionality and as such a matter of interest for historical-critical exegetes. It is not to say that Israel's traditions all contained the same theo-logy, which Childs did not believe to be the case. It is to say that Israel's traditions were all looking in the same direction; they are theo-centric. ${ }^{73}$ This basic Israelite stance is important, for it excludes a number of approaches which claim that Israel's God-talk was simply a cover for an alternative agenda, such as political manipulation or the construction of its communal identity. Israel's faith may have political or existential implications and it may have been influenced by its political and existential context, but its intentional focus is on God. Israel's traditions are theocentric and not anthropocentric. ${ }^{74}$

${ }^{70}$ This thesis can be tested by applying the following framework to the many examples of concrete exegesis found in Childs' Introduction and in his commentaries on Exodus and Isaiah. For an analysis of these two commentaries, see the appendix below.

${ }^{71}$ Childs, "The Canon," 39 (emphasis mine).

72 For Israelite tradition as response, see also P. Miller, "Israelite," 9.

${ }^{73}$ Cf. P. Miller, "Israelite," 9.

${ }^{74}$ This is also Childs' criticism of J. Sanders' "canonical criticism" and provides a basic element in his rejection of Sanders' focus on the canonical process instead of the product of the canonical process. See, e.g. Introduction, 59, 61. Sanders, however, describes his own approach as theocentric ("Christian Faith," 185). For a similar statement in a historical-critical context see Seebass, Wesen, 6: "der letztendlich entscheidende Gegenstand fast aller Texte des Alten Testaments (ist) sein Gott." He draws similar hermeneutical consequences. He concludes his study with a chapter on the "substance of Biblical faith," which opens as follows: "Es wäre der Würde und dem Gewicht der erarbeiteten Stoffe nicht angemessen, wenn man auf bloß literarischer, analytischer Ebene von Erwöhlung und Verwerfung oder von der in der atl. Tradition so seltenen totaien Vergebung redete. Man behandelte die Stoffe gleichsam mit abgewandtem Gesicht, wenn man sich ihrem Glauben und der in ihnen ousgesprochenen Erkenntnis Gottes verschlösse" (131). Cf. also Miller, Isroelite, 9: "the character and work of God as testified to by the witness of Israel has been a matter of continuing interest. It is surely the subject par excellence of Scripture." See also C. Wright, Ethics, 23-47 


\subsubsection{Theological Content}

The next component in Childs' interpretation moves beyond Israel's "God saturated stance ${ }^{\prime \prime 75}$ to the reality of God himself. Israel is not just oriented towards God, it does in fact identify him. Regardless of how this identification is achieved, Israel's theocentric gaze was orientated towards a reality that exists independently of its perception, such that that which it "saw" cannot be said to have been purely constructed out of its own psychological, spiritual, or intellectual resources. ${ }^{76}$ This theological reality is the ontological precondition of Israel's tradition which stood over and against this tradition and functioned as the criterion for its claim to truth and authority. This perspective, too, has important implications, for it excludes those approaches to Israel's traditions which claim that they thought they were talking about God but were in fact giving expression to something else, such as a sub-conscious neurosis or unacknowledged existential need. Israel did in fact identify God's will, so that when Childs describes Israel's traditions as "religious," he is not only describing their intended content, he is also describing their actual source."

\subsection{3. "Canonical" Function}

It is not enough, however, to simply identify "God" as the basic reality standing behind and unifying the diversity of Israelite tradition, as this term could mean a variety of things. Depending on how one views God's mode of revelation and the purpose behind that, one will construe the nature of Israelite tradition differently (cf. the difference between Barth and Bultmann). ${ }^{78}$ As such, Childs adds a further element to his construal which constrains the way in which God and Israel relate to each other. According to Childs, the divine reality is rendered by the tradition according to a particular telos: personal and communal transformation. Israel's traditions are not just oriented to the reality of God, they are also oriented to the reality of Israel. The nature of the relation, however, is important. Israel's traditions are focused on God for the sake of Israel. What Israel should become is determined by the reality of God himself, who is the sole content of Israel's tradition, who stands over and against Israel as judge and redeemer. This understanding is the basis for Childs' critique of David Kelsey's hermeneutical theory, who defends the position that the Bible's authority does not rest on any specific content or property of the text, but lies in the

${ }^{75}$ Childs, Isaiah, 31.

${ }^{76}$ In contrast to German pre-War Neo-Protestantism, for example, Israel's religion is no "Ausprägung seiner >Volksseele<" (Bächli, Barth, 324).

"For a defence of the term "revelation" in this connection, see Childs, Old Testament, 20-27. Cf. Barth, Dogmatik, 29.

${ }^{78} \mathrm{Cf}$. Childs, Biblical Theology, 588-589. See 4. below. 
function to which biblical patterns have been assigned by the 'imaginative construals' of a community of faith. ... [T] he theological issue turns on whether one can do justice to the function of scripture when it is so loosely related to its subject matter, that is, to its reality. $^{79}$

This understanding also distinguishes Childs' approach from that of Bultmann, for whom the Sache of tradition is not an alternative dimension of reality but rather the existential issue of authentic human existence ${ }^{80}$ (cf. 4.1.). When Childs claims that the totality of Israel's traditional forms (narrative, law, liturgy, song etc.) all serve the same kerygmatic function, he understands this to mean that the traditions functioned as vehicles for the reality of God himself (who, as the goal of history, is eschatological; see the discussion of the "old" and "new" above), and not as vehicles for a subjective experience of "eschatological existence" (which for Bultmann is an anthropological category). ${ }^{81}$ Israel's traditions point to this ontological reality and as such they are "deictic." ${ }^{82}$ Furthermore, this "proclamation" is oriented towards a communal goal, which is the raison d'être for the tradition's very existence. ${ }^{83}$

The significance of this universal function for Childs' canonical thesis can be seen in the fact that a near synonym for "kerygmatic" or "proclamatory" is "canonical." "Canon," Childs came to say, is primarily a "quality of the text" ${ }^{84}$ and not an issue of reader-response aesthetics or "literary form," whether final or not. At this point we can see a close analogy to the patristic definition of canon outlined above (2.1.). Regardless of an actual formxavwv could refer to both Scripture and various creedal statements for the Church Fathers-"canon" refers to the function of a body of tradition to authoritatively communicate the salvific reality of God to a future generation of faith. And yet, its capacity to do this is derivative of that reality, which is the actual "canon," l.e. "rule" for faith and practice. Childs effectively takes this Patristic term as it has been applied to apostolic tradition (as interpreted by Hägglund) and applied it to the entire scope of Israel's religious

${ }^{79}$ Childs, Biblical Theology, 81-82.

${ }^{80} \mathrm{Cf}$. Childs, Biblical Theology, 81.

${ }^{81}$ When Childs says that "kervgmatic reading" is "Christological reading," he is using this phrase in the referential sense that Scripture functions to point to the objective reality of Christ (Biblical Theology, 66). Note also that for Childs the category of "eschatology" references another dimension of reality that intersects with ours, and not our personal attitude within our dimension of reality (Cf. 3.2.). See also Old Testament, 23. Contrast this to Bultmann, Christ, 51 (cf. also 4.1.).

${ }^{82}$ Childs, Isaiah, 445.

${ }^{83}$ Cf. Childs, "Midrash," 51.

${ }^{84}$ Childs, Isaiah, 3. 
traditions. The " $E$ " source, for example, was already in some sense "canonical" before it was integrated into what became the Pentateuch and it did not cease to be canonical once the editorial process both changed its form and thus shifted its semantic content. ${ }^{85}$ The challenge this editorial process may pose to Childs' claim that Israel's traditions contain a single content will be dealt with more fully below. For now, it suffices to note the hermeneutical implications this "emic"-turned-"etic" view has for Childs' interpretation of the tradition. Regardless of the epistemological question of whether we can actually perceive a tradition's referential content, Childs' construal excludes as inadequate "postmodern" approaches which ignore the question of the nature of the traditions' referent, ${ }^{86}$ along with narrative approaches which fail to reckon with the relation between the world "within" the text and the world outside it. ${ }^{87}$ It is also to be differentiated from theological approaches which claim that a particular methodology can turn the text into a witness. According to Childs, the traditions are already a witness, they do not become a witness when read in a certain manner. ${ }^{88}$

\subsubsection{Summary: Continuity within Diversity}

Having covered the basic building blocks of Childs' concept of Israelite tradition, it is helpful at this juncture to summarize these blocks according to their inner relationship. I am aware of the inevitability of oversimplification, but I hope that this very schematic

${ }^{85}$ Childs is not the only one to use the term in this way. For another random example, see Koch, Formgeschichte, 202.

${ }^{86}$ E.g. Childs, Struggle, chapter 17. Gunneweg appears to be confusing "epistemology" and "ontology" in his derogatory characterization of these kinds of claims (in this case he is critiquing $\mathrm{H}$. Gese) as "Offenborungspositivismus" ("Interpretation," 73). A rejection of the epistemological stance of "positivism" does not automatically lead to a rejection of the existence of an objective referent of the text ("revelation"). Whether and how one can identify this reality is a separate issue to a confession of its existence. Gunneweg's rejection of the prioritization of "reality" over "Daseinsverständnis" is grounded in a dogmatic presupposition about the nature of "faith" $(73, \mathrm{fn}$. 13), yet dogmatics can also provide a way of bridging the epistemic gap he wishes to keep open (e.g. in the work of $K$. Barth, cf. 4.2.). The same point can be used to refute Brueggemann's epistemological critique of Childs in "Canon Fire." For a helpful discussion of the relation between subject and object in post-modern epistemology, see Smith, Foll. For an interesting example of a postmodern Christian philosopher propounding a "referent saturated" (my phrase) form of theological exegesis, see J.-L. Marion, "Eucharistic."

${ }^{87}$ Childs appreciates Sternberg's Poetics; cf. Biblical Theology, 19-20.

${ }^{88}$ Contra G. Steins, "Kanon." Steins also agrees with Childs' historical-critical thesis, but goes beyond Childs by trying to develop a means of methodologically securing the moment by which Israel's past traditions are actualized. The implication is that they are inert until application of the method allows them to become a witness. Childs is far more Barthian, in that the only thing the Bible becomes is the Word of God, and that is something beyond methodological control. See, e.g. Childs, Biblical Theology, 724. It is interesting to note that Steins' attributes Childs' "ambiguity" to method to a ">barthianisch< anmutende Aversion gegen >profane< Wisschenschaft" ("Bibellektüre," 60). Cf. 
presentation will serve as a useful framework for reading Childs' more subtle exegesis. This summary will be nuanced as we proceed, but my thesis is that even at this basic level it holds across the breadth of Childs' theoretical and exegetical work. In short, the elements of "anterior reality," "theocentric orientation" and "canonical function" can be arranged according in a sequence. In terms of "causality," we may present the movement as follows:

1. religious reality $\rightarrow$ 2. religious perception $\rightarrow 3$. religious proclamation.

On this model, that which is the object of scholarly Biblical study is ultimately the product of a "divine cause" (without wanting to imply any special theory of causality)." This religious reality is not the only force at work in Israel's life, but Childs insists that it is the primary force at work. As discussed above, the question of the manner in which the divine reality relates to the human is a basic theological issue that theologians will have to struggle with. But this does not free us to abandon the dialectic and collapse the divine into the human. ${ }^{90}$

In terms of Israel's conscious response, we may present it as follows:

1. reality (res) $\leftarrow 2$. perception (of res) $\rightarrow 3$. proclamation (of res).

According to this pattern, part 2, Israel's perception/experience, looks in two directions at once. It intentionally looks back to the reality itself-Israel's conscious involvement is not bypassed in this process-and it looks forward to the community it wishes to communicate that reality to. The reality itself, then, is a central element of each stage. It is present as the ontological condition of Israel's tradition, as the content of that tradition's experience and as the content of its proclamation. From beginning to end it is all about die Sache, the res, the something else behind, in, and if the tradition achieves its function, in front of Israel's witness. ${ }^{91}$ One could call this basic movement the "temporal unity" (the horizontal dimension) $)^{92}$ of Israelite tradition.

In light of everything we have discussed so far, however, this "temporal unity" also implies an "ontological unity" (a vertical dimension) behind the totality of Israelite tradition.

${ }^{89}$ Childs never answers the question of how God inspires Scripture. See Childs, Struggle, 309. What he does do, however, is exclude the possibility that God secondarily appropriates what was initially purely human speech. Cf. Childs, "Speech-act."

${ }^{90}$ Childs, Old Testament, 25.

${ }^{91}$ Childs himself does not use the language of Ricoeur. Cf. Thiselton, New Horlzons for the metaphor.

${ }^{92}$ See, e.g., Childs, Old Testament, 23. 
Whereas this horizontal pattern can be multiplied each time a tradition comes into being, such that we can conceive of a multiplicity of moments of divine revelation $\rightarrow$ human response $\rightarrow$ human proclamation spread across Israel's history, the reality itself always remains the same. It is certainly a rich and multifaceted reality-hence the diversity sketched out above-but it is a single reality none-the-less. Again, Childs' justification for positing this broad unity across time and space is grounded in Israel's own witness. As we will see, not only is the very act of collecting, shaping, and interrelating various traditions a confession of the oneness of the reality to which they independently witness, Childs anchors this basic confession in a more fundamental view of the nature of reality itself. In an early work on the cultural function of Israel's memory, for example, Childs writes that it "serves a far more important role than merely providing illustrations from the past. It serves in making Israel noetically aware of a history which is ontologically a unity. There is only one redemptive history. ${ }^{\prime 93}$ Again, in his discussion of the manner by which Israel related "myth" and "history," Childs states that

The prophetic hope of the new age was pictured in terms of God's former redemptive acts. However, the last events were now to fulfil the original purpose of the first. The return to the past signifies the continuity in the one will of God; the newness of the end indicates the full intensity of the light which at first shone only in dim reflection. The new of the Endzeit became the criterion for determining what was qualitatively new at the Urzeit. ${ }^{94}$

If we imagine that Israel's "illustrations from the past" and that the various presentations of myth and eschatology, for example, represent different traditions, each responding to and attempting to perceive the unity of the "one will of God," the basic pattern undergirding Israel's tradition history can be nuanced to look as follows (whereby $\mathbf{A}$, B, C, represent different traditions, such as the P-source, Isaiah ben Amoz, and the author of Qohelet):

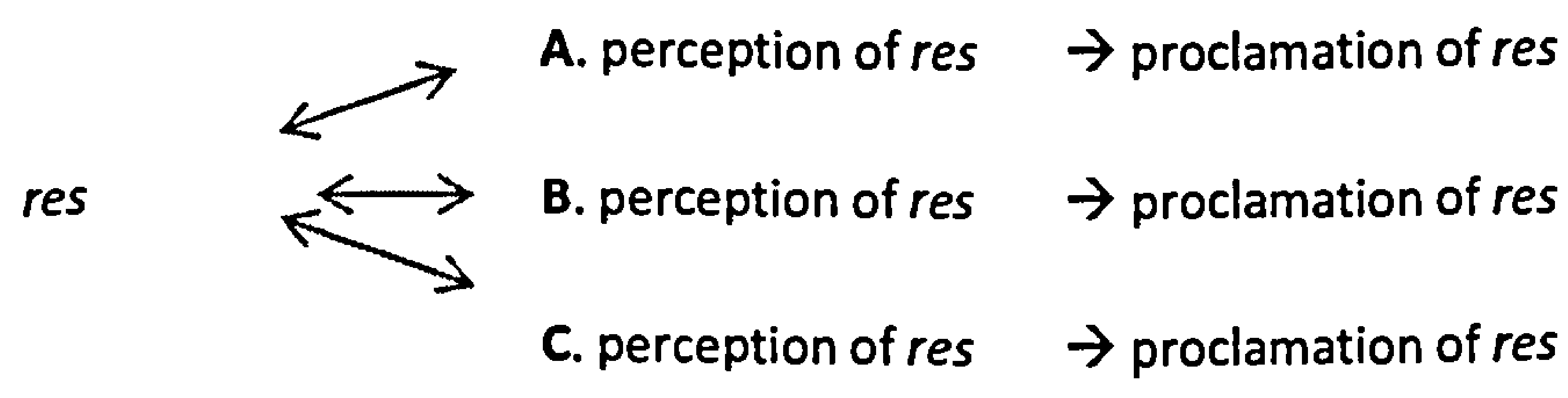

${ }^{93}$ Childs, Memory, 51 (emphasis mine).

${ }^{94}$ Childs, Myth, 81 (emphasis mine). 
It is helpful to rephrase this pattern in terms of the traditional form critical categories of form, function, context and content:

- In terms of form, we simply have, at this stage, immense diversity. Given the very flexibility of human communication, it is not possible to reduce Israel's traditions to a finite number of fixed genres, let alone one over-arching genre.

- In terms of function, we find one overarching purpose, that of witnessing to the reality of God, the res; it can incorporate a diversity of "sub-functions" (education, exhortation, liturgical re-enactment, poetic evocation etc.).

- In terms of context, we have the overarching category of the "community of faith" which, despite changes in its political, social and cultural structure, consistently provides its traditions with the framework for determining their function, which is ultimately kerygmatic or "canonical."

- Finally, the content of Israel's traditions, their res, is always the reality of God, regardless of what aspect of that identity is brokered in each particular case. The content which they point to is at the same time the reality which generated their existence.

In our attempt to ask the question of the unity undergirding the diversity of Israel's traditions, we have followed Childs in asking how the traditions themselves perceived this matter. We have seen that Childs discerned a basic stance that can be found across the breadth and depth of Israel's traditions. Regardless of the details of Israel's diverse theologies and the various traditional forms by which these theologies have been preserved and actualized, their source is the ontological reality of God, a being who has actively revealed his self and his will to Israel and entrusted this knowledge to it for the sake of further generations of the faithful. We have also touched on something of the nature of this reality, namely its "eschatological quality" as an alternative dimension of reality that breaks into the old, wishes to be understood in terms of the old, and yet which explodes the old and infuses it with new content (witness the Biblical language of "new creation, new birth, new Jerusalem, life in the Spirit" $).{ }^{95}$ We will look in more detail at Childs' grasp of the content of this reality shortly. For now, it is important to note that at this stage Childs' model does not require either the concept of textuality or of a "final form

${ }^{95}$ Childs, Old Testament, 25. 
of Scripture" for it to work. These concepts are derivative of this more foundational situation and must be perceived in light of it.

\subsection{Initial Hermeneutical Implications}

I stated above that Childs desired to develop his hermeneutic of the church's Scripture in light of the nature of that Scripture. In order to highlight the primacy of Israel's lived experience for Childs' thought over against claims that he is interested in a self-referential literary "canon," it will help to take stock of the significant hermeneutical implications that Childs already draws at this level of analysis, before looking more closely at how this relates to the Bibles in our pews:

- "Theo-referential" interpretation (due to function): If one assumes the validity of Childs' claim that Israel's traditions desire to point beyond themselves to a theological reality, it is incumbent upon the interpreter to move beyond an analysis of the tradition's "external features," such as its formal structure, use of language, sociological context, cultural influences, etc. to the question of the identity of the theological reality it is trying to communicate. Sachgemäße exegesis which wishes to be der Sache gemäß, must be interested in the question of theology. Everything else is simply prolegomena. ${ }^{96}$

- Correlative interpretation (due to content): If it is the case that the theological referent of a tradition is identical with that of another tradition, no matter how contradictory the traditions may seem to be, it is incumbent upon the interpreter to move beyond the theo-logy of a single strand to think about the theo-reality undergirding the two. ${ }^{97}$ Thus, the descriptive analysis of the tradition's "God-talk" must lead to the interpreter's own talk of God.

${ }^{96} \mathrm{Cf}$. Childs, "Interpretation," 443. Ricoeur says something very similar, in Minear, Bible, 19.

${ }^{97} \mathrm{Cf}$. Childs, Biblical Theology, 724-725: "The productive epochs in the church's use of the Bible have occurred when these two dimensions of scripture [i.e. text and content] constructively enrich and balance each other as establishing an acknowledged literal sense. Unfortunately, the history of exegesis has more often been characterized by severe tension between a flat, formalistic reading of the text's verbal sense which is deaf to its theological content-this was Luther's attack on Erasmus - or by a theological and figurative rendering of the biblical text which ran roughshod over the language of the text to its lasting detriment-this was Calvin's attack on the Libertines (Inst.I.IX.i)." Cf. Seebass, Wesen, 7: "Immerhin sei nachdrücklich darauf hingewiesen, daß ein SichVerstehen auf Gott auch auf dem Grund des Christus Jesus ohne die Worte der hier behandelten Vorzeit nur rudimentär möglich ist und Mangel leidet. Denn das eigentliche Wunder in Christus Jesus ist ebenfalls ... Gott in seiner Bekanntmachung." 
- Dialectical interpretation (due to context): If it is the case that the tradition's witnessing activity consists in a witnessing to God for the sake of Israel, such that Israel itself might know the fullness of its tradition's divine referent, it is incumbent upon the interpreter to consciously situate his or herself within the context of the living tradition of the People of God, for it is only here that the full contours of that reality can begin to be grasped and perceived. Critically appropriated church tradition is thus an indispensible interpretive horizon within which critical Biblical tools must be put to use. ${ }^{98}$

These three hermeneutical implications, each tied to a particular aspect of Childs' construal of the nature of ancient Israelite tradition, parallel Childs' understanding of the relation between exegesis, Biblical Theology and Dogmatics as outlined in his Biblical Theology and further developed in his article "Does the Old Testament Witness to Jesus Christ?" The question arises as to whether it is necessary for him to bring in the concept of a final form of Scripture at all in order for him fulfil what, as we saw above, is in fact his primary goal: theological interpretation of Israel's historical witness (not text) for the knowledge of God. On the basis of what we have seen so far, it is conceivable that theologically fruitful exegesis could simply consist in the critical disentanglement of the "spaghetti" of traditions that constitutes the final form, situating each tradition in its historical and cultural context, discerning their basic theological content, and then bringing the various theologies that arise into dialogue with each other, guided by the Church's more mature dogmatic formulations. ${ }^{99}$ Evidently, Childs felt that there is more to be said about the nature of Israelite tradition.

It is helpful here to note the similarity between Childs' construal of Israelite tradition and the task of exegesis to that of the teacher whom he admired so much: Gerhard von Rad. Like Childs, von Rad attributed the primary force at work in Israel's history to the reality of God himself, "das lebendige Wort Jahwes, wie es an Israel ... je und je ergangen ist. ${ }^{100} \mathrm{He}$ also argued that this external (ontological) ground of Israel's traditions, the "Offenborung Jahwes," was at the same time the conscious object of Israel's faith, for it

${ }^{98}$ Cf. Louth, Mystery; cited favourably by Childs in Biblical Theology, 87.

${ }^{99}$ This comes quite close to his thesis in "Interpretation," 438: "Approaches which start from a neutral ground never can do full justice to the theological substance because there is no way to build a bridge from the neutral, descriptive content to the theological reality." Childs' Introduction of ontological categories in this essay is done in terms of his historical-critical grasp of Scripture and not despite it.

${ }^{100}$ G. von Rad, Theologie, 125. Cited in Schmidt, Glaube, 19. 
was that which "Israel selbst als den eigentlichen Gegenstand seines Glaubens angesehen hat." ${ }^{101}$ This fact has consequences for his appreciation of the nature of Israel's traditions, which he consequently characterized as "Träger, Mund." ${ }^{102}$ Finally, this overall construal of the nature of Israelite tradition led von Rad to draw similar hermeneutical conclusions to those outlined above: The divine revelation itself is the "wesentlichste Gegenstand einer Theologie des AT. ${ }^{103}$ In contrast to Childs, however, von Rad never shifted his primary focus to the present form of what Israel itself came to call "Scripture," opting instead to engage in precisely the disentangling activity sketched out above. ${ }^{104}$ Given the strong similarities between these two Old Testament scholars, the question is inevitably raised as to how Childs moved beyond von Rad's approach, yet all the while retaining his basic insights. This question is important, because it is the manner in which Childs made this move that proves decisive in grasping what he meant when he talked about the derivative reality he came to call "the final form of Scripture." In relation to von Rad's approach, the move would seem fairly minimal, yet it has decisive consequences for the entire enterprise of Biblical exegesis. Again, as in every stage of our construal of Childs' thesis so far, this move was perceived by him as being a factual statement about the nature of Israelite tradition itself and not as a dogmatic imposition "from above"; as such, it is a matter of concern for historical-critical exegesis.

We will turn to analyse this additional element within Childs' construal shortly. Before we do so, however, it will be helpful to make a brief detour in order to look at the way in which these issues were framed by a dogmatic theologian whose thought decisively influenced both Childs and von Rad: Karl Barth. ${ }^{105}$ Thus far, I have grounded Childs'

${ }^{101}$ Von Rad, Theologie, 127. Cited in Schmidt, Glaube, 19.

${ }^{102}$ This is Schmidt's summary, Glaube, 19. The language echoes that of Hägglund, who states that Scripture is "Träger der Offenbarung, Vermittler der Heilswirklichkeit" ("Bedeutung," 161). See also Driver's citation of von Rad in Childs, 131.

${ }^{103}$ Von Rad, Theologie, 125; cited in Schmidt, Glaube, 19. See Childs' critique in Biblical Theology, 102-103. Similar assumptions are held by H.-J. Kraus, in e.g. Theology.

${ }^{104}$ See, for example, his independent treatment of the disentangled $J$ and $P$ sources in his Genesis commentary.

${ }^{105}$ The key texts by Childs on this matter are "Interpreter" and "Exegete" (which is unpublished; I am grateful to Driver, who got it from Christopher Seitz, for making this paper available to me). Xun, Theological, 225-236, provides useful bibliographic references for the secondary literature, though his own claim that Childs objected to Barth's idea that revelation is also in the text (231) and thus his conclusion that Childs' "disregard of the doctrine of biblical inspiration exemplifies his lack of competence in matters of dogma" (267) is patently false, as our discussion of "infusion" and "resonance" below will show (4.2.). Xun's own analysis of Barth makes no mention of his key doctrine of the "three forms of the Word of God," and so cannot count as an adequate summary of Barth's own views on the matter (on which, see 4.2. and 4.3. below; pace Xun, Barth also rejected 
theological motivation for doing historical-critical research in his confession of his (partially) communally mediated experience of an alternative dimension of reality which evoked a desire for more of the same, and thus his study of the human witness of others who authoritatively mediate a knowledge of that same reality. Childs himself never said too much about the actual content of that reality. This is no doubt due to the fact that as a Biblical scholar his academic life was committed to clarifying the "conceptual foundation ${ }^{\prime 106}$ by means of which this reality could be most adequately articulated, rather than with clarifying the contours of the reality itself. ${ }^{107}$ However, as indicated above (2), Childs' critical construals do seem to stand in some kind of dialectic with a particular set of dogmatic assumptions, so a brief excursus into the thought of his theological hero will help clarify the steps outlined so far by setting them within a broader theological framework. in doing so, I do not wish to claim that Childs simply bought Barth's dogmatic theology wholesale. An analysis of the differences between the two theologians on this level go beyond the scope of this thesis. My purpose is simply to illustrate how the kinds of points made so far have been made from an entirely different angle, an angle which starts with a dogmatic construal of the substance of the faith and not with an historical construal of the nature of Israelite tradition. An outline of Barth's thought here is also necessary, for, as Driver has pointed out, Barth himself has been variously received in the Anglo-Saxon world. ${ }^{108}$ My own construal will help the reader to grasp my own angle on the matter and thus the manner in which I will later move to "fill in the gaps" of Childs' canonical thesis by showing how it assumes a particular, "Barthian," doctrine of revelation (in 4. below).

\subsection{Excursus: Barth on the Stance of Theology}

Given that my purpose is to illuminate what I have said about Childs' thought thus far, an extensive account of Barth's theology is not necessary. In particular I will purposely postpone discussion of the essential element in both Barth's and Childs' system, namely the Holy Spirit, until section 4. below. For now, I will limit my analysis to a few summary

being labelled "neo-orthodox," cf. KD III/3, vii and Childs, "Interpreter," 33). For a briefer yet more sensitive discussion see Driver, Childs, 89-93. Scalise, perhaps, makes the strongest statement of affinity in "Theological," 197; cited in Driver, Childs, 89, fn. 36. See also McGlasson, Invitation, 91-92.

${ }^{106}$ McGlasson adopts the phrase from Neil B. MacDonald and applies it to Childs in Invitation, 93. Cf. MacDonald, Barth, 115.

${ }^{107}$ Cf. Childs, "Exegete," 17. Childs understands his exegetical work to offer "exegetical controls" for dogmatics (Exodus, 438).

${ }^{108}$ Driver, Childs, 92: "Frei's Barth is hardly more Childs' than Torrance's is." 
statements taken from Barth's Einführung in die evangelische Theologie ${ }^{109}$ as these relate to my discussion of Childs so far. This little work seems particularly apposite as a dialogue partner not only because of its size but also because of its scope. ${ }^{110}$ According to the preface, this "introduction" represents Barth's "swan song," an opportunity at the end of his teaching career to give a brief and summary account (Rechenschaft ablegen ${ }^{111}$ ) of the main elements of his thought up until this point of his life (1962). ${ }^{112}$ In order to highlight the relations to Childs' thought, I will adopt the same categories as in 3.3. namely content, community, function, and form. This will be followed by Barth's hermeneutical conclusions.

\subsubsection{Content}

In my presentation of Childs above, I attempted to emphasize the historical angle of his approach. We saw, however, that for Childs a neutral analysis is ultimately impossible, for his own historical experience always already pre-determined for him a perspective from which to view Israel's historical reality. Israel's testimony to the in-breaking of an alternative dimension cannot be reduced to psychology or sociology. What for Childs was presented in existential terms, for Barth can be presented as a methodological axiom: The starting point of theology must be determined by the reality of its object of inquiry: God himself (who is the "von ihrem Gegenstand her notwendige Ausgangsposition"). The subject-matter/object/content/res of theology ("Gegenstand") is the "law" ("Gesetz") that determines theology's method. ${ }^{113}$ In fact, for Barth, submitting to this principle is not just a matter of common sense. God himself has appointed the "law" by which he may be known, so that the law is "von innen zugewiesen,"114 it is the "[von] ihm selbst gewiesenen Weg." Who is this God and what is this "law"?

Barth cannot talk of God other than in relational categories. The "information" that theology has to acquire does not consist in an "idea" that can be reduced to a string of propositions, it consists in the relationship that God has set up between himself and

${ }^{109}$ English translation: Evangelical (1963).

${ }^{110}$ Professor Pangritz has also suggested in private communication that this is the best place to start for a summary of Barth's thought.

111 "Rechenschaft geben" is Barth's primary term for the task of Dogmatics; cf. Barth, Dogmatik, 9-16.

${ }^{112}$ Barth, Einführung, 7. He died six years later (1968).

${ }^{113}$ Barth, Einführung, 24. In this sense, "Dogmatics" is like any other Wissenschaft (Barth, Dogmatik, 9).

${ }_{114}$ Barth, Einführung, 24. Grover translates this as "determined by the impetus [zugewiesen] which it receives from within its own domain," (Evangelical, 16), but "impetus" obscures the active agency by which God provides the means. Cf. the similar phrase in Einführung, 11.

115 Barth, Einführung, 11. 
humanity, a reality established within our created time and space. ${ }^{116}$ Whatever God is in se is revealed in God pro nobis, so that his action towards, amongst, and for humanity provides the framework in which he is to be known. ${ }^{117}$ An immediate corollary is that Biblical God-talk first and foremost makes use of relational terminology. For Barth, that which is revealed is God's "Heiligkeit, aber auch seine Barmherzigkeit als der Vater, Bruder und Freund, aber auch seine Macht und Hoheit als der Eigentümer und Richter des Menschen ... und also ... sich selbst als der Gott des Menschen." "118 Given that God is always a God "with us," his self-revelation has the effect of a "doppel Erschließung," so that humanity itself is revealed for what it is, "als ein Geschöpf, ... als sein Sohn und Knecht." 119 Whatever theology is about, then, it is first and foremost about a relationship of love that exists between God and man, a relationship established, sustained, executed and consummated by God's own acts (Tun) in our own created dimension of history. ${ }^{120}$ Theology must have a "narrative" dimension, and Barth's term for this particular history is the Immanuelgeschichte, the "History/Story of God-is-with-us." This history is ultimately "good news" (Evangelium). 121

It is important to emphasize that this "story" of divine-human relationship reflects a genuine "history" as this term is normally used (inmitten der sonstigen Geschichte). ${ }^{122}$ It is not a narrative grammar that a community tells itself in order to structure its identity, though identity construction may be a positive consequence. ${ }^{123}$ Notice the way Barth describes the witnesses to this history: They are people who "were there" (dabel waren); "contemporary" (zeitgenössisch) with the events of revelation; visual and aural witnesses to things that occurred in their moment in history (Seher seiner zu ihrer Zeit geschehenen

${ }^{116}$ Barth, Einführung, 26-29.

${ }^{117}$ Cf. Barth, Dogmatik, 18.

${ }^{118}$ Barth, Einführung, 27-28. Note also the relational categories used to describe that which Israel's witnesses saw and heard, namely "Jahves väterliches, königliches, gesetzgeberisches und richtendes Handeln in der Geschichte Israels: seine freie, aufbauende aber auch verzehrende Liebe in dessen Erwählung und Berufung, in der gütigen, aber auch strengen und zornigen Führung dieses Volkes, die Gnade seines unermüdiichen Widerspruchs und Widerstondes gegen das Gebaren des unverbesserlichen Gotteskämpfers [i.e. Israel]." This is the content of Israel's witness. Cf. also Dogmatik, 21.

119 Barth, Einführung, 28.

${ }^{120}$ Barth, Einführung, 27. Barth does not talk of "profane" or "holy" history, but he clearly believes that God has acted in time and space in such a way as to alter humanity's stance within time and space.

${ }_{121}^{12}$ See, e.g., Barth, Einführung, 103.

122 Barth, Einführung, 192; 37 ("im Raum und in der Zeit")

${ }^{123} \mathrm{Cf}$. C. Wright on the "motive clause" in Ethics, 23-47. 
Taten). ${ }^{124}$ Whatever it is that God did, it has been preserved by means of a human testimony to it, and because God's acts are past, these witnesses are both original (ursprünglich) and unique (einzigartig). ${ }^{125}$ We live in the present, so our access to God's acts is through the testimony of these witnesses. Revelation is mediated (mittelbar), so that if the church wishes to grasp the revelation itself, it must develop tools of interpretation that do justice to the actual nature (faktische Eigenart) of revelation's human medium. For Barth, a primary characteristic of human communication is its historical, cultural, and psychological particularity. These witnesses fulfilled their task "ein Jeder im Horizont seiner Zeit und ihrer Probleme, seiner eigenen Bildung und Sprache. ${ }^{126}$ It follows that because the theologian is required to ask after their authorial intention, ${ }^{127}$ he or she must utilize the tools of historical criticism. In other words, theology "hat zum Lesen und Verstehen auch dieser Texte alle bekannten und erreichbaren Hilfsmittel, Regeln und Massstäbe der Sprachund Stilkunde, der vergleichenden Welt-, Kultur- und Literaturgeschichte gewissenhaft in Anwendung zu bringen." 128

We thus see that Barth's construal of the "substance" (Gegenstand) of the faith as a divinely established relation between humans and God in created time and space leads to a hermeneutical commitment to the tools of historical criticism as a means for unlocking the message of those who were there when it happened. ${ }^{129}$ The witnesses witness to the establishment, sustenance, and consummation of a divine relation with a human community. Indeed, as we will see, they rendered this witness primarily for the community, such that it would fulfil the implications this relationship entails. As such, the category of community so important for Childs is brought into the heart of the theological discipline. God exists in community, his witnesses witness to that community, and they do this for the sake of the community. Inquiring into the Gegenstand des theologischen Erkennens, then, necessarily entails asking about the nature and purpose of this communal partner of God.

\subsubsection{Community}

Although Barth affirms that God's intention is to commune with humanity as a whole, God has decided to do this through his communion with a particular segment of humanity,

\footnotetext{
124 Barth, Einführung, 34-35.

125 Barth, Einführung, 191-192.

${ }^{126}$ Barth, Einführung, 36.

${ }^{127}$ Barth, Einführung, 192: "Intention der Autoren."

128 Barth, Einführung, 192.

129 See 3.5.4. below and the comments in Bächli, Barth, 330-331.
} 
one which then functions as a medium of God's purposes to the rest of the world. ${ }^{130}$ In addition to this, God does not only commune with a particular community, he does this in a particular manner, such that the "us" and the "with" in the story of "God-is-with-us" need to be further qualified. The community (eine menschliche Stommesgemeinschoft) ${ }^{131}$ is called "Israel" and the nature of the relationship is that it is one of mutual obligation, i.e. it is covenantal (Bund). This covenant constitutes the relationship, ${ }^{132}$ such that Barth can say that the "Gegenstond des theologischen Erkennens" is the "Bundesgeschehen" (event of the covenant). ${ }^{133}$ The Immonuelgeschichte thus finds its further specification as "die Geschichte Gottes und seines Isroels, Isroels und seines Gottes. ${ }^{134}$ We thus find that the theological discipline must not only avail itself of methods that are adequate to the humanity of God's partner and their witness, it must choose methods that do justice to the particularly "Israelite" nature of this piece of humanity. 135

The substance of Christian faith is a divine-Israelite relationship, but it is also a covenantal divine-Israelite relationship. A relationship that is to be genuinely covenantal must be a relationship in which both partners fulfil their covenant obligations, otherwise the relationship ceases to be one of genuine mutuality (my phrase). This contingency introduces a major aporia (my phrase) into Israel's history, for according to Israel's own

${ }^{130}$ This includes Christ as a true human (Einführung, 31).

${ }^{131}$ Barth, Einführung, 29.

132 Barth, Einführung, 29: "Der Bund ist das Zusammensein dieses Gottes und dieses Volkes, in der ihnen gemeinsamen Geschichte."

${ }^{133}$ Barth, Einführung, 220. Bächli sees the influence of Eichrodt, Theologie, here, though Barth was selective and critical (Barth, 324-325). Interestingly, in his section on the Old Testament's witness to the identity of God, the only Old Testament theology Childs references is Eichrodt's. The same applies to his treatment of the issue of faith (Biblical Theology, 359, 601).

${ }^{134}$ Barth, Einführung, 30; Evangelical, 22. See also Bächli, Barth, 130, and McKnight, "Israel," 344.

${ }^{135}$ Barth believed that Israel's very institutions, such as its charismatic leaders, klngs, priests, and prophets, witness to the "covenant" (KD 1/2, 89-103; cited in Băchli, Barth, 330-331). Arguably, this focus on the nation itself ("nicht ein Volk wie ein anderes, sondern ... Tröger der lhm zuteil gewordenen Offenbarung"'; Bächli, Barth, 330; citing Barth, KD 1/2, 95) implies that the on-going history of Israel in modern Judaism, including the founding of the State of Israel in 1949, may continue to witness to God. This is certainly the position of the Synod of the Rhineland-Palatinate Protestant Church, which proclaims the "Einsicht, daß die fortdauernde Ex/stenz des jüdischen Volkes, seine Heimkehr in das Land der Verheißung und auch die Errichtung des Stoates Israel Zeichen der Treue Gottes gegenüber seinem Volk sind." (9). Barth himself struggled with this question, for theologically speaking Israel's history reached its fulfilment in Christ and thus ought to have come to an end. It did not, however, such that the Jewish people remain a mystery for Barth, a "möchtig in die Weitgeschichte hineingestellte Fragezeichen." (Barth, KD III/3, 245; cited in Klăs, "Staat," 315). Kläs' article discusses Barth's thought here in the context of his doctrine of predestination and is very helpful. For a modern systematic attempt to wrestle with this question eschatologically, see Jenson, "Israel." For various interpretations of the New Testament on ethnic Israel, see McKnight, "Israel," 345. 
testimony, it did not fulfil its obligations, thus leaving the relationship as God intended it an unfulfilled reality. This introduces a disconnect between Israel's lived experience and the message of those who would witness to the Bundesgeschehen. Israel's prophets witness to the beginnings of the reality (es hebt in ihrer Geschichte an), but the lived experience of Israel itself was perfectly capable of pointing in the opposite direction. It thus follows that an "objective" analysis of Israel's actual historical experience (even if possible) would not fully reveal the reality God intended to incarnate in that experience. Israel's history "an sich und als solche" is a history of brokenness and thus the prophetic witness to that history is a witness to something that remains to be fulfilled. If God's will is to be realized, Israel's lived experience must ultimately point beyond itself. ${ }^{136}$ This was known and yearned for by its prophetic interpreters who had an eye to the nascent reality itself. As such, the testimonies now found within the Old Testament are fragmentary; they are not "das ganze Wort."

The fullness of the reality, "das ganze Wort," has now arrived in the form (Gestalt) of Jesus. ${ }^{138}$ Jesus fills the vacuum created by Israel's negation of God's covenantal intentions by being the perfect, Israelite, covenant partner. As such, Jesus himself is the Bundesgeschehen. Perhaps one could say that for a moment the story of Immanu-el became the story of Immo-el (God-is-with-him) ? $^{139}$ Be that as it may, by being what Israel should have been, Jesus also fulfils its mission (Sendung) as the Mittler der Völker by creating a space whereby humanity at large can enter into his perfect communion with his Father. ${ }^{140}$ The Immo-el story is by definition an Immanu-el story, with the "us" now referring to all of humanity and the "with" referring to a covenant that has already been vicariously fulfilled.

In a fundamental sense, then, Israel's history is over, having now reached its goal in Christ. Jesus does not extend Israel's history, like a new Moses or Joshua, he realizes it in his own person. ${ }^{141}$ The time of expectation is over, the substance is here. Is there any point in speaking of Israel at all then? Is the category of "community" replaced by that of an individual?

${ }^{136}$ Barth, Einführung, 27: Israel's history "weist über sich selbst hinaus auf eine Vollendung hin, die in ihr zwar Ereignis zu werden drängt, aber noch nicht Ereignis wird."

${ }^{237}$ Barth, Einführung, 32.

${ }^{138}$ The implication of Barth's argument is that Jesus is the Vollgestalt; the witnesses to himwhether Israelite/church history or the prophetic/apostolic witness-are partial Gestalten.

${ }^{139}$ This speculation is my own, not Barth's.

${ }^{140}$ Barth, Einführung, 30-31.

${ }^{141}$ Barth, Einführung, 30. 
Barth's answer is "no," for we live in a time of eschatological tension, the time of the "already" but the "not yet." The substance came and then went again (cf. 10.3, below), so that rather than living in the time of expectation of fulfilment we live in the time of remembering the fulfilment. ${ }^{142}$ As such, if I may paraphrase the apostle Paul, we still only see the substance "in a mirror dimly" (1 Cor 13:12). The substance revealed latterly in Jesus of Nazareth has required the further witness of the apostles, now collected into a New Testament, which looks back to the one who was what the Old Testament was expecting. In this moment of eschatological tension, waiting for the final consummation of God's covenant plans with humanity, we have the partial testimony of a New and an Old Testament, both seeking to elucidate the single reality of God's Bundesgeschehen. We are still waiting for das ganze Wort, and in the meantime we are dependent on the various forms of the witness (Gestalten) to the one Word. The church is thus faced with a dialectic, in which the Vollgestalt of God-in-Christ can only be glimpsed through the mutual illumination of the partial Gestalten of the prophets and the apostles. As Barth puts it,

Der Bund Gottes mit dem Menschen besteht weder bloss in der einen, noch bloss in der anderen, sondern als Geschichte des Tuns Gottes in der Folge und also in der Einheit dieser beiden Gestalten. Und so ergeht auch das Wort von diesem Bund in dieser Einheit: als das in der Geschichte Israels und als das in der Geschichte Jesu Christi gesprochene Wort des einen Gottes. ${ }^{143}$

I have thus far introduced a distinction between Israel's "objective" history-Israel's history within the flow of created time $e^{144}$-and the testimony of prophets who interpret the true meaning of that history. Both categories are important. Israel's objective history is important, for it is the arena within which God acts and its transformation is the goal of his activity. The testimony of its prophets, however, is also important, for God's activity within history remains at best inaugurated but not consummated and thus in need of interpretation. The same applies to Jesus' history, which, until his second advent, will also remain veiled to the world. The apostolic testimony to this history, then, sets it within its necessary interpretive framework, which is God's eschatological goal of divine-human communion. Barth concludes from this that the reality itself-das gonze Wort-can only be adequately grasped by the church when it interprets the testimony to what God has done,

${ }^{142}$ I am going beyond Einführung into KD $1.2 \S 14$ in order to elucidate how I see Barth's logic holding together; my understanding is informed by Henneke, "Miskotte," 10. In Elnführung Barth does not talk of eschatological tension.

${ }^{143}$ Barth, Einführung, 33; also, 16; 28, 36, 38.

${ }^{144}$ On created time see MacDonald, Metaphysics, 2-23. 
for it is only that testimony which has managed to see the logos contained within historical events and words. We cannot go "behind" the testimony to get to the logos itself, for we do not have the immediate relation to it that the prophets and apostles had. Importantly, Barth grounds this decision in the nature of the reality itself and not in a theory of language or textuality. Thus, he can say that

Es gibt ... keine Geschichte [lsraels] an sich und als solche, sondern nur die, die von ihrem Ursprung in Gottes gutem Willen in der Ueberwindung des Gotteskämpfers Israel ihrem Ziel in der Heraufführung des dem göttlichen seinerseits treuen menschlichen Bundespartners, die also der Geschichte Jesu Christi entgegeneilt ... [und] heimlich ... schon in sich enthielte. ${ }^{145}$

This is an ontological statement about the true nature of Israel's history "an sich" and not a decision made in hindsight by the church about how it might want to view that history. ${ }^{146}$ For Barth, "history" is a predicate of revelation and not the other way around. ${ }^{147}$ Any historical-critical account of Israel's history which fails to factor in this dimension of its existence-regardless of whether it can be objectively proved or not-will fail to do justice to the phenomenon under its scrutiny. Given that Barth believes that it is the testimony of the prophetic and apostolic interpretation of that history which brokers this information, we turn now to the question of the form and function of Israel's traditions.

\subsubsection{Form and Function}

God's act in history of establishing, maintaining and consummating a divine-human covenant has produced, indeed "appointed," its witnesses, "vehicles" who mediate this reality to others. The reality itself is primary, and the witness is secondary. This can be seen in Barth's account of the reason for the diversity found within the prophetic and apostolic traditions. So far I have focussed on the human particularity of the witnesses as an explanation of the diversity that confronts the interpreter. Yet for Barth this fact was only incidentally significant (beiläufig). The real reason for diversity is the profundity (Fülle) of the theological reality itself which evoked its manifold witness. ${ }^{148}$

"[Der] Grund dieser Differenzierung ... liegt in der objektiven Vielfältigkeit, der Kontrastheit dessen, was sie bezeugen: in der bis ins Einzelne und Einzelnste unendlichen Bewegtheit der Geschichte des Bundes, des Verkehrs, des Gegensatzes und der Gemeinschaft zwischen Gott und Mensch, von der sie

\footnotetext{
145 Barth, Einführung, 32.

${ }^{146}$ Cf. Webster, "Barth," 83.

${ }^{247}$ The language is Burnett's ("Historical Criticism," 291) though it is not applied to Barth.

${ }^{148}$ Barth, Einführung, 42.
} 
Kunde geben."149

This is why Barth speaks of "Zeugen" in the plural. The one, dynamic (bewegt) reality of God's covenantal plan positively requires the diversity of the forms that we find in the prophetic and apostolic tradition. It is no accident that alongside prophets "in the narrower sense of the term,"150 we also find, for example, prophetic narrators, lawyers, poets and teachers of wisdom. Diachronically, too, there is a diverse tradition-historical process, in which each new generation entered into a dialogue with its predecessors, listening to their answers and somehow incorporating them into their own. ${ }^{151}$

Behind this diversity of form, then, is the continuity of its ultimate content-a major concern of Childs. Again, as for Childs, there is another element of continuity that is derivative of this content: the continuity of function. The content of the witness is the covenant and the function of the witness is to point to that covenant. As with Childs, Barth understood this kerygmatic function to be an actual property of the texts themselves and as such amenable to historical-critical scrutiny. In the context of defending historical-critical approaches to the Bible, Barth says the following, not as a contradiction of that approach, but as an essential element of it:

Es geht um die allgemeine Voraussetzung, dass es neben anderen auch solche Texte gebe, die nach der Intention ihrer Autoren und in ihrer faktischen Eigenart nur als Bezeugung und Verkündigung eines Inmitten der sonstigen Geschichte angeblich oder wirklich stattgefundenen göttlichen Handelns und Redens gelesen und erklärt werden können, an deren Aussage man, will man sie nicht in diesem Charakter würdigen, nur vorbeilesen kann. ... Warum sollte es nicht nach nüchtern historisch-kritischem Urteil auch solche rein kerygmatische und also sachgemäss nur als solche zu interpretierenden Texte geben? Die biblisch-theologische Wissenschaft setzt voraus, dass es solche gebe und dass sie es im Besonderen im Alten und Neuen Testament eben mit solchen Texten zu tun habe: mit Texten, deren Aussage wohl wle die aller anderen Texte objektiv zur Kenntnis genommen, die aber nur entweder mit dem Nein des Unglaubens oder mit dem Ja des Glaubens Ihrem Sinn entsprechend verstanden werden können, die also nur in ständiger Berücksichtigung dieses ihres kerygmatischen Charakters sachgemäß zu erklären sind. ${ }^{152}$

${ }^{149}$ Barth, Einführung, 42.

${ }^{250}$ Barth, Einführung, 36.

${ }^{151}$ Barth, Einführung, 37.

152 Barth, Einführung, 192-193. These statements are similar to an earlier critique of historicism in Biblical exegesis by Martin Kähler in "Biblische Theologie," especially p. 96: "Endlich kann die geschichtliche Forschung ouf diesem Gebiet einer Frage nicht ousweichen, weiche ihr Gegenstond 
I quote Barth at length here in order to emphasize the point that, contrary to many critics, Barth was not "a declared enemy of historical criticism." 153 Barth had no special theological hermeneutic, ${ }^{154}$ rather he was simply interested in approaching the Bible in a manner that was sachgemäß (i.e. der Sache gemäß; "appropriate to its object"). Barth's categories of "Bezeugung" (witness) and "Verkündigung" (proclamation) are text immanent; they are "appropriate" (sachgemäß) to their character, their authorial intention, something that is amenable to "sober" (nüchtern) historical-critical judgement. Barth here is speaking out a direct challenge to the Biblical critics of his day: If you do not honour this essential element of Israel's tradition you will miss the actual meaning of the text (vorbei lesen). ${ }^{155}$

I believe it is Barth's emphasis on the centrality of the kerygmatic function of Israel's traditions that allowed him to not emphasize the concept of "textuality" per se in the sense that the so-called Yale School came to do. ${ }^{156} \mathrm{He}$ was primarily interested in referentiality, regardless of the medium, so that when he comes to talk of Israel's traditions in the form of text-a form which now applies to all of Israel's sacred traditions from the past-their nature as texts is derivative of their primary function of witnessing to the logos of God as contained within Israel's historical experience. The act of writing them down is only one stage of a longer process of continual witnessing. First came the word "viva voce" which was then" zum Gedächtnis der folgenden Generationen wohl auch schriftlich niedergelegt oder niederlegen lassen." 157 The "canonical process" (a phrase Barth did not use ${ }^{158}$ )

selbst als ihr grundlegende entgegenträgt: der Frage, ob sie es bloß mit den Resten einer religiösen Literatur oder mit den Urkunden, Erzeugnissen und Schilderungen einer Geschichte zu tun hat, welche durch Gottes Offenbarung herrschend bestimmt ist. Dieser Frage aber läßt sich nicht mit bloßer Quellenkritik herbeikommen. Je nach ihrer Beantwortung-und diese hat nicht nur die Wahl zwischen nein und ja, sondern auch das ja kann verschieden gestalten-ändern sich nachweislich die maßgebenden Voraussetzungen der höheren Kritik ... , und wandelt sich die Wertgebung für den biblischen Stoff, sofern den einen nur die allgemeinen religös-sittlichen Anschauungen, den anderen auch geschichtliche Tatsachen in ihrer übergeschichtlichen Tragweite zu dem maßgebenden Inhalte zählen."

${ }^{153}$ Burnett, "Historical Criticism," 291; Childs, "Interpreter," 33. Childs recounts that Paul Hanson (some time before 1969) called Barth a "latter-day Fundamentalist" (Childs, "Exegete," 4).

${ }_{154}$ Webster, "Barth," 84.

${ }^{155}$ Webster considers Barth's term "testimony" to be a "genre," and as such "is especially fitting for depicting how a creaturely entity may undertake a function in the divine economy, without resort to concepts which threaten to divinise the text, since ... testimony is not about itself but is a reference beyond itself" (Holy, 23). This is similar to Childs' argument that categorizing the text as "witness" actually guarantees the integrity of the exegetical discipline (Childs, "Interpretation"). See also Webster, "Barth," 82-83.

${ }^{156}$ Cf. McCormack, "Forward." For Childs' response to Lindbeck, see his "Excursus III: The canonical approach and the 'new Yale theology'" in New Testament, 541-546.

${ }^{157}$ Barth, Einführung, 36. Barth is apparently in line with classic Reformed theology here, cf. Heppe, Reformed Dogmatics, 15, cited in Guretzkie, Filioque, 86, fn. 154. 
consisted in a collecting (Samm/ung) of witnesses, and the criterion for the selection was their capacity to witness to theological reality (kraft ihres Inhalts).

\subsubsection{Hermeneutical Implications}

Although I will say more about both Barth's and Childs' concept of God and Scripture (see 4. below), we can already see that there is much that unites them. The common ground that has been revealed so far can be summarized as follows:

- God leaves his dimension of reality, enters ours, and creates something new. For Childs I have spoken of "the radically new," "eschatology;" for Barth I have spoken of the establishment of a divine-human covenantal relation. ${ }^{159}$

- God's entering our reality is proleptic, a foretaste of a fullness yet to come. This reality is good for us, an object of desire.

- God's act establishes a community which witnesses to him in a multitude of forms yet all generated by and oriented to a single referent. "Scripture," as a textual medium of Israel's and Christ's witness, is derivative of this primary function.

- The community thereby established and equipped for its task is fully human and remains so. ${ }^{160}$

- The community is in possession of traditions which function to enable it to witness to God's covenant with it. ${ }^{161}$

- There is no single method that can guarantee objective interpretation, just an adequate stance oriented towards the object. Theology must make use of the best methods available, "dem jeweiligen Stand ihrer Erkenntnis entsprechend." ${ }^{162}$ Childs' categories seem to have remained broadly form critical. According to Bächli, Barth too was interested in this approach, though

The search function in The Digital Karl Barth Library (http://solomon.dkbl.alexanderstreet.com/) did not return any results for this phrase.

${ }^{159}$ Elsewhere Barth interprets the object of faith as explicitly Trinitarian (Dogmatik, 17-18), which I take to be here implicit in his relational definition of Christ as God's partner. Like Childs, Barth characterizes this revelation as a "von uns Menschen schlechterdings neuen, uns unzugänglichen, unbegreiflichen Wesen und Werk" (Dogmatik, 21). And like Barth, Childs emphasizes the centrality of covenant (Biblical Theology, 413-451).

${ }^{160}$ Cf. Barth, Dogmatik, 20.

${ }^{161}$ Cf. Barth, Dogmatik, 23.

162 Barth, Einführung, 9. Cf. fn. 88. 
he was not satisfied with the way it was implemented. ${ }^{163}$ The critical criterion to which they must be submitted ever anew is their capacity to do justice to the nature of the material at hand.

- The diversity of the community's traditions is derivative both of its historical and cultural particularity as well as the profundity of its referent.

We turn now to look at the similar hermeneutical implications that Barth has drawn. As above, I adopt the basic categories employed for Childs in 3.4.:

Theo-referential interpretation (due to function): Webster rightly picks up on the character of "witness/proclamation" as a communicative function when he says: "To interpret a text is to read it for what it is; but the biblical text is a human witness to revelation, and so, if it is to be read as what it is, it must be read with an eye to its function of testifying to revelation. ${ }^{\prime 164}$ Hermeneutically, if we are to be obedient to this function, it would be more appropriate to say that we must read with an eye to its referent, the Bundesgeschehen. The human witness is God's "selbst gewiesen Weg" (self-appointed means) ${ }^{165}$ for making the gospel known. It thus follows that the interpreter, if he or she is to fully grasp what the tradition (latterly textualized) is about, must follow the "pointing finger" of the witness-through and not despite all its particularity-to that which is witnessed to. Barth thus sees a parallel between the stance of the original witnesses vis-àvis their object and the stance of the theologians of today to come to those witnesses: They must both respond to the divine Word. ${ }^{166}$ Respecting diversity in this process is necessary, not only because the medium is human, but also because the referent is profound.

It was Barth's passion for the Biblical referent that had so inspired Childs on his return to the States after having spent four years with him Basel. ${ }^{167}$ In an informal colloquium in 1969 he talks with admiration of Barth's desire and indeed capacity "to go through the text, to the reality," with the consequence that the text itself "becomes a transparency, that the walls that separate the Apostle from the reader are dissolved, and one then begins to confront the reality itself." 168 For Barth, "exegesis can never rest content with talking about the 'Deuteronomic view of covenant', or of 'Paul's concept of faith'. Rather the goal is to

\footnotetext{
${ }^{163}$ Bächli, Barth, 93-94; he references Barth, KD 1/1, 548. Cf. Barth, Dogmatik, 16.

${ }^{264}$ Webster, "Barth," 83 (emphasis mine).

165 Barth, Einführung, 11-12.

${ }^{166}$ Barth, Einführung, 39.

${ }^{267}$ Childs, "Interpreter," 30.

${ }^{168}$ Childs, "Interpreter," 34.
} 
move from the witness to its content-to talk about covenant, and faith, the reality itself."169

To return to our diagrams, the orientation of exegesis looks like this:

\begin{tabular}{|c|c|c|c|c|}
\hline Bundesgeschehen & \multirow[t]{4}{*}{$\leftarrow$} & human witness & \multirow[t]{4}{*}{$\leftarrow$} & Biblical exegete \\
\hline Evangelium & & Evangelist & & evangelischer Theologe \\
\hline Content & & primary witness & & secondary witness \\
\hline election, judgment etc. & & prophets, priests, etc. & & exegete \\
\hline
\end{tabular}

Comparative interpretation (due to content): Function leads to theo-referential reading, but the nature of the referent also has its hermeneutical implications, for if the profundity of the revelation necessitates a diversity of witness, the exegete must seek the unity within the diversity. ${ }^{170}$ Barth's metaphor for this act is Zusammensehen, "seeingtogether," syn-opsis. ${ }^{171}$ An extended quote is again helpful, for he illustrates his desire to maintain the correct balance between the diversity of the tradition and the unity of its theological substance:

Die theologische Erkenntnis, der intellectus fidel [wird]-nicht zu einer egalisierenden, unifizierenden, identifizierenden, wohl aber zu einer sammelnden, alies Einzelne der Peripherie in seiner Besonderheit würdigen, aber von deren Mitte her zu ihrer Mitte hin versammelnden Erkenntnis. ... Sehen ist im theologischen Erkenntnisakt wohl ein aufmerksam genaues Hinsehen jetzt auf diese, jetzt auf jene besondere Gestalt seines Gegenstandes, aber eben als solches auch ein Zusammensehen je dieser Gestalt mit seinen anderen, und dann entscheidend: ein Einsehen des einen Gegenstandes nun eben in dieser Gestalt, bzw. ein Einsehen dieser Gestalt als einer Gestalt des einen Gegenstandes. Um dieses Hinsehen, Zusammensehen, Einsehen, geht es im theologischen Erkennen: wie in der biblischen Exegese, so In den Bestandesnaufnahmen [sic] und Analysen der sog. Kirchen;, Dogmen- und Theologiegeschichte. 1172

The exegete, if he or she wishes to be "object-tive," in the sense of being adequate to the nature of the object, ${ }^{173}$ cannot interpret Israel's various traditions apart from their

${ }^{169}$ Childs, "Exegete," 8. Cf. Webster, "Barth," 83.

${ }^{170}$ Barth, Einführung, 33, 63.

171 Barth, Einführung, 99; the interesting translation is Glover's in Evanglical, 89.

172 Barth, Einführung, 99.

${ }^{173}$ Cf. Torrance, Barth, 179-186: "As it has turned out, does not theology bear a closer comparison with an exact science, such as physcis, which restricts its activities to the limits laid down by the nature of its concrete object, and develops a method in accordance with the nature of its object, bracketing it off from every world-view (either as an a priori condition or as an a posteriori product), and involving an open mind about what may lie beyond the limits of its own area of 
context. This context is certainly their cultural context, but only as a vehicle to their true "ontological" context, which is the reality of the one God who undergirds and permeates the whole. Interpretation in this context is a difficult process which involves a sequential move from "looking at" to "looking together" to "looking in" (in-sight) (Hinsehen to Zusammensehen to Einsehen), such that, at the end of the journey, the exegete discovers that each form is "a form of the one object." 174 This is the challenge of genuine (sachgemäß) exegesis: learning to see anew, learning to see the one object (Gegenstand) within the forms (Gestalten) that mediate it. Barth compares this activity to the task of circling up a high mountain, "which, although it is one and the same mountain, exists and manifests itself in very different shapes."175 ${ }^{170}$ link this to our discussion of Childs above (3.3), we can present the stance of the object-ive ${ }^{176}$ interpreter as follows:

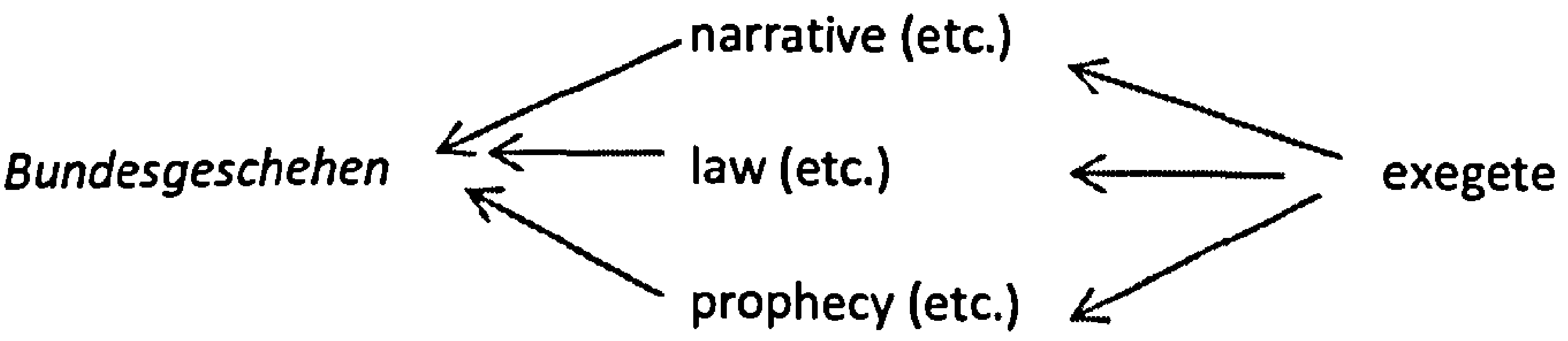

Dialectical interpretation (due to context): The object of theological research is God's covenant with a human community, a community which has been called into being. This community witnesses to God by embodying the relationship whereas its various prophetic and apostolic traditions function to enable the community live up to this relationship. In other words, the community is the object of God's action and the vehicle of God's selfrevelation in the world ${ }^{177}$ and it is within this community that the prophetic/apostolic traditions acquire their function and meaning. For Barth, contemporary theological enquiry is analogous to the work of the prophets and apostles, in that its work is to enable the community (the church) to be true to its being (as existing in the covenant relation between the Son and his Father) by pointing it to this reality through its exegesis of the prophetic/apostolic tradition. The community is the context within which exegesis has its

knowledge?"; cited in Louth, Mystery, 50-51. Torrance goes on to argue that the experimental method has no place in theology and therefore is not like the exact sciences.

${ }^{174}$ Barth, Evangelical, 89.

${ }^{175}$ Barth, Evangelical, 34; Einführung, 43. For an overview of various criticisms and possible answers concerning Barth's (and thus also Childs') commitment to the theological unity of Scripture, see Diem, Dogmatics, 98-100.

${ }^{176}$ For an emphasis on the language of "objectivity" see Barth, Dogmatik, 18.

177 Cf. Barth, Dogmatik, 13. 
function. ${ }^{178}$ As context, the theologian speaks to the church and for the church, but he also speaks with the church in that the work of his predecessors in the faith provides him with a necessary hermeneutical guide to interpretation. ${ }^{179}$ This is not because church tradition is an additional source of revelation alongside the Biblical tradition but because the nature of interpretation as a complex "syn-opsis" of the totality of that tradition in regard to its single subject matter is a complex matter requiring the help of others. ${ }^{180}$ The subjectivity and inherent sinfulness of the interpreter is an additional obstacle which constantly threatens to pervert his secondary witness. Authoritative tradition, then, which has been recognized to effectively preserve the truth ${ }^{181}$ in its full scope, provides the exegete with a "working hypothesis" within which to start his analysis. Barth mentions here in particular the "Dogmen, Symbole und Konfession"182 of the church as being especially valuable. I have termed this exegetical movement in this context as "dialectical," though Barth does not use the term itself, for it seems that he is assuming a hermeneutical circle. One comes to the Biblical traditions through the lens of tradition as a working hypothesis in order to illuminate the subject matter of those traditions, but one may also return to tradition in order to critique it in light of that subject matter.

Interestingly, it seems that our capacity to critique tradition in the light of the reality of God is also applicable to the tradition's decision concerning the outer boundaries of the Biblical canon. ${ }^{183}$ Yet, similar to his attitude to the creeds, one's stance must be one of awe and respect first and then criticism of the decision in light of the reality itself. Hence, the decision to start with the "canon" (whether Catholic or Protestant seems irrelevant here) is an "Arbeitshypothese" (p. 52). Barth is nevertheless confident that if one starts with this assumption, one will find that "it was worth it" (p. 53), that revelation does in fact occur when canonical Scripture is read (for Barth's actualism here, see 4.2. below).

A simple diagram could look like this.

Res $\leftarrow$ primary witness $\leftarrow$ secondary witness (living tradition of thechurch) $\leftarrow$ exegete (potential secondary witness)

${ }^{178}$ Barth, Einführung, 46.

${ }^{179}$ Cf. Barth, Dogmatik, 9: theological criticism takes place "am Maßstab der heiligen Schrift und nach Anleitung [der kirchlichen] Bekenntnisse."

${ }^{180}$ Cf. Barth, Dogmatik, 10-11. This will be further explicated in 4. below.

${ }^{181}$ Barth, Dogmatik, 14.

${ }^{182}$ Barth, Einführung, 54. They are "Dokumente ihres Kampfes."

${ }^{183}$ Childs has similarly spoken of the "search for the Christian Bible." Cf. 4.5.2.1. 
We thus find ourselves in a similar position to the conclusion of $\underline{3.3}$. above. Both Barth and Childs are interested in "substance," and both believe that the road that leads to it is through the historical witness of the traditions of Israel and the church. The traditions are now latterly preserved in textual form and gathered together as a canon of "Scripture," but there is nothing so far that would lead to the conclusion that either Barth or Childs would be interested in final form exegesis. For both, the textuality of Israel's tradition is derivative of a more fundamental concept: the living witness of Israel, Christ, the prophets and the apostles, regardless of the form this witness takes. If paintings or video clips could mediate this reality better than text (and if they had been available at the time), I see no reason why the framework outlined thus far could not just as easily operate with a "canonical Museum" as with "canonical Scripture." The various witnesses would be the various objects arranged in the museum and the "canon," the "rule" governing the authoritative scope of those witnesses, would be the extent and boundary of the collection. Or again, thus far there is no compelling reason not to believe that Israel's and even the Church's contemporary liturgical practice cannot itself be "canonical." In this case, the theologian interested in "substance" would simply visit a cultic service on a regular basis, experientially and intellectually enter into its movement and over time construct an intellectual account of the reality that provides the logic of the liturgy and which comes to expression through its enactment. ${ }^{184} \mathrm{As}$ in 3.4 . above, we are faced again with the question of why, given that both Barth and Childs subscribed to the atomizing theories of the development of the text that reigned in their day and ours, ${ }^{185}$ as well as given their commitment to the on-going function of the community of faith as witness, they did not in fact read the Bible in historical criticism's typical de-constructive manner ${ }^{186}$ (or in Childs' case, why he never remained at that level of analysis), or why liturgical forms are not given equal priority alongside other forms of witness. Does it not do the church a service to disentangle the apparent confusion of the sources in order to present discrete and comprehensible "theologies of $E$ " or "J" or Isaiah ben Amoz over against the theology of his later post-exilic redactors? The diversity of perspective that would ensue would not in itself pose a challenge to either Barth's or Childs' theology, for their God is a mystery that can only be progressively perceived through the

${ }^{184}$ E.g. Marion, "Eucharistic."

${ }^{185}$ Though much less so than ours, as the variety of methodologies has expanded and older diachronic approaches have become less popular.

${ }^{186}$ Childs recalls that Barth "was open to all the historical-critical questions. But then he would keep asking, 'what do you make of this, and what do you mean by that', and he would watch you like a hawk" ("Exegete," 2). 
interplay of a diversity of parts. And given that God is a mystery, is not the church's lived liturgical experience a vital medium of on-going revelation, alongside other forms?

For Childs' part, the move to so-called "final form interpretation" was essentially a move along the same line of inquiry that we have seen him follow so far, and not a sudden switch mid-career to do something else. As a historical critic, he simply pushes the question further: "What is the nature of Israel's tradition? We thus pick up where we left off at the end of 3.4 .

\subsection{The Nature of a Trajectory}

\subsubsection{The Challenge of Diachronic Diversity}

My description of Childs' view of Israelite tradition thus far has been one-sided in that it has emphasized "synchronic" diversity. The point has been made that a diversity of forms (e.g. narrative [saga, myth, historical report], law [casuistic, apodictic], prophecy [cult, literary, oral], liturgy [Northern, Southern], wisdom [practical, speculative, eschatological], etc.) contain, ultimately, a single content, namely the reality of the self-same God. This concept of diversity across forms and traditions needs to be supplemented by the idea of diachronic diversity within a single strand of tradition. Historical-critical scholarship has demonstrated that books which in their current form appear to be a unity, even those ascribed to a single author (e.g. Isaiah 1:1), are in fact the product of a long history of growth in which, for example, the originally spoken oracles of a historical prophet or the originally enacted patterns of a cultic liturgy (e.g. the Psalms) have been collected, shaped, and expanded into new compositions in which the semantic content of older stages has been decisively altered (in principle this can also apply on the purely oral and liturgical level; cf. the sections on form and traditio-historical analysis in Childs' Exodus commentary).

Whereas the assertion of diversity per se does not necessarily pose a problem to traditional Jewish and Christian exegesis, for the richness of the tradition has often been seen as an indicator for the richness of its subject matter (cf. Heb 1:2), the claim that the form within which the tradition itself has been received does not correspond to its original composition (e.g. much Mosaic law does not stem from Moses; Daniel's prophecies are in fact made in retrospect and even then, associated with events that failed to deliver what was promised) ${ }^{187}$ has generated much resistance on the part of the church and synagogue.

\footnotetext{
${ }^{187}$ See the relevant sections in Childs, Introduction.
} 
Childs, as we have seen, operates within this tension. On the one hand he wishes to respect critical analysis of the Bible, for his faith demands that it be illuminated through the historical testimony of the prophets and apostles. On the other hand, his commitment to do this arises from his position within a church whose foundations have often been shaken by the results of such critical analysis. Witness Childs' admiration for the work of Gunkel; ${ }^{188}$ yet at the same time he can say that every "Psalm we exegete ruins it for the church." ${ }^{189}$ How does Childs provide his "theological response"190 to the critics he admires so much?

As in our discussion of the nature of the unity of Israelite tradition per se in $\underline{3.3 .}$ above, so here we see that the issue of "anterior reality" is central to Childs' construal of the nature of Israelite tradition-historical development. In other words, an adequate assessment of the diachronic layering that one finds within one particular tradition depends on one's grasp of the reality undergirding that process. As we saw in $\underline{3.2}$, so here, the classic critical responses each in their own way assume a particular theory of unity in growth, such that this question itself is not alien to the enterprise. Some, for example, have assumed a progressive evolution in religious sophistication arriving at the more spiritual religion of Jesus, himself a precursor to more Enlightened scientific rationality; others see the class struggle of the economically disenfranchised or the development of a heightened sense of spiritual interiority as the driving forces in the development of the tradition. Depending on one's value system, there is also space for retrograde development within the tradition, whereby the initial bright insights by certain profound individuals were later sullied by men driven by more prosaic instincts. Wellhausen, for example, identified the former with Israel's prophets and the latter with their legalistic redactors. Whatever one's theory of history may be, some framework needs to be present as a working hypothesis in order to interpret and evaluate the diversity within the trajectory of Israel's faith. As in $\underline{3.2}$. above, Childs affirms the findings of critical scholarship. His attempt to interpret the framework within which this development took place, however, is confessional, in that he attempts to take Israel's own perspective seriously as a true account of its historical experience.

${ }^{188}$ Cf. Driver, Childs, 105-136 for the details.

${ }^{189}$ Childs, "Interpreter," 35; cf. also Interpretation, 508-511, here with explicit reference to Gunkel.

${ }^{190}$ Childs, Introduction, 511. 


\subsubsection{Israel's Perspective: Economy and Ontology}

According to Childs, Israel's tradition is aware that it has undergone a development, that it has a history. This is evident from its historical narratives, both in that they recount a "history of religion" and in that this history was "canonized," l.e. accepted as a vehicle of revelation, a witness to the reality of God himself (cf. 3.3.1.). History, for Israel, is part of God's "economy of salvation," the plane on which he makes himself known. It has a "pedagogical" function (my phrase), in that through history Israel is to grow in the knowledge of its God, who himself forever remains the same. As with Israel's traditions per se (3.3.), so with their historical development, we see that a concern with "external reality" is central to their witness. If history is a history of growth in the knowledge of God, history involves both change and continuity: a change in the adequacy of our grasp of a referent that itself remains the same. This principle is paradigmatically present in Childs' exposition of Exod 6:2; as with his analysis of Deut 31 (3.3.), the principle can be extended to Israel's entire tradition-historical development:

To the patriarchs God revealed his peculiar relationship by means of different names. He was 'Eternal God' (El Olom), or 'God Almighty' (El Shoddai). Each new dispensation within God's economy received a different revelation of his name. However, the name of God revealed to Moses, Yahweh, made clear the continuity of the divine revelation between the past and the future. According to Ex. 6.2, God said to Moses: 'I am YHWH. I appeared to Abraham, to Isaac and to Jacob as God Almighty (EI Shaddai), but by my name YHWH I did not make myself known to them.' ${ }^{191}$

In other words, Israel perceived its history as a history of the "progressive revelation" of the reality of God. ${ }^{192}$ In his Exodus commentary, Childs emphasizes Israel's understanding of the primary force at work in this process, which is neither time itself nor an immanent capacity within human consciousness, but God, who enters into Israel's time and space in acts of redemption that point beyond themselves to their author (cf. 3.5.):

[T] he significance of the name Yahweh was carefully explained to Moses: 'Ehyeh asher ehyeh' ('I am who I am', or 'I will be who I will be'). God's being is not a static entity, but God makes known to Moses how he would learn of his true nature through his acts of redemption. Israel would understand who he was by what he did on her behalf. ${ }^{193}$

${ }^{191}$ Childs, Old Testament, 38-39.

${ }^{192}$ By "progressive revelation" 1 simply mean ongoing revelation that leads to growth in knowledge. I am not alluding to a particular theory of progressive revelation.

${ }^{193}$ Childs, Old Testoment, 39. Cf. Barth's approach to dogmatics in 3.5 . 
From his interpretation of the narrative, Childs draws a theological, indeed an ontological, conclusion:

[T] he whole focus [of Exod 6:2] falls on God's revealing of himself in a majestic act of self-identification: I am Yahweh. Although there is a history of revelation which includes a past and a future, the theocentric focus on God's initiative in making himself known tends to encompass all the various times into the one great act of disclosure. To know God's name is to know his purpose for all mankind from the beginning to the end. ${ }^{194}$

This is Childs' interpretation of Israel's own perspective, his attempt to get inside their world view in order to orient his own. ${ }^{195}$ The conclusion is that, according to Israel itself, revelation involves both a horizontal and a vertical dimension. Horizontally, God reveals himself over time and through the events that constitute time; vertically, the active subject remains the same, such that the horizontal history of revelation functions to point to the eternal-even if "dynamic" 196 -object of revelation itself. To use classic Christian terminology, Israel testifies that knowledge of God involves a move from economy to ontology (cf. 3.5.1.)..$^{197}$

So much for Israel's emic perspective. We turn now to Childs' historical-critical thesis concerning the nature of Israel's tradition-historical development.

\subsubsection{Childs' Perspective: Dialectic and Growth}

\subsubsection{Function, Content, and Context}

Discussion of tradition history (Überlieferungsgeschichte) brings us into a realm where issues of "text," "Scripture," and "final form" finally come into view, for it is the case that at some stage in Israel's history its traditions were "textualized," collected, and edited into scriptural corpora. Yet, as stated at the end of my section outlining the "building blocks" of Childs' canonical thesis (3.4.), the entity of the "final form of the text" cannot be appreciated without assessing first the nature of Israelite tradition per se. "Canonical Scripture" is not a self-evident phenomenon. As we have seen, for Childs, any account of

${ }^{194}$ Childs, Exodus, 119 (emphasis mine).

${ }^{195}$ This is not to deny the circularity of interpretation, of course; a decision needs to be made nevertheless.

${ }^{196}$ Childs submits to the classic doctrine of the ontological or immanent Trinity, which holds that God's being "is in loving;" cf. Biblical Theology, 82; McGlasson, Invitation, 192-193. Cf. also Barth, Dogmatik, 34: "Gott selber ist... geschichtlich."

${ }^{197} 1$ should add here that after this move has been made, one can also think in the opposite direction. This is the direction of movement found in Barth's Dogmatik im Umriss; e.g. "Dieser Ratschluß Gottes wurde in der Zeit ausgeführt ..." (35). 
the nature of the canonical text must factor in its function within the community of faith. This basic stance allows for a fair bit of nuance in Childs' actual exegesis of the final form of the text, for it means he is not allowed to treat it as a "disembodied" book.

For a start, Childs affirms that each link in the tradition-historical chain, whether a cultic liturgy (e.g. the so-called "Zion tradition"), a historical prophet (e.g. Isaiah), a collector of oracles (e.g. Baruch), or an anonymous author of glosses, possesses the same characteristics outlined in 3.3. Each tradent, in his own way, was interested in witnessing to a divine reality in such a manner that this reality would impinge upon later generations of the faithful. From the outset, then, we see that there is nothing intrinsic to Childs' canonical thesis that must automatically flatten the diachronic dimension of the text. With the model outlined so far, it is perfectly possible to imagine that the various strands of Israelite tradition are like a string of pearls in which each tradent-now latterly and only incidentally connected by its current literary form - renders his or her witness immediately and autonomously to God without any reference to the context in which this is embedded. This is not too far off some representations of Israel's tradition history, in which editorial glosses in prophetic oracles are seen to be the idiosyncratic intrusions of theologians with an entirely different agenda to the text they are editing, or in which editors of the Pentateuch's source documents rather randomly stuck traditions together which were never really understood to have much to do with each other. In this case, theo-referential exegesis would have the task of isolating these traditions in order to identify a message that was intended and understood by the kerygmatic editors to be read in isolation from the literary context of the text they were editing. Childs is certainly open to elements of randomness like this. He considers the "appendix" to the books of Samuel to be only tenuously connected to what went before, for example, and is thus committed to factoring this into his interpretation. ${ }^{198}$ We will see something of the nuance in Childs' exegesis of the final form of the text below. For now, I wish to focus on the primary nature of editorial expansion.

As a rule, Childs considers the kind of low level intentionality associated with the "string of pearls" approach (this is my metaphor) to be unlikely, if only for the reason that

${ }^{198}$ Childs, "Response." Nevertheless, the subject matter of God remains the same. See Childs' handling of the "diversity" within ancient Israel between the Law and the Prophets, yet their common subject matter in God in Isaiah, 18. I briefly touch on the subject of the Samuel appendix in relation to the rest of the book as well as Ps 24 below (9.1.3.). 
he does not believe that form and function can be separated. ${ }^{199}$ An editor edits a text because he wishes to make a new statement with an old text that is now transformed by his editorial activity. It belongs to the logic of the process itself that a new entity is produced. For example, Psalm 2 as linked to Psalm 1 and consciously placed at the head of the Psalter is a different kind of entity to Psalm 2 as an element in a coronation ceremony, even if the words remain the same. Judgements that the editorial process was random need to be justified rather than assumed.

The transformatory effect of editorial activity, however, poses an interesting question to a hermeneutical approach that wishes to respect the historical intentionality of the entire string of prophetic "authors" involved in the development of what came to be our current literary form. If it is the case that editorial activity creates a new entity, how does Childs relate the different layers of tradition? As indicated in 2.1. Childs holds that the "literature has no life apart from Israel's life, institutions, and offices." 200 At no point have we said that the mere "date" of a composition accords it superiority over that which is old, such that it can be simply superseded. Yhwh is not a better revelation than El Elyon because it is chronologically later. ${ }^{201}$ In relation to Psalm 2, does this mean that Childs must reckon with the discrete witness of what is in fact two different entities, Ps 2 as liturgy and Ps 2 as the "gate of the Psalter," for the meaning of the psalm in each case is different? The answer turns on the nature of Israel's "institutions, and offices."

As we have seen, Israel saw itself as living in a history of encounter with God, ${ }^{202}$ an encounter moreover that was mediated through a succession of "men charged with the task of leadership and instruction," ${ }^{203}$ men who were "agents of God's rule." ${ }^{204}$ The key concept here is that these men were agents of something else-Childs also uses the term "vehicle"-and it is this something else that mattered most to the agents themselves, to those who received the message, and to the God who inspired their activity. Neither Moses, for example, nor those who listened to him and treasured his words, were interested in Moses' limited perspective on the nature of the reality he was confronted with, but in the

199 Cf. Childs, Biblical Theology, 72; "Midrash," 51.

${ }^{200}$ Childs, "Retrospective," 375.

${ }^{201}$ This still applies, even if we follow Seitz's interpretation that the revelation of the name in Exod 6 consists in filling an old name with new content, i.e. the word "Yhwh" was already known but the Exodus event fills it with new content. Cf. Seitz, Word, 229-250.

${ }^{202}$ Childs, "Canonical Shape," 47.

${ }^{203}$ Zimmerli, Old Testament, 81.

204 Childs, Old Testament, 108. 
reality itself. There is an intrinsic act of subordination in the activity of genuine witnessing: Moses points away from himself, he is nothing more than the servant of the reality. This reality was the content of his witness and it was the object (Barth said Gegenstand; 3.5.1.) of the tradents' theological interpretation. As the content of the tradition, it was also the criterion for their interpretation of the tradition, the "rule" (regula) or "litmus test" (my phrase) for any adequate understanding of their message. Moses came and went, but the reality he testified to remained the same, even as later generations grew in their knowledge of it.

This very particular understanding of the religious office as a vehicle for an unchanging reality that progressively makes itself more profoundly known through a history of revelation leads to the peculiar dialectic that constitutes Israel's tradition history. On the one hand, these men of God were authoritative messengers of God, such that Israel sought to subordinate itself to their testimony as binding up its construal of its life with God. Childs claims to be speaking for the Israelite perspective when he says that it "is impossible to have free-floating literary constructs which are totally without historical rootage because authority ultimately rests on divine communication through these prophetic messengers." 205 "From the coercion of the biblical text, Israel learned how to correctly understand [its] new ... situation. ${ }^{\prime 206}$ On the other hand, the God that they witnessed to continued to act in Israel's history, revealing himself in ever new ways (3.6.2.). Predicated upon the assumption of the ontological unity of the referent of the original witnesses and the source of their experience of further revelation, the tradents of the authoritative traditions not only learned how to "correctly understand" their new situation through the prophetic (and later apostolic) tradition, they also learned how to correctly understand the tradition itself. To return to our paradigm from Exod 6: Having experienced the fullness of El Elyon in the Exodus as the one who is also Yhwh, El Elyon could never be the same for Israel again. Now this old name was now understood in a more profound sense, in a sense that was more "accurate," "truer" to its original referent, even though Abraham himself may not have grasped it. Abraham and his descendants authoritatively mediated the reality of God, such that later generations were constrained to understand this God through their witness, but the limited horizon of Abraham and his immediate descendants did notindeed could not, given the nature of their activity-limit the potential meaning their

${ }^{205}$ Childs, "Retrospective," 362.

${ }^{206}$ Childs, Isaiah, 22. 
tradition would acquire in the light of the history of revelation. On the one hand, Yhwh must be understood as the God of the Patriarchs-there is no redemption without promise and a goal-yet El Elyon must be understood in the light of Yhwh: The goal of the promise is to be reached though the "furnace" of Egypt. For the tradents of the Patriarchal tradition, Abraham's own subjective horizon was irrelevant. It is not important to understand what he thought or how he interpreted his personal theophanies. What mattered was the "theos" himself, who necessarily extends - though does not abrogate-Abraham's limited horizon.

For Childs, this dialectic took place at the level of the redaction of the tradition. New situations were understood in light of the inherited tradition, and these new situations led to a deeper understanding of the content of those traditions. Significantly, given the hermeneutical function of editorial activity, this deeper understanding was factored into the shape of the original prophecy, thus enabling it to more adequately fulfil its true theocentric function of brokering the reality of $\operatorname{God}^{207}$ We can present this dialectic using two diagrams. On the one hand, the tradents of the tradition were committed to the authority of that tradition, and so interpreted fresh revelation of the same subject matter (res) through that lens:

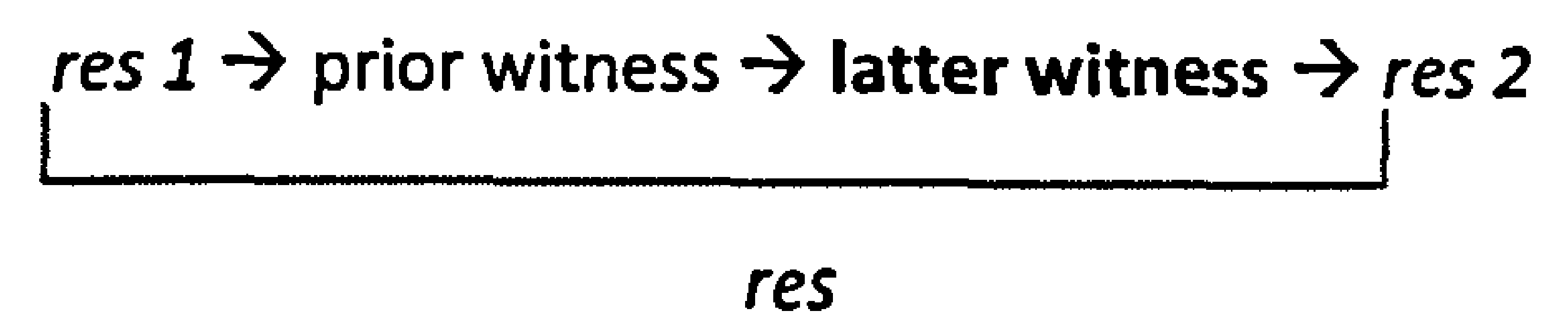

Childs uses the language of "force" or "coercion," to which the latter tradents responded (cf. 4.2.). On the other hand, fresh revelation coerced interpretation of the old, so that "when the interpreter moves from the reality of God manifested in action back to the [prior tradition] ${ }^{208}$ for further illumination of the divine plan, he or she is constrained to listen for a new song - a song that breaks forth from the same ancient sacred [traditions] ${ }^{209}$ of Israel. ${ }^{210}$ Childs can say that in light of fresh revelation, the earlier tradition-whether cultic, oral, or textual-was "infused ... with the full ontological reality of God." It

${ }^{207}$ Childs' Isaiah commentary is replete with this kind of analysis. See, for example, his treatment of Isaiah 1:2-31 (22).

${ }^{208}$ In this context Childs is talking about the final form of Scripture, but it applies to every level of its evolution.

209 Original: "texts"

${ }^{210}$ Childs, "Nature," 124. 
"resonates with a fresh voice." 211 Coercion is exerted on the interpreter not just from the direction of the tradition but from the direction of divine revelation itself:

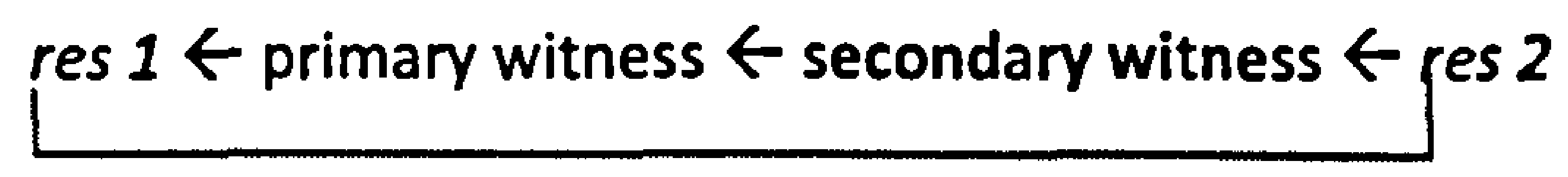

res

Of paramount importance in this dialectical process, both for Israel-according to its historical intentionality - and for Childs, as a confessional interpreter wishing to submit to the truth-telling stance of the tradition, is the unity of the res, the subject matter. Throughout the process of tradition-historical growth, Childs is adamant that whatever "transformation" there has been in meaning, it is a transformation in the direction of a deeper grasp of the one referent. He talks of editors seeking to "critically enrich earlier parts of the corpus ... as a means of clarifying and deepening a grasp of the substance to which scripture [or the tradition at an earlier stage] as a whole points. ${ }^{\text {212 }}$ His phraseology is not always so clear, however, which can lead to the impression that he is not interested in extra-textual referentiality but only in what the latest editors thought. For example, Childs can say

Recent redactional criticism has shown that often a biblical text has been subsequently interpreted within a literary framework which has the effect of reinterpreting the text in a manner different from its original meaning. In other words, a later redactor has interpreted the text according to a different referent, that is, according to another understanding of its reality. One thinks, for example, of the later redactional framework constituting chapters 6-9 of Isaiah which now interprets the term Immanuel in a highly messianic fashion, which was not clear in the earliest level of the tradition (cf. Isa. 7.14). ... The task of critical exegesis involves a careful analysis of the relation of both levels of the text's witness, but also an analysis of the effect of the redacted text on its understanding of the referent. ${ }^{213}$

Childs' talk here of "a different referent" may lead to the impression that he thinks that the tradents were talking about different things. The meaning of the word "referent" in this context, however, is constrained by his use of the word "reality." Childs insists that the reality remains the same, despite the change in "referent," so that here there term "referent" refers to a different dimension of the one reality.

211 Childs, "Nature," 124.

212 Childs, Isaiah, 102.

${ }^{213}$ Childs, Biblical Theology, 84. 
For example, the reality may be the promise of the redemption of Zion. An older layer of the tradition may have referred to Zion as a historical referent; a later "re-interpretation" may have placed this historical referent into an eschatological context, affirming the salvation of Zion, yet Zion only "as far as it was truly Zion," which was a "faith reality, distinct from a merely political entity. ${ }^{214}$ Childs insists that this theological interpretation of Zion was already implicit within the older concept, which emphasized the historical nature of Zion as a concrete socio-political reality. ${ }^{215}$ In the case of Isaiah 1:21-26, which contains the illustration I have just made, exegesis must take into account both levels of the tradition, but, given the "ontological unity" of the reality, the hermeneutical activity of the editors has the effect of brokering that one reality in its more profound dimension. In other words, the editors are fulfilling the older tradition's theocentric function; they are not perverting or destroying it.

Another example is the manner in which historical narratives are "broken" (my phrase) by later editors: "[B]oth past and present events are often restructured by an eschatological perspective which views an occurrence as a manifestation of God's righteous rule. ${ }^{\text {216 }}$ Chronology is often inverted in favour of a different "history," the history of God in se as this is manifested in various ways on the temporal plane of God pro nobis. Thus, in relation to the complex fusion of temporal perspectives in Isaiah 51:9-16 (creation, Exodus, redemption from Babylon), Childs can say,

[T] salvation. Because the content of God's redemptive intervention, that is, its substance, is the same, the three events have been fused together as a unified ontological witness to the one purpose of God concerning his people. ${ }^{217}$

The difficulty this form of the rendering of the witness causes for modern interpreters is due to the fact that the tradents of Israel's tradition had a different grasp of the nature of "truth." For a modern critic, an inverted chronology is simply "wrong," measured according to a standard of truth taken from outside the tradition. Within the tradition itselfaccording to its emic perspective - it is only by such inversion that one can catch a glimpse of the truth, the actual reality that is present in events otherwise disassociated by created

${ }^{214}$ Childs, Isaiah, 22.

215 Childs, Isaiah, 22.

${ }^{216}$ Childs, Biblical Theology, 101. For an illustration in relation to the books of Samuel, see 9.1.3. below.

${ }^{217}$ Childs, Isaiah, 403-404. 
time. The divine economy may be temporal-Barth has said that God's very being is "geschichtlich"218 - but its sequence does not always correlate smoothly with world history. In other words, what is at stake in a canonical exegesis, an exegesis that aims to read the effect of the tradition and the various ideas behind it, is dogmatic and not historical-critical. It rests upon a desire to respect and submit to Israel's own definition of what constitutes "truth." 219

This differentiation between a divine and a "profane" history introduces the concept of Sachkritik, "criticism according to content," which Childs claims is constitutive of the canonical process. We should note Childs' fuller formulation of the peculiar hermeneutical dialectic that constitutes Israel's inner-Biblical reception history (Rezeptionsgeschichte): The editors were concerned "for the truth of the witness, which is measured by its faithfulness to its theological context rather than by modern criteria of testing the accuracy of a biblical text according to the original sequence of events." ${ }^{220}$ Propelled forward through the dialectic of interpretation in the light of further divine revelation, Israel grew in its understanding of the reality of this God. This reality itself provided the criterion for interpretation of the witness itself, a "rule of faith" that guided proper exegesis. This was necessarily so because of the basic assumption of the truthfulness of the tradition. As such, Israel's interpretation of prior tradition consisted in a "ruled reading," a "theo-critical" reading (my phrase) that "was not simply reflective of private, idiosyncratic agenda, but which arose from actual communal practice and belief,"221 l.e. within the context of the community of faith. This theo-critical reading resulted in a theo-critical shaping of the tradition itself:

Israel shaped its literature confessionally to bear testimony to what it received as containing an established range of truthful witness. At the same time, the biblical editors subordinated other voices, either by placing them within a negative setting, or omitting them altogether as deleterious to Israel's faith. ${ }^{222}$

${ }^{218}$ Cf. Barth, Dogmatik, 34.

${ }^{219}$ Note that Childs says that the canonical shape of the text has a hermeneutical effect on its reader, but "especially to the extent in which he or she identifies religiously with the faith community of the original tradents" (Biblical Theology, 71; emphasis mine).

${ }^{220}$ Childs, Isaiah, 102 (emphasis mine).

${ }^{221}$ Childs, "Brueggemann," 230.

${ }^{222}$ Childs, "Brueggemann," 230. 
As Sachkritik, later tradition does not just represent a fuller presentation of the reality of God, it is a critical, theological judgement concerning the manner by which earlier tradition ought to be interpreted. ${ }^{223}$

I mentioned above (2.1.) that Childs subscribed to a definition of "canon" that was influenced by Hägglund's article on the meaning that the term had for the early church. The

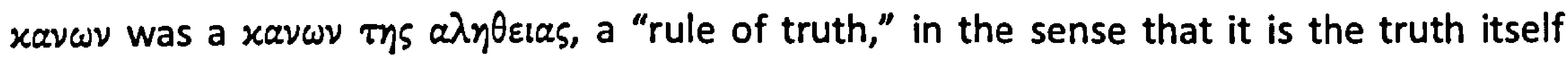
which functions as the criterion, the "canon," for whatever human statements are to be deemed true. The truth is the content of the authoritative tradition, the Gegenstand of its witness, and tradition is "canonical" in the derivative sense that it mediates this truth. We now see that Childs understands this hermeneutical principle to be operative within Israel's tradition history. To return to our paradigm from Exodus 6, it is the reality of redemption itself, experienced in the Exodus, the return from Babylon, in the answer to the prayers of the saints and in the resurrection of Christ that provides the names El Elyon, Yhwh, Jesus Christ, the LORD, with their true content, even as that reality is always seen partially through the witness of these various experiences. Each witness is theocentric-and that according to its own intention-such that the hermeneutical activity of the tradents of the tradition, itself a theocentric process and thus in continuity with the original prophetic intention-consists in an act of illuminating the reality itself. This is the meaning of the phrase "canonical process." It does not primarily reference the evolution of a corpus of texts, it refers to an ongoing attempt to witness to a divine reality in as adequate a manner as possible.

I am straining here to characterize Childs' understanding of the tradition-historical process as a thesis that goes through the classic historical-critical construals and not despite them by focusing on the overwhelmingly theocentric function of the tradition and the "alethiological" implications this has for Israel's own grasp of reality. Pace Brueggemann, Childs is not interested in nullifying "the entire modern period of

${ }^{223}$ This is the heart of Childs' critique of Brueggemann's "false dialectic," which, by playing canonical traditions off one another (core testimony vs. counter testimony), ignores the judgement the tradition itself has already rendered concerning the manner by which the traditions must be appropriated. This is illustrated in relation to Brueggemann's interpretation of Qohelet. Cf. Childs, "Brueggemann." Brueggemann's response avoids Childs' claim by referring to the limitations of human epistemology: Childs is subjective and so has no right to tell us "what the Bible says." Not only is a response to Childs' concrete proposals missing, the issue of human epistemology necessarily requires thinking about the function of the Holy Spirit, something Brueggemann does not go into. Cf. 4.2. below. 
interpretation and the historical-critical project as a failed attempt." ${ }^{224}$ In a certain sense, all attempts at Biblical interpretation have "failed" to do justice to its subject matter, hence the need for Childs to engage in the ongoing process of hermeneutical reflection in the modern period. But the main point here is that Childs accepts the challenge critical method poses to traditional Christian and Jewish exegesis and seeks to take that challenge seriously. Childs' claim that the tradition is kerygmatic in nature is a historical-critical-perhaps even form-critical-statement and not an attempt to ignore criticism. The statement that the canonical process is dialectical is a historical-critical statement that reckons with the growth of the tradition and looks more closely at its nature. Childs' qualms with historical criticism only start when a supposedly neutral method embodies dogmatic presuppositions about the nature of truth from the outset (Childs spoke of "historicism," for example) and it is there, at the level of dogma, that he draws the line. Focus on the final form is not an arbitrary decision to stick with the form the church and synagogue has always profited from most; it is his own dogmatic commitment to a theory of truth as this is brokered by Israel itself and not as our modern categories dictate this. Given that it is ultimately the issue of "truth" that is at stake, one can perhaps see why Childs fought so insistently for his thesis throughout his career, despite intense opposition. Canonical interpretation is not a method-Childs' always strove to be descriptive and not prescriptive in his analysis of Israel's traditions-it is a stance vis-à-vis Israel's witness, which is a stance vis-à-vis the reality of God.

We are not yet finished with Childs' canonical thesis. In order to help us understand the vision he tried to communicate however, it will be helpful to quote a New Testament scholar whose analysis of the "alethiology" of the authors of the New Testament and the basic hermeneutical conclusions he drew from that are fundamentally the same as the approach we have been outlining so far. ${ }^{225}$ The following is a catena of quotes $I$ have garnered from Paul Minear's The Bible and the Historian:

The category of history does not appear in these texts and it becomes quite misleading when the texts are forced into conformity to the modern category. By contrast the category of the heavens, so absent from modern historical discussion, is assumed to be the ultimate reality. Historians are primarily concerned with placing all events within earthly time and the temporal process; biblical writers are essentially concerned with the eternal purposes and time-transcending activity of the creator of the heavens and the

\footnotetext{
224 Brueggemann, "ABC," 426.

${ }^{225}$ Childs" "blurb" on the back of the book is glowing.
} 
earth. ${ }^{226}$... The conception of endless, unilinear, one-way time must be modified if we are to accept the apostolic testimony. ... If the end has actually been inaugurated, then historical time is capable of embracing simultaneously both the old age and the new. No methodology whose presuppositions on time are limited to the old age will be adequate to cope with the historicity of the new age or with the temporal collision between the two times. ${ }^{227}$... How should we speak of an ultimate reality that conjoins the divine and the human? [The author of Revelation employs a literary device, that is] by telling one story in such a way as to embrace many stories. But this is more than a literary device. It is a way of perceiving reality. He saw each story as fully historical, and yet as fully eschatological. ... He perceived each separate place and time in terms of its content, that corporate historical action that "filled it." He discerned behind this action a transhistorical model that linked each story to the others. ${ }^{228}$... This is a comprehensive rather than a disjunctive mode of seeing and thinking. It apprehends events in terms of their inner structure as responses to God's action. ... Behind this mode of viewing was a distinctive ontological stance, to which we should give more attention than we usually do. ${ }^{229}$... Early Christian apocalyptic has been rightly called "the mother of Christian theology" (E. Käsemann). It should also be called the mother of Christion ontology, because it viewed historical decisions and events in the light of an ultimate concern for their ultimate context in the purpose and action of God. ${ }^{230}$

If the "canonical quality of the tradition" has more to do with the ontological reality of God than with a closed corpus of texts, then, in the light of these statements, we can see why the later form of the tradition is theologically so important. If there is one divine reality ("heaven," "the eternal purposes and time-transcending activity of the creator"), and if this reality is present as the true "content" of disparate historical events, such that it "fills" these events, and if the tradition-historical process consisted in witnessing to this one reality-i.e. it was "canonical" - in such a manner that it sought to see the "one story" within the many "stories" (akin to Barth's Zusammensehen; the circling of the mountain by the intellectus fidei; cf. 3.5.4.), and if this process was theo-critical (Sachkritik), such that it factored this fuller vision into the hermeneutical shape of the tradition itself, one can see the force of Childs' claim that the true object of an exegesis that wishes to submit to the function of the tradition is the fuller form that that tradition came to take. Final form interpretation is derivative of this one principle: It is the end process of a dialectic between form and substance that was oriented to giving full expression to substance through the

\footnotetext{
226 Minear, Bible, 23 (emphasis mine).

227 Minear, Bible, 55 (emphasis mine).

228 Minear, Bible, 66 (emphasis mine).

229 Minear, Bible, 63 (emphasis mine).

${ }^{230}$ Minear, Bible, 70 (emphasis mine).
} 
form. And, as in every stage of our analysis so far, it is necessary to emphasize that Childs understands this description to be a historical description of the nature of Israel's tradition itself. Thus:

The decision [to read the final form] is not derived from a higher evaluation of the last level of redaction per se, but rather in the entire critical assessment provided by the final form of the text as to what is normative for Israel's faith involving all the different levels. It is constitutive of canonical shaping to offer this theological Sachkritik on the tradition in its entirety. ${ }^{231}$

We may try to illustrate the nature of the trajectory as follows, in which the dashed arrows refer to the direction of the witness's focus and the bold arrows the source of coercion, the "force" involved in the process:

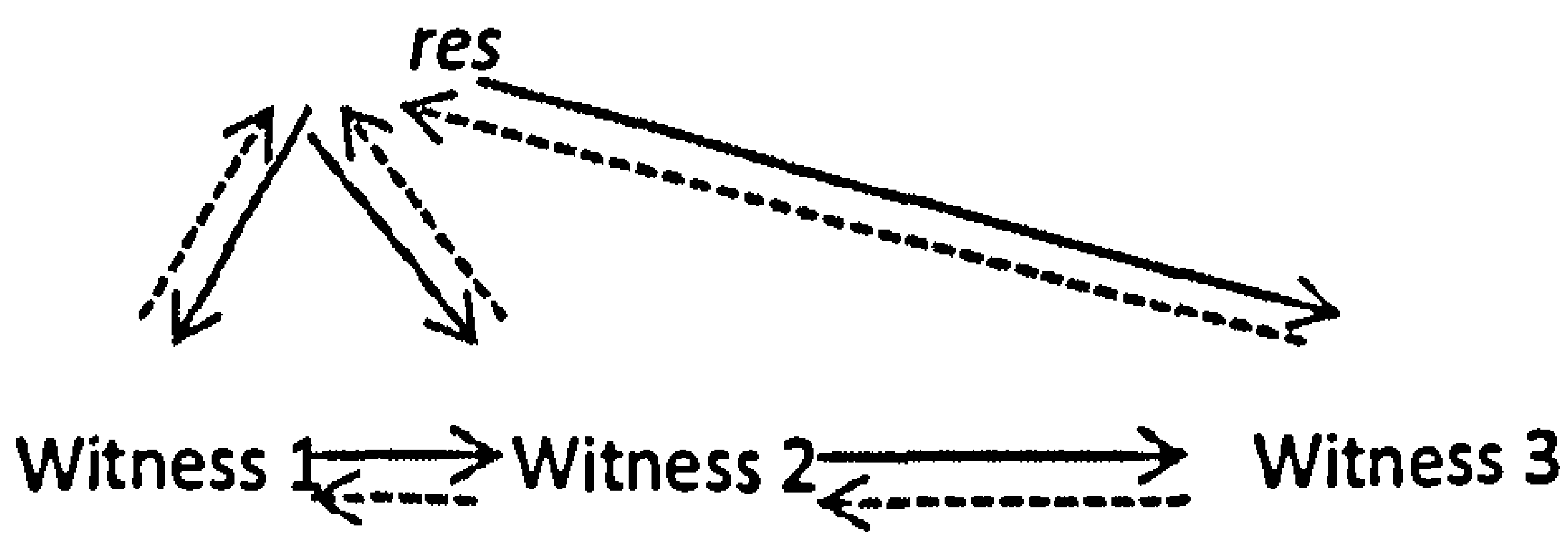

For the sake of explication, we can interpret this process in light of our paradigm case in Exod 6 (3.6.2.). This is a heuristic exercise; it is not to say that Childs believes in the total historicity of the Exodus narrative. We will turn to the question of the relation between emic and etic history below. For now, we are interested in the basic principle undergirding the "canonical process." We can apply the diagram to Exod 6 as follows: God revealed himself to Abraham as El Elyon; Abraham recounts this to his children. Abraham and the tradition springing from him is Witness 1 . Witness 2 is Moses, who receives the fresh revelation of God at Sinai, a revelation of the one who is identical to the one known by Abraham. The revelation himself (i.e. God as the res) points Moses back to Witness 1, yet in light of the revelation Witness 2 understands Witness 1 in a new dimension. Witness 2 renders his own witness by taking the tradition of Abraham and transforming it in order to do better justice to the reality itself. The result is a Patriarchal tradition rendered through the lens of Exodus, Sinai, etc. Witness 3 is a post exilic-prophet, who now better grasps the implications of all that God has been saying through Witness 2. In the light of fuller revelation, this earlier witness is once again shaped, perhaps through the insertion of

\footnotetext{
${ }^{231}$ Childs, Isaiah, 441. Childs' critique of von Rad is simply that he did not grasp the critical nature of the tradition-historical process and thus did not derive the correct hermeneutical implications; Introduction, 157.
} 
additional sources, perhaps through glosses. Regardless of how (i.e. the form), the result is a renewed witness, Witness 3 , which in its present form is able to do better justice to the fullness of the single reality of God (the res).

The modern interpreter stands after "Witness 3," as it were. How do we relate to each stage of the process, i.e. Witnesses 1 to 3 , that modern critical tools, with more or less success, manage to disentangle? Because the process was consistently theocentric, digging back to earlier levels is not wrong per se-the entire process was a response to revelation-but it will produce exegetical results that are inadequate according to the standards the traditions themselves wished to set. Childs spoke in this context of "decanonizing" the Bible. In light of our definition of the "canon," this does not simply mean that historical criticism has transformed the authoritative shape of canonical Scripture into a form different to the one the church has received. As we have seen, Childs grounds authority in the original testimony of the prophets in the context of the community of faith and not in a disembodied text. "De-canonization" in this context means that subjecting the more mature version of the tradition to the critical criterion of chronological sequence (a modern "canon of truth") is to subject the tradition to an alien grasp of reality, an alien "canon of truth," which is foreign to the Bible's own confession of the priority of salvation history-the history that constitutes the eternal life of God and unfolded into our temporal sphere for our sakes. In other words, it is to know better than the Bible about that which is really real, and thus to drown its capacity to render its own version of reality. If we are to submit ourselves to the function of the tradition and thus orient our gaze to the substance it is straining to articulate, knowledge of the growth of the tradition (e.g. the move from Witnesses 1 to 3) must serve our understanding of the mature form of that articulation (e.g. Witness 3 ) and not decide that an earlier stage knew better.

More nuance is required, however, if we wish to understand Childs' understanding of the tradition-historical process, for designating the "final form" as a piece of theologicalcriticism over against everything that went before is still not to say how that criticism is rendered. Until now I have emphasized the unity of the function of the tradition-historical process, i.e. it is "canonical," "ruled," "kerygmatic," "proclamatory," it functions to register and communicate more adequately a reality only partially testified to in the past. Implied in this definition of function is also the unity of the Sitz im Leben in which and for which this process took place, namely, the community of faith. The question of form, however, the manner in which this canonical function has been exercised, has not been further specified 
beyond our statement in $\underline{3.3 .4}$. that there is no single form. Within the framework of a tradition-historical process that was specifically canonical, it is now time to look at the nature and significance of the medium of "text."

\subsubsection{Form}

Childs notes that "increasingly in the late pre-exilic and post-exilic periods Israel's tradition was given a written form and transmitted by scribal schools ... [T] growing tendency towards the textualization of the tradition. ${ }^{\prime 232}$ As we have seen, Israel was committed to various human institutions as "agents of God's" rule (3.6.3.1.), so that textuality was always a derivative phenomenon, a preservation of the witness of these men of God. The text was, as Childs put it, a tradent of authority, always linked with a specific prophetic figure in order to sustain its authority. ${ }^{233}$ But, regardless of contemporary qualms about the relative efficacy of spoken or written language to achieve its communicative goals, Israel considered the prophetic message in textual form to be fully adequate to the prophetic function of mediating the kingdom of God. "The prophet serves as the living voice of God now preserved in a living text of Scripture. ${ }^{\prime 234}$ We thus have no disjunction within Israel's own world view. The form changes, yet the form is not what matters. The function of the prophet/text is that of "vehicle," and this can adequately be fulfilled by a text.

Evidence for fluidity of the move from prophet to prophetic text can be found within Israel's own testimony, so that the historical development of written Scripture as a vehicle of witness that overtakes and even replaces the people who generated the message (an etic view) corresponds to Israel's own internal self-perception (an emic view). Childs illustrates this in regards to one of the most central figures in the Biblical tradition: Moses:

Within the Pentateuch, Moses' writing activity is closely tied to his mediatorial role in receiving the divine law at Sinai. Whereas God himself is portrayed as writing the decalogue (Ex. 34:1; Deut. 4:13; 10:4), Moses not only proclaims the 'words and ordinances' of God to the people (Ex. 24:3), but he is also commissioned to write them (v. 4; cf. 34:27). The significance of Moses' writing of the law receives its clearest formulation in Deut. 31 . The context of the chapter is the impending death of Moses, and his commissioning of the writing of the law. Several crucial points are made in the chapter. The law,

${ }^{232}$ Childs, "Analysis," 360.

${ }^{233}$ Childs, "Retrospective," 375.

${ }^{234}$ Childs, "Rerospective," 375. Despite Barth's designation of the spoken word as the viva vox (3.5.3.) we will see in 4.2. that he also gives a dogmatic account of Scripture's capacity to be a living voice. 
which derived from God's speaking to Moses, applies to every successive generation of Israel (31:11-13). It serves as a witness to God's will (v. 28). The law of God has now been transmitted for the future generations in the written form of scripture. It is placed next to the ark in book form to be read to the people periodically (10ff.). Indeed, the original role of Moses as the unique prophet of God (34:10) who proclaims the word of God as a witness (31:27ff.) will be performed by the book of the law in the future (31:26ff). Moses will shortly die, but his formulation of the will of God will continue. Throughout the rest of the Old Testament the identification of the divine law with Moses' writing of it in a book is continued (Ezra 6:18; Neh. 13:1; II Chron. 25:4). ${ }^{235}$

According to Israel's testimony, then, a text is fully capable of doing the job of the historical prophet. Within an emic perspective there is no tension between text and person because it is the function of the person that mattered, and that function was mediatorial. The etic, historical-critical perspective, which understands the Law of Moses the be the result of a number of different authors, can be brought into relation to this emic perspective within Childs' framework when it is claimed that the expanders of the tradition understood themselves to be fulfilling the same function as the original prophet, namely that of mediating the divine will. Ascribing later laws to prophets who never authored them was thus not an act of deception but rather a testimony that the content of these later traditions is the same as that first witnessed to by their now pseudonymous authors. Concerning the Sinai event, for example, "one historical moment in Israel's life has become the norm by means of which all subsequent history of the nation is measured. If a law functions authoritatively for Israel it must be from Sinai, if it is from Sinai, it must be authoritative." ${ }^{236}$ Whatever the historical Moses may have said, the reality that was breaking forth through his activity can best be perceived when his activity is now interpreted within the context of a redacted whole.

It is interesting to note here how Childs' historical-critical reconstructions relate to his interpretation of Israel's emic perspective. Given the necessity for the presence of a historical "agent of God's rule" at the head of the trajectory and the need for a "theological link" between the later editorial whole and its origin, Childs cannot countenance that the Pentateuch was constructed entirely in the Hellenistic period, for example. There must

${ }^{235}$ Childs, Introduction, 133-134.

${ }^{236}$ Childs, Old Testament, 55. From a Jewish perspective on this concept of extension, see Milgrom, Leviticus, 1-2. 
have been a historical Moses and a chain of some sort linking the editors to his person. ${ }^{237}$ Thus, he can speculate that perhaps the role of Moses was continued in an office and that later persons added material in his name. ${ }^{238} \mathrm{He}$ is quick to label this as speculation, but it is important to note that his canonical thesis is in fact grounded in a particular construal of the development of Israelite religion. There are limits to what is possible. We see a similar impulse in his response to H.G.M. Williamson's theory that the oracular units present in the opening chapter of Isaiah stem from the historical Isaiah: "The argument remains, of course, speculative, but helpful in showing the high level of continuity of chapter 1 with the preaching of Isaiah, even when redactionally shaped." ${ }^{239}$ Childs' approach requires continuity between the historical prophet and the tradition associated with him. In the light of this constant attempt to hold the emic and the etic together, then, we can see the full weight-could one say audacity? - of his statement concerning the "authorship" of the final form of the book of Isaiah. The historical Isaiah, whose name stands as a superscription of the entire collection in Isa 1:1, did not write the book associated with him, but the historical Isaiah ben Amoz did, in some substantial sense, author it:

The resulting shape [of the book of Isaiah] bears a truthful witness to the selfsame divine reality first testified to by the eighth century prophet Isaiah, but then continually unfolded, modified, and enriched by successive generations of prophetic tradents to serve as Israel's authoritative scripture, a prophetic word that stands forever $(40: 8)$ and accomplishes its divine purpose $(55: 1)^{240}$

This development from historical prophet to canonical text can take place in various ways, which do not necessarily require the presence of a prophetic text at every stage of the process. In an earlier period, when Childs was more confident about our capacity to

${ }^{237}$ For Childs' commitment to the historicity of Moses as the author of written law for the people of Israel, see Introduction, 62-63. This historical moment is the beginning of the canonical process (62-67).

${ }^{238}$ Childs, Introduction, 134. For a discussion of the historicity of Moses within the framework of the former German critical consensus, see W. H. Schmidt, Glaube, 94-98.

${ }^{239}$ Childs, Isaiah, 16.

${ }^{240}$ Childs, Isaiah, 449 . Similar sentiments appear to be expressed by Berges in his introduction to the book of Isaiah. Having noted the shift in "Forschungsparadigma" from a diachronic to a more synchronic mode of reading, he brings up the issue of original prophecy as follows: "Wer zum Propheten gelangen will, kommt am Buch nicht vorbei. Nur in ihm ist das Echo seiner Stimme zu vernehmen" (Jesaja, 50; also p. 9, 10). It is difficult to see, however, how this works out in practice, as he sees little historical connection between the parts, Deutero-Isaiah being tacked on to protoIsaiah for more pragmatic rather than theological reasons (36-45). Which prophet is he talking about? 
reconstruct this process, ${ }^{241}$ he proffered complex tradition and form critical hypotheses concerning the manner in which the dialectic between oral, cultic tradition and the growth in the knowledge of God took place. He could speculate, for example, on the existence of two forms of the Mosaic office rooted within cultic institutions in the pre-monarchic period, both rooted in sacred oral traditions that exerted their own theological force upon the form these cultic traditions took. This development lies behind the canonical text, explaining how source critical approaches cannot do justice to the present tensions in the final form. Nevertheless, the growth was a growth of knowledge, so that even at the pretextual stage we have the "canonical process" in action. ${ }^{242}$ Despite this fact, however, Childs also claims that with the advent of the textualization of the tradition, something new happens. "[R]egardless of the exact nature of a text's prehistory, a new dynamic was unleashed for its interpretation when it was collected with other material and assigned a religious role as sacred scripture. ${ }^{243}$ In other words, the literary turn created "a new medium of witness," unleashed ... a set of forces which then tended to operate according to laws quite distinct from those at work in the development of oral tradition." ${ }^{245}$

This dynamic can be illustrated in relation to Isaiah $6: 13$, which contains a jarring postexilic gloss. After the threat of unrelenting judgement-Israel is like a tree burnt to a stump-we suddenly read: "Holy seed is its stump." This form of textual extension (Fortschreibung) "is a response to the coercion of the prophetic text on late scribal transmitters of the tradition." 246 Elsewhere isaiah had spoken of a remnant and so the editors identified this stump with the remnant, for whom there is hope after judgement has taken place. "The force of the entire narrative of chapter 6 , particularly in the larger

${ }^{241}$ Childs' awareness of the fragility of such theories grew over time. I believe that the relative luck of such analysis in his Isaiah commentary is not so much due to the fact that he wished to focus on the product of the process rather than the process itself-he insists that the knowledge of the process serves our understanding of the final form-but because he simply felt that it was not possible to sufficiently reconstruct much of the process.

${ }^{242}$ Childs, Exodus, 344-360. For more detailed analysis of Childs' Exodus and Isaiah commentaries, see my appendix below.

${ }^{243}$ Childs, "Response," 54.

${ }^{244}$ Childs, "One Gospel," 25. Childs applies the phrase to Luke's use of the "report genre," but the concept can be expanded.

${ }^{245}$ Childs, "Midrash," 53. Seeligmann's term was "Kanonbewusstein;" see his "Voraussetzungen." For Childs' relation to Seeligmann, see Driver, Childs, 173-174.

${ }^{246}$ Childs, Isaiah, 58. 
context of chapters 1-12, strove for an exposition of the meaning of v. 13."1247 Thus, this act of retrojection is not the "tendentious reading back of a subsequent political agenda," but is rather

part of a process of canonical shaping that stems from a holistic reading of the larger prophetic corpus. The witness to God continues to grow in richness and understanding. This true subject matter is then often extended to earlier portions of Isaiah without attention to the age of its discovery, but rather only to the truth of its witness when measured according to its theological substance. Thus the portrayal of God's rule in 2:1-4 and again in 4:2-6 resonates with elements of Isaiah's vision of chapter 6 and is grounded in the reality of God's eschatological rule, revealed to the prophet in chapter 6. Likewise, 2:6ff. also reverberates with the imagery of God's glory, but here revealed in terror (2:21). The point to emphasize is that canonical shaping develops from a holistic wrestling with the subject matter of the biblical text, and as comprehension grows through encounter with the living God it begins to infuse the entire book with a truthful witness to the one story of God's salvific purpose with Israel. ${ }^{248}$

In this example we see that there is, in fact, an element of self-referentiality which is gradually built into the developing corpus of Scripture. The meaning of a verse is sought in a form of "intertextual" exegesis which drew on the broader context. But the point is that this form of self-referentiality is something created by the tradents themselves and is always to be understood in light of their activity. One cannot bracket out the critical questions of form, function, and context when interpreting the final form of the text, for there are various ways in which intertextual interpretation can be practised. There is a diversity within the canonical process that needs to be respected and factored into our reading of the final form, not only because this is in fact what the text is, but also because, as we saw above (2.1.), Childs himself is committed to the historical witness of the "prophets and apostles." Synchronic exegesis is an act of obedience and not an act of defiance. One example of Childs' desire to attend to the precise nature of the process and thus to draw the requisite hermeneutical conclusions can be seen in his shifting evaluation of the nature of Third Isaiah. In an earlier stage of his career, he can differentiate the three "Isaiahs" as follows:

[T]here is an enormous difference between Second Isaiah's use of First Isaiah and "Third" Isaiah's use of Second. In the latter instance far more is involved than the influence of earlier prophetic preaching. The author of Third Isaiah is

\footnotetext{
${ }^{247}$ Childs, Isaiah, 58.

${ }^{248}$ Childs, Isaiah, 59.
} 
clearly working with written texts which are quoted, adjusted, and adapted. ${ }^{249}$

In an academic context that emphasized oral tradition, Childs emphasized the exegetical nature of Third Isaiah's activity. Yet thirty years later, in a new context emphasizing "the force of textualization of the oral tradition into a written corpus," Childs feels constrained to counteract an over-emphasis on the genre of Third Isaiah as pure Schriftprophetie by drawing attention to the fact that Israel's testimony is always grounded in Israel's lived reality:

First, Third Isaiah remains a prophetic collection, both in form and content, which means there is an encounter with actual historical realities, albeit seen in the light of the divine. This dimension dare not be flattened simply into a type of learned scribal activity dealing exclusively with literary texts. Second, not every occurrence of a parallel can be assigned to an intentional reuse. A critical assessment must be made that reckons with the theological substance at stake beyond merely identifying formal parallelism discovered by the perusal of a concordance. ${ }^{251}$

Once again, we see that for Childs exegesis is always oriented to the substance of the text, and a critical reconstruction of the text's historical quality is an aid to this. Pure synchronic reading does justice to neither the text itself nor its substance. Final form exegesis as a form of obedience to prophetic intentionality, which is a "canonical" intentionality (cf. 3.3 .3 .), requires that the exegete focus on the reality he was pointing to beyond his own limited horizon, a reality which has now been registered in the final form of the text. Yet precisely because final form exegesis is an act of obedience to the intentionality of the historical prophets, one must still attend to the various ways in which the tradition grew into the final form. Childs thus talks of the need to be aware of "different degrees of consciousness" 252 within the canonical process. For example, purely synchronic types of exegesis which "evaluate the present composition consistently on the same level of intentionality throughout" fail to deal with "the historical dimensions of the canonical process which established a scale of intentionality." 253 Thus, "The actualization of the Exodus traditions by Deuteronomy which von Rad, for example, studied reflects a very different process from the proto-midrashic, inner-biblical exegesis of texts of the exilic and

${ }^{249}$ Childs, "Midrash," 53.

250 Childs, Isaiah, 2. Childs calls this a "paradigm shift."

${ }^{251}$ Childs, Isaiah, 462.

252 Childs, "Response," 54.

${ }^{253}$ Childs, Introduction, 630. 
post-exilic periods." 254 Proper Biblical exegesis requires maintaining the diachronic and synchronic in their proper proportionality, yet both dimensions oriented to enriching our grasp of their single content.

This concern for proportionality can be seen in Childs' evaluation of the nature of the relation between the two Testaments within the Christian canon. Childs has argued that Christians must respect the plain sense of the Old Testament, bringing its theological content (to which the plain sense witnesses) into dialectic relation with that of the New Testament. His reason for arguing this, however, is once again grounded in the form and communal function of the Christian Bible itself. In other words, his approach is descriptive and not prescriptive, arising from the same "form critical" categories I have used throughout this analysis. His primary insight regarding this form of canonical shaping is that the testaments have been simply "juxtaposed." 255 There have been no attempts to editorially link them together by means of glosses or the insertion of later material into older texts, in a manner similar to what we have seen in individual books such as Isaiah 256 (Jesus' name is not inserted into Isaiah 53 , for example). In short, this form of canonical shaping is of a different order than the canonical shaping that gave us the individual books within each of the Testaments. Behind the form is a certain logic, which Childs identifies as follows: The early church confessed that in Jesus something radically new emerged. His life was not just an extension of Israel's history (cf. Barth, 3.5.2.) and as such the New Testament is not a "midrashic" extension of the Old Testament. Rather, it "tells its own story." On the other hand, the early church also confessed that the fulfilment identified in the New Testament did not drown out the promise of the Old Testament, so that it felt constrained to maintain the Old Testament in its integrity as its own witness to the Christ. In light of the subject matter, then, the early church created a two-Testamental canon characterized by simple juxtaposition. The hermeneutical significance is that it is the resulting "effect" (cf. 3.6.3.3.) of the juxtaposition, rather than a single editorial intentionality, that should guide theological interpretation of the entire Christian canon. By means of simple juxtaposition, the church confessed that the substance of the faith is to be found in the dialectical interplay of the parts, whereby each part retains its own integrity. This is one example of the "scale of intentionality" Childs seeks to identify within the Bible.

\footnotetext{
${ }^{254}$ Childs, "Fishbane," 512.

${ }^{255}$ Childs, Biblical Theology, 77-79.

${ }^{256}$ Childs, Biblical Theology, 75.
} 
It is of a different order to the relation of, say, Second to First Isaiah. Or again, within the Old Testament itself, the three major prophets (Isaiah, Jeremiah, Ezekiel) constitute a unity of a different kind to that of the 12 Minor Prophets, which have been editorially interlinked. ${ }^{257}$ In each case, however, regardless of the scale of intentionality, Childs affirms the tradition's confession that the subject matter, the Gegenstand, is always the same, namely they all witness to the reality of God.

We thus see that even when one asserts the dominance of "text" or "scripture" as the sole medium by which Israel's witness was later rendered, there is still scope for diversity. The primary co-ordinates that guide Childs' thinking are not literary structuralism or dogmatic propositionalism but a form of extended "form criticism." What matters to Childs is what Israel's prophets and apostles functioned to do within their Sitz im Leben, which is the life of the "community of faith." Because function is intimately tied to form, interpretation must take into account the nature of the manner by which Israel rendered its witness. We have also seen that, according to the logic of his confessional starting point, Childs is not committed to one particular form of the tradition, whether oral, cultic, or scriptural. When Childs does decide to take Israel's tradition as Scripture seriously, it is because the scriptural nature of the tradition was considered by the tradition to be an integral part of the form itself, the medium by which the kerygmatic function was accomplished. Finally, we have seen that Childs argues that the "fuller form" (my phrase) should be the object of interpretation, not because this is the form that the church has always lived from, but because of the logic of the inner-dynamic of the tradition-historical process itself. Editors shaped their material is such a way as to fulfil and extend the original function of the prophets, thus placing later development under their "aegis," as it were, by allowing their limited testimony to do better justice to the divine referent they functioned to mediate (thus Barth's phrase Vollgestalt seems to be a good analogy to Childs' "final form"; cf. 3.5.2. 9.4.2.). This is the reason why dogmatic theology turns again and again, as if by reflex, to the final form of the text: It is the locus of revelation's Vollgestalt.

\subsubsection{In What Does the Final Form Consist?}

We have reached an important milestone in the journey from the message of a historical prophet within Israel to the printed English language Bibles in our pews. The

${ }^{257}$ See especially Seitz, Prophecy. 
prophetic word became text, it grew into a literary composition, and then the process of growth was ended. The result was a phenomenon that Childs has called "the final form" of the text, or, in light of its function, the "canonical shape" of the text. It is not the case, however, that we are in a position to fully answer the question posed as the title of the section: "What is the final form"? There are two further problems that need to be addressed: the minor issues concerning the historical diversity of textual versions and the scope of the Christian canon, and the more significant issue of the identity of the reality to which Israel has consistently responded.

Concerning the historical issues: In one sense it would be more accurate to speak of final forms in the plural than of a final form in the singular. In terms of the literary development of individual books, we have, for example, two versions of Jeremiah (MT and $(X X)$; in terms of textual recensions, we have a variety of versions, which in turn have been variously taken to be authoritative by different communities of faith; in terms of scope, the outer boundaries of the Christian canon have to this day not been fully resolved. For an approach so committed to the hermeneutical significance of form, this diversity is important and an account needs to be given of it. Nevertheless, I have termed these difficulties minor because, as we have seen, Childs' approach is not grounded in the existence of a single text. Far more central than "text" are the categories of communal context and the function of tradition. It is in terms of these two coordinates that "form" acquires its meaning. Analysing Childs' response to the fact of textual and canonical diversity, however, will require asking more precisely about the nature of the literature itself, the "ontology" of Scripture, as it were, for Childs' understanding of function of the sacred literature within the community of faith-regardless for now which form of the text and the outer boundaries of those texts-involves an assumption concerning the very reality it points to. In other words, the nature of the res is constitutive for his interpretation of the verbum, which in turn provides him with his answer to the aforementioned historical issues. We will therefore postpone a discussion of these complex issues until after our discussion of the res (see 4.5.2.1. and 4.5.2.2. below).

In touching on the historical issue of the nature of the final form we have also touched on the theological issue: To what degree can one talk about the nature of a cultural, literary phenomenon without also talking about the nature of the context out of which it grew? I started my analysis of Childs' understanding of the nature of the Israelite tradition with precisely this question of context: Is there an "anterior reality" that undergirds and unites 
the whole and if so, what is it (3.2.)? We saw that this kind of question belongs to the task of historical-critical analysis per se, and we saw that Childs strove to answer this question in an emic manner. The move from the recognition of diversity to the question of unity took us through Israel's own vision of the ground of its being, which is the reality of a God who has revealed himself through the very traditions under consideration for the sake of guiding and shaping his people. We have seen that from within Israel's own perspective, this process involved a developmental dimension-God revealed himself progressively over time-and that the phenomenon of "Scripture" was understood to be an adequate vehicle for preserving and continuously communicating this reality. From an etic perspective, we have seen that Childs correlates the emic perspective with a theory of historical growth of the tradition. Literary growth consisted in a dialectic between authoritative, sacred tradition and the ongoing experience the community had of the referent of that tradition. Therefore, growth in the literature correlates to growth in theological understanding, and the editors' hermeneutical activity correlates to the prophetic function of witnessing to God. It thus seems reasonable to repeat our question: In light of such a thesis, is it possible to offer a description of Israel's verbum without offering an account of the res itself?

I am not aware that Childs' thematizes a particular construal of the res in his canonical approach, though he certainly states a position on the issue. Apart from my treatment of Barth, for whom the res is clearly a dynamic phenomenon-a covenantal history between man and God (3.5.) - I have not tried to clarify the particular nature of this res for Childs. Given that this term is often understood in static categories (cf. Aquinas" "analogy of being"), ${ }^{258}$ in order to avoid misunderstanding of his terminology Childs makes a rare ontological statement about the nature of God himself:

according to the Bible the reality of God has no true being apart from communion, first within God's self, and secondly with his creation. God is one whose being is in loving which is grounded in a freely given commitment toward humanity and this relationship is constitutive of his being. ${ }^{259}$

How does Childs' evidently Trinitarian theology relate to his understanding of the canonical process? Is there a parallel between his historical-critical construals and the divine economy, both pro nobis and in se? Though Childs does not factor in an account of the nature of God into his canonical thesis, his presentation of the goal of his analysis

${ }^{258}$ Childs, Biblical Theology, 82.

${ }^{259}$ Childs, Biblical Theology, 82. Childs cites the very Barthian theologian A. Torrance, "Suffer," 352ff. 
consistently implies the reality of God as an essential ingredient. Thus, he says that "the issue at stake [in evaluating the tradition] is the nature of the Bible's historicality and the search for a historical approach which is commensurate with it. ${ }^{\prime 260} \mathrm{He}$ is clearly assuming that "history" itself can have more than one dimension. Again: "To take the canon seriously is to stress the special quality of the Old Testament's humanity which is reflected in the form of Israel's sacred scripture. ${ }^{\prime 261}$ Not only can history have another dimension, so can human being within history.

We will close the chapter dealing with Israel's verbum with one of Childs' most succinct summaries of the hermeneutical significance of the "final" form of the literature (relatively speaking, see above as well as $\underline{4.5 .2 .1}$ and $\underline{4.5 .2 .2}$.). This quotation will function as a handy bridge to our discussion of the Bible's res, for it not only assumes the historically descriptive categories that have been used throughout this analysis so far, but also goes beyond them to indicate that a particular grasp of the reality undergirding these traditions has equally significant hermeneutical implications.

The reason for treating the final form of Scripture with such seriousness lies in the peculiar relationship between text and people of God which is constitutive of canon. The shape of the biblical text reflects a history of encounter between God and Israel. Canon serves to describe this unique relationship and to define the scope of this history by establishing an end to the process. It assigns a special quality to this particular segment of history which is deemed normative for all future generations of this community of faith. The significance of the final form is that it alone bears witness to the full history of revelation. Within the Old Testament neither the process of the formation nor the history of its canonization is assigned an independent integrity. These dimensions have been lost or purposely blurred. Rather, canon asserts that the witness to Israel's experience with God is testified to in the effect on the biblical text itself. It is only in the final form of the biblical text in which the normative history has reached an end that the full effect of this revelatory history can be perceived. ${ }^{262}$

This quotation illustrates the thoroughly derivative nature of the significance of the final form. First and foremost, there is an "anterior reality," the "history of encounter between God and Israel." Without this history there would be no tradition-historical process in the first place and thus no need for a final form. Then there is context: This extra-textual history of divine-Israelite relationship requires knowledge and obedience on

\footnotetext{
${ }^{260}$ Childs, Introduction, 71 (emphasis mine).

${ }^{261}$ Childs, Introduction, 71 (emphasis mine).

${ }^{262}$ Childs, "Canonical Shape," 47-48.
} 
the part of the Israelite partner. In particular, it requires knowledge of the reality of the relationship itself, its "full history," and not a theoretical acquaintance with the ways this reality may have been understood by others at different stages in Israel's history. Given that only the full reality is "normative," the community can only be content with the fullest form of the tradition. The final form is only significant because of the purpose of the tradition within this context of divine-human relationship. This links up to function: Because of the communal need to understand the "history of encounter between Israel and God," the tradition functions to "describe," "define," and "assign a special quality" to this reality. Because of the communal need to know this history in its fullness, as only the fullness is normative, the tradition "purposely blurred" the history of formation behind the final form. The final form of the text arises out of this divine-human history and for the sake of this divine-human history. Is there an additional hermeneutical implication beyond what we have discussed so far $(3.4 . ; 3.5 .4$.$) ?$

Childs says that by virtue of the history that generated the final form, exegetes should attempt to interpret "the effect on the Biblical text." With the term "effect," he is not referring to the aesthetic intention of the shapers of the tradition. Rather he talks of "the full effect of this revelatory history." The subject of this effect is not the intention of any particular tradent, but the full force of the history of revelation itself which has impacted, "coerced," the tradents of the tradition. In a similar manner, he talks of the Biblical text "reflecting" an encounter between God and Israel. Here we receive our primary clue concerning the hermeneutical significance of the true context of Scripture. There is another agency involved in the creation of Israelite tradition beyond that of its human tradents and this agent, too, has left his imprint. Thus far I have tried to exclude talk of the actual reality of God from our analysis of the canonical approach. When we factor in the element of divine agency into the process, apparently non-theological sounding terms such as "vehicle," "force," "coercion," "response," take on a new dimension of meaning. We will now turn to look at the nature of this God before concluding our analysis with a more developed set of hermeneutical implications than those found in 3.4 . and 3.5.4.

\section{Res: The Shape of Israel's God}

Talk of the "effect" of the "history of revelation" upon the form of Biblical tradition moves our analysis of the nature of that tradition to a plane beyond that of historical inquiry, for it assumes the presence of an agency that is transcendent, beyond the 
categories of created time. Unless Biblical scholarship is willing to deny the existence of the presence of a divine reality within Israel's history altogether, it is necessary to ask the question of whether the nature of this reality ought to impact our understanding of the tradition it "evoked," and thus whether our grasp of the res has hermeneutical implications.

A significant contributor to Biblical hermeneutics is Rudolf Bultmann. ${ }^{263}$ His thoughts on the matter at hand are particularly interesting because of the continuity and discontinuity of his thought with that of both Barth and Childs. On the one hand, they share a similar hermeneutical starting point: Interpretation must be oriented to the particular nature of the subject matter of the text. On the other hand, they have very different interpretations of the subject matter of the Bible (i.e. its res, Sache, Gegenstand, content, substance etc.), and this leads them to draw radically different hermeneutical conclusions. This fact alone should be proof of the relevance of our inquiry. We shall start with an analysis of Bultmann's hermeneutical contribution and particular formulation of the res (4.1.) and compare this to Barth's formulation (4.2.) in order to see how differing opinions at this level shape our approach to the Bible.

\subsection{The Hermeneutical Significance of the Res: Bultmann's Contribution}

Bultmann emphasizes the significance of the concept of "pre-understanding" (Vorverständnis) for the task of Biblical exegesis. He argues that "interpretation ... is always based on principles and conceptions which guide exegesis as presuppositions." ${ }^{264}$ As a result, before we start to read a text we must always pose the following hermeneutical question: "[W]hich conceptions are right and adequate?"265 According to Bultmann, the answer to this question depends on the nature of the subject matter (Sache) ${ }^{266}$ of the text itself. In other words, the content of the text dictates the kinds of questions and methods one ought to use to interpret the text. The crux is that unless the interpreter has a prior relation to or knowledge (Vorverständnis) of this reality, he or she will not possess the

\footnotetext{
${ }^{263}$ Cf. Thistelton, Horizons.

264 Bultmann, Christ, 46.

265 Bultmann, Christ, 48.

266 Bultmann, Christ, 49.
} 
necessary pre-conceptions to be able to understand the text. ${ }^{267}$ Bultmann calls this prior relationship between interpreter and the content of the text a "life-relation."268

We thus see that the nature of "that which the text is about," its "res," is key to hermeneutics. As a result, Bultmann shares Childs' and Barth's presupposition that our approach to the text must correlate to its "content," its "Sache," i.e. it needs to be "sachgemä $\beta^{\prime 269}$ (cf. 3.4. 3.5.4.). When it comes to the traditions contained within the Bible, Bultmann also shares Childs' and Barth's theological presupposition that these traditions emerged as a response (Antwort) to the activity of God himself within human history (they are "durch Gott ermächtigt," "durch sein Handeln erschlossen"), ${ }^{270}$ such that God's revelation impacts (i.e. it is "treffend") ${ }^{271}$ those who, as a result of this event, experienced a transformation in their view and approach to life in general (i.e. they had a "durch das Kerygma geweckten Selbstverständnis"). ${ }^{272}$ As such Biblical faith (Bultmann's primary text here is the New Testament) ${ }^{273}$ is "Glaube an das Kerygma," which is the Word of God. ${ }^{274}$ In light of the hermeneutical significance of Vorverständnis, then, Bultmann asks whether it is necessary for the interpreter to already have a knowledge of this "Word" before one interprets the text: "[K]ann der Glaube in den Blick gefaßt werden, ohne daß sein Woran, sein Gegenstand, mitgesehen ist?"275 In other words Bultmann, like Barth (and Childs), raises the question of the relevance of a knowledge of the substance of the text for our ability to read it.

We have already seen part of Barth's answer to this question (for the rest, see $\underline{4.2}$. below) : The Word of God is the reality of God himself, who exists in covenantal communion with Israel and as such is an objective reality who has entered our dimension of time and space. This personal divine reality has acted in history in such a way as to evoke a witness to himself, which is Scripture. As a result, Scripture is "kerygmatic," it has a

${ }^{267}$ Cf. Bultmann, History, 119. Cf. Bultmann, Christ, 49.

${ }^{268}$ Bultmann, Christ, 49.

${ }^{269}$ Bultmann's phrase in Theologie, 586.

270 Bultmann, Theologie, 587.

271 Bultmann, Theologie, 587.

272 Bultmann, Theologie, 588.

${ }^{273}$ Gunneweg argues that Bultmann's logic can equally be applied to the Old Testament, see "Interpretation."

${ }^{274}$ Bultmann, Theologie, 587.

${ }^{275}$ Bultmann, Theologie, 587. 
"deictic" function. ${ }^{276}$ Scripture points away from itself to something else, the "object" of the "proclamation." As such, Scripture has a concrete semantic content, one that can be known and portrayed-imperfectly, never exhaustively, but adequately to God's purpose of self-revelation -in various secondary forms, in particular in the form of church doctrine and preaching. In light of Bultmann's theory of "life-relation," the hermeneutical implication is that the interpreter must have personal knowledge of this reality, must be acquainted with church tradition, and must read with an eye to the theological referent (cf. 3.5.4.)..$^{277}$

Bultmann's understanding of the "Gegenstand" of Biblical faith is radically different. Though he can talk of the impact of the Word of God upon the primary historical witnesses, the "effect" of the impact of this Word upon those who witness it is the diametrical opposite to that seen by Barth and Childs (cf. Childs' understanding of "effect" in 3.6.3.3.). The result of the impact of revelation upon the witnesses is not that they now turn to point others towards that reality (the "history of revelation" or the "Bundesgeschehen") ) $^{278}$ but that their general subjective stance towards the world is altered; they have acquired a new mode of existence that is characterized by "authenticity." That which is evoked (geweckt) is not a "witness," a signpost to another reality, but a new "self-understanding" (Selbstverständnis). Bultmann thus reverses the direction of the prophetic and apostolic gaze: They are not ultimately interested in God himself (a theocentric gaze) but in the question of how one can exist meaningfully in the present (an anthropocentric gaze, to use Childs' terminology). Although the opposite claim is found within the Bible itself (cf. 2 Cor $4: 5)$, Bultmann claims that his existential interpretation is what they really meant when using this kind of referential language. ${ }^{279}$ Whereas Childs moves from an experience of God and to exegesis (2.1.), Bultmann's starting point is the experience of yearning for God, i.e. from a feeling of his absence. He then extrapolates from this experience an understanding of the primary motivation of the tradents of the tradition:

${ }^{276}$ As Childs puts it, the Bible "points referringly ... To recognize that the Bible offers a faithconstrual is not to deny that it bears witness to realities outside the text" (New Testament, 545).

${ }^{277}$ For a brief example see Barth's treatment of the virgin birth in light of the declarations of Nicaea in Dogmatik, 127-129.

${ }^{278}$ Bultmann claims that this reality is veiled to us anyway because of the falsely objectifying nature of every human theological system that seeks to represent this reality (Theologie, 577-588). Whereas Childs interprets "medium" as "vehicle" for the res, Bultmann sees it as obstacle to the kind of res Childs and Barth are interested in, i.e. the content of the Word of God.

${ }^{279}$ See Diem's helpful analysis of Bultmann in Dogmatics. 
Man has a knowledge of God in advance, though not of the revelation of God, that is, of His action in Christ. He has a relation to God in his search of God, conscious or unconscious. Man's life is moved by the search for God because it is always moved, consciously or unconsciously, by the question about his own personal existence. The question of God and the question of myself are identical. ${ }^{280}$

In this sense, Bultmann's approach is purely etic, for it claims to know better than the tradents themselves about the real issue at stake in their message. The substance of the text is not, in fact, "rechte Lehre" (a derogatory term), ${ }^{281}$ but rather the reality of authentic existence. Given that this is the substance of the tradition, this is what must be retrieved by the exegete. The Word of God which impacts the tradents is not an ontological reality that wishes to reveal itself through their language, but an existential challenge to decide to live authentically. Thus, whereas Barth defines the "Word" as the "Bundesgeschehen," and Childs talks of a "history of revelation," Bultmann talks of human struggle to come to terms with its existence in ever changing historical circumstances. This, according to Bultmann, is the thread of continuity throughout the history of theology; "die besteht nicht im Festhalten an einmal formulierten Sätzen, sondern in der ständigen Lebendigkeit, mit der der Glaube von seinem Ursprung her die ständig neue geschichtliche Situation verstehend bewältigt." ${ }^{282}$ The Ursprung may well be a necessary precondition, but it is not the content of that origin that matters but the manner in which this reality was interpreted. ${ }^{283}$ Continuity in the tradition is not ontological but existential. As such, Bultmann defines the Word of God itself in purely existential terms: It is "das anredende Wort Gottes, als fragendes und verheißendes, als richtendes und begnadigendes Wort." ${ }^{284}$ What matters is the quality of response it evokes, and not the content of the Word itself.

${ }^{280}$ Bultmann, Christ, 52-53.

281 Bultmann, Theologie, 588.

282 Bultmann, Theologie, 587-588.

${ }^{283}$ Thus, Bultmann can start his New Testament theology with a chapter on the proclamation of the historical Jesus - the Ursprung-but then say that this proclamation is only the pre-condition (Voraussetzung) of New Testament theology proper, which consists in the manner by which this proclamation was interpreted (Theologie, 1-2). Diem claims that this commitment to the existence of an origin stops Bultmann's approach turning into pure anthropology (Dogmatics, 69).

${ }^{284}$ Bultmann, Theologie, 589. Caputo argues that even in his atheistic phase, Heidegger, who stands behind and to a degree with Bultmann, spoke of "being" in very theological terms similar to those used by Bultmann here. Thus, he "viewed the relationship between being and thinking in Parmenides and Heraclitus in kerygmatic terms, arguing that these early Greeks took being to be 'addressed' to man, that it laid claim to man, and that the Greeks conceived the being of man in terms of responsiveness and answerability to this claim" ("Heidegger," 280). It should be added that one major criticism of Bultmann's thesis is that the term "kerygma" is never used in the New Testament in the way he uses it himself. Cf. Diem, Dogmatics, 132. 
Bultmann draws from this definition of Scripture's true substance the necessary hermeneutical implications. Given that the content, the res, of Scripture is not the ontological reality of God but authentic human being, ${ }^{285}$ we may only understand the Bible when we understand it in this light: "das Kerygma ist als Kerygma nur verständlich, wenn das durch es geweckte Selbstverständnis als eine Möglichkeit menschlichen Selbstverständnisses verstanden wird. ${ }^{\mathbf{2 8 6}}$ Given the necessity of a personal experience of the res before one interprets the verbum, i.e. the need for a "life-relation," the question is raised as to how the interpreter may best prepare him or herself to understand the text properly (i.e. sachgemäß). It is clear that Barth's and Childs' experience of God will not do, for the content of this experience was not God but their own historically conditioned attempt to find meaning. "Offenbar kann der Forscher nicht seinen Glouben als Erkenntnismittel voraussetzen," ${ }^{287}$ neither can the doctrine of the church be of use for by definition Scripture is not interested in doctrine. In addition to this, one cannot expect to find a theological unity within Scripture, either diachronically or throughout its traditionhistorical development, for, regardless of the claims of the tradents, what was really happening in their testimony was their expression of authentic existence in response to a divine challenge, and not the communication of a reality that can be expressed in concrete terms. For Bultmann, the primary question the exegete must ask is not, "What does this text say about God," but rather, "How is human existence understood?" The object of exegesis is the human explication of the Word, and not the Word itself. In order to acquire the right life-relation in order to hear the Bible's answer, we need to struggle to live authentically ourselves, "im Wissen, daß existentielles Selbstverständnis ... nur im Vollzug der Existenz und nicht in der isolierten denkenden Reflexion wirklich ist." ${ }^{288}$ Finally, the tool that may enable us to do this is modern existential philosophy. This philosophical school is dedicated to analysing the same subject matter that Scripture itself witnesses to, namely human existence. ${ }^{289}$ The contribution of this branch of philosophy is not that it provides us with interpretive guidance but that its imperative to decided to live authentically gives the interpreter the correct "pre-understanding" to be able to interpret the text. "Without this

\footnotetext{
${ }^{285}$ This is Childs' interpretation of Bultmann in Biblical Theology, 81.

${ }^{286}$ Bultmann, Theologie, 589.

287 Bultmann, Theologie, 589.

${ }^{288}$ Bultmann, Theologie, 589.

${ }^{289}$ Bultmann, Christ, 55, 57. See Caputo's helpful article, "Heidegger and Theology." E.8. p. 275: "When Bultmann "applied" [Heidegger's] Being and Time to Christian theology he was "deformalizing" the existential analytic and articulating it in terms of a historically specific, existentiell ideal, namely, historical Christianity."
} 
decision, without the readiness to be a human being, a person who in responsibility takes it upon himself to be, one cannot understand a single word of the Bible as speaking to his own personal existence. ${ }^{290}$ And if one cannot do this, then one has not grasped the substance of Scripture.

We have seen that Bultmann, in contrast to Barth (and Childs), is not interested in the question of God's ontological being but rather in the question of human existence. Yet this does not stop him from critiquing Barth's approach on another level. According to Bultmann, even if the true subject matter of Scripture was God himself, given the limitations of all human culture and language we would not be able to access that reality anyway. ${ }^{291}$ Whereas for Barth Scripture is a vehicle of revelation of God, for Bultmann it would be an obstacle, for the reality would always be hidden in the time-conditioned categories of its tradents. This point about the historically conditioned nature of the witness has been picked up by other confessionally oriented Old Testament scholars as a justification for a form of diachronic analysis which asks about the content of the thought of the tradents and not of the reality that they strove to point to. Thus, W.H. Schmidt can cite Bultmann's dictum that the Biblical witness is always rendered in human language and conclude: "D.h., Gegenstand der Theologie kann nur das Zeugnis des Glaubens, die Rede von Gott, die Aussage des Offenbarungsverständnisses sein," rather than God, the "Offenbarung" itself (in this context he is critiquing von Rad). As a result, "Ist die 'Theologie' nicht auch insofern zur 'Religionsgeschichte' hin offen?'292

The weakness of Schmidt's argument here is that it will not do to simply cite Bultmann on the humanity of the witness and then conclude that exegesis must necessarily be anthropocentric for, as we have seen, Bultmann's unbothered insistence that we cannot penetrate the human language to its referent is itself grounded in a dogmatic presupposition. Bultmann can make this caveat because he believes that the divine Word is ultimately about creating authentic existence through an act of; it is not an act of divine self-revelation (Schmidt does not mention this dogmatic presupposition). Schmidt may well be right that the "Unterscheidung von ... Gottes Tat und Menschen Wort ... läßt sich nicht sprachlich fixieren," ${ }^{293}$ but unless one wishes to affirm with Bultmann that "God's deed" is

\footnotetext{
290 Bultmann, Christ, 57.

291 Bultmann, Theologie, 588.

292 Schmidt, Glaube, 19. See also Gunneweg, "Interpretation."

293 Schmidt, Glaube, 19.
} 
pure address, one cannot consider the matter of the relation between verbum and res to be closed. It all depends on how one defines the res.

We will now turn to briefly look at the way in which verbum and res are related in Barth's thought. Barth's thought here is complex and it is not my intention to analyse it in all its detail. Rather, my goal is simply to set up the basic lineaments of his understanding of the presence and reality of God in history in order to clarify Childs' own understanding of the effect of this activity within the canonical process. In entering upon this discussion it is important to note that we are not leaving the theological realm of the identity of God nor the historical realm of the nature of the canonical process, as if discussion of the relation between witness and referent were a second order hermeneutical complexity that needed to be resolved after the theological and historical work has already been done. Rather, the issue is central to the very being of the God who reveals himself and thus a constitutive element of the tradition-historical development of the Bible itself. In short: To the duo of God and witness, verbum and res, Barth adds a third entity missing from Bultmann's speculations: spiritus. It is within the interplay of the three that the true nature of the canonical process and its subject (matter) come to light, and this will provide us with the final framework for elucidating the hermeneutical proposals that go under the rubric of "the canonical approach."

\subsection{Verbum, Res, and Spiritus: Barth's contribution}

For Barth, the argument that the human nature of the witness hinders it from being able to mediate the reality of God does not do justice to the sheer scale of the problem. Regardless of the nature of the witness to revelation, the revelation itself is such that even without a human medium it would be impossible for fallen humanity to grasp it. Barth grounds this impossibility in God's holy majesty and the fact that he is wholly "other." In other words, he is not "just another phenomenon within the world of human experience;" 294 there is an "infinite qualitative distinction" 295 separating him from the creature. As such, in order for us to apprehend revelation at all, regardless of the medium, we need a miracle. God himself must intervene in order to open our eyes. The moment of understanding, then, is the result of God's own action; it therefore has the character of a divinely inspired event. The "God, who cannot be 'objectified", ... renders himself a possible

${ }^{294}$ Hart, "Revelation," 42.

${ }^{295}$ Guretzki, Filioque, 65. 
object of human knowing in an act of supreme divine condescension, entering into the world of our conceptuality and experience and somehow giving himself to be known within its terms." ${ }^{296}$ The result is the establishing of "an unnatural or supranatural correspondence between the media of revelation and of God." ${ }^{297}$ In other words, a "person, an event, a text which in itself is not God and veils God nonetheless becomes transparent to faith and refers faith beyond itself appropriately to God." ${ }^{298}$

The power within which this ever-occurring event takes place is the Holy Spirit, so that "evangelische Theologie ... nur als pneumatische Theologie möglich und wirklich werden kann." 299 The Spirit enters into our created time and space so that its objective work in the Biblical exegete becomes the ground for his or her subjective "apprehension of revelation." Barth talks of the Spirit in terms of "power," a "verborgenen, ungreifbaren, unverfügbaren Macht." ${ }^{300}$ This Spirit is the same one who not only operates today within the church as it engages in Biblical exegesis, it has been "gegenwärtig und wirksam" throughout the entire tradition-historical process that gave us the present form of Scripture. ${ }^{301}$ This power of the Spirit is a creative power (schöpferische Macht) who relates to those it inhabits as a master to a servant. This Spirit, then, is the ultimate force at work in the production of the various witnesses to revelation-either the historical prophets, their written Scripture, or contemporary "secondary" witness in the form of commentary-for both the Biblical tradent and the modern exegete "kann [ihr] Denken und Reden nur von ihr kontrollieren lassen und nicht umgekehrt." ${ }^{302}$

Barth's understanding of the agency of the Holy Spirit throws Childs' language of "infusion," "force," "coercion," and "effect" 303 into a new light (see point 1 of my analysis of Childs' confession in 2.1.). If we saw in section 3.6.3.3. that the final form-along with every stage beforehand-registered the "effect" of an impact, we must understand the force of this impact to be the reality of God himself in his Spirit. ${ }^{304}$ The "coercion" or "forces"

\footnotetext{
${ }^{296}$ Hart, "Revelation," 44. Hart cites, GD, 359. Guretzki talks of revelation as "gift" (Filioque, 66).

${ }^{297}$ Hart, "Revelation," 47.

${ }^{298}$ Hart, "Revelation," 46. Hart cites GD, 175; CD 1/1, 165f., 227-47.

299 Barth, Einführung, 64-65. By "evangelical," Barth does not mean Protestant, but any form of theology which orients itself in light of the "evangel," the good news of the covenant, which is the substance of Scripture and faith. Cf. Einführung, 11.

${ }^{300}$ Barth, Einführung, 60.

${ }^{301}$ Barth, Einführung, 60.

${ }^{302}$ Barth, Einführung, 61.

${ }^{303}$ Welker uses the language of "weight" ("Sola Scriptura?").

${ }^{304}$ The same applies to Childs' own experience; cf. 2.1 .
} 
that impinged from the outside upon Israel's tradents were certainly their Scripture and their historical context, but undergirding these factors is the more primary reality of God himself. Childs explicitly states that this reality is an objective part of Israelite tradition history that must be factored into any interpretation of its nature:

Because the major force in the history of growth was the continued impact on the Jewish community of the reality of God mediated through its authoritative writings, it is a fundamental misunderstanding to attribute the development within the prophetic corpus merely to extrabiblical sociological or historical influences. ${ }^{305}$

This gives Childs' claim of the ontological unity undergirding the tradition its most secure foundation. The capacity of the tradents to grasp the truth of the tradition does not lie ultimately in their interpretive skill and integrity, but in the power of God.

Having identified the true nature of the force at work in the tradition-historical process then, we are in a position to grasp Childs' answer to the question of the nature of Israelite tradition: Israelite tradition is an ongoing human vehicle of the self-revelation of God in the power of his own Spirit for the sake of the community of faith, which through this tradition must itself become a vehicle of revelation to the world (cf. $\underline{3.5}$.). This mode of mediated, self-referential and salvific divine activity has not changed today. All that has changed is the medium itself, the form. Rather than the various cultic, oral, or fragmentary documentary traditions that were sufficient for Israel at some point in the past, the Holy Spirit has bequeathed us a canon of Scripture, and it is this form that provides the (theo-)critical hermeneutical framework by means of which the traditions of the past are to be actualized for the interpreter by the infusing activity of the Spirit in the present. ${ }^{306}$

\subsection{The Noetic and the Ontic dimension}

I would like to clarify the nature of the interrelation of verbum and res by means of the same diagrams that I have used above (3.3.4. 3.5.4.). One can represent the relation "economically," in terms of what Guretzki calls revelation's "noetic structure," ${ }^{307}$ i.e the

${ }^{305}$ Childs, Isaiah, 265 (emphasis mine). In the same paragraph Childs talks of the forces of Scripture and history. See also Webster, Holy Scripture, 29-30, for the work of Spirit throughout the tradition-historical processes, including our present age. Welker, "Sola Scriptura?" also talks of the reality of God leaving an impress on the form of the traditions: "The historical, the cultural, and the canonical weight of scripture are only a mirror and reflection of the theological weight bestowed upon scripture by its content and object, by the living God" (383).

${ }^{306}$ Cf. Childs, "Nature."

${ }^{307}$ Guretzki, Filioque, 98. 
manner by which revelation comes to us, and one can represent the relation "ontologically," i.e. in terms of what Barth and Childs hold to be the logically and ontologically prior basis for the divine activity that lends it its particular form. First we look at the noetic structure:

exegesis (verbum [+res]) $\leftarrow$ exegete (in Spiritus) $\leftarrow$ that which is exegeted (verbum [+res])

Exegesis in this context is the explication of the res of Scripture for the community of faith, which is the fruit of the work of the Spirit within the exegete who reads Scripture for within the Isaianic redactor, for example, who read and updated the earlier prophecies-1 include all the tradents of the tradition within the term "exegete"). In the power of the Spirit, a sachgemäße exegesis truthfully communicates the res of the Scriptural verbum, so that by means of its own secondary word it becomes a new form of the one Word of God. ${ }^{308}$ Though Scripture is the norm that structures commentary, in the power of the Spirit commentary and Scripture-distinct in their functions-become transparencies to a single reality. As Barth puts it: "[T]o the extent that proclamation [here: exegesis] really rests on recollection of the revelation attested to in the Bible and is thus obedient repetition of the biblical witness, it is no less the Word of God than the Bible." ${ }^{309}$ Two forms, one substance, "two entities ... set initially under a single genus ... Scripture as the commencement and present-day [exegesis] as the continuation of one and the same event, Jeremiah and Paul at the beginning and the modern [exegete] of the Gospel at the end of one and the same series." ${ }^{310}$ It should be clear that the ongoing work of the Spirit is also required for the reader of the exegesis to be able to identify this one substance. ${ }^{311}$ Without it, both commentary and Scripture remain a "burnt-out crater," 312 the "impress of revelation" ("Eindruck von Offenbarung"), "a human worldly factor side by side with other factors. ... The signpost has become meaningless. ${ }^{\prime 313}$ It is only in the power of the Spirit that Childs" confession to be entering "into an activity of faith long in progress" (2.1.) acquires its full significance.

${ }^{308}$ Barth typically talks of "proclamation," by which he usually thinks of "preaching," when talking about the "third" form of the word of God (the first being the incarnate Christ). Yet preaching, creed, and tradition are, ideally, all forms of Biblical exegesis. Cf. Bächli, Barth, 24.

${ }^{309}$ Barth, CD 1/1, 120; cited in Guretzki, Filioque, 99.

${ }^{310}$ Barth, $C D 1 / 1,102$; cited in Guretzki, Filioque, 98.

${ }^{311}$ Cf. Diem, Dogmatics, 178, a New Testament perspective.

312 Barth, Romans, 65, 74; cited in Guretzki, Filioque, 66.

${ }^{313}$ Barth, Romans, 74; cited in Guretzki, Filioque, 66, fn. 61. 
If it is the case, however, that the primary verbum of Scripture and the secondary verbum of commentary are both made transparencies of a single reality, namely God, and if it is the case that the subject of this revealing activity is the same as the object who is revealed, i.e. God, a theoretical account of the nature of Israelite tradition will need to supplement the temporal sequence by which this tradition is actualized (vergegenwärtigt) with an account of the res itself, within whom both Scripture and exegete have their own derivative being. Here we come to the question of "theology proper," the question of theological ontology and not just epistemology. Given that, In light of the "infinite qualitative distinction" between God and man, only God can make himself known, and given that God wishes to make himself known, to articulate the one always requires an articulation of the other. ${ }^{314}$ As Alan Torrance puts it, God is "not only the Subject-matter of theological discourse, but ... [also] the essential condition of its actuality and possibility. ${ }^{\text {"315 }}$ In other words, Barth's understanding of the nature of God has formal significance: Form and content are inextricably interlinked. ${ }^{316}$

The interrelation here between God's self-revelation in time and God's eternal beingtraditionally labelled the "economic" Trinity and "immanent" or "ontological" Trinity-is highly complex and still a matter for ongoing dogmatic research, as Guretzki has indicated. ${ }^{317}$ Barth himself went through a development in his understanding of the relation between the persons of the Godhead and the various stages in the linear process of revelation (event, primary witness, secondary witness), ${ }^{318}$ first correlating the Father, Son, and Spirit with reality, Scriptural witness, and proclamation respectively, and then, in a later refinement (or correction), describing the relations in "perichoretic" terms, seeing all three persons present in each stage. ${ }^{319}$ In connexion with this complex question we can only note that, according to Barth's system (and that of traditional Christian theology), ${ }^{320}$

${ }^{314}$ Cf. Torrance, "Trinity," 74.

${ }^{315}$ Torrance, "Trinity," 74.

${ }^{316}$ Cf. Torrance, "Trinity," 72; Hart, "Revelation," 53; Guretzki, Filioloque, chapters, 2,3 and 5. As Barth puts it: "God reveals Himself, He reveals Himself through Himself, He reveals Himself. God, the Revealer, is identical with this act in revelation and also with its effect" (CD 1/1, 296 [emphasis original]; cited in Torrance, "Trinity," 77).

${ }^{317}$ See especially chapter 5 in Filioque.

${ }^{318}$ Diem talks of Scripture and proclamation as "primary" and "secondary" witnesses respectively (Dogmatics, 96-97).

${ }^{319}$ Guretzki, Filioque, chapters 2 and 3. Gureztki offers a "generous" interpretation that tries to see Barth as supplementing an older view, but he does not feel it is likely.

${ }^{320}$ Cf. McGlasson, Invitation, 193-196; Jüngel, Geheimnis, \$23, 505-512. 
the question of God's being is not irrelevant to the question of hermeneutics. ${ }^{321}$ However, as I have tried to demonstrate from the outset of my portrayal of Childs' canonical thesis, the canonical approach is founded upon an understanding of the nature of Israelite religion that not only poses the question of its external ontological grounding-which is the etic question-but seeks to answer that question by taking into account Israel's own testimony to the matter-the emic question. Having established Childs' understanding of Israel's emic perspective in $\underline{3.3}$. and $\underline{3.6 .2}$. above, and having illustrated how Childs integrated this perspective into a historically grounded etic theory of tradition-historical growth, it is worth taking a stab at representing what could be called an ontological etic perspective on the reality within which Scripture and exegete subsist (one which Childs might have approved of). ${ }^{322}$ I would thus supplement the linear "noetic structure" with the following "ontological structure" of revelation:

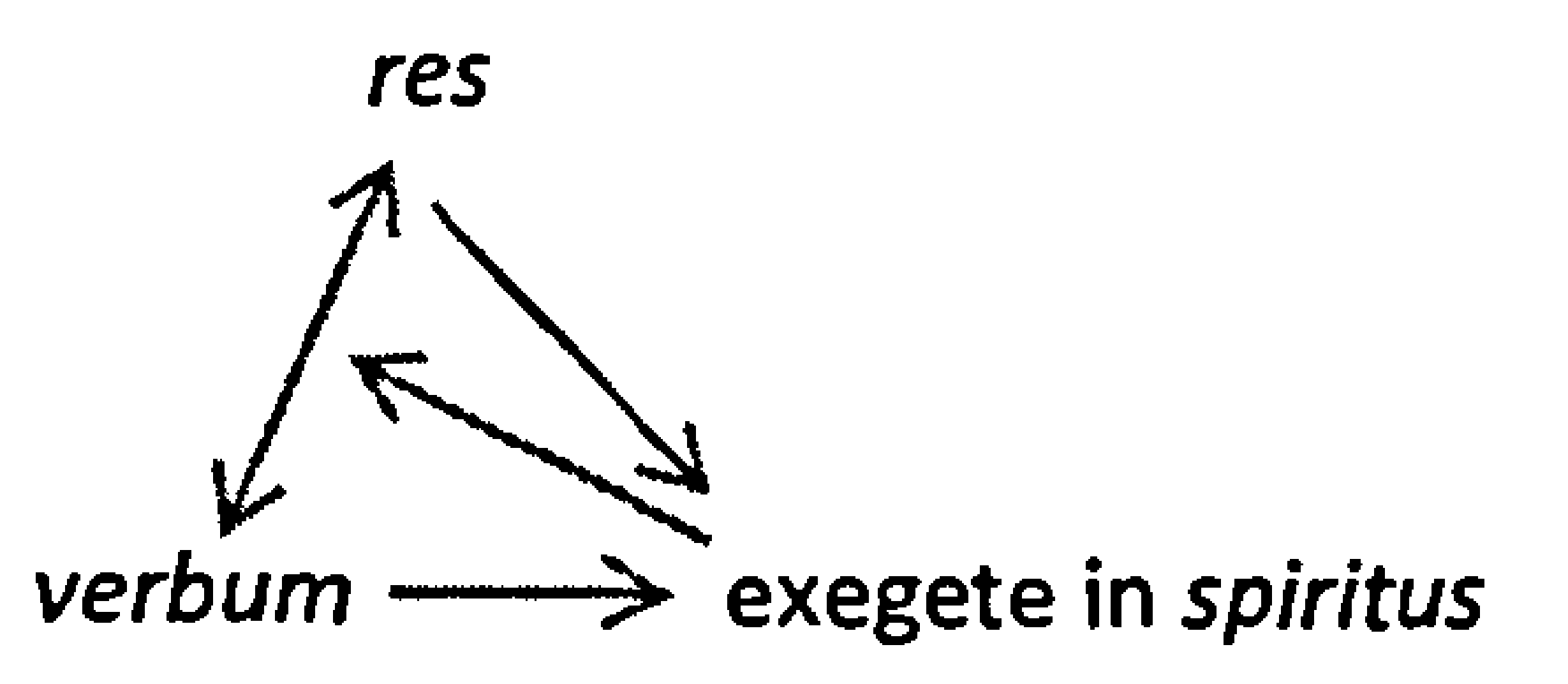

According to this diagram, the exegete is moved by the Spirit-himself emanating from either the Father or from the Father and the $S_{0} n^{323}$ - in order to enable him or her to participate in the eternal relationship of the Father and the incarnate Son. This mutual relation is the Bundesgeschehen that we saw was the content of the res within Barth's theology (3.5.), yet now on the plane of uncreated rather than created time. The Father's creation of Israel, including its fulfilment in the human Christ, as a means of enabling human knowledge of himself, is the unfolding of the ontologically prior self-knowledge of

${ }^{321}$ Cf. McGlasson, Invitation, 193-194: "dogmatics begins with the doctrine of the Trinity in order to orient dogmatic reflection to the God of the biblical witness from the outset and there to discover a God of glorious life and unconditional love."

${ }^{322}$ Childs barely articulates a doctrine of revelation (cf. also Xun, Theological, 271). Nevertheless, in his discussion of the identity of God he makes the kind of statements that have been made so far. See especially Biblical Theology, 82; 351-382 and Driver, Childs, 254-264. The exegetical significance of the distinction between the economic and the immanent Trinity can be seen in Isaiah, 423 . The only explicit reference that Childs makes to Barth's doctrine of "three forms of the Word" (Driver has confirmed this for me) is his expression of enthusiastic appreciation in his unpublished paper, "Exegete," 7, where he notes that for Barth, "The text is alive, it speaks."

${ }^{323}$ This is the subject of the Filioque debate. Barth has his own version of the Filioque: the Spirit proceeds from "the-common-being-of-the-modes-of-being-of-Father-and-Son;" cf. Gureztki, Filioque, 181. 
God the Father by God the Son, the "eternal Israel," who knows the Father perfectly and within whom the exegete must be brought to stand if he or she is to know the Father. ${ }^{324}$ It follows that the three forms of the verbum outlined in our linear diagram-the object to be witnessed to (the human covenant partner), the witness to the object (the prophetic and apostolic witness), and the interpretation of the witness (the church's sach-gemäß and therefore kerygmatic exegesis)-are all contained in the one verbum of this diagram. ${ }^{325}$ They belong to our dimension of reality and yet, in the power of the Spirit, they point beyond themselves to the res. ${ }^{326}$ Hart talks of the "veil of Christ's flesh" becoming transparent "to a depth of reality to which the created form now points and corresponds," 327 with the consequence being that theology must not be too Christocentric. ${ }^{328}$ And yet the res is only known in the human verbum, so that there can be no "discarnate logos." ${ }^{329}$ Just as the Word speaks of the Father, the Father speaks the Word. Does this eternal speaking and obedient responding find its economic expression in the dialectic between Scripture and church tradition, within the church's constant struggle to grasp the whole within the shape of the particular? $?^{330}$ This form of exegesis has been known as allegory, and Louth's defence of the approach portrays it as the salvific overcoming of a "dissociation of sensibility" between "spirituality" and "theology," the heart and the mind..$^{331}$ Be that as it may, locating Scripture and the activity of exegesis itself within the "economic embrace" of the "immanent Trinity" serves not only to potentially sharpen our gaze to the form that Scripture and, as we will see, exegesis, should take, it also serves to make us aware of the true nature of the exegetical task, which is derivative of something prior and far more significant. Exegetical description of the effect of the

${ }^{324}$ Cf. Torrance, "Trinity," 77: knowledge of God belongs to God himself, our knowledge is derivative.

${ }^{325}$ Cf. Diem, Dogmatics, 97: "Through these two witnesses [i.e. Scripture and preaching] the being of Jesus Christ is incarnate historically. ... . Certainly these various times ... have a historical continuity even in earthly history. But again they receive their material identity from a dogmatic presupposition, namely their potential contemporaneity as the speech and action of God."

${ }^{326}$ Christ is ascended in the flesh and some would argue he always had flesh, cf. Jenson, "Us;" Farrow, Ascension.

${ }^{327}$ Hart, "Revelation," 53.

${ }^{328}$ Hart, "Revelation," 53, referring to GD, 91. See Seitz's treatment of the relationship between Father and Son in the Nicene Creed in "Maker."

${ }^{329}$ Hart, "Revelation," 53. See also Guretzki, Filioque, 67.

${ }^{330}$ Cf. Diem, Dogmatics, 178: "the Church is never confronted immediately by Scripture in its bareness. Just as according to the Synoptics Jesus Himself must open to the disciples the mind of Scripture, so that later Church has Apostolic doctrine which with Apostolic authority appeals to the Lord Himself as the key to the right understanding of the Bible." See also 1.

${ }^{331}$ Louth, Mystery. 
interplay of the verbum and the res is not ultimately a matter of communicating information to the curious, it is about the exegete him or herself participating in the eternal communion between God and his "significant other," 332 and thereby becoming a vehicle of salvation and sanctification to others, another form of the one Word of God. This is the substance of canonical Scripture, which is also the substance of reality itself:

[K]nowledge of God [is] a form of participation within the divine life, within God's Self-knowledge into which we are taken as 'secondary, subsequent subjects' (CD II/1, p. 181). The taking up of humanity into the 'event' of God's being is more than simply knowledge, however, it is humanity's salvation - a salvation which is fulfilment, 'the supreme, sufficient, final and indestructible fulfilment of being, ${ }^{333}$

To conclude this section: Talk of knowledge of the substance of Scripture as "the fulfilment of being" brings us back full circle to our opening analysis of Childs' confession of faith in 2.1. There we saw the reason for Childs' entire endeavour was his experience of and desire for "knowledge of God." It is surely not a coincidence that the pattern of events thereby set in motion echoes the "Trinitarian grammar" ${ }^{334}$ we have outlined thus far: Objectified by the activity of a divine Subject (the Father), Childs is moved to enter the community of faith, the "Israel of God" (the Son), and standing within their/His "activity of faith," he becomes a responsive subject himself, yearning for and expecting the visitation of the Spirit and thus the continuance of Its work of "infusion." ${ }^{335}$ Thus, having followed Childs on his journey to Scripture and through that to the ontological ground of Scripture, we find that the prophets and the apostles stood within the very same embrace that moved Childs to analyse their testimony in the first place.

${ }^{332}$ On the importance of maintaining the independent subjectivity of the Persons of the Trinity rather than, say, dissolving them into pure relationality, see Volf, Likeness.

${ }^{333}$ Torrance, "Trinity," 89.

${ }^{334}$ Torrance, "Trinity," 75.

${ }^{335}$ Cf. Farrow, "Church," 116: "The Nature and Purpose of the Church $(\S 9)$ rightly speaks of the church as creatura Verbi et creatura Spiritus. For lex orandi agrees with lex credendi that "without the Spirit there is no seeing the word of God, and without the Son there is no approaching the Father" (Irenaeus, Epid. 7; cf. Rom. 8). The church is that new humanity which God's two hands are molding into the divine image for communion with the Father, which is the church's goal. The Word himself is incarnate as the head of the church, on whose behalf "through the eternal Spirit [he] offered himself unblemished to God" (Heb. 9:14; cf. Eph. 5:25). The Holy Spirit is the church's animator and guide, its cohesive force and fructifying power." 


\subsection{Res and Form Criticism (Childs and Gerstenberger) ${ }^{336}$}

The dialectical nature of the relation between verbum and res can be illustrated by contrasting Childs' canonical approach with that of an Old Testament scholar who shares many of Childs' historical-critical assumptions and yet who differs concerning the nature of the true content and context of those traditions, and thus the most adequate mode of interpretation. ${ }^{337}$ Erhard Gerstenberger, like Childs, affirms that the texts of the Bible are documents of genuine human interpersonal communication and as such cannot be extracted from their sociological context. Again, similarly to Childs, Gerstenberger asserts that in "interpreting texts we must consider immediately the reality behind the text," for, he tells us, "Text without reality does not exist." ${ }^{.338}$ In order to access this dimension of the text, both of these scholars draw on form criticism, which pays attention to the function of the various forms of tradition within a sociological context. The difference in their approach does not consist in their methodological starting point-Gerstenberger and Childs were close colleagues for five years at Yale (1959-1964) before Childs turned to focus on the "final form" - but in their dogmatic starting point, l.e. their understanding of the ultimate content and context of the tradition.

Gerstenberger's perspective is that the major force at work in the editorial growth of the tradition is the human existential question of identity and the regulation of society. Because this is a general human phenomenon that can be observed in many cultures, he concludes that "the formation of the Torah was a very normal process of text production. A particular group ... used older materials in an updated form in order to articulate its own existence, conduct worship services, educate young people, administer justice, and so on." ${ }^{339}$ In light of this ultimate content, the "reality" within which the traditions are situated is their Sitz im Leben des Volkes. Though Gerstenberger may share Childs' convictions about diversity within the tradition, in light of his identification of the primary force at work with the human attempt to understand God (rather than the human response to a God that stands over against it and defines it), it is logical that he denies the possibility of a "Biblical theology. ${ }^{1340}$ Furthermore, this community is a phenomenon of the past: We are not part

${ }^{336}$ I am grateful to Gerstenberger for taking the time to discuss my interpretation of his and Childs' work with me. He has personally confirmed the adequacy of the understanding of his work presented here.

${ }^{337}$ This section thus parallels my comparison of Bultmann and Barth in 4.1, and 4.2.

${ }^{338}$ Gerstenberger, "Canon," 30.

339 Gerstenberger, "Canon," 25.

${ }^{340}$ Note the plural in the title of his book: Theologies In the Old Testoment. 
of this community, we have a different knowledge base and our existential needs are not the same. Thus, if we are to utilize the tradition in the present, our rule of faith lour "canon", as Childs would put it) must be our understanding of "the structure of contemporary reality." This is the Sache that orients our Sachkritik, that gives us "some sort of orientation as to the path and goal of biblical exegesis. The exegete and his or her community pose their problems, ask their questions, open their lives in the face of a God who is ready to help now." ${ }^{341}$ Gerstenberger's conclusion is inevitable: "[W]e have to find our canon in our time." 342

Gerstenberger's existential and sociological framework is clearly etic, yet I have argued that Childs too works with an etic framework. Our grasp of reality never remains the same, so that a purely emic perspective is impossible. ${ }^{343}$ Each generation must formulate anew the question of the nature of the reality within which human culture itself has its being, holding our construals in tension with the phenomena before us. The difference our answer to this broader question makes to our interpretation of the parts can be illustrated by looking at the way Gerstenberger's description of the form, function, and Sitz im Leben of the formation of Scripture in the post-exilic period resonates within a Childsian framework. According to Gerstenberger:

The focal point of all activities probably was the assembly of the congregation. Here all vital concerns met, and here the authoritative will of Yahweh was experienced in the reading of scripture. Divine instructions for the members' life, admonitions, chastisement, absolution, and comfort occurred in the assembly. Thereafter, the Word of God accompanied the members into their daily routines, being remembered, restudied, and rehearsed whenever necessary. ${ }^{344}$

Childs can affirm everything that Gerstenberger has said here. The only difference is that he takes Gerstenberger's language literally. For Childs, Gerstenberger's claim that Israel "experienced" "the authoritative will of Yahweh" is more than a phenomenological description of what Israel said about what it thought had happened, it is a true description of the actual content of that experience. There really is a God, this God really is Yahweh (and not another God), he really did reveal his will in the context of the community of faith,

${ }^{341}$ Gerstenberger, "Canon," 26.

${ }^{342}$ Gerstenberger, "Canon," 26.

${ }^{343} \mathrm{And}$, in the light of progressive revelation, such an attempt is undesirable; cf. 3.6.2.

${ }^{344}$ Gerstenberger, "Canon," 25. For Barth's special sympathy for form criticism see Bächli, Barth, $12,20,25,94$, and 324 . Diem also draws heavily on the logic of "proclamation" as a "function" of Scripture recovered by form criticism (Dogmatics). 
and this act of divine revelation really did "accompany" the Jews as they went from Scripture back to the world. But precisely because Childs takes Gerstenberger literally here, he cannot adopt Gerstenberger's conclusion that "the formation of the Torah was a very normal process." A tradition-historical process generated by the fact of the self-revelation of the named God of Israel is hardly a phenomenon like any other. It also does not follow that Israel's question about either God or its own Identity is the decisive force at work in the process, but rather God's question to us. If we take Gerstenberger's words literally, the "reality" of the text can only be the Sitz im Leben des Volkes (i.e. the "community of faith") in a derivative sense. According to its own testimony, the Volk understood itself to be responding to a living reality other than itself, one that called it into being, sustained it and guided it. Understood now in light of our etic Trinitarian framework (4.3.), it is likely that Childs would say that the true context of both Scripture and community is their Sitz im Leben Gottes, both economically in terms of his plan of salvation and immanently in terms of God's own eternal inner-dialogue. ${ }^{345}$ This is the true reality "behind the text," without which the text "does not exist." In the light of our hermeneutical discussion above, this would mean that it is this reality that ought to provide us with "orientation as to the path and goal of biblical exegesis."

It is time to turn to the hermeneutical implications.

\subsection{Hermeneutical Implications}

\subsubsection{A Historical Tension}

Before looking at Childs' own proposals, a brief historical perspective will set the context. In the light of Scripture's function as a vehicle that reveals the self-same divine reality, one would expect to be able to identify "family resemblances" within the history of the community of faith's interaction with its tradition. ${ }^{346} \mathrm{~A}$ glance at Childs' own analysis of this topic reveals his consistent emphasis on the specifically thematic nature of theocentrically oriented Biblical interpretation (cf. 3.4.), a stance that spans the entire traditionhistorical process from the activity of the first editors to post-Biblical exegesis. This continuity can be illustrated in relation to his analysis of the story of the manna and quail in Exodus 16:1-36.

${ }^{345}$ On Scripture as being God's speech-act, see Webster, Holy Scripture, 5.

${ }^{346}$ Cf. Child, Struggle, 299-324, where Childs identifies six "constitutive features" of traditional Christian exegesis. I have analysed Childs' canonical approach in terms of these six categories in Sumpter, "Childs." See also Trier, Theological Interpretation, 42-43. 
At the level of the composition of the story itself, Childs notes an anachronism: The jar of manna is to be placed "before the Testimony" (v. 34), even though the Ark has not been built yet. In terms of the history of composition, this tension provides evidence for the presence of various originally independent traditions which have only latterly been brought together by an editor. In terms of the purpose of this particular editorial move, however, Childs insists that the editor's desire was to make a theological point: "A jar of manna which is the sign of God's sustaining mercy is kept alongside the tablets of the law. ... [T] point of the text focuses on the testimony that the manna and the tablets belong together before God. In New Testament terminology, the gospel and the law cannot be separated." ${ }^{347}$ The chronological framework is certainly important, for this is the overall shape the tradition has received, yet intersecting and interrupting this sequence is another concern: the nature of God's activity in history. This thematic mode of appropriation continued within the broader canon. Deuteronomy 8 contrasts the manna with bread and suggests that Israel learned humility through the eating of this food. The Priestly writer emphasizes the exact matching of the individual need. For the Psalmist, the failure to respond to the gift of manna provides a major testimony to Israel's unbelief which leads to judgement. ${ }^{348}$ Again, the New Testament continues this basic stance by avoiding the midrashic method, which attempts to "harmonize difficulties and render the material pliable for fresh practical application. ${ }^{\prime 349}$ Childs explains the contrast as follows:

It is theologically significant to note that basically the New Testament does not follow this lead in its handling of the manna stories, although it does make considerable use of midrashic tradition. Rather, it finds its warrant in the Old Testament for selecting certain themes from the variety and elaborating on these. The gift of manna is above all a gracious sign of God's care which sustains a rebellious, murmuring people and seeks to point them to an apprehension of the real meaning of provision through this divine favor. Because this selective process already operates within the Old Testament, the New Testament approach does not provide a sharp contrast, as is frequently the case; rather, it extends and develops the direction taken by Deuteronomy and the Psalter. Even John's use of the tradition, which marks the furthest extension of the Old Testament in the direction of Philo's exegesis, begins with themes which are firmly anchored in the Old Testament. Indeed, his christological interpretation moves far beyond the Old Testament text but retains the central theme of 'heavenly bread which brings life to those who 
eat. $^{.350}$

The thematic focus was continued in later post-Biblical interpretation: "The manna stories were frequently used by the early church Fathers as a homiletical vehicle for a great variety of themes," though often lacking originality in Childs' judgement. ${ }^{351}$ The first real break in this tradition came in the high Middle Ages, when Jews started wrestling with the question of whether the manna was a natural phenomenon or not. The issue was taken over by the Church after the Reformation and continued until the $19^{\text {th }}$ century..$^{352}$

Childs' affirmation of the New Testament's "thematic" approach-in continuity with the Old Testament, he claims-and his resistance to Judaism's "midrashic" mode of appropriation, reflects the basic principle in the canonical process that I have been emphasising: Sacred tradition is theo-referential, not self-referential. If "intertextuality" takes place, its function is "deictic," i.e. it enriches our grasp of a theological reality that can be analysed thematically, beyond the repetition of the letter. Childs sees a basic similarity between this approach and allegory, which he distinguishes from midrash as follows: "Midrash works at discerning meaning through the interaction of two written texts, allegory ... finds meaning by moving to another level beyond the textual. It seeks to discern meaning by relating it referentially to a substance (res), a rule of faith, or a hidden eschatological event." ${ }^{\prime 353}$ When later Christian writers struggled to develop a form of "ruled reading" by which to access Scripture's content, they were thus working out the implications of the basic nature of the genre of the text itself. Interestingly, Childs sees an analogy here between Medieval allegory and historical critical method, for both are committed to going through the text to its extra-textual referent. ${ }^{354}$ The primary difference is their respective understandings of the nature of the referent, the res or the skopus of the text (cf. 4.4.)..$^{355}$ In light of this analogous stance, both approaches also suffer from the same kind of weakness: obliteration of the witness - the sensus literalis-for the sake of an

350 Childs, Exodus, 303.

351 Childs, Exodus, 297.

352 For the details, see Childs, Exodus, 297-299.

${ }^{353}$ Childs, "Intertextual," 182-183. See also Childs, Struggle, 299-322 and Childs, "Allegory." This insight already distinguished Childs from Hans Frel in 1969. See their dialogue in "Interpreter," 56.

${ }^{354}$ Cf. Childs, "Sensus Literalis." See also Barr's response, "Literal," Childs' response to this, "Critical Reflections," and Barr's final response in "Allegory."

${ }^{355}$ Irenaeus appealed to God's one redemptive purpose; Origen appealed to multiple levels of meaning in Scripture in which the reader is led from the external to internal as part of the divine pedagogy; Augustine appealed to God's ultimate intention: love of neighbour. Cf. Childs, "Jesus Christ," 10. 
abstract theory, whether theological or historical (either the sensus spiritualis or "originalis"). Childs lists the parallel dangers as follows: ${ }^{356}$

1. The medieval application of the various senses often threatened to destroy the significance of the literal sense. In the same way, historical criticism threatens to destroy the integrity of the literal sense, which now functions as a window to a historical reality behind the text.

2. Just as within (bad) medieval allegory all control of exegesis was lost through the abuse of the multiple senses, critical biblical interpretation can become a speculative enterprise as the fixed literary parameters of the plain sense dissolve before hypothetical reconstructions.

3. The canonical process which shaped the text to function as scripture for a community of faith is denigrated, as it is now assumed that there are other avenues to truth beside the tradition. The medieval parallel is seen in the tension between text and tradition. Finally, an insurmountable gap arises between the historical sense, now fully anchored in the past, and the search for its present relevance for the modern age. The medieval parallel is seen in the attempt by some Christian theologians to abandon all concern with the literal sense of the text in order to construct a relevant theology.

Given the inseparability of form and content, both the church and the academy must constantly measure their theorizing in light of the plain sense of the text. As we have seen, for Childs this can only be the plain sense of the final form of the text, which was intentionally shaped in order to function as a "critical norm ... on how the tradition functions authoritatively." ${ }^{357}$ Thus having distanced himself from midrash as a viable means of Christian exegesis, Childs affirms that the dangers inherent in allegory mean that interpretation can never ignore the critique of the synagogue. Childs characterizes the hermeneutical tension between these two communities as follows: "Where the Jews were saying, read the text! read the text!, the Christians said, there's something behind the text. ${ }^{\prime 358}$ The Church needs to listen to both, form and substance, and that is part of the

\footnotetext{
${ }^{356}$ Childs, "Sensus Literalis," 90-92.

${ }^{357}$ Childs, "Sensus Literalis," 89.

${ }^{358}$ Childs, "Interpreter," 61.
} 
ongoing "mystery of Israel." "F59 "For the Christian church the continuing paradox of faith lies in its encounter through the Jewish Scriptures with the selfsame divine presence which it confesses to have found in the face of Jesus Christ." ${ }^{360}$ No wonder Childs characterizes Christian exegesis as a "struggle." 361

How, then, should the exegete deal with this tension between form and content? Consonant with the logic of the verbum as a formal medium of a living, personal res the requirements for exegesis include both a formal, text oriented procedure as well as the acquisition of a subjective stance. We look at each in turn.

\subsubsection{A Multiple-Level Approach to Scripture}

Childs calls for "a single method of interpretation which takes seriously both the different dimensions constituting the text as well as distinct contexts in which the text functions. ${ }^{\prime 362}$ He has in mind three levels that must always be held together as part of an integrated whole, although there is no fixed point of entry. The movement is circular, encompassing "both the movement from text to reality as well as from reality to the text..$^{363}$

1. Thus, one avenue of access is the discrete voice of each testament, heard in its own right. This requires attention to historical, literary, and canonical contexts. In classic terminology, this means reading the text for its sensus literalis. Such a move, however, does not involve bracketing out theological questions because, as we have seen, it is the nature of the text to talk about and respond to God.

2. Another avenue of access takes into account the whole of the two-testamental Bible, perceived as a combined witness to one God. A relationship of content is pursued by means of structural similarities and dissimilarities where care is taken not to fuse the contents of each witness. The results should not contradict the literal/historical reading but rather extend it. ${ }^{364}$ "Once again, a theological

${ }^{359}$ Driver's treatement of the "mystery of Israel" greatly aided my understanding of this theme in Childs' thought (in Childs, 184-208).

${ }^{360}$ Childs, "Witness," 64.

${ }^{361}$ The word is common in Childs' writings, though see especially the title of his book: Struggle.

${ }^{362}$ Childs, "Witness," 61. A similar analysis can be found in Biblical Theology, 379-383.

${ }^{363}$ Childs, Biblical Theology, 381.

${ }^{364}$ Cf. chapter 1 of Frei, Eclipse. See also Childs, Biblical Theology, 14. 
relationship is pursued both on the level of the textual witness and on that of the discrete matter (res) of the two collections." 365

3. The final entrance operates on the basis of the Christian confession that the Bible constitutes a theological unity, despite its two-testamental division. Here, the full reality of the subject matter of scripture, gained from a close hearing of each separate testament, is explored. This stage, however, is not a final step. True to the logic of the hermeneutical spiral, we should then return to the text in the light of the "full-blown reality of God" and allow it to affect our perception, yet not in such a manner as to drown out the historical and literary readings. ${ }^{366}$ The sensus spiritualis must be perceived within the sensus literalis.

At this point we may pause to address an issue raised in 3.6.3.3. concerning the actual raw material for exegesis. In other words, which textual version should be read and what is the scope of the canon? This is a good juncture to discuss these issues, for Childs' response to them is analogous to the dialectic between form and substance we have just discussed. In other words, the attempt to move from the plain sense to an apprehension of the fullness of revelation itself parallels both the polarity between the narrower "Protestant" canon and the broader "Catholic" one, ${ }^{367}$ as well the distinction between the protoMasoretic text and the various versions. ${ }^{368}$

\subsubsection{Which Canon?}

Concerning scope, Childs sees two principles at work. On the one hand, the establishment of the scope of the narrower canon was concerned to preserve the purity of the witness. The principle for selection was the decision already made by the community that serves as God's special vehicle of revelation: the Jewish people. "[T]o use a different collection of Old Testament writings from those accepted by the Jews appeared as a threat to the theological continuity of the people of God." ${ }^{369}$ On the other hand, the establishment of the parameters of a broader canon was concerned to emphasize the catholicity of the Christian faith-by which I understand Childs to mean formulations of the fullness of the reality itself-which was expressed in an unbroken continuity of sacred

${ }^{365}$ Childs, "Witness," 62.

${ }^{366}$ Childs, Biblical Theology, 381-382.

${ }^{367}$ These adjectives are cyphers for a more complex historical reality.

${ }^{368}$ For a helpful overview of the technicial details, see Seitz, "Two Testaments" and especially Wagner, "Septuagint."

${ }^{369}$ Childs, Biblical Theology, 65. 
tradition from its risen Lord to his church. ${ }^{370}$ The tension between these competing approaches mirrors the tension between form and content, sensus literalis and sensus spiritualis, verbum and res. On the one hand, one must acknowledge the fragmentary nature of all revelation. In hope that God will act, one reads to grasp the reality witnessed to, starting from within the "inner parameters" of the narrower canon, which Childs associates with "form," and moves towards to the outer parameters of the broader canon and church tradition, which Childs associates with "substance." Childs understands the narrower canon to be a sphere in which one may be confident that this is the place where our theology may be critiqued by the norm of the Word. Yet text and referent are distinct and Scripture as critical norm is insufficient in practice to identify the fullness of the latter, hence the need for the catholicity of church tradition, with its affirmation of a broader yet more ambiguous canon and creeds, which function to guide our grasp of the substance of the Word. Within this dialectic, the exegete "searches" for the Christian Bible, as the "hearing of God's Word is repeatedly confirmed by the Holy Spirit through its resonance with the church's Christological rule-of-faith." ${ }^{371}$

\subsubsection{Which Version?}

The same dialectic is found regarding the relation between the Masoretic Text and the various translations. Given the presence of a significant interpretative element to scribal activity, Childs understands the history of textual transmission to be part of the canonical process. ${ }^{372}$ Nevertheless, consonant with his desire to attend to form and function, Childs also notes a distinction between an earlier and a later phase. The earlier phase was characterized by the freedom with which editors could shape the literature with great hermeneutical effect; the later phase is characterized by a different concern, namely that of textual preservation. This latter phase was "focused on preserving and maintaining the traditions rather than creating them." ${ }^{373}$ Childs argues that in 1 C.E. the proto-Masoretic text had been established by the Pharisaic-rabbinic party as a norm over against tradition. ${ }^{374}$ This is the Jewish community that has survived the destruction of the second

${ }^{370}$ Childs, Biblical Theology, 65.

371 Childs, Biblical Theology, 67.

${ }^{372}$ Childs, Introduction, 523. Cf., e.g., van der Kooij, "Exegese." For an Evangelical view, see Waltke, "Aims," 100; cited in D. Hays, "Jeremiah," 135.

${ }^{373}$ Childs, Introduction, 95.

${ }^{374}$ Here Childs differs to the position of Neusner, who says that Judaism did not make this kind of distinction. Cf. Driver, Childs, 184-193. In defence of Childs' position concerning the period in question, see Groom, Linguistic Analysis, 91. 
temple and, given that Childs is committed to preserving the "ontological unity of the people of God," he respects this community's decision. As such, he suggests that the church's "canonical text" be that which lies behind the Masoretic text: the proto-Masoretic text, that "official Hebrew text of the Jewish community which had reached a point of stabilization in the first century $A D$, thus all but ending its long history of fluidity. ${ }^{1375}$

Nevertheless, as with the "catholic canon," so with the versions: The various translations and recensions were often the result of the coercion of the broader theological matrix that constituted the interpreters' horizon, and as such may provide pointers for the text's appropriation. ${ }^{376}$ As Childs puts it: there is a "dialectical relationship of text and canon which seeks to relate what was written with what was heard. ${ }^{1377}$

\subsubsection{Acquiring the Proper Stance}

In addition to the formal move between "the outer boundaries" of tradition and the "inner boundaries" of Word, the miraculous event character of successful exegesis means that the exegete must also acquire the requisite stance within God's economy of revelation (cf. 2.1.). As for Barth (4.2.), so for Childs, "the interpreter's fuller grasp of God's reality ... is ... a response to a living God who graciously lets himself be known. Much of the success of such an exegesis depends on how well God's presence has been understood. ${ }^{\prime 378}$ As we have seen, there is no method that can guarantee the occurrence of this event (not even the one in 4.5.2.), nor can one conjure up the work of the Spirit. Nevertheless, as we saw above (2.1. and 4.3.), there is a "noetic structure" to revelation, "a logic within the Christian rule of faith." Childs identifies five pointers: ${ }^{379}$

1. The Bible must be regarded as the main vehicle for encountering the living God. "To speak of moving beyond the Bible always signals a return to the wilderness and a loss of divine blessing." 380

2. The Bible accrues its proper authority when it is read and celebrated in the community of the church. That means that the Bible must be read as addressing

${ }^{375}$ Childs, Introduction, 100. As of 1943, this is close to the official Catholic position, cf. Brunert, Psalm 102, 80. Tov points out that the term "Masoretic Text" is "an abstract unit reflected in various sources which differ from each other in many details" (Textual Criticism, 22).

${ }^{376}$ Goldingay, for example, refers to the versions in order to see "whether they raised questions about exegesis or text," (Psalms:1, 12). Note Waltke's account of Justin Martyr's manner of dealing with differences between the MT and Greek translation ("Textual Criticism," 60).

${ }^{377}$ Childs, New Testament, 522-523. Cf. Wagner, "Septuagint" and Seitz, "Two Testaments."

${ }^{378}$ Childs, Biblical Theology, 382.

${ }^{379}$ Childs, "Cultural Change," 210-211.

${ }^{380}$ Childs, "Cultural Change," 210. 
issues of life and death, as a guide for faith and practice, and as a critical theological norm.

3. Faithful interpretation should be able to identify a "family resemblance" with all past interpreters of "genuine understanding and insight" (Augustine and Bernard, Luther and Calvin, Pascal and Wesley, Kierkegaard and Kähler; cf. 4.5.1.). "The likeness arises from the serious encounter with the selfsame God who shapes obedient response into Christian likeness. ${ }^{\text {"381 }}$

4. Faithful reflection also demands faithful action. "Where there is true understanding of the Scriptures, by necessity, there arises an imperative for evangelism and mission, a care for the impoverished and suffering. ${ }^{\text {"382 }}$

5. Finally, the function of the Holy Spirit as a continuing guide in faith means that understanding must grow and be renewed. "Our understanding of the Bible can never be static. Its pages continue to radiate fresh guidance into the knowledge of God and his Son, Jesus Christ." ${ }^{\text {"383 }}$

\section{Testing the Validity of Childs' Canonical Thesis}

How can we test the validity of Childs' thesis? There are two types of validity that need to be accounted for: internal validity (is the proposal internally coherent in itself?) and external validity (does it do justice to the form and content of Scripture?). ${ }^{384}$

Part I of this study constitutes my response to the former challenge. I have attempted to delineate Childs' understanding of Israel's scripture in terms of its form and content in a manner that is rational. By rational I do not mean "rationally required" but "rationally allowable." ${ }^{385}$ One may decide that the theory does not correspond to external reality, but one can nevertheless judge whether the propositions affirmed entail each other. The critical question is whether I have managed to present Childs' approach in such a manner that the correct implications have been drawn from the propositions asserted (cf. 1.). ${ }^{386}$

${ }^{381}$ Childs, "Cultural Change," 210.

${ }^{382}$ Childs, "Cultural Change," 211

${ }^{383}$ Childs, "Cultural Change," 211. For a treatment of this issue within the context of Old Testament theology, see Childs, Theology, 41.

${ }^{384}$ For the distinction, see MacDonald, Metaphysics, 54.

${ }^{385}$ See the helpful discussion in the prologue of MacDonald's Metaphysics (xxi-xxiii).

${ }^{386}$ Cf. MacDonald, Metaphysics, 25-26, 29. 
Part II will respond to the second challenge. In this section I do not claim to prove that Childs' "canonical context" is in fact a necessary requirement for proper exegesis, but that, if it is assumed as a working hypothesis, it is both workable and effective in fulfilling the goal of exegesis. Objectively proving Childs' approach would require measuring it in light of an independent understanding of the form and content of Israel's Scripture, one held to be true according to a commonly agreed standard of truth (cf. 1.). My goals are more humble. I simply wish to do canonical interpretation in terms of the framework outlined above in the hope that it leads to desirable results. I leave it to my reader to judge the value of my interpretation of Childs' approach by the fruit it produces in the following section.

A final clarification is required. We saw in 4.2. that it is only the Holy Spirit who can effect genuine apprehension of the subject matter of Scripture. In light of this "ontological prerequisite," how can it be possible to verify the validity of exegesis? As Childs puts it: "There is no objective criterion by which this knowledge can be tested beyond that of the reality of God himself." ${ }^{\text {387 }}$ This is where the concept of "infusion" becomes helpful, itself an element of revelation's noetic pattern, for it states that the means by which God reveals himself in Scripture is through the practice of exegesis itself. In other words, in the act of revelation the truth of God and the truth of the text become one. The interpreter does not abstract from the text a hidden message, nor does he try and correlate the text to an external ideological structure; rather, he struggles to achieve precisely that which all interpreters-whether explicitly confessional or not-aim at in interpretation: the meaning of the text itself. ${ }^{388}$ The Spirit blows where he wills and no one can know how and when he will work. But the noetic structure within which this happens mirrors that of any other act of reading. In short, the decisive critical question is this: Does the canonical approach illuminate for the reader the meaning of the text itself?

${ }^{387}$ Childs, Biblical Theology, 382.

${ }^{388}$ See Childs' critique of Wolterstorff's special hermeneutic and his endorsement of Thiselton's general hermeneutic in "Speech-act." 


\section{Part II}

Psalm 24: Entering the Dialectic 


\section{A Canonical Approach to Psalm $24^{389}$}

\subsection{The Nature of the Task}

The canonical approach is not a method, as Part I has demonstrated. Rather, it is a network of interrelated propositions concerning the nature of the Biblical text (the verbum), and the ultimate reality within which it subsists, to which it points, and of which it is a vehicle (the res). As we have seen, Childs' interpretation of the verbum was constrained, to a degree, by the question of human intentionality. These texts are kerygmatic in that they "witness" to a divine reality beyond themselves and they are "canonical" in that they do so authoritatively in order to shape future generations of the faith in the truth of God. This witness has a diachronic dimension in that it is multi-layered, yet it also has a synchronic dimension, in that this layering consisted in a theological critique of what went before in the light of a fuller understanding of God, the res of the tradition. The divine reality himself is not only the object of the verbum's witness, but also its subject, being directly involved in its production. This involvement renders a unity that goes beyond the horizon of each individual tradent of the tradition. It also renders possible a unity within the history of faithful interpretation. Finally, this res has a concrete, Trinitarian shape. He is the eternal Bundesgeschehen ${ }^{390}$ who has opened himself into created time in order to bring humanity into that communion (cf. 4.3.).

In Part II I will adopte Part I as my working hypothesis. My goal is to demonstrate that this kind of framework can increase one's "reader competence" and thus serve as an aid for progressing along the hermeneutical spiral towards the reality witnessed to by the text (cf. 1.). ${ }^{391}$ To use Bultmann's terminology, Childs' thesis will aid my Vorverständnis of the text (4.1.). Specifically, drawing upon Part I will mean posing the following kinds of questions to Psalm 24:

${ }^{389}$ The choice of Ps 24 as the text with which to exemplify my understanding of Childs' canonical approach is quite fortuitous. I initially intended to write my PhD thesis on Old Testament anthropology and my supervisor recommend that I start with an exegesis of Psalms 15 and 24. In my research on methodology I became hooked on Childs and the result is the current work. I chose Ps 24 over Ps 15 simply because its content is more multifaceted and thus more interesting (cf. 9.2.3.2.1.).

${ }^{390}$ On the appropriateness of this category as a description of God's being, see Jenson, Systematic Theology:1, 222: $\S 13: \mathrm{VI}, 221-223$. In answer to the question, "What kind of being does God have as the one God?" Jenson claims that God is an event ("God is what happens between Jesus and his Father in their Spirit ... God is what happens to Jesus and the world"), a person ("As triune ... all his acts cohere to make the one act that he personally is"), a decision, and a conversation ("Language is the possibility of historical being; the word as address and response is its actuality").

${ }^{391}$ Barton, Reading, 11. 
- Is Psalm 24 theocentric, and that at all levels of the tradition? $?^{392}$

- Is Psalm 24 kerygmatic, again, on every level of the tradition?

- Can one plausibly and fruitfully ${ }^{393}$ posit the presence of a single divine referent throughout the growth of the tradition as well as parts of its reception history (i.e. is there an "ontological continuity")?

- Can the presence of a divine force be plausibly and fruitfully posited as a factor within the historical growth of the text?

- Can a dialectic between verbum and res be plausibly and fruitfully posited?

- Does the shaping of the tradition function as a theological Sachkritik and does the final form provide a more developed theological horizon (rather than political manipulation, for example) $?^{394}$

The first great challenge to such an enterprise is the enormity of its scope. Christopher B. Hays correctly summarizes the difficulty as follows:

The intellectual entrance fee for writing good theological exegesis must be very steep. If Childs or his heirs want to claim an elevated status for their project, that ambition should come with an even higher standard of training and preparation than "mere" historical-philological scholarship. Childs certainly met any standard that anyone could set, but not every theological interpreter does. ... [T] There are few who can and will ever master all of the necessary skills. It may be that the array of tools one needs to conduct theological biblical criticism is so extensive that canonical criticism is not really a young scholar's game. How then could theological exegesis be carried out without requiring one person to master both biblical studies and theology? ? $^{395}$

I would like to believe that the kind of exegesis that Childs' demanded is not an impossibility and that scholars with Childs' comprehensive vision will not remain a rare species. Nevertheless, as a "young scholar," I recognize my limits and do not claim that the piece of canonical exegesis that follows is the definitive answer to the question of the substance of Ps 24. My goal is more tentative. Part II intends to demonstrate what an

${ }^{392}$ In 3.3. above I distinguished between "theocentric focus," which refers to the intentionality of the tradents, and "theological content," which is a faith commitment on the part of the interpreter that God himself was actually refered to.

393 "Fruitfully," because my purpose is not only to demonstrate the possible viability of Childs' approach but also to demonstrate its ability to improve our understanding of the text at hand.

${ }^{394}$ See sections 3.3, 3.5.4 3.6.3.3 and 4.5.

${ }^{395}$ Hays, "Bard," 151. See H.G.M. Williamson's similar comments in his review of Childs' Isaiah commentary: "He is ... right that most of us stop short of taking this final step in the exegetical task, because there are few indeed who can master both the historical and the theological disciplines that it requires" ("Isaiah," 124). In my opinion, part of the solution to this problem lies in the way in which the theological curriculum in seminaries ought to be structured. 
integrated, cross-disciplinary interpretation along the lines sketched out in Part I may look like, and I hope that those amongst my readers who are specialists in the respective fields will be generous in their critique. My emphasis here is on the potential coherence that can be achieved between the various fields as they orient themselves around the single text of Psalm 24. My claim is that Childs' thesis can help us see this coherence and may therefore help specialists communicate more effectively across disciplinary boundaries in a united effort to achieve a single goal: the illumination of the content of the Biblical text. This does not free me, however, from the responsibility of making my arguments as plausible as possible within the framework of contemporary scholarship. To that end, I have done my best to interact with the secondary literature and naturally expect my interpretation to be critiqued according to the scholarly standards current in each discipline.

\subsection{The Structure of the Presentation}

I will present my exegesis of Psalm 24 according to a similar logic as that found in Part I, i.e. according to a dialectic between verbum and res:

1. Verbum 1 (7.): In this section I will make an initial synchronic (7.3.) and diachronic (7.4.) probe into Psalm 24, inquiring into its literary structure, potential unity, historical contexts, and communicative functions. Following Childs' commitment to general scholarly method (cf. $\underline{3 .}$ ) I will anchor this discussion in a brief review of methodology (7.1.).

2. Res 1 (8.): The foregoing analysis will reveal that the primary force at work in the composition of Psalm 24 was mediated through the experience of the liturgy within the Jerusalem temple as well as the historical experiences of the conquest and the exile (7.4.3.). The centrality of the temple as the originating context for key elements of the psalm raises the question of the nature of the reality that was experienced within the temple. This provides the departure point for an analysis of the "metaphysics of heaven," in particular its shape and the way in which this shape relates to the form and content of Psalm 24.

3. Verbum 2 (9.): The nature of the reality experienced within the temple as well as through history suggests that the singular pattern thus far identified ought to appear elsewhere in the tradition. The immediate literary context of Psalm 24-its superscription (9.1.) and position in the Psalter (9.2.)-as well as the historically related Isaianic tradition (9.3.) provide confirmation of this assumption and sharpen 
our interpretation of the content of Psalm 24 itself. Not only does exegesis highlight dogma, the perspective raised by dogma sharpens our further exegesis.

4. Res 2 (10.): The discussion of Ps 24's relation to its divine source in Res 1 focused on God in se. Yet the doctrine of the Trinity implies an economic dimension: God pro nobis. This dimension of God's reality accords better with the canonical function of Ps 24, understood both on its own as well as within the broader literary context outlined in Verbum 2. This section turns to the preaching of a contemporary systematic theologian (Eberhard Jüngel) (10.1.) as well as the exegesis of the early Church Fathers (10.2.) in order to see how a particular construal of the gospel may both help and hinder our appreciation of the inner dynamic of Ps 24 . In light of this analysis, it is suggested that Douglas Farrow's account of the ascension provides the most promising avenue for further reflection on the substance of Ps 24 (10.3.).

This dialectical presentation also has a linear, sequential logic, which again reflects the presentation of Childs' theory found in Part I. The move from Verbum 1 to Verbum 2 is a move from individual text to its broader literary context. The move from Res 1 to Res 2 is a move from the immanent Trinity to the economic Trinity (cf. 4.3.).

\section{Verbum 1: Form, Content, Context, Function}

\subsection{Methodological Considerations}

We have seen that Childs' approach was strongly influenced by the assumptions of form criticism (3.3.; 4.4.). Although this approach is no longer a dominating force in contemporary interpretation, it is still practiced, albeit with new variations, ${ }^{396}$ and its various concerns continue to live on in other fields of inquiry (speech-act theory emphasizes genre and function; poetics gives the question of form a new dimension). ${ }^{397}$ in order to ground my exegesis in contemporary method I will provide my own summary and synthesis in the light of Childs' concerns outlined in Part I.

${ }^{396}$ Cf. Barton, YABD:2, 839. See the various contributions in Sweeney/Ben Zvi (eds.), Changing Face.

${ }^{397}$ Cf. Blum, "Formgeschichte." In response to his concluding question, "Do we really need the label of 'form criticism' ... ?" (45) I respond that I am simply using it because it is an established term in English scholarship and because of Childs' association with the method early on in his career. 


\subsubsection{Contemporary "Form Criticism"}

"Text without reality does not exist." ${ }^{398}$ This is the slogan of Erhard Gerstenberger (cf. 4.4.), a contemporary practitioner of a mode of interpretation developed initially by Gunkel and put to theological use by scholars such as von Rad, Westermann, Wolff, and Zimmerli. At a minimum, this reality is understood to be the text's human-to-human communicative context (cf. 4.4.) and the means by which this context is identified is an analysis of the text's form, function, and content. ${ }^{399}$ Although recent research has tended to focus on identifying the communicative function of larger chunks of discourse rather than reconstructing original units, ${ }^{400}$ the principles of the discipline as originally formulated by Gunkel are still widely respected. ${ }^{401}$ The centrality of "function," for example, has been highlighted by recent speech-act theory, which seeks to understand the "illocutionary force" of texts, i.e. the task to which language is put. ${ }^{402}$ Again, as in classic form criticism, identifying the illocutionary force of a text requires situating it in its communicative context, and that requires identifying its genre, ${ }^{403}$ i.e. the typical communicative conventions of the culture within which this communicative act takes place. ${ }^{404}$ These considerations, therefore, will be addressed in our interpretation of Psalm 24: We will ask about its genre, which will necessitate inquiring further into its particular content and shape (‥3.), function and communicative context (7.4.).

398 Gerstenberger, "Canon," 30.

399 Cf. Barton, YABD:2, 838-841.

${ }^{400}$ Barton, YABD:2, 839; see especially the various contributions in Sweeney/Ben Zvi (eds.), Changing Face.

${ }^{401}$ On the contemporary relevance of Gunkel, see Blum, "Formgeschichte." Gunkel framed the question of function as follows: "welche Wirkung wird erstrebt?" (Einleitung, 37). Nasuti also argues for the priority of function "as one of the primary determinants of how texts are grouped" ("Sacred Songs," 128). Cf. Van Leeuwen, "Language," 83: "To accomplish a certain function, an artefact must have a certain 'shape' and certain features of content ... So it is with literary genres: their common function creates a recognizable group of features. Genres have a certain gestalt, with functions and features that appertain thereto."

${ }^{402}$ Vanhoozer, "Language," 33, and fn. 73. "The illocutionary act is the touchstone, the aspect that breathes semantic life into what otherwise would be a lifeless chain of signifiers" (34).

${ }^{403}$ Vanhoozer, "Language," 35: "As with langue, so with parole: The general principle is that context disambiguates. ... If understanding is a matter of recognizing the nature of communicative action (e.g., what it is), and if the literary context is the best clue to the meaning of the text as a whole, then identifying a text's genre is of the utmost importance" (emphasis original). Although 1 have drawn on Vanhoozer here, I have done so only to outline speech-act theory as it applies to normal human communication. I am not adopting Vanhoozer's broader attempt to correlate speechact theory with a theory of "Scripture acts" and divine discourse.

${ }^{404}$ Sparks, ATSHB, 10. 
We may note two significant theoretical developments in genre analysis: an increased focus on the particularity of each individual text in contrast to "pure types" 105 and a recognition of the capacity of texts to transcend their original communicative context and speak to new ones. Concerning the former, Sparks draws a helpful contrast between analytical genre, i.e. typical communicative conventions, and intrinsic genre, i.e. the particular, unique act of communication that makes every text ultimately sui generis. ${ }^{406}$ Each composition has a mixture of both the typical and the unique. ${ }^{407}$ Sparks describes their interaction from the perspective of the reader as follows:

At first glance, it seems that the intrinsic uniqueness of each text would create problems for readers, since this implies that every text is in some sense new to us. Although there is some truth in this observation, many of the interpretive problems implied by this scenario are resolved because the text is similar enough to other text types that we recognize. ... This grouping of similar texts ... [helps] us adjust our generic expectations, which may be either broadened or narrowed, depending on the situation. ${ }^{408}$

In relation to Childs' approach, we have seen that he too affirms both elements of continuity and uniqueness in Israel's literary heritage. The cypher "canonical" intends to highlight that which is peculiar to the particular body of literature collected as canonical scripture, despite the generic typicality of much that is contained within it. As far as Psalm 24 is concerned, it will be insufficient to attempt to identify a general category (or a series of categories) within which to set the Psalm, we must also treat it as something unique, with its own profile and individual statement. Generic similarities with other texts serve to guide us to the text itself, to its "intrinsic genre."

${ }^{405}$ Cf. Blum, "Formgeschichte."

${ }^{406}$ Sparks, ATSHB, 10. Blum, citing Richter, makes a similar distinction using the terminology of "genre" vs "form": "'Genre' is ... a concept for an 'ideal' and 'typical' form, which does not exist in reality; it is obtained through the process of selection (abstraction), which holds several features of a form to be characteristic, though it disregards others. 'Genre' is therefore a theoretical result of scholarship; in actual literature only the forms exist. It is, however, not pure theory. For if related forms existed independent of each other, one must conclude that a certain structural pattern has preceded the individual form, which consists of a certain number of structural rules," in Richter, Exegese, 132; cited in Blum, "Formgeschichte," 34, fn. 6.

${ }^{407}$ Conventions are necessary because, as Van Leeuwen puts it, "nothing that communicates is absolutely new ... . The absolutely new is literarily unrecognizable" ("Form Criticism," 75; emphasis original). Longman III makes the following three points concerning genre: "(1) genre explains the possibility of communication in a literary transaction; (2) genre rests on expectations that arise in readers when they confront a text; (3) authors can be coerced in composition to conform to genre expectations" ("Israelite Genres," 182).

${ }^{408}$ Sparks, ATSHB, 10. 
I have mentioned that recent scholarship tends to invest less energy in reconstructing original independent literary units and their sociological contexts and focuses instead on broader units of discourse. This development may be due to a number of factors, such as the uncertainty of the results of such hypothetical reconstructions, the feeling that the fruit of such analysis is of little relevance, or the excitement generated by different critical questions (e.g. redaction or reader-response criticism). ${ }^{409}$ Recent work on Biblical poetics, however, also points out that texts can be intentionally designed in order to speak to new contexts beyond the horizon of the one within which they were originally generated. From within the concerns of form criticism, Van Leeuwen notes that although locating a text in a concrete institution such as "the temple, cult, synagogue, or shrine" ${ }^{\text {"410 }}$ is helpful, it is not necessarily the most important determinant of meaning. Rather,

More helpful is to ask concerning the human functions and problems that a genre seeks to address. ... [F]or example ... Matters of religion are human functions, and while certain institutions may specialise in those functions, prayer, adoration, celebration, sacrifice, piety, and religious instruction are not per se institutional functions. One must ask of genres, What recurring human problem, general or particular, is this piece of communication seeking to address or solve ? $^{411}$

This insight is particularly helpful when it comes to analysing the kinds of texts found in the Bible which have intentionally obscured their original function for the sake of a theological witness to later generations of faith (cf. $\underline{3.6 .6}$..$^{412}$ Van Leeuwen's insights on this matter will be particularly helpful for our analysis of the kind of text that Psalm 24 is, so 1 quote him at length:

... literary production permits the adaptation of primary genres to new contexts, functions, and the creation of new genres based on the extension and combination of primary oral or inscriptional genres, or of previous literary genres. This generic fecundity is rampant in Scripture, both on the micro- and macrolevels.

This means that while all human utterances and writings employ genres and possess social location and function, it does not follow that writings always reveal their social or historical settings. Genres can be adapted for a variety of purposes outside their original contexts, whether oral, inscriptional, or literary. Specifically, genres and their subunits can be adapted in a literary culture into

409 YABD:2, 839.

${ }^{410}$ Van Leeuwen, "Form Criticism," 82.

411 Van Leeuwen, "Form Criticism," 82.

${ }^{412}$ A basic characteristic of most of the Biblical literature, according to Childs. See Childs, Introduction. 
larger works, for purposes different from their original ends. The power of genres is that even when modified and adapted, their original, primal force is evoked. Indeed, larger literary works ... often serve not a specific life setting but many, and try to address human existence comprehensively, by creating a literary world that implicitly encompasses all human situations. One must distinguish life setting as a generative source of genre (via the author) from the implicit life setting that is intrinsic to a genre's meaning (as when a poet writes a love poem). Both of these types of "life setting" must be further distinguished from life setting as communicative target, that is, of those to whom the literary [sic] wishes to speak. The last is initially local, but may ultimately be universal in its intended audience. ... what Gadamer called the text's Wahrheitsanspruch. What more-than-local truth claims are being made about reality in forms and language alien to $u s ?^{413}$

This again links up with Childs" understanding of the "canonical process" (3.6.) in which sacred traditions (generated in a life setting as their source) went through a process of reinterpretation (e.g. "extension," "combination"), oriented towards a particular theological goal (Wahrheitsanspruch) for a future audience that no longer shares in the original context (life setting a communicative target). Whereas Childs talks of hermeneutical reshaping, Van Leeuwen talks of the creation of a "literary world." The implication is that although the original setting remains relevant (their "original, primal force" may continue to be evoked), the literary medium can be exploited in such a manner that the text becomes relatively self-referential; it sets the co-ordinates for its own interpretation. For Psalm 24, then, we will have to look for indications of literary artistry, inquire into their function as well as ask about the continuing effect of older genres on the newer context.

Some scholars ascribe the ability of a text to become its own context to that particular function of language that Jakobson calls "aesthetic" or "poetic." Given its hermeneutical significance, we will look more closely at the nature of this linguistic function.

\subsubsection{The "Poetic Function"}

The poetic or aesthetic function within an act of communication is a "relational concept" in that it exists alongside a number of other linguistic functions (e.g. expressive, appellative,

${ }^{413}$ Van Leeuwen, "Form Criticism," 81. See Sparks, ATSHB, 8, for more details on "generic assimilation" and "generic extension." This dimension of genre is also recognised by Kreuzer/Vieweger, if only as a Randbemerkung: "Gattungen unterliegen daher im Verlaufe einer langen Geschichte Veränderungen. Die Gattungsgeschichte geht diesem Entwicklungprozess nach und versucht dabei, die zu untersuchende Einheit in diesen Entwicklungsprozess einzuordnen," (Proseminar, 78). The focus here, however, is on the development of the "generic convention" itself, rather than the particular text which creates its own genre 
or denotative). ${ }^{414}$ The meaning of a text is constituted through the interplay and relative prominence of these various functions. Jakobson, for example, claims that epic poetry, the lyric, and poetry are all dominated by the "poetic function," yet their varying relations to the other communicative functions means that they cannot be reduced to one genre called "poetry." ${ }^{415}$ With this understanding we find that Jakobson's theory is in accord with our discussion of form criticism above (7.1.2): No matter how much the poetic function dominates a particular text, interpretation cannot ignore its broader historical and ideological context (on the latter, see 7.1.2.3. below). ${ }^{416}$

The poetic or aesthetic function within an act of communication "comprises the focus within the verbal message on the verbal message itself." ${ }^{417}$ In other words, the focus is upon the form or the design of the message as a means of communication, rather than simple referential description. In particular, Jakobson and his followers understand this form to consist in "parallelism" or "juxtaposition," whereby the linear sequence of, say, a predominantly referential text, is replaced by a series of repetitions characterized by "equivalence in difference." 418 This sameness and contrast is used as the major means of constructing the whole sequence of the text. ${ }^{419}$ As Berlin describes it: "One selects from a group of similar or paradigmatic elements, and one then arranges the selected item, along

\footnotetext{
${ }^{414}$ Waugh, "Poetic Function," 57-58; Sternberg, Poetics, 40.
}

415 "Epic poetry, focussed on the third person, strongly involves the referential function of language; the lyric, oriented toward the first person, is intimately linked with the emotive function; poetry of the second person is imbued with the conative function and is either supplicatory or exhortative, depending on whether the first person is subordinated to the second or the second to the first" (Jakobson, "Poetics," 357; cited in Waugh, "Poetic Function," 59). Waugh talks of a "hierachization" of functions within a text, so that it "is the relations between the major functions which are relevant, rather than any absolute and isolationist definition of any particular function" ("Poetic Function," 58, 59). On the relationality of the functions, see also Landy, "Jakobson," 112, and Sternberg, Poetics, 40.

${ }^{416}$ Waugh, "Poetic Function," 72-73: "a poem does not exist in a vacuum: it is part of a general historico-cultural context and indeed depends on that context for its interpretation. Nor is it sealed off from a literary context. It may adhere to or, on the contrary, combat literary norms and values, but in some way the literary conventions of the times are relevant; the poetic code or codes which exist with the poem provide an important, overarching context; and a given poem may be meant for certain kinds of readers and certain kinds of reading, etc. In this respect, the poem is highly contextualized." See also Weber, "Entwurf," 135. This dimension of the text often goes under the vague rubric of "intertextuality." See La Neel-Tanner, Intertextuality, for the various way of conceiving this phenomenon and possible applications to the Psalms.

${ }^{417}$ Waugh, "Poetic Function," 58 (emphasis original). What follows is my summary of Waugh's summary of Jakobon's approach. This article is cited approvingly by Miller (Israelite, 245-248; 668) and Berlin, Parallelism, 10-13.

${ }^{418}$ Jakobson' famous formulation is as follows: "The poetic function projects the principle of equivalence from the axis of selection into the axis of combination" ("Poetics," 358; cited in Waugh, "Poetic Function," 63). On the non-linearity of poetry, see also Niccacci, "Poetry."

${ }^{419}$ See also Berlin, Parallelism, 6. 
with items selected from other groups, into a contiguous or syntagmatic chain. ${ }^{\text {"120 }}$ The elements to be juxtaposed apply to every level of the language, including phonetics, grammar, lexis and semantics, 421 and their pairing can extend beyond poetic lines to include larger sections of text, such as the strophe, stanza, or even entire poems (cf. 9.2.3.2.1.). As a result of this particular kind of structuring, the linearity that is proper to most texts is not only altered, it is enriched by a non-linear dimension, for now "it is the interpretive relation between linguistic signs which is important. ${ }^{1022}$ We will look at each in turn.

\subsubsection{Linearity}

According to Robert Alter, despite the repetitiveness that often obtains between parallel pairs, there is a general pattern or "rule of thumb" by which a semantic shift takes place as the reader moves from colon A to colon B. This movement consists in a "heightening or intensification ... of focusing, specification, concretization, even what could be called dramatization." ${ }^{423}$ Alter characterizes this "structure of intensification" as "incipiently narrative,"

If ... one recognizes that the semantic orientation of the system of apparent repetitions ... is toward a focusing, a heightening, a concretization, a development of meaning, it is possible to see that the movement generated between versets [i.e. cola] is then carried on from line to line into the structure of the poem. ${ }^{425}$

It follows that our interpretation of Psalm 24 should be sensitive to this sense of subtle linear development.

\subsubsection{Non-linearity}

Despite this sense of "narrative" development, parallelism also complexifies the sequence, for the pattern of juxtapositions weakens "metonymic or syntagmatic relationships-i.e., the relationships of contiguity in time and space, and of cause and effect," ${ }^{426}$ in favour of metaphorical or paradigmatic relationships. ${ }^{427}$ Berlin talks of

${ }^{420}$ Berlin, Parallelism, 7.

${ }^{421}$ These categories provide the framework for Berlin's own analysis in Parallelism.

${ }^{422}$ Waugh, "Poetic Function," 67.

${ }^{423}$ Alter, Poetry, 19. See also Yonah, "Expanded Repetition," who describes the semantic relation between many parallel terms as "hyponomia" (590, fn. 17).

${ }^{424}$ Alter, Poetry, 28.

425 Alter, Poetry, 29.

${ }^{426}$ Lodge, Writing, 104; cited in Waugh, "Poetic Function," 66-67. 
parallelism's "binocular vision": "Like human vision it superimposes two slightly different views of the same object and from their convergence produces a sense of depth." ${ }^{\prime 428}$ The result is that that "the relation between word and object is called into question," thus problematizing a 'literal' (i.e. referential) reading of the text. ${ }^{429}$ This "profound alteration of the referential function ${ }^{\prime 430}$ is significant in light of the centrality of referentiality for Childs' understanding of the text of the Bible (e.g. 3.3.). Poetry's self-contained structure does not dispense with referentiality, it enriches it. Waugh, for example, can say that where the poetic function predominates, the "denotative precision arrived at by 'practical language' gives way to connotative density and wealth of associations." ${ }^{431}$ The terseness of juxtaposition, which does not provide an explicit explanation of the nature of the relationship, creates an interpretive "gap," an "ellipsis," that invites the interpreter to "oscillate between semantic planes" and "acknowledge possibilities of the code. ${ }^{\mathbf{4 3 2}}$ Thus, "with a minimum of means a maximum of meanings is generated." 433

The consequence for our interpretation of Psalm 24 is that we must relate the sequential dimension to the symmetric (cf. 7.3.2.4.3.2.).

\subsubsection{Ideology}

As stated above, the "semantic fecundity" generated by the internal structure of a poetic text is just one function among others. It serves a particular communicative goal and must be interpreted in relation to it. This relates to another important element of Childs' canonical thesis: The texts of Scripture are theocentric (3.3.) and they are oriented towards

${ }^{427}$ Waugh, "Poetic Function," 68. Sternberg takes a similar stance in relation to narrative art (e.g. Poetics, 43, 47). See also Weber, "Entwurf," 134-135, who, citing Lotman, "Vorlesungen," talks of the poem as "eine mehrdimensionale, eine räumliche bzw. Stereometrische Struktur."

${ }^{428}$ Berlin, Parallelism, 99. See also Alter, Poetry, 10, citing, Shklovsky from"Art": "The purpose of parallelism, like the gerenal purpose of imagery, is to transfer the usual perception of an object into the sphere of a new perception - that is, to make a unique semantic modification." Cf. Weber, "Entwurf," 132: grasping the form of a text is important, "weil in seiner ,Gestalt" eben wesentlich der "Gehalt' zum Vorschein kommt."

${ }^{429}$ Waugh, "Poetic Function," 67, 68.

${ }^{430}$ Waugh, "Poetic Function," 68. See also Ellen Davis, "Psalm 22," for an illustration of the capacity of the poetic function to "demand of its audience a high level of imaginative engagement, not only with the language of the text, but, more deeply, with the reality to which it refers" (95; emphasis mine).

${ }^{431}$ Erlich, Formalism, 185; cited in Waugh, "Poetic Function," 68. Cf Jakobson, "l'art poétique," 542: "il s'agit dans le langue poètique [sic] d'un changement essential du rapport entre le signifiant et le signifié, ainsi qu'entre le signe et le concept;" cited in Waugh, "Poetic Function," 67.

${ }^{432}$ Waugh, "Poetic Function," 68, 73, respectively.

${ }^{433}$ Waugh, "Poetic Function," 73. This is not to say that Waugh believes that there is no determinate meaning, cf. p. 74: there is also "equivalence under isomorphic transformations." 
instructing future generations in the faith (cf. 3.3.3.). The relation between the "ideological" function and poetics within Scripture has been particularly emphasized by Meir Sternberg. ${ }^{434} \mathrm{His}$ basic thesis is that the primary goal of Biblical narrative art is "ideological," by which he means it serves the purpose of inculcating a particular view of God, the self, and the world. ${ }^{435}$ As far as Biblical narrative is concerned,

... it is hard to separate the ideology from the art. ... Its model of story telling ... adopts techniques for their functional value rather than any intrinsic worth. And among the principles that determine tactical choice, the glorification of God largely figures. ${ }^{436}$

As such, the Bible "follows its own code in suiting a poetics to a world picture. ${ }^{0437}$ This is not to say that the Bible necessarily invents its own poetics (though Sternberg does think that Israel's "ideology" is responsible for its creation of "realistic narrative"), it is to say that it draws upon the techniques at its disposal and uses them to serve its own theological goals. As such, the Biblical narrator is an "artful ideologist."

True to his thesis, Sternberg goes on to make explicit theological statements about the content of the faith of the authors of the segments of Biblical literature that he is interested in. He talks of a "cultural [i.e. theological] imperative" that "addresses a people defined in terms of their past and commanded to keep its memory alive," which commandment they incorporated into the "narrative texture and composition" of their traditions. ${ }^{439}$ This explains the overwhelming presence of history, ${ }^{440}$ yet it is a history guided by a particular kind of God with his own goals for the people that are constituted by that history. Through the particular art of the narrator, "God shapes the world plot with a

${ }^{434}$ Poetics. This book is cited by Childs in critique of those literary approaches which bracket this dimension out (Biblical Theology, 20).

${ }^{435}$ As such, his use of the term is different to its popular meaning as unethical manipulation. For lack of this kind of ideology in the Bible, see Miller, Isroelite, 629-647. Sternberg's talk of "goal," "purpose" or "communicative function is equivalent to speech act theory's "illocutionary stance." See his appreciation of the theory in Poetics, 9.

${ }^{436}$ Sternberg, Poetics, 119. See also the section "Form and Doctrine," 35-40.

${ }^{437}$ Sternberg, Poetics, 179.

${ }^{438}$ Sternberg, Poetics, 38. This approach has a different emphasis to that of Miller (/sroelite, 233249), whose approach to the question of the theological significance of poetry in the Bible is more to inquire into the nature of poetry per se, rather than to look at the kind of theology the poetry is made to serve.

${ }^{439}$ Sternberg, Poetics, 31.

${ }^{440}$ As we have seen (7.1.2.1.), even within poetry there is a strong "narrative impulse" (Alter, Poetry, 28). 
view to getting his creatures to 'know' him." ${ }^{441}$ Yet there is an important epistemological gap separating this God from those he would reveal himself to, one which needs to be maintained. To this end, the Bible's "unique rules of discourse" are deployed to educate the reader concerning his finitude, God's magnitude, and the need to stay constantly engaged with this God through an interpretive process Sternberg calls the "ordeal of understanding." 442 This function is realized through techniques such as "objective" depiction, multiple viewpoints and intentional ambiguity created through "gapping" (cf. 7.1.2.1.). Biblical aesthetics "twists" the way to knowledge, exposes us to our ignorance, and forces us to evaluate agents and actions according to particular norms that are revealed piecemeal throughout the entire composition. Consonant with the poetic function discussed above, in poetic narrative part and whole are interrelated so that reading is an ongoing process, a dialectical movement between each pole. Sternberg summarizes as follows:

Biblical history ... stretches as a long series of demonstrations of divine power followed by tests of memory, gratitude, inference from precept and precedent, or, in short, of "knowledge," with further demonstrations staged in reward and punishment. God ultimately figures not only as the norm and source but also as the object and tester of knowledge. And by the narrator's art, the historical tests applied to the fathers in the world are perpetuated in the discourse addressed to the sons as a standing challenge to interpretation. ${ }^{443}$

It is not necessary to go into the details of Sternberg's understanding of the Bible's poetics and ideology; it is sufficient to note that this theological dimension is an integral part of the context of a poetic composition and thus must be factored into an interpretation of the text. Whereas Jakobson's poetics makes room for a variety of functions within a piece we may wish to call "poetry," Sternberg highlights the centrality of

441 Sternberg, Poetics, 48. According to Childs, this is the purpose, the goal toward which God's self disclosure pointed: "God revealed himself that all may see and know how God is" (cf. Isa 45:5-7) (Old Testament, 45).

${ }^{442}$ Sternberg, Poetics, 47.

${ }^{443}$ Sternberg, Poetics, 48 . On the relationship between theology and composition in the minor prophets, see Seitz, Prophecy. Von Rad was also sensitive to the theological function of Biblical poetics: "Die künstlerische Eigenart der Dichtungen Israels steht zweifellos in einem sehr engen ... Bezug zu seinem Glauben, von dem sie letztlich ihre Prägung empfangen haben. Denn der Glaube ist es, der sich die Form und den Stil schafft" (Theologie:I, 362). Von Rad does not, however, explicate the significance of, for example, the "asyndetic" juxtapositions that characterize Hebrew poetry. The benefits this awareness would have had for his interpretation for creation, for example, can be seen if one compares his interpretation of the relation of creation and history in the Psalms (in Essays, 131-144) with Berlin's interpretation of Psalm 114 (in "Psalm 114). Robinson also wrestles with the theological function of poetry in "Songs." 
theology to an understanding of Biblical poetics. My own position on this matter will arise in the course of interpretation (see especially 7.3.2.4.3.2.).

\subsubsection{Structure of Presentation}

In the following sections (7.2), the methodological insights sketched out above will be distributed over two parts (7.3.; 7.4.). After the translation and text critical notes, the first part will deal with the "synchronic" dimension of the text, the second part will look at the "diachronic" dimension. Although this separation is ultimately artificial (for the poetic function is a "relational concept," cf. 7.1.2.), for analytical purposes this prior emphasis on the particularity of the text will set the parameters for interpreting its historical contexts and functions. ${ }^{444}$ Thus, in 7.3 . I will be looking at "the verbal message itself" in terms of the "literary world" created by its text internal syntagmatic and paradigmatic relationships. We will see that "gaps" are created, which "twist the way to knowledge" and invite us to explore the "possibilities of the linguistic code." This will provide the context for exploring in 7.4. issues of analytical/intrinsic genre, both in terms of source as well as communicative target. The most significant element of the analysis will be our determination of the psalm's "illocutionary force," especially as this relates to the "human functions and problems" addressed by the author(s). In the following section (‥8) we will think more thoroughly about Gerstenberger's form critical maxim: "Text without reality does not exist" (7.1.1.).

\subsection{Text and Translation}

\subsubsection{Translation and Poetic Structure}

The letters in superscript refer to the text critical comments in 7.2.2. The choice of translation is discussed in the commentary below (7.3.2.).

\begin{tabular}{|c|c|c|c|c|}
\hline $\begin{array}{l}\text { Strophes } \\
\text { and } \\
\text { stanzas }\end{array}$ & $\begin{array}{l}\text { Verses } \\
\text { (MT) }\end{array}$ & Cola & Translation & Masoretic Text \\
\hline & 1 & & Of David. A psalm. & לְדְוֹד מִזְמוֹר \\
\hline 1 & & a & Yhwh's is the land and what fills it, & 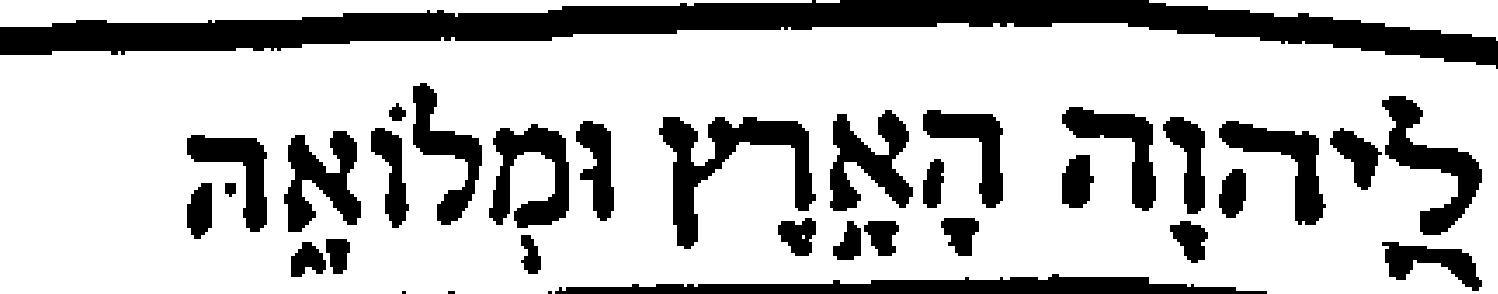 \\
\hline
\end{tabular}

${ }^{444}$ This is standard practice now amongst many form critics. See, e.g., the editor's forward to the FOTL series by Knierim/Tucker.

${ }^{445}$ The suffix is technically a subject rather than an object suffix, in contrast to $1 \mathrm{~b}$. However, 1 have opted for this translation in order to maintain the end rhyme of the third person feminine suffix which rounds off every colon. 


\begin{tabular}{|c|c|c|c|c|}
\hline & & b & $\begin{array}{l}\text { World-Disk }{ }^{446} \text { and those who }{ }^{c} \text { inhabit } \\
\text { it, }\end{array}$ & 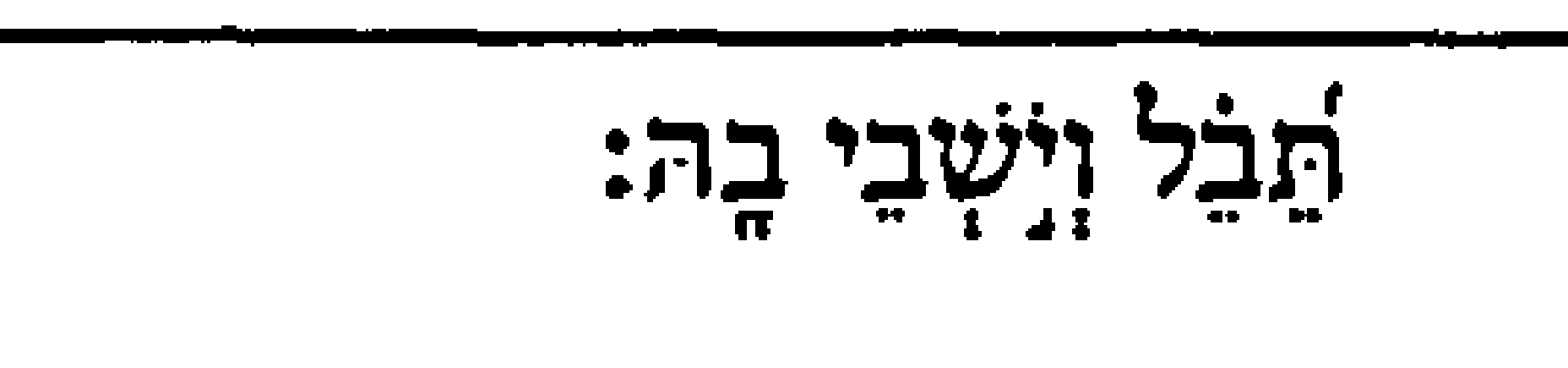 \\
\hline & \multirow[t]{2}{*}{2} & $a$ & $\begin{array}{l}\text { for }{ }^{d} \text { he is the one who, upon the seas, } \\
\text { founded it }\end{array}$ & 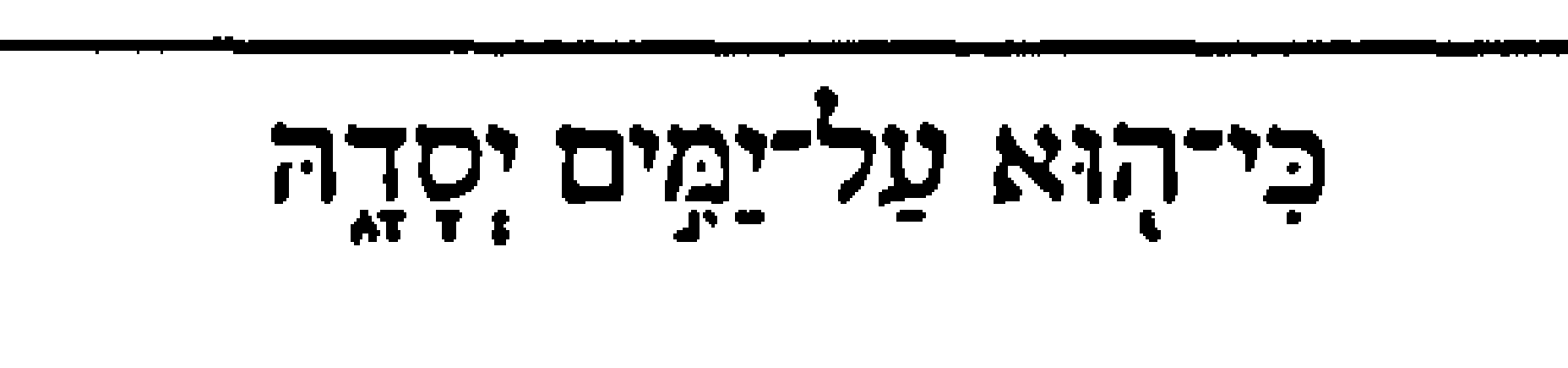 \\
\hline & & $\mathrm{b}$ & and upon currents established ${ }^{{ }^{*}}$ it. & 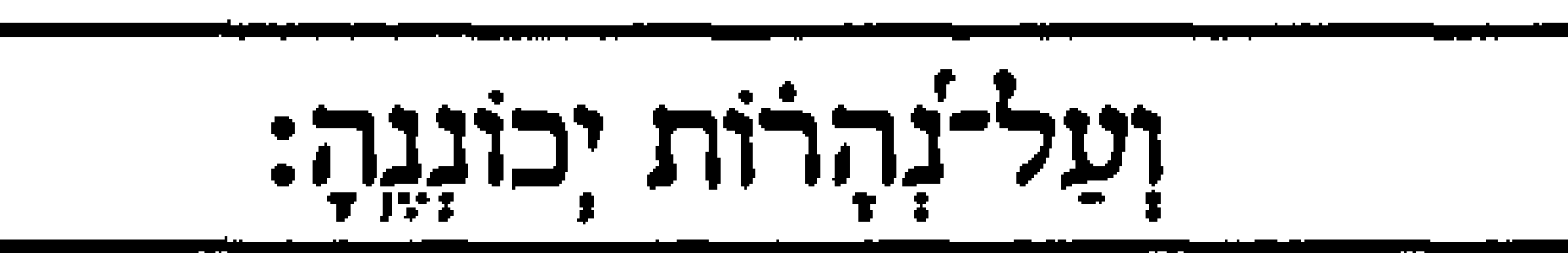 \\
\hline \multirow[t]{5}{*}{$\| \mathrm{A}$} & \multirow[t]{2}{*}{3} & a & Who may ascend Yhwh's mountain? & 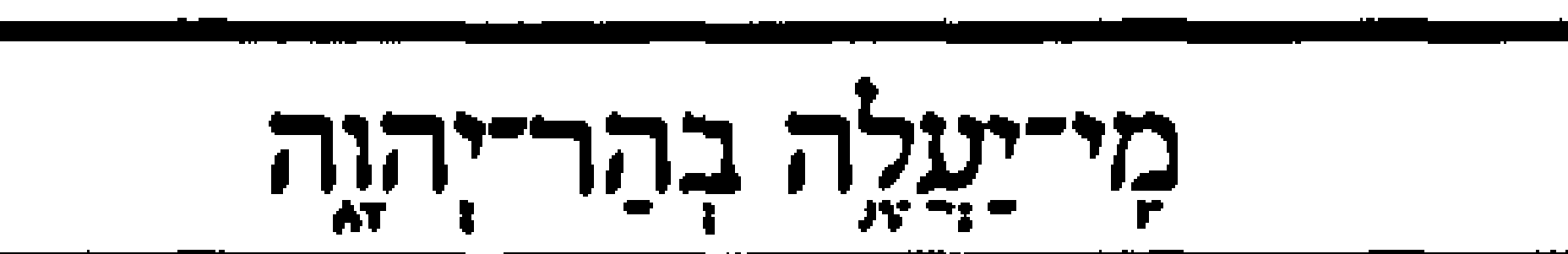 \\
\hline & & $\bar{b}$ & $\begin{array}{l}\text { And who may stand in the place of } \\
\text { his holiness? }\end{array}$ & 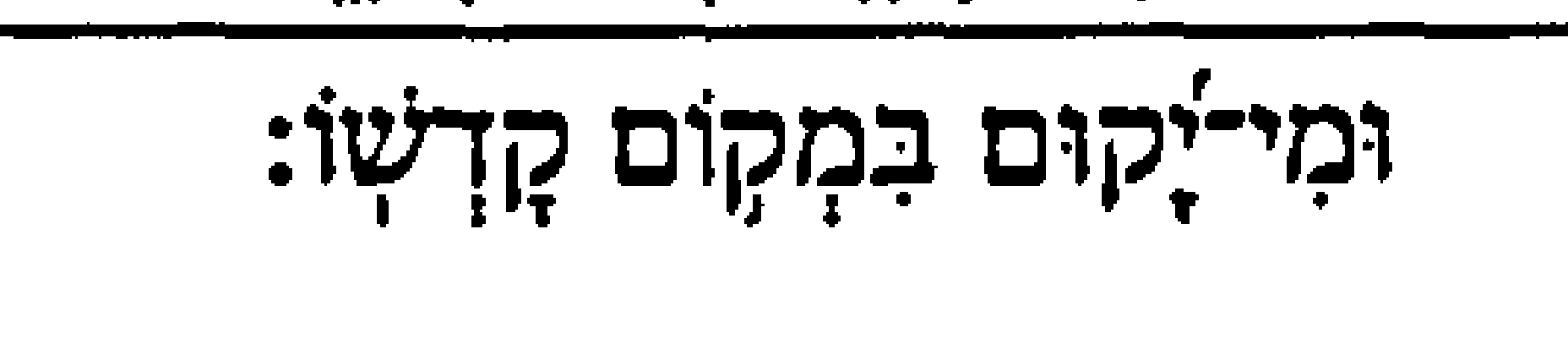 \\
\hline & \multirow[t]{3}{*}{4} & $\bar{a}$ & $\begin{array}{l}\text { One innocent of deed and pure of } \\
\text { disposition, }\end{array}$ & 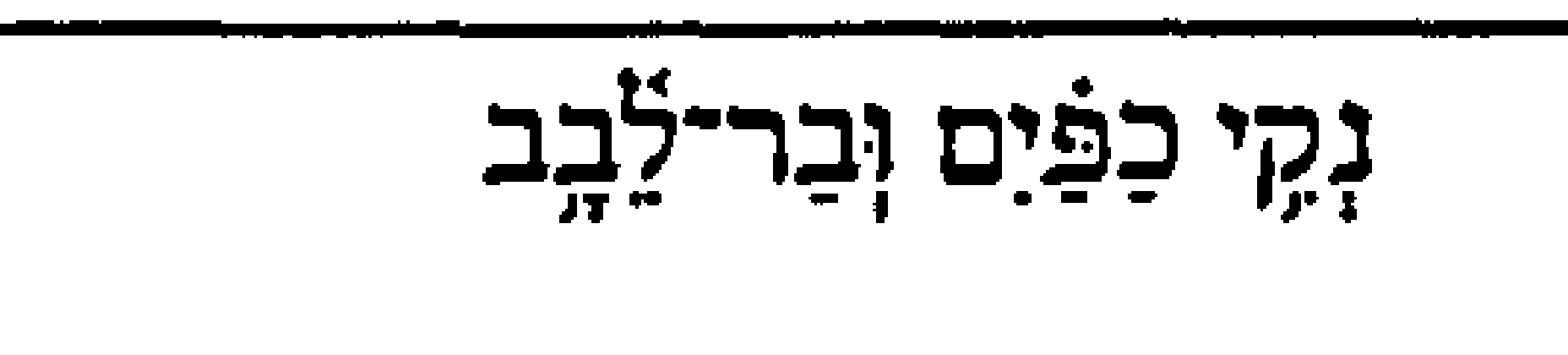 \\
\hline & & $\bar{b}$ & $\begin{array}{l}\text { who has not set his heart ' upon } \\
\text { deceit }\end{array}$ & 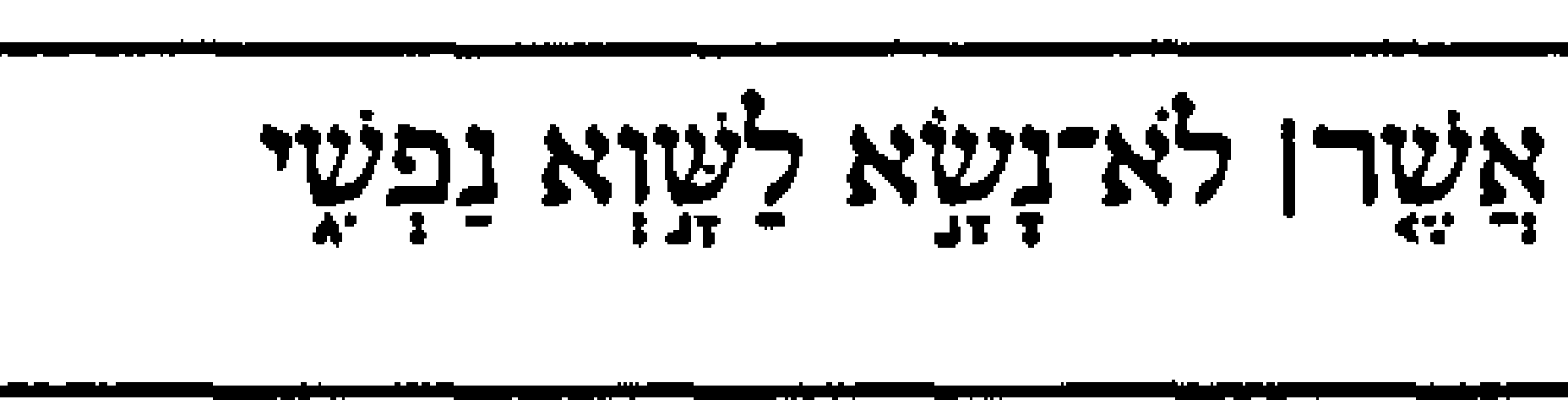 \\
\hline & & c & and has not sworn to deceive. & 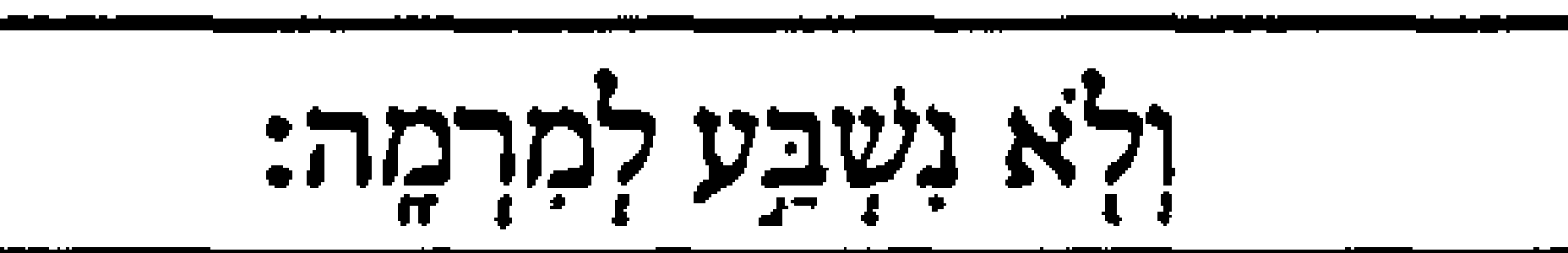 \\
\hline \multirow[t]{4}{*}{ II B } & \multirow[t]{2}{*}{5} & $\mathbf{a}$ & $\begin{array}{l}\text { May he / He will receive a blessing from } \\
\text { Yhwh }\end{array}$ & 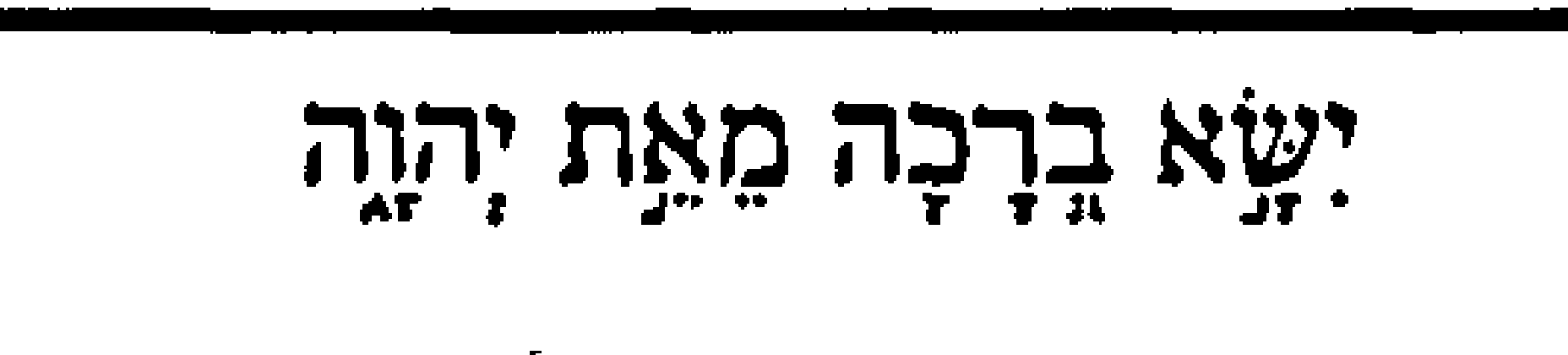 \\
\hline & & b & $\begin{array}{l}\text { and a righteous act from the God of } \\
\text { his salvation. }\end{array}$ & 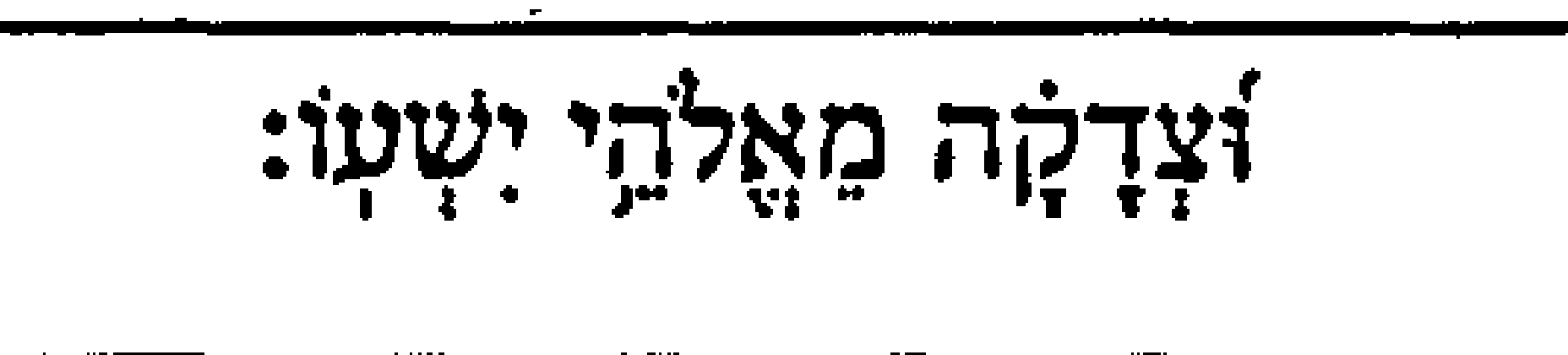 \\
\hline & \multirow[t]{2}{*}{6} & a & $\begin{array}{l}\text { Such is the generation of those who } \\
\text { seek him, }\end{array}$ & 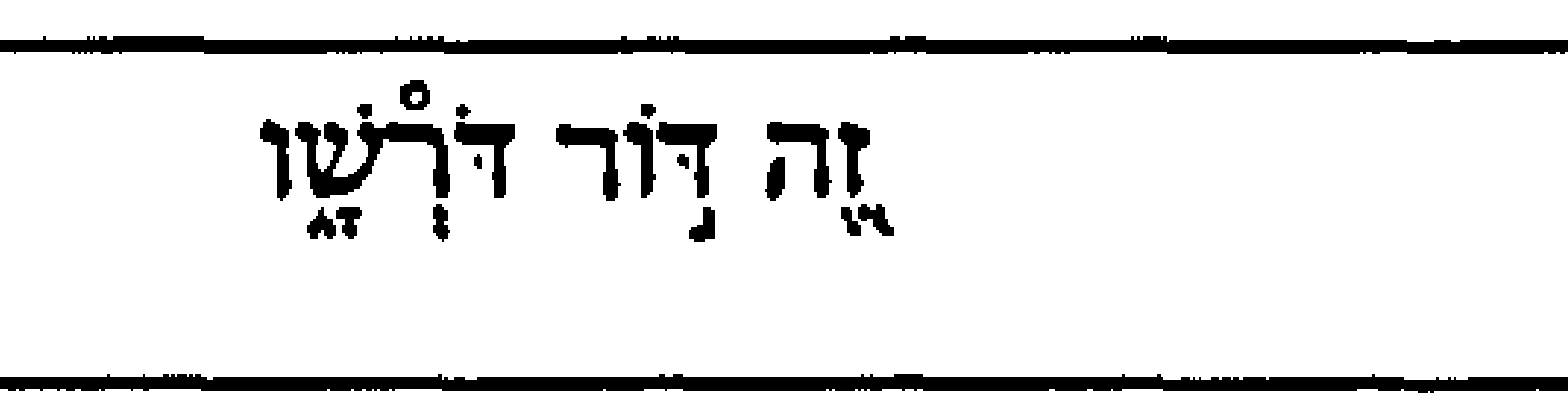 \\
\hline & & $\bar{b}$ & $\begin{array}{l}\text { who search out your face: Jacob. } \\
\text { (Selah) }\end{array}$ & 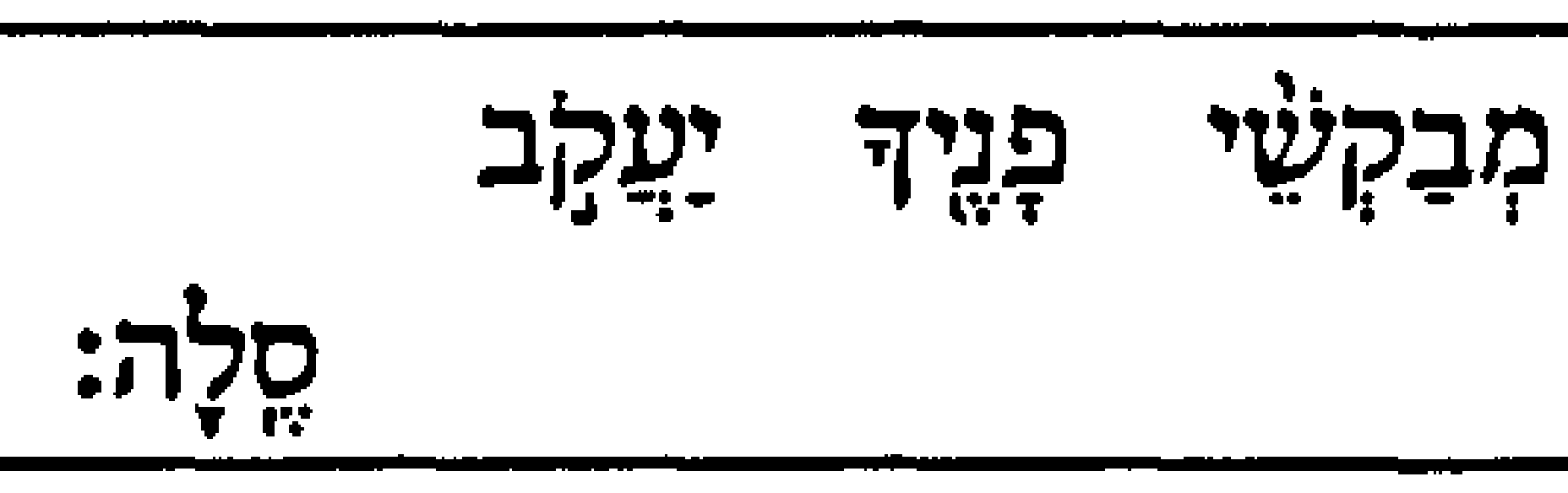 \\
\hline \multirow[t]{6}{*}{ III A } & \multirow[t]{3}{*}{7} & $a$ & Life up your heads, gates & 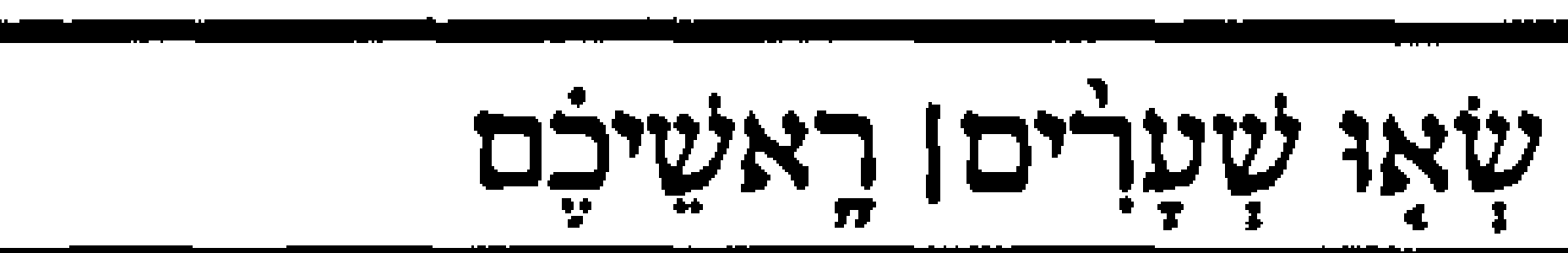 \\
\hline & & $\bar{b}$ & $\begin{array}{l}\text { and lift yourselves, entrances of } \\
\text { eternity }\end{array}$ & 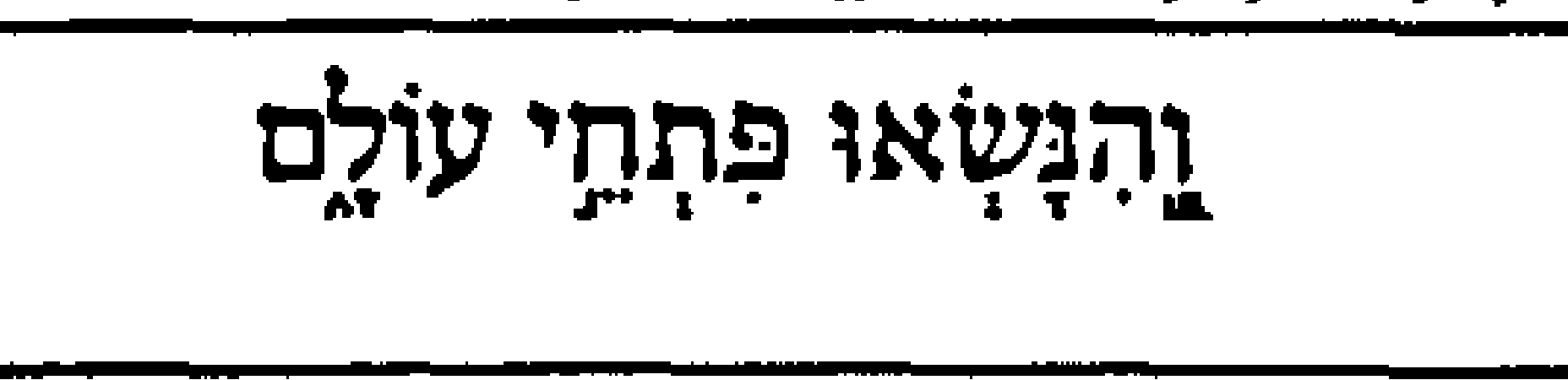 \\
\hline & & c & that the king of glory may enter! & 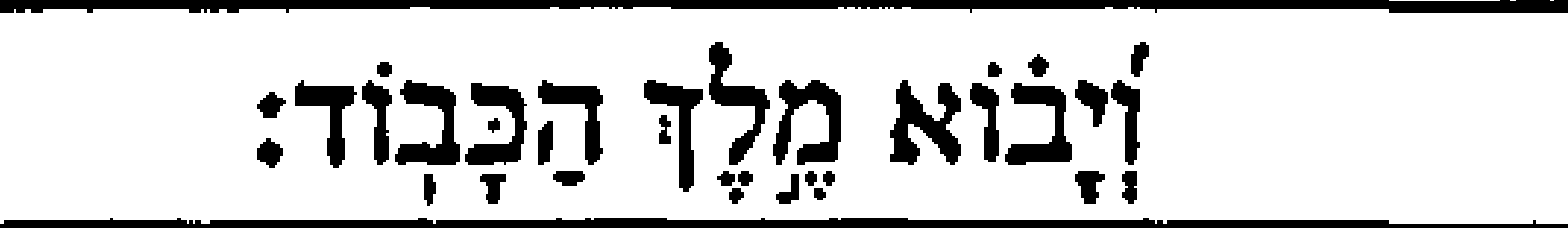 \\
\hline & \multirow[t]{3}{*}{8} & $\mathbf{a}$ & Who is this king of glory? & 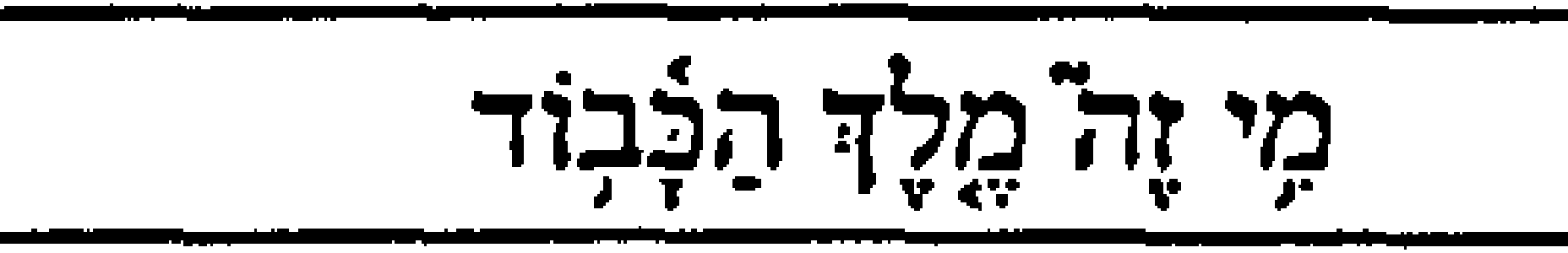 \\
\hline & & b & Yhwh, mighty and heroic & 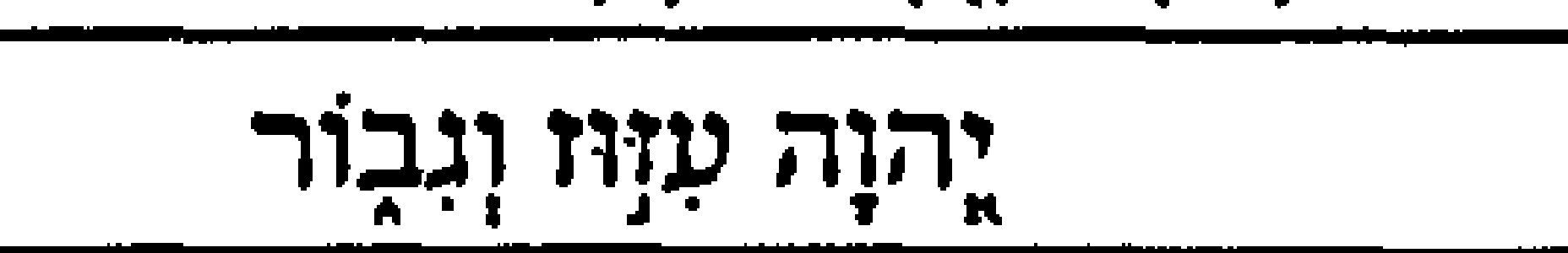 \\
\hline & & c & Yhwh, a hero of war. & 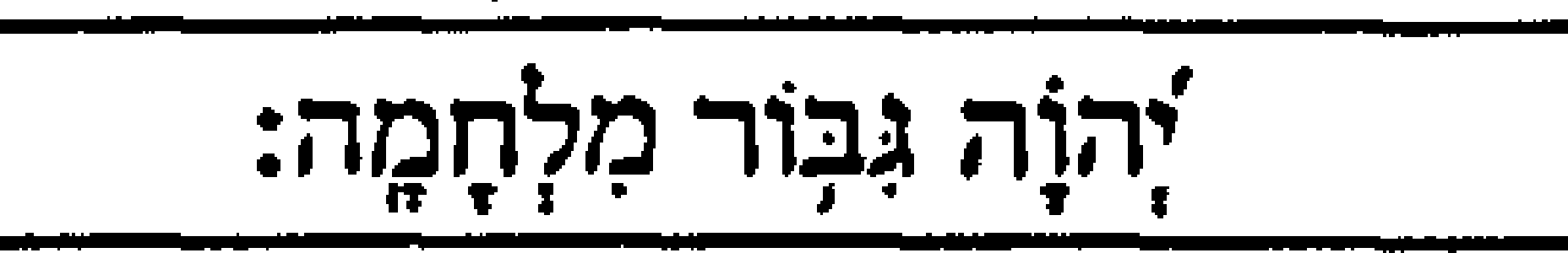 \\
\hline \multirow[t]{4}{*}{ III B } & \multirow[t]{3}{*}{9} & a & Lift up your heads, gates, & 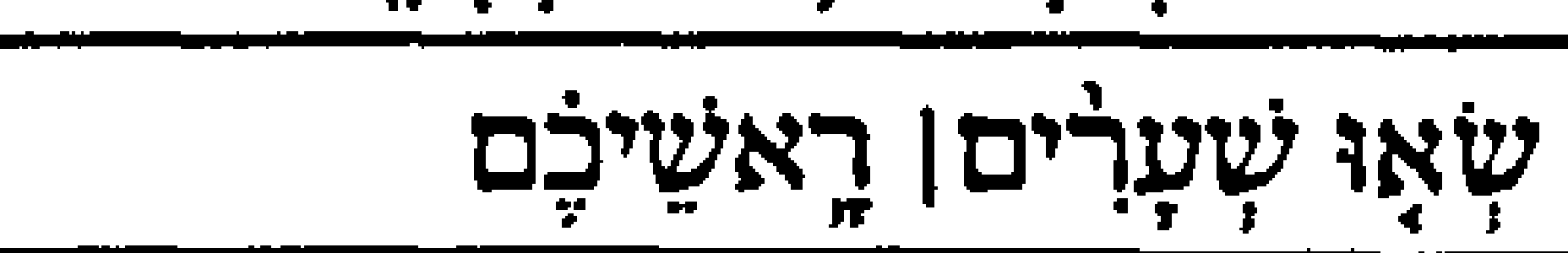 \\
\hline & & b & and lift, 'entrances of eternity, ${ }^{k}$ & 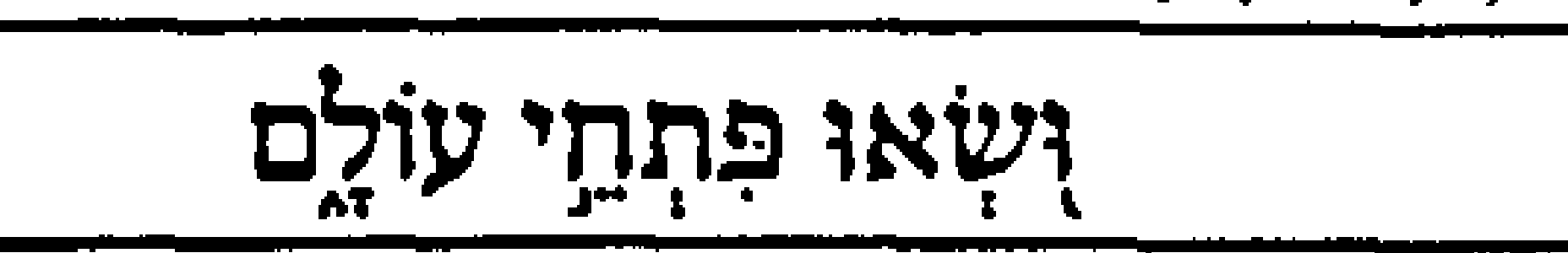 \\
\hline & & c & that the king of glory may enter! & 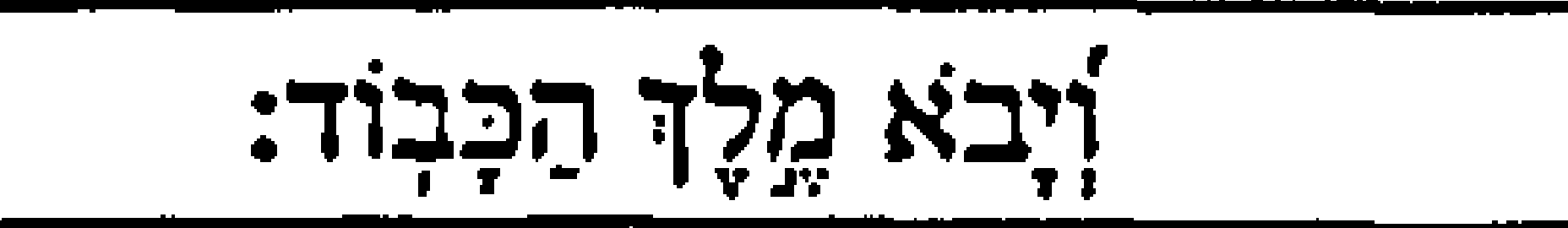 \\
\hline & 10 & $\bar{a}$ & Who is then, this king of glory? & 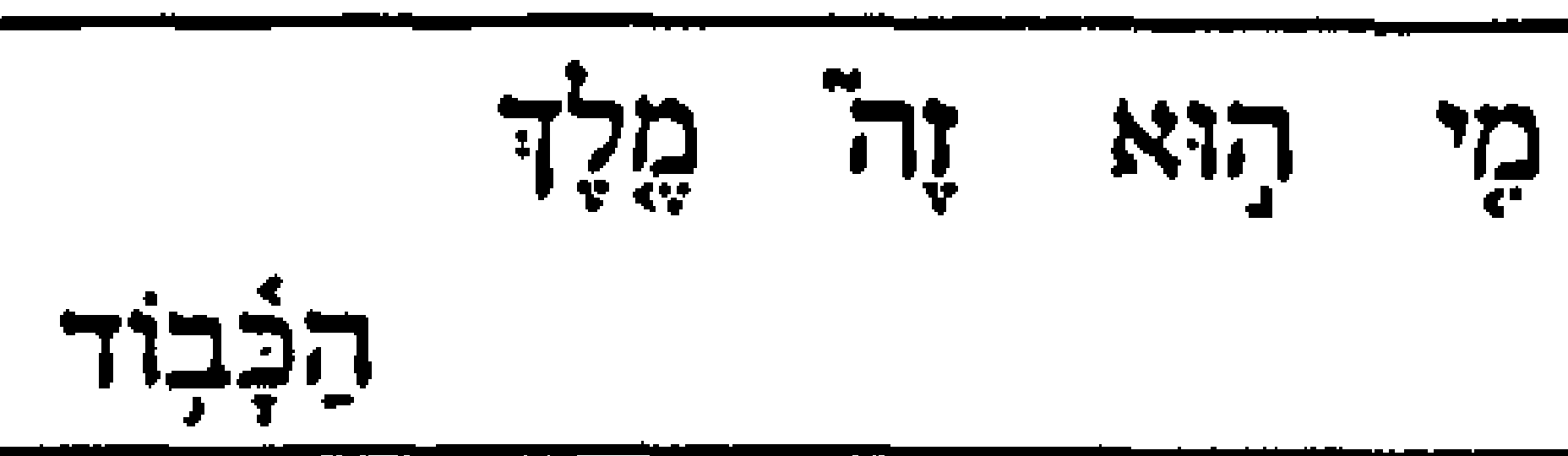 \\
\hline
\end{tabular}

תבל IS שאול תהום (Cf. Waltke \& O'Connor, IBHS, 240; van der Merwe, Grammar, 188; Davidson, Syntax, 23 (rem. 4)), hence my use of capitals and no definite article (as in the Hebrew). In contrast to all translations I am aware of, l opt for the concrete terms "land"/"earth-disk" instead of "earth"/"world." The connotations of the latter terms obscure the message of the strophe (cf. commentary below: 7.3.2.1.). See also Keel, Weltsymbolik, 24, who claims that in the Psalms "die Welt als Kompositum von zwei (oder mehreren) Teilen gesehen wird. Sie ist kein einheitliches Gebilde wie der griechische "Kosmos" oder unsere "Welt"."

${ }^{447}$ For this translation, see $\underline{7.3 .2 .3 .1 .}$ 


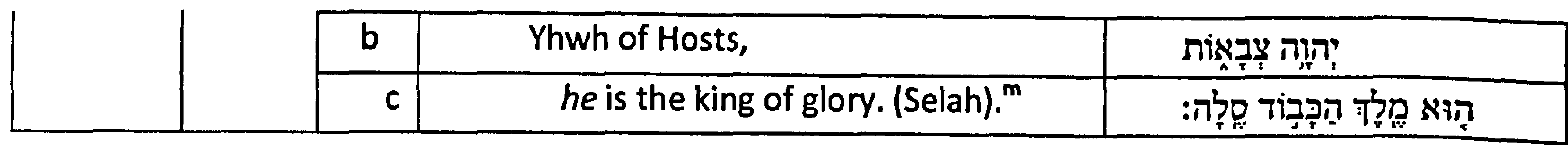

\subsubsection{Textual notes}

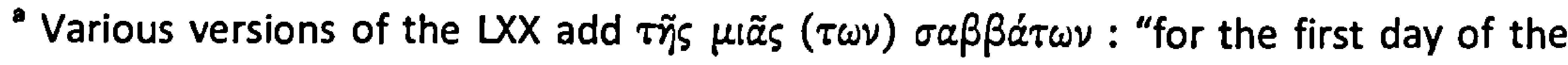
week." This is a Jewish addition that refers to the day of the week on which the Psalm was to be sung by the Levites in the Second Temple. ${ }^{448}$ According to Beckwith, interpreters have not been able to identify the logic by which the LXX and the Mishnah appoint certain Psalms to certain days of the week. ${ }^{449}$ The Talmud attributes the decision to the theme of creation..$^{450}$

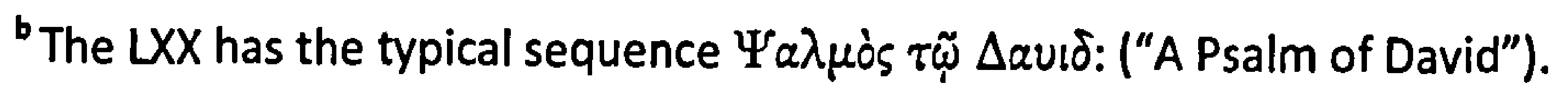

"LXX and Peshitta add "all" ( $\pi \alpha \dot{\nu} \nu \tau \varsigma_{,}=3$ ). This is probably a gloss in order to clarify the universal character of the statement. ${ }^{451}$

ḍִִ is missing in LXX, Symmachus and Theodotion. Jerome's Psalterium Gallicanum has quia ("because"). MT makes clear what is implicit in LXX.

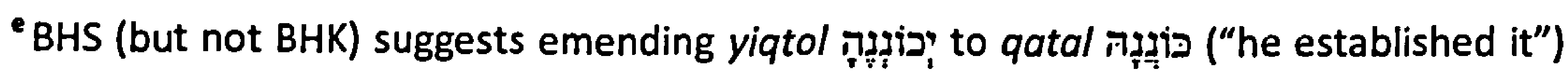
in order to synchronise the tense with qatal הִָָּ in the previous colon. Despite ongoing debate concerning the translation of the qatal//yiqtol sequence in poetry, the pattern is common and should be retained. ${ }^{452}$

'The Masorah in BHS gives us the first indication that the ketiv is unusual with its warning: כן כת :this is how it is written." Many Scholars reject the first person singular suffix and follow the versions (including the Targum and the Cairo Geniza) as well as a

${ }_{448}^{4}$ Rahlfs, Psalmi, 30-32.

449 Beckwith, "Levites," 500.

450 "On the first day what did they sing? [Ps. 24, which begins]: 'The earth is the Lord's and the fullness thereof, [the world and they who live therein].' [This psalm was used] because [on Sunday God] took possession and gave possession and was ruler over his world [without the heavenly hosts, who were created on the second day]" (tractate Rosh haShannah, in Neusner, Babylonian Talmud:6b, 190; cf. Tamid, in Babylonian Talmud:22c, 31).

${ }^{451}$ Seremak, Psalm 24, 41; Briggs, Psalms, 218.

${ }^{452}$ See, e.g., Berlin, "Grammatical Aspects." 
number of Hebrew manuscripts ${ }^{453}$ in replacing it with the third person singular suffix נפשו, which is a smoother reading. Nevertheless, the tradition represented by BHS is very old. Although aủtoũ is included in Rahlfs' critical text, he shows hesitancy in the apparatus by

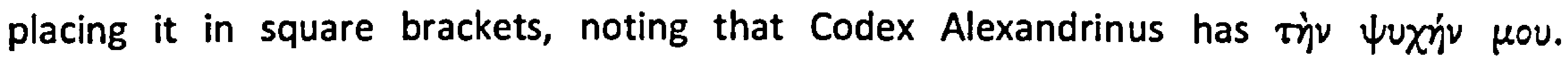
Steingrimmson, however, believes that Alexandrinus was influenced by proto-MT. ${ }^{454}$ Delitzsch notes that the major Jewish commentators (Saadia, Juda haLevi, Abulwalid, Rashi, Kimchi, Zohar, etc.), with the exception of Elias Levita, took נפשי to be the authoritative reading, ${ }^{455}$ though this obviously does not make it the original reading. Goldingay simply keeps both possibilities open. ${ }^{456}$ Although I opt for נפשו as the original reading, given the authority of proto-MT (cf. 4.5.2.2.) I discuss a possible meaning with נפשי in footnote ${ }^{600}$ below (section 7.3.2.2.), given the possibility that the change may have been intentional.

For the translation of [שא נפשו [אל as "set one's heart upon", see the ESV's translation of Prov 19:18. ${ }^{457}$ According to Freedman-Willoughby, the phrase נשא לב has a similar meaning to נפש and לב בנשא נפש can be used synonymously when they function as a personal pronoun. ${ }^{459}$

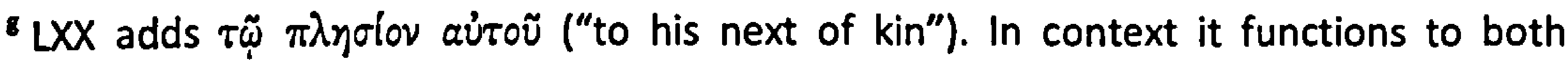
supplement and limit the requirement ${ }^{460}$ and is universally seen as a gloss. Spieckermann and Seybold see this as evidence that the ethical injunctions were interpreted in light of the Ten Commandments. ${ }^{461}$

h I follow the Qere, which has the plural participle זדרָּ. It is supported by LXX, various Hebrew manuscripts, the Cairo Geniza, and the Targum. Some commentaries cite the parallel מבקשr (plural form) as corroborating evidence, although this argument alone is

453 Seremak, Psalm 24, 41: "viele andere hebräische Codices und einige Ausgaben der hebräischen Bibel, z.B. Biblia Ven. (1766), Psalt. Basil. (1547), schreiben ivפ"

454 Steingrimmson, Gerechtigkeit, 71.

455 Delitzsch, Psalmen, 245.

456 Goldingay, Psalms:1, 359.

457 "Discipline your son, for there is hope; do not set your heart on putting him to death."

${ }^{458}$ TWAT:V, 641.

459 TWAT:VII, 426.

460 Seybold, Psalmen, 103.

${ }^{461}$ Spieckermann, Heilsgegewart, 199, fn. 6; Seybold, Psalmen, 105. 
insufficient given the poetic technique of grammatical parallelism (see also Ps 145:4; cf. note ' below). If the singular is retained, then the relation between דורשי likely to be appositional: "such is a/the generation that seeks him." ${ }^{1462}$ The difference in meaning is insignificant. H. Schmidt emends the suffix so that it corresponds to the second

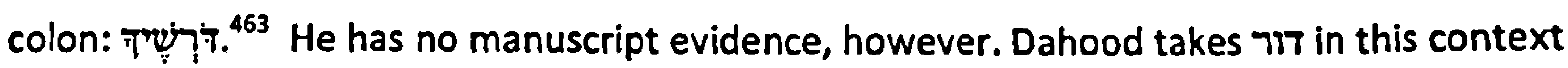
to be equivalent to עולם (he refers to Pss $12: 8$ and 22:31, though this interpretation is not necessary), זה to mean "the one of" (cf. Jdg 5:5), and דרשיו to be an imperative with suffix, giving him the unsual reading: "The One of Eternity seek" $(=\prime d d m$, "El, the One of Eternity"). ${ }^{464}$ No other commentator has followed his suggestions.

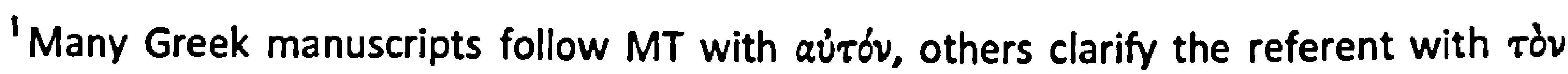
xúprov. Rahlfs takes this to be an expansion of the Old Greek. ${ }^{465}$

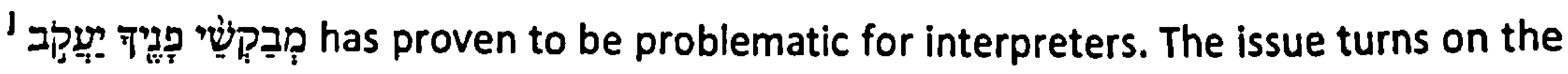
syntactic relation of "Jacob" to "your face": As Tromp puts it, is it a matter of apposition, aphaeresis or apostrophe? ${ }^{466}$ The natural meaning of the syntax is that the "righteous generation" described in v. 4 consists in those who seek the "face of Jacob," who is now being addressed in the second person. The ancient versions appear to have struggled with this by providing a variety of alternatives. ${ }^{467}$ Thus, $L X X$, which is followed by the Vulgate,

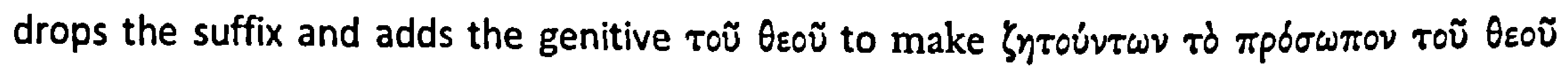
Iaxw $\beta$ ("those who seek the face of the God of Jacob"). The Peshitta, on the other hand, also adds "God" yet keeps MT's suffix, rendering the reading: "your face, O God of Jacob." The Targum has a third person pronoun and gives an interpretative expansion: "who seek the brightness of his face, Jacob." ${ }^{468}$ Other versions, however, reflect MT (Aquila, Symmachus, Quinta, Sexta, Jerome's Psalterium Gallicanum, and Vetus Latina). ${ }^{469}$

${ }^{462}$ Goldingay, Psalms, 356, fn. d. Briggs is one of the few who prefers this reading: "This is a generation which resorts to him" (Psalms, 213).

463 Schmidt, Psalmen, 42.

${ }^{464}$ Dahood, Psalms, 151-152.

${ }^{465}$ Rahlfs, Psalmi, 113.

${ }^{466}$ Cf. Tromp, "Jacob."

467 For a helpful overview, see Tromp, "Jacob."

${ }^{468}$ This softens the anthropomorphism. Other manuscripts have "the face of his Shekinah." $\mathrm{Cf}$. Stec, Targum, 62.

469 Dahood, drawing on supposed Ugaritic parallels, keeps the consonants but changes the vowels to provide us with "O you who search for the presence of Jacob" (Psalms, 150). The kaph in 
In his detailed analysis of this phrase, Tromp argues that the MT appears to contain the oldest text, for the diverging versions give the impression that they are struggling with a difficult text ${ }^{470}$ (note also the masorah). If we are to stick with the MT, the natural reading of Jacob as a vocative leaves us with the following difficulties: For a start, the face of בקש Jacob-let alone as a corporate entity-is never sought in the Bible; instead, the idiom פנים is a technical term for seeking God in his sanctuary. ${ }^{471}$ In terms of the parallelism, Botha notes that "בקש form a word-pair and thus probably have one and the same object, so that the second person suffix in "your face" must be understood to refer to the same person as the third person suffix in the previous colon ("who seek him"), thus as a reference to YHWH." ${ }^{\mathbf{4 7 2}}$ Furthermore, interpreting Jacob as a vocative also creates tension with the theocentric focus of v. 5, where it is Yhwh who is the object of the pilgrimage and not a human social group (whether ethnic or not). ${ }^{473}$

Scholars who wish who stick with the MT have sought to provide a different interpretation of the syntactic function of Jacob. Until recently, the typical move was to see "Jacob" as a specification of "generation" (effectively following the sense of the Targum). There are two syntactical possibilities: one can either understand "Jacob" as the subject of the participles ("those who seek your face, i.e. Jacob"), ${ }^{474}$ or as their predicate ("those who seek your face are Jacob"). ${ }^{475}$ Yet Tromp rightly notes that although both cases are possible,

this case is understood to be an emphatic 'כ within a construct chain. Tromp is sceptical: Dahood "is apparently unable to furnish a second example of this use" ("Jacob," 272). He also questions the applicability of Ugaritic parallels (where ki was written without $-y$ ). Cheyne offers a rather drastic

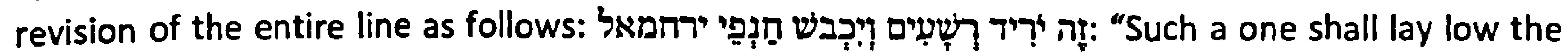
wicked, he shall trample on the profane ones of Jerahmeel" (Psalms, 102; 104).

${ }^{470}$ Tromp, "Jacob," 275; citing Bäthgen, Psalmen, 69. Bäthgen nevertheless argues that the conjectures of either the LXX or the Peshitta were correct conjectures, for the MT has preserved a very old scribal error.

${ }^{471}$ TWAT:I, 757-767.

472 Botha, "Questions," 539-540.

${ }^{473}$ See the relevant entry in $D C H$. Besides Yhwh, the only other personal pronoun that is the object of the verb is Solomon (1 Kgs 10:24, $2 \mathrm{Chr} 9: 23$ ), yet here his royal function is parallel to that of Yhwh in Ps 24: People sought his benefits by entering his courts to listen to him. The only personal pronoun as object of דרש is Yhwh.

${ }^{474}$ E.g. Hitzig; Delitzsch. Delitzsch writes: "The predicate, which has assumed several forms, concentrates itself in the one word עביע, which it all along had in view" (Psalms, 413).

${ }^{475}$ König; substantially, Briggs. Tromp, "Jacob," 277, adds: "The difference with the preceding translation seems to consist in this, that the answer 'Jacob' is the final link in a small chain of answers." The Midrash Tehillim simply does not treat the verse (cf. Braude, Midrash, 343). 
the syntax is strained. ${ }^{476} \mathrm{He}$ thus concludes that we should read יעקב as a vocative: "those who seek your face, 0 Jacob $^{\prime 477}$ and justifies this by referring to the eschatological pilgrimage of the nations to Zion, whose task is to seek the face of Jacob (Isa 2; Mic 4; Zech $2: 15) .{ }^{478}$

Despite its ability to do justice to the apparent syntax of the line, Tromp's interpretation does not resolve the problems raised by the context of the verse outlined above, neither does it correspond to the prophetic parallels. In Isa 2:2-5 (= Mic 4:1-5), for example, Yhwh is the object of the pilgrimage and not Jacob. ${ }^{479}$ Furthermore, although the nations seek Yhwh's "righteousness" in Zion, it is not imposed as a condition of ascent (Ps 24:4). Israel/Jacob also has a different function. Although it certainly has the function of being a light to the nations by virtue of its righteousness, the light shines on Yhwh and not on the nation itself..$^{480}$ Yhwh is sought because of Israel, Israel itself is not sought.

A recent approach to Ps 24:6 is to understand its syntax in light of the poetic device of chiasm. Botha and Goldingay argue that an $A B C / C^{\prime} B^{\prime}$ pattern can be identified. In their interpretation, "generation" corresponds to "Jacob" and "him" corresponds to "your face" (with ellipsis of in v. 6b), rending the meaning: "this is what Jacob looks like." ${ }^{481}$ The

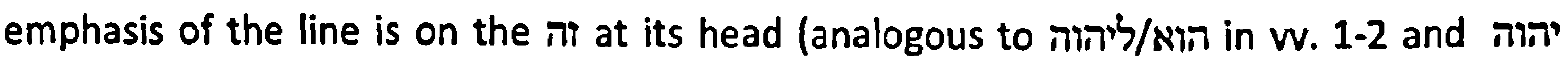
הוא/צבאות in v. 10) and not on the revelation of the name, indicating that the identity "Jacob" is being interpreted in light of $v$. 4. The implication is that the author of the line is

${ }^{476}$ According to my search using the Andersen-Forbes syntax database, three other examples of a demonstrative pronoun "completed" by three clauses in apposition are 2 Sam 11:3, $1 \mathrm{Chr}$ 9:33, and $1 \mathrm{Chr} 23: 24$.

${ }^{477}$ Tromp, "Jacob," 278; see also Andersen, AFPMA.

${ }^{478}$ This is followed by Lohfink, "Bund;" Hossfeld, Psalmen:I, 159, 160; Seremak, Psalm 24; Podella, "Transformationen;" Spieckermann, Heilsgegenwart. The latter two interpreters, however, simply dismiss this verse as a redactional expansion which does not fit particularly coherently with the rest of the psalm.

${ }^{479}$ I am not aware that Jacob is ever sought in this manner in the Old Testament. Seremak's claim to see this in Ps 47 is clearly strained (Psalm 24, 74).

${ }^{480}$ In the context of Isaiah, Berges states: "the identity of the People of God as "Jacob/ Israel" and as "Zion/ David" centers on the call to be witnesses to Yahweh as the only true God. This function is made possible because God glorifies himself first in Jacob (44:23) and then in the community of Zion (55:5)" ("Witnesses," [10], the page number is provisional).

${ }^{481}$ Botha, "Questions," 539-540; Goldingay, Psalms:1, 360-361. See also Lescow, "Exegese," 6768. Fokkelman also follows this interpretation, but without mentioning chiasm (Mojor Poems: 3, 43, fn. 62). Van der Lught, Cantos, argues that these kinds of abrupt second person addresses often occur, as here, at the junction between two higher order poetic units (in this case stanzas). Michael Fox and John Hobbins both spontaneously read the verse in this manner when I showed it to them in private conversation. 
aware of alternative proposals and so wishes to make his own claim about the identity of "the true Jacob." Given that Jacob here is characterized by the moral qualities presented in v. 4, it would appear that we have a similar process of (re)definition found amongst Israel's prophets, especially Isaiah. ${ }^{482}$

In this thesis I have followed the interpretation of v. 6 as a chiasm, particularly because of the way it mirrors the function of the pronouns in vv. 2 and 10. In other words, it functions to identify the "true Israel." It should be pointed out, however, that none of the variants significantly changes the meaning, for the verse still functions to characterize Israel in terms of v. 4. At best, the emphasis is shifted from "Jacob" to "generation." This is confirmed when we see how close Kraus' interpretation of the verse mirrors mine (cf. 7.3.2.2.1.), even though he follows the LXX: "The 'true Israel' consists of human beings who subordinate daily life to the demands of the תורה. That is the way of the 'generation' that is cultically prepared and that appears before Yahweh (דור here has the meaning 'type of human being')." ${ }^{\prime 483}$

"LXX reverses vocative and object, rendering the following possible translation: "Lift

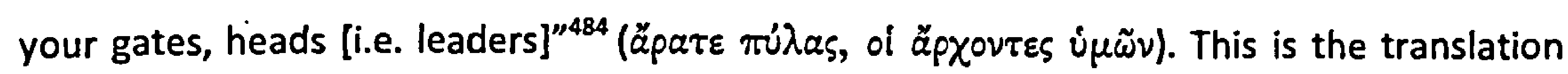
offered by the Bohairic and Sahidic versions, as well as Jerome's Psalterium Gallicanum. ${ }^{485}$ The syntactic connection between "yours" ( $(\tilde{\mu} \omega \tilde{\nu})$ ) and "gates" ( $\pi \dot{\lambda} \lambda \alpha \varsigma$ ) is awkward, however. Ernst Kähler suggests that this awkwardness is a result of the difficulty the translators had with the Hebrew text. ${ }^{486}$ He argues that for the Greek translator the term "leaders" (or "princes") referred primarily to demonic beings, as in the book of Daniel (Dan 10:13 LXX). He then concludes that the section was read eschatologically: The LXX "mußte den Psalm als Prophetie auf eine endgültige, seigreich endende Auseinadnersetzung des

${ }^{482}$ It should be pointed out that this does not exclude priestly authorship of the psalm, despite a common tendency amongst Old Testament scholars to pit priest and prophet against one another. For a rejection of this approach in relation to Ps 24, see Koch, "Tempeleinlaßliturgien."

${ }^{483}$ Kraus, Psalms:1, 314. On the meaning of דור as "a cross-section of the community in time," see Hunter, "Righteous," 189). The term is often used in polemical contexts to label a generation in terms of its moral qualities, a prominent example being the "wicked" generation that died in the wilderness (cf. Deut 32:20; Ps 95:10; see also Jer 7:29; Isa 53:8) (TWAT:Il, 193).

${ }^{484}$ Goldingay, Psalms:1, 356. Kähler notes that the variant reading $\dot{\eta} \mu \tilde{\omega} \nu$ has to do with the difficulty of relating $\dot{u} \mu \tilde{\omega} \nu$ to its referent (Te Deum, $48, \mathrm{fn} .3$ ). The comma provided by Rahlfs is an attempt to clarify the syntax.

${ }_{485}$ Kähler, Te Deum, 48.

${ }^{486}$ Kähler, Te Deum, 48. 
'Königs der Herrlichkeit' mit den den Besitz 'ewiger Tore' behauptenden, überirdischen Mächten verstehen. ${ }^{\prime 487}$

' This reading has been supported by commentators on grounds of style (it preserves the repetition with v. 7$)^{488}$ and on grounds of grammar (there is no other example of an intransitive (שָׁ). ${ }^{489}$ Goldingay, however, defends MT on poetic grounds: variations of this kind are typical of Hebrew poetry (cf. note ${ }^{\mathrm{h}}$ above). ${ }^{490}$

m סֶָ is missing in LXX. Its position in Psalm 24 correctly concludes each poetic $\operatorname{stanza.}{ }^{491}$

\subsection{Poetic Form}

The pervasive presence of parallelism at various levels within the poem (line, strophe, stanza, even the poem itself; see 7.3.2. below) clearly indicates that this psalm is dominated by the poetic function. An important constraint upon its meaning, therefore, in addition to other genre characteristics that we will treat below (e.g. liturgical, see 7.4.2.; on the relative nature of the poetic function, see $\underline{7.1 .2}$. above), is the contour of its selfcontained literary shape as it utilizes the syntagmatic and paradigmatic dimensions of language. Psalm 24 is, furthermore, a typical example of specifically Biblical poetry, for its parallelisms consistently conform to Alter's "rule of thumb" (the latter parallel always creates a semantic specification of the former $[7.1 .2 .1 .1]^{492}$ and its overall structure conforms to apparent norms of proportionality found elsewhere in the Bible (7.3.1.). We should thus be prepared to find a linear and a symmetric dimension to its meaning (7.1.2.1.; 7.1.2.2.) as well as a strong theocentric focus (7.1.2.3.).

\subsubsection{Structure and Proportion}

There is a general consensus that Psalm 24 consists of three clearly distinct thematic sections: ${ }^{493}$ Verses $1-2$ proclaim the identity of the owner and therefore ruler of the

${ }^{487}$ Kähler, Te Deum, 50.

${ }^{488}$ E.g. Craigie, Psalms, 210.

${ }^{489}$ E.g. Briggs, Psalms, 219; Gunkel, Psalmen, 105.

${ }^{490}$ Goldingay, "Repetition."

491 Fokkelman, Major Poems, 41, fn. 57.

492 Due to space I have limited discussion of the nuances of many of the parallelism, especially line-internal parallelisms, to the footnotes.

${ }^{493}$ Goldingay rightly. characterizes the shifts in content as "abrupt" (Psalms:1, 358). 
inhabited world along with the grounds for this claim; vv. 3-6 illustrate the identity of those who may enter his presence in his sanctuary along with a description of what awaits them upon arrival; w. 7-10 portrays the identity of the lord himself who has already arrived and is about to enter the self-same sanctuary. ${ }^{494}$

These thematic divisions are reinforced by their conformity to what some scholars consider to be the "prescribed proportions" of Biblical poetry. ${ }^{495}$ The Psalm as a whole has ten lines, a typical size according to Hobbins. ${ }^{496}$ Apart from w. 4 and 7-10, all of the lines are bicola, again the standard length for the Hebrew verse-line. ${ }^{497} \mathrm{Vv} .4$ and 7-10 are tricola. ${ }^{498}$ According to van der Lugt, tricola can occur anywhere within the rhetorical structure of a poem, ${ }^{499}$ so the appearance of one in v. 4 (at the beginning of a strophe in the middle of a stanza) is not unusual. The piling up of tricola at the end of the psalm in a concluding and indeed climactic stanza is, however, typical. ${ }^{500}$ In addition to this, w. 7-10

${ }^{494}$ Van der Lugt has a helpful summary in Cantos, 257.

${ }^{495}$ Fokkelman, Reading; van der Lugt, Cantos; Hobbins, "Regularities." Fokkelman defines a Biblical poem as "the result of (on the one hand) an artistic handling of language, style and structure and, (on the other hand) applying prescribed proportions to all levels of the text, so that a controlled combination of language and number is created" (Reading, 35). Even Spieckermann, who approaches the psalms in the traditional literary-critical vein as Wellhausen and does not avail himself of these kinds of poetic analyses, can say that Ps 24 "ist so stark gestaltet, daß er kein Zufallsproduk sein kann" (although he removes colon 4aß; p. 200).

${ }^{496}$ Hobbins, "Regularities," 580. For the Psalm having ten lines see Van der Lugt, Cantos; 159; Fokkelman, Major Poems, 41; Weber, Psalmen:I, 129; Botha, "Questions," 537-538. In informal personal communication Hobbins suggested the poem has twelve lines. Consistent with his theory that a colon cannot have more than three stress units, he takes $\mathrm{vv} .4$ and 10 to consist of two poetic lines each, rather than two tricola, which is the opinion of the other scholars above. I have opted for the majority interpretation as this feels more natural given the tight syntax of the verses, but the difference does not affect my interpretation. A twelve line poem is also a typical length (Hobbins, "Regularities," 580). I am very grateful for the time Hobbins, Weber, Michael Fox, and Phil Botha have taken to discuss the poetic structure of Psalm 24 with me

${ }^{497}$ Van der Lugt, Cantos, 522.

498 So, for example, Fokkelmann, van der Lugt, Weber, Botha, Girard.

${ }^{499}$ Van der Lugt, Cantos, 532.

${ }^{500}$ Van der Lugt, Cantos, 532: "Two-line strophes composed of tricola only, usually mark the end of a higher unit; ratio $2: 1(<22: 11) . "$. It should be noted that these findings are not undisputed. The field of Biblical poetics is still contested (especially regarding the existence of strophes, cf. van der Lugt, Cantos, 69-74), though there does seem to be a growing consensus that prosodic units group themselves in either twos or threes (Hobbins), possibly fours (Harshav, Weber, Fokkelman, van der Lugt), but not more (e.g. two stress units per colon, two cola per line, two lines per strophe, two strophes per stanza [although van der Lugt, for example, does affirm the existence of four line strophes, e.g. Pss 44:6-7; 72, 137, the majority are two or three lines; Cantos, 68]). See Fokkelman, Reading, 37; Hobbins, "Regularities," 568. Van der Lugt does not believe Biblical poetry has a regular meter, and therefore does not start his analysis at the level of the colon but at the strophe. 
constitutes a refrain, ${ }^{501}$ a typical rhetorical device for marking the macro-structure of a psalm, in particular its conclusion. ${ }^{502}$ The rhetorical structure of the psalm, then, indicates that the final stanza functions as some kind of conclusion within the structure of the whole. This impression will be confirmed when we look at the content of the psalm (7.3.2.).

There is a further consensus amongst those scholars who affirm the existence of strophes in Biblical poetry ${ }^{503}$ that the bicola in Ps 24 are combined to form a regular series of two-line strophes ${ }^{504}$ (again, the typical length of a strophe). ${ }^{505}$ According to, inter alia, Terrien, Weber, Botha, Vos, Fokkelmann, and van der Lugt, these strophes are further bundled up into stanzas. There is a consensus amongst these scholars concerning the following division: Verses 3-4.5-6|7-8.9-10, 1.e. w. 3-6 and 7-10 constitute two stanzas consisting of two sets of two-line strophes each. The two stanzas thus mirror each other proportionally ${ }^{506}$ which, when taken together with other structural and thematic parallels (cf. 7.3.2.) affirms that these two sections are to be read in juxtaposition to each other. The refrain format in $w$. 7-10 makes the strophic division quite clear. For $w .3-6$, beyond the proportional fit (i.e. the consistent presence of the number two), there may also be a parallelismus stropharum ${ }^{507}$ according to a linear pattern $\left(A B / A^{\prime} B^{\prime}\right)$. The opening line of each strophe $\left(A / A^{\prime} ; W .3,5\right)$ concerns the "destiny" 508 of the righteous person (interior of Yhwh's temple; Yhwh's blessing and righteousness), ${ }^{509}$ whereas the conclusion of each strophe $\left(B / B^{\prime} ; w .4,6\right)$ concerns the identity of the righteous person himself (he is

${ }^{501}$ Van der Lugt defines a refrain as follows: "a repetition of an unbroken series of words, roughly in the same sequence and encompassing at least a colon, with a framing function on the level of the macrostructure of a poem" (Cantos, 490; emphasis original).

${ }^{502}$ Cf. van der Lugt, 435, 490. "The refain [sic]-strophes in Psalm 24 (w. 7-8 and 9-10) form a complete canto [i.e. stanza] of four verselines, balancing the 4-line canto $w .3-6^{\prime \prime}$ (499). On van der Lugt's analysis (which often differs from Fokkelman or Weber, for example) similar cases to Ps 24 can be found in Pss 56:4-5, 10c-12; 62:2-3, 6-7; 114:3-4, 5-6 and 144:7-8, 11 (w. 7-8 is a 3-line strophe) (492).

${ }^{503}$ For a helpful historical overview of scholarly opinion on the issue of strophes see van der Lugt, Cantos, 3-68.

${ }_{504}$ E.g. Botha, "Questions;" Weber, Psalmen:l; Fokkelman, Major Poems 3; van der Lugt, Cantos; Terrien, Psalms. According to van der Lugt's overview one could can add Köster (1837), De Wette (1856), Schlottmann (1885), Schildenberger (1960) (Cantos, 260; Botha has updated his opinion in "Questions" since the essay reviewed by van der Lugt [1994]).

${ }^{505}$ According to, e.g., Hobbins, Fokkelmann, and van der Lugt.

${ }^{506} \mathrm{Cf}$. Van der Lugt, Cantos, 499.

507 Van der Lugt, Cantos, 32 . The phrase was coined by Hans Möller, Strophenbau.

${ }^{508}$ I mean destiny here in the broad sense of the future that awaits him. This theme is basic to both the Psalm and the Psalter, and arguably scripture as whole. See Creach, Destiny and my discussion of the Psalm in its canonical context in $\underline{9}$.

${ }^{509}$ Regarding v. 5, cf. Spieckermann, Heilsgegenwart, 203: The reception of blessing and righteousness does not occur in the temple gate but in the temple itself. 
righteous and called Jacob; זr refers back to v. 4). ${ }^{510}$ It is also arguable that the semantic shift between the parallel cola conforms to Alters "rule of thumb," on which, see $\underline{7.3 .2 .2 .}{ }^{511}$

There is uncertainty about the status of w. 1-2. Fokkelman and Botha see this strophe as the first of a three-strophe stanza. The only argument provided for this, however, is that there the geographical theme from $w$. 1-2 are carried over into $w$. 3-4 along with reference to the divine name in the first colon of the opening verses. ${ }^{512}$ Yet not only have many commentators concluded that $w$. 1-2 are thematically more closely related with the final rather than the second stanza ${ }^{513}$ (cf. 7.4.2.1.), a number of commentators have seen that the broad theological horizon of creation in w. 1-2 somehow provides a rhetorical "foundation" for what follows. ${ }^{514}$ Given the rhetorical significance of this strophe-length section within the context of the psalm as a whole, we will now look at its poetic status in more detail.

${ }^{510}$ So Girard, Psaumes:2, 205, who talks of a "bornes d'inclusion." The inclusio, however, is a matter of description and identification, and not a common concern for correct worship. See my translation of שוא below (7.3.2.2.). This pronoun cannot be taken as evidence that a concrete group of pilgrims is being referenced (e.g. Kraus, Psalms:1, 311; Goldingay, Psalms:1, 360), for it can just as easily refer to subject matter within the psalm. Waltke/O'Connor claim that in this context the deictic function of the pronoun has been weakened to that of "characterizing" (IBHS, 311). See also Botha, "Questions." A parallel example is 'זה in Exod 15:2b: "Such is my God" (a statement made following a description of his deeds in w. 1-2a; cf. Durham, Exodus, 200, who cites BDB, 260-262 to back up the translation).

${ }_{511}$ A further argument for the poetic constancy of Ps 24 is its meter. Cf. Spieckermann, Heilsgegenwart, 200: "Alle Kola haben drei Hebungen bis auf eine Ausnahme in v. 10, wo aber leicht ersichtlich das metrische Gleichmaß bewußt als stilistisches Signal für eine inhaltliche Akzentsetzung "gestört" worden ist." See also Girard on w. 7-10, Psaume:1, 206: $3+3+3+, 3+3+3,3+3+3,3+2+3$ ("quatre vers quasi isométriques").

${ }^{512}$ Botha, "Questions," 542. Fokkelman's stanza analysis is rather suspect to me given the presence of two contradictory analyses of the stanza structure of this poem in his book Reading. On p. 119 he takes w. 1-3 to be a single strophe, whereas on p. 214 he follows the majority of recent interpreters in seeing w. $1-2$ as being the first strophe, followed by $3-4$ and then $5-6$. The latter pattern is taken up in his Major Poems, 41 and is adopted here. Fokkelman's analysis on p. 119 seems very odd to me. It is based on purely formal criteria, namely his desire that the two "halves" of the poem mirror each other exactly in terms of proportions. In order to achieve this he has to separate the question in v. 3 from its answer in v. 4. He then concedes, however, that this proportional analysis does not work perfectly because $v .4$ is a tricolon, which appears to undo his analysis! It is odd that this psalm is taken to be a prime example of "the stanza convincingly asserting itself" (119). For an overview of suggested poetic divisions, see van der Lugt, Cantos, 260.

${ }_{513}$ e.g. Craigie, Psalms; Podella, "Transformationen."

514 E.g. Weber, Psalmen:I, 130: "Die eröffnenden Verse 1-2 bilden (auch wörtlich!) das 'Fundament' der nachfolgenden anthropologisch-ethischen und theologischen Aussagen und bereiten zugleich beide Aussagen vor." Weber is uncertain as to the prosodic status of w. 1-2. He does not elaborate on its rhetorical function within the whole, either. If they are the "foundation" for what follows, then it is exegetically significant to know how they "ground" what follows. 


\subsubsection{The Special Function of Verses 1-2}

Van der Lugt has argued for the existence of a "half-length stanza" 515 (or "canto"). 516 The half-length stanza has a special rhetorical relationship to the stanzas that either follow or precede it ${ }^{517}$ and can be identified by certain criteria, all of which are present in Ps 24:12. In terms of position, they either begin or end a composition (in PS 24 it opens the psalm). ${ }^{518}$ In terms of proportion, they are never more than half the length of the following stanzas, often exactly so. This also applies to Psalm 24, where the stanza is the length of a strophe and half the length of the following stanzas $(2|4| 4) .{ }^{519}$ According to van der Lugt's theory of "transition markers," certain keys words mark the boundaries between sections..$^{20}$ In our case, this boundary marker is the pronoun "who" (v. 3). ${ }^{521}$ Interestingly, the pattern of verbal repetitions also fits into a common pattern whereby key words or concepts from the opening half-stanza are repeated in the second strophe of the following two stanzas (the pattern is a $\left.\left|b . a^{\prime}\right| b^{\prime} . a^{\prime \prime}\right) .522$ This is also the case in Ps 24 . Many scholars have noted the network of demonstrative pronouns that unites the psalm into a whole, ${ }^{523}$ yet it is also the case that the "this" (הוא) of the concluding line of the first strophe/stanza (v. 2) finds its parallel in the "this" in w. 6 (הוא) , the concluding lines of the following two stanzas. ${ }^{524}$ This indicates that a primary function of the psalm is deictic (cf. 3.3.3. 4.1.), i.e. it points to the true identity of God and his people.

The thematic distinctiveness of w. 1-2 within the psalm can be seen when one compares its content with that of the following two stanzas. Scholars have long noted that

${ }^{515}$ Van der Lugt, Cantos, 72. See also pp. 441-443; 507-521.

${ }^{516}$ This is the Kampen school's term for "stanza."

${ }^{517}$ Van der Lugt, Cantos, 507.

518 In concentrically shaped Psalms it can appear in the centre.

${ }^{519}$ Van der Lugt, Cantos, 441-443. On van der Lugt's analysis, the following Psalms have halfstanzas with exactly half the number of verselines as the identical stanzas: Pss 24, 64, 122 (2.4.4.); 5 (3.6.6), 14, 47, 53, 111, 112 (4.4.2.); 109 (12.12.6) (441).

${ }_{520}$ Van der Lugt, Cantos, 507.

521 I am not certain how significant these "transition markers" are for determining structure. Van der Lugt allots different dividing powers to different terms (cf. chapter $V, 87$ ). A counter example can be found in Ps 24 itself: In W. 7 and 10 מ concludes a strophe. Fokkelman is highly critical of Van der Lugt's "excessive attention to repeated words and their positions" (Major Poems:3, 99).

${ }^{522}$ Van der Lugt, Cantos, 511. Girard may have been the first to pick up on the structural connection of w. 1-2 with the rest of the psalm (Psaumes:2, 206). Seen historically critically, however, there is a clear thematic connection (see 7.4.2.).

${ }^{523}$ Fokkelmann, Weber, Botha, van der Lugt.

${ }^{524}$ This does not take into account the pattern created by the question pronouns "who" in w. 3 , 8 , and 10. 
stanzas II and III parallel each other in ways not the case for half-stanza 1.525 Each stanza is structured by a question and answer format. In each case the question concerns the identity of the one who may enter the sanctuary and the answer involves a description of this person in terms of his qualities and deeds. Both stanzas depict a temple-ward movement. These structural and thematic characteristics create a stanza level parallelism that binds them close together and sets them apart from vv. 1-2 (cf. 7.3.2.4.3.). We must now ask how these opening verses relate to what follows.

The most significant element of van der Lugt's theory of the half-length stanza is his understanding of its rhetorical function within the psalm as a whole. Such stanzas often have "a special theme in the development of the subject matter of the poem." 526 In many cases the content of this theme is left unspecified, the following cantos revealing what remains unsaid in the introduction. ${ }^{527}$ In a doxology, for example, we may find a call to praise, the reason for this being the subject matter of the main cantos. In Ps 18 we have a general description of God's relation to the psalmist ( $w .2-3$ ) whereas the rest of the psalm illustrates what this looks like. ${ }^{528}$ Psalm 44 opens with a preparatory indication of God's saving acts in the past; stanza II is their realization and elaboration. ${ }^{529}$ It would appear, then, that B. Weber's intuition that w. 1-2 are somehow "foundational" for what follows is borne out by the rhetorical structure of the psalm. Can one say that the "theme" of half-stanza $I$ is "developed" in the following two stanzas? (The answer is yes! See 7.3.2.4.3.).

The question of the relation of $\mathrm{vv}$. 1-2 to the rest of the psalm is an example of the importance of Biblical theology for Biblical exegesis (cf. 4.5.2.), for many scholars have struggled to see a connection between God's establishment of the earth, the temple, pilgrimage, and God's militant activity. ${ }^{530}$ The bulk of my exegesis will consist in following Ps

\footnotetext{
525 Earlier examples are Wellhausen, H. Schmitt, Gunkel.

526 Van der Lugt, Cantos, 505.

${ }^{527}$ Van der Lugt, Cantos, 520.

${ }^{528}$ Van der Lugt, Cantos, 508.

529 Van der Lugt, Cantos, 511.
}

530 This can be seen in the early attempts to separate the psalm into two or three distinct compositions (e.g. Wellhausen, Graetz, Baethgen, Duhm, Briggs, Kittel; see Hammann, Psalm 24, for overview of research). If unity is sought, it is argued that three separate compositions were united for a liturgical event (e.g. Nötscher, Lamparter, Gunkel, Mowinckel, Kraus. Nötscher makes this connection clear: "Die drei Teile des Psalms, die sich nach Form und Inhalt sehr verschieden, deutlich von einander abheben, bilden von Haus aus wohl keine Eineheit; aber ihre Verbindung ist nicht zufällig, sie geschah vielmehr für den liturgischen Gebrauch" [Psalmen, 44]). Yet even those approaches which have a purely synchronic starting point struggle to see the unity. Girard, for example, states: "A première vue, l'hymne initial n'a guère de lien terminologique ni meme 
24's particular configuration of these themes, but for the sake of establishing the peculiar hermeneutical priority of $w$. 1-2 as a vantage point for reading the rest of the psalm, I will supplement our considerations of form by clarifying how the thematic content of w. 1-2 make them particularly apt as an introduction to almost any Biblical text and, given the content of stanzas II and II, Psalm 24 in particular.

\subsection{Creation as the Horizon for the Interpretation of Psalm 24}

Verses 1-2 ground Yhwh's ownership of the world in his establishment of it as a viable living space in the face of threat to that viability (7.3.2.1.). This opening half-stanza expresses a foundational Biblical concept, one used to ground or warrant other theological assertions. This function can be seen in its rhetorical deployment and in its role within Biblical narrative and theology.

\subsection{The Rhetorical Function of Yhwh's World Dominion}

Texts sharing the syntax and vocabulary of $w$. 1-2 tend to not only share other themes found in Ps 24 (law, temple, warfare/judgement/liberation), the element of creation has a decisive rhetorical function in relation to their overall communicative purpose. A brief look at some of the texts collected by Seremak ${ }^{531}$ reveals the following functions:

In 1 Sam 2:8 Yhwh's establishing of the earth is the grounds of his ability to intervene in history and establish justice (cf. Ps 102:26; Hab 3:8-9), ${ }^{532}$ something taken up in Isa 48:13 in relation to Babylon ${ }^{533}$ (see also Isa $51: 13,16 ;^{534}$ in Zech $12: 1$ it is part of an expanded formula introducing an oracle of salvation). ${ }^{535}$ This can be good news for those who are on his side, which is why in Pss 90:2, 93:3-4, 96:13, 104:5 Yhwh's world ownership (as creator) is cited as grounds to praise him (hence the common classification of Ps 24:1-2 as doxology). In Ps 89:12 and Isa 48:13 the fact of his world ownership functions as evidence of Yhwh's

thématique avec le reste" (Psaumes, 206). Goldingay affirms Mazor's statement (in "Psalm 24," 303) that the Psalm is "baffling" because the psalm "comprises three self-contained brief sections that are unusually unrelated to each other" (Psalms:1, 356). See also Oeming, Psalmen, 158: "sein Gedankengang [ist] nicht leicht nachvollziehbar."

See Harner's statement on the difficult nature of Isaiah's "holistic" theology: "[O]ur categories of thought seem inadequate when we ask about the relation between salvation faith and creation faith for II Isaiah" ("Creation," 305).

${ }^{531}$ Seremak, Psalm 24, 63-138. His analysis of these verses in relation to Ps 24 is of limited significance for my purposes, however, as I do not agree with his interpretation of Ps 24 , which is heavily dependent on a different reading of $w .4$ and 6 (see 7.3.2.2.).

${ }^{532}$ Cf. 9.1 .3$.

${ }^{533}$ Note the polemical assertion of identity, אני אני (v. 15), as in Ps 24:2 and 10.

${ }^{534}$ Cf. 9.3 .

535 Lloyd, Minor Prophets 2, 514. See Childs, Biblical Theology, 387-388. 
universal kingship, which is expressed in his righteousness towards his people. Yhwh's power in creation to save is drawn upon in Isa 45.18 in order to explain the purpose of that power: As in Ps 24:1-2, Yhwh creates for the sake of life and not chaos (cf. Ps 119:90). ${ }^{536}$ The rhetorical function is thereby to instil trust into an exiled and doubting 'Jacob' (cf. 9.3.) On the other hand, the universal scope of Yhwh's realm-all the world and all people-is often evoked by the prophets in order to instil fear into those who would distort this order with their wicked schemes (Isa 18:3; 24:2; 26:9; Ps 33:9; 97:4). In Nah 1:5 this is backed up by means of rhetorical questions (cf. Ps $24: 3,7,10$ ). It would appear, then, that Ps 24:1-2 is only good news for some. The need to be on Yhwh's side leads Jer 10:12 to refer Yhwh's creative activity as part of his strategy to persuade Israel to worship Yhwh alone and not idols. "Pre-existence" in relation to the world is itself grounds for awe and respect, which can be seen in Prov 8:26, 31's claim that due to Wisdom's presence at this primordial period, she should be accorded honour and respect. Practical implications can be drawn from Yhwh's lordship over the land. In Lev 25.23 the fact of Yhwh's ownership of the land of Israel sets limits on Israel's property rights. In Ps 50:12, a globalized version of this fact sets limits on the significance of Israel's animal sacrifices. Finally, there is an emotive dimension. Deut 10:14 contrasts the universality of Yhwh's domain and the particularity of his election in order to show the extent of his grace (cf. Ps 9:8; Job 38:4; the move from the universal to the particular in found in the move from half-stanza I to stanzas II and III; cf. 7.3.2.4.3.1.). In light of all this, it is not surprising that one of the purposes of the plagues of Egypt was to let Pharaoh and Egypt know that the earth belongs to Yhwh (Exod 9.29). The appropriate response is fear ( $v$. 10), which leads to obedience (Gen 22:12; 42.18; Ps 24:3-6).

We may thus affirm Robert Jenson's claim that the doctrine of creation became a "rule of faith" within Israel, one that was used to warrant other assertions. ${ }^{537}$

Beyond these examples, it is worth pointing out the significance of creation in Isaiah 40-66, which makes the most extensive use of these traditions. ${ }^{538}$ Childs' summarizes the rhetorical function of creation within the book as follows:

${ }^{536}$ Cf. Ludwig, "Earth." For the function of creation faith in the broader canon, see Childs, Biblical Theology, 384-389.

537 Jenson, Systematic Theology:2, 3.

${ }^{538}$ Cf. Childs, Biblical Theology, 387-388; Harner, "Creation," 302: "creation faith here is not simply the supporting basis for salvation faith. Within the total context of II Isaiah's thought, it forms an integral part of his proclamation." This strengthens the connection between Isaiah and Ps 24 established in 9.3. below. 
The issue at stake lies in the credibility of God in the eyes of his exiled and disheartened people $(40.27 \mathrm{ff}$.). What are the grounds for believing in the promise of new things and a glorious future? The dominant disputation genre of the prophet's oracles confirms his aim of persuasion and confrontation. ... Because God is the creator God who brought the world into being, who sustains it by his power, who establishes it in justice, he is able to execute his new promise of salvation to Israel in which the entire universe participates (55.12f.). It is not a great step to the promise of the creation of the 'new heavens and new earth' (Isa. 65.17) when the disharmony within the creation is removed and the just rule of God promised by First Isaiah is fulfilled (11.1ff.). The apocalyptic dimension of the promise lies in the portrayal of the agonizing death of the old age before the triumphant entrance of God's rule (Isa. 24.1ff.; Zech. 12.1ff.; 14.1ff.; Dan. 12.1ff.)..$^{539}$

These elements are not only found in Psalm 24, they constitute the basic thread of Biblical eschatology (cf. 7.3.2.4.3.2.1. below), which brings us to the function of creation within the "Biblical narrative."

\subsection{The Canonical Function of Creation}

The rhetorical use of creation and Yhwh's universal dominion needs to be set alongside the theological function of creation within Israel's faith. ${ }^{540}$ Again, we will look in more detail later at the particular function of this theme within Psalm 24 as a whole (7.3.2.4.3.2.1.) ; for now I simply wish to briefly underscore its programmatic significance with the theology of the Old Testament.

Old Testament theology has traditionally emphasized the historical nature of Biblical faith: Yhwh intervenes in history to save his people. Childs affirms this truth on a historical level: "Israel undoubtedly first came to know Yahweh in historical acts of redemption from Egypt." ${ }^{1541}$ Yet on the other hand, "the present canonical shape has subordinated the noetic sequence of Israel's experience of God in her redemptive history to the ontic reality of God as creator." ${ }^{542}$ We can see this in the priority given to $P$ (Gen 1) over J (Gen 2 and following), with the result that Gen 2 "now functions as a detailed rehearsal of creation which prepared the way for the subsequent history of human alienation (chs 3-13)." 543 Though

${ }_{540}^{539}$ Childs, Biblical Theology, 388. See also Hermisson, "Jakob und Zion."

${ }^{540}$ An example of this move is Harner's essay on creation in Deutero-Isaiah which goes beyond identifying its rhetorical function as an "auxiliary" argument for something else (cf. von Rad, Essays, 131-143) to attempt to see it as "an integral part of the total structure of thought in II Isaiah, with at least a relative independence of its own" ("Creation," 229). Von Rad sensed this already in the essay here alluded to.

${ }^{541}$ Childs, Biblical Theology, 385. See his defence of von Rad's thesis on pp. 109-110.

542 Childs, Biblical Theology, 385.

${ }^{543}$ Childs, Biblical Theology, 385. 
the question of the exact nature of the relation between creation and the meaning of history is still debated, ${ }^{544}$ it is clear that in the canonical process the former came, somehow, to provide the theological horizon for the latter. ${ }^{545}$ Israel's institutions of Sabbath and covenant (Exod 31:16-17) are derived from creation and are presented as its climax so that one can speak of God's dwelling with his people as being the realization of his intention in creation (cf. 3.5.)..$^{546}$ The element of divine desire in this movement is underscored by the designation of the place of his earthly dwelling as being the place of his "rest" (מנוחה; 2 Chr 6:4-11; see also Ps 132:8, 14; cf. Ps 78:69). This divine desire was fulfilled when the Ark, the special locus of his presence, was brought into the sanctuary under Solomon. ${ }^{547}$ Yet the true fulfilment of that moment was postponed, rendering it a proleptic foretaste of a final arrival yet to come. This constant deferral appears to be a theme of the historical books, where Israel's sin consistently defers the Lord's final arrival into an eschatological future. ${ }^{548}$ Given the Endzeit/Urzeit pattern of Biblical eschatology, ${ }^{549}$ this Advent-pattern was projected into the future-perhaps even into eternity-so that themes from Genesis and the historical books are taken up afresh in prophecy and apocalyptic. Protology is not forgotten, however, for that great moment of final arrival is portrayed as an act of new creation, now projected from the beginning to the close of history. 550

In light of this significant canonical function, it seems appropriate when Knierim insists that the best vantage point for coordinating OT theologies is "the universal dominion of Yhwh in righteousness and justice. ${ }^{.551}$ The universality of Yhwh's rule represents the most extensive realm to which he relates (the quantitative aspect); the righteous quality of that

${ }^{544}$ Cf. especially Kraus, "Schöpfung und Weltvollendung," Aufsätze, 151-178; Knierim, "Cosmos and History," in Task, 171-224.

${ }_{545}$ For the following see Childs, Biblical Theology, 385-389.

${ }^{546}$ Childs, Biblical Theology, 386. See also Rendtorff, Theologie:2, 149-158. Note the parallels between the temple and the garden of Eden (cf. Bartholomew/Goheen, Drama, 42). See also van Leeuwen, "Cosmos," 413: "for Israel the goodness of the primeval creation (and its gradual renewal in the nation's founding events of exodus, Sinai, and conquest) is the norm for Israel's action in history and the goal of its history." For creation as the norm of history in a more Biblical theological perspective, see Knierim, Task, 171-224.

${ }^{547}$ Von Rad, Essays, 98. On creation as a microcosm of a palace or temple, see now van Leeuwen, "Cosmos."

548 Von Rad, Essays, 95-102.

${ }^{549}$ See Petersen, "Eschatology," 576-580; Bartholomew and Goheen, Drama, 90; Knierim, Task, 171-224.

${ }^{550}$ Childs, Biblical Theology, 388.

551 Knierim, Task, 15 (emphasis original). 
rule represents the most basic mode of Yhwh's relation to this reality (the qualitative aspect). Concerning the former, Knierim states that "human history, Israel's election, and individual existence receive their meaning because they all are part of and have their place and function in Yhwh's dominion of his world." 552 Concerning the latter, Knierim believes that the theological validity of all other kinds and degrees of relationship between Yhwh and reality "can be understood only to the extent to which they reflect implementations or manifestations of Yhwh's universal dominion in justice and righteousness. ${ }^{2533}$ Knierim has made his own proposals on how creation, history, and Israel relate. ${ }^{554}$ I will argue that Psalm 24 has already started this process (cf. 7.3.2.4.3.2.1.).

In conclusion, it appears that the form, the rhetoric, and the content of $w .1-2$ ought to serve as a horizon for the interpretation of the content that follows.

\subsubsection{Content}

Having now established the outer structure of the psalm (7.3.1.), we turn to look at its content within the parameters set. Due to limited space it is unfortunately not possible to cover every detail of this rich piece of poetry. In what follows, I will point out the most salient points for the interpretation of the whole on a stanza by stanza basis. ${ }^{555}$ Beyond comments on prosodic, syntactical, and semantic issues (much of which is relegated to the footnotes), I will highlight three key features of the psalm: its consistent interest in foundational theological issues, its polemical tone, and its understanding that the people and places that come into contact with God must be like him. I will then inquire into the relation of the parts as they create one coherent whole (7.3.2.4.). This will involve looking into the "literary world" created by the text. ${ }^{556}$ In particular it will involve looking at the literary representation of space and time,,$^{557}$ dimensions that a number of scholars have

552 Knieriem, Task, 15. History is "the realm in which the struggle for the meaning of creation is waged" (175). See the chapter "Cosmos and History" for a rejection of the under-privileging of creation theological within the broader construals of Old Testament theology.

553 Knieriem, Task, 15.

554 See especially "Cosmos and History in Israel's Theology," in Task.

555 For the most detailed poetic and syntactic analyses of Psalm 24, see Botha, "Questions;" Weber, Psalmen:l; Goldingay, Psalms:1; Fokkelman, Major Poems:3; Hirsh/Aschkenasy, "Psalm 24."

${ }^{556}$ For an application of this idea to the Psalms, see Seybold, Poetik, 213-227; "Die Spannung zwischen der erfahrenen und der gedeuteten Welt ist es, welche der Poesie ihre Dynamis verleiht. Die Psalmen haben daran Teil." (213); "Wir nennen diesen poetologischen Aspekt Perspektivik, weil die Textperspektive als die ordnende Sinnprojektion zu verstehen ist" (214).

${ }^{557}$ According to Seybold, in order to grasp the spatial dimension one should pay attention to geographical description and the use of prepositional phrases; for the temporal dimension one should pay attention to verbal tense/mood, particularly as they relate in sequence(Poetik, 213). 
seen to be of primary significance for Psalm $24 .{ }^{558}$ The possibilities opened up by this analysis will provide a framework for inquiring more thoroughly into issues of historical context, growth, and communicative function (7.4.).

\subsubsection{Half-Stanza I}

Our psalm opens with a declaration of ownership. ${ }^{559}$ The "fronting" of the name of Yhwh, the "central figure of the Old Testament," emphatic personal pronoun at the head of the sub-clause v. 2 (cf. translation) ${ }^{561}$ clearly makes identification a primary function of this section. ${ }^{562}$ Verses 1-2 are interested in proclaiming who the owner/creator is and not what it is he has done, as if to say, "Yhwh is the one, and not someone else ... ."563 The syntactic foregrounding of the owner, however, is counterbalanced by a phonological emphasis on the earth, for each colon ends with the end-rhyme $a h, a h, a h, h a{ }^{564}$ The referent of these pronouns indicates that the emphasis

${ }^{558}$ Girard, Psaumes:2, 208 ("terrestre [v. 1-2], entre terre et ciel [v. 3-6], et celeste [v. 7-10])"; Hirsch/Ashkenazy, "Psalm 24;" Spieckermann, Heilsgegenwart, 200 (",De mundo', ,De homine' und ,De Deo"); Seybold, Poetik, 219-220; Psalmen, 106 ("Urzeit [1f.] und Gegenwart [3ff.] mit der Vergangenheit und ihrer Offenbarung [7ff.]"). My own interpretation differs from these interpretations in various ways, especially in its assigning a central perspectival role to the opening half-stanza (w. 1-2) and the nature of the juxtaposition of stanzas II and III.

${ }^{559}$ Gerstenberger finds the opening "suprising" (Psalms:1, 117). He does not say why, but it may be because no other pericope in the Old Testament opens with such a declaration (Seremak, Psalm $24,63)$. From the outset, then, one feels that one is dealing with something unique. Psalm 24 is not a typical psalm.

560 TWAT:III, 534, 550.

${ }^{561}$ Cf. Muraoka, Grammar, $\$ 154 f f$, p. 536, with explicit reference to Ps 24:1. Though in poetry this syntactic devise of "fronting" does not necessarily indicate emphasis (Miller, Israelite, 242-245), there are a number of indications that this is the intended effect in Psalm 24. For a start, opening the poem with the designiation of the owner instead of the possession inverts the normal word order (Gerstenberger, Psalms:1, 117). Metzger notes that emphasis on identity is a characteristic of related texts ("Eigentumsdeklaration," 39 [referencing Pss 95:5; 89:12; 74:16; 24:1-2; Ezek 29:3]). There is also the unnecessary repetition of the pronoun in v. 2, which is itself part of a network of emphatic pronouns (זה הוא) and personal names (יעקב ) uniting the whole psalm (Girard, Fokkelman, Weber, Botha, van der Lugt; cf. 7.3.1.) Finally, Jakobson's thesis that all levels of a language, including "contiguity relations" (Waugh, "Poetic Function," 66) can be transposed to the axis of equivalence, indicates that the similar logical structure found in the following two stanzas (identity constituted through activity, see below) are set in conscious juxtaposition to w. 1-2.

562 Cf. Botha, "Questions," 544.

${ }^{563}$ Otto, "Kultus und Ethos," 174; Broyles, Psalms, 128; Gerstenberger, Psalms, 117; Mays, Psalms, 120: "The confession has a polemical function. The declaration that the LORD is owner is an intentional denial that anyone else is."

${ }^{564} \mathrm{Cf}$. Hirsch/Aschkenasy, "Psalm 24," 25; Botha, "Questions," 540. Van der Lugt refers to this as "epiphora" (Cantos, 258). The ending has different syntactic functions:, מלָָּ, "of it," "in it," and as the object of two transitive verbs in v. 2. 
does not lie on the inhabitants ${ }^{565}$ of the earth but rather the earth-disk itself (תבלאיזר), which is the ground for the existence of the inhabitants. ${ }^{566}$ Further emphasis is created by the elision of the identity of the owner in the two B-cola. According to Berlin, this functions to withdraw our attention from that which is elided and focus it on that which is repeated. ${ }^{567}$ The spotlight, therefore, moves to-and-fro between the owner and the owned.

Concerning the relation between Yhwh and the earth-disk, the content and terminology of w. 1-2 indicate that the issue is less one of explaining the genesis of Yhwh's place of dominion per se than with this sphere's perdurance in its quality as lifesustaining. ${ }^{568}$ One could say that that which Yhwh owns by right of construction is "Lebensraum." ארץ is "specified" (cf. 8.1.2.1.) as תבל, a "Bezeichnung für die bewohnbare Welt ..., als Teil von 'æræs (manchmal auch umgekehrt) und als Gegensatz zu mid̆bār." 570 The emphasis is on its fruitfulness for human habitation. This is underlined by the term which, like תבל, usually denotes fruitful abundance and contrasts with "das Verödetsein der Erde" (Ezek 12:19; 30:12; 32:15; 36:38). ${ }^{571}$ In light of this its parallel, שבים, appears to

${ }^{565}$ Görg, TWAT:III, 1012-1032, identifies as the main subjects of the verb 2 humans, angels, God, and the tabernacle, which is God's earthly throne, though it can also be used for animals.

${ }^{566}$ God does not "found" the inhabitants/fullness of the earth, he founds the earth. Another indication of this may be the rare presence of the preposition $ב$ between the construct and the pronoun it governs (ישבי בהיה ישביה), especially could also have been possible. The preposition has a spatial function, emphasising the where of the activity rather than the who (cf. Gesenius, Grammar, $\$ 130 a)$. In Ps 33:8, where the inhabitants are being addressed, the preposition is missing.

${ }^{567}$ Berlin, Parallelism, 97

${ }^{568}$ Pace Gunkel, "Psalm 24." This is a general ancient Near Eastern concern, cf. Keel, Bildsymbolik, 13-53, especially p. 48: "Die Mächte, die [die Welt] bestimmen, interessieren [den Menschen] mehr als die Bauart des Weltgebäudes, von der man sich (je nach Ausgangspunkt) die verschiedensten, niemals koordinierten Vorstellungen machte." See also p. 9. It is therefore inappropriate to label non-Biblical "creation myths" as "primitive" (Craigie, Psalms, 212). It is also inappropriate to ascribe to W. 1-2 the status of a "dogma" of creation, as Fabry and van Meerten do (TWAT:VIII, 550). Walton attempts to develop a "functional" view of creation in Gen 1 in "Creation," though his rationalistic tendency to overly demythologize robs terms like "water" of the rich nuances indicated by Keel. Can one say the Bible perceives no threat to creation (60)? See Childs, Biblical Theology, 107-118.

${ }^{569}$ A standard word pair according to Wilson, Psalms:1, 447.

570 תWAT:VIII, 548 (emphasis mine). Wright suggests that the difficult construct phrase can either indicate "the whole earth" (due to cosmological associations, cf. Job 37:12) or "the inhabited earth" (due to associations of fruitfulness, cf. Prov 8:31) (NIDOTTE:4, 237). See also Metzger's interpretation of Ps 89:12-13, where תרץ in terms of its content ("Eigentumsdeklaration," 41-42).

${ }^{571}$ TWAT:IV, 885. See also Keel, Bildsymbolik, 48-53; Metzger, "Eigentumsdeklaration," 42-43, esp. fn. 14. Contra Kraus, Psalms:1, 313, who sees מלואה referring to everything material. I do not 
indicate those who benefit from this fruitfulness. Again, the verbs used to describe Yhwh's act of constructing (כון/OTh the "life sphere" usually connote actions in the past as they relate to present states of affairs. Whereas qal 70 has the more general meaning of "laying a solid foundation, ${ }^{\prime 572}$ polel כון emphasizes the element of duration. ${ }^{573}$ In addition to this, כון (hiphil or polel) has a "funktionale Ausrichtung" that specifies the nature of God's act. Creation is "auf Lebenserhaltung und -förderung ausgerichtet." Indeed, Koch believes that the term has been used in Ps 24:2 specifically in order to emphasize תבל function as "ein mit Regen getränktes Fruchtland." 574

Beyond vocabulary, two connotations of the imagery underscore the quality of Yhwh's territory as being specifically "pro-(human)life." The imagery of establishing land upon the

understand Spieckermann's claim that מלא is a practical synonym for God's כבוד (Heilsgegenwart, 200; cf. Isa 6:3), for God does not own his glory.

572 TWAT:III, 670.

${ }^{573}$ NIDOTTE:2, 616. Cf. Pss 93:1, 96:10, $1 \mathrm{Chr} 16: 30$. There is uncertainty concerning the temporal reference of the yigtol form of כון. The apparent randomness of the verb tenses/aspects used within Hebrew poetry has often been noted (Miller, Israelite, 241-242) and it appears that there is still no consensus on the matter. Niccacci has a go at finding a consistent pattern behind the verbal system in poetry by utilising the pragmatic concepts of foreground/background ("Poetry"). 1 had a go at applying this approach to this verb on my blog (http://narrativeandontology.blogspot.com/2009/05/second-line-information-in-poetic.html). This synchronic approach is distinct from diachronic approaches, which look to ancient Ugaritic parallels in order to discover an ancient preterite form (see Craigie, Psalms, 110-113) (For the tension between synchronic/diachonric in Biblical linguistic study, see Waltke/O'Connor, Introduction, \$1.1b, p. 4). For a helpful (informal) online overview, see Bekin, "Verbs" (though he is wrong to say that יכוננה has a nun paragogic ending, p. 1). For an example of the ongoing disagreement, however, see Tatu, "Lunn," who notes how the results of Lunn's recent analysis of word-order in Hebrew poetry is diametrically opposed to the results of another study recently carried out by Fariss (145). In Lunn's view, the use of an archaic preterit in the second colon, a more difficult form known to erudite poets, functions as "defamiliarization," a technique whereby the reader is forced to pause, thereby extending the artistic experience (see Bekins, "Verb," for a brief overview). Berlin, inter alia, notes that the qatal-yiqtol switch is common a common stylistic devise in parallelism ("Grammatical Aspects"), though the function is to create variation and not to indicate a change in temporal perspective.

574 TWAT:IV, 104. Again, the root in these stems "bezieht sich ... nie auf die Schöpfung insgesamt, sondern auf herausragende Werke, denen eine ordnende und heilvolle Wirkung für andere Kreaturen zukommt. ... Genaugenommen meint hekîn [or kônēn] nicht einen schöpferischen Akt als solchen, sondern ein Ausstatten und Zurüsten bereits erstellter Größe. So hat JHWH die Erde gemacht, um sie (lo + inf.) hernach heilsam zu gestalten (hiph) (Jer 33, 2)" (104). See also Spieckermann, Heilsgegenwart, 80-86, especially p. 82, where he states that although the concept of creation can be present with the use of these terms, we must beware of the "Gedankliche Gefälle und Artikulationsweise ... . Erde und Erdkreis sind als Eigentum Gottes da, welches bestehende Bestizverhältnis auf seine Entstehung hin bedacht wird. Die Tat des Anfangs erklärt den gegenwärtigen Besitz." According to Walton, "Creation," 52, the Bible has a "functional ontology, something only exists when it has a role and purpose in an ordered system." 
waters echoes Canaanite stories of Baal's conquering of the waters of chaos in order to establish his temple upon Zaphon (cf. 7.4.2.2.). According to Spieckermann, the function of this ancient myth is not so much to explain the creation of the cosmos, but its continual sustenance. ${ }^{575}$ Within our Psalm, this is backed up by the emphasis on stability in the face of watery threat. ${ }^{576}$ The implicit fear is the question of whether the earth might "be washed away." $" 577$ The means by which Yhwh ensures the continuance of this treasured sphere of existence is also telling: He acts as a "skilled engineer building an edifice on a marshy base." ${ }^{.578}$ As elsewhere in the ancient Near East, the world is understood to be like a cosmic house, of which human temples and houses were microcosms. ${ }^{579}$ This connotation is brought out by the terminology. As in our verses here, creation in the ancient Near East and Old Testament is often portrayed as a "binary process" of "building" (for which the roots מיס are common) ${ }^{580}$ and "filling" (מלא, in various Semitic languages). ${ }^{581}$ The result is "a house filled and provisioned with good things ... , a place to celebrate with abundance. Literal and metaphorical 'houses' inevitably impiy a 'world." 582

${ }^{575}$ Spieckermann, Heilsgegenwart,80-81. Keel points out that we should beware of taking such myths too literally. Talk of turbulent waters beneath the earth function to explore ultimate questions of the source and security of life and as such allowed for an openness concerning the appropriate imagery. "Für den [Alten Orient] weist die empirische Welt als Manifestation und Symbol über ihre vordergründige Wirklichkeit hinaus" (Bildsymbolik, 47). As such, the deadly power of water can be set in parallel to the wilderness (paradoxically, if we simply focus on the material element I Cf. Jer 51:42-43), darkness, the grave, the realm of the dead and the enemies of Israel (Keel, Bildsymbolik, 53-68. See also TWAT:III, 656; TWAT:IV, 289-290). In Job, we learn that God has suspended the world over nothingness (Job 26:7) (Keel, Bildsymbolik, 46).

${ }^{576}$ The nature of the water as unstable is emphasized by the semantic specification of the parallelism. $D^{\prime}$ is the general terms for larger expanses of water, נהרות (here as the plural of amplification, TWAT:IV, 283) is more particular. Typically it refers to perennial rivers, yet the focus is on the flow of the water and in cosmological contexts such as this one it refers to the currents of the ocean (Stadelmann, World, 162; TWAT:IV, 284). As such, both terms denote the "Ozean, der die Welt umflutet" (TWAT:IV, 284), yet with the focus on movement (note the verbal form of in Isa 2:2, Jer 51:44; Mic 4:1) and thus the opposite of the stability denoted by the verbs of which these nouns are the objects. Stadelmann notes that "in the description of the sea the biblical authors are more impressed by the movement of its waters than by its colours" (World, 157. See also TWAT:III, 655). When this is the case the associations are entirely negative: The sea threatens to destroy Yhwh's world.

577 Goldingay, Psalms:1, 358.

${ }^{578}$ Goldingay, Psalms:1, 358.

579 Van Leeuwen, "Cosmos," 399.

${ }^{580}$ Van Leeuwen, "Cosmos," 408-409.

${ }^{581}$ Van Leeuwen, "Cosmos," 400.

${ }^{582}$ Van Leeuwen, "Cosmos," 400. See also Knierim, Task, 199: "The fact of creation out of chaos alone represents more than a merely quantitative event. It is a good event." Translators often opt for "world" as the best translation for , because of its holistic implications. 
This focus on the quality of this piece of real estate as a platform ${ }^{583}$ or sphere within which human (ישב) life can flourish gives a powerful existential dimension to the polemical ${ }^{584}$ affirmation that it is Yhwh who is the one who is the creator and therefore rightful owner of this realm (and not some other deity). The one to whom honour and obedience (cf. stanza II) are due is the one who secures the very grounds for the addressee's existence and, in light of the fruitfulness of that reality (מלא), the condition for his or her happiness. Yet this anthropocentric dimension-God's activity for us-does not detract from the theocentric focus. The agent of all the verbs is Yhwh and their initiative lies in his will alone. ${ }^{585}$ Regardless of the benefits this reality has for those that inhabit it, its raison d'être lies in the LORD's own purposes. This pattern of divine and human benefit is found in the following stanzas. In stanza II the revelation of God's will serves the creation and maintenance of a properly functioning human society (wv. 4- 5). Yet these rules are set up as conditions for entry into his presence. For whatever reason, "faithfulness within the community" (Gemeinschaftstreue, צדקה/צדק) is something that God himself desires. In Stanza III the warrior God already anticipated in v. 5 (אלהי ישעו) is revealed as havingpresumably-redeemed the righteous (cf. 7.3.2.4.3.2.). Yet he appears as one entering his own sanctuary, the place described elsewhere as the place of his rest (מנוחה; cf. 2 Chr 6:411 ; see also Ps $132: 8,14$; cf. Ps 78:69; 7.3.1.2.1.2.)..$^{586}$

\subsubsection{Stanza II}

We noted above that there is a possible parallelismus stropharum between w. 3-4 and 5-6, creating an $A B / A^{\prime} B^{\prime}$ pattern (7.3.1.). In addition to this, the semantic shift between the strophes accords with the pattern of specification typical of Biblical parallelism in general (7.1.2.1.). The former line in each case explicates the latter in terms of its consequences. Thus, whereas $A(v .3)$ portrays the destination, i.e. Yhwh's sanctuary, $A^{\prime}(v .4)$ tells us what

${ }^{583}$ Cf. TWAT:VIII, 548: תבל could denote the "im Urozean schwimmende Erdscheibe."

584 Gerstenberger, Psalms:1, 117: "V. 1 is ... a militant affirmation seeking to establish or defend Yahweh's overlordship (see also Psalms 81; 93; 96)."

585 See especially Knierim, Task, 198-199; "To the extent which [Israel] is certain of the world order, it is certain because of its trust in Yahweh" (199).

${ }^{586} \mathrm{Cf}$. Levenson, "Temple," 297-298: "The world which the Temple incarnates in a tangible way is ... the world of creation, the world not as it is but as it was meant to be and as it was on the first Sabbath. ... The Temple is to space what the Sabbath is to time, a recollection of the protological dimension bounded by mundane reality." 
happens when one gets there, i.e. blessing and righteousness is received. ${ }^{587}$ Again, whereas $B(v .4)$ describes the characteristics of the one who may enter, $B^{\prime}(v .6)$ makes the rhetorical point that if one accords with this description, one belongs to the true Israel (cf. 7.3.2.2.1.). In addition to this, v. 6 does not just specify v. 4, it also climaxes the entire stanza by providing the opening question with its final answer: The true Jacob is the one who may enter.

There are two elements of stanza II that are particularly significant: 1) the concern (continued from w. 1-2) with issues foundational to Israel's faith; 2) the reciprocity expected of relationships, both human-human and human-divine.

\subsection{Identity and Destiny}

Stanza II opens with a "Grundsatzfrage." where, as we saw above (7.3.1.2.1.2.), Israel's and God's hopes would be consummated. It is also the place where heaven and earth intersect. ${ }^{589}$. In relation to $w .1-2$, one could say

587 "Mit 5 wird die Einlaßantwort zu Tora, d.h. zur theologischen Belehrung über die Heilsgüter, die das Heiligtum zu bieten hat" (Seybold, Psalmen, 105). See also Goldingay, Psalms:1, 360: "A double promise is attached ..., going beyond the question though perhaps only making explicit what was implicit in it." That the verb refers to an event within the sanctuary, and thus denotes a moment one step beyond the ascent and "worship" of v. 3, may be indicated by Ps 27:7-14. According to Wagner, the Sitz im Leben of this "individual lament" is within the temple (TWAT:I, 764). The psalmist is persecuted by the kind of people described in Ps 24:4b (cf. Ps 27:12), has experienced God's salvation in the past (v. 9), and yet must wait for his salvation to come again (v. 14). The element of waiting with confidence is emphasized, so that our v. 5 may represent a promise that those who are righteous will indeed receive that which they seek $(v .6)$ from Yhwh, despite the time it takes.

Verse 3 is also further specified in that Yhwh is presented as the source of blessing, and not the physical location itself. Cf. Keel, Bildsymbolik, 100: "Die biblischen Denker lehnten die mythische Vorstellung vom Raum als unveränderlich ab. ... Heiligkeit kommt einem Raum nur durch eine Verbindung mit dem Gott Isroels zu" (TWAT:II, 470). This, in contrast to Israel's cultural context.

${ }^{588}$ Podella, "Transformationen," 125. Podella notes the terminological and conceptual proximity of the question in v. 3 to the Sinai epiphany in Exod 19 (Podella, "Transformationen," 125; Seremak, Psalm 24, 139-194). Apart from in Exod 19:12-13 and Deut 5.5, there is no other

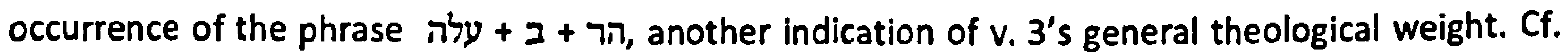
TWAT:V, 97. (Interestingly, Seremak notes that the preposition is only used of the people; for the Moses the preposition 2 is used [140]).

${ }^{589}$ Spieckermann, Heilsgegenwart, 206; Girard Psaumes:1, 207: "Par ces embrasures, on peut entrevoir la manifestation du Dieu du salut (v. 5b) ... . Dans notre psaume, š"ārîm et p"tāhîim désignent, ne pas les portes du Temple de Jérusalem, mais, sans doute, les portes du monde céleste, échappont aux limites du temps [" ouvertures de toujours ॥] et de l'espace [" élevez vos têtes \#, ...]. De ces portes d'en haut, les portes du Temple d'en bas ne sont que l'ébauche et la figure." The association of "meeting place with God" is also strongly connoted by the use of the term "mountain" in general, cf. TWAT:IV, 1118.). ${ }^{589}$ Indeed, the very act of ascension connotes approach towards majesty. Keel notes that the composers of statements of Zion's majestic height were fully aware that this language did not accord with the surrounding geography (Bildsymbolik, 102). Although a 
that it is the place where the quality of life (fruitfulness in stability) indicated in the halfstanza may be experienced most fully. ${ }^{590}$ On whatever level we understand the original reference of Ps 24:3 (historical, metaphorical, or eschatological pilgrimage, for example), the act of entry represents a move into the heart of Biblical hope (see also $\underline{9.3 .2 .}$.). ${ }^{591}$

As is to be expected in the light of such a significant question, the criteria for entry similarly touch on fundamental theological issues.

For a start, the criteria for entry imply that the one who would enter must be characterised by commitment to "social solidarity" (Gemeinschaftstreusein; צדק/צדקה, cf. Ezek 18:5-9), clearly a primary concern of Israel's broader tradition. ${ }^{592}$ Yet, in light of texts

modest ascent was certainly necessary in order to move from outer gate to the temple in the centre, the primary function of such language is go give expression to "die Mächtigkeit der von Jahwes Gegenwart gezeichneten Lokalität." (101). See also the interpretation of w. 7-10 below. For a fascinating study of the general West Semitic context, see Smith, "Deities," especially 3-6: "At its core, temples serve as points of intersection between divine presence (theophany) and human presence (pilgrimage). At the core of intersection is ritual, which provides the context for divine presence with blessing from the divine side and human presence of priests and pilgrims with their offerings from the human side" (4).

${ }^{590}$ Childs characterizes the cult as "the conduit through which God lavished his benefits" (Old Testament, 168). The Edenic architecture of the temple (Keel, Bildsymbolik, 118; Smith, "Deities," 5, 7) emphasizes its function as "ein Bereich intensivsten Lebens und Segens" (Keel, Bildsymbolik, 108; cf. w. 1-2), indeed the salvation historical narrative of Israel's deliverance from Egypt was presented as being fulfilled in Zion (105, 108; cf. w. 7-10). As such, it is not surprising to hear about the "Sehnsucht" for the temple that is expressed in the psalms (157; cf. Pss 23:6; 27:4). Indeed, it is the peculiar characteristic of the Psalter as a whole to give expression to Israel's "starke emotionale Beziehung zum Tempel' (Rendtorff, Theologie:2, 151). The psalms provide us with little information on what the participants in the cult actually did (150), indicating that that which they do thematize is that which really matters: the gift of the fullness of life (cf. Childs, Old Testament, 155-174).

591 The sense of movement towards a goal is emphasized by the semantic development from v. $3 a$ to $3 b$, which is climactic. There is a general consensus that קום in v. 3b represents "die End- und eigentliche Sinnphase eines komplexen liturgischen Vollzugs" that began with the "ascent" (עלה) in v. 3a (TWAT:VII, 1258. See also Steingrimmson, Gerechtigkeit, 85, 88: "Aufsteigen um zu bleiben"). The second colon is thus "resultativ." Podella translates as follows: "wer zieht hinauf zum Berg YHWHs, und wer steht (infolgedessen) an seiner heiligen Stätte" ("Transformationen," 120). It is difficult to know what kind activity קום refers to. Hossfeld simply talks of a "kultische Haltung" synonymous with עמד In Jer 70:10 (Psalmen:1, 159). For the second temple period, Ostermeyer states: "Die im Jerusalemer Tempel übliche Gebetshaltung war das Stehen (Lk 1,10; vgl. Mischna Taanit IV,2). In Abgrenzung dazu zeichnet sich das Beten der Qumrangemeinde durch die Prostration aus (vgl. die Bezeichnung "Haus der Niederwerfung" für die Gebetsstätte der Essener, CD [=Damaskusschrift] $X I, 22)$. Auch unabhängig vom Tempel war das Gebet im Stehen sowohl bei Juden (polemisch: Mt 6,5 par.) als auch bei Christen in der Antike (Mk 11,25) eine gebräuchliche Gebetshaltung." ("Gebet," §2).

592 Cf. von Rad, Theologie:I, 375: the "gate liturgies" of Pss 15 and 24 consist in questions about the pilgrims' צדקה, the most fundamental Biblical term "für alle Lebensbeziehungen des Menschen" (368). Cf. Koch, "Tempeleinlaßliturgien," 46. For a discussion of the concept, see Childs, Biblical Theology, 487-491 
such as Lev 19, which associate holiness (cf. v. 3) with both the ritual and the ethical, ${ }^{593}$ Ps 24 has made the "prophetic" move of focussing on that which it considered to be more fundamental: the ethical (cf. Mic 6:6-8). ${ }^{594}$ This can be seen in the ethical rather than ritual terminology $(\text { נקי/בר })^{595}$ used in the merism ${ }^{596}$ in v. $4 a$ to describe the total life of the righteous person (i.e. in terms of intention 597 /action). The same applies to v. $4 b-c$, which represent a "practical realization"598 of the content of v. $4 a{ }^{599}$ The relation of the cola within this tricolon is clarified when one sees them joined by a symmetric pattern ( $\left.A B / B^{\prime} A^{\prime}\right)$ in which the movement within the opening colon (v. 4a) is inversely mirrored in the concluding two. The unusual phrase בר לבב in its description of

${ }^{593}$ Milgrom, Leviticus, 212-213. See also Rendtorff, Theologie:2, 85; DOT:P, 425.

594 Micah 6 is close to Ps 24 in terms of form. McConville also lists 1sa 5:1-7; Hos 6:6 and Amos $5: 24$ as being paradigmatic for the idea that "Israel" cannot truly be itself in the absence of a love of righteousness and justice ("Prophetic Writings," 630). It should be added here that the proximity of Ps 24:3-6 to prophetic concerns does not necessarily make this text prophetic in its origin. As Koch has pointed out ("Tempeleinlaßliturgien," 55-56), Micah's answer in v. 8 implies that the pilgrim should already know the answer to the question. This could imply that such "torah-entrance litrugies" as found in Pss 15, 24 and Isa 31 are older and form the precondition of the prophetic message.

595 בר 5or see TWAT:I, 843. For cultic usage, the terms (844). (See also Podella, "Transformationen," 126). For נקר see TWAT:V, 595. נקי also always has primarily ethical purity in view, which functions as the foundation for cultic purity (TWAT:V, 600). As for the semantic relation of the terms, the first quality, נק ("free from guilt/punishment," TWAT:V, 595) is predicated upon the presence of the latter, בר ("purity"). Purity is the standard in light of which one is judged to be innocent. God's law-the criterion for innocence-can be described as "pure" (e.g. Ps 19:9), yet, as is to be expected, it is itself not "innocent" (for the syntactic relations of 'ps, see the entry in DCH). The adjectives correspond to their nouns. Whereas "hands" can be either "innocent" or "pure," the heart is never describe as innocent (see the entry for ל in DCH).

${ }^{596}$ Botha, "Questions," 541. Cf. Ps 33:15. For similar merisms using לב see TWAT:IV, 426.

597 The heart is the "Entscheidungszentrum Im Menschen," the source of one' deeds, which is why in Deut 15:9 the command to obedience starts with a warning about the heart (cf. TWAT:IV, 438). Again, this is the logic behind the prophetic promise of a "new heart": when God writes his torah on the heart (Jer 17:2; 31:32; Ezek 36:26-27; cf. Ps 51), the result is submission to the divine will (TWAT:IV, 439, 444). As with all our parallelisms so far we have a move towards "the heart of the matter," in this case from effect to cause

${ }^{598}$ TWAT:IV, 443.

599 According to Hossfeld, this is a common Old Testament pattern: "Typisch ist das Herausstreichen der Gesinnung, um auf diese Weise ein umfassendes Verhalten von innen heraus zu betonen." In relation to Ps 15:2 he states: "Überblickt man die Trias der Partizipialsätze in V. 2, dann ergibt sich von der Semantik her eine Hierarchie. An oberster Stelle steht der erste Partizipialsatz über den tadellosen Wandel, der das gesamte Verhalten umfaßt. Ihn zu- und untergeordnet sind die folgenden Partizipialsätze über das gerechte Tun und das wahrhaftige Reden" ("Nachlese," 147). See also Steingrimmson, Gerechtigkeit, 27.

${ }^{600}$ Concerning the third person suffix, see text criticism above (7.2.2.). Spieckermann's contention that this is a reference to the third (or second, depending on how you divide the text) commandment (Exod 20:7) cannot stand, for nowhere do we hear humans swearing by Yhwh's soul (the only person who swears by Yhwh's "soul" is Yhwh himself, where $I$ is used; cf. Amos 6:8; Jer 51:14; Jer 44:26 and Hossfeld, Psalmen 1, 159). The phraseology may, however, explain the suffix as a scribal mistake, given that the formulation of Exod 20:7 is very similar and that the parallel colon in 
the desires of one's heart, ${ }^{601}$ whereas לא נשבע למרמה parallels נקי כפים in its depiction of the kind of activity that can flow from one's heart. More specifically, both cola refer to deception, ${ }^{602}$ perhaps in a juridical context, ${ }^{603}$ a crime elsewhere associated with the harm it causes to social harmony (שלום; it is often associated with, e.g., theft, fraud, exploitation, murder, adultery; idolatry is mentioned only once in Jer 7:9). ${ }^{604}$ The juridical association is strengthened by the temple context, for the temple was a centre for the administration of

v. $4 \mathrm{~b}$ is also about swearing. A further impetus may have been the coercion of reading Ps 24 in light of Ps 15, which addresses its question to Yhwh himself (Ps 15:1), implying that Yhwh gives the answer. The potential effect is that both "tables" of the Decalogue are recreated within v. $4 \mathrm{bc}$, the first colon referring to the "religious" dimension of evoking Yhwh (Exod 20:7, the first tablet), its parallel referring to the social dimension of giving false witness in court (Exod 20:16, the second

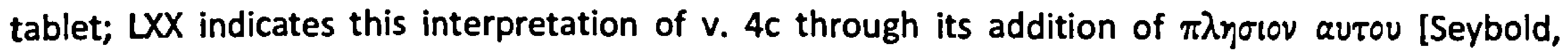
Psalmen, 105]). The scope of the responsibility on the part of the pilgrim is thereby simply expanded. For a modern midrash, see Hirsch's translation: "Who has not lifted up his soul which is mine unto vanity" (Tehillim, 299).

${ }^{601}$ Reiterer translates נשא לשוא נפשו as "(Seinen Sinn) auf Betrügerisches (richten)" (TWAT:VII, 1107); Freedman-Willoughby similarly translates it as "Bedachtsein ouf Betrug." TWAT:V, 641. The phrase נשא נפש in general functions "ein Wunsch, ein Interesse und eine bestimmte Anteilnahme ouszudrücken (Deut 24, 15; Spr 19, 18), eine Begierde nach Sünde (Hos 4, 8), Bedachtsein auf Betrug (Ps 24, 4 ...), aber auch Vertrauen auf JHWH (Ps 25, 1; 86, 4; 143, 8; vgl. KIgl 3, 41)" (641).

שוא basically means "Wirkungslosigkeit, Trügersiches," which, although it can have the broader connotation of idolatry, in most places it refers to falsehood or deceit (NIDOTTE:4, 53; Reiterer talks of שוא's "nähe zur Lüge" and defines נשבע למרמה as "gewollt irreführende Versprechen" [TWAT:VII, 1107]). Shepherd suggests that this meaning is primary, so that the term only refers to idols "inasmuch as they are ineffective and therefore false" (NIDOTIE:4, 54). This basic meaning is the exclusive meaning of מרמה, which only refers to deception, specifically the attempt "bestimmte Verhältnisse zu verheimlichen oder zuzudecken" (TWAT:VII, 524). In poetic uses of שוא, the second colon specifies the content of the otherwise vague term. A similar concern for swearing false oaths is found in the generically related Ps 15:4. We can thus conclude with Shepherd that the issue at stake here is not idol worship, as has been occasionally suggested (Botha, Seremak, Dahood, Lohfink; see TWAT:VII, 1107-1108) but "basic integrity" (NIDOTTE:4, 55). The discrepancy between word and intention also correlates with the concern of the opening colon (v. 4a), which demands internal as well external purity.

${ }^{603}$ See Lang's analysis of the institution of the assertive (rather than promissory) "exculpatory oath" (Reinigungseid; in "Verbot"). In cases in which there was not enough evidence to condemn a defendant, the defendant was required to swear by oath (שבעה) that he or she was innocent (Lang refers to Lev 5:20-26; 19:11-12; Zech 5:1-4; 8:16-17; Sir 23:11). In such cases, the legal system was powerless to enforce justice and so was dependent upon the honesty of defendant. In relation to Ps 24, Zech 8:16-17 shows a number of linguistic and conceptual connections, for it connects honesty "in the heart" (cf. Ps 24:4a; Ps 15:2), pure intentionality (Zech 8:17; Ps 24:4b), and the swearing of false oaths within the city gate (שבעת שקר; Ps 24:4c; Ps 15:4c). Clements' excellent analysis of Ps 15 ("Worship and Ethics") supports this understanding. He refers, for example, to Exod 20:10-13 for background (79).

${ }^{604}$ TWAT:VII, 985. See Lev 19:11-13; Jer 7:9; Zech 5:3-4; Mal 3:5. 
justice. ${ }^{605}$ These associations, in turn, have implications for the meaning of the re that is received upon arrival (v. 5). That which Yhwh has to offer appears to be some kind of reintegration of the falsely accused into society ${ }^{606}$ (hence the common translation of צדב as "vindication," even "justification"

In light of this, the paradigmatic righteous person in v. 4 appears to depict a person who has been falsely accused for committing some crime. On this pattern, the "Jacob" of $v$. 6 could be identified with the so-called "poor" (אביןן, עני), a key group found throughout the Psalter and the prophets (e.g. Isa 14:32; Zeph 3:12), ${ }^{610}$ indeed a category of person embodied in the Psalter by none less than the persona of the David of the historical superscriptions (cf. 9.2.). Note the proximity of Kraus' description of this group to the situation in w. 3-5:

In their need the "poor" take refuge in the temple area and plead with Yahweh for his intervention and defeat of the enemies. ... The enemies' persecution ... can take a great variety of forms: slander, cheating, banishment ... or ... a magically effective curse. ... The "poor" are the most intensive frequenters of Zion. They can be called the ידעי שמך (Ps 9:10, "those who know thy name"), because they stand in familiar association and intimate communion with the God who is present in his שם. Above all, however, the עני experiences the wonder of God's turning to him to provide his salvation with the kind of strength that can turn his fate and renew his life. Thus the "poor" become the

${ }^{605}$ See, e.g., Kraus' commentary on Ps 7 in Psalms:1, 169, along with bibliographic references for more detailed studies by H. Schmidt and Beyerlin. Concerning the "poor," whose voice dominates the psalter, Kraus says that, in their need, they "take refuge in the temple area and plead with Yahweh for his intervention and defeat of the enemies" (Psalms:1, 93). For the more historically sceptical, the juridical function of the temple is still an open question. See Gerstenberger, Psalms:1, e.g. p. 95 .

${ }^{606} \mathrm{Cf}$. Gerstenberger on the function of Ps 17: "The supplicant has been able to prove his innocence. Now the official prayer service has to break through that deadly circle of divine punishment and social ostracism" (Psalms:1, 95).

${ }^{607}$ For the latter see especially Spieckermann, Heilsgegenwart, 204.

${ }^{608}$ Cf. Kraus, Psalms:1, 77: "the צ'ציק is the socially faithful person who lives in accordance with the covenant. When he becomes עy, needy, his צדקה is in doubt ...; but that is precisely the subject of the prayer songs of an individual: the צדיק צמבקה through Yahweh's helpful intervention."

${ }^{609}$ This is a common theme of all the so-called "entrance liturgies" (Pss 15; 24:3-6; Isa 33:14-16; mic 6:6-8; Ezek 18:5-18). According to Koch, "es wird überall gegen ein unrechtmäßiges Gewinnstreben und damit gegen wirtschaftliches und soziales Unrecht Stellung genommen" ("Tempeleinlaßliturgien," 59; emphasis original).

${ }^{610}$ According to Botha, the "description of 'those who seek him' is a well-known self-designation of the final editors of the Psalter," those who thought of themselves as the "poor" or "wretched," the messianic pious ("Questions," 546). He cites Hossfeld/Zenger, Psalmen:I, 157, 160, who point out the following parallels: Pss 9:9-13, 18; 14:6; 22:24-25, 27; 73:1-, 15; 112:2. 
outstanding recipients of the ישועה ("deliverance"). They are the witnesses of the effectual gracious presence of God and the legal aid of him who is enthroned on Zion, אל-עליוl: Pss. 9:18*; 10:17*; 18:27*; 22:26*; 25:9*; 37:11*; $69: 32^{*} ; 147: 6^{*} ; 149: 4^{*}$. Thus we can say that the "poor" on Zion enjoy unexampled privileges that have their basis in this alone, that Yahweh is the God of the helpless. ${ }^{611}$

The desire to ascend mount Zion, then, appears to be less a matter of pilgrimage but rather the desire to experience "redemption" (cf. v. 5b) from affliction experienced in everyday life. That we are touching, once again, on paradigmatic theological issues, is confirmed by Fabry's statement that within the Bible the discrepancy between the tongue and the heart is particularly "verachtenswert." Indeed, "Für den Psalmisten gehört dieses Gespaltensein zwischen boshaften Herzen und heuchlerischer Zunge gerade zur Definition des ræša (Ps 28, 3; 41, 7)."

The implied division within Israel between the righteous and unrighteous in v. 4 is a fitting context for the climactic and polemical statement of identity found in v. 6. Here the symmetric pattern uniting the two cola $\left(A B C / C^{\prime} B\right.$ ' $A$ ') establishes a parallel between "Jacob" and "this/such is" ${ }^{613}(\mathrm{Ar})$, ${ }^{614}$ creating the sense: "such is ... Jacob." ${ }^{615}$ The fronting of the pronoun indicates that the reader is already aware of the existence of a group that claims to be "Jacob;" the concept of such a named "generation" is clearly not being introduced for

${ }^{611}$ Kraus, Psalms:1, \$10, 93-94. See also Clements, "Worship and Ethics," 89, who suggests that Ps 15, a psalm mirroring the structure and content of Ps 24:3-6, grew out of cases where the falsely accused sought asylum in the sanctuary.

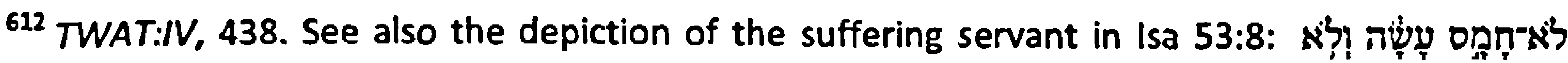

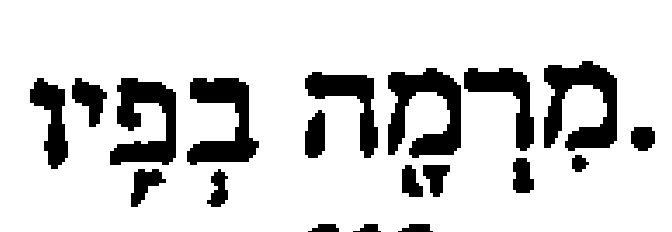

613 "Such is" is the NIV's translation.

${ }^{614}$ With ellipsis of $\mathrm{ir}$ in the second colon.

${ }^{615}$ Cf. Botha, "Questions," 539-540:" "בקש form a word-pair and thus probably have one and the same object, so that the second person suffix in 'your face' must be understood to refer to the same person as the third person suffix in the previous colon ("who seek him"), thus as a reference to YHWH." This chiasmus provides a viable solution to the verse's difficult syntax, an option not considered by Tromp ("Jacob"). If read as a vocative, the reading would be unusual, for it would imply that the nations would be seeking the face of Jacob, something that never occurs in the Old Testament. Tromp's allusion to the "pilgrimage of the nations' motif in 1sa 2:2-5 (=Mic 4:1-5), and Zech 2.15 (followed by Hossfeld and Lohfink) does not work because in these text's Yhwh is the object of the pilgrimage and not Jacob and because there torah is what one ascends to receive, rather than being the criterion determining who may ascend. The function of Jacob/Israel in Isaiah is to point beyond itself to God; cf. Berges, ("Witnesses," [10]: "the identity of the People of God as 'Jacob/Israel' and as 'Zion/David' centers on the call to be witnesses to Yahweh as the only true God. This function is made possible because God glorifies himself first in Jacob (44:23) and then in the community of Zion (55:5)." (Page numbers for Berges, "Witness," are based on my copy of the electronic file and are thus relative to the unpublished version. The work is forthcoming.) 
the first time. ${ }^{616}$ The point that is being made is that those who would claim to be God seekers (cf. Isa 58:2), the true "Jacob," must look like the righteous one in v. 4 in order to be justified in their claim.

Verse 6 indicates once again the presence of foundational theological issues. The question of the identity of the "true Israel" is an important theme amongst the prophets, ${ }^{617}$ especially Isaiah, who uses the different names "Jacob/Israel" intentionally. ${ }^{618}$ According to Berges, Isa 41-48 uses "Jacob" as an identity marker for "Israel in exile," the post-exilic rhetorical device of Rollen- und Problemdichtung. ${ }^{620}$ Similar to Ps 24 , Berges argues that the aim of the tradents of the Isaianic tradition was to encourage those within its circle "to remain faithful to their vocation of being the offspring of Jacob/ Israel." 621 Yhwh himself has provided a means for doing this through the "furnace of exilic affliction" (Isa 48:10). The goal is that the blind and deaf "servant" Jacob/Israel would develop into the faithful servant of Yhwh through accepting in faith and proclamation the advent of his redemption (see 9.3.3. below for a further development of this theme). ${ }^{622}$

${ }^{616}$ The word 7 in this context refers to a particular cross-section of the Israelite community a one point in time (cf. Hunter, "Righteous," 189). It is often used in polemical contexts to label a generation in terms of its moral qualities, a prominent example being the "wicked" generation that died in the wilderness (cf. Deut 32:20; Ps 95:10; see also Jer 7:29; Isa 53:8) (TWAT:II, 193). Given that Jacob here is characterized in light of moral qualities presented in v. 4 , it would appear that we have a similar process of (re)definition found amongst Israel's prophets, especially Isaiah. For similar interpretation see Kraus, Psalms:1, 314 (who nevertheless depends upon the LXX).

${ }^{617}$ Zobel states that in the prophets, "Jakob [ist] zu einer Bezeichnung geworden, die etwas wie die Idee Israels in der Geschichte verkörpert" (TWAT:III, 777). Again: "In ihm zeichnet sich die Erwählung Israels schon im Voraus ab" (773).

${ }^{618}$ See, for example, Polliack's interpretation, "Jacob," 77, fn. 13: "Considering Deutero-Isaiah's audience, the constant naming of Jacob appears deliberate, since he is addressing exiled Judaites as if they were Israelites, thus appropriating to them the full status of Jacob's descendants. In this he provides an answer to the problem that so preoccupied his generation, namely, who is real Israel?" (emphasis mine; cited in Berges, "Witnesses," ' 6 ' [publication and thus page number are forthcoming]). Berges points out the connections between the designation of Israel in exile as "Jacob" and the tradition of Jacob in Genesis: "Just as the patriarch Jacob is characterized by sin and election, so are all those who belong to him (cf. Isa. 41.8-9; 43.10; 44.1-2; 48.10; 49.7)" (Jesaja, 99; translation mine). See also Baltzer on Isa 44:5: "[A]s far as we can see, "Jacob/Israel" was not a political entity at this time; it was rather a program. The person who used this name for himself was making a confession of faith" (Deutero-Isaiah, 187). Note also the use of הז ליהוה in this verse.

${ }^{619}$ Berges, "Witnesses," [6].

${ }^{620} \mathrm{~A}$ "technique by which theological problems of post-exilic times are enclosed in a literary figure" ("Witnesses," [5]).

${ }^{621}$ Berges, "Witnesses," [1].

622 Berges, "Witnesses," [10]. This perspective seems to imply a "conversion" on the part of Jacob: "The connotation of 'Jacob, the betrayer' is not erased, clearly seen in 43:27: 'Your first ancestor sinned,' or in 48:8: 'from birth you were called a rebel,' but this negative image does not stand in the foreground. What stands in the center is the renewed election of Jacob/ Israel in 


\subsection{Reciprocation}

The use of the term ("righteous act") ) $^{623}$ to describe that which the righteous individual will receive ${ }^{624}$ from Yhwh indicates that there is a "dialektischen Verhältnis" between supplicant and supplicated (cf. $1 \mathrm{Kgs}$ 8:31). This meaning is inherent within the term itself. Whereas both צרכה anclude the concept of "anything prosperous or beneficial,"626 "righteous act" (צדקה), with its added "legal" dimension of "that which is right," ${ }^{267}$ implies an "assumed relationship" within which it functions (hence the proposed

exile: ... The chiastic structure 'Israel-Jacob// Jacob-Israel' and the mention of Jeshurun in Isa 44:2 (cf. Deut 32:15; 33:5.26; Eccl 37:25) underline the change from 'Jacob, the crooked one('aqob: uneven, deceitful, sly) to 'Jacob,the 'straight/ just one' (yashar)" ("Witnesses," [6-7]).

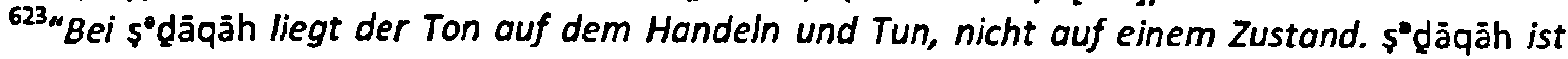
sædæq in Funktion" (TWAT:VI, 913). צדק, being in the B colon, specifies the content of the blessing, ברכה , in colon A. Pace Goldingay (Psalms:1, 360), who refers to Westermann (Blessing), the two terms do not refer to two different modes of God's activity (cf. TWAT:I, 839). The term "blessing" can refer both to God's salvific acts within history as well as to processes within nature (e.g. Gen 22:17; 24:60; 2 Sam 7:29; Deut 28:7; Lev 26:6, cf. TWAT:I, 839).

${ }^{624}$ The syntax of v. 5 is difficult. Andersen and Forbes consider v. 4 to be a single nominalized subject of the predicate $k$ י, rendering the rather long sentence: "One who has clean hands ... will receive a blessing." There are two problems with this. First, it will leave the question posed in v. 3 at best only indirectly answered, for explicating the benefits of temple entry is not the same as simply stating who has access to it. This function is fulfilled by v. 4 alone. Second, if there is strophe separating v. 4 from v. 5 (cf. 7.3.1.), this would be a very harsh case of enjambment. For Fokkelman syntactic unity is a key to identifying the boundaries of a strophe (Reading, 89; for an example, see $p$. 97. His definition of enjambment only applies to cola or lines, p. 226). As such, it appears that we are dealing with a clause-initial yiqtol. This still does not fully resolve the interpretation of the verb, however, for in prose many scholars believe that yiqtols in clause-initial position are volitive or jussive (i.e. "may he receive ..."), even when a long form is present (Niccacci, "Poetry," 251). Niccacci has tried to argue that this principle also applies to poetry, though he admits "that a volitive meaning is not always clear-sometimes it may even appear excluded, e.g., when it refers to the past" (251-252). As with the discussion of verbal tense in poetry, this issue has not been resolved. Unless one is to insist that this phrase is a liturgical fragment cited by a priest to a pilgrim at the sanctuary gates (in which case it functions a promise and is thus indicative), the difference in meaning is not so significant. If נשא is volitive, it expresses a wish similar to the imperatives in $\mathrm{w} .7$ and 9. Perhaps the meaning of "may such a person receive a blessing/righteous deed" corresponds to v. 6's concern to circumscribe the identity of Jacob in light of v. 4 ("Such a person is Jacob [not some other description]"). In the face of conflicting construals of Jacob's identity, an element of longing on the part of the speaker may unite w. 5 and 6. If, on the other hand, v. 5 is simply declarative or promissory, it interprets more specifically what will happen to the one described in $v$. 4 (cf. 7.3.1.). Its function here may be to further explicate v. 3. In both cases, we learn that entering the sanctuary is the locus for the reception of particular divine gifts.

${ }^{625}$ Spieckermann, Heilsgegenwart, 204.

${ }^{626}$ Aitken, Semantics, 132. Cf. TWAT:I, 829: "in der Regel [ist] 'Segen' die von JHWH ausgehende Kraft, die dem Menschen Glück und wohlstand bringt." Concerning righteousness, Childs states that the nominal forms are "often identified with salvation or with actions proclaiming or sustaining the welfare of a community or individual" (Biblical Theology, 487).

${ }^{627}$ TWAT:VI, 908. 
translation "Gemeinschaftstreue "). ${ }^{628}$ The deed involves mutuality, whereby Yhwh's intervention to save is grounded in his faithfulness to his covenantal obligations (Ps 36:7). ${ }^{629}$ This element of mutual covenant responsibility fits the context of the stanza: just as those who enter Yhwh's presence for blessing must be righteous-i.e. live according to what is right-so Yhwh displays his righteousness by providing for the needs of the righteous. $^{630}$

Beyond this mutuality in terms of obligations, stanza II also evinces an "ontological" mutuality, for the "Jacob" of v. 4 is "holy," just as Yhwh's mountain is holy (שTק, v. 3; cf. Lev 19:2). Holiness is "that which is consistent with God and his character," wording of the question in v. 3 already anticipates the answer given in v. 4. Smith has shown how temples in the ancient Near East and in the Bible participate in the "power of the deity," by which he means "ontological participation." ${ }^{1632}$ Just like the deities they house, temples are characterized by qualities such as magnitude, strength, duration, beauty, and holiness. In stanza II, the human worshipper must be like the place that is like its divine inhabitant. ${ }^{633}$ This reciprocity can also be seen in stanza III, where the gates of the temple are characterized as "eternal" and are called upon to "lift their heads" to make room for the entrance of the divine king.

\subsubsection{Stanza III}

We saw in our discussion of structure and proportion (7.3.1.) that a concluding series of tricola is often used to climax a psalm. ${ }^{634}$ The climactic nature of this stanza can be seen in

${ }^{628}$ Childs, Biblical Theology, 487. See also Creach, Destiny, 2-5.

${ }^{629}$ Childs, Biblical Theology, 487. Goldingay translates צדקה as "faithfulness" (Psalms, 360). Johnston defines Yhwh's "righteousness" as "das positive, heilsame Eingreifen JHWHs" (TWAT:VI, 913).

${ }^{630}$ Cf. Keel, Bildsymbolik, 111: "Die Tore des Jerusalemer Tempelbezirks standen als Tore der Gerechtigkeit' nur 'Gerechten' offen $(118,9 f)$. șdq bedeutet aber nicht nur Gerechtigkeit, sondern auch das mit ihr verknüpfte Heil, 'die Tore der Gerechtigkeit' sind zugleich 'die Tore des Heilsbereichs'." It is interesting that a discussion of social ethics is missing from Smith's fascinating presentation of how deities and their characteristics are expressed or mediated through temples ("Deities"). This may be because stanza II is a post-exilic insertion into an older liturgy (see 7.4.2.3.). I see no immediate evidence to confirm Hossfeld's and Spieckermann's claim that "Segen und Heil sind Gaben, die den verdienten Lohn übersteigen" (Psalmen 1, 160; Heilsgegenwart, 204, respectively).

${ }^{631}$ AYBD:3, 237.

${ }^{632}$ Smith, "Deities," 10.

${ }^{633}$ Cf. Kraus, Psalms:1, 70: "Only the פעל־צדק (Ps. 15:2*) may enter through the שעריצדק (Ps. 118:19*)."

${ }^{634}$ Weber, Psalmen:l, 131, calls this a "Schlussfanfare." 
other elements of its form. Each line apart from the final one has either a 1:1:(1) (w. 7, 9) or a (1):1:1 pattern (v. 8), whereby the (1) denotes a colon that is somehow distinct from the other two. ${ }^{635}$ In the final line (v. 10), however, we have a 1:(1):1 pattern, for the third colon simply reiterates the content of the first. This repetitive frame around the name "Yhwh of hosts" also creates a "break" in the otherwise steady process of semantic specification between the cola, creating the effect of a wave hitting a breaker and then rolling back on itself. Finally, if one counts meter, ${ }^{636}$ it is also the only line to have a pattern of $3+2+3$, as opposed to the steady $3+3+3$ found everywhere else. ${ }^{637}$

This formal emphasis on $v$. $10 \mathrm{~b}$ accords with the content. The entire stanza is permeated with a similar question of identity as the one found in the other two stanzas of the psalm. Through the rhythmic repetitions and steady intensifications of each parallel colon, the enunciation of the divine name "Yhwh of Hosts" represents the highpoint of the stanza. It functions as the "key" or "password" that, one presumes, was sufficient to open the gates of the sanctuary. ${ }^{638}$ In its current position within the psalm, it also appears to function as the highpoint of the whole. Given the polemical function of this enunciation, 1 will discuss it at the appropriate juncture below (7.3.2.3.2.). For now it is sufficient to note that it shares the same militant connotations as the all the other epithets used to describe Yhwh within the stanza, for the "hosts" refer to armies. ${ }^{639}$ Who these armies are is debated. Kraus rightly warns against seeking a single answer here, for the term appears in various traditions with various presuppositions. ${ }^{640}$ Whereas many scholars see a reference to God's heavenly hosts, angelic beings who do his will, the phrase may also refer to the military

${ }^{635}$ The tricolon in v. 3 has the following pattern: (1):1:1. According to John Hobbins, this patterning, whereby one element is distinct from the other two, is characteristic of tricoloa (personal communication; he attributes this insight to Benjamin Harshav).

${ }^{636}$ Yet another debated aspect of Biblical poetry.

${ }^{637}$ Cf. fn. 511.

${ }^{638}$ One can debate which particular gates are intended, whether those of the temple or one of the forecourts (cf. TWAT:VIII, 368, , for the various gates in precincts of the Jerusalem sanctuary); their specification in $v$. $7 \mathrm{~b}$ as "entrances of eternity" indicates that precise topographical specification is exegetically insignificant (and seems, to my mind, to exclude a reference to the gates of the city, as older commentators committed to Davidic authorship claim [e.g. Delitzsch]). Some commentators trace the content of the liturgy in stanza III back the shrine of Shiloh, which was then later used in Jerusalem. Morgenstern has a fascinating paper drawing connections between Ps 24 and the Eastern Gate in Jerusalem ("Gates").

639 "The concepts [עזוח ועבור] refer to the institution of the 'holy war,' in which Yahweh as the deus praesens, as 'war God' and hero, substituted for Israel (cf. Exod. 15:3*; Josh. 6:17*; 2 Sam. 5:10*) (Kraus, Psalms:1, 85).

${ }_{640}$ Kraus, Theology, 19. He cites von Rad, who warns against making "'an element of cultic epiclesis as old as this is in all circumstances capable of rational explanation" (Theology:1, 19; cited in Kraus, Psalms:1, 85). 
hosts of Israel (cf. 1 Sam 17:45). Hossfeld states that in the context of Ps 24:2-7, it is impossible to decide. ${ }^{641}$ Yet perhaps it is not necessary to decide. Wildberger rightly points out that the two ideas do not necessarily cancel each other out, for "God became actively involved, along with his heavenly hosts, in the battles of those who belonged to him" (cf. Josh $5: 141 . .^{642}$

\subsection{Reciprocation}

Just as the sanctuary and its legitimate visitors participate in God's holiness (7.4.2.2.) so do its entrances participate in God's durability and size. ${ }^{643}$ Their durability can be seen in their specification (B colon) as "entrances of eternity" (פתחי עולם, w. 7, 9). A further nuance may be indicated. In light of the etymology of פתח (opening) and parallels such Hos 2:17 (פתח תקוה) and Gen 28:17 (שער השמים), one could also say that they open up onto eternity. ${ }^{644}$ The portals give access to God's dimension of reality, a realm within which

641 Hossfeld, Psalmen I, 161.

${ }^{642}$ Isaiah 1-8, 30. This "tension" between Israel as the subject of its own military campaigns and the angelic forces of Yhwh as the true driving force behind them is almost paradigmatically portrayed in the juxtaposition of two battles against the Philistines in 2 Sam 5:17-21 and w. 22-25. In both cases the Philistines come up against David and David "inquires" of the LORD. In the first battle, he is simply told to "go up," which he does and is victorious in battle. In the second, he is told "don't go up." Instead, they must hide themselves and listen for "the sound of marching in the tops of the balsam trees," (v. 24) a reference to the heavenly army doing battle on Israel's behalf. In both cases, the victory belongs to Yhwh (V. 20). Cf. Fokkelman's commentary on the section in Throne and City.

${ }^{643}$ Smith, "Deities."

${ }^{644}$ Cf. Bartelmus, TWAT:VI, 846-848 notes that the term פת is often associated with a "Gottesbegegnung." He sees a direct parallel between Elijah's meeting with God at the "entrance of the cave," the function of the "entrance of the tent of meeting" as the "Berührungspunk von himmlischer und irdischer Sphäre" (848), and Ps 24:7,9. For this reason he follows Kraus' suggestion that עולם refers to "heaven" (Psalms:1, 315) by translating the construct relation as "Pforten zur Ewigkeit" (847, emphasis mine). Eternity is that which the gates open onto and thus by implication the destination to which the one outside the gates desires access. This idea of moving towards a goal is potentially underscored by the semantic parallelism between שתח שער and The combination of the two in a construct relation (פתח השער, never the other way around) denotes that part of the gate which is the actual "Durchgangsteil der Toranlage," "der eigentliche Torduchlaß." 644 Although פתח alone can be synonymous for gate (and here the term is in the plural), given the specification of the gates in terms of that which they open onto, it seems reasonable to assume that etymological connotation of "opening" serves here to the next stage of a movement towards a goal: conceptually we are brought from the gate to its "opening" and then on to its "heavenly" interior. See also Sulzbach, "Journey", who talks of post-exilic Judaism's understanding of the gateway of the temple as a "vehicle into the divine realm." 
Yhwh himself dwells (Pss 93.2b, 5b) ) $^{645}$ and that reflects his nature (Jer 10:10; Isa 40:28; Pss $90: 2 ; 92: 8-9 ; 102: 12-13$ etc.). ${ }^{646}$

Concerning size, Bloch-Smith has argued that the large size of the accoutrements in the temple reflects the grandeur of the deity. ${ }^{647} \mathrm{~A}$ similar symbolism appears to be at work here when the gates are commanded to lift themselves in order for God to enter ("heads" here apparently means "lintels"). ${ }^{648}$ Just as in v. 3 humanity must "ascend" the "mountain" to access God in his "highness," so here the portals of eternity must make room for a God who is of massive proportions. ${ }^{649}$

\subsection{Polemics}

As with the name "Yhwh" in half-stanza I and the name "Jacob" in stanza II, the title "the King of Glory" ${ }^{650}$ (wv. 7c, 9c, a unique epithet in the Old Testament, though cf. Ps 29:3)

${ }^{645}$ Spieckermann, Heilsgegenwart, 206.

${ }^{646}$ Goldingay, Psalms:1, 362; Hossfeld, in Hossfeld/Zenger, Psalmen:I, 160. Keel's summary is helpful: " 'wIm [ist] hier eher als die Sphäre Gottes zu verstehen. Während die Menschen wie Schatten dahingehen, bleibt Gott für immer (I'wlm; 102, 12f 29, 10 u.a.). An dieser Zeit partizipiert natürlich auch die Tempelanlage. Die Tempeltore sind (jedenfalls in Jerusalem) nicht so sehr uralt als vielmehr immerfort dauernt, unerschütterlich wie der Zion $(125,1)$. Sie haben teil an der Unerschütterlichkeit des Himmels" (Bildsymbolik, 151).

${ }^{647}$ Bloch-Smith, "King of Glory;" Smith, "Deities." Maier talks of "a religious understanding of space, for which in respect to the temple (the hill of God), the place of God's presence, the categories earthly and heavenly are set aside, because the sanctuary represents the entire cosmos" (Ladeheiligtum, 66-67; cited in Kraus, Psalms:1, 315).

${ }^{648}$ Goldingay, Psalms:1, 362. Although the idiom נשא ראש may also refer to the subjective stance of joyful reception (Hossfeld mentions it as one possibility in Psalmen:l, 160), the reflexive verb in $v .7 b$ indicates that is the dimensions of the one entering that matters and not the emotional state of the gates he wishes to pass through. This interpretation is also followed by Day, "Ark," 69 (with further supportive bibliography). It is difficult to imagine why the gates would rejoice in this context.

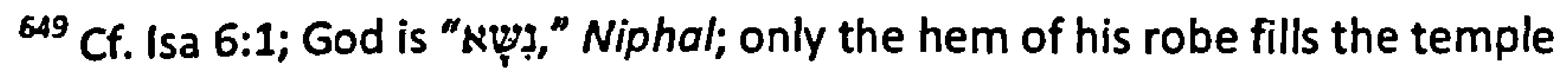

650 "Glory" "suggests the visible splendour of a monarch ... The visible honor is then assumed to be an appropriate outward expression of the figure's intrinsic majesty" (Goldingay, Psalms:1, 595). The term is often associated with phrases found both in stanza II as well as in stanza III, which helps us clarify its meaning. Weinfeld notes that the visibility of God's glory makes it, at times, interchangeable with the word "face" (פנים, cf. v. 6) (TWAT:IV, 34. See also DOT:P, 822). Ps 63:2-3 could be read as the words of one who has passed through the gates: "My God ... I seek you (שחר)...

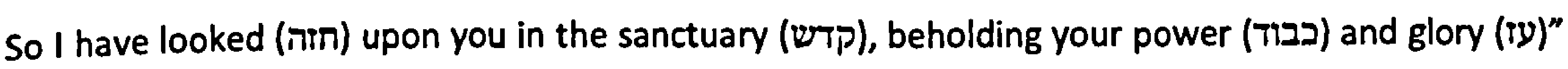
(ET, w. 1-2). The reason why the psalmist desires this is because, if God is faithful (2צ'), God's "glory" is powerful to save (ישע) (cf. Ps 24:5), two other terms that often belong to the semantic field of בבוד (cf. Ps 62:7-8; Isa 58:8; 62:1-2) (TWAT:IV, 34, 37). Finally, this ability to save connects with two other terms that often occur with בבורה and which are found in v. 8: עבור (TW, 26, 28). God can save because of his military strength. For this reason כבוד can sometimes be translated as "starke Kriegesmacht" (TWAT:IV, 26; citing R. Weiss, 1976, 299). In light of these verbal 
assumes that those who read the psalm are already acquainted with the title $e^{651}$ (note the definite article). The title is gradually filled with content through a climactic series of descriptions of character (v. 8), culminating in the cultic title of Yhwh of Hosts (v. 10). The implication is that there are a number of candidates who would claim the title and that the psalm is presenting us with its own. ${ }^{652}$ This makes sense in a history of religions perspective. According to Kraus, appellations involving the title "king" "belong to a religious-cultic complex of conceptions that played an important role in the Canaanite-Syrian area," whereby the emphasis was on the preeminence of one deity over other deities. This connotation was then picked up by Israel and appropriated to its own God, Yhwh. ${ }^{654}$ For Kraus, Ps 24:7-10 functions as a witness to this piece of theological Sachkritik. ${ }^{655}$ The Israelites are claiming that the true content of this title is revealed to be that of the God of Israel, understood in particular in his association with the traditions of the Ark as the palladium for holy war (on which, see 7.4.2.1.)..$^{656}$ Given the political and militant content of this title, the claim that Yhwh is the King of Glory and not someone else is inevitably polemical. ${ }^{657}$ Yet the polemical thrust of the stanza could be just as powerful within innerIsraelite debates of a later age, especially when those who had been exiled were tempted to abandon belief in the power of God to save. Neither Baal nor Marduk is the king characterized by glory. ${ }^{658}$ Israel's prophets favoured the term as part of their attempt to encourage Israel to either fear or trust in the power of their God to accomplish what he purposes (cf. 9.3.3.).

connections, then, it would appear that this King of Glory is the one whose salvation is sought within his courts by the righteous in stanza II. This, of course, raises the question of why that which the pilgrim seeks in the temple is outside the temple.

${ }^{651}$ Spieckermann, Heilsgegenwart, 206.

${ }^{652}$ Cf. Broyles, Psalms, 131: "verses 7-10 do make it sound as though this was the first occasion on which the titles 'Yahweh of Hosts' (one prominent at the Shiloh sanctuary; see 1 Sam. 4:4; again 2 Sam. 6:2) and King of Glory ('King' was a prominent titel int eh Jerusalem sanctuary) were linked." See also Seybold, Psalmen, 106, who believes that either both titles are being ascribed to Yhwh or that the older one, i.e. King of Glory, is being "geschmükt" with the newer one, Yhwh of Hosts.

${ }^{653}$ Kraus, Psalms:1, 82.

${ }^{654}$ Kraus, Psalms:1, 84.

${ }^{655}$ Cf. 3.6.3.1.

${ }^{656}$ Kraus, Psalms:1, 85; Theology, 19; Ollenburger, Zion; AYBD:3, 304. This association was also picked up by Jewish midrash, cf. Kähler, Te Deum, 44-46.

${ }^{657}$ See, for example, the commentaries by Seybold and Hossfeld. See also Wolff's comments on the hymnic passages in Amos in Joel/Amos, 217.

${ }^{658}$ Cf. Creach, Destiny, 117: "This claim [of Yhwh's superiority over other deities in Ps 24:7-10] must have been particularly important for those who experienced exile. As a captive people, 'the Lord reigns' was an essential claim. ... This message is connected directly to the experience of the righteous on Zion." 


\subsubsection{The Psalm as a Whole}

Having looked at the stanzas in relative isolation from each other, we turn now to look at the unity of the Psalm.

\subsection{Theocentric focus}

The first thing to be noted is the theocentric focus of the psalm (cf. 3.3.1.). Each stanza is essentially about God, as lord and owner (w. 1-2), as law-giver and justifier (w. 3-6), and as warrior. Although humanity appears within the psalm as well (v. 1b, wv. 3-6; implicitly in w. 7-10 as the objects of either wrath or salvation), they are ensconced within the reality of Yhwh's intentions, activities, and rule ${ }^{659}$ (note also the network of pronouns that structure the psalm; cf. 7.3.2.4.2.).

The priority of Yhwh's reality as the horizon for interpreting everything else finds formal expression in a concentric pattern $\left(A B A^{\prime}\right)$. The only stanza in which humanity actively does anything is the second (בקש/דרש/נשא/עלה/קום). In stanzas I and III it is God who is the prime actor (בוא/יסד/כוז). The effect is that Jacob is enveloped by Yhwh.

Finally, this subordinate role of Jacob within a setting established by Yhwh's will is further emphasized by the poetic representation of time and space: Jacob's time and space, in contrast to that of Yhwh's, are "unrealized" (see 7.4.4.3.1.).

\subsection{Kerygmatic Function}

Psalm 24 is about God, yet it is written for Israel, as can be seen in its consistent concern to persuade the reader about the true identity of this God and his covenant partner (I have used the term "polemic"; cf. 7.3.2.1. 7.3.2.2.1. 7.3.2.3.2.) ${ }^{660}$ The implication is that the psalm has been composed for some internal conflict within Israel concerning its true identity and allegiance. This rhetorical function has been most emphasized by Phil Botha, who argues that the network of pronouns in the psalm (הז: v. 2, 10 [twice], a form of inclusion; $\mathrm{nt}$ in v. 6) "were intended to facilitate emphatic identification-respectively of who YHWH is and who those people are who stand in the

659 This comes out in Jacquet's thematic summary of the Psalm: the psalm celebrates the grandeur of Yhwh (wv. 1-2), the demands of Yhwh (w. 3-4), the favours of Yhwh (w. 5-6), before acclaiming Yhwh as king (cited in Stuhlmueller, Psalms, 157).

${ }^{660}$ I see some concept of covenant implied in the reciprocal exchange of צדקהת/צד; cf. 7.4.2.2. 
right relationship to him. ${ }^{\prime 661}$ As such, according to Botha, the questions in Psalm 24 are a rhetorical technique that function as "a confirmation of the consensus of the religious community about what the profile of a worshipper of YHWH should look like, and to assure this group that they are the true believers who will receive the blessing of YHWH, those who will be helped by him (v. 5)."

We can agree with Botha that the literary structure of the text with its juxtaposition of the question and answer schema and network of pronouns fulfils a rhetorical function targeted towards a community of faith. As Botha argues, regardless of any original cultic roots, the Psalm's poetic structure now functions as its own context (cf. 7.1.2.). I have two issues with Botha's interpretation, however. For a start, as we saw above in our discussion of genre (7.1.1.), a text's historical roots continue to influence its meaning in changed situations. The question of the cult cannot be so easily dispensed with in a synchronic reading. We will deal with this shortly (7.4.). Second, his interpretation does not do justice to all the poetic features of the Psalm, for it does not take into account the rhetorical function of half-stanza I over and against the two other stanzas (cf. 7.3.1.2.), nor does it take into account the movement of semantic specification between the stanzas (cf. 7.1.2.1.). We will turn to this issue now.

\subsection{Parallelismus Stantiarum ${ }^{663}$}

Julius Wellhausen was perhaps the first to pose the problem of the relation of the final two stanzas in Ps 24 in its final form. To my mind his critique has still not been adequately responded to. He puts it thus:

It is hardly possible to make out a connection of $w$. 7-10 with the preceding verses. For in w. 3-6 we are told the conditions on which men may come to $\mathrm{JHVH}$ at Jerusalem, whereas here the allusion is to an entry of JHVH Himself into Jerusalem. ${ }^{664}$

661 Botha, "Questions," 544.

662 Botha, "Questions," 546-547. "The purpose is not to exclude worshippers, but to give an assurance to those who recognise themselves in the description" (547). "Psalm 24 in its present form is not a liturgy, but a meditative poem from the post-exilic period which sought to outline the religious profile of the worshipping community more clearly and to reconfirm the consensus that they would be vindicated as the true Israel when YHWH reveals his true power and glory" (550).

${ }^{663}$ I am grateful to Christopher M. Hays for inventing this neologism for me. There is no a strict Latin equivalent for the word "stanza;" this version is based on the etymological root.

${ }^{664}$ Wellhausen, Psalms, 174 (emphasis original). This was also picked by older interpreters, e.g. Schmidt, Psalmen, 44; Gunkel, "Psalm 24." Many today assume stanza II was opposed in light of a the pre-existing stanza III, e.g. Weber, Hossfeld, Spieckermann. Vos claims that the juxtaposition of 
In stanza II God is in the temple and is himself the destination of a human ascent. The initial imperative of v. 7, while abrupt, initially appears to fit into the basic temple-ward trajectory established in stanza II. Whereas $\mathrm{w}$. 3-6 were concerned with the issue of who may ascend (עלה) the hill to the temple, the command for the temple gates to open in v. 7 leads to the expectation that we are about to witness the entry of the group just described, now about to be "received" by Yhwh on the other side. The juxtaposition of the future oriented questions and answers in w. 3-6 with the imperatives of $w$. 7-10 give the impression that a consummation is taking place: That which was a potentiality in w. 3-6 is now being realized. It is a shock, then, to discover that it is not Jacob who is about to enter but the very deity who Jacob wished to seek inside the temple in w. 3-6. ${ }^{665} A$ transformation appears to have taken place: Whereas the true Israel has been told that it may ascend to Yhwh, the moment of arrival is filled by Yhwh himself. Botha is certainly right to pick up on the rhetorical function of the questions within the poetic frame of the psalm-the artistic juxtaposition of parts implies that more is involved than the fragmentary preservation of scripts from a liturgy (cf, 7.4.3.)-yet the content of the juxtaposition involves more than the question and answer schema: There is a meaningful development between the two juxtaposed stanzas in terms of the representation of time and space. ${ }^{666}$

In terms of the representation of space, Fokkelman has drawn the following conclusion:

In strophe 2, the righteous person went up into the temple; in strophes 4-5 the gates are opened so that his God can enter. The movement of both characters seems to merge, which raises the expectation that they will meet inside the sanctuary. ${ }^{667}$

themes makes Ps 24 unique (Theopoetry, 141). Girard also emphasizes the disconnected impression made by first glance at the psalm as a whole: " $A$ première vue, l'hymne initial n'a guère de lien terminologique ni meme thématique avec le reste" (Psaumes, 206). Earliest recorded Jewish usage also marked a caesura between w. 6 and 7. According to Kähler, the entire psalm was read at the end of the morning service in the second temple. When the Levites reached $v .6$, a horn was blown and the congregation bowed down. On Rosh Hashanah, only w. 7-10 were read (Te Deum, 46).

${ }^{665}$ That the figure outside the temple is identical to the one inside the temple is not only established by the use of the same name (יהוi), but also by his militant characteristics, which belong to the same semantic field as Yhwh's designation in v. 5 as אלהי ישעו ("the God of his salvation").

${ }^{666}$ Craigie thus hits the nail on the head when he says that the "problem of the psalm as a whole pertains to the nature of the interrelationship between the three parts" (Psalms, 211).

${ }^{667}$ Fokkelman, Major Poems:3, 44. See also Hossfeld in Hossfeld/Zenger, Psalmen:l, 157: "So bewegen sich im Tempel JHWH und der Mensch aufeinander $z u$ und begegnen sich." Podella, "Transformationen," 127, picks up on the parallel movement but not the expected meeting on the 
There is an equivalence in movement leading to a potential meeting on the other side of the gates. And yet the movement of the two figures is unequal. Assuming that the sequential ordering of the stanzas is intentional, I will unpack the particular manner in which the stanzas both parallel and develop each other. This movement is a major key for understanding the unity of the psalm (cf. 7.3.2.4.3.2.).

\subsection{Time, Space, and the Realization of a Journey \\ 7.3.2.4.3.1.1. Half-stanza I}

In terms of space, our psalm opens with a series of universals. Yhwh's dominion consists in all the earth, all people, and all fruitfulness, and it is secured in the face of an allencompassing primal threat. In terms of action, Yhwh's work has already been accomplished. His deed lies in the past ${ }^{668}$ and has constituted him for who he is. He is rightfully the owner now because of what he has done in the past. The verbal mood is the indicative. ${ }^{69}$

\subsection{2. Stanza II}

All of a sudden, there is a dramatic shift in scene. Each of the aforementioned universals is reduced to the uttermost particularity. Spatially/quantitatively, the earth is replaced by a particular mountain, humanity is replaced by named group ("Jacob") and the universally available "fullness" has been replaced by a limited form of blessing dispensed to the few under certain conditions. Consonant with the function of parallelism, the equivalence between the stanzas (the language of geography, demography, identity, and blessing) creates the framework for our apprehension of the differences. ${ }^{670}$ Note also the shift in prepositions. Whereas before Yhwh was above the earth (לע, twice), he is now in it ( $ב$, twice). The fullness that was in the earth (by implication, cf. $ב$ in v. 1b) is now received

other side: "Der parallele Aufbau der beiden abschnitte V. 3-5.7-10 markiert zwel verschiedene Wege in das Innerste des Tempeis: den Weg des einziehenden Königsgottes auf seinen Thronsitz und den Weg des einzeinen zu Gerechtigkeit und Segen." Weber does not develop the image of parallel movement (like Broyles, he suggests that we imagine that Yhwh entered the temple before Jacob, who then follows him). He nevertheless picks up on the motif of ascension: "Den ganzen Psalm durchzieht eine Bewegung von unten nach oben (hinauf auf den Tempelberg, Erheben der Tore)" (Psaimen:I, 130). I am not certain why he says the whole Psalm, however. Neither God nor humanity moves in Ps 24:1-2 (at best one can imagine the earth disk being set upon the ocean currents, but his is hardly a parallel movement to stanzas II and III).

${ }^{668} \mathrm{Cf}$. footnote 573 for the difficulty of the determining the tense of יכננה in v. 2.

669 On the importance of shifts in verbal mood for the composition of psalms, see Futato, Psalms, 192; Fokkelman, 87, 208-209.

${ }^{670}$ For this function of parallelism, see Fokkelman, Reading, 14-35. 
from Yhwh (מן, twice). Indeed, it requires intentional participation on the part of Jacob: He must ascend and worship.

In terms of time, it is noteworthy that within the framework of the poem Jacob exists as the answer to a question about possibilities. The "such is" of v. 6 indicates that Israel itself is being challenged to become like the figure described in v. 4. Within the context of the Psalm, the figure of stanza II remains a desideratum, a potential reality that must be realized. The verbs may even be translated as follows: "who may ...." "such a one could ... . ${ }^{\prime 671}$ In contrast to the assertion of identity in $\mathrm{w} .1-2$, then, Jacob's actions must yet be accomplished. It is tempting to say that the verbal mood has switched from the indicative to the subjunctive, though this does not exclude the fact that the author believes that such a community does in fact exist amongst those who follow his teaching. ${ }^{672}$

The contrast between realized and unrealized action that exists between stanzas $I$ and II is mirrored in the relation between stanzas II and III ( $A B A^{\prime}$ pattern).

\subsection{3. Stanza III}

The spatial focus is particularized even further in stanza III, for whereas the perspective of stanza II was one of ascent (עלה), ${ }^{673}$ the perspective of stanza III is one of arrival (בוא). In contrast to Jacob, Yhwh is now-almost-there: He is standing before the gates waiting to go in. ${ }^{674}$ In terms of the parallel temple-ward movement set up by the juxtaposition of stanzas II and III, then, stanza III brings stanza II one step closer towards its goal. ${ }^{675}$ And yet,

671 Jacquet, Psaumes, 570 : "avec la nuance modal de l'imparfait: qui pourra gravir ... . D'où la traduction du ritual des Askenazim: qui ose gravir, qui ose fouler." See also Beuken's exegesis of the relation between w. 14-15 and v. 17 in Isa 33 (Jesaja, 287). Whereas in w. 14-15-verses which echo the same genre as Pss 15 and 24:3-6-the figure is only a hypothetical reality, in v. 17 this figure becomes a reality through the use of the second person singular suffixes. "[Die Figur] existiert an dieser Stelle nicht mehr nur hypothetisch, sondern tritt in den Kreis prophetischer Handlungsträger ein." Isa 33 realizes Ps 24 in more ways than one (see 9.3.2.).

${ }^{672}$ One thinks of the disciples of Isaiah and the Suffering Servant, considered to be the remnant of the true Israel (Berges, Jesaja). Cf. Ps 14.

673 indicates the goal of the ascent. One could translate, "ascend ... in order to stand."

674 Cf. Podella, "Transformationen," 125: "Der Bewegung YHWHs zu seinem Thronsitz im Allerheiligsten entspricht die Abfolge, hinaufziehen' und, stehen' am Ort des Heiligtums, wobei die Begriffe hr yhwh und mqwm qdšw im Unterschied zu V. 7-10 das weitere topographische Umfeld des Tempelgebäudes markieren, dieses selbst allerdings nicht benennen."

${ }^{675}$ Cf. Podella, "Transformationen," 125-126: "Schon Kurt Galling hatte gesehen, daß das Ziel der Wallfahrt gar nicht erreicht werde, da V. 5 bei der bloßen Ankündigung des Segens stehen bleibe. ... [Es wird] ja nicht einmal gesagt ..., daß überhaupt jemand hinaufsteigt." Podella, however, makes the odd move of claiming that the non-arrival of Jacob in the temple indicates a rejection of the temple as the source of blessing, replacing it with torah obedience. He then says that the cultic 
whereas Yhwh's entry appears to consummate the trajectory set up by Jacob's would-be ascent in w. 3-6, it represents a kind of recapitulation of the journey that he himself had already taken between stanzas I and II. In stanza II Yhwh has moved into his creation, so that by stanza III he has already once taken up residence in his temple. The fact that he must now re-enter it after having waged a battle outside implies a detour within the consummation of the divine plan. The pattern can be found in Ezekiel, where the divine glory (בבוד, cf. w. 7, 10) leaves his temple for a short while in order to inflict war upon his own people (the Israel that was not true to its identity) so that Jerusalem would be purified for his return. The implication is that those who are not like the true Jacob of v. 6 will be the enemies against whom he fights in w. 7-10.

In terms of time, the verbal mood also changes once again, for now we are suddenly confronted with a series of imperatives. Having gone from the past (stanza I) to a hypothetical future (stanza II), we are suddenly jolted into the present (stanza III). The temporal shift from potentiality to actuality mirrors the spatial shift from bottom to top, beginning to end, initiation to consummation. The journey has been fulfilled so that the gates must now be opened. This can be expected to happen, for whereas Jacob has yet to constitute his identity by means of obedience, Yhwh has already constituted his: His victorious battle lies behind him, so that he truly is the Glorious King, Yhwh of Armies. This temporal aspect of consummation, then, creates an inclusio with stanza I. That which Yhwh purposes, he achieves. His world and his journey have already been consummated. All that remains is for Jacob to do the same. It would appear the kerygmatic function of Psalm 24 consists in precisely this call to Jacob to truly be Jacob, given his place within the divine economy (cf. 7.4.3.).

\subsection{Summary: Linear Development and Symmetry}

The transitions between the stanzas of Psalm 24 are abrupt. Despite clear signs of conscious juxtaposition, the movement from one stanza to the next are elliptical, leaving it to the reader to work out the subtle logic of the constellation. ${ }^{676}$ This rhetorical technique

experience behind the ritual in w. 7-10 is transposed to the act of obedience in w. 4-5 (he ignores v. 6 as an editorial addition-in my analysis it is the centre of the psalm). He calls this a "'Demotisierung' von Abläufen im Tempelinneren ... eine Auslagerung tempelgebundenen Heilsgeschehens ouf die Alltags- und Volksebene" (127). He thereby abandons the poetic world created by the poetic shape of the psalm.

${ }^{676} \mathrm{Cf}$. Terrien's introduction to the question of the logic of Ps 24 's composition: "Is there a rhythmic, strophic, and theological unity that links these seemingly disparate elements? If they belong to autonomous sources, why should a psalmist bring them together, and for what occasion? 
accords with Sternberg's work on the ideological function of Biblical narrative. In 7.1.2.3. we learnt that the Biblical authors often intentionally "gap" their information in order to "twist the path to knowledge," forcing readers to enter into the "ordeal of interpretation." Gapping causes one to recall the broader picture, to seek to situate the part within the whole and then return to interpret the parts again. Having set the literary parameters for interpretation (we will deal with historical and theological parameters in $\mathbf{7 . 4}$.), what broader logic can help us make sense of this constellation?

To summarize what we have seen so far: We have identified the peculiar function of $\mathrm{w}$. 1-2 over against the rest of the psalm, both in terms of structure (opening half-stanza) as well as in terms of content (creation: the horizon for Old Testament theology). We have seen that stanzas II and III deal with distinct issues: a theoretical question about the conditions for human entrance to God's presence in the sanctuary and a dramatic appearance and confrontation between God himself and the gates of his sanctuary. Yet we have also seen that these two distinct scenes are so juxtaposed that a comparison is being made. In terms of continuity, both figures are set on a temple-ward trajectory, both are identified in terms of their deeds and this identity is climaxed in the enunciation of a particular name or title. The juxtaposition creates the impression that they will meet each other on the other side of the gates. In terms of discontinuity, Yhwh appears to realize a journey that is for Jacob only left open as a possibility. This in turn links up with half-stanza I, where there too Yhwh is the one who successfully constitutes his identity through his deeds. Jacob's yet to be realized ascent is therefore enclosed in a reality that has already been realized by Yhwh. We have also noted the presence of a polemical note throughout in which identities are being established in the face of conflicting options. Finally, we have noted the presence of theological issues that are basic to Israel's faith throughout the psalm.

To repeat the question: What is the logic of this constellation? Of decisive significance is the special function of half-stanza I over against stanzas II and III: Creation appears to set the horizon for Yhwh's deeds within history. Hans-Joachim Kraus has written an important essay on the function of creation within Biblical eschatology and apocalyptic ("Welt und

Ancient poetry, secular as well as sacred, often appealed to the imagination of its sayers or singers, for it adopted, at times, modes of evocation without offering sings of transition or movement. The pre-Islamic Arabs described their poets as those who perceive and even predict reality. Did the Hebrew psalmists sometimes use an elliptic style, passing from one theme to another, without being explicit on the complex continuity of the whole?" (Psalms, 246). 
Weltvollendung"), ${ }^{677}$ in which he works out four basic characteristics that can be found across the board. ${ }^{678}$ These four points appear so apposite to the mysterious structure of our psalm that they could almost function as a commentary upon it. I will therefore simply list Kraus' theses in the order in which he presents them and apply them to Psalm 24.

\subsection{1. Ps 24 as Witness to the Consummation of Creation}

1. We have seen that W. 1-2 are not concerned with the question of origins per se but with the quality of Yhwh's created dominion as Lebensraum, as a sphere of stability within which human life may flourish. In eschatological and apocalyptic thought it is creation in this quality that is the goal of the consummation of the world, i.e. its future. ${ }^{679}$ Yet consonant with the typical Biblical Urzeit-Endzeit pattern, this image was taken from traditions of the original creation. A similar state characterized the Garden of Eden as well as P's concept of humanity as the image of God (Gen 1, cf. Ps 8). "Eschatologie und Apokalyptik ... dekken [sic] die durch die Geschichte Gottes mit seinem Volk heraufgeführte Erfüllung dieses Ersten und Letzten, dieses Eigentlichen und Bestimmenden auf." ${ }^{180}$ We can thus imagine half-stanza $l$ is both protological as well as eschatological, an image of God's original creation plan and the goal of his consummation of that plan. ${ }^{681}$ This two-way glance into the past and the future is supported by the presence of the temple in stanzas II and III, as well as God's militant intervention in stanza III (see point 3 below). I have already mentioned the Edenic quality of the temple as a place of creational fullness (7.3.1.2.1.2.). According to Kraus, strands of Israel's tradition believed the fullness of creation to be actually present within the temple, a form of "präsentische 'Eschatologie'." ${ }^{\prime 62}$ The temple in both stanzas, then, may be understood as one particular place in our space and time where the reality of stanza $I$ is proleptically realized, a "condensation," as it were, of the universals of stanza । into the

${ }^{677}$ Aufsötze, 151-178.

${ }^{678}$ Kraus, Aufsätze, 174-175.

${ }^{679}$ Kraus, Aufsätze, 174: "Die erhoffte und verkündete Weltvollendung wird dem Menschen das Leben in voller Sinnerfüllung, in unbegrenzter, vom Tode nicht mehr bedrohter Herrlichkeit schenken." ${ }^{680}$ Kraus, Aufsätze, 174.

${ }^{681}$ Cf. Koehler, Theologie, 72: "Die Schöpfung ist in der Theologie des Alten Testaments ein eschatologischer Begriff. Daß Gott der Schöpfer der Welt ist, besagt, daß er die ganze Zeit, alle Zeiten beherrschend und gestaltend, zielsetzend und vollendend umfaßt" (cited in Kraus, Aufsätze, 159).

${ }^{682}$ Kraus, Aufsätze, 159. He formulates this as a tentative question: "Sind Ursprung und Zielbild alles Seins, das Erste und das Letzte, in Glauben und Lehre Gegenwart?" (159). For a stronger affirmation of the presence of creation within the temple, see Knieriem, Task, 171-224; Levenson, "Temple." 
particularity of a mountain top-indeed of a space behind the gates of a sanctuary on the mountain (עולס) (cf. ‥4.3.). The difference between stanzas II and III is that in the former the Lord is already present within that realm; humanity is to join him and participate in it. In the latter, Yhwh himself must re-enter it. In light of wv. 1-2, this parallel movement appears to be the realization of God's creation plan. Halfstanza I functions as the ground and telos of the events that ought to and will (respectively) take place within the time and space of stanzas II and III.

2. The heart of this eschatological "new creation" is perfect communion (Gemeinschaft) between humanity and God. This was experienced by Israel (and humanity, cf. Gen. 9) historically in the covenant, yet it has its eternal ground in the Garden of Eden where the Lord walked with Adam and Eve (cf. Rev 21.3). ${ }^{683}$ Just as God entered his creation in Gen 2, so does he enter his creation in the move from stanza I to stanza II. ${ }^{684}$ This initial move is not repeated in stanza III, for there Yhwh is returning from a battle, he is not moving in from heaven above. According to eschatological hope and the protological image of the Garden of Eden, a creation from which God remains purely transcendent (as in stanza I) is not the paradise that God wishes for himself. Similar to God's resting on the seventh day, this move to take up residence in creation is not only pro nobis, it is an "innergöttliche Angelegenheit." 685 We can thus imagine the shift from God being above the earth to being in it along with the poetic particularization of time and space to represent a move towards the consummation of his creation intention in w. 1-2.

The theme of communion is further undergirded by the mutuality between God and humanity in stanza II. Jacob's holiness must reflect Yhwh's holiness, Yhwh's righteousness is a response to Jacob's righteousness. Finally, the juxtaposition of the parallel temple-ward trajectories between stanzas II and III implies a move towards each other, shortly to meet on the other side. Does stanza III consummate stanza II in any way?

3. The main theme of eschatological and apocalyptic proclamation is the coming rule of God, something that will appear before all nations and result in the

${ }^{683}$ Kraus, Aufsätze, 174. See also Volf, Likeness, for a systematic-theological perspective: "The all-embracing framework for an appropriate understanding of the church is God's eschatological new creation. ... The future of the church in God's new creation is the mutual personal indwelling of the triune God and of his glorified people" (128).

684 Does this move reflect the move from Gen 1 to Gen 2 ?

${ }^{685}$ Kraus uses the phrase in relation to God's resting on the seventh day in Gen 1 (Aufsötze, 157). 
transformation of creation. "Die mythologischen Bilder werden zu Chiffren des schlechthin Neuen, sie sind Signale, die von der Wirklichkeit des kommenden Geschehens sprechen." ${ }^{1686}$ In Isaiah, for example, this coming is presented as a return of God to his temple, bringing an Israel purified by the fire of exile and the repentant nations in his train (cf. also Exod 15:3, 17; 7.3.3. 9.3.). ${ }^{687}$ New creation breaks out in the wilderness on the way. ${ }^{688}$ Given the juxtaposition of stanzas II and III, it makes sense to imagine that in w. 7-10 Yhwh is being presented as one who is returning to the temple he had once inhabited in stanza II, having now accomplished the job of purifying/saving his people through war in order to be able to enter paradise with them. ${ }^{689}$ His mission will be consummated when he crosses the threshold to the place of his rest (מנוחה), the place of his own dimension of reality (עולם). As in Gen 2, Yhwh wishes to inhabit this dimension with his human counterpart, a Jacob who is holy, righteous-and in particular socially just (צדקה). The crux of the matter is that Jacob must himself truly be just. We have already noted the openness of stanza II-"this would be Jacob, if only you would be like him." Yhwh will certainly enter, but will he have a Jacob to enter with him? In light of the theocentric focus of the whole psalm, this is as much an issue for God as it is for Israel. This brings us to Kraus' final point:

4. The consummation of creation according to God's plan cannot happen without ethnic Israel. Israel is the vehicle by which God comes into the world and Israel is the epicentre from which global transformation occurs. ${ }^{690}$ This could explain the juxtaposition of the human and divine temple-ward trajectories: They will meet beyond the gates, for Yhwh does not wish to enter his own future (see 8. below) without a righteous Jacob. Given that this is the case, the Old Testament witnesses to Yhwh's struggle to get a sinful Jacob to enter his future with him. This struggle may explain Yhwh's entry in his capacity as warrior. Seitz talks of God's "strange" and "alien" work with Zion in the book of Isaiah (cf. 28.21). On the one hand, the Lord attacks those who threaten the inhabitants of Zion, as found too in the Psalms;

${ }^{686}$ Kraus, Aufsätze, 175.

687 Podella, "Transformationen," 122.

${ }^{688}$ Kraus, Aufsätze, 166-168. Epiphany."

${ }^{689}$ Cf. Terrien, Psalms, 150: Ps 24 "declares, poetically and musically, the advent of the Last

${ }^{690}$ Kraus, Aufsätze, 175. He cites John 4:22: "Salvation comes from the Jews." 
on the other hand "God also can fight against his own people, in these same familiar terms (28.21-22; 29.1-4) .... Precisely because of his 'unconditional' endorsement of Zion, God may have to take up arms against his own people. ... Israel becomes a threat to Zion, as it were ... " (cf. 9.3.). ${ }^{691}$ If we take Zion as a cypher for God's paradise, those in Israel who do not become the true Jacob threaten God's future of perfect communion with his human counterpart. In stanza

III God enters that future through the gates of the temple having cleansed the obstacles on the path, so that there really can be a divine-human fellowship on the other side of the gate.

In interpreting Psalm 24 in this eschatological manner, I have striven to remain within the parameters of Psalm 24 as a relatively ${ }^{692}$ self-contained narrative world. This is legitimate, for such an approach is required by a text dominated by the "poetic function." Yet we cannot remain at this level, for, as we have seen, the poetic function is a "relational concept" (7.1.2.), one which co-exists alongside other linguistic functions that have their being within a particular historical and cultural matrix. We have already touched on the conative function in our talk of the Psalm's polemical edge (the call to become Jacob; 7.3.2.2.1.), and we have also seen the referential in our talk of the Psalm's deictic function (the witness to the economy of God; 7.3.2.4.1. 7.3.2.4.2.). In order to clarify and deepen our interpretation, therefore, we need to factor in the diachronic dimension into our text by inquiring into the psalm's trajectory of growth as a vehicle of communication within a living community of faith. What are the "human functions and problems" that are being addressed, the generic conventions that constrain the potential meaning of the words, the generative matrix within which the parts evolved, and the primal forces that may be being evoked (7.1.1.)? In other words, what is the broader "human reality" within which Psalm 24 exists?

691 Seitz, Isaiah 1-39, 72. The same point is made by Roberts in relation to the so-called Zion Tradition: "[T]he Psalter's emphasis on 'righteousness and justice' as foundational to Yahweh's rule provided a two-edged sword that could just as easily be turned against Israel as against any other nation. An Israel that perverted justice and oppressed the poor was just as much a threat to the stability of the created order as was any other sinful nation, and thus Israel was just as much a potential object of divine judgment as any other nation" ("God's Imperial Reign," 218).

${ }^{692}$ Relative, for the elucidation of the nature of the relation of the parts has already required us to take into account broader Biblical patterns. 


\subsection{Communicative Function}

My interpretation is not the first to note the "eschatological" dimension of Psalm 24. In the modern period, however, it is a minority position. ${ }^{693}$ This is understandable, for the kind of eschatological interpretation that I have proposed depends heavily upon the subtle interplay of the parts of the psalm in their poetic composition. Dominant aspects of the language and form of the psalm, however, indicate that Psalm 24 has its roots in the praxis of the liturgy of the Jerusalem temple rather than in prophetic visions of God's big plan. ${ }^{694}$ It would appear then, that the eschatological shape of Psalm 24 is secondary, a reworking of older cultic rites according to a transformed view of those rites' theological referent. This process of the eschatologizing of the cult has been noted by many scholars, both in terms of prophetic adaptation of cultic ritual (cf. $\underline{9.3 .2 .)^{695}}$ as well as in terms of the editing of the Psalter itself (cf. 9.2.), so that this particular move from cultic origin to prophetic literature is not unusual. Indeed, in the article just discussed, Kraus believes that the temple liturgy behind Psalm 24 served as a paradigm for prophetic conceptions of the future. ${ }^{696}$ in order to grasp the reality witnessed to by our Psalm, therefore, we will have to inquire into its roots and transformations.

\subsubsection{Structure of Presentation}

I will present my diachronic analysis along the following lines: First, I will establish Psalm 24's original cultic context along with the diverse origins of the various parts (7.4.2.). I will then propose a theory of the history of the growth of the psalm (7.4.3.). Finally, I will

\footnotetext{
${ }^{693}$ Terrien provides the most recent interpretation along these lines. He points out that almost no modern critic "mentions the astonishingly numerous affinities of Psalm 24 with the Isaianic material. Among the few exceptions, besides J.D. Smart ["eschatological"] ... , are B. Stade (1899), and T.K. Cheyne (1904)." He also mentions E.J. King (1898), but fails to mentions the doctoral dissertation on Ps 24 by Hamann, who also reads Ps 24 along exclusively eschatological lines. See also Willis, "Ethics," 158, who points out that the eschatological view has not enjoyed wide reception.

${ }^{694}$ The eschatological interpretations proposed so far do not take into account the liturgical dimension, leading to the conclusion that psalm was original composed to be an eschatological tractate. As I will show, there does not need to be a strict either-or. A purely prophetic interpretation, however, needs to account for the fragmented nature of the psalm. The juxtapositions are clear, but the poetic structure is not so obvious that it was composed from scratch by a singular poet. We need to reckon with editorial activity.

${ }^{695}$ See Podella, "Transformationen," 107, for a couple of references.

${ }^{696}$ Kraus, Aufsätze, 164: "Kultische Vorgänge und Hymnen der Psalmentradition werden hier le.g. Isa 52:7-10] aufgenommen. Zum großen Fest zog Jahwe über dem Thronsitz der Lade in das Zionheiligtum ein. Die Jahwe-Königs-Hymnen jubelten ihm zu. ... Alle diese Traditionen werden jetzt bei Deuterojesaja in das neue, eschatologische Geschehen hineingenommen." See his interpretation of Psalm 24 in Psalms:1.
} 
conclude my analysis by inquiring into the communicative function of the shaping the tradition into its current form (7.4.3.).

\subsubsection{Cultic Origins}

Apart from the few scholars who hold that Psalm 24 was originally eschatological, ${ }^{697}$ there is, as far as I can see, a universal consensus that Psalm 24, whether in part or as a whole, is rooted in the liturgical experience of ancient Israel. ${ }^{698}$ Beyond that consensus, however, there is disagreement over whether the psalm as whole is a script belonging to a single ceremonial procedure (e.g. Mowinckel) or whether it is a literary composition that has incorporated liturgical fragments for a new use (e.g. Gunkel). ${ }^{699}$ This division of opinion in fact runs through Psalms interpretation in general and has still not been resolved to this day. ${ }^{700}$ Hossfeld and Zenger argue for a middle path, one which sees the psalms as being rooted in the cult according to their original forms ("Grundfassung"), yet detached from that "Sitz im Leben" through a redactional process that involves not only the final shape of the individual psalms but also the shape of the canonical Psalter as a whole. ${ }^{701}$ This model appears most adequate for interpreting Psalm 24. ${ }^{702}$ Following Kraus and Podella, we will start our analysis with the final stanza. ${ }^{703}$

\subsubsection{Stanza III}

This stanza is generally taken to presuppose a festival procession of some kind in which Yhwh, enthroned upon the Ark of the Covenant, is brought into the sanctuary. Arguments for its liturgical character are as follows: The clear, rhythmic, and repetitive structure as well as its climactic parallelism (cf. Pss 29:1-2; 93:3-4) evokes Canaanite-influenced poems of the pre-exilic period (e.g. Pss $93 ; 77: 17-20) .{ }^{704}$ Its dramatic form or "theatrical character," ${ }^{705}$ including its antiphonal or contrapuntal exchange of voices, gives the

${ }^{697}$ Cf. fn. 69393.f

${ }^{698}$ This interpretation is ancient. Calvin held to it and even ancient interpretation associated it with either David's or Solomon's liturgical act of bringing the Ark into Jerusalem or the temple respectively. For an overview of interpretations see Botha, "Questions;" Willis, "Ethics;" Lorentz, Ugarit-Texte, 249-252.

${ }^{699}$ Craigie, for example, poses this question (Psalms, 211). He tends towards the latter interpretation (212).

${ }^{700}$ Zenger, "Psalmen," 319; Creach, "Cult."

701 Zenger, "Psalmen," 319. This is the approach of Childs, cf. Introduction, 504-525; Biblical Theology, 191-195.

${ }_{702}$ Kraus, too, reckons with "adaptions, extensions, and contemporisings" of originally cultic psalms (Psalms:1, 68).

703 Kraus, Psalms:1, 312; Podella, "Transformationen," 121.

${ }^{704}$ Hosffeld, Pslalmen:I, 157. Seybold calls the verses "litaneiartig" (Psalmen, 105).

705 Podella, "Transformationen," 112. 
impression that it was a piece to be performed.$^{706}$ The language of kingship, glory, Yhwh of Hosts, and the phrase "eternal gates" imply a temple context ${ }^{707}$ (for the ceremonial function of the temple gates, see Ps 118:19-20; Isa 26:2; Ezek 43:1-12; 44:1-3). ${ }^{708}$ Finally, it would appear that the King of Glory's presence was located upon the portable Ark, a sacred object that elsewhere appears to have been used in regular ceremonial processions. ${ }^{709}$

This final point is contested on both counts. The argument is that the Ark is not mentioned in the verses and so cannot be assumed to be present and that there is no evidence that there were ceremonial processions with the Ark in Israel. Once it had been deposited in the temple it remained there. ${ }^{710}$ Both arguments have most recently been counteracted by Broyles and Day. ${ }^{11}$ Concerning the presence of the Ark within w. 7-10, Broyles provides the following five arguments: ${ }^{72}$ First, Yhwh is presented as physically crossing a boundary, indicating that his presence is localized in some manner and may be transported past a point in space. Second, the special name "Yhwh of Hosts/Armies" is uniquely associated with the Ark (e.g. 1 Sam 4:4; 2 Sam 6:2). ${ }^{73}$ Third, the title King of Glory points to the function of the Ark as a royal throne (e.g. Pss 47:8; Ps 97:2; 99:1; Ps 132:7-8); elsewhere the Ark is associated with God's glory(-cloud) (e.g. Lev 16:2; Num 10:33-34; 1 Sam 4:21-22; $1 \mathrm{Kgs} 8: 10)$. Fourth, the military context fits the function of the Ark as a war palladium (e.g. Num 10:35; Josh 6:4-13). Finally, Broyles believes that "seeking the face of God" has a special connection to the Ark in certain passages (e.g. Ps 105:4).

Concerning evidence for the use of the Ark in regular processions, the following arguments may be adduced: The Ark remained in the temple up until the destruction of the Temple (586 B.C.E.) (cf. Jer 3:16; $1 \mathrm{Kgs} \mathrm{8:8)}{ }^{714}$ It was only when Josiah ordered the Levites to stop carrying the Ark that what surely must have been processions ended ( $2 \mathrm{Chr} 35: 3)^{715}$

${ }_{706}^{706}$ Podella, "Transformationen," 113; Hunter, Psalms, 132-133.

${ }^{707}$ Cf. Spieckermann, Heilsgegenwart, 200; cited in Podella, "Transformationen," 121.

${ }^{708}$ Gerstenberger, Psalms:1, 118.

709 Broyles, "Cherubim-Ark;" Day, "Ark."

${ }^{710}$ E.g. Hossfeld, in Hossfeld/Zenger, Psalmen:I, 157; Spieckermann, Heilsgegenwart.

${ }^{712}$ Broyles, "Cherubim-Ark;" Day, "Ark."

712 Broyles, "Cherubim-Ark," 152. He has a sixth argument, namely that the ascent of the pilgrims in v. 3 (עלה) echoes the language of the Ark being brought up to Jerusalem (עלה, Hiphil). I do not believe, however, at w. 3-6 belong to the same liturgy. See 7.4.2.3.

${ }^{713}$ Day, "Ark," 69.

714 Day, "Ark," 65: Jer 3:16 indicates that the Ark cannot have disappeared much longer beforehand, $1 \mathrm{Kgs}$ 8:8 indicates that the Ark was still in existence a considerable time after Solomon.

715 Broyles, "Cherubim-Ark," 155. Gerstenberger cites the following pieces of evidence in the Psalms for processions in Israel: Pss 68:25-28; 132:6-7; 48:13-14 (Psalms:2, 518). 
Processions occurred in Israel (Ps. 68:25), as elsewhere in the ancient Near East, ${ }^{716}$ and the contexts in which the Ark is mentioned often imply liturgical procession, including shouting and the playing of trumpets (Josh 6; 2 Sam 6; 1 Kgs 6; 1 Chr 13-16). Within the Psalter, Ps 132 evokes the scene portrayed in 2 Sam 6-7, apparently re-enacting the bringing up of the Ark in a cultic ceremony (compare v. 8 with the "Song of the Ark" in Num 10:35). Verses 1017 indicate that this ritual took place during the reign of a monarch. ${ }^{717}$ In response to the argument that the Ark is not named, it can be pointed out that the fact that Yhwh was understood to dwell upon it meant that he could be directly addressed without the Ark having to be mentioned in the same sentence (e.g. Num 10:35; ${ }^{718}$ cf. 2 Sam 6:5, where "before the Ark" is interpreted to mean "before Yhwh"). ${ }^{719}$

Establishing the presence of the Ark within the generative context of the composition of $w .7-10$ is important, for it grounds these verses in the traditions of Israel rather than dissolving them into Canaanite myth (cf. 7.4.2.2.). ${ }^{720}$ As Kraus puts it, "the ark with its traditions is the guarantee of continuity with the early history." "721 The name "Yhwh of Hosts" "points back to the time before the kings, when the association of the 12 tribes gathered at Shiloh" and provides, Kraus argues, for the presence of the "basic transmissions of salvation history," which are "the foundation of the people of God gathered at Jerusalem. ${ }^{\prime 722}$ Indeed, "the foundations of the cultus and the monarchy lie in the time of David," so that David's bringing of the Ark into Jerusalem (cf. 2 Sam 6) constitutes the "foundational historical event." ${ }^{723}$ । have already indicated how foundational this event was within Israel's theology (7.3.1.2.1.2.): The arrival of the Ark in

${ }^{716}$ Keel, Bildsymbolik.

${ }^{717}$ Day, "Ark," 67. See Day and Broyles for details on the presence of the Ark, even when not explicitly mentioned, in other psalms. Broyles argues that the reason why the Ark is mentioned so little within the Psalms is that as of Josiah's day processions with the Ark ceased.

718 Day, "Ark," 70.

${ }^{719}$ Ps 132:8 makes clear, however, that Yhwh was still considered to be an entity distinct from the Ark.

720 "If the dimension of history is overlooked, mythical and ideological categories of interpretation force their way into the exposition of the Psalms;" Kraus, Psalms:1, 73; cf. Noth, "Jerusalem," in Essays, 132-144; "God, King, and Nation," in Essays, 145-178.

${ }_{721}$ Kraus, Psalms:1, 62.

${ }^{722}$ Kraus, Psalms:1, 73. Specifically in relation to Ps 24:10, he states: "Here we clearly see how significant those events which are described in the story of the journey of the Ark from Shiloh to Jerusalem are for the cultic act of the entrance ... . The "password for admittance" emphasizes decisively that the entering God is the God of the old Israelite sanctuary at Shiloh, the "war hero" יהוה צבאות (v. 10*)" (Kraus, Psalms:1, 314-316). See also Broyles, Psalms, 131.

${ }^{723}$ Kraus, Psalms:1, 62. 
Jerusalem was "the crowning achievement of Israel's wars" 724 and the moment of consummation of God's plans for his people. It was the locus of his presence during the various wars that were a prerequisite for Israel to arrive at their divinely determined destination and thus a factor in Israel's victories (cf. 9.1.3.2. 9.1.3.3.). For this reason, Kraus suggests that the ritual procession of the Ark into the temple functioned to commemorate the founding event when David brought the Ark to Jerusalem (cf. Ps 132). "This basic event is the foundation and the center of the present worship." 725

Yet Kraus also talks of the "enlargement of the horizon of Old Testament worship" 726 when subjected to Canaanite influence. In particular, "Canaanite cultic traditions were instrumental in first displaying the comprehensive sphere of influence of Yahweh and in seeing new relations." ${ }^{727}$ It would appear that the tradition of the arrival of the Ark in Jerusalem has undergone similar theological expansion. We have already seen this within stanza III (cf. 7.3.2.3.2.). The title "King of Glory" appears to be of ancient Jebusite origin, now applied to Yhwh of Hosts. ${ }^{728}$ Yhwh takes on those qualities. Further possible Canaanite influences are the term "hosts" as applied to Yhwh. Though the phrase may mean the armies of israel, it may also mean the heavenly hosts (cf. 7.3.2.3.2.). Finally, the term "portals of eternity" points to a cosmological dimension that goes beyond the historical experiences of redemption from Egypt and the conquest of the land ${ }^{729}$ (cf. 7.4.3.). A correct interpretation of these verses within their historical context must, therefore, maintain a healthy tension between the two traditions. ${ }^{730}$ The issue of the degree to which w. 7-10 can be mythologized or not becomes particularly acute when they are read in connection with stanza l.

724 Craigie, Psalms, 214.

${ }^{725}$ Kraus, Psalms:1, 69.

${ }^{726}$ Kraus, Psalms:1, 83.

${ }^{727}$ Kraus, Psalms:1, 83. In terms of a theory of the theological grounding of Israelite law, see Otto, "Kultus und Eth05," 178: "Kanaanäisch vermittelte Motlve Jerusalemer YHWH-Königs- und Schöpfungstheologie wollen die Universalität YHWHs zum Ausdruck bringen, die zum theologischen Begründungszusammenhang der Universalität pragmatischer Vermittlung des Gottesverhältnisses über den Kultraum hinaus im Alltagsleben Israels wird."

${ }^{728}$ See also Seybold, Psalmen, 106: "Es verbinden sich Glaubensaussagen verschiedener Epochen, der Vorkönigszeit wie der Königszeit, aber auch-und darin lst der Sinn der Komposition dieses Psalmes in seinen Teilen zu sehen-Urzeit (1f.) und Gegenwart (3ff.) mit der Vergangenheit und ihrer Offenbarung."

${ }_{729}$ Anderson wonders whether the phrase refers to the "gates of heaven" (cf. Gen 28:7), "since in antiquity the earthly Temple was usually associated with its heavenly counterpart" (Psalms, 205).

${ }^{730} \mathrm{Cf}$. Childs, Biblical Theology, 109-110. 


\subsubsection{Stanza I}

The close thematic connection between stanzas III and I has only become clear since the discoveries of the myths of ancient Israel's neighbors. In particular, the imagery of temple building, warfare, kingship, and conflict with "Sea" (Yammu/Naharu) are essential elements of the so-called Baal cycle discovered at Ugarit. ${ }^{731}$ In this narrative, the divine king whose realm is the sea, appropriately called Yammu/Naharu (cf. נהר/ים, Ps 24:2), attempts to subordinate the weather God Ba'lu (Baal). Ba'lu defends himself and successfully conquers Yammu (with the help of other deities). Having now become a king himself, he inevitably desires to build for himself a palace/temple upon mount Sapānu (Zaphon), something he achieves after much negotiation with 'llu (El), the chief deity. Despite the obvious differences to the Biblical narrative, this collocation of elements is found elsewhere in the Old Testament (e.g. Pss 29, 93, 95, 74, 89). The difference to the Baal Cycle is that these texts, similar to Ps 24:1-2, make a connection between Yhwh's battle with the sea and the creation of the world. The presence of this motif, however, is also found in the Enuma Elish, where Marduk creates heaven and earth out of the conquered carcass of Tiamat, a sea monster. The centrality of creation to these two bodies of tradition has led J. Day to identify possible allusions to the theme of creation elsewhere in the fragmented Ugaritic literature and to suggest that such a primordial conflict between Baal and Yam may have functioned as a prelude to El's creation of the world. ${ }^{732}$

Given this thematic collocation along with the ritualistic contexts of myths such as the Enuma Elish, scholars have been quick to see an original mythical and ritual connection between stanzas I and II of Ps $24 .^{733}$ In stanza I we have Yhwh's primordial destruction of those forces which threaten his potential rule, in stanza III the victorious warrior king now ascends to his throne as king in his temple, the victory over his watery foes now lying behind him. ${ }^{734}$ The entrance of the Ark through the temple gates thus "re-enacted the final movement of a narrative pattern of great significance in the religious culture of the ancient world. ... Creation, kingship, and temple were closely connected. The entrance liturgy of

731 COS:1, \$1.86, 241-274.

732 YABD:I, 546.

733 "Ps 24,1-2.7-10 dürfen somit innerhalb eines umfangreicheren Verweiszusammenhangs gelesen werden, der die Koinzidenz zwischen der Stabilität des Kosmos und YHWHs Gegenwart im Tempel hervorhebt Der kultisch-rituelle Haftpunkt für die Vergegenwärtigung dieses Zusammenhangs ist in Israel wie auch in Mesopotamien das Neujahrs-Herbstfest" (Podella, "Transformationen," 123).

${ }^{734}$ Clifford, for example, reads Ps 24 entirely within this mythical framework (Psalms, 133-137). 
verses 7-10 is the dramatic version of the confession of verses 1-2. ${ }^{735}$ Bloch-Smith has even suggested that this basic narrative was recapitulated in the architecture of the Jerusalem temple. "Upon defeating the chaotic forces of nature, as represented by "the molten sea', the god of the Israelites accepted the sacrificial offerings and entered the Temple bestowing blessings on the king and the people, as recorded on the pillars flanking the temple entrance (named Jachin and Boaz), plausibly to be construed as a single sentence, specifically a blessing formula ... [i.e.] 'may he [Yahweh] establish [the temple/king/people] in strength'."136

This mythic connection is valuable, for it helps us to see how the temple entry scene in stanza III is the "narrative climax" of an event started in stanza I (as we have already seen in the poetic structure, cf. 7.3.2.3.). The battle that lies behind Yhwh of Armies is a battle with the primordial forces of the ocean, the chaos that would threaten the order and stability of his kingdom. In light of what we have seen about the Ark above, however (7.5.2.1.), we need to ask whether this interpretation over-mythologizes the historical traditions associated with that cultic object. As Kraus has pointed out, the danger of over-interpreting the Biblical material in light of ancient Near Eastern parallels is that the particular witness of the Biblical material is drowned out. ${ }^{737} \mathrm{~A}$ number of scholars have pointed out the potential presence of both Canaanite and Israelite traditions with w. 7-10. Seybold states that "Reminiszenzen an den Chaoskampf (vgl. 29; 93 u.a.) sind angebracht, aber wohl auch an Erfahrungen in den frühen JHWH-Kriegen, die Israel zu führen hatte. ${ }^{1738}$ Though we may think of the "journey" from stanza I to III as consisting in Yhwh's consummation of creation by entering his temple after having conquered the chaotic forces that would threaten it (cf. Gen $1: 2$; Ps $33: 7 ; 104: 6 ; 7.3 .1 .2 .1$.), Kidner is surely also correct to point out that the "ascent completes a march begun in Egypt."739

We thus need to ask about the particular manner in which Israel related "Canaanite creation myth" and "Israelite history." Fishbane suggests that we see the relation in terms

${ }^{735}$ Mays, Psalms, 123. Cf. Broyles, Psalms, 128: w. 7-10 "alert us to the fact that creation order is not a given, rather Yahweh must continue to exert his heroic strength to maintain it."

${ }^{736}$ This is Smith's summary of Block-Smith, "King of Glory" (in "Deities," 6).

737 See also Childs, Biblical Theology, 113-116.

${ }^{738}$ Seybold, Psalmen, 106. There are of course scholars who only see the presence of historical traditions in stanza III, e.g. Kraus.

${ }^{739}$ Kidner, Psalms, 115. He goes on: "indeed the psalms that are quoted in I Chronicles 16 as sung on this occasion [i.e. the bringing of the Ark into the temple under Solomon] look back as far as Abraham and on to the coming of the Lord as Judge" (Psalms, 115). 
of "correlation." As he puts it, "there is a sense that all of God's mighty acts are correlated, from the earliest victories over archaic monsters down to and including the salvations wrought for the people of Israel past and present. ${ }^{\prime 740}$ Thus, in relation to the interweaving of creation and Exodus motifs in Ps 114, Berlin can conclude that "[i]n these archetypes of divine deliverance, historic time unites with mythic time, history's God with nature's God, and Israel's temporal experience is brought into the framework of eternity." ${ }^{741}$ This intermingling of the temporal and the eternal is perhaps most clearly demonstrated in Isa 51:9-11, a "classic example of how the Hebrew Bible appropriated ancient Near Eastern tradition for its own purpose." ${ }^{172}$ In the context of encouraging Israel to trust in Yhwh's provision for the second Exodus from Babylon, the prophet opens with a reference to Yhwh's overcoming of chaos at creation. This imagery of watery depths is then immediately reinterpreted as the waters of the Reed Sea (Exod 14:22), through which the redeemed passed when fleeing the Egyptians. Finally, the scene shifts again to that of Babylonian exiles returning to Zion. According to Childs, these three depictions do not represent "three separate events spread along a historical trajectory," but rather

three moments in the one purpose of God for Israel's salvation. Because the content of God's redemptive intervention, that is, its substance, is the same, the three events have been fused together as a unified ontological witness to the one purpose of God concerning his people. ${ }^{743}$

We have already touched upon this phenomenon of the ontological unity of the Biblical tradition above (3.3.4.), particularly in relation to the New Testament approach to history (3.6.3.1.), and examples can be given to show that this approach is basic to much ancient interpretation of the past in general. ${ }^{744}$

${ }^{740}$ Fishbane, Biblical Myth, 41; cited in Berlin, "Myth and Meaning," 67.

${ }^{741}$ Berlin, "Myth and Meaning," 68. This pattern is also found in relation to Leviathan in the Old Testament, the water sea monster defeated by Yhwh. In Ps 74:12 his defeat is placed in the context of creation, in Isa 27:1, however, it is eschatological. Day explains: "That a conflict originally associated with creation should become an element of eschatological imagery is explained by the principle Urzeit wird Endzeit (= the primeval time becomes the end time), which is attested elsewhere in apocalyptic literature, as in the notions of Paradise regained and a new heaven and a new earth" ("Leviathan," in YABD:4, 296). Cf. 7.3.1.2.1.2.

742 Childs, Isaiah, 403.

${ }^{743}$ Childs, Isaiah, 403-404. Cf. 3.6.3.1.

${ }^{744} \mathrm{Tim}$ Furry gave a fascinating paper on this subject at the 2008 conference "The Grandeur of Reason" (Rome, 1-4 September) under the title: "Scripture and History: The Perplexity of Dissociation of the Past from the Present." It has been published on his blog in two instalments: 1) http://timshadyud.blogspot.com/2008/09/rome-paper-part-1.html; http://timshadyud.blogspot.com/2008/09/scripture-and-history-part-ii.html. He discusses the way 
In light of these considerations, the relation of the two stanzas may be interpreted in terms of consummation and recapitulation. ${ }^{745}$ Consummation presupposes a temporal dimension. An event that started in the primal past (w. 1-2) now achieves its purpose within the present experience of the worshipping community (w. 7-10). There is a glorious king who has established his authority over the total sphere of the earth, and he has realized this status within the sphere of history as Yhwh of Hosts, the God who has liberated, formed, and successfully guided his chosen people to Zion (cf. Exod 15). The establishment of the cult on Zion by David as the culmination of a history of warfare is an event of cosmic significance, ${ }^{745}$ and this reality is celebrated and, given the dramatic nature of the event, re-experienced in a phase of "liminality" 747 by each generation that participates in these ceremonies. ${ }^{748}$ We may thus agree with Girard who says that the experience of the liturgy catapults "la communauté cultuelle dans un monde qui dépasse infiniment l'ici bas, par delà les portes de l'éternité," yet the historical traditions associated with the Ark means that the event is not "supra-circonstancielle." ${ }^{1749}$ It is precisely by means of the circumstantialities of the historical victories of the palladium of Holy War that Yhwh's cosmic kingship has been established on earth (note the historical references in the "enthronement Psalm," Ps 47). As Berlin put it, the myth and the ritual situate Israelite

in which the modern era has constructed a particular view of history that embodies both epistemological and ontological assumptions. A key concept here is that of "anachronism," by which the past is considered to be disassociated from the present in an absolute manner. This approach to history contrasts to that of, for example, the medieval historian Bede, who subordinated (while still respecting) the "facts" of history to the "vera lex historiae," the "res," which means "the event's significance in doctrinal and moral instruction." This approach represents a "desire for being" rather than the modern desire for "knowledge," for it is characterized by a study of the past that wishes to become again like that which was before. Louth describes a similar approach amongst the Church Fathers with their interest in allegory. They did not reject history, but tried to move through it, from fides to intelligensia (Louth, Mystery, 74, 116-117). See Childs' attempt to appropriate this approach in the modern period in section 4.5.2.

${ }^{745}$ Girard brings both dimensions to expression when he says that the relation between the stanzas is "une sorte de parallélisme climactique élémentaire" (Psaumes, 207).

${ }^{746}$ Otto describes the mythic representation of chaos water in the relation Ps 93:3-4 as an expression of the "Tiefendimension von empirischer Entfremdungserfahrung ... : Die Erfahrung des Scheiterns von Leben ist nicht Oberfläche empirischer Wirklichkeit, sondern hat metaempirische Tiefendimension" ("Kultus und Ethos," 174-175).

${ }^{747}$ See Podella's summary of Turner's theory of ritual structure in "Transformationen," 105.

${ }^{748}$ See Podella, "Transformationen," 100-102, for the dramatic nature and effects of ritual.

${ }^{749}$ Girard, Psaumes, 207. 
history "within the framework of eternity." This history is "mythologized," but it is not superseded. ${ }^{750}$

At the same time, in addition to the climax, there is an analogy of structure. Yhwh subdues his primordial enemies $=$ Yhwh subdues his historical enemies. The two realities shade into each other. The result of both battles is Yhwh's sovereignty within the sphere that he has established for himself. Mysteriously, Yhwh's primordial victory does not just find a realization within history, it is recapitulated somehow. In Childs' terminology, the "substance" of God's intervention is always the same (see, e.g., 4.4.). This manner of thinking may find its correlate above in our discussion of the relation between the immanent and the economic Trinity (4.3.). ${ }^{752}$ on which see 8.

\subsubsection{Stanza II}

This pattern of consummation and recapitulation can arguably be found in transformed form in stanza II. As stated above (7.3.2.4.3.2.), in stanza III Yhwh does not enter his temple for the first time; this act has already been achieved in the move from stanzas I to II. The battle motif, however, has now been transferred from Yhwh to Jacob. According to Davidson, "Order and chaos find their counterpart in the forces of good and evil which shape our lives." 752 The move from stanza I to stanza II, then, may be conceived as a move from Yhwh's work to its consummation (i.e. his taking up residence in his temple) accompanied by a concomitant invitation to humanity to participate in that victory and its fruit (made uniquely available from within the temple) by overcoming the "chaos/evil" that

750 Whereas Berlin talks of "mythologization" of Israelite history, Childs talks of the "demythologization" of pagan myth (Isaiah, 403). The categories "myth" and "history" probably say more about post-Enlightenment thought than about indigenous ancient Israelite categories.

751 Note Otto's phraseology: "In [der Schöpfung] also sind die Kräfte des Chaos gebändigt, alle empirischen Negativerfahrungen prinzipell transzendiert" ("Kultus und Ethos," 175; emphasis mine). That which has happened in principle must be realized in history. For Otto, this realization takes place through obedience to the norms promulgated in w. 3-6 rather than through Yhwh's historical intervention:"Im normgemäßen Handeln realisiere sich die Chaosüberwindung, die die Bedingung ihrer Möglichkeit im Ein-für-Allemal der Schöpfung habe" (176). Note how the cosmic language of Ps 93:1 is transferred to the individual in Ps 15:5c.

752 Davidson, Vitality, 86. See also Roberts, "God's Imperial Reign," 220; Craigie, Psalms, 212-213: "in the context of worship, the motifs of order and chaos are transformed into moral concepts, good and evil." See also Otto, "Kultus und Ethos," 175: "Normgemäßes Handeln auch der Solidarität mit dem sozial Schwachen in der Gesellschaft wird zur pragmatischen Aneignung und Realisierung von Schöpfung und damit zur Aneignung der in der Schöpfung begründeten Überwindung der Negativaspekte von Leben " (175; emphasis original; cf. Ps 93:1 and its application to the individual in Ps 15:5). 
exists within society and the human heart (Cf. PS 51). ${ }^{\text {s3 }}$ A further thematic connection with the rest of the psalm is the emphasis on Yhwh's sovereignty, in this case as the one who sets out laws to be followed. ${ }^{\text {?st }}$

In light of these connections and the material fact that stanza II is now part of a single psalm, some scholars have argued that this stanza belongs to the same cultic Sitz im Leben discussed above. The question and answer format is understood to indicate a ritualized exchange between pilgrims and priests at the temple gates. In light of stanza III. Yhwh is understood to also be outside the gates amongst the pilgrims, present by means of the portable Ark. After the completion of the confession of innocence $(v .6)$ and the liturgy of $w .7-10$, the gates are opened and the whole company enters. ${ }^{\text {.ss }}$ The question posed in v. 3 is thereby sharpened to mean: "Who may participate in this victory procession?"

There does indeed appear to be a liturgical ritual behind w. 3-6. Not only did the laity approach priests in order to receive torah-instruction (Zech 7:1.7; Hag 2:1.9; 2 Sam 21:1$6)_{1}^{757}$ the exact structure of $w .3-5$ (excluding $v .6$ ) is found in $P_{s} 15(2,2$.$) and isa 33:14-16$ (cf. 9.3.2.), with similar structures found in Mic 6:6-8 and Ezek 18:5-17 (questionanswer-confirmation [promise]). ${ }^{758}$ This structural pattern with variation in content has led most scholars to conclude that these texts draw upon actual ritual practice within ancient Israel, a so-called "torah-entrance liturgy. "

${ }^{753}$ The French bishop Jacques-Benigne Bossuet made the following theological application: "D'où vient qu'll a établl son Eglise sur les eaux plutot que sur lo terre, puisque ce qui es établi sur l'eau ne prend point de racine? C'est qu'll veut que l'Eglise soit comme un novire qul vogue sur les eaux de ce monde, et qui est agitée tantót par les afflictions, qul sont oppelées des eaux, tantót por l'hérésie, que saint sude compare aux tempétes et aux flot dcumants" (cited in Jacquet, Psoumes, 572).

${ }^{754}$ E.g. Craigie, Psalms, 211; Otto, "Kultus und Ethos," 175. Cf. Creach, Destiny, 34: "God is in control of the world. The following question about who may ascend the 'holy hill' is really a question of who acknowledges this fact." Here, God's sovereignty is the motivation for obedience.

755 See, for example, Kraus, Psalms:1; Broyles, Psalms. See Loretz, Ugarit-Texte and Willis, "Ethics," for an overview of various reconstructions.

${ }^{756}$ Broyles, Psalms, 128-129. He goes on: "Yahweh's temple or royal palace symbolized the achievement of world order ... Thus, only those who conform to Yahweh's right order may enter his royal palace" (cf. 7.4.2.2.). This interpretation is followed by, e.8., Kraus and Hunter.

757 Kraus, Psalms:1, 226; see also Galling, "Beichtspiegel." Wolff calls this an Unterweisungsgespräch (Micah, 167).

758 Gerstenberger, Psalms:1, 117.

${ }^{759}$ See, e.g., Koch, "Tempeleinlaßliturgien;" Steingrimsson, Gerechtigkeit; Otto, "Kultus und Ethos"; Hossfeld, "Nachlese." 
however, that the ritual lies behind wv. 3-6 and has been secondarily adapted for its current literary context in the Psalm, now understood as a literary whole: $:^{760}$

1) We have already noted the incongruity of the two parallel trajectories in w. 3-6humanity to God behind the gates of the temple-and w. 7-10-God to eternity behind the gates of the temple (7.4.4.3.). We have seen that the pattern reflects the narrative structure of much Biblical eschatology, but at the level of single כבוד Soctions cannot be reconciled. A temple without God's these two section is one that is devoid of its occupant (cf. $1 \mathrm{Kgs} \mathrm{8),} \mathrm{so} \mathrm{that} \mathrm{it} \mathrm{is} \mathrm{difficult} \mathrm{to} \mathrm{imagine} \mathrm{how}$ a liturgical drama could be meaningful if it consists of a request to enter God's presence when, as some claim, the sacrament of that presence is outside amongst the pilgrims. None of the proponents of the theory of a single cultic event account for Wellhausen's critique and it is not resolved by positing the presence of the Ark amongst the pilgrims. This is presumably the reason why Gunkel suggests that two different entrance poems were juxtaposed and then prefixed with a creation hymn for the occasion of an unknown festival. ${ }^{761}$ In light of our historical analysis above (7.5.2.1.) it would appear that stanza II has been inserted between stanzas I and III, which originally belonged to a single liturgical event. Given the poetic analysis above, it is not evident, however, that the occasion for this shaping activity was a new ritual (see point 4 below).

2) Verse 6 is unique to Ps 24 amongst the "torah-entrance liturgies" in its supplementation of the promise (v. 5) with an act of identification (v. 6). Given the thematic and structural significance of this element within the psalm as a whole (7.3.), it would appear that this verse has been added to the liturgical form specifically for this composition, perhaps drawing inspiration from the older stanza III. ${ }^{762}$ Its effect is to heighten the correlation between the other two stanzas (cf. $\mathbf{W}$. $2, v .10)$ and thus sharpen the nature of the question posed in v. 3 by giving it a cosmological/salvation-historical/eschatological context. It also raises a question mark over the ability of Israel to participate in that event.

${ }^{760}$ Hossfeld makes a similar case for Ps 15 in Hossfeld/Zenger, Psalmen:l, 15-17. He concludes: "Die Einzugsliturgie haben wir nur in indirekter Wiederspiegelung vor uns" (17).

${ }^{761}$ Gunkel, Psalmen, 102. "man hat damals zwei Einzugsgedichte verschiedener Art verbunden und dem Ganzen eine einleitende Lobprisung vorausgestellt; die Liturgie würde auf ein Fest führen, an dem man den Einzug der Gemeinede ins Heiligtum und den Advent des Gottes feierte und zugleich der Weltschópfung gedachte" (6).

${ }^{762}$ Hosseld and Weber, for example, take this view. 
3) A number of scholars also believe that the use of the root נשא is intentional ( $v$. 4 and 5). It further binds stanza II to stanza III with its fourfold use of the same root in w. 7 and $10^{763}$

4) Koch has traced a possible tradition-historical trajectory whereby the original ritual has impacted Israel's tradition in various ways, gaining new functions as prophets drew upon the genre and adapted it to their own rhetorical purposes. ${ }^{764} \mathrm{~A}$ number of scholars see a similar "canonical process" at work within Psalm 15, often taken to be the most basic form of this liturgy. ${ }^{765}$ In light of the indications that stanza II has been composed in light of stanza III (see 2 above), it seems logical to suppose that a ritual act of question-and-answer at the gates of the sanctuary has been adapted for the context of $w$. 1-2/7-10 and inserted between them. The poetic analysis in section $\underline{7.3}$. and $\underline{7.4}$. above, therefore, should provide us with a clue as to the intention behind this shaping.

We must now inquire into the communicative function of this insertion. A helpful clue is provided by Clements in his analysis of Ps 15 . His starting point is the observation that the context for the prohibitions in Ps 15 (as in Ps 25:4, cf. 7.4.2.1.) appears to be a situation in which the normal mechanisms of the law were either vulnerable or ineffective (cf. 7.3.2.2.). ${ }^{766}$ Given that the crimes denoted were beyond external control, Ps 15 seeks to

\footnotetext{
${ }^{763}$ Fokkelman, Major Poems:3; van der Lugt, Cantos; Weber, Psalmen; Otto, "Kultus und Ethos;" Hossfeld/Zenger, Psalmen:I. No one, however, has been able to provide a convincing explanation for the possible meaning that is generated by the repeated use of the verb. The individual usages appear to be too different from one another.

${ }^{764}$ Similar to Ps 24 , the prophetic parallels also indicated that various genres have been woven together for a new context. For Gunkel, Isa 33 is a paradigm case for this type of reworking of tradition (cf. "Jesaja 33"). Similarly, Mic 6:1-8 is "a self-contained, artistic composition in which various speech forms have been fused together" (Wolff, Micah, 168), in this case torah instruction and a legal procedure. Wolff argues that the questions in $w .6-8$ have been formulated in light of the lawsuit speech in w. 3-5. Otto talks of the theological "grounding" of Ps 24:3-6 in its new context, albeit according to a contentious theory of the development of sacral law (cf. Hossfeld's rejection of this in "Nachlese") and in light of an alternative-cultic-interpretation of the phrase נשא לשוא נפשי (v. 4; see my exegesis in 7.4.2.).

${ }^{765}$ See Hossfeld, "Nachlese," for an overview and evaluation. Hossfeld's conclusion is that oldest elements on Ps 15 ( $v .1$ 1-2; 5c) have their source in a pre-exilic temple entrance liturgy, now refracted through the lens of "wisdom." "Der Grundpsalm bedenkt das grundsötzliche verhältnis von Kult und Alltag, nicht den ienzelnen und wiederholten Akt der Zulassung oder die erste und einmalige Aufnahme in den Tempelkult. Insofern erscheint er wie das reflektierte Ergebnis einer Betrachtung der gesamten vorexilischen Kultkritik der Propheten wie in Am 4,4f.; 5,21ff. oder Hos 6,6 und 8,13 oder Jes 22,13 (vlg.1,10-17) oder Jer 6,20 und 7,4-12 und 7,21" (154). Clements, however, does not believe it is possible to locate the source of influence too clearly, as the kinds of problems found in Ps 15 "were endemic to most ancient societies" ("Worship and Ethics," 81).

${ }^{766}$ Clements, "Worship and Ethics," 82.
} 
inculcate the correct "emotional and psychological patterns of thinking that [the] community as a whole had embraced in accepting its religious foundation." ${ }^{167}$ This thrust can be seen in its focus upon "moral inwardness" and the appeal for the individual to "engage in an exercise of heart-searching." ${ }^{1768}$ The means for doing this is provided by the opening rhetorical questions in v. 3 , which are now no longer attached to an ancient ritual but gain their meaning from their literary context in the psalm. By the time of the composition of the Psalm, Clements claims, the reference to the temple ("tent") had acquired a metaphorical meaning; it had become a category for defining the community of loyal Jews, ${ }^{769}$ accompanied by possible eschatological associations. ${ }^{770}$ This broader framework, therefore, functioned to motivate the faithful to obedience by situating the commands in a broader theological horizon. ${ }^{771}$

It would appear that a similar function can be ascribed to the framing of w. 3-6 with w. 1-2/7-10, albeit here in a theologically far more complex manner, for now creation is the horizon and we must reckon with a parallel move on the part of Yhwh (cf. 9.2.3.1.). I will now explicate the effect of this example of "canonical shaping" by drawing the threads of my analysis together by presenting a possible tradition-historical development of Psalm 24.

\subsubsection{Outline of a Possible Tradition History}

According to the theory of the history of Israelite religion touched upon above (7.5.2.1.; see also 7.3.1.2.1.2.) there is a primary level of tradition which focused on Yhwh's redemption of Israel from Egypt. ${ }^{772}$ Given the historical, "noetic," nature of these traditions, one can talk of their predominantly "horizontal" nature. ${ }^{773}$ These traditions were brought to Jerusalem with David's adoption of this site as his capital and thus came into contact with Jebusite religious conceptions which, as B.W. Anderson argues, "are oriented primarily

${ }^{767}$ Clements, "Worship and Ethics," 80.

${ }^{768}$ Clements, "Worship and Ethics," 85.

769 Clements, "Worship and Ethics," 90.

770 Clements, "Worship and Ethics," 90-92. The "openness of such a term [as 'tent', v. 1] may have helped retain its meaningfulness" (90).

${ }^{71}$ Clements does not use the phrase "broader theological horizon," but it is central to Otto's thesis ("Kultus und Ethos"). A primary difference between Clements and Otto is that Otto focuses on the way in which the commands in Ps 24:3 and Ps 15 were theologically grounded in creation (cf. Ps 24:1-2; Ps 15:5). Clement, on the other hand, is less interested in the theological justification for the commandments than in the means by which the community is encouraged to abide by them.

772 See also Childs, Biblical Theology, 110.

${ }^{73}$ Childs, Biblical Theology, 110. 
in the vertical axis of the relation between the celestial and mundane realms." ${ }^{\text {"774 }}$ The marriage of these two traditions was not forced, for there was already an "eschatological

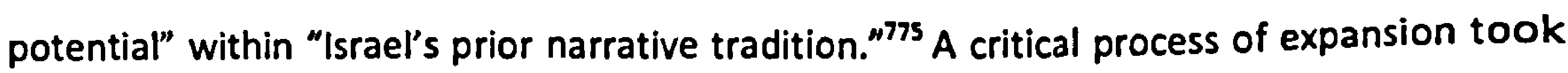
place, as can be seen in the polemical nature of Ps 24:7-10 (King of Glory $\rightarrow$ Yhwh of Hosts) along with the fact that the Israelite Ark participates in a mythic ritual pattern found throughout the Ancient Near East (the deity establishes a temple after having conquered the "chaotic" ocean). By means of this development, the "noetic" dimension of Israel's experience has been integrated into the "ontic." Indeed, within the process of "poetic actualization" in the psalm, the noetic has been subordinated to the ontic. ${ }^{76}$ The historical events associated with the Ark, in particular that climactic moment of the Ark's arrival in Jerusalem, are understood to be the realization in history of God's original creation intention, as well as a replication of the substance of that founding act. ${ }^{m 7}$

The context of this integration was liturgical, which means that it was registered by its original audience on an experiential level. Podella has strongly emphasized the "dramatic" or "theatrical" nature of the temple liturgy, in which the participants do not simply observe what is going on but become part of the drama itself. ${ }^{778}$ The purpose of this drama is not just to communicate doctrine or to keep alive memories, it is an event (Geschehen), a mimetically portrayed reality into which the participant enters. ${ }^{779}$ The effect of this experience of an alternative dimension of reality is that it transforms those who participate in it. "Die Teilnehmer gehen 'in die im Kulte dargestellte' göttliche Wirklichkeit hinein und werden von dieser absorbiert und verwandelt." ${ }^{780}$

774 Anderson, "Introduction," 10; cited in Childs, Biblical Theology, 114. Anderson refers to Pss 47; 91; 93-99.

775 Childs, Biblical Theology, 110.

${ }^{776}$ See Childs' treatment of the subordination of Gen 2 to Gen 1 in Biblical Theology, 110.

777 For a similar view, see Roberts, "God's Imperial Reign," 214-215: Israel's "political victories were further expressions of a far more fundamental creative role of the divine king. Yahweh as the divine king defeated all the mythological powers of chaos, thus creating and establishing and orderly and stable world in which Israel and all the other nations could live. Note how in Psalm 24 Yahweh's primeval victories over Sea and Rivers that led to the establishment of the world and God's hegemony over it (W. 1-2) precede any possible allusions to the more historical victories in $w .7-$ 10. ... [Regarding Ps 89, T]he Judean king, in defeating his historical enemies, is participating in Yahweh's mythological victory over the powers of chaos."

778 Podella, "Transformationen," 102.

779 Podella, "Transformationen," 99.

${ }^{780}$ Podella, "Transformationen," 100; citing Mowinckel, Psalmstudien:Il, 19. 
Given the fragmented nature of the liturgy present in our psalm (and in the Psalter in general), ${ }^{781}$ it is impossible to know what exactly happened. The recapitulatory and consummatory nature of the enacted relation between creation and historical salvation gives the impression that the liturgical participants were re-enacting a foundational pattern that characterizes Yhwh's ways in the world: conflict for the sake of Israel/humanity $\rightarrow$ victory for the sake of Israel/humanity $\rightarrow$ arrival with Israel/humanity. Participation in this drama would have taken the individuals involved out of ordinary time and space and transferred them into what Kraus above had described as an "immanent (präsentische) eschatology" (7.3.2.4.3.2.1.). The paradigmatic nature of this pattern (w. 1-2) would have enabled it to be flexibly applied to a number of historical situations ( $\mathrm{Wv}$. 7-10), such as the founding events that lead to the Davidic dynasty (cf. Ps 132) or of Israel's battles in general (cf. Ps 47). This flexibility would have enabled the ritual to be reinterpreted as a future event in which Yhwh would once again conquer evil and secure Zion (cf. 7.3.2.4.3.2.1.). ${ }^{782}$

As a further development we may posit the growing prophetic critique of Israel's sin. Koch's analysis of the tradition-historical growth of the so-called "torah-entrance liturgy" (wv. 3-5) concludes that "die Frage nach der rechten Beschaffenheit der Kultgenossen ein immer größeres Gewicht erhält." ${ }^{1783}$ We have already seen how Micah and Isaiah adopted the structure of this liturgy as part of their rhetoric to get Israel to practice the kind of righteousness found in Ps $24: 4$ (7.4.2.3. cf. 9.3.2.). It seems plausible to suppose that the final form of Psalm 24 belongs to this same trajectory, especially as scholars are becoming progressively aware of the eschatological nature of much redactional work in the Psalms and the Psalter. ${ }^{784}$ The rhetorical function of composing w. 3-6 in light of w. 7-10 and including it within only these fragments of a doubtless more comprehensive ritual appears to be to provide the prophetic challenge of v. 6 with a broader theological horizon (cf. Clements on PS 15 in 7.4.2.3.). Obedience in the establishment of a just society is presented as a participation in Yhwh's creative activity and a necessary means by which that activity is

781 Cf. Kraus, Psalms:1, 68.

782 "In the Psalms we find a remarkable correspondence between the wonders that are portrayed in the reenactment [of past history] and the 'works of Yahweh' for which the worshipers hope or which they experience. In the time of trouble they sing, "I will call to mind the deeds of the Lord; yes I will remember thy wonders of old. I will meditate on all thy work, and muse on thy mighty deeds" (Ps. 77:11-12*)" (Kraus, Theology, 35).

${ }_{783}$ Koch, "Tempeleinlaßliturgien," 58 (emphasis original).

${ }^{784}$ See, e.g., Childs, "Psalter," in Introduction; Zenger, "Psalmen;" Mitchell, "Lord." 
to be consummated. Human obedience alone will not secure this reality however, for it requires Yhwh's own intervention to bring it to its goal. Obedience, then, is a matter of aligning oneself with the grain of the cosmos (w. 1-2) and the inevitable course of history (w. 7-10). This can be a source of great motivation to those who would be righteous in the face of opposition, for not only do w. 7-10 now include a promise that Yhwh will ultimately intervene to save and bring them "home," the encasement of the human trajectory within a framework of divine accomplishment ( $A B A^{\prime}$ pattern, cf. 7.3.2.4.1.) implies that the foundation has already been laid "once and for all." ${ }^{1785}$ This encouragement also contains a warning however, for the polemic against false gods $(w .2,10)$ is now extended to include a polemic against the false pretensions of those who would claim to be Israel without the appropriate inner attitude and outer praxis. The expanded horizon intensifies the extent of the nature of one's activity, for according to Ps $\mathbf{2 4}$ disobedience places one on the same side as those primeval forces already vanquished at creation (w. 1-2). Just as certain as that evil was once vanquished, so will all those who participate in it on the day of the Lord (wv. 7-10).

In terms of the form critical vocabulary discussed above (7.1.1.) we can say that the "analytical genres" of torah-entrance liturgy and processional have been combined to create a new piece of literature, one now dominated by the "poetic function" and thus designed to function as its own literary context. Given the literary nature of the medium, the theological nature of its content and the kerygmatic nature of its function, could one not say that these old genres have been transformed into the new one of "sacred scripture"? ${ }^{786}$ Yet this focus on the literary dimension does not rule out the value of our analysis of the text's diachronic growth. As Van Leeuwen stated above, "the original primal force" of the old genres can still be evoked (7.1.1.). In light of the experiential nature of liturgy and the "vertical dimension" of temple spirituality, it seems likely that whatever it was that was experienced in the temple played a decisive role in the development of the categories that led to the canonical shape of Psalm 24. The connection between original event and final form is made more historically plausible when one follows those scholars who argue that the tradents responsible for both the redaction of the Psalter as well as Isaiah were Levitical temple singers, a group whose historical continuity spans the pre-exilic

${ }^{785}$ Cf. Otto, "Kultus und Ethos." For reflection on how the content of eschatological hope may effect ethical behaviour in the present, see Carroll, "Eschatology and Ethics."

${ }^{786} \mathrm{Cf}$. Koch, "Einlaßliturgien," 58, who does not use the term "scripture" yet talks of the way the cultic rituals continued to impact later generations in their transformed literary medium. 
to the post-exilic period. ${ }^{787}$ The ongoing influence of prior liturgical experience on final poetic form plays a role in Podella's exegesis of Psalm 24. Podella sees in the juxtaposition of w. 3-5 and w. 7-10 (excluding v. 6, which he eliminates as an editorial intrusion) ${ }^{788}$ a contrast between two alternative ways of accessing the quality of life present within the temple: ethical behaviour in mundane contexts and liturgical experience within the cult. The editorial shaping of the psalm has led to a "Demotisierung' von Abläufen im Tempelinneren ..., die der Öffentlichkeit unzulänglich waren." The result is "eine Auslagerung tempelgebundenen Heilsgeschehens auf die Alltags- und Volksebene." 789

In the light of our analysis above we have seen that these two stanzas are to be correlated according to a different schema: Torah obedience does not replace the temple as the locus for experiencing divine blessing, it is the precondition for arriving at the place where it is present (whether in the here or now or in the "heavenly Zion"). Yet Podella has, uniquely amongst commentators, picked up on an important dimension of the meaning of the text. We may rephrase the question in terms of Childs' analysis of the canonical process: What are the forces that are at work in the composition of the canonical material 3.6.3.3.; 4.2.? How are we to imagine the "Heilsgeschehen" experienced in the temple and its relation to perceptions of the ultimate theological context of Israel's liturgy and history? And how can we know anyway?

\subsubsection{The Forces at Work in the Canonical Process}

Scholars tend to be reserved when it comes to speculating about the nature of and means by which God was encountered in the temple. When an attempt is made, the language of the social construction of reality lies ready to hand. Thus Creach, drawing on Brueggemann, talks of the "world making" effect of the act of praise. 790 "The cult of the Jerusalem temple offered a view of an alternative reality in which the righteous found protection and in which God's righteousness was really in control. For that reason the temple was for the righteous a place of orientation, of order and evidence of God's

${ }^{787}$ Susan Gillingham ("Zion Tradition"), for example, has most recently argued that the shapers of the Psalter were Levitical priests. Berges argues that Levitical tradents were responsible for the final composition of the book of Isaiah, placing much weight upon the historical continuity of this group through the exile to the post-exilic period (Jesaja; "Witnesses"). He sees the same group behind the penultimate redaction of the Psalter ("Knechte").

788 Podella, "Transformationen," 118.

789 Podella, "Transformationen," 127.

790 Creach, Destiny, 31. 
reign." ${ }^{\prime 791}$ Mowinckel, however, used language far more redolent of ontological presence. The psalms, he says, are "an expression of that experience of God which the cult seeks to further," "792 "a reaction to the encounter with the holy." "793 He concludes:

It may often look as though the initiative lies with the congregation, on the human side. But seen from the point of view of cult and religion it is rather the other way round: the initiative lies with God. True enough, it is man that 'searches for God,' 'seeks God,' but he can, and does so, because the deity first 'revealed himself' and taught man where and when and how to seek him. This is a fundamental idea of all religion, and not least in Israel. The deity represents a reality and a power which is different from the human, he belongs to the sphere termed 'the holy', he is experienced as something 'different' and 'separate' -... Through the cult this effective and wonderful 'power' is imparted to the partakers, the congregation or the society. ${ }^{794}$

While not wishing to deny the influence of culture in the construction of our view of the holy, within a canonical approach which, as the term "canonical" implies, takes the confession of Israel to be true (cf. 2.1.), an adequate evaluation of the nature of the impact of liturgical experience must surely not only reckon with the socio-psychological dimension (Gerstenberger's primary understanding of the term "reality," cf. 7.1.1.; see also 4.4.) but also the theological, i.e. the reality of divine presence. ${ }^{795}$ This issue is raised by our psalm itself, which takes Yhwh's פנים (v. 6), "the characteristic expression for the secret of Yahweh's presence in Israel's worship," ${ }^{796}$ to be the goal of Israel's pilgrimage (note also כבו7 in w. 7-10)..$^{797}$

The problem is that we have almost no information concerning the happenings within the Jerusalem temple and so the question of what was experienced there and then must remain a mystery ${ }^{798}$ (on Ps 73 , see 8.2 .). Despite this, Kraus does not feel that one can

${ }^{791}$ Creach, Destiny, 124.

792 Mowinckel, Worship, 31.

${ }^{793}$ Mowinckel, Worship, 9.

${ }^{794}$ Mowinckel, Worship, 16-17.

795 In the context of a discussion of theophany within the Jerusalem cult, Kraus states, "God's coming has become history, that is, an event that forms the basis of history" (Theology, 32).

${ }^{796}$ Kraus, Theology, 39. Concerning Ps 24, Kraus speculates: "Most probably it was especially in connection with the processional ceremony involving the Ark and the throne of cherubim that Yahweh's coming to his people and appearing to them was experienced, and those participating in the worship encountered the "face of Yahweh," the "face" that was then present in the debir" (Theology, 39).

797 "In the Psalms, כבור is also an expression which refers to the revelation of the presence of Israel's God (see especially Ps. 26:8*; but also Ps. 24:7-10*; 29:3*, 9*; etc.)" (Kraus, Theology, 39).

${ }^{798}$ Kraus, Theology, 103. 
ignore the question of the identity of the "divine content,' the 'uniquely divine' in the Psalms." His own answer to the question of how we should perceive this reality is as follows:

Only by constant listening and paying attention to the nuances in the Old Testament texts can we hear the word that testifies to the God of Israel. A theology of the Psalms can only hint at this acute exegetical process, or perhaps, bring together observations and insights derived from the exegetical process, place them in relation to each other, reflect on them, and interpret them. ${ }^{799}$

In other words, the reality of God experienced within the temple is the same reality at work in the total growth of Israel's tradition, now preserved in all its diversity yet singularity of reference in its canonical form (cf. $\underline{3.2 .}$ ). The implication is that the same ontological reality is knowable, albeit now through the different medium of canonical scripture. This assumption of a singular source and referent behind the entire process from the inner sanctuary to final form of the text may provide us, then, with the justification for attempting to grasp the nature of the "Heilsgeschehen" that Podella claims fed into the poetic shape of Psalm 24. Our tools of analysis will have to be of a different kind to those used for religious-historical comparison or cult-critical reconstruction, ${ }^{800}$ they will have be to theological-exegetical (cf. 3.4.; 3.5.4.; 4.5.). The scope of texts for interpretation will have to be the entire canon, for a Christian cannot think of ultimate divine realities without incorporating God's self-revelation in Christ. The nature of the interpretation will have to be "theo-referential" (cf. 3.4. 3.5.4.), for it is only at the level of the "substance" of the tradition that the bridge between canonical scripture and ancient experience can be posited to exist.

This kind of theological exegesis would of necessity flow into systematic theology, that discipline concerned with weaving together the various strands of the Biblical witness, "integrating them into a coherent and systematic account of the Christian vision of reality." 801 Providing such an analysis here is clearly beyond the scope of this work. Instead, I will tentatively suggest a possible point of contact between the historical issue raised above (i.e. "what was experienced on the other side of the gates?") and the work of one particular systematic theologian whose approach shows many points of contact with that

799 Kraus, Theology, 41.

${ }^{800}$ Cf. Kraus, Theology, 40-41.

801 McGrath, "Doctrine," in DTIB, 177. 
of Childs: Robert Jenson. The point of contact between Jenson and Psalm 24 is Jenson's proposal of a metaphysic of "heaven," the very reality that the cultic participants and Biblical tradents desired to experience on the other side of the gate (cf. 7.3.2.3.).

\section{Res 1: Force}

In what follows, I will present Jenson's "revisionary metaphysic" as he unfolds it step by step, relating each section to our discussion of Psalm 24 above and drawing the appropriate conclusions. ${ }^{802}$

\subsection{The Location of Heaven}

"What is heaven?" Jenson asks. His answer: "As Scripture speaks of it, heaven is part of creation, God's pied-à-terre within his creation. ... God's own place is just God himself, heaven is his created throne, as earth is his footstool. ${ }^{1803}$ Furthermore, heaven is that "starting point in creation from which God moves through creation toward us; it is wherever in creation God has taken residence in order to come to us within creation, in order that his coming to us will be an inner-creaturely event. ${ }^{1804}$ Although the Bible often talks of heaven as being "above" us, this is not the only place where it is located. Jenson encourages us to attend to

parallel constructions in which the Lord's riding heaven's storms-up thereand his riding the temple's cherubim throne-over there or in there-are the same thing; or to the passages in which the Lord's speaking to Israel from heaven and his speaking from the fire and the storm on the mountain are conflated; or to the Chronicler's version of Solomon's prayer dedicating the temple, where worshippers' prayers to the Lord emphatically above are to be directed not up but in whatever geographical direction the temple lies. ${ }^{805}$

This understanding of heaven does not just cohere with Psalm 24, it appears to be exemplified by it. We have already identified spatiality as one of the key elements of the psalm's poetic world (7.3.2.4.3.2.). God's location shifts from being above the world (w. 1-

802 Jenson's theory in "For Us" is presented within the broader context of a discussion of the incarnation and the logos asarkos. His theory concerning the existence of the logos asarkos is highly controversial, but it seems to me that his theory of heaven can stand on its own, regardless of what one thinks of this broader theological concern. For those interested, his most recent defense of his position on this front can be found in his article, "Logos Asarkos."

803 "For Us," 80.

804 Jenson, "For Us," 80 . This echoes Barth: "[T]he world is not without the fact that from its beginning in creation the gracious address and lordship and presence of God are concretely true and actual even within its own constitution" (CD:III/1, 224; cited in Macdonald, Metaphysics, 87).

805 Jenson, "For Us," 80. 
2) to within the world (w. 3-6); he also appears to move towards humanity from the temple (cf. Ps 18:8-16) and then back again (the move from stanza II to stanza III; cf. 7.3.2.4.3.1.3.). As we have seen, the where of God's presence, i.e. the location of heaven, is of key significance for its concerns.

Jenson's further specification of the manner by which heaven in located in our time and space clinches the strong analogy between his theory and the imagery of Ps 24:

[I]n Scripture, heaven has 'gates,' that is, stipulable places in creation that specifically locate that boundary from which the Lord moves towards us. No doubt the firmament, through a door into which the seer John looked, was one such gate. But Bethel, geographically marked by Jacob's stone, was a gate of heaven, and then the temple was the gate of heaven. For Christians, the gate is the body of Christ, that is, the church is the gate for the world, and the Eucharist is the gate for the church. ${ }^{806}$

Jenson is using the word "gate" in a metaphorical manner to denote a point of intersection between heaven and earth. Psalm 24's direct address to the "portals of eternity" ( $w .7$ and 9) could function as the root metaphor for this image.

Having established where heaven can be, we now need to ask what heaven is. This metaphysical question too echoes Psalm 24's concerns, for the question of who may ascend to the gates is explicated in terms of what is to be found there (cf. 7.3.2.2.): Yhwh's presence and blessing (v. 5).

\subsection{The Nature of Heaven}

There are four points to be noted about the nature of heaven: it is future, it is communal (cf. 7.3.2.4.3.2.1.), it is the consummation of creation and, most significantly, it is the place for the consummation of God's own being. We start with its futurity:

$[H]$ eaven is located in space precisely and only by its gates. ${ }^{807}$ What is on the other side of those gates is also in creation, but it is not in another piece of space. That is, heaven is not in creation's present tense. Consider what John the Seer saw when the firmament-gate of heaven opened and he was permitted to look through. What he saw was 'what must take place after this': he saw the future, as the Spirit anticipates it for and in God's triune life. ${ }^{808}$

806 Jenson, "For Us," 80-81.

${ }^{807}$ Jenson presents this statement as a suggestion and not as a clear dogmatic pronouncement.

${ }^{808}$ Jenson, "For Us," 81 (emphasis mine). See also Jenson, Systematic Theology:1, 217: "It is in that [God] is Spirit that the true God avoids-so to speak - the timelessness of mere form or mere consciousness. Therefore such paired denials and affirmation as as the following must always be to 
Jenson refers to a New Testament text to back up his theory, but a similar case can be made in relation to Ps 73, a psalm, furthermore, that has a significant thematic connection with Ps 24. Psalm 73 contains a personal narrative of an experience of God within the precincts of the sanctuary (w. 17-28). ${ }^{809}$ The psalmist was troubled by the fact that the righteous suffer and the wicked are prosperous. He tries to understand this using rational means, but it is too difficult for him. He then enters the sanctuaries of God (v. 17) ${ }^{810}$ and is "confronted by the reality of God in a theophany (cf. Job 40:1ff.*). " 811 That which was incomprehensible to the psalmist on the basis of reason and daily experience is now put into an entirely different perspective. The significant thing about nature of his revelation is that it concerns the future, namely the final destiny of the wicked and himself (אחר w. 18-20). He discovers that Yhwh will actively intervene in judgement and salvation, a future reality so secure that it transforms the psalmist's perception of the present; now he realizes that he always has been protected by Yhwh's right hand (v. 23). ${ }^{812}$ In short, that with which the psalmist is confronted is the future, the ultimate end of created beings. ${ }^{813}$

Psalm 73 does not just provide support for Jenson's understanding of heaven, it has a significant thematic connection with Ps 24 , which strengthens the impression that a

hand: God is not eternal in that he adamantly remains as he began, but in that he always creatively opens to what he will be; not in that he hangs on, but in that he gives and receives; not in that he perfectly persists, but in that he perfectly anticipates."

${ }^{809}$ Cf. Kraus, Psalms:2, 86: "Through the medium of personal experience suprapersonal truth is proclaimed." For an overview of interpretations as to whether the reference to the temple is literal or metaphorical see Zenger, "Psalm 73," in Hossfeld/Zenger, Psalms:2, 230-232. Zenger takes the latter view: "What one sought by visiting the Jerusalem Temple, namely an encounter with the presence of Yhwh that rescues from death and expands life, was given to the petitioner immediately (and outside the Temple) in an "experience of God." Zenger recognizes that his own metaphorical interpretation is not compulsory.

${ }^{810}$ The plural may refer to the various precincts within the sanctuary (Zenger, Psalms:2, 222, footnote $g$ ).

${ }^{811}$ Kraus, Psalms:2, 89. Kraus talks of either this possibility or the reception of a "revelation." Zenger classifies the revelation as "'theologized wisdom,' or even as 'revelation wisdom' or 'mystical experience wisdom"' (Psalms:2, 223-224) adding that the insight was "something revealed to him by God himself" (225). In the context of the sub-collection Pss 15-24 (see 9.2.), another description of a "mystische Gottesgemeinschaft" can be found in Ps 16 (cf. Hossfeld/Zenger, Psalmen:I, 108).

812 "That it is really the whole course of his life that is in view is visible from the sequence of time periods: v. $23^{*}$ is the past, v. $24 a^{*}$ is the present, and v. $24 b^{*}$ is the future" (Zenger, Psalms:2, 233-234).

${ }^{813}$ It is interesting to note how this revelation echoes what Hiebert has claimed is a basic pattern behind Old Testament theophanies: Yhwh reveals himself as a warrior-king by conquering his enemies and establishing an order based on divine law (Hiebert, "Theophany," in YABD:6, 505511; See also Creach, Destiny, 111: "Zion is the place where God's people experienced God's nearness and consequently, God's just reign;" "Zion is the place where God's reign is experienced and known and, therefore, the place where the righteous are most at home" [154]). 
common root experience lies behind the final form of both compositions. At two key structural points (cf. the repeated term אך) we have a reference to the "pure in heart" (בר לכב) and the innocence of hands (נקיון) (W. 1, 13; cf. Ps 24:4); in direct contradiction of Psalm 24:3-5..$^{814}$ We are told, however, that such behaviour as required in Ps 24 is pointless (73:13), for the wicked prosper and the righteous do not. The Psalmist's experience, then, is a negation of the promise found in Ps 24:5. Yet just as the commandment in Ps 24 is set within the context of God's future intervention (v. 7-10), so too is the psalmist's mind changed by an almost eschatological vision ${ }^{815}$ of his own destiny: He will be taken up by Yhwh's "glory" (כבו7; cf. Ps 24:7, 9). ${ }^{816}$ Both psalms situate the imperative to obedience within the context of God's ultimate plans. The latter psalm roots this insight in a revelation received in the temple (We should also not forget that the gates are called the "portals of eternity," i.e. they open up onto God's temporal frame; cf. 7.3.2.3.2.).

Not only do we see that the reality experienced within the temple is the future (= präsentische Eschatologie; cf. 7.3.2.4.3.2.1.), there is also a correlation between Jenson's theory of the content of that future and the future portrayed in Ps 24. For a start, Jenson claims that "[h]eaven is a mode of God's final kingdom, which is the future of creation." 817 If we start with the second clause, we see that whatever this future is, it is the consummation of that which was at the beginning. The move towards the future is a move

814 Cf. Goldingay, Psalms:2, 408.

${ }^{825}$ Kraus, Psalms:2, 89: "What is אחרית? The reference is undoubtedly to the final outcome ("la solutione," G. Castellino), the final event that explains everything, the visible appearance of a situation now still veiled (cf. Lam. 1:9*; Deut. 32:28f.*; Isa. 47:7*)." See also Zenger, Psalms:2, 237, for the function of this "eschatological" image in the collection of Asaph-psalms.

${ }^{816}$ For a review of translation possibilities, see Zenger, Psalms:2, 233-234. I follow Kraus' interpretation: "As the lightning of the consuming terror of God snatches away the basis of life of the כביטוד (w. 18ff."), so Yahweh in the phenomenon of the light of his appearance in glory) takes hold of the אחרית (Psalms:2, 91). It is not necessary to insert ב to follow this reading. See also Gerstenberger, Psalms:2, 72: "by glory."

Another potential thematic connection between Pss 24 and 73 is concern for the integrity of the "true Israel" (Ps 73: 1, 15; Ps 24:6). Zenger argues that v. 1 original read: טוב לישר אל ("Good to the upright is God"), but was changed to טוב לישראל at an early, pre-Masoretic stage in order to fit it to its context at the head of the sub-collection Pss 73-83. "On the one hand this is about "Israel" in contrast to the wicked foreign nations who have destroyed the Temple and oppress Israel, and on the other hand it is about the mass of "pure" poor and guiltless suffering people in Israel, to whom the psalm attributes the label "Israel." Psalm 73 proclaims to both these bearers of the signification "Israel" the goodness of God" (Psalms:2, 237).

${ }^{817}$ Jenson, "For Us," 81 (emphasis mine). This reality is the "the absolute possibility that is the final reality of historical being" (82). 
from a protology to eschatology, an original state and it consummation. Heaven as a reality that is the climax of a movement accords with the poetic structure of Ps 24 outlined above (7.3.2.4.3.2.): The proleptic inauguration of the kingdom in stanza II and its consummation in stanza III is the realization of the protological reality witnessed to in half-stanza I.

The first part of the sentence further defines the future of creation as a kingdom, by which Jenson means a "perfect kingdom, a community of fulfilled and fulfilling love. ${ }^{1818} \mathrm{We}$ thus have a further connection with the poetic shape of Ps 24 as outline in 7.3 .2 .4 .3 .2 . above: The protological reality testified to in stanza I finds its consummation when perfect communion is achieved within its realm. Heaven is the future of creation understood as the place of perfect communion between God and man.

Yet this construal does not do full justice to Jenson's metaphysic, for it creates the impression that heaven is a space that exists purely for humanity, an accommodation made by God for his creatures in order to dwell with them, one not otherwise necessary for his own perfect existence. According to Jenson, however, heaven is also the place where God's own destiny is fulfilled! ${ }^{819}$ For Jenson, it is not just God's creation pro nobis that is constituted when communion is achieved, it is his very being himself, in se. ${ }^{820}$ His being is constituted by an event of dramatic causality (in particular the Resurrection, though arguably the Ascension would be a better fit; cf. 10.3.); his life "is ordered by an Outcome that is his outcome" 821 (Barth had said that God is "geschichtlich"; cf. 3.5.1.). As such, heaven is not only future to us, it is future to God himself. ${ }^{822}$ This is possible because God is a community of persons: the Father and the Son in the Spirit. Jenson relates his metaphysics of heaven to his theological ontology as follows:

For God ... this [kingdom of communion] is truly future and is not simply dissolved into a timeless present. But because God as Spirit is fully God for and with the Father and Son, God's future is not unavailable to him; indeed it is

818 Jenson, "For Us," 82.

819 Jenson is aware of how unusal this proposal is, but he claims that commitment to "abstract aseity" is a product of the theology of pagan Mediterranean antiquity (Systematic Theology, 160).

820 "In the singular and absolute contingency of God, a specific future is decided to be God's future" (Jenson, "For Us," 82). Jenson can therefore say that God is a story.

821 Jenson, Systematic Theology:1, 160.

${ }^{822}$ Cf. Jenson, Systematic Theology:1, 160: "The Spirit is God as his and our future rushing upon him and us; he is the eschatological reality of God, the Power as which God is the active Goal of all things, as which God is for himself and for us those 'things not seen' that with us call for farith and with him are his infinity." 
present in his life as an agent of that life. ${ }^{823}$

The ... personal agency of that future is the Spirit, who opens the Father and the Son to it. ... [T] he Spirit is the one who frees the Father and the Son for each other, so that their mutuality is not that of source and emanation ... but of Father and Son, Speaker and Word, so that their mutuality can be love. ${ }^{824}$

Consonant with the logic of the relation between the economic and immanent Trinity (cf. 4.2.), we may see a connection not only between the poetic structure of Psalm 24 (7.3.2.4.3.2.1.) and the function of heaven within God's economy, there is also an analogy with the structure of the being of God himself. ${ }^{825}$ The protological/teleological reality in stanza I corresponds to the work of the Spirit, who "creates" heaven-i.e. God's future-by enabling the space within God whereby the Son and Father may meet each other and commune ${ }^{826}$ (As we have seen, half-stanza $I$ itself is primarily interested in the quality of Yhwh's stabilized realm as "Lebensraum" rather than the mere fact of its having been created [7.3.2.1.]). Stanza II portrays the divine partner, the Son, who, through his act of obedience as the divine Logos, ${ }^{827}$ is to make that space what it should be, a place of communion (cf. 10.3.)..$^{828}$ Stanza III portrays the actual consummation of this communion

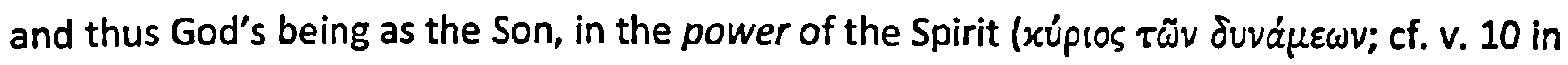
the $L X X)$, ascends to the Father across the threshold of the heavenly gates that separate the two from their common future. ${ }^{829}$ The tension noted by Wellhausen between stanzas II

823 Jenson, "For Us," 81.

824 Jenson, "For Us," 82.

825 Jenson's interpretation has not remained undisputed in Systematic Theology.

${ }^{826}$ Cf. Jenson, Systematic Theology:1, 157: "[W]e have already many times noted and said where in fact the Spirit stands: at the End of all God's ways because he is the End of all God's ways. The Spirit is the Liveliness of the divine life because he is the Power of the divine future. He is the one who, when he in time gives a 'down payment' on the Kingdom, gives precisely himself. He is the Love into which all things will at the last be brought, who is thus the fulfilment not only of created life but of the divine life. One observation alone would be sufficient: in Jesus' proclamation the power of the Spirit and the pressing immanence of the Kingdom are the same thing [cf. Matthew 12:28 par.]." Jenson notes, however, that "the tradition has acknowledged none of this within the developed doctrine of Trinity."

${ }^{827}$ Cf. Jenson, Systematic Theology:2, 6-7.

${ }^{828} \mathrm{Cf}$. Jenson, Systematic Theology:1, 201: "Christ is risen into the Kingdom, and Christ is risen into God. He is located in the heaven seen by the apocalyptic prophets [cf. pp. 196-197], and he is located in the triune life. Thus he is himself the presence of God in heaven; he is what makes it heaven."

${ }^{829}$ For Jenson, this act of "giving" on the part of the Spirit happens supremely in the resurrection. 
and III (7.3.2.4.3.) is thereby resolved at the level of the substance of the text, for the being of the one ascending Zion is the same in both stanzas. ${ }^{830}$

There is thus an analogy between the poetic "narrative" of Ps 24 and the narrative structure of the divine reality, as understood by Jenson. This is not to say, of course, that Ps 24 was originally composed as a piece of metaphysical speculation. It is also not to say that the primary concern of the psalm was with theological ontology at all. As we have seen, its primary coordinates are salvation-historical, God's ways with Israel and the cosmos, and not God's own inner dynamic (7.3.2.4.3.2.). But the logic of the interrelation of the economic and immanent Trinity demands that a correlation does indeed exist. The preceding analysis functions to suggest that the ultimate force in the tradition-historical shaping of Ps 24 is the divine reality himself (cf. 7.4.4.), in se yet expressed pro nobis.

These thoughts are only a probe at best, however, and there remain difficult issues raised by the psalm that systematic theology must wrestle with (how are we to understand the presence of "battle" in the immanent Trinity, for example?). ${ }^{831}$ In addition to this, we

${ }^{830}$ Suprisingly, there is an medieval Jewish midrash that interprets the King of Glory in stanza III to be the messiah (cf. Kähler, Te Deum, 47-48). According to Rivka B. Kern Ulmer, the language of deity is quite often used to describe the messiah in such texts as found in the Rabbati (personal communication).

${ }^{831}$ Jenson raises the "conceptually and morally nearly unmanageable" question of whether the Crucifixion must be "an intermediate good", and thus also the fallenness of creation (Systematic Theology:2, 20). As part of his reflections he notes that the life of God is a drama. "Since this drama is God's, its conflict is infinite, the conflict of death and life" (23; cf. Ps 24:1-2; 3-6; 7-10). He concludes that this must remain a mystery as long as one attempts to resolve it conceptually "from the outside." Interestingly, given the original Sitz im Leben of Ps 24's various parts, he nevertheless concludes that this mystery "can be inhabited liturgically" (24). His quote of Maximus the Confessor" is helpful: "The one who knows the mystery of the cross and the tomb, knows the reasons of things. The one who is initiated into the infinite power of the Resurrection, knows the purpose for which God knowingly created all" (Centuries (PG 90), 1108A-B; cited in Jenson, Systematic Theology:2, 24). David B. Hart provides the following summary of Jenson's thought on this issue: "not only does God overcome death for us in the death and resurrection of Christ, by virtue of His transcendence; He in fact overcomes death for Himself, indeed constitutes Himself as transcendent of death by way of His confrontation with death upon the cross and His triumph over death at Easter. Which is also to say that-inasmuch as God has eternally decided to determine His identity in this man-God has eternally elected the world of sin, death, and the devil 'alongside' His election of the Son as the context in which the drama of triune love must be played out. Thus, even the fallenness of our world falls within the story of God's life as Trinity, but only insofar as that fallenness is overcome by God in Christ. There is sin only that we might be saved, for it is as the God who saves that the Father determines Himself in His Son, and raises the Son by the Spirit, and draws us into that mystery. The triune "event" that God is, then, involves the cross of Christ not as something incidental or subsidiary, but as (so to speak) its axis: the moment in which the Father's love for the Son and the Son's obedience to the Father arrive at their crisis, and in which the Spirit lifts up that love and obedience into an eternal living future" ("Robert Jenson;" emphasis original). Hart himself is critical (does this smack of German idealism?). He poses, for example, the following question: "If it is true 
have already noted Guretzki's concerns about the complexities of attempting to "map" the Biblical narrative to persons of the Trinity (4.3.). ${ }^{832}$ Nevertheless, bringing our poetic and historical analysis into dialogue with Jenson's thoughts on the nature of "heaven" has illuminated the narrative coherence that our prior analyses have already touched upon. Jenson's thought provides a possible "canonical" parameter for testing the validity of interpretation (cf. the definition of "canon" in 2.1. above), and at the same time-assuming that he is not too far off the truth-it protects us from interpretations of the psalm informed by an inferior grasp of their ultimate referential content. An analysis at this juncture of the relationship between various interpretations of Psalm 24 and the theological convictions of the commentators would no doubt be helpful, but this would unfortunately go beyond the scope of this work. The question may at least be raised, however, to what degree, for example, Kraus' dogmatic presuppositions have led him to downplay the mythological connection between w. 7-10 and w. 1-2, for he chooses to focus solely on the "horizontal" dimension of Yhwh's arrival in Jerusalem (which parallels Christ's arrival in the world). ${ }^{833}$ One wonders, too, what theological dynamic is at work in the approaches of Creach and Podella, who subordinate the significance of the temple to torah. The latter scholar even plays them off against one another. Whereas Creach has a tendency to talk of the torah being a "replacement, or at least a surrogate for the temple," 834 Podella goes one step further and claims that the redactional intention behind Ps 24 is to facilitate "eine Auslagerung tempelgebundenen Heilsgeschehens auf die Alltagsund Volksebene. ${ }^{1835}$ The function once fulfilled by the temple, i.e. communication of the

that, in order for God to transcend death, He must triumph over it in time, is death then an independent reality over against God?"

${ }^{832}$ Though Jenson believes that something like this is possible, see Systematic Theology:1, 116: "As a hermeneutical principle, [the Western emphasis on the one substance of the Trinity] easily distorts the biblical narrative, telling us to read "the Trinity" at places where we manifestly should see one of the three."

${ }^{833}$ Kraus, Psalms:1, 316. Childs does in fact critique Kraus' over-emphasis of the economic over the immanent Trinity (Biblical Theology, 649). A further inadequacy of relating Ps 24 to Christ's entering our world is in the psalm he is entering heaven and not earth. I get the impression that the interpretation of this psalm as an Advent psalm is a relatively late, Protestant phenomenon. For most of its history it appears to have been read as an Ascension psalm (cf. 10.2.)

${ }^{834}$ Creach, Destiny, 148. This is not said as part of his exegesis of Ps 24 but part of his theology of the Psalter. Ps 24, however, would appear to provide a corrective to this view, as torah is here the means of entering the temple. A similar question mark may be raised concerning his tendency to replace the category of "creation" with pure "divine presence," another theological tendency challenged by the canonical shape of Psalm 24.

${ }_{835}$ Podella, "Transformationen," 127. 
presence of God, is now transferred to torah obedience. ${ }^{836}$ Our analysis of Ps 24, both literary and theological, has suggested a different correlation. The temple-or better: the eschatological reality within the temple-does not stand in tension with the law and is not replaced by it; it is the purpose and outcome of obedience to the law. This is so for Israel and it is so for God (This perspective is confirmed by Ps 24's broader literary context; see 9.2.)..$^{837}$

\subsection{Psalm 24 as a "Mini Dogmatics"}

At every stage of our analysis of Ps 24 , we have seen that it is a theologically dense composition. It touches on themes of foundational significance for Israel's understanding of God (creation, identity, righteousness, eschatological hope, threat). Its roots are in the liturgical practice of that place of (proleptic) arrival where the horizontal experience of redemption in history was reconfigured within the horizon of eternity. The poetic shape of the final form factored in the experience of human sinfulness and thus functioned to call Israel to realize its true identity in obedience in order to fully participate in the God's salvific activity. Finally, we have now seen that Ps 24 's structure appears to reflect the very structure of God's kingdom of communion itself, both in se and pro nobis.

A number of commentators have concluded that, whatever the meaning of the final form of the text is, ${ }^{838}$ something of comprehensive theological import is being communicated. Whereas Hossfeld talks of a "knapper Abriß der vorexilischen Tempeltheologie" 839 and Seybold of a "Dokumentation der für den Tempel in Jerusalem grundlegenden Glaubesvorstellungen" that "fasse anhand einschlägiger Texte zusammen, was dieser heilige Ort theologisch bedeutet," ${ }^{840}$ Spieckermann and Oeming go one step further and talk of "einer ,kleinen Dogmatik'." ${ }^{841}$ Oeming's interpretation comes

${ }^{836}$ This is ironic, given Podella's critique of Barth's downplaying of the liturgical dimension. In this connection, Levenson's critique of the antipathy of Protestant Old Testament scholars towards the temple is interesting ("Temple"). For a similar interpretive move at the level of the final form of the Psalter, see Brown's interpretation in 9.2.3.1.

${ }^{837}$ Even Ps 1 ends with a veiled reference to the temple, eschatological or not (v. 5; note especially its current function as joint entry to the Psalter alongside $P_{5} 2$ ).

${ }^{838}$ Hossfeld, Seybold, Spieckermann, Oeming all restrain from providing definitive interpretations.

${ }^{839}$ Hossfeld, in Hossfeld/Zenger, Psalmen:I, 157.

${ }^{840}$ Seybold, Psalmen, 104. He adds: "in der Funktion eines tepos גoyos." I am grateful to Seybold for taking the time to listen to an outline of my thesis at the 2010 Oxford Psalms Conference.

${ }^{841}$ Oeming, Psalmen, 159; Spieckermann adds "eine Kleine tempel-theologische Dogmatik" (Heilsgegenwart, 208). 
particularly close to mine when, noting wisdom elements in the psalm, ${ }^{842}$ he tentatively asks whether " der Psalm zu einer bestimmten Sicht des Daseins erziehen [will]?"843 We can agree with Hossfeld, Seybold, and Spieckermann that Psalm 24 is rooted in the pre-exilic cult, yet we can agree with Oeming that these traditions have been shaped with a pedagogical purpose in mind (cf. 2.4.3. ), one with a comprehensive theological vision that goes beyond the concerns of the pre-exilic temple community, even while echoing them in a new configuration. In light of all that has been said so far, we can define the content of this "mini dogmatics" more concretely:

Psalm 24 witnesses to the ultimate shape of the divine economy in a bid to motivate a wayward Israel to realize its own identity by presenting it as a constitutive element within that economy. Drawing on the experience of God mediated by the historical experiences of conquest, arrival, and then loss through the exile, interpreted in light of the authoritative rituals originating in the cult as well as Israel's prophetic traditions, a basic structure of divine movement has been portrayed whereby Yhwh fulfils his creation intention by calling and facilitating his elected people to reflect his order of righteousness within society. That Yhwh will enter the true Zion with his true people is a future promise. The question is whether they intend to participate in the

${ }^{842}$ Cf. Kraus, Theology, 15-16: "[T]he reflective thought, experiential knowledge, and teaching of wisdom literature show unmistakable signs of the beginnings of the formation of theology in the Psalms. The clearly didactic features of wisdom statements in the Psalms thus provide a significant starting point for a theology of the Psalms."

${ }^{843}$ Oeming, Psalmen, 159. Similar to Spieckermann, who speaks of de mundo (wv. 1-2), de homine (w. 3-6), and de deo (wv. 7-10) (Heilsgegenwart, 208), Oeming continues: "Danach beschreibt der erste Teil das Wesen der Welt: Sie ist Gottes Schöpfung. Der zweite Teil erläutert, was der Mensch seinem Wesen nach ist (bzw. sein soll): Er steht unter der Forderung Gottes, seines Schöpfer, kann sich aber auch des Segens und der Hilfe Gottes erfreuen, wenn er nach Gott fragt. Schließlich entfaltet der dritte Teils des Psalms das Wesen Gottes: Er ist der verborgene Gott, der jedoch prösent werden und durch uralten Pforten in diese Welt eintreten möchte." This final sentence is odd yet widely held amongst Christian theologians who wish to draw a connection between the Psalm and Advent (see, e.g., Jüngel's sermon, "Psalm 24, 7-10," in Predigten, 25-30 and the central place the psalm has for Advent in the Evangelsiches Gesangbuch; cf. 10.1.). It is odd, because in the Psalm God is not entering our world but his own (cf. 10.1.3. 10.2.3.; 10.3.). 
same heavenward journey. In doing so, they will participate in the fullness of the divine being himself. ${ }^{244}$

\section{Verbum 2: The Broader Literary Context}

I have so far made a case for seeing Psalm 24 as the result of a dialectic between authoritative religious tradition on the one hand (temple liturgy; historical narratives; prophetic tradition) and the experience (in history but particularly in the temple) of the Trinitarian God on the other. If what I have said so far carries any water, then it is to be expected that the same dialectic continued after the composition of Psalm 24 into its current form. A case for this thesis can indeed be made, and this will now occupy us in the following sections. We will first inquire into the meaning of the Davidic superscription (v. 1; see 9.1.) and then look at Psalm 24's canonical placement within the Psalter (see 9.2.). Finally, we will follow some leads to the book of Isaiah (see 9.3.).

As argued in Part I, Childs' canonical thesis states that the broader canonical context served to enrich the reader's grasp of the subject matter of the individual texts (see, e.g., 3.6.3.). The following analysis, therefore, does not intend to present either a purely redactional history of the canon nor a purely synchronic reading of the same, it will endeavour to demonstrate how a grasp of Ps 24's literary-canonical context may enable us to better understand the inner dynamic of the psalm itself. In a similar manner to the relation between Verbum 1 and Res 1, section 10. will endeavour to relate these literary and tradition-historical observations to the Christian confession of the Bible's dogma.

${ }^{844}$ Cf. Jörg Jeremias' theory of the kind of theocentric redactional work practiced in the postexilic period: "So sehen wir die Propheten der spätpersischen und hellenistischen Zeit mit der Suche nach einem Gesamtwillen Jahwes beschäftigt. Zu diesem Zweck beziehen sie die mannigfachen überlieferten Einzelworte bzw. -texte der vorausgehenden Propheten aufeinander, um das eine Wort hinter den vielen Wörtern aufzudecken und insbesondere das Verhältnis von göttlichem Gerichts- und Heilswillen zu klären. Sie machen dabei, wie oben an Joel 2 gezeigt, keineswegs an der Grenze der prophetischen Schriften Halt, sondern beziehen die großen Texte des Pentateuchs mit ein. Die kanonische Funktion der Prophetie ist weit älter als der faktische Abschluss des prophetischen Kanonteils." And again: "[Am Ende der prophetischen Überlieferung im Alten Testament] steht das Bemühen, die vielfältigen schriftlichen Zeugnisse von einem Reden Gottes durch Propheten zusammenzufassen, aufeinander zu beziehen und nach dem einen übergreifenden Willen Gottes zu fragen. Die Disziplin einer 'Theologie der Prophetie' ist keine moderne Erfindung, sondern längst schon in der späten Prophetie selbst angelegt. Die kanonische Funktion der Prophetie ist weit älter als der faktische Übergang der Prophetie in kanonische Dignität" ("Wesen," 13-14). 


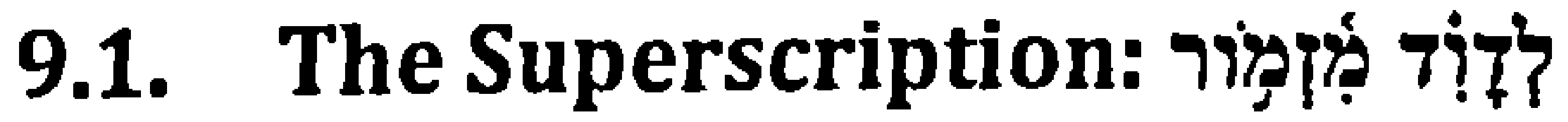

My decision to interpret Psalm 24 without reference to its superscription follows general historical-critical practice, for it is almost universally accepted that superscriptions are later editorial additions. ${ }^{845}$ In line with other ancient scribal practices, the original function of some of these superscriptions would have been to provide instructional and/or compositional information about the psalm it preceded, apparently within the context of the cult. ${ }^{845}$ Psalm 24's superscription is particularly brief, providing information about its genre and, it would appear, its "author" (see 9.1.). The word order is also the reverse to what is usually the case (one normally finds מזמור לדוד), ${ }^{847}$ which is a possible sign of the editorial shaping of the Psalter as a whole (see 9.2.). . $^{848}$ refers to the manner in which the poem is to be performed: Its singing is to be accompanied by the harp. ${ }^{849}$ In light of our diachronic analysis above, this must be a secondary use to which the redacted psalm was put. Zenger even doubts that it has any liturgical value at all. The term "ist vermutlich im Zusammenhang mit der "Davidisierung" der Psalmen ... entstanden ... und knüpft an die biblische Tradition von David als "Leierspieler" (vgl. 1 Sam 16, 14-23; 18, 10) an." ${ }^{850}$ The interpretation of the preposition $\zeta$, however, is far more complex.

845 Futato, Psalms, 119, lists the following three reasons: "(1) [T] person and thus give the impression of being editorial; (2) only 116 psalms have titles in the MT, while all but Psalms 1 and 2 have titles in the LXX, thus a certain fluidity in the titles appeared at a fairly late stage in the compiling of the book of Psalms; (3) Psalms 14 and 53 are apparently two different versions of the same original psalm. .. The titles are not identical. ... The difference in titles suggests that the titles were added independently and, therefore, that at least one of the two was added after the original composition of the psalm." He nevertheless argues that they are authoritative, for the following three reasons: "(1) The New Testament at times treats the titles as Scripture and builds arguments on this material (see Mark 12:35-37; Acts 2:29-35; 13:35-37). (2) The title to Psalm 18 is embedded in the canonical text of 2 Samuel 22:1. ... (3) The standard phrase

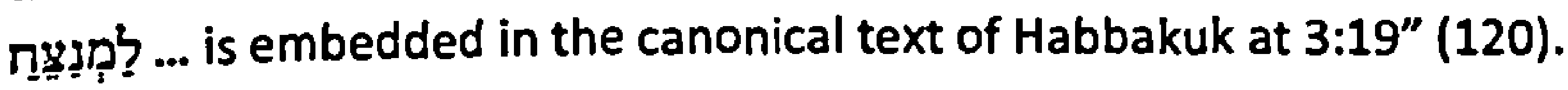

846 Wilson, Editing, 140: "[l]t seems clear that the s/ss were not added editorially to aid in the definition of the structure of the Psalter. They are for the most part descriptive statements of cultic origin which refer to the ps to which they are attached" (144). See also Gerstenberger, Psalms: Part $2,536$.

${ }^{847}$ Gerstenberger lists the following examples of Psalm 24's word order: Pss 101 and 110 with wordier examples in Psalms 32; 40; 44; 47-49; 109; and 139 (Psalms:1, 117).

${ }^{848}$ This has only been suggested by Hossfeld, in Hossfeld/Zenger, Psalmen:I, 159: "Entweder wird Ps 24 als Schluß der Psalmengruppe der 'Psalmen Davids' 19-24 oder als Überleitung zur Psalmengruppe Von David" 25-28 betrachtet." Gerald Wilson, however, can see "no immediately apparent significance for the variation in order" (Psalms, 447).

${ }_{849}$ Zenger, "Psalmen," 311.

${ }^{850}$ Zenger, "Psalmen," 311. 


\subsubsection{The Complexity of titit}

Goldingay lists six possible English translations of ל: "to," "belonging to," "for," "on behalf of," "about," and "by," and points out that its meaning as a genitive is less common than its other meanings. Not only is there ambiguity within the Psalter (e.g. Ps 72:1), some scholars claim that the meaning the phrase לדור changed for its readers over time; ${ }^{851}$ Kleer even argues that its meaning develops across the Psalter. ${ }^{852}$ In the Old Testament in general "David" not only refers to the historical person, it can also "refer to a subsequent Davidic king or to a coming David (see Jer. 30:9; Ezek. 34:23-24; 37:24-25; Hosea 3:5)." "853 Though these passages are from the prophets, Rendtorff suggests a similar interplay between the historical David and "David" as a symbol of the Davidic dynasty in Ps $132 .{ }^{854}$

\subsubsection{Canonical Pointers}

What is one to do with this seemingly inherent ambiguity in the Psalter? On the one hand, the ambiguity may be purposeful. Given the theological potency of David's persona for later generations of Israel, it might be expected that this persona be related to in various ways. It is conceivable, for example, that one and the same psalm be "by" the historical David, "for" future or contemporary Davidic kings, and "about" the eschatological David to come..$^{855}$ On the other hand, the history of tradition has employed various editorial

${ }^{851}$ Zenger suggests the following stages: "auf der ältesten Stufe, wohl in der Epoche des Exils, meint die Notiz: der Psalm ist zu lesen in Schicksalsgemeinschaft mit dem verfolgten und geretteten David; im 5. Jh. Wird die Notiz, ausgehend von Ps 51, im Sinne der fiktiven Verfasserschaft Davids verstanden; ab dem 4.Jh. Meint die Notiz nicht mehr den 'historischen' David, sondern den David der kommenden Heilszeit, so vor allem in Ps 108-110.138-145" ("Psalmen," 314). Kleer claims that "the beginning of the Davidization of the Psalter can be traced back to the identity crisis the Judeans experience during the exile. In spite of this, David was still not portrayed as the author or poet of the psalms during this period. The starting point for this motif in terms of tradition history lies in the composition of the books of Samuel. ... [The conception] of the books of Samuel was the impetus for the explicit, multi-staged Davidization of the Psalter" (Sänger, 124; cited in Vos, Theopoetry, 48. See also Goldingay, Psalms:1, 27.

${ }^{852}$ Kleer, Sänger. He argues that in the first two books of the Psalter the phrase refers to the historical David, in the last two it refers to the future David.

${ }^{853}$ Goldingay, Psalms:1, 26-27.

${ }^{854}$ Rendtorff, "David," 63. Zenger even draws a parallel between David and the nation of Israel: "'David', der Psalmendichter und Psalmenbeter, ist die Idealgestalt des vor und mit seinem Gott lebenden Israel" ("Psalmen," 324). See also Gillmayr-Bucher, "Psalm Headings," who draws a parallel between David/Judah and Saul/northern Israel.

${ }^{855}$ Hossfeld/Zenger, Psalmen:I, 16 offer the following hypothesis: "Mit der sprachlich mehrdeutigen Zuweisung l $l^{\mathrm{e}}$ dawid dürften dabei zumindest zwei Aussageintentionen verbunden sein: 1. Mit der Verfasserangabe "von David" wurden diese Psalmen als paradigmatische Gebete Davids zum "Nachvollzug" angeboten. "David" gab diesen Psalmen eine hohe geistliche Dignität. 2. In der Bedeutng "für David" wurde den Psalmen durch diese Überschrift zugleich die Kraft zugesprochen, daß Israel in und mit diesen Psalmen seine "davidische-messianische" Würde bzw. Sendung einüben und realisieren könne-mitten in Verfolgung und im Leiden an der eigenen Schuld, wie David!" 
techniques in order to give this persona within the Psalter a particular profile, as well as configure him into a broader construal of God's plan of salvation. Grasping both the profile and the plan can in turn help identify the hermeneutical function the superscription ought to have for our reading of Psalm 24.

The clearest editorial technique for profiling the David of the Psalms ${ }^{856}$ can be found in those superscriptions in which the older phrase לדוד has been expanded to include information about the circumstances in which the psalm was composed. ${ }^{857}$ The effect is that the superscription indicates the authorship of the Psalm ${ }^{858}$ and their function is "intertextual," i.e. they point the reader of the psalm to the Book of Samuel as a context for interpretation..$^{859}$ One may legitimately query whether these superscriptions are relevant for our Psalm, which lacks such an extension. ${ }^{860}$ However one interprets the growth of the tradition, ${ }^{861}$ it remains the case that within the biographic superscriptions the original element has been retained and transformed. We may thus ask with Futato: "Does [the] historical note encourage us to find in the life of David the historical setting of other psalms that have no such information in the title?"862 The answer is a qualified "yes," for a number of reasons.

Futato offers a brief example of a multi-level reading of the identity of the king in Ps 89 in Psalms, 123-125.

${ }^{856}$ I emphasize the David of the Psalms because, as Nogalski points out, David is portrayed differently within the Psalms, the Book of Samuel, and Chronicles (in "David").

${ }^{857} 13$ Psalms are usually counted: Pss $3 ; 7 ; 18 ; 34 ; 51 ; 52 ; 54 ; 56 ; 57 ; 59 ; 60 ; 63 ; 142$. In "Psalm Titles," Childs excluded Ps 7 on form critical grounds, arguing that the preposition על refers here to a melody rather than a person. I have not come across an interpreter who has responded to this suggestion.

${ }^{858}$ Childs, "Psalm Titles," 138: "Whatever the expression 7 may once have meant, the claim of authorship now seems most probable. This point is confirmed by the final clause in those titles which specify a particular historical incident in David's life as providing the occasion for composition."

${ }^{859}$ Cf. Mays, "David," 155: "the notion of the David of the Psalms is an intra-textual reality. The notion arises from looking at the text in terms of certain relations to which the texts themselves guide the reader. It is a product of the Old Testament, not just separate books, and its function and effect is hermeneuticc; its usefulness has to do with the interpretation of the text as Scripture and in liturgy."

${ }^{860}$ Nogalski has stated that "the image of 'David' facilitated by these psalms is not a literary character who develops across the Psalter. These biographic notes are designed to connect specific narrative episodes with particular psalms. Relatedly, these superscriptions do not appear to represent a redactional shaping of the Psalter" ("David," 190).

${ }^{861}$ See Kleer, Sänger, for one detailed redactional theory.

${ }^{862}$ Futato, Psalms, 118. Ironically, Futato, following other "final form interpreters" such as Wilson and Goldingay, goes on to assign little interpretive significance to the Davidic titles, with or without historical superscription. Cf. p. 121; also Wilson, Psalms:1, 128. 
An important witness to the "Davidization" of the psalms is the postscript at Ps 72:20: "This prayer concludes to the so-called "second Davidic Psalter" (PsS 51-72), a collection in which most of the psalms carry the superscription $777^{863}$ and thus clearly ascribes these songs to David himself. ${ }^{864}$ This collection of psalms is related to the "first Davidic Psalter" (Pss 3-41) both in terms of the common superscription as well as their similar structure and content. ${ }^{865}$ Vos, drawing on Kleer and Mays, argues that the source for such an interpretive move was the book of Samuel, which portrays David as a gifted musician at his first appearance, summarizes his life with a psalm (2 Sam 22), and lets him recite a poem as his last words before his death (2 Sam 23). ${ }^{866}$ The associations of David with the cult in Chronicles and Nehemiah seems to affirm this trajectory. ${ }^{867}$ In addition to this, Millard points out the close association of the other named "authors" of the psalms with David (the exception being Moses). ${ }^{868}$ These observations have led some interpreters to attempt to read the Psalms as in some sense related to this important Biblical figure. Patrick Miller, for example, argues that Ps 2, joined to Ps 1 , functions as a dual introduction to the Psalter as a whole by setting forth their basic subject matter (torah and kingship), thereby providing the reader with a hermeneutical lens. ${ }^{869}$ Miller sees this

${ }^{863}$ The final לשלמה is possibly a prayer by David for his Son; cf. Wilson, "Royal Psalms," 89; Kleer, Sänger, 126.

${ }^{864}$ Kleer, Sänger, 126.

${ }^{865}$ Hossfeld/Zenger, Psalmen:l, 15.

${ }^{866}$ Vos, Theopoetry, 48; citing Kleer, Sänger, 126 and Mays, "David," 146, 148, and 155.

${ }^{867}$ Cf. Rendtorff, "David," 54, who mentions Neh 12:36; 1 Chr 23:5; 2 Chr 29:26-27 as references to David's musical instruments and $1 \mathrm{Chr} 6: 16 ; 16: 4-7$ etc. as references to David's founding of the cult. Though Childs ("Psalm Titles," 148) dates Chronicles earlier than the addition of the historical superscriptions, Nogalski ("David," 189-190) and Rendtorff ("David," 54) date it later.

${ }^{868}$ Millard, Komposition, 232: "Die Orientierung auf David ist innerhalb des masoretischen Textes am deutlichsten: Fast die Hälfte der Psalmen sind Davidpsalmen, die Psalmen der levitischen Sängergilden sind innerhalb der Welt der biblischen Texte Werke des von Dovid eingesetzten Tempelpersonals: in 1Chr 16, 6.7 tritt explizit Asaph als Sänger von Davidpsalmen auf, wobei die dann in 1 Chr 16 gebotene Auswahl von Psalmen im masoretischen Text des Psalters ohne Überschrift gehalten ist. Daß die Auswahl der Psalmenautoren im masoretischen Text auf David bezogen ist, zeigt auch die Namensverwendung von Heman Ps 88: nach 1Chr 15,17.19; 16:41f.; 25,4-6 ist auch Heman, der einzige im Psalter konkret genannte Korachite, von David eingesetzter Tempelsänger. Asaph, Heman und Jedutun sind nach 2Chr 5,12 auch noch unter Salomo Tempelsänger, sie wirken bei der Einweihung des Tempels (2Chr 5) mit. Insofern kann auch Jedutun im Psalter als Sänger Davids vermutet werden, obwohl Ps 62,1 (עלי:דוּרוּן) personenuntypisch formuliert und Ps 62 zusätzlich als Dovidpsalm eingeführt wird. Auch in Esra 3 loben die Asaphiten ausdrücklich Gott im Auftrag Davids (Esra 3,10b)." For another influential attempt to work out the significance of this, see Wilson, Editing.

${ }^{869}$ Miller, "The Beginning," 88. See Rendtorff, "David," 60, who also sees a Davidic voice in Ps 2 on the basis of the presence of the word nin both Pss 2 and 18. See Wenham, "Psalms," 341, for a recent overview of theories. 
argument strengthened by the fact that there is "nothing that excludes or prohibits reading most of the psalms in the first half of Book 1 of the Psalter has coming from the mouth of the king. ${ }^{\prime 870} \mathrm{~A}$ recent commentary on the Psalms by Howard Wallace attempts to read almost all of them as in some sense related to David. ${ }^{871}$

In light of this, it is interesting to note that when it comes to actual exegesis, some proponents of a Christian, "final form" approach struggle to integrate David into their exegesis. Futato feels the need to apologize for not locating other psalms in the life of David in his actual exegesis ("I must admit ...") ${ }^{872}$ and Wilson has to give what appears to be an extended apology as to why David has no hermeneutic function in his exegesis of even those psalms that have biographical superscriptions. The reason he gives for this is instructive. He writes the following in his commentary on Ps 3:1:

[T] he attempt to spell out the specifics of the setting behind the distress of the psalmist and to identify the enemy precisely as Absalom often has the unfortunate effect of so fixing the historical reference that the reader is distanced even further from the psalm and hindered from appropriating its insights for personal application. ${ }^{873}$

I would like to suggest that the answer to the problem of the nature of the Davidic context and its ongoing hermeneutical significance turns on one's definition of "history" (cf.

${ }^{870}$ Miller, "Beginning," 89, citing Eaton, Kingship. The significance this theory has for Psalm 24 can be seen in the fact that all the psalms given by Miller as parade examples of the themes introduced in Pss 1-2 (torah and kingship) are found within what is now generally recognized as the chiastically constructed sub-collection of Pss 15-24: for torah we have Pss 15, 19, and 24; for kingship we have Pss 18, 20, and 21 (cf. 9.2.).

872 Wallace, Psalms.

872 Futato, Psalms, 121.

${ }^{873}$ Wilson, Psalms: 1,128 . This is a surprising statement from someone who elsewhere claimed that "the final effect within the psalter [of adding these expansions] has been to provide a hermeneutical approach to the use of the pss by the individual. As David, so every man!" (Editing, 171). For a helpful critique of this kind of de-Davidization of the Psalms, see Nasuti, "Historical Narrative," 145: "At first sight, this interpretive tradition would seem to limit the psalms to David and distance them from their later users. In fact, exactly the opposite hermeneutical possibility seems to have been realized. As many recent interpreters have noted, the link with David became one of the most significant means by which later generations have been able to appropriate the psalms. Such generations have seen this link with David as an invitation to identity with David as a representative human figure and to imitate him through the praying of his psalms. In Sacred Songs he states: "both the classic form-critical enterprise and the more recent work of Westermann and Breuggemann may be seen as generalizing moves away from individual historical authors. With respect to the question of authorship, however, the practical import of this move is to make progressively easier an identification of the reader with the supposed 'original context.' In reality, however, such a context is more an ideal construct, representing what one sees as either distinctively Israelite or universally human" (160-161). See, for example, an interesting critique of Brueggemann on pp. 148-149. 
3.6.3.1.). What does it means to locate a psalm within the "historical context" of David? Is the Bible's concept of historicity, or at least that of the editors of the Psalms, the same as ours? In order to understand the Psalter's understanding of David's "historicity," I suggest that we look at the way this is construed in the books of Samuel. The Psalter itself points us in this direction. All of the historical psalm superscriptions refer to circumstances found in these books. Their elliptical nature (e.g. Pss $63: 1 ; 142: 1$ ) appears to function as an invitation to turn to this corpus in order to interpret the Psalms. ${ }^{874}$ Kleer's attempt at a redactional analysis of the Davidization of the Psalms and the "Psalmisierung" of the David of Samuel also points to overarching connections between these two books. ${ }^{875}$

\subsubsection{The David of the Books of Samuel}

\subsubsection{Two Histories, Davidic and Divine}

Many studies of the characterization of David in the books of Samuel focus upon the "realistic" nature of his literary presentation, earning the book the accolade of being the first example of "genuine" historical writing in the Bible. ${ }^{876}$ David is a fully rounded character rather than a didactic type, a man with strengths and weaknesses whose various decisions set in action a chain of historical events according to a seemingly immanent pattern of cause and effect. ${ }^{877}$ Yet according to the canonical presentation of the final form there is another dimension to this apparently "secular" understanding of history. Childs responds to von Rad's claims about the realism of the portrayal of David as follows:

${ }^{874}$ Cf. Rendtorff, "David," 54; Mays, "David," 155. Nogalski wishes to point out the difference between these two corpora when he says that not "only do [the superscriptions] draw upon narrative traditions about David rooted in Samuel and the Deuteronomic History, they also react to the presentation of David in that corpus" ("Reading David," 190). However, though one can argue that the David of the Psalms is designed to "correct" the image of the David found in the books of Samuel (I find Nogalski's argument a bit exaggerated; compare, e.g., his interpretation of David's reaction to Nathan's judgement following the Bathsheba event to that of Seebass in Wesen), it is also possible to see significant continuity, a continuity that "envelops" diversity (see especially Steins, "Geschichte").

${ }^{875}$ Kleer, Sänger, 11-128. The direction of influence was reciprocal (Wechselwirkung). Childs, too, believes that the certain Psalms (e.g. Pss 78 and 132) as well as Chronicles drew upon the canonically interpreted David within Samuel for inspiration (Introduction, 279-280). Hossfeld/Zenger point out that the Psalter, like Samuel, emphasizes David's suffering, in contrast to his portrayal in Chronicles ("Antwort," 337).

${ }^{876}$ Von Rad, "The Beginnings of Historical Writing in Ancient Israel," in Essays, 166-204. Perdue, "David," provides an overview of a number of proposals that focus on literary characterization.

${ }^{877}$ For Alter this is the genius of the book: Samuel is "probably the greatest single narrative representation in antiquity of a human life evolving by slow stages through time, shaped and altered by the pressures of political life, public institutions, family, the impulses of body and spirit, the eventual sad decay of the flesh," a brilliant example of "the Bible's astringent narrative economy, its ability to define characters and etch revelatory dialogue in a few telling strokes" (David, ix; cited by Satterthwaite in "David," DOT:HB, 198). 
A warrant for such a claim does lie in the new approach to historical writing reflected in Samuel. However, it is crucial for the theological question to recognize that this approach to history has been subordinated within the canonical context and that the theological importance of this history has been located elsewhere. ... The theological weight of interpretation in the canonical perspective rests on a history which has been harmonized, typologized, and even proverbialized! ${ }^{878}$

This "supra-historical" dimension of the book is the subject of an article by Georg Steins with the appropriate title, "Geschichte, die im Rahmen bleibt." ${ }^{179}$ According to Steins, the history portrayed in Samuel is intentionally framed by two psalms: one by Hannah (1 Sam 2, "ein prophetisches Summarium") and one by David, sung at the end of his career as a summary of that career ( 2 Sam 22=Ps 18). The psalms function as a "theologischdoxologischer Gesamthorizont" that interprets the nature of the intervening realistic narrative. ${ }^{880}$ All that happens in between these two psalms-even those parts where the causal network of history appears to be the primary force at work in David's life-are to be seen "als Handeln des göttlichen Königs, des Schöpfers und Richters der Ganzen Welt." 881 The agenda undergirding the unfolding of history is thus ultimately grounded in God's will. Its purpose: "Gott setzt seine Königsherrschaft gegen die Mächte des Chaos definitiv durch." ${ }^{1882}$ Similar to our analysis of the relation of myth and history in Ps 24 (7.4.2.2.), Steins picks up on mythological motifs within our two psalms (1 Sam 2:8; 2 Sam 22:5-20) and concludes that by means of their hermeneutical function within the book as a whole the "Geschichtserzählungen werden transparent auf diesen mythischen Urkonflikt hin, die Wirklichkeit wird gedeutet als Auseinandersetzung zwischen Tod und Leben." ${ }^{883}$ This is not to eradicate the David of history as an agent of that history, it is to explicate the true ground of his deeds. Yhwh fulfils his plan for Israel and the cosmos by means of the free agency of David. ${ }^{884}$ This dialectic is found within the psalm in 2 Sam 22 itself. Part 1 (w. 210) portrays in mythological terms Yhwh's intervention to save his king, part 2 (vv. 33-50) mirrors this by celebrating David's victory over his historical enemies. "Beide Teile handeln

${ }^{878}$ Childs, Introduction, 279.

879 Steins, "Geschichte."

${ }^{880}$ Steins, "Geschichte," 198; 202. See also Childs, Introduction, 272-273; 278.

881 Steins, "Geschichte," 201. See also Kleer, Sänger, 34. Kleer argues that there are "zahlreiche Stichwörter, die Ps 18 mit den Davidserzählungen der Samuelbücher verbinden können," though he is cautious about their intentionality (29).

${ }^{882}$ Steins, "Geschichte," 198.

${ }^{883}$ Steins, "Geschichte," 208.

884 On the issue of God fulfilling his will by means of human free-will see Jenson, Systematic Theology:2, 22-23 ("precisely when we freely choose, we fulfil his choosing"). 
trotz der Unterschiede in der dominierenden Metaphorik von einem Rettungsgeschehen, in dem nach Ausweis der Überschrift ( $v .1)$ alle Rettungserfahrungen des Königs verschmolzen sind." 885

Of particular significance is the representation of David in the concluding psalm of the book, now to be read in relation to the similarly poetic "last words of David" in chap. 23:1-7. The key to David's success is his wisdom (chap. 23) and his obedience to torah (22:2132). ${ }^{886}$ In particular in 2 Sam 23, "Das Schicksal Davids wird mit der Zwei-Wege-Lehre literarisch und theologisch entschlüsselt. David ist das Bild des Gerechten und Gottesfürchtigen, er gelangt in den Rang des Musterisraeliten." ${ }^{887}$

We thus see that David's history is encased within another history, a divine history of cosmic proportions that is grounded in Yhwh's own plan (cf. the ABA'chiasm in Ps 24, 7.3.2.4.1.). ${ }^{888}$ This history is not just confined to the books of Samuel, it has already been prepared for within the larger canonical narrative. The institution of the monarchy, for example, is already anticipated in the traditions of the patriarchs (Gen 17:6, 16; 35:11; 49:8-10) and in the oracles of Balaam (Num 24:17). ${ }^{889}$ Deuteronomy 12 is a particularly significant intertext, for it portrays a definitive future moment in the unfolding of the divine plan. The Lord promises Moses in the wilderness that there would be a time when Israel would enter Canaan and he would give them "rest from your enemies all around so that you live in safety" (v. 10). At that time the Israelites would bring their offerings "to the place that Yhwh your God will choose as a dwelling for his name" (v. 11). ${ }^{890}$ We have already touched on the significance of this event within the ordo salutis above (7.3.1.2.1.2.). According to some interpreters, ${ }^{891}$ this moment of arrival is portrayed in 2 Sam 5-7 (cf. 1

${ }^{885}$ Steins, "Geschichte," 203 (emphasis original). Concerning w. 38-39 and 43 Gerstenberger comments: "it is unheard of to claim victory in the first person. The prophets reserve this kind of boastful speech for Yahweh (e.g., Isa 63:1-6). Could these verses originally have been a divine communication? Or could the speaker of these words be a specially designated vice-regent of Yahweh?" (Psalms, 99).

${ }^{886}$ Steins, "Geschichte," 204. Kleer talks of a consistent Deuteronomic redaction (Sänger).

${ }^{887}$ Steins, "Geschichte," 205.

${ }^{888}$ Cf. Block, "God," in DOT:HB, 352: The significance of David lies in his "significance in the divine scheme."

${ }^{889}$ Block, "God," DOT: HB, 351. Kleer sees an allusion to the Balaam oracle in the "last words of David" (2 Sam 23:1-7) (Sänger, 65).

${ }^{890} \mathrm{Cf}$. Satterthwait, Histories, 125; Fokkelman, Throne and City, 214: "The peace under David lin 7:1] is .. a special fulfilment of God's ancient promise of giving the people rest in the promised land."

${ }^{891}$ E.g. Satterthwaite, Histories, 125; Block, "God," DOT:HB; 352. Block adds: "This conviction is strengthened by 2 Samuel 7:1, in which the narrator explicitly links Daivd's impulse to build a permanent residence for Yahweh with Yahweh's granting of rest to David" (352). 
Kgs 8:29). Given the canonical significance of this event, we will analyse it more closely in order to see whether it may shed further light on the particular shape of the "historical context" within which the "canonical David" lives and has his being.

\subsubsection{2 Samuel 5-8}

Consonant with such a portentous moment in Israel's history, the stories of David's capture of Jerusalem (chap. 5), the transfer of the Ark to the city now named after him (chap. 6), and his reception of God's promise of a dynasty (chap. 7), mark a significant juncture within the book as a whole. ${ }^{892}$ In terms of the narrative development, Campbell states that chap. 7 marks the beginning of a "new epoch" in the history of Israel. ${ }^{893}$ Childs and Fokkelman see this section as the high-water mark in David's career, the climax of the time of "blessing" before David's sin with Bathsheba in chap. 11 introduces the time under the "curse." 894 In particular, the narrative of the transfer of the Ark in chap. 6 has a special sacral quality about it. Campbell points out that the sacrifices and blessings indicate that this "is no ordinary event" ${ }^{895}$ (cf. 7.4.2.1.). Fokkelman claims that from a literary perspective this sacral, almost "transcendental" ${ }^{296}$ quality of the event has been factored into the presentation of the narrative itself. On the one hand, God is repeatedly presented as the real agent behind the events of David"s life, ${ }^{897}$ to such a degree that there is "no other Act [i.e. chaps. 5-8] in the books of Samuel which so clearly puts God forward as the agent as this one does" ${ }^{\prime 898}$ (cf. 9.1.3.1.). On the other hand, this block of chapters has a special treatment of time that is not strictly chronological. Events from 2 Sam 9-20 are anachronistically brought forward into chap. 8 , for example. ${ }^{899}$ The reason, Fokkelman suggests, is that the narrator aims for completeness at precisely this juncture of the narrative. David's victories, chronologically achieved during the post-Bathsheba time of the curse, are here placed "under the one thematic denomination which is stated in the key

${ }^{892}$ For a structural analysis see, e.g., Klement, /I Samuel.

${ }^{893}$ Campbell, 2 Samuel, 64. Concerning the conclusion of chap. 6, Campbell states: "With it, something definitive is achieved; 'then all the people went back to their homes' (v. 19b)" (66).

${ }^{894}$ Childs, Introduction, 275-277; Fokkelman, Throne and City, 267: "David's long march to the top has received its climax in ch.7, but is quickly followed by a tremendous anti-climax: the fall of David in ch.11."

${ }^{895}$ Campbell, 2 Samuel, 66.

${ }^{896}$ Fokkelman, Throne and City, 266.

897 Interestingly, according to Klement's thesis of a parallel chiastic structure between chaps. 78 and 21-24, chap. 6 corresponds to the concluding psalm in chap. 22 (I/ Samuel, 83). This psalm is also found with the sub-collection of Psalms 15-24 as Ps 18 (see 9.2.).

898 Fokkelman, Throne and City, 155.

${ }^{899}$ See also Klement, II Samuel. 
sentence 'so Yahweh gave David victory everywhere where [sic] he went'. ${ }^{900}$ This gives chap. 8 a "proleptic" character, which, when combined with the fact that the narrator forgoes a clear time scheme for the single-event occurrences of chaps. 5-8 and their possible succession, leads Fokkelman to the conclusion that the Act seems to "avoid susceptibility to simple chronology." He concludes:

Such an uncomplicated ordering of events in time is difficult to separate from the transtemporal importance, or, what is more, the transcendental dimension, of these events: the choice of the city of Jerusalem, its sacred status and the promise of a lasting dynasty, given by a deity whose blessing rests upon Zion, appear to rise above the compulsory chronology of consecution which dictates that ordinary events should appear in their allotted space in text. ${ }^{901}$

Once again, we see here the interweaving of "secular" and "sacred" history, a witness to the fact that David's history-canonically interpreted-is perceived to be a thread within the fabric of divine history. Fokkelman underscores the significance of this event within context of the books of Samuel as a whole when he claims that these chapters (Act 10) constitute the "sacral centre of gravity of the entire composition." ${ }^{902}$ It would seem, then, that if one were to choose one particular locus within the canonical portrayal of David in Samuel in order to understand that portrayal, this would be a significant place to look. I am suggesting, in other words, that these chapters -in particular chapter 6-reveal a decisive element of the shape of the divine and Davidic history that constitutes David's canonical persona. ${ }^{903}$ The relevance of this suggestion for our study can be seen in the strong connections between 2 Sam 6 and Ps 24.

\subsubsection{2 Sam 6 and Ps 24}

Connections have long been made between 2 Sam 6 and Psalm 24, albeit it on different levels. When reading the psalm in relation to Israel's history, the majority of the church fathers along with more conservative modern interpreters consider the historical events reported in 2 Sam 6 to constitute the original context for the composition of the liturgy in

${ }^{900}$ Fokkelman, Throne and City, 156.

${ }^{901}$ Fokkelman, Throne and City, 157.

902 Fokkelman, Throne and City, 155.

903 For the "Davido-centric" nature of these chapters, see Fokkelman, Throne and City, 156, 160: "The whole Act is occupied with presenting God's sanctioning of David. ... (The strikingly frequent use of David's name in 5:1-3 shows that] what we are concerned with ... is the highly personal experience and the highly personal new possession of the individual David." 
w. 7-10. ${ }^{904}$ Goulder's recent article ("David") also interprets the psalm along these lines, showing how one could think of these two texts in historical conjunction. Our analysis above (7.3. and 7.4.), however, renders this thesis historically unlikely. I have followed H.-J. Kraus (7.4.2.), who suggested that these verses were composed for a ritual commemorating the historical events that lie behind 2 Sam 6, a suggestion also made by A.A. Anderson in his commentary on Samuel. ${ }^{905}$ This interpretation may be strengthened by Rosenstock's recent article which claims that a ritual pattern influenced by the Baal Cycle undergirds the liturgical events described in 2 Sam 6 (cf. $\underline{7.4 .2 .}$..$^{906}$

More significant than these diachronic hypotheses, however, is the similar pattern that these two texts share. Concerning Ps 24, I have argued that it represents a theological interpretation of the cult in the context of a grasp of the ultimate nature of God's ways with Israel and the world. The result of this interpretation is an eschatological narrative. It tells us that God's creation is consummated when he enters into communion with a distinct people-Israel-in a distinct location-Zion (stanzas I to II). This divine human communion is realized upon human obedience to God's revealed will and ascent into his presence. According to the poetic format of this narrative, the juxtaposition of stanza II with stanza III was interpreted in both linear as well as symmetrical terms (i.e. in parallelism). Symmetrically, the Lord and Jacob enter into their common future together, a reality that is consummated upon their arrival. At the same time, however, the implied element of spatial and temporal actualization created the impression that it was the Lord himself who would consummate Jacob's journey. Finally, in light of the prophetic material, the apparent double entry between stanzas II and III implied that in stanza III the Lord is returning to his temple having cleared the obstacles to his path by acts of militant judgement.

All these elements-even the last one!-are also found in the canonical portrayal of David's history in Samuel, particularly as this reaches a climax in 2 Sam 6 . The element of

904 Hammann, Psalm 24, 1. He also refers to Grotius (1645), Clericus (1736), Venema (1787), Hengstenberg, Delitzsch and Riehm for this view. Delitzsch considers it one of two possibilities, the other (for him more likely) being that it was sung when the Ark returned to Jerusalem having accompanied Israel's forces in battle. Jewish interpretation tended to associate the psalm with Solomon's transfer of the Ark into the temple (Hammann, Psalm 24, 2; Kähler, Te Deum, 44-46).

${ }_{905}$ Anderson, 2 Samuel, 109: "It is very likely that in due course the transfer of the ark to the city of David became an annual event (or an integral part of such a cultic occasion), as suggested by Pss 24,78 , and 132 , in particular. This need not imply that the present description of the original events was largely influenced by the existing liturgy although there could have been some interaction (e.g., in the distribution of food in v 19). This type of influence is detectable in the Chronicler's version of the ark story."

${ }_{906}$ Rosenstock, "2 Samuel 6." 
creation (stanza 1) has already been touched upon in the discussion of the psalms that frame the books (9.1.3.1.): David's history makes sense as part of a cosmic divine history. ${ }^{907}$ The element of obedience (stanza II) to God is also present: Up until this point David is portrayed as a man after God's own heart. This explains Carlson's characterisation of the preceding chapters as the history of David under the blessing. ${ }^{908}$ In the more immediate context of 2 Sam 5-8, Fokkelman notes that David is described in 2 Sam 5:25 by means of a "formula of obedience," words, he claims, that are typically used of Moses. ${ }^{909}$ The

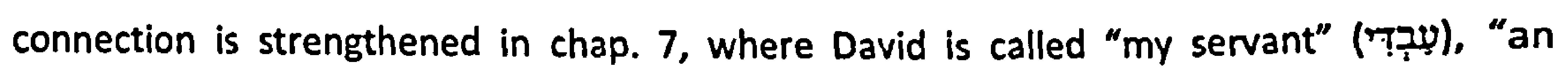
honorary title with which, once again, we are more familiar in reference to Moses (see also Pss $18: 1 ; 19: 12$; section 9.2.3.2.). In this way the reciprocity of the king and his God becomes great and intimate" ${ }^{\prime 910}$ (cf. 7.3.2.2.2.). This, then, is the reason for David's success, as the constant emphasis on the agency of God throughout David's endeavours indicates. $^{911}$

The emphasis on the true agency of Yhwh behind and in David's accomplishments also accords with the actualization of stanza II by stanza III: Israel/David desire entry to the place of blessing; however it is that they/he will ascend the mountain, it is Yhwh of Hosts who will get them there. This may also explain the preference for the special title יהוה in both of our texts. In Ps 24:10b it climaxes the psalm (7.3.2.3.2.); in 2 Sam 5-8 it is a "characteristic title of this Act." ${ }^{912}$ The name is particularly emphasized in 6:2. ${ }^{913}$ Campbell claims that such a precise naming of the Ark is unique in the Bible, ${ }^{914}$ whereas Fokkelman claims that "so much emphasis is rarely to be found during narration." 915

Another point of connection is the parallel entry of the Lord and his people into his chosen place (stanzas II and III). This is particularly seen in chapter six, in which the Ark at

${ }^{907} \mathrm{Cf}$. Klement's structural hypothesis regarding the relation between 2 Sam 6 and 2 Sam 22 (II Samuel, 83); cf. fn. 897. Childs provides a further link back to the Song of Hannah in 1 Sam 2 when he claims that the messianic promise found there is confirmed in 2 Sam 7 (which is integrally connected to chap. 6) and reiterated in 2 Sam 22 (Introduction, 276).

${ }^{908}$ Carlson, David; discussed in Childs, Introduction, 275-277.

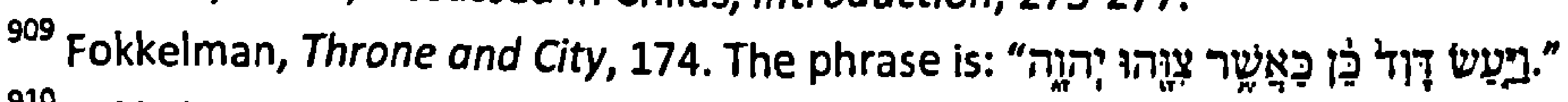

${ }^{910}$ Fokkelman, Throne and City, 175.

${ }^{911}$ Fokkelman provides 6 examples of this in Throne and City, 153. See 2 Sam 5:10b, 12, 19, 23$24 ; 6: 4-6 ; 7: 4-16 ; 8: 6,14$.

912 Fokkelman, Throne and City, 164.

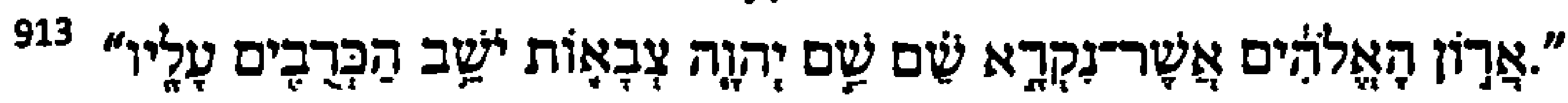

914 Campbell, 2 Samuel, 65.

${ }^{915}$ Fokkelman, Throne and City, 180. 
the centre of the liturgical process is referred to as Yhwh himself (2 Sam 6:4-5). Indeed, just as in stanza III, Yhwh is ascending Zion as a warrior. Furthermore, there is also the same ambiguity we found in stanza III concerning the identity of the object of Yhwh's "militant" aggression. There we asked whether Yhwh was entering Zion having slain the enemies of Israel or unrighteous within Israel (cf. 7.3.2.3. 7.3.2.4.3.2.1.). In 2 Sam 5, the enemy is clearly identified with the Philistines. Yet, as the incident with Uzzah demonstrates (6:7-10), this does not mean that Yhwh cannot break out against his own people if he feels fit (The juxtaposition appears intentional; note the use of the root פרץ in $6: 8$ in relation to an Israelite and in 5:20 in relation to the Philistines). ${ }^{916}$ Interestingly, the death of an Israelite causes David to pose a similar question to the one posed in Ps 24:3: "How can the ark of the LORD come into my care?"917 (cf. the similar question in 1 Sam 6:20 following the Ark's slaughter of 70 Israelites). ${ }^{918}$ God's "attack" upon an Israelite underscores both his holiness as well as his freedom from human manipulation. Nevertheless, when his conditions are met, blessing for Israel is the purpose of God's entry (Ps 24:5). This is experienced in the house of the foreigner Obed-Edom (v. 10) and it is the conclusion of the ceremonies upon Zion itself (v. 18; though note the curse of Michal, v. 23).

It might be expected that the element of the Lord's entry and then re-entry is not to be found in the books of Samuel, but I believe it is implicitly present in various ways and at different levels. The reason for Yhwh's abandonment of his temple in Ezekiel and Isaiah is the sin of his people and thus his need to re-establish his presence on his own terms. This has already been seen in the shocking interruption of the joyful ceremonies in chap. 6 as David danced before the Lord on his way into Jerusalem. Not only has an apparently inappropriate act caused a break in the proceedings, the place where the Ark was hastily deposited was the home of an uncircumcised Philistine, a representative of the nation just defeated in chap. $5 . .^{919}$ Is it too much of an interpretive stretch to suggest that this

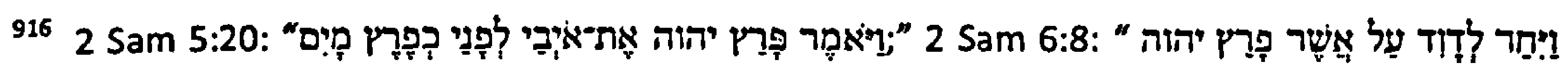

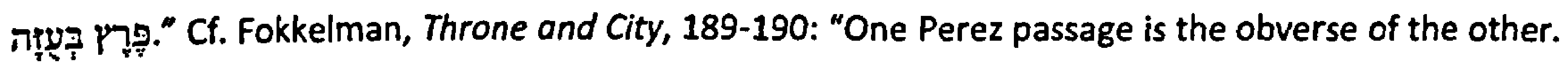
The dialectic between the two creates space for a better awareness of Yahweh's freedom which passes human understanding."

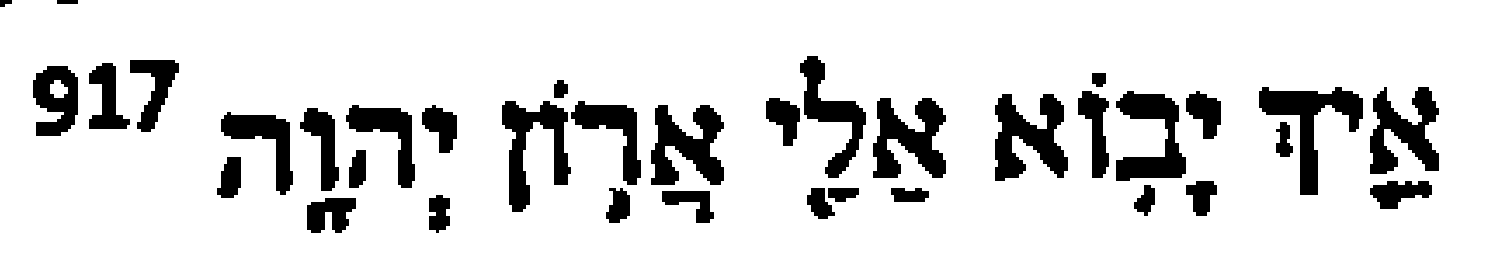

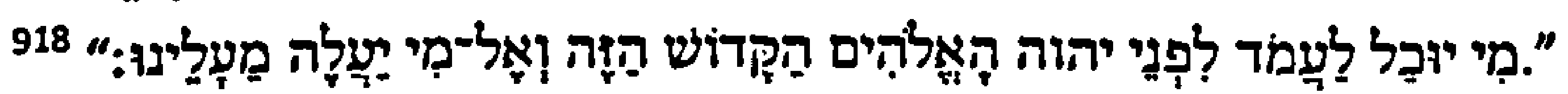

${ }^{919}$ Campbell (2 Samuel, 66) and Fokkelman (Throne and City, 192) consider Obed-Edom to be a Philistine. Anderson notes that he could be seen as a Philistine, but is inclined to see him as a Israelite, noting that in Chronicles he is interpreted to be a Levite (2 Samuel, 104-105; this inevitably explains Keil's opting for this interpretation in Commentary:2, 592). Fokkelman notes the irony that 
embodies the principle of divine "exile," whereby Yhwh chooses to go to the "other side" until such time as he sees fit to return? The connection is subtle, but the pattern appears at other levels of the narrative. Anderson sees a mirror parallel between the opening and the closing of the so-called "Ark Narratives" which reflects this same pattern:

The present setting of 2 Sam 6 is very apposite; as the first part of the Ark Narrative began with two defeats of Israel by the Philistines and the loss of the ark [to the Philistines-P.S.] (1 Sam 4:1b-11), so the second part of the Narrative is preceded by two humiliating defeats of the Philistines by David and the loss of their gods ( 2 Sam 5:17-25). The old era had ended with the departure of the glory of Israel (1 Sam 4:21-22) and the new era has dawned with the return of Yahweh's favor and blessing. ${ }^{920}$

The cause of the departure of the glory of God to the Philistines (note the name "Ichabod" in 1 Sam 4:21; cf. "King of Glory," Ps 24:7, 9) was the presumptuousness of Israel. It was God himself who orchestrated his return. And yet the return to Kiriath-jearim was only a foretaste of a greater return, pending the arrival of the right person (cf. Ps 24:3) to bring it to the place it should be (cf. ip in in 2 Sam 6:17). In this light, 2 Sam 6 does not just consummate Deut 12, it consummates 1 Sam 4 by raising the hope that "the ark will at long last return to the mainstream of Israel's life, now in Jerusalem." exile" of the Ark is being ended within chap. 6, it is recapitulated in miniature in the Uzzah/Obed-Edom events.

The cycle repeats itself, however, after chap. 6. As we have seen, after 2 Sam 11 David's ascendency takes a sharp plunge, as his sin with Bathsheba and laxity concerning the behaviour of his sons gradually brings chaos to the nation. ${ }^{922}$ The "exile" that now takes place is David's, as he flees before his son Absalom back into the wilderness. This time, the Ark stays in Jerusalem as David hopes that his cause will be pleasing enough to God that he might one day be able to re-ascend the mountain of the Lord ( 2 Sam 15:24-25). By implication, a city and an Ark without its true human counterpart is incomplete in the eyes of God (The same implication drawn in Ps 24; cf. 7.3.2.4.3.2.1.).

Obed-Edom may well have come from the city of which David was a pseudo-vassal some ten years previously (Throne and City, 192).

${ }^{920}$ Anderson, 2 Samuel, 100.

${ }^{921}$ Campbell, 2 Samuel, 69.

${ }^{922}$ Von Rad understands this part of David's history to be the "expiation of dire guilt" (Essays, 196). 
The "anti-climax," as Fokkelman puts it, after 2 Sam 11 fits into a broader pattern that stretches throughout the Deuteronomic History and into the Psalms and Chronicles. Von Rad has sketched this pattern in his article, "A Rest for the People of God. "923 He notes that on the one hand the notion of "rest" for the people of Israel (מָin) is central for Biblical faith and is found in "various books of the Old Testament, compiled at different periods." "924 Yet in the Biblical portrayal of this rest there is "uncertainty concerning the time at which 'rest' began.."925 Thus, on the one hand, the rest was actually granted to Joshua (Josh 21:43$45),{ }^{926}$ and then to David (2 Sam 7:1, 11). After David's period of "curse" von Rad argues that Solomon's period came the closest to achieving this goal (1 Kgs 8:56). According to the books of Chronicles "rest from all enemies round about" becomes "a gift which God grants from time to time to pious kings. ... Between whiles, however, the book tells once more of bloodshed and strife and apostasy from Yahweh." ${ }^{927}$ We thus see that Israel's history consists in a cycle of redemption and warfare. Israel does enter the fullness of the promised land, again and again, but because they continually forget Yhwh the promises are never completely fulfilled. ${ }^{928}$ The hope of a fulfilment of this rest, one in which Israel wholly enters into the "rest" of its God (2 Chron 6:4; Pss 132:8; 95:11) remains open within the Old Testament, pushed into an eschatological future (cf. Heb 3:7-11)..$^{929}$ of significance here is not how this cycle will be one day resolved, but the fact of the cycle itself, and David's role within it. ${ }^{930}$

${ }^{923}$ Von Rad, Essays, 94-102.

${ }^{924}$ Von Rad, Essays, 94. The term "rest" "is not peace of mind, but the altogether tangible peace granted to a nation plagued by enemies and weary of wandering. It is also a direct gift from the hand of God" (95).

${ }_{925}$ Von Rad Essays, 97.

${ }^{926}$ Childs makes a similar statement concerning the Judges: "Each judge brought Israel just for a moment into her 'rest', almost as an eschatological participation of God's rule which was immediately forfeited" (Old Testament, 113).

${ }_{927}$ Von Rad, Essays, 97. He references 1 Chron 22:9; 2 Chron 15:15; 22:30.

928 Von Rad, Essays, 95.

929 Von Rad, Essays, 99-100.

${ }_{930} \mathrm{McConville}$ makes the interesting observation that Deuteronomy intentionally does not name the place that God will choose in order to forestall too readily identifying the place or moment of its realization: "the 'place the LORD will chose' brings for ever into Israel's life the principle that the covenant must always be renewed in a life of decision that finds itself constantly at Horeb, being called into covenant in an open history consisting of many times and (perhaps) many places. There is power in this concept for the prophetic critique of all institutionalism that has lost sight of its foundational purpose" (Deuteronomy, 233). 


\subsubsection{David as a Vehicle of God's Redemption of Israel}

We have established that the canonical David was a free agent who submitted to Yhwh's will and thereby benefited from Yhwh's support in the various wars that he fought. We have also seen that at work within this history is the cosmic history of Yhwh's own agenda, one which he is implementing through David. This divine history shares the same shape as the one constructed in the twenty fourth Psalm: Yhwh realizes his creation intentions by entering created time and space in order to take up his dwelling amongst his people Israel on mount Zion in order to be among them and bless them (cf. 1 Chron 23:25). ${ }^{931}$ The road to fulfilment involves conflict, one major element of which is the conflict between Yhwh and his own people as a result of their rebellion to his will. To the degree that Yhwh finds his righteous "Israel/Jacob," to that degree he comes closer to finally realizing his purpose in creation. The books of Samuel indicate that in David, Yhwh almost found his "Jacob" (before David's "fall" in chaps. 11 and following), and so he almost consummated his will in Zion in 2 Sam 6. Despite David's sin however, the promise of a dynasty remains (2 Sam 7:14-15). Indeed, for the rest of the Deuteronomic history David becomes the ideal standard against which all other kings are to be measured. This idealized David is the partner that Yhwh seeks, both in the behaviour of Israel's king and its people. ${ }^{932} \mathrm{He}$ also becomes the standard for the messianic hope. ${ }^{933}$

The significance of David for the hope of Israel as a nation is a final component of Samuel's portrayal of his identity that is of significance for our interpretation of the superscription of Psalm 24. The covenant between Yhwh and David is not only for David and his offspring, it is designed to benefit Israel. In other words, David does what he doesand Yhwh through him-for the sake of Israel. Commenting on 2 Sam 7:12, ${ }^{934}$ Fokkelman says:

[T] The throne of David is a phenomenon in the service of a much greater project: this history of God and his people. And the divine election of David, glorious though it is, is only a means used to benefit the covenant between

${ }^{931}$ The Chronicler makes this conjunction even clearer by putting the following statement on David's lips: "David said, 'Yhwh the God of Israel has given peace to his people and he dwells now in

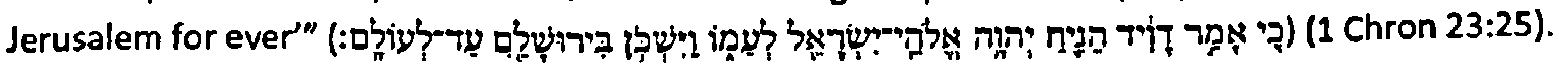

${ }^{932}$ The idealization already starts in 2 Sam 22 and 23; cf. Kleer, Sänger, 11-76.

${ }^{933}$ For a brief overview of the Old Testament theology of (Davidic) kingship, see Childs, Old Testament, 115-120.

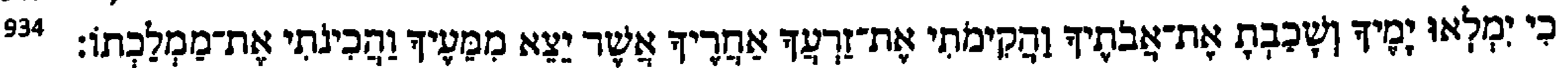


Yahweh and Israel. David recognises this himself at this point. ${ }^{935}$

However we are to understand the precise nature of the relation, David is the means by which Israel achieves its rest. ${ }^{936}$ David is the vehicle by which the nation enters into the very rest of God himself ( 2 Chron 6:4; Pss 95:11; 132:8). Is it possible to express this in terms of Psalm 24 by saying that David is the vehicle by which God gets his Jacob on Zion? We are getting ahead of ourselves, for answering this question requires looking more closely at the identity of David in the immediate literary context of Psalm 24. We will turn to this next (9.2.), after briefly summarizing what has been learnt so far.

\subsubsection{Summary: David in the Context of Psalm 24}

Campbell defines the genre of 2 Sam 6 as "theological narrative." ${ }^{937}$ In other words, its "function is to grapple with theological problems and assertions through the medium of narrative. ${ }^{\prime 938} \mathrm{He}$ points out that this is not to disparage the broad historicity of the events thereby described, but the final form does reconfigure them within a different level of discourse. ${ }^{939}$ We have identified a similar function for the final form of Psalm 24: One time liturgy has now been reconfigured according to a theological construal of the basic shape of Yhwh's ways in the world, both at its beginning (protology) and at its end (eschatology). We now see that according to the books of Samuel this same pattern is played out within history, in the time between the beginning and the end. The impression is created that Psalm 24 offers us a pattern of temporal movement that can be found in all temporal moments. There is thus significant truth in Goldingay's listing of multiple possible contexts in which to situate the scene at the gates in stanza III (David's capture of Jerusalem; the transfer of the Ark to Jerusalem; a re-enactment of this transfer at Sukkot; the return of Yhwh from a general battle; the return of Yhwh from exile). ${ }^{940}$ Psalm 24 does not wish to be

935 Fokkelman, Throne and City, 166. See also his comments on chap. 7 on p. 219. Cf. Campbell, 2 Samuel, 64: "In the text, David plays a subordinate role to YHWH; he is God's instrument in the coming of the ark to Jerusalem, inaugurating a new epoch in Israel."

${ }^{936}$ For a similar relation between Moses, God, and Israel, see Gary Anderson, "Gethsemane."

${ }^{937}$ Campbell, 2 Samuel, 66.

${ }^{938}$ Campbell, 2 Samuel, 231.

939 E.g. Campbell, 2 Samuel, 64: "Event and text should not be confused. In the event, for most interpreters, David in a brilliant move consolidated his position by bringing the ark to Jerusalem. In the text, David plays a subordinate role to YHWH; he is God's instrument in the coming of the ark to Jerusalem, inaugurating a new epoch in Israel." Klement's discussion of chiasm and aspect provides an additional cognitive-perceptual dimension to the structuring of history in Samuel (II Samuel, 8698).

${ }^{940}$ Goldingay, Psalms:1, 162. 
anchored to any one moment in Israel's history, ${ }^{941}$ it is a construal of the theological structure of all of Israel's history.

We may thus conclude that Psalm 24 represents David's own "historical-eschatologicalcosmic context," the ultimate "historical" framework within which he has his being (cf. 9.1.2.). The function of the superscription לִ in Ps 24:1a, then, is to make the canonical David a constitutive element within this divine history. One could try to go beyond this and provide an more concrete theory of "Davidic composition." For example, one could image that David composed the psalm for some occasion, perhaps he was reflecting theologically upon his role within the broader scheme of things. ${ }^{942}$ The editors of Psalm 24, however, do not appear to be interested in this level of association, and given the complexity of the superscription לדוT outlined above (9.1.1.) we should not try to push this question too far. Other clues have been left, however, by which the editors of the Psalter have sought to "Davidize" Ps 24. Recent research has suggested that the sequential ordering of the Psalms in the final form of the Psalter follow a particular theological logic and that the figure of David is key to this. We will therefore now turn to the sub-collection of Psalms for which Ps 24 functions as the concluding frame, Pss 15-24, in order to uncover the particular manner in which the canonical tradition confessed David to be present within Psalm 24.

\subsection{The Sub-Collection of Psalms 15-24}

The nature and function of the editorial shaping of the Psalter has been much discussed in recent years, with the result that traditional "Psalmenexegese" is being

${ }^{941}$ Cf. Futato, Psalms, 122. Futato, however, draws the wrong conclusion. Having affirmed the importance of historical context for interpretation according to the canonical intentionality of the superscriptions, he claims that due to the ambivalence by which the psalms can be located, historical context cannot, in fact, "play much of a role in the interpretive process other than illustrating in a general way the kind of situation in which a given psalm rose. .. the historical information in the titles gives the impression that the psalms are time-bound, while the psalms themselves seem rather timeless" (122). My argument here is that none of the psalms are "timeless," they all participate in the special time of the divine economy. This will become clearer in what follows below.

${ }^{942}$ E.g. Kohlbrügge, Auslegungen, 200 , who imagines David sitting in his palace reflecting on the significance of the temple within the divine economy. Interestingly, even within this conservative historical framework, Kohlbrügge claims that the substance of David's reflections go beyond his immediate context. Thus, in relation to w. 3-6, Kohlbrügge asks, "Hat David den sichtaberen Berg Zion gemeint, den Er von seinem Palaste aus erblickte, oder die sichtbare Wohnung, worin die hölzerne Bundeslade war, gleichsam als ein greifbares Unterpfand der Gegenwart Gottes? Ich antworte: "Ja", sofern es Schatten zukünftiger Dinge waren; ich antworte "Nein", sofern Er wußte, daß diese sichtabren Dinge aufhören würden" (200). 
progressively supplemented by "Psalterexegese." ${ }^{943}$ Evidence for such compositional activity is as follows: semantic, compositional, and generic connections between strings of psalms (iuxtapositio; concatenatio) (e.g. Pss 3-14; 20 and 21;90-92; 111 and 112; 105 and 106); psalms with obvious framing functions (Pss 1 and 2; 146-150; position of the royal psalms); grouping by means of superscriptions (e.g. Pss 42-49; 73-83; 84-85; 87 and 88 ); the "Davidization" (Davidisierung) of the Psalter (Davidic ascriptions; biographical contextualization; Ps 151 in the LXX and 11QPs; ${ }^{a}$ cf. 9.1.1. 9.2.2.); the Elohistic Psalter; the division of the Psalter into five books. ${ }^{944}$ Interpreting the extent, function, and thus meaning of this editorial activity, however, has proven to be far more complex, as has been illustrated in a helpful exchange between Matthias Millard and Hossfeld and Zenger in the journal Biblical Interpretation. ${ }^{945}$ Given the lack of consensus concerning the "message" of the Psalter as a whole ${ }^{946}$ (if indeed there is a single message), ${ }^{947}$ it seems most advisable for now to focus on smaller units within the Psalter rather than attempt to interpret each psalm within the context of the whole. Much is disputed, even at lower levels, but a number of articles have been produced that make strong claim for Psalms 15-24 being a chiastically ordered sub-collection. This was first argued by the French structuralist Pierre Auffret; the theory was then developed along redactional lines by Hossfeld and Zenger; recently, the final form has been interpreted theologically by Miller and then Brown. ${ }^{948}$ Hossfeld and Zenger argue that this sub-collection is one of four that structures the first book of the Psalter: $3-14 ; 15-24 ; 25-34 ; 35-41.949$ Evidence for this is the pattern of "corner psalms" (Eckpsalmen) that are related to each other (e.g. the "entrance liturgies"

${ }^{943}$ The terms are Zenger's, in "Psalmen," 312. See also the introduction to the commentary by Hossfeld and Zenger in Psalmen:I. Childs' chapter on the Psalter in his Introduction was the major impetus for this line of research. For an overview of recent theories, see also Wenham, "Psalms."

${ }_{944}$ Taken from Zenger, "Psalmen," 311-316.

${ }^{945}$ These two scholars critically evaluate their respective approaches to the final form of the Psalter (generic-compositional or redactional), highlighting the complexity of the issue along the way. See Millard, "Anmerkungen," "Repons;" Hossfeld/Zenger, "Antworten." Rendtorff mediated with a series of questions in "Fragen." Barbiero attempts to provide another approach to the first book of the Psalter: pure synchrony (Erste Psalmbuch).

${ }^{946}$ See Murphy, "Psalter."

${ }^{947}$ In contrast to some approaches, Childs' was very reserved concerning the unity of the book. He concludes: "Above all, one senses the variety within the canonical process. Although the psalms were often greatly refashioned for use by the later community, no one doctrinaire theology was allowed to dominate" (Introduction, 522).

${ }_{948}$ Auffret, Sagesse, 407-438; Hossfeld/Zenger, "Berg JHWH's;" Miller, "Psalms 15-24;" William Brown, "Psalms 15-24." All this in sharp contrast to Gunkel/Begrich, who saw "keine innere Beziehung" between Pss 15-20; 22-24 (Einleitung, 3)!

${ }_{949}$ Hossfeld/Zenger, Psalmen:I, 12. Barbiero argues that the first book of the Psalter has an independent profile within the context of the whole (Erste Buch, 719). 
of Pss 15 and 24) and the presence of central psalms that are distinct from the surrounding collection in terms of form and content (Pss 8; 19; $29 ; 38) .{ }^{950}$ We will therefore focus our. attention on the function of Psalm 24 in this sub-collection, drawing upon all that we have learned so far about Biblical poetics and genre (7.1.), the message of Psalm 24 (7.2. - 7.4.), and the identity of the canonical David (as found in Samuel; 9.1.).

\title{
9.2.1. The Structure of Psalms 15-24
}

Defenders of the editorial unity of Pss 15-24 claim that it has a chiastic structure, ordered according to the genres of the psalms. Brown presents the structure as follows: ${ }^{951}$

A Ps 15 (entrance liturgy)

B Ps 16 (song of trust)

C Ps 17 (prayer for help)

\author{
D Ps 18 (royal psalm) \\ X Ps 19 (creation/torah psalm) \\ D' Pss 20-21 (royal psalms) \\ C' Ps 22 (prayer for help)
}

$B^{\prime} \quad$ Ps 23 (song of trust)

$A^{\prime} \quad$ Ps 24 (entrance liturgy).

\subsubsection{Chiasm and Aspect}

Before looking into the meaning of this arrangement, it is necessary to take into account the function of chiasms in the ancient world. Herbert Klement's brief summary of this issue points out the proximity of this literary device to parallelism (discussed above: 7.1.2.) and highlights its cognitive dimensions. ${ }^{952}$ Klement claims that "the widespread use of chiasm in antiquity is to be seen as an indicator of varying conceptions of the discursive ideal." 953 Similar to our treatment of parallelism above (7.1.2.), there can be both a symmetrical and linear dimension to chiasm. On the one hand, the symmetrical

${ }^{950}$ Hossfeld/Zenger, Psalmen:I, 12-13. They admit that the structuring is clearer for the two central subunits $(15-24 ; 25-34)$ than it is for the framing subunit.s

951 Brown, "Psalms 15-24," 260.

952 Klement, "Chiasmus and Aspektive," in /I Samuel, 86-98.

${ }^{953}$ Klement, // Samuel, 89, drawing on Welch, "Introduction," in Chiasmus. 
juxtaposition of the parts can function to "compare, contrast, juxtapose, complement, or complete" each other. ${ }^{954}$ On the other hand, "a marked degree of intensification can be introduced through the system both by building to a climax at the centre as well as by strengthening each element individually upon its chiastic repetition." 955 Klement contextualizes these insights with reference to Brunner-Traut's work on ancient cognizance. Accordingly, chiasm feels so foreign to a modern Western readership because we have been trained to think in terms of perspective: all the parts of a phenomenon-temporal or spatial-are linked to one another and viewed from a single standpoint. If one part is moved, this affects all the others. The ancient world, however, tended to think in terms of aspect, which attempts to view a single object from multiple perspectives simultaneously. ${ }^{956}$ The Biblical writers, then, were interested in a

gradual comprehension, a succession of perceptions in contrast to an overall view. Aspectival perception brings the manifestations into a bilateral relationship. By this an overview is given of a subject in which its individual parts are grasped and combined into a cumulative structure of these same individual parts. ${ }^{957}$

Finally, Klement notes what one could call the theological benefits of such a mode of perception: "Such an aspectival view can show greater congruity with actuality, because in this way objects and people are depicted in a way which is more in accordance with their being than would be possible with a mere spatial portrayal of their visible surface." 958

The implications for our interpretation of this sub-collection of psalms are thus similar to the principles by which I related the stanzas within Psalm 24. On the one hand, we need to be sensitive to the "typicality" of the images created: Rather than being contiguous in time we can see them as various portrayals of a single reality, juxtaposed with the intent of more fully grasping its "being." On the other hand, we need to be open to a sense of forward movement, not so much by means of sequential development in time as by an

954 Freedman, "Preface" to Welch, Chiasmus, 10; cited in Klement, II Samuel, 87.

${ }_{955}$ Freedman, "Preface" to Welch, Chiasmus, 10; cited in Klement, /I Samuel, 87.

956 See also Keel, Bildsymbolik.

957 Klement, II Samuel, 89-90. Given the connections I am seeking to make between the canonical shape of Samuel and the Psalter, it is interesting that Klement treats this subject in the context of the structure of the books of Samuel.

${ }_{958}$ Klement, II Samuel, 91 (emphasis mine). He also points out that aspectival perception is "more strongly attached to the typical than the concrete." 
intensification of the subject matter. ${ }^{959}$ In light of my analysis of Psalm 24 so far, I will propose that the subject matter that is being explored in the final form of Psalms 15-24 with an aim to fully grasping the fullness of its being is the divine economy of salvation as this incorporates human history, embodied in the figure of David. I will now ground this claim exegetically.

\subsubsection{The Dialectic of Divine and Human History}

\subsubsection{The Outer Frame}

According to the logic of a chiasm, the centrepiece is highlighted in some manner. The same applies to the outer frames in those chiasms in which there is a sense of forward movement. In the case of Pss 15-24, all of the aforementioned interpreters ascribe hermeneutical significance to both the framing psalms (Pss 15 and 24) as well as the central psalm of this collection: Ps $19 .{ }^{960}$ These structurally significant psalms contrast with the remaining psalms within the collection by their theologically reflective character. Whereas the majority of the psalms in the Psalter, especially in the first book, are far more "existential" in their struggle with God and human kind, Psalms 15, 19, and 24 appear to transcend the fray and reflect upon the basic issues of israelite faith. ${ }^{961}$ Psalms 15 and 24 are not concerned to claim righteousness for any particular individual or community but to reflect theoretically upon its nature. Ps 19 has a "very objective, distant, and meditative" quality about it. 962

In terms of the content of these framing psalms, Miller points out their common interest in torah. Its saliency within the framing psalms makes it the "alpha and omega" of the entire collection, an observation confirmed when one notes that the intervening psalms are overwhelmingly concerned with the actual righteousness of a particular

${ }^{959}$ None of the interpretations of Pss 15-24 emphasize this dimension of the collection enough. This can be seen, above all, in Hossfeld and Zenger's characterization of the chiasm as a "palindrome" ("Berg JHWHs," 169). This is despite the fact that all recognize-albeit without making this fact programmatic for their interpretation-that Ps 24 somehow "climaxes" the collection (e.g. Miller, "Psalms 15-24," 139). Brown can open his exposition with the statement that, "As a whole, the collection began with seeking entrance to YHWH's holy hill and concludes, climactically, with YHWH's presence on the hill" ("Psalms 15-24," 265), yet his interpretation is entirely symmetric, working from the inside (Ps 19) outwards. His individual treatment of the parallels does, however, pick up on consistent elements of intensification in the linear arrangement of the psalms.

${ }_{960}$ Auffret, Sagesse, 407-438; Hossfeld/Zenger, "Berg JHWHs;" Miller, "Psalms 15-24;" William Brown, "Psalms 15-24."

961 It is thus inaccurate for DeClassé-Walford to characterize Pss 19 and 24 as "praise" ("Intertextual Reading," 146. They are far more "objective" than that, as Gerstenberger and Goldingay point out in their commentaries on Ps 19.

${ }^{962}$ Gerstenberger, Psalms:1, 101. 
individual. ${ }^{963}$ Miller concludes that Psalms $15-24$ is "a collection of psalms or prayers centring around the love and obedience of torah and the king as the embodiment of that way or that ideal"964 (see 9.2.3.2.2.). Yet Miller's hypothesis does not take every dimension of the framing psalms into account. In addition to the law we also find the theme of creation in Pss 19 and 24. Furthermore, there is a linear theological development between the psalms, starting in Ps 15 and climaxing in Ps 24. We will start with the latter point, which is inspired by a structural observation made by Auffret.

\subsection{Climax}

Auffret has rightly pointed out the parallel structure between Pss 19 and 24, whereby Ps 24:1-2 parallels Ps 19:1-7, with its focus on creation, and Psalm 24:3-6 parallels Ps 19:811, with its focus on the law. He also sees a further parallel between Ps 24:7-10 and the concluding verses of Ps 19, w. 11-13. ${ }^{965}$ I believe, however, that a different and more helpful pattern emerges if we include the final section of Ps 19 under the rubric of law and then read all three framing psalms in relation to each other in linear sequence. If we do so, the following pattern emerges:

Ps 15 (entrance torah) $\rightarrow$ Ps 19 (creation/torah) $\rightarrow$ Ps 24 (creation/entrance torah/arrival).

As form critics have long recognized, the structure of question-answer-promise that comprises the entirety of Ps 15 is found in miniature form in the middle of Ps 24 . Their common concern is not torah in and of itself, ${ }^{966}$ but that to which obedience to torah can guarantee access, namely blessedness, i.e. the reality to be found behind the gates of the temple (cf. 8.2.). In other words, the issue of obedience is framed in terms of the fruit that it may bear, which itself is portrayed in terms of a journey of ascent. Goldingay makes the following insightful comment in relation to Ps 19 " $B$ " (W. 8-11): "[P]eople [are not] expected to be attached to Yhwh's expectations for selfless reasons, as if obedience were its own reward. ${ }^{\prime 967}$ This is an important corrective to Brown's interpretation that in Ps 19 it

\footnotetext{
963 Miller, "Psalms 15-24," 128. The editor took his cue from Psalm 1.

964 Miller, "Psalms 15-24," 130.

965 Auffret, Sagesse, 437: "On pourrait donc écrire ... : 24, 1-2 (I) et 19A (I'), 19B (II) et 24, 3-6 (II'), 24, 8-10 (III) et la majeure partie du second volet (III'), ce qui donne cette fois dans leur ordre d'apparition : I'.II (19).III' (second volet).I.II'.III (24)."

${ }_{966}$ Pace Brown, "Psalms 15-24."

${ }^{967}$ Goldingay, Psalms:1, 293.
} 
is the torah itself that is the "ultimate object of desire. ${ }^{\text {"968 }}$ Brown then effectively decides to establish Ps 19-by virtue of its central position-as a kind of "canon within the canon" (not his phrase) by allowing it to critique the surrounding psalms. Thus, by means of a metaphorical "transference of meaning," the temple is replaced by torah and military conquest by obedience ( $c$. a similar move made by Podella in 8.2. .) ${ }^{969}$ If, however, we see that torah is a means to something else, i.e. life, then we see that torah is subordinated to the reality to which it provides access, a reality presented as being beyond the gates of a temple towards which one must journey. In a sense, the Psalter is presenting torah as the "vehicle" that gets one up the mountain and into the sanctuary. In this perspective, Ps 24 consummates Ps 19, as passing the test of entry (torah obedience) brings one to that which torah promises. ${ }^{970}$

\subsection{Creation}

The theology of creation is most clearly developed at the centre of this composition in Ps 19. In terms of the climactic development outlined above (9.2.3.1.1.), this makes perfect sense. I have already argued that that which is found on the other side of the gates of the sanctuary (Pss 15 and 24) is the perfection of creation (e.g. 7.3.2.4.3.2.1. 8.2.). As such, Ps 19 relates to Pss 15 and 24 in the same way in which stanza I in Ps 24 relates to stanzas II and III: It sets these institutions in their proper context. Yet PS 19 itself does not mention the temple; instead it correlates creation with torah and the fruit of obedience to it (cf. Ps 1). Hossfeld argues that the effect of the juxtaposition of these two entities within the psalm is that the temporal order found in creation (w. 2-7) is seen to be of the same substance as the order generated by the torah within society (w. 8-15). ${ }^{971}$ In other words, that which creation does for the temple in Ps 24 is here achieved for the torah: The Lord's

${ }_{968}^{968}$ Brown, “Psalms 15-24," 273.

${ }^{969}$ Brown, "Psalms 15-24," 270: "As the ultimate object of desire, torah provides the celestial portal that replaces the earthly temple and the personal piety that displaces royal victory."

${ }^{970}$ Brown does note this dimension of the collection: "As a hole, the collection began with seeking entrance to YHWH's holy and concludes, climactically, with YHWH's presence on the hill" ("Psalms 15-24," 264). This should be qualified by the statement that the collection is climaxed with Yhwh's entering of the hill and not his mere presence upon it.

${ }^{971}$ Hossfeld, in Hossfeld/Zenger, Psalmen:I, 134: "Insgesamt bietet der Grundpsalm $19^{2-11}$ eine weisheitliche Zusammenschau von Schöpfung und Willensoffenbarung JHWHs. Die seit Schöpfungsbeginn sich im stetigen Lauf der Gestirne (Sonne) manifestierende Ordnung der Zeiten setzt sich fort in der das menschliche Leben fördernden Tora." He considers Ps 19 to be a Vorläufer of Sirach 24. 
revealed will is set within a cosmic context and thus the fullest theological horizon for the significance of obedience to it. $^{972}$

We can thus interpret the development between Pss 15-19-24 as a process whereby the question posed in Ps 15:1 is gradually embedded within its fullest theological context. First (Ps 15), the question itself is posed: Who may have access to the fullness of life (cf. v. 5c)? The answer is obedience to God by facilitating social justice (cf. Clements' interpretation in 7.4.3.). Second (Ps 19), this act of obedience is seen as being a part of the total order of creation itself, investing obedience with a cosmic significance. Finally, having established the cosmic dimension of obedience to God's will, Ps 24 adds a new element: It is God himself who brings the torah obedient to their full destiny, new creation behind the doors of the temple (the pattern being as follows: $B / A \cdot B^{\prime} . / A^{\prime} . B^{\prime \prime} . C$ ). The third stanza of Ps 24 is thus the consummation of both the human question posed in Ps 15:3 ("who may ascend") and the divine will witnessed to in Ps 19:1-7 ("the heavens declare the glory of God"). $^{973}$

Auffret's parallel between Ps 24's stanza III and Ps 19:12-15 may also be enlightening in this context. ${ }^{974}$ The function of the final section within Ps 19 is to introduce an element of threat to God's gift of the torah. ${ }^{975}$ As Hossfeld puts it, "Ihre Belehrung kann sowohl erleuchten als auch warnen. ${ }^{12 b}$ trögt den Tun-Ergehen-Zusammenhang ein." 976 The weakness of the "servant of the Lord's" capacity to fulfil the law is emphasized in v. 13. Goldingay translates w. 12-13a as follows: "Who can understand wanderings?-free me from secret acts, / yes, withhold your servant from the willful." 977 This verse "begins from a ... general puzzlement at the human inclination to go off the rails. The mystery of human sin is the fact that we all go astray even though we can see that God's expectations make

972 In terms of their theory of the presence of a community of the "poor" in the final redaction of the Psalter, Hossfeld/Zenger state that the "Schicksal des Armen und seiner Gemeinde ist umfangen von der Vollkommenheit der kosmischen Ordnung der Zeiten und der stärkenden Anwesenheit der Tora (Ps 19)" (Hossfeld/Zenger, "Berg JHWHs," 182). See also p. 176: God defends righteousness as "'Sinn' nicht nur seiner Geschichte mit David als König Israels, sondern als 'Sinn' seiner Schöpfung (Ps 24, 1-2) überhaupt."

${ }^{973}$ Brown is thus on the ball when he states that in Ps 24 to ascend is, "in effect, to scale the pinnacle of creation" ("Psalms 15-24," 267). It is a pity that he undoes this insight by deconstructing the significance of the temple for the collection with the observation that the temple gets no mention in Ps 19.

974 Auffret, Sagesse, 437.

975 On the double capacity of the law to give life and bring death in the Old Testament, see Childs on Law and Gospel in Biblical Theology, 533-536. Cf. Ezek 20:25-26.

${ }^{976} \mathrm{Cf}$. Hossfeld in Hossfeld/Zenger, Psalmen:I, 134. Pace Brown.

977 Goldingay, Psalms:1, 194. 
sense, in the way w. 7-11 have described."978 This is to bring up the same ambiguity identified in stanza III and 2 Sam 5-6 concerning the identity of God's ultimate enemy, as well as the measures he must take to implement his will. ${ }^{979}$ The concluding stanza of PS 24 and thus of this sub-collection does not clearly answer this question, being merely juxtaposed to stanza II as it is. It does promise the reader, however, that Yhwh's plans for. the cosmos will be consummated, and demands that the means of our participation in that consummation is the path of obedience to his righteous will. The question, even at this level of canonical editing, is still whether we will be part of that process or not (cf. 7.4.3.).

In conclusion, then, we can say that the framing psalms of the sub-collection portray, in the form of an inverse funnel, the basic elements of God's ways in the world: the offer of life consequent upon the fulfilment of divine torah (social justice) (B); the continuity of such torah with the structure as well as the purpose of the cosmos, along with the genuine human responsibility for obedience to that torah (A.B') ; finally, all the preceding, along with a vision of Yhwh's bringing such people to the life promised by torah in an act of violent judgement and redemption $\left(A^{\prime} . B^{\prime \prime} . C\right)$. The frame's focus, therefore, is theocentric, for it functions to point the reader towards the divine reality. This interpretation provides a corrective to Hossfeld and Zenger's anthropocentric interpretation of the collection as being a response to the post-exilic community's "tiefe Identitätsängste und -krisen." "98o Although it may well be the case that such an identity crisis was experienced by the postexilic community, it seems inadequate to interpret the function of the collection to be primarily "Identitätsbildung." ${ }^{181}$ Identity is certainly central to this composition (cf. Pss 15:1; $24: 3,6)$, but the witness of the final form of the Psalter is that it is the divine reality that constitutes the context for answering the question of identity and not the other way

${ }_{978}^{9}$ Goldingay, Psalms:1, 194.

979 Goldingay notes that the petition "free me from secret acts" in Ps 19:13 is "asking for strength, not forgiveness" (Psalms:1, 195).

${ }^{980}$ Hossfeld/Zenger, "Berg JHWHs," 167. On the tendentious nature of their theory of a "community of the poor," see Millard, "Anmerkungen," who notes that there is currently no external evidence for such a community (323). Hossfeld and Zenger recognize this problem in their response: "Die fehlende, sozialgeschichtliche Arbeit' für die Perserzeit ist ein schmerzliches Manko; der eben genannte Befund unterschiedlicher Armenperspektiven ist davon unabhängig" ("Antworten," 336). I believe that Hossfeld is currently running a project funded by the Deutsche Forschungsgemeinschaft that seeks, in part, to answer this question.

981 Cf. Hossfeld/Zenger, "Berg JHWHs,"168: "Daß gerade die Teilsammlung Ps 15-24 zur Befragung auf den in den Psalmenredaktionen sich vollziehenden Prozeß kollektiver ldentitätsbildung geeignet ist, zeigt schon die die Gruppe Ps 15-24 eröffnende Doppelfrage in Ps 15,1 an, die in Ps 24,3 erneut aufgegriffen wird, um dann in Ps 24,6 mit einer kollektiven Identitätsaussage resümierend beantwortet $z u$ werden." I reject their interpretation of Jacob in v. 6 as a vocative. For arguments, see 7.3.2.2. 
around. The primary force at work in the composition is the desire to grasp the reality of God and then challenge Israel to be who it should be in light of that reality. The priority of a theocentric focus is strengthened 1) by the fact that the question is posed to Yhwh (Ps 15:1) in the context of a pilgrimage to him and 2) by the way in which the identity of Jacob in Ps 24 is embedded within the reality of the Lord's activity (cf. 7.3.2.4.1.; for a theoretical discussion of theocentrism, see 3.3.1.).982

The question of identity is given a sharper profile in the intervening psalms, to which we now turn.

\subsubsection{The Intervening Psalms}

We have already noted the symmetric mirror pattern of the collection as a whole (9.2.). Similar to the sequence Pss 15-19-24, however, this symmetric pattern is enriched by a linear development, for the second element of each parallel pair "intensifies" the former (cf. 9.2.2.; see also Robert Alter's "rule of thumb" for semantic development in parallelism in 7.1.2.1.). The effect of this compositional move is not to create a narrative sequence, but rather to deepen our grasp of the true subject matter of each of the psalms by progressively embedding them within a broader theological horizon (cf. 9.2.2.). ${ }^{983}$ Having already treated the parallel pair Pss 15/24 above, we turn to the remaining pairs.

\subsection{Parallelismus Psalmorum ${ }^{984}$}

- Psalms 16 and 23: Gerstenberger designates the genre of these two psalms as "Songs of Confidence." The common theme is trust in the Lord and the joy of his presence. The difference between them is that the description of the reality experienced by the sufferer is portrayed in far more metaphorical detail in the second psalm than in the first. Whereas Ps 16 limits its imagery to that of the stationary property of land (a single strophe in w. 5-6), Ps 23 consists almost entirely (three of four strophes) of the complementary metaphors of

${ }^{982}$ Cf. Brown, "Psalms 15-24," 265: "As the whole, the collection began with seeking entrance to YHWH's holy hill and concludes, climactically, with YHWH's presence on the hill. Psalm 24, thus, finishes the collection on both a strongly corporate and theocentric note."

${ }_{983}$ None of the commentators on the collection of Ps 15-24 have picked up on this programmatically, though it does appear occasionally in Brown's interpretation of the individual psalms.

${ }^{984}$ Thanks to Chris Hays for this neologism. 
movement towards a goal: the temple. ${ }^{985}$ Not only is the imagery far richer in Ps 23, it resonates with Israel's core theological tradition of Exodus/New Exodus: "Er ist das Bekenntnis eines 'Frommen', der sich gegenüber seinen Feinden dezidiert als Glied des beim Ersten Exodus geschaffenen und im Zweiten Exodus erneuerten Gottesvolkes behauptet." ${ }^{986}$ In this manner, Ps 23 embeds the nature of the psalmist's hope in a broader salvation-historical horizon and prepares the way for the imagery of arrival in Ps $24 .{ }^{987}$

- Psalms 17 and 22: Gerstenberger defines both of these psalms as "Complaints of the Individual." The difference between them is a matter of poetic intensity and scope of theological vision. Whereas Ps 17 appears to be a fairly typical complaint consisting of invocation, protestation of innocence, petition, complaint, and imprecation, ${ }^{988}$ Ps 22 is a "Mischgebilde heterogener Gattungselemente (Klage, Bitte, Lob, Dank und hymnische Lobwünsche mit Zukunftsansagen)." 989 The complaint in Ps 22 is embedded in a cycle of affirmations of confidence ( $v v$. 4-6; 10-11) and concludes with what Gerstenberger designates an eschatological hymn of praise. ${ }^{990}$ The imagery has "greater poetic intensity [and] ... pathos" - Davis talks of "extravagance" - than Ps $17 .{ }^{991}$ The plight of the petitioner starts "lower"-both he and his persecutors are "dehumanized"992 - and ends "higher": a vision of universal praise, "far exceeding in size and inclusivity any that Israel has ever known." "993

985

Cf. Zenger, in Hossfeld/Zenger, Psalmen:I, 152: "Der Psalm setzt mit dem Bild vom Unterwegssein ein, deutet die Gefahren des Wegs an, stößt zur Ankunft in einem schützenden Haus vor und schließt mit der Betonung vom fortwährenden Bleiben in diesem Haus."

${ }_{986}$ Zenger, in Hossfeld/Zenger, Psalmen:I, 152. See also Wallace, Psalms, 60.

${ }_{987}$ Zenger, in Hossfeld/Zenger, Psalmen:l, 153.

${ }_{988}$ Gerstenberger, Psalms:1, 108.

${ }_{989}$ Hossfeld, in Hossfeld/Zenger, Psalmen:l, 144.

${ }^{990}$ Cf. Davis, "Psalm 22," 96: this is the psalm's "chief formal peculiarity: namely, the fact that nearly a third of the poem stands at the antipodes from lament." See also p. 104: "In joining the protracted cry of agony with an equally extravagant anticipation of joy, this psalm is striking among the laments for its dramatization of the essential connection between Israel's articulation of distress and its recognition of the God who saves."

991 Brown, "Psalms 15-24," 66-67. Davis, "Psalm 22," 97. Hossfeld talks of "extremer Rechts- und Todesnot" (in Hossfeld/Zenger, Psalmen:1, 146).

992 Davis, "Psalm 22," 98: "The psalmist is despised as a worm (v. 7), reduced to bestial roars of pain (v. 2); the enemies who beset him are bulls (v. 13), lions (v. 14), dogs (v. 17), wild oxen (v. 17). The proliferation of animal imagery portrays a total collapse of the psalmist's social world."

993 Davis, "Psalm 22," 101. See p. 96: "the last ten verses of this lament are an extravagant portrayal of the circles of those who offer praise to Israel's God. Those circles radiate outward in both space and time, as the psalmist's own praise extends to encompass the congregation of Israel, the foreign nations, generations yet unborn, even-and most remarkably-the dead." 
This realm for this praise is the kingdom (מלכות) of God. In this way, Ps 22 has brought us one step closer to the inauguration of that kingdom in Ps 24.

- Psalms 18 and 21-22: The common denominator for these two psalms is their focus upon the fate of the king. The difference is that in Ps 18 it is the king himself who speaks, in Pss 20-21 an unidentified group speaks for him. ${ }^{994}$ Both parallel pairs are concerned with the salvation of the king, yet in the second pair the king's salvation does not only serve himself, it serves the community. The existence of a broader community does come into view in Ps 18 (v. 28), but in Pss 20-21 the destinies of the king and the people are "interwoven," the people depend on the king and the king depends on the people. ${ }^{995}$ This explicit interweaving is also to place the destiny of the individual in Ps 18 into a broader theological context, for it affirms that which we saw concerning David in the book of Samuel: The king is ultimately a vehicle for the salvation of the people of God (9.1.3.4.). And, as in Samuel, these two psalms affirm that God is the motor.

We saw in 9.2.3.1. that the outer frame of Pss 15-24 was concerned with key theological issues: the identity of those who may enter "paradise," the function of the law, creation as a horizon for history, and the consummation of history by the advent of the Lord. In the intervening psalms a different tone is sounded. Miller discerns in the oscillation between confidence (Pss 16; 23), petition (Pss 17; 22) and thanksgiving (Pss 18; 20-21) the basic structure of prayer. ${ }^{996}$ The move from frame to content, then, is a move from the "heights" of theological reflection to the "depths" of human struggle in the ambiguities of conflict and persecution. ${ }^{997}$ Similar to the structure of the book of Samuel, the intervening

994 The king may be speaking in Ps 20:7.

995 Goldingay, Psalms:1, 311, 312.

996 Miller, "Psalms 15-24," 133.

${ }^{997}$ Miller pads this out in his exegesis of the thematic and verbal connections between the psalms in the collection and the semantic movement between them. Beat Weber comes to a similar pattern in his theory of a threefold opening to the Psalter in Pss 1-3: "Im Fortlauf des Psalter [sic] erweist sich das Beten als cantus firmus. Das zeigt sich daran, dass das Beten ab Ps 3 sich kontinuierlich fortsetzt. Zwischendurch wird dieses aber immer wieder für Momente stillgestellt und mit königs- und weisheitstheologischen Momenten reflexiv vertieft. Dafür verwendet die Psalterredaktion die Technik der Einfächerung von Königs- und Weisheitspsalmen (meist an strategischen Stellen)" ("Buchouvertüre," 842-843). Interestingly, Goldingay also sees a similar function in Isa 33, a text which takes up the same entrance liturgy that lies behind Pss 15 and 24, within the composition Isa 1-33. These two framing texts have a generalized reference, in contrast to the intervening historically oriented oracles. He concludes: "Setting chapters 1 and 33 around 
psalms represent lived history within the framework of God's basic plan (cf. 9.1.3.). Yet our treatment of the parallelismus psalmorum has shown that even these more "existential" psalms participate in a forward movement in which the expressions of hope, plea, and thanksgiving receive a progressively more profound theological grounding. The figure of these psalms is like the figure found in the books of Samuel: caught up in the contingencies of history yet participating nonetheless in a divinely driven movement towards a particular destination, indeed, God's holy hill on Zion. It remains to briefly sketch the identity of this figure in this collection.

\subsection{The David of Psalms 15-24}

The superscriptions, especially in Ps 18:1, make it clear who the main protagonist of this drama is: David, King of Israel, servant of the Lord (עבד יהוה; Pss 18:1; 19:12, 14; cf. the use of this title in Samuel in 9.1.3.3.). According to Miller, the conjunction of Psalms 18 and 19 in particular and the common use of this honorific title in these psalms portray David as God's "torah-keeping servant." 998 David has fulfilled the Deuteronomic law on kingship (Deut 17:14-20) and passed the basic Israelite test, as displayed in Pss 15 and 24:4 (cf. 1 Kgs 15:5). ${ }^{999}$ In line with the thrust of the Deuteronomic law, this collection also has the effect of "democratizing" David and "royalizing" the people (cf. Ps 8, the centre of the subcollection Pss 3-14), ${ }^{1000}$ for David is being presented as nothing other than a true Israelite. The David of these psalms "embodies faithful Israel and models Israel's ways with the Lord." 1001 The message that is communicated is that any Israelite can "fulfill the torah piety that is exemplified in the king and reflected in the answers to the liturgical questions of Pss 15 and 24." ${ }^{1002}$ Expressed in terms of the poetic shape of Ps 24 (7.3.2.4.3.2.1.): The true Jacob who may ascend the hill of the Lord with the Lord alongside him as his redeemer and partner is not only someone of Davidic lineage, it is open to all who subordinate themselves to the same pre-requisite of obedience. In this case, David is a role model.

chapters 2-32 invites readers to see the message of chapters 2-32 as a particular concrete application of the more general points made in chapters 1 and 33." (Isaiah, 185). See 9.3.2. below.

${ }_{998}$ Miller, "Psalms 15-24," 128: Pss 18 and 19 envision "God's rule through a torah-keeping servant." He notes that the torah-psalm Ps 119 has the largest cluster of self-references to the servant in the Psalter.

${ }_{999}$ Miller, "Psalms 15-24," 129-130. See also p. 131: "There is no explicit reference to the king in Ps 15 nor to the human king in Ps 24. It is only from the center that we move backward and forward to see in those psalms a reflection of the one who fulfils the righteousness they seek."

${ }^{1000}$ See, e.g., Zenger, "Psalmen," 312.

1001 Miller, "Psalms 15-24," 130.

${ }^{1002}$ Miller, "Psalms 15-24," 131. 
It is possible to take the metaphor of "democratization" too far, however. We saw in the books of Samuel that David is also a vehicle for the redemption of Israel and not just a role model. In a sense, his righteousness is for the benefit of Israel. In other words, despite his apparent democratization along the lines of Deut 17 , his special royal function as saviour of the people is not obliterated within the divine economy. This function appears in Pss 20-21, as well: David is the means of the redemption of those who will rejoice in his redemption $(21: 2,14) .^{1003}$ It is his righteousness that guarantees the success of his battle for Israel's sake (Ps 18:21-25). Creach makes this point in his analysis of Pss 2, 89, and 72: "[T]he king's primary task is to look out for the destiny of the righteous." ${ }^{1004}$ How does this tension between David as the redeemer of his people and David as one who is redeemed relate to our interpretation of Psalm 24? This brings us back to the question posed at the end of 9.1.4.: How, exactly, is David present within the Psalm?

Our analysis of Pss 15-24 has provided us with two options. On the one hand, David could be the exemplary Israelite who illustrates to others what true torah obedience and what the fruit of that obedience looks like. On the other hand, he could also be the vehicle by which God gets his Jacob on Zion in stanza III. The latter interpretation might be favoured by the narrative in Samuel, and it is strengthened when we read about the righteous David of Ps 18 (=2 Sam 22) and his victories for his people in Pss 20-21. Yet, as we have noted, Miller and Hossfeld /Zenger also identify a democratizing move, whereby David is not "in front of" but "alongside" Israel as a figure to be emulated. ${ }^{1005}$ The significance of this dimension may be seen in that the king does not appear in the framing psalms, that according to Ps 24:6 the prerequisites for entry are understood to be achievable by all, ${ }^{1006}$ and in that the central psalm in the sub-collection Pss 3-14 (PS 8) explicitly "royalizes" the typical בן אדם/אנוש (w. 5-9). As a counterweight to the books of Samuel, one might refer to Second and Third Isaiah, in which it is Yhwh himself who brings the cleansed remnant to Zion from exile, with no explicit mention of a Davidic saviour (Isa

${ }^{1003}$ This tension appears to be constitutive for the Psalter. According to Ps 1:1, happiness is for the one who meditates on torah, according to Ps 2:12 it is for the one who seeks refuge in the king.

${ }^{1004}$ Creach, Destiny, 89; see pages 86-110. Miller's statement, therefore, that David "is a representative figure, and never more so than as the one who lives by the Lord's Torah" ("Beginning," 91) goes too far.

1005 From a redactional perspective, Hossfeld/Zenger can say, for example: "Die armentheologische Erweiterung [in Ps 18:21-25] macht die Lebenserfahrung des Königs David von Ps 18 zum Typos des Armen Israel" ("Berg JHWHs," 179). The righteous person becomes the "königlicher Mensch."

${ }_{1006}$ Hossfeld/Zenger, "Berg JHWHs," 168; Miller, "Psalms 15-24;" 131. 
40; 62). ${ }^{1007}$ In Isa 44:2 Jacob themselves are called the Lord's עבד; in Isa 55:3 the covenant with David is democratized. ${ }^{1008}$

The tension between these two portrayals of the way of salvation is also found at the opening of the Psalter. According to Ps 1:1, it is the torah-obedient who may experience life; in Ps 2:12 it is all those who take their refuge in the Davidic king on Zion. The inclusio formed by the two אשר-clauses binds these two construals together as two sides of a coin, but it is wrong to resolve the tension by preferring one psalm over the other. ${ }^{1009}$ Somehow, God's will is that he alone is king within Israel, ruling through his law (Ps 1), yet at the same time he installs his human king who himself becomes the conduit of that rule (Ps 2). A similar tension can be said to exist on the level of the editing of the Masoretic Psalter as a whole. ${ }^{1010}$ Wilson has argued that all the psalms up until Ps 89 are concerned with the Davidic monarchy, whereas after this there is a shift in emphasis to the monarchy of Yhwh. ${ }^{1011}$ Others, such as Mitchell and Creach, argue that Davidic kingship is not lost from view in Books 4 and 5 of the Psalter, ${ }^{1012}$ though Creach admits that there is a change of emphasis. In Book 4 (Pss 90-106), "the responsibility of the monarch to establish justice for the poor, to ensure the destiny of the righteous, is transferred from human king to Divine King, at least temporarily."1013

Framing the tension in this manner ought to cause us to take a closer look at the various construals of Israel's salvation found in the books of Samuel and the latter parts of

${ }_{1007}^{10}$ In Isa 60 it is the foreign nations that bring back the dispersed.

${ }^{1008}$ Baltzer, Deutero-Isaiah, 470-471; Creach, "Shape," 73.

${ }^{1009}$ This is Miller's mistake in his essay "Beginning." His democratizing interpretation too readily resolves the "tension" he rightly sees between Pss 1 and 2 when he says: "While Psalm 2 invites the reader to hear the voice of the Lord's anointed in the following psalms, Psalm 1 says that what we hear is the voice of anyone who lives by the Torah, which may and should include the king" (91-92). As Pss 2, 18 (cf. w. 44-46, 51), and 20-21 illustrate, there are prerogatives that belong to the king alone.

${ }^{1010}$ The final book of the Psalter has a different scope and order in the Qumran scroll 11qPsa. For an analysis see Wilson, "Qumran."

${ }^{1011}$ Wilson, Editing. Miller ("Beginning;" "Psalms 15-24") is one of many scholars sympathetic to this view.

${ }^{1012}$ Mitchell, "David;" Creach, Destiny, 109: "the biblical tradition itself continued to maintain monarchy at least as a category for understanding faith long after the historical kings of Israel and Judah passed from the scene." See, e.g. Pss 101; 110; 132.

${ }^{1013}$ Creach, Destiny, 103. In his article "Shape," Creach argues that the covenants in Second Isaiah and Book Four seem to carry similar promises, for there is a parallel between the democratization of the Davidic covenant in Isa 55:3 and Ps 105:42-43, where "Abraham, and his descendents are presented as the 'servants of Yahweh' and Yahweh's 'chosen ones' (73). This is part of his theory that Book 4 was shaped with Isa 40-55 as a model. 
Isaiah. Critical scholars have long noticed the coexistence of pro- and anti-monarchial strands within the books of Samuel themselves. ${ }^{1014}$ Childs argues that neither of the two traditions (or sources, depending how one sees it) has been subordinated to the other; they remain in tension within the final form of the text. ${ }^{1015}$ On the one hand, the existence of a monarchy did not belong to God's original plan with Israel so that the request for its establishment is taken to be a rejection of the rule of God. This strand could be correlated to Ps 1, where the responsibility of obedience lies with the whole of Israel as Yhwh's polity. On the other hand, the establishment of the monarchy is an act of God, one accompanied by his blessing and the gift of the Spirit. Though the history of Israel's monarchy did not prove to live up to the standards demanded of it, the particular Davidic trajectory traced out above (9.1.3.) may be related to the salvific function of the king in Ps 2. Either way, the final form does subordinate both people and king to torah. The "basic issue of Israel's faith has not been determined by the change of the political structure. Israel, along with its new king, must still decide for or against God"1016 (1 Sam 12:25).

One can posit a similar ambiguity in the book of Isaiah (cf. 9.3.3.). On the one hand, the messianic king proclaimed in Isa 1-39 seems to disappear from view. On the other hand, a new mysterious figure bearing the same title ascribed to David in 2 Sam 7, Ps 18:1 and Ps 19:12, 14-עבד יהוה-gradually takes centre stage (Isa 42:1-4; 49:1-6; 50:4-11; 52:1353:12). ${ }^{1017}$ This figure also bears a complex relationship to the community at large, at times being characterized as Israel itself, at other times being understood to be a servant to Israel (e.g. Isa 49:5). The complexity continues as he appears to bear "offspring" (ערז, Isa 53:10),

1014 See Childs, "Samuel" in Introduction, for an overview.

1015 Cf. Childs, Introduction, 277: "Significantly the shape which the final form of the book took did not seek to suppress either of the accounts, or to harmonize the approaches in such a way as to remove the tensions within the text. However, a strong case can be made that the present ordering of the chapters offers a particular canonical interpretation of the diversity within the traditions."

${ }^{1016}$ Childs, Introduction, 278.

${ }^{1017}$ Creach briefly suggests a connection between David cast as a suffering figure in the psalms and the figure Second Isaiah identifies as the "servant of the Lord," without going into too much detail (Destiny, 109). "David is one who knows humiliation and shame, 'a man of suffering and acquainted with infirmity" (Isa. 53:3). Kingship is transformed in the Psalter by its exclusive association with David and, in turn, by the characterization of David as God's servant who bears the shame of the people" (109). See also Barbiero, Erste Psalmbuch, 723: "Die ganze vierte Einheit [i.e. Pss 35-41] ist ... von der Theologie der deuterojesajanischen ,Knecht JHWHs' geprägt." 
the so-called "servants" (עבדים), who go on to continue his mission in the remaining chapters of the book (Isa 56-66; for more details, see 9.3.3.). ${ }^{1018}$

The ambiguity of the role of David within the ordo salutis displayed paradigmatically in Psalm 24 appears, then, to be constitutive for larger sections of the Old Testament. Childs' portrayal of the diversity within the Old Testament's messianic hope supports this view. ${ }^{1019}$ Yet, just as within Samuel the final form provided an angle from which to view the diversity-both king and people remained subordinate to the law ${ }^{1020}$-it is arguable that the final form of Isaiah provides a perspective from which to interpret the complex interplay between communal responsibility and representative saviour within God's plan. The book has one of the most complex structures in the Old Testament and much remains mysterious, but its vision is directly related to the concerns of Ps 24 and so may bring us a step closer to grasping its inner dynamic - now read in the context of its superscription and its position within Pss 15-24. To this we now turn. ${ }^{1021}$

${ }^{1018}$ Creach has posited a similarity of structure between the book of Isaiah and the Psalter that echoes this ambivalent concern with the monarchy: "Isaiah and the Psalter have a first major section that recounts significant aspects of the Davidic monarchy, with a primary interest in 'seeking refuge in Yahweh', as I have argued elsewhere. Both of these sections end with an emphasis on exile: Isaiah offers a prediction of it (Isa. 39), while the Psalter laments that it has taken place (Ps. 89). The next portion of both books addresses exile with comparisons of humanity's ephemeral nature with the steadfastness of Yahweh, among other interests" ("Shape," 75).

${ }_{1019}$ Childs, Biblical Theology, 453-455.

${ }^{1020}$ Childs, Introduction, 277.

${ }^{1021}$ There are two further dimensions of Pss 15-24 that have not been discussed: the possible catchword relationships between consecutive psalms and the function of this collection within the first book of the Psalter as a whole. Miller, Hossfeld/Zenger and Barbiero treat the former dimension in their analyses. I have avoided it because this kind of analysis is too uncertain. As Millard has pointed out ("Anmerkungen"), it is difficult to be certain how much a shared vocabulary is due to a shared tradition-historical background which is highly formalized and how much is due to editorial intentionality. The analyses of these scholars are indeed interesting, but I decided that this level of analysis was not necessary for me to say what I need to say. I have avoided the second issue for similar reasons: there is still much work to be done on the logic of the first book of the Psalter. Barbiero's Habilitationsschrift (Das erste Psalmbuch) deserves more analysis, but I reject his purely synchronic approach (19-29) and am suspicious of the weight he lends to every kind of verbal repetition between psalms. His observation on the symmetric structure of the first book is certainly interesting, however. He sees a symmetric pattern whereby the two central units (Pss 15-24; 25-34) are concerned with the "Institutionen des Heils," whereas the surrounding two units focus on the corruption of the world (719-722). This fits with the cyclical pattern I identified in the historical books: There is an "up and down" whereby salvation is tasted and then lost again. Note, for example, how Pss 15-24 are immediately surrounded by communal lament (Pss 14 and 25). See also the massive dip from Ps 2 to Ps 3 (cf. Wallace, Psalms, 20-21; Weber, "Buchouvertüre"). 


\subsection{The Book of Isaiah}

\subsubsection{Isaiah and the Psalms/Psalter}

Connections have long been made between the traditions contained in the Psalms and the book of Isaiah. On the level of tradition-history, scholars generally believe that the message Isaiah ben Amoz was influenced by the Jerusalem cult tradition. ${ }^{1022}$ Kraus, for example, argues that the general image of an "advent" of the Lord in Ps 24:7-10 has shaped Isaiah's eschatological vision of a returning divine king. ${ }^{1023}$ There is also a consensus that Isa 33 has picked up and processed the same "torah-entrance" liturgy that stands behind Pss 15 and 24:3-6 (along with Mic 6:6-8 and Ezek 18:5-17; cf. 7.4.2.3.). Indeed Ollenburger has argued that Isaiah was engaged in "consistent, reflective exegesis of [the symbol of Zion] within the Jerusalem cult itself." ${ }^{1024}$ On this account, the primary direction of influence was from temple liturgy to prophetic proclamation, as I have argued for the tradition-historical growth of Psalm 24 (7.4.3.; with theological analysis in 8.). ${ }^{1025}$ It is arguable, however, that the influence went both ways, particularly at the level of the final form of individual psalms and of the Psalter. For Psalm 24, for example, I have followed a number of scholars in seeing a potential Isaianic influence on the theology of w. 3-6, though this theology is now inseparable from the structure and message of the final form of the psalm (7.4.3.). This approach has been strengthened by redactional studies which see parallels between the final form of the Psalter and Isaiah. ${ }^{1026}$

Although the issue of the direction of influence is relevant for our grasp of the relationship between Psalm 24 and Isaiah, I will not go into this matter here. The primary reason for this is the complexity of the question: Scholars are still debating the dating and structure of the book of Isaiah as a whole, and so an analysis along these lines will have to be the subject of a separate study. In what follows, therefore, I will remain at the level of thematic patterning. We have already seen that a thematic approach is constitutive for

${ }^{1022}$ Clements, Isaiah, 72, citing von Rad, Theology:1, 149: "It can be shown, of course, that wideranging and comprehensive as his message is, it rests on quite a small number of religious concepts, all of them furnished him by tradition, and in particular the Jerusalem tradition." Willis claims that the connection between Isa 2:2-5 and the songs in that Psalter that thematize Zion is so strong that one could be forgiven for mistaking it for such a song ("Isaiah," 313).

${ }^{1023}$ Kraus, "Welt und Weltvollendung," 164, with an explicit reference to Isa 52:7-10.

1024 Ollenburger, Zion, 129. As such, Isaiah was a "prophet exemplar of the Jerusalem cult tradition and its Zion symbolism" (53).

${ }^{1025}$ Berges, for example, argues that not all the motifs found in Deutero-Isaiah are found in the Psalter, in particular the motif of the servant Jacob/lsrael. It would be odd for the psalms to be so selective in their use of Isaiah ("Witnesses," [1]; page number forthcoming).

${ }^{1026}$ For example, Creach, "Shape;" Berges, "Knechte." 
Childs' approach, for it assumes the ontological unity of the divine source that ultimately generated the canonical tradition (4.5.1.). Indeed, as our treatment of Isa 33 below will show (9.3.2.), such a thematic approach is warranted by the Isaianic tradition itself. In order to get a clearer handle on the question of the nature of the presence of David within the canonical-poetic world of Psalm 24, therefore, we will start with Isa 33 and move out from there to the book as a whole.

\subsubsection{Isaiah 33}

The "woe oracle" (Weheruf) that opens Isa 33 (v. 1) indicates that this chapter starts a new unit, indeed the concluding unit of a series five woe oracles stretching from chaps. 2831. ${ }^{1027}$ This series is interrupted by two supplementary oracles in 32:1-8 and 9-20. ${ }^{1028}$ All these oracles are concerned with the tense relation between Yhwh and Zion-in short Zion does not live up to Yhwh's moral standards-and they function to continue another set of woe oracles found in chaps. 24-27, in this case focussing on Yhwh's relation to the nations. Like Zion, they too have all fallen short of the Lord's standards. ${ }^{1029}$

Within this overarching composition, chap. 33 plays a highly significant role. Whereas the preceding oracles have a relatively high degree of historical referentiality, chap. 33 is more abstract in nature, having the same air of theologizing that I have claimed for Pss 15, 19 , and 24 within the sub-collection of Pss 15-24 (9.2.3.1.). In this sense, its function within the book is also similar to Isa 1, "which provided an anticipatory summary of the message of Isaiah." ${ }^{1030}$ Goldingay and others thus argue that chaps. 1 and 33 create a frame around the intervening oracles. ${ }^{1031}$ Similar to the function of Ps 24 as the conclusion of the framework of Pss 15-24, Isa 33 "invites readers to read the intervening chapters as a particular concrete application of the more general points being made in 1 and $33 . " 1032$ In other words, it sets the theological horizon for the interpretation of the whole. ${ }^{1033}$

\footnotetext{
${ }^{1027}$ For a brief overview of the structure see Berges, Jesaja, 79-82.

${ }^{1028}$ Beuken, Jesaja, 36-37.

${ }^{1029}$ Beuken, Jesaja, 36-37.
}

${ }^{1030}$ Goldingay, Isaiah, 184. Beuken characterizes chap. 33 as a "koleidoskopische Übersicht der Verkündigung des Propheten in Jes 1-32" (Jesaja, 256). The means by which chap. 33 achieves this is through intertextual reinterpretation of other parts of the Isaianic tradition. Goldingay, Childs, Beuken, are just some of the scholars who pick up on this, though the credit goes to Beuken for originally having identified it (in "Jesaja 33").

1031 Goldingay, Isaiah, 184.

1032 Goldingay, Isaiah, 185.

${ }^{1033}$ In particular, its sets the historical events in Isa 36-39 in their true theological context. Cf. Seitz, Isaiah 1-39, 235. This historical description of salvation itself was to become a "type' that 
What are the "general points" found in this chapter? Its inner coherence, as we found for Psalm 24, is difficult to grasp, for it consists of a "jerky and puzzling" amalgamation of various liturgical forms. ${ }^{1034}$ The credit goes to Beuken for having provided a plausible theory of the coherence into which these forms have been shaped. ${ }^{1035}$ In short, he has concluded that the chapter presents a vision of the form (Gestalt) Zion is to take after the threat of its enemy has been overcome (i.e. "Zion in der Heilszeit"). Within the context of the final form of the book, he argues that this vision is presented as the answer to a question raised in 27:13, ${ }^{1036}$ namely, "Auf welche Art und Weise gewinnt die Anerkennung JHWHs in Jerusalem angesichts der Tatsache Gestalt, dass an dem Ort das Gegenteil, die Verkennung JHWHs, triumphiert $(28,12-15 ; 29,13-16 ; 30,1-2.10-11 ; 31,1-2.6-7) ?^{\prime 1037}$ The answer begins with the equivalent of Ps 24's final stanza: The Lord attacks his enemies in order to fill Zion with משפט וצדקה (Isa 33:5). Similar to the ambiguity in Ps 24:7-10 and 2 Sam 5-6 concerning the identity of the object of the Lord's wrath, Isa 33 oscillates in its depiction of the sinners as being both outside (v. 1 ) and inside (v. 14) Zion (see 7.3.2.4.3.2.1.; 9.1.3.3.). ${ }^{1038}$ In other words, the criteria for participation in the new Zion are ethical and not ethnic. ${ }^{1039}$ Beuken concludes by setting the transformed "torah-entrance liturgy" in v. 1416 within its literary context: "Somit enthält das literarische Modell der Einlassliturgie eine Art narrative Auflösung. Das Gericht, das im Buch bereits von Anfang an angekündigt wurde, ereignet sich visionär jetzt." ${ }^{1040}$ Beuken understands the vision of Isa 33 to consummate the entire movement of chapters $1-32 .^{1041}$

foreshadows God's final restoration of Zion and comforting of Jerusalem spoken of in chapters 40$66^{\prime \prime}(236)$.

${ }^{1034}$ Goldingay, Isaiah, 184. Blenkinsopp, Isaiah:1, 435: "a disjointed and uneven sequence of mostly brief passages."

${ }^{1035}$ Childs follows Beuken's article "Jesaja 33," which stands behind his 2010 commentary, very closely (Childs, Isaiah, 244-249).

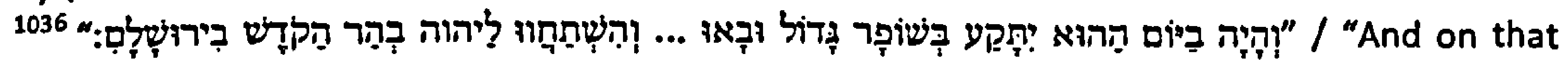
day a great shofar will be blown and they will come ... and do obeisance to Yhwh on the holy mountain in Jerusalem."

${ }^{1037}$ Beuken, Jesaja, 38. Cf. Berges, Jesaja, 80: "In Jes 28-33 geht es darum, wie das Gottesvolk aussehen muss, damit Jhwh als gerechter König vom Zion aus herrschen kann."

${ }^{1038}$ Beuken, Jesaja, 283-284; Berges, Jesaja, 80. Note that the goal of this intervention is that they might know the Lord's נבורה (v. 13; cf. Ps 24:8).

${ }^{1039}$ Beuken, Jesaja, 294. He argues that v. 13 refers to both the nations (רחוקים) as well as to the sinners in Zion (קרחבים), a kind of "merismus" (282).

${ }^{1040}$ Beuken, Jesaja, 284.

${ }^{1041}$ The scribes at Qumran seemed to have picked up on this too. Goldingay notes how a Qumran scroll leaves a space after chap. 33. For Goldingay, this chapter closes off the first half of the 
The fruit of Yhwh's violent intervention (note the imagery of fire in v. 14) is that those who survive-i.e. those who have fulfilled the ethical criteria of v. $15^{1042}$ (cf. Ps $24: 4$ ) -will dwell in Yhwh's dimension of reality (cf. Ps 24:3; on Yhwh's inhabitation of Jerusalem, note the reference to אהל in v. 20 [cf. Ps 15:1]; on participation in his dimension of reality, note the repetition of שכומ/מרום in w. 5 and 16). ${ }^{1043}$ The promise is thus a more detailed exposition of what will happen when the righteous generation of Ps $24: 6$ cross the threshold to meet the victorious divine King on the other side (on the messianic identity of this king, see $\mathrm{fn} .1051)$. The reality depicted is a Zion that has been transformed into a paradise, in particular one in which the themes of "stability" and fruitfulness found in the protological/eschatological part of Ps 24 (vv. 1-2) have finally been realized (v. 20). Beuken echoes my own comments upon the central theological significance of the imagery found in Ps 24 for Biblical theology (7.3.2.): Isa 33 depicts "die Erfüllung von Israels kühnsten Erwartungen (Gen 15, 18-21; Dtn 11, 24; Jos 1, 4; Jes 27,12), die insbesondere mit dem König aus dem Hause Davids verbunden sind (1 Kön 5, 1-5; Ps 72, 8-11)." ${ }^{1044}$ We thus have an inversion of the pattern found in Ps 24: Instead of moving from blessing to judgement and the threshold of consummation, we move from judgement to blessing, "across" the threshold as it were. Isa 33 takes Ps 24 one step further, for it portrays the moment of fulfilment, i.e. the reality beyond the "gates."

This eschatological (rather than Ps 24's predominantly protological) perspective is consonant with Isa 33's function within the book as a whole, for it does not only look back to the events of chaps. 1-39,,$^{1045}$ it also looks forward to later chapters with their more

book quantitatively, thematically, and verbally (Isaiah, 184). For more details of just how these chapters fit into the overall thematic patterns and narrative development of chaps. 1-32, see the rest of Beuken's exegesis, but especially p. 296.

${ }^{1042}$ Similar to my construal of the representation of time (7.3.2.4.3.1.2.) Beuken can say of the move from v. 16 to v. 17: "[Die Figur in v. 17] existiert nicht mehr hypothetisch, sondern tritt in den Kreis prophetischer Handlungsträger ein" (Jesaja, 28).

${ }_{1043}$ Beuken, Jesaja, 286 (that which is promised is "JHWHs eigene[r] Bereich"), 290.

${ }^{1044}$ Beuken, Jesaja, 288-289. In relation to the imagery of land, he states: "Somit wird die Verheißung erfüllt, die Abraham weggehen ließ, aus der Israel hervorgegangen ist und die Mose am Ende seines Lebens noch vergönnt war ('das Land sehen': Gen 12,1;13, 15; 48, 15; Num 13, 18; 14, 23 ; 27, 12; 32, 1.8-9; Dtn 1, 8.35-36; 2, 31; 3, 25.28; 32, 49.52; 34, 1.4; Jos 2, 1; 5, 6)" (288).

1045 In addition to the battle motif, Beuken also sees in the communal confession of divine kingship in v. 22 a fulfilment of the individual one in 6:1 and 24:3 (Beuken, Jesaja, 292). See also his comment on the term ע in v. 24: "Mit dem Terminus 'Schuld" (II) gelangt ein wichtiges Isotop in Jes 1-39 zu einem vorläufigen Ende. JHWh, der Heilige, hat den Kampf gegen jede Form der Sünde in Israel $(1,4 ; 5,18 ; 6,7 ; 22,14 ; 27,9 ; 30,13 ; \mathrm{vgl}$. den Nomen, der Heilige [Israels] im Kontext dieser Belege: 1,$4 ; 5,19 ; 6,3 ; 30,12)$ und in der Völkerwelt $(13,11 ; 14,21)$ aufgenommen" $(295)$. This 
developed portrayal of the salvific consummation in the future. Beuken identifies several motifs in addition to the judgement $\rightarrow$ salvation pattern that links Isa 33 to the second major part of Isaiah (40-55), namely: עון; 33:24; 40:2; divine kingship: 33:22; 41:21; 43:15; 44:6; 52:7; the lament in 33:2 and various places in Isa 40-55; the tent metaphor: 33:7; 54:2-3; the call to recognize that which God is doing: $33: 13 ; 40: 21,28 .{ }^{1046}$ Without going into detail about the particular manner and function of the various connections between Isa 33 and the rest of the book, it is clear that this chapter has a paradigmatic function within the context of the book as a whole, providing us with a framework for interpreting the basic message of Isaiah. ${ }^{1047}$ This is one reason why Beuken assigns chap. 33 to one of the final editorial stages in the composition of the entire book (chaps. 1-66). ${ }^{1048}$

We thus find that Isa 33 not only subscribes to a similar theological vision as Ps 24, drawing, in part, upon similar liturgical traditions, it also shares a similar hermeneutical function within the literary form of the text: It provides the reader with a paradigmatic expression of the ultimate shape of the Lord's ways. Within this framework, history is to be understood. If, as Beuken argues, the eschatological drama in Isa 33 presents us with "den Kern jesajanischer Verkündigung," ${ }^{1049}$ then it is to be expected that the later development of Isaiah's message in chaps. 40-66 will, in some sense, be contained within the parameters set out in chap. 33: Yhwh will come to Zion in devastating judgement against sinners, both within and without Israel; Yhwh will set up his messianic kingdom within Zion (cf. v. 17 and fn. 1051), which will mean peace, security, and blessing for those who have been deemed fit to participate in it. As we have seen, Isa 33 shares these elements with Ps 24. An additional element that Beuken believes is implicit within Isa 33 and that accords with the poetic shape of Ps 24 is that those who benefit from Zion's future will be returnees, i.e. people who have completed a journey from exile "up to" Zion (cf. Ps 24:3). ${ }^{1050}$ This motif is clearly present elsewhere in the book (e.g. Isa 40; 62).

creates another connection to Psalm 24, which is similarly interested in "holiness" (cf. 7.3.2.2.2. 7.3.2.3.2.).

${ }^{1046}$ Beuken, Jesaja, 269, citing here too the work of Williamson, Isaiah.

1047 Beuken, Jesaja, 264: "Das Kapitel spiegelt folglich den Kern jesajanischer Verkündigung wider: JHWH übt auf dem Zion seine Herrschaft als exklusives Recht aus (V 22; vgl. 6, 1.5; 8,18; 18, 7) und macht diesen Ort somit zu einer uneingeschränkt sicheren Wohnstätte für sein Volk $(28,16) . "$

1048 Beuken, Jesaja, 37-38.

${ }^{1049}$ Beuken, Jesaja, 264.

${ }^{1050}$ Beuken, Jesaja, 37: "Kap. 33 [beschreibt,] welcher Gestalt Zion sein wird, wenn die Exilierten aus der Fremde zurückkehren." 
There is one element within Isa 33, however, which is not explicitly found in chaps. 4066 and which is only implicitly present in Ps 24 by virtue of its superscription, namely the presence of the Davidic king as the one who rules over the renewed Zion (v. 17). ${ }^{1051}$ In other words, according to the vision of Isa 33, the David of the superscription in Ps 24:1 is to be found on the other side of the gates. Indeed, he presides over that reality. Yet how did he get there? In Isa 33 the agent of salvation is exclusively Yhwh (see also v. 22); the king plays no explicit role in redeeming the city. ${ }^{1052}$ We are thus left with the same ambiguity that concluded our analysis of the function of David in Pss $15-24(9.2 .3 .2 .2.) .^{1053}$ On the one hand, according to the trajectory represented by Psalm 2, we might have expected the king to have played a role in the redemption of Zion. Yet here it is only Yhwh. On the other hand, according to the trajectory represented by Psalm 1, we might expect the king to simply be a beneficiary of Yhwh's redemption, consequent upon his own fulfilment of Yhwh's righteous will (Isa 33:14-16). In the final section of our treatment of the broader literary context of Psalm 24 (Verbum 2), we will now explore how the rest of the book of Isaiah responds to this inner-canonical tension.

\subsubsection{The Servant and the Servants}

Isaiah 33 ended with the statement that the inhabitants of the New Jerusalem would

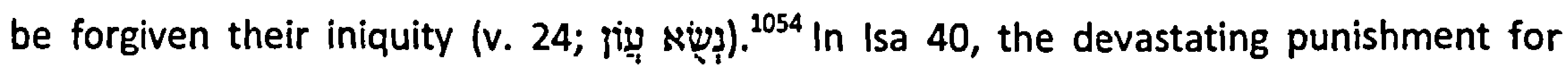
Israel's sin-God's "invasion" of Israel by Babylon-is now in the past, his people's iniquity

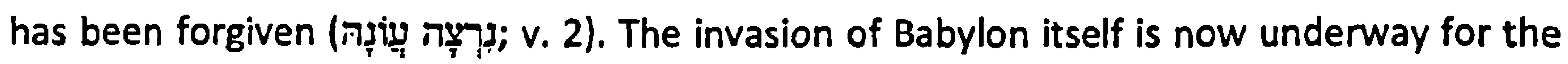
sake of the redemption of his cleansed people. All that remains is for them to return to Zion alongside their divine shepherd King. From the perspective of Ps 24 , then, Isa 40 takes

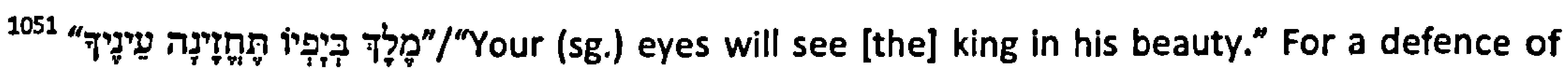
the messianic reference of this verse, along with contrary positions, see Beuken, Jesaja, 287-288, who is followed by, e.g., Childs and Blenkinsopp (Berges disagrees: Jesaja, 80-81). Beuken sees this promise as the fulfilment of Isa 32:1-2. He is also open to the possibility that the editors have shaped that material in such a way that a divine referent may also be read into the text.

${ }^{1052}$ According to Berges, the Isaianic tradition as a whole plays down the active role of the monarchy (Jesaja, 64). Commenting on this verse, Childs says: "Indeed, there will be the anticipated messianic king, but his function remains as always to serve as an earthly representative of Israel's true heavenly king. Jerusalem will be transformed because Yahweh will be 'for us' in all his majesty. Most assuredly, Yahweh is Israel's judge, ruler, and above all, king" (Isaiah, 248).

${ }^{1053}$ Goldingay makes a similar point in relation to the messianic prophecy in Isa 9, which does not "make explicit the link between the gift of a new king and the people's deliverance from their oppressors. These might be two parallel or sequential gifts of God, rather than the new king being the means of deliverance. In any case, the stress lies on the fact and the fruit of the king's 'rule' ... At the moment the burdensome yoke of their oppressor lies on Israel's shoulder, but the descent of rule onto this man's shoulder enables and/or symbolizes that yoke's removal" (Theology:2, 479-480).

1054 Jüngling, "Jesaja," 389. 
off where our psalm concludes: at the threshold of the new reality alongside the victorious King. Just as half-stanza I, with its creation of a good order over against chaos had provided the condition for the possibility of the ethical behaviour of Jacob in stanza II, so God's cleansing of his people by the fire of exile has rendered them fit to ascend to Zion alongside him. ${ }^{1055}$ If this analogy works, we see here the ability of the imagery found in Ps 24 to operate at different levels. From the perspective of Isa 40 , stanza III is both past and present. It is past, for the invasion of the unrighteous within Zion (cf. Isa 1) is over. It is present, for the invasion of unrighteous Babylon is underway. In both cases, the Lord's purpose is to create a space where the creational fecundity found in half-stanza I may finally come to fruition. For this, he needs a righteous Jacob to ascend the mountain with him.

At this point, Isaiah adds a twist. In that Israel ascends to Zion (= Ps 24:3) in the power of what Yhwh has achieved for them (= Ps 24:1-2 // 7-10), Israel becomes Yhwh's "witnesses" (עד) to the nations (e.g. 43:10, 12; 44:8). ${ }^{1056}$ Rendtorff notes how Israel's calling to be a witness is primarily a passive phenomenon, something that "in seiner Existenz liegt und in dem, was Gott jetzt mit ihm tut." ${ }^{1057}$ By returning home, Israel gives public testimony to the reality of God, actualized in what is happening in Israel's life now. This, then, adds a further dimension to Ps 24, for it is now the case that in that Jacob steps out of the "shadows," as it were, to ascend Zion, he fulfils a divinely ordained function: He bears witness to the nations of the reality of God (Note the universal horizon of Ps 24:1: Are the nations implicit addressees?). Accordingly, we may read Isaiah 40 and the chapters that follow as an analogous call to Israel to realize its true identity within the context of God's salvific work. ${ }^{1058}$

Jacob/Israel the witness is also addressed as "servant" (עבד; e.g. 42: 19; 43:10; 44:1, 2, 21). This fact is significant, for it shapes our interpretation of a mysterious text that appears

${ }^{1055}$ How it is that the "furnace of the exile" in fact purifies Israel is not clear to me, but the logic appears to be that not only is Israel purified, it is expected to live out that purification. This appears analogous to the Pauline relation between the indicative and the imperative.

${ }^{1056}$ See, e.g., Berges, Jesaja, 94-97, for a brief overview. He believes that that which is witnessed to is Yhwh's uniqueness and his ability to control history.

${ }^{1057}$ Rendtorff, Theologie:2, 175. On the passive role of Israel as servant outside of the so-called servant songs, see Wilcox/Paton-Williams, "Servant Songs," 87. Hermisson (in "Jakob und Zion") tries to clarify the content of the witness further: Israel witnesses to Yhwh's power to save from "death," which creates a direct parallel with the witness of the fourth servant song (52:13-53:12).

${ }^{1058}$ For the concept of "Jacob" realizing his true identity in Isa 40-48, see Berges, "Witnesses." 
to be in both continuity and discontinuity with the surrounding oracles: Isa $42: 1-4$. This is the first of the four so-called "servant songs" (49:1-6; 50:4-9; 52:13-53:12). As Childs states in his commentary on Isaiah, the "issue of the servant songs remains a hotly debated problem without a wide consensus for its resolution." ${ }^{1059}$ in what follows, I will simply outline the lineaments of an approach to interpreting these texts which takes their position in their literary context to be hermeneutically significant (primarily Wilcox/Paton-Williams; Childs; Seitz; Beuken; Goldingay). ${ }^{1060}$ My hope, as stated, is to further illuminate something

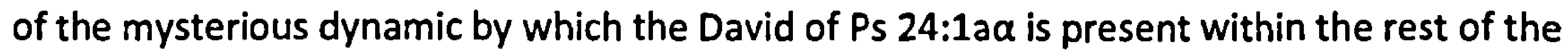
psalm.

Isaiah 42:1-4 is the first text where God's servant (v. 1) gets active. His task is to bring forth justice (משפט) to the nations (v. 1). Childs takes this to be some kind of commissioning by the Lord, given as a mysterious response to Israel's complaint in 40:27 that God has disregarded their right (משפט). ${ }^{1061}$ Yet who exactly this figure is remains uncertain, indeed "the reader is left in considerable confusion." ${ }^{1062}$ Childs argues that the text has purposely blurred any possibility of recovering an original historical referent. In the context of the final form, the title of "the servant" has already been explicitly applied to Israel. Childs, therefore (along with the other scholars just mentioned), concludes that the servant is "in some way Israel." He does not push this any further: "[A]t this point in Second Isaiah the mystery of the servant as Israel remains." ${ }^{1063}$

${ }^{1059}$ Childs, Isaiah, 291.

${ }^{1060}$ This interpretation differs to that of another interpreter of the final form of the text, Ulrich Berges, who believes that the servant figure remains the same throughout isa 40-66 (cf. Jesaja; "Witnesses").

${ }^{1061}$ Berges believes that "that which is right" is the confession of the uniqueness and power of Yhwh. This interpretation takes its cue from the immediately preceding lawsuit scene between Yhwh and the gods: "Der Entscheid in der Frage "Jhwh oder die Götter" gehört also mit zu dem Recht, für das der Knecht Jakob/lsrael Zeugnis ablegen soll. Der Rechtsstreit mit den Göttern der Völker und die Einsetzung des Knechts für Israel und die Völker sind zwei Seiten ein und derselben Medaille" (Jesaja, 95).

1062 Childs, Isaiah, 324.

${ }^{1063}$ Childs, Isaiah, 325 (emphasis original). Jüngling ("Jesaja," 390-391) takes this servant to be an individual, distinct from the servant in the surrounding passages. Blenkinsopp (Isaiah 40-55, 210211) argues that at an earlier redactional level the text could have applied to Cyrus. Nevertheless, "Much of what is said in these verses could also be said of Israel either projecting an ideal Israel or an Israel in the guise of one of the great figures from its past ... or an individual who undertakes to speak and act for Israel. That we should leave open the possibility of such an innerbiblical relecture ... is suggested by the language of servanthood elsewhere in these chapters" (211). Berges ("Witnesses") points out the interplay of singular and plural nouns in chaps. 40-48 in order support his thesis that corporate Israel is being presented in the guise of an individual. 
The next clue comes with the second servant song in 49:1-6, "an intentional literary continuation of $42: 1-6(5-9) .{ }^{1064}$ Goldingay succinctly summarizes what the intervening chapters have taught us about the servant and his mission as follows:

Jacob-Israel is Yahweh's servant (41:8-9)

Yahweh's servant has a specific role to fulfill (42:1-4)

Jacob-Israel cannot fulfill that role (42:19)

Nevertheless Jacob-Israel is still Yahweh's servant (43:10; 44:1-2, 21, 26; 45:4; 48:20). ${ }^{1065}$

In short, Israel refuses to fulfil its role. To draw an analogy with Ps 24 once again: The hypothetical Jacob of stanza II refuses to step out of the shadows and climb the mountain, despite the fact that Yhwh has created the conditions for this possibility (stanzas I and III). At the same time, the Lord does not change the basic structure of his ways, for his plan nevertheless must factor in the reality of an obedient Jacob (see the final point in 7.3.2.4.3.2.1.). The urgency of the implied imperative of Ps $24: 6$, therefore, remains.

Isaiah 49, located at a significant structural junction in Second Isaiah, ${ }^{1066}$ shows Yhwh's way of dealing with the problem. In 48:16 a new individual voice had been introduced: "And now the Lord GOD has sent me." Chapter 49 picks up the voice and interprets God's new strategy. The passage describes in the first person the servant's commissioning, equipment, and divine mission in language that parallels the first servant song (42:4//49:1; 42:1//49:6; 42:3//49:4; 42:6//49:6). ${ }^{1067}$ Yet in v. 3 a new element is added: "And [Yhwh] said to me, You are my servant, [you are] Israel, in whom I will be glorified." ${ }^{1068}$ Childs understands "Israel" to be predicative and concludes that here an individual figure has been designated as Israel. "In place of the corporate nation Israel, which up to this point has always borne the title, 'my servant' $(41: 9 ; 42: 1,19 ; 44: 1 ; 45: 3)$, a single figure now

${ }^{1064}$ Childs, Isaiah, 382.

1065 Goldingay, Isaiah, 281.

${ }^{1066}$ l.e. chapters 40-48 | 49-54/55. Blenkinsopp sees chap. 55 as a bridge to chaps. 56-66. He argues that the integrity of this unit is indicated by the framing references to the "servant" at the beginning (49:1-6) and the "servants" at the end (54:17), as well as the repetition of the Exodus theme in 52:11-12 and 55:12-13 (Isaiah 40-55, 298-299). Goldingay points out a shift in interests from Jacob-Israel to Jerusalem-Zion; from the fall of Babylon to the restoration of the holy city (Isaiah, 280). See also Jüngling, "Jesaja," 390-391.

${ }^{1067}$ Childs, Isoiah, 383.

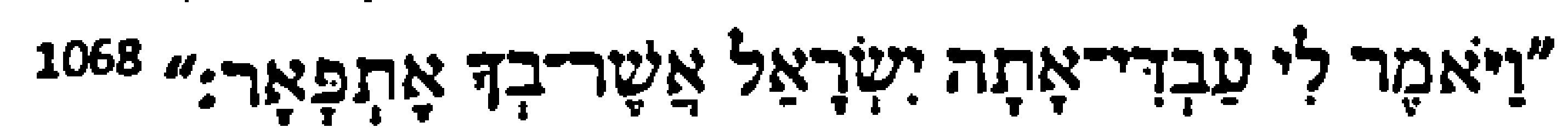


carries the title and even office." ${ }^{1069}$ This is not to say that collective Israel has been replaced by an individual prophetic figure, but rather this individual is "a faithful embodiment of the nation Israel who has not performed its chosen role (48:1-2)."1070 The servant thus acquires a dual role: Whereas collective Israel was to be a light to the nations (by enacting Ps 24:3-6), the mysterious individual servant is to be a witness to both Israel and the nations by enacting himself the same mission (w. 5-6). ${ }^{1071}$

In the following chapters "the servant, now the embodiment of Israel (49:3), moves to center stage and his response in suffering obedience is set in striking contrast to the complaints of Israel." ${ }^{1072}$ Israel's refusal to receive God's proffered salvation (50:1-3) forms the immediate context for the third servant song (50:4-9). Whereas resistance to the servant's message was already indicated in $49: 4,{ }^{1073}$ in this poem the negative response intensifies into physical violence (cf. e.g. Ps 22 for analogous suffering). The servant does not retreat from this, indeed "the speaker offers himself as a victim of abuse and does so as the price to be paid for fulfilling his mission." 1074 In this suffering at the hands of his own people, ${ }^{1075}$ Childs sees "a clear transfer from Israel, the servant nation, to Israel, the suffering individual who now embodies the nation's true mission." ${ }^{1076}$

${ }^{1069}$ Childs, Isaiah, 384 (see 384-385 for corroborating evidence, e.g. the stark individualization of the imagery, evidence that the servant has undergone a history of activity within a concrete temporal sequence, the change in the servants mission [i.e. to bring back Jacob]). This interpretation is followed by Wilcox/Paton-Williams, Seitz ("Servant Songs"), and Goldingay (Isaiah, 283). Blenkinsopp also sees an act of transfer taking place, but it is a transfer of the task given to Cyrus to an individual representative of Israel (Isaiah 40-55, 300): "the task of bringing about the will of Israel's God in the political sphere that Cyrus was unwilling to perform will now be undertaken by Israel itself by means of its prophetic representative." Berges argues that the servant remains corporate throughout ("Witnesses"), yet the switches between singular and plural forms that he provides as evidence are all taken from chaps. 40-48, not afterwards. Yet the point of the aforementioned scholars is that the shift takes place after chap. 49.

${ }^{1070}$ Childs, Isaiah, 385. See also Goldingay, Isaiah, 283: "It can hardly be that the task of being a light to the world is taken away from Jacob-Israel. That would go against the often-reasserted commitment of chapters 43-44. But the prophet is integral to the achievement of that aim." Here, Childs, Goldingay, and Seitz are more nuanced than Wilcox/Paton-Williamson and Blenkinsopp when talking of "transfer."

${ }^{1071}$ Goldingay, Isaiah, 283: "Yahweh enables the prophet to see more clearly the significance of seeking to draw Jacob-Israel back to God. Fulfilling this ministry will also bring about the fulfilment of a second mission. The way in which any minister is engaged in mission is by fulfilling a ministry to the congregation that itself has the task of mission."

${ }^{1072}$ Childs, Isaiah, 390.

"But I said, I have laboured in vain, I have spent my strength for nothing and vanity."

1074 Blenkinsopp, Isaiah 40-55, 321.

${ }^{1075}$ Blenkinsopp, Isaiah 40-55, 319.

${ }^{1076}$ Childs, Isaiah, 395. 
Interestingly, w. 10-11 introduces a theme central to the kerygmatic function of Ps 24: the call to Israel to realize its true identity. As in Ps 24, the means for doing this is obedience to God's will (v. 4). The new dimension introduced by Isaiah is that this revelation is mediated by the one who is himself obedient (Isa 50:5). Those who would be the true Israel must be obedient to the voice (קול) of the servant of Yhwh (v. 10). ${ }^{1077}$ As we will see in the context of the fourth servant song, the result is "justification," just as the torah obedient of Ps 24 receive צדקה. Again, along the lines of Ps $24: 6$, a further result is a division within Israel, this time into "those who believe and those who oppose" the servant. $^{1078}$

In the final servant song of the series (Isa 52:13-53:12), we discover that the servant's work was not in vain, for a group of disciples does appear within Israel. Though the servant song is framed by divine speech (52:13-15; 53:11b-12), a "we" group appears in the middle (53:1-11a) that testifies to having understood the significance of the servant's mission within God's economy. ${ }^{1079}$ The nature of this work remains mysterious-whether interpreted diachronically or synchronically-but the following points can be established: The function of the servant in bringing שלום to Israel comes as a surprise to those who received him; indeed, those who now confess him were those who once rejected, persecuted and even physically killed him. ${ }^{1080} \mathrm{~A}$ conversion has taken place on the part of the guilty. The means by which they receive their peace is mysterious. The servant's death is described as an שָָ a "guilt offering," which in its cultic context is "the indispensible means for the removal of guilt and liability for punishment in especially serious cases of encroachment on holy objects and places. ... The idea behind this type of reparation sacrifice is that ... the transgressions and the guilt of the sacrificial adepts die with the

1077 See Childs, Isaiah, 395-396, on the difficult syntax. He concludes: "A challenge is extended to anyone who rightly fears the Lord, and thus identifies with the message of the servant, to trust in God even though it still involves walking on a path of darkness, just like the servant" (396).

${ }^{1078}$ Childs, Isaiah, 414.

${ }^{1079}$ Childs, Isaiah, 412. Tentatively, Blenkinsopp, Isaiah 40-55, 323. Berges also takes this "we" group to be members of the people of Israel rather than the nations: "The 'We' have heard the message and seen the one who has been smitten by God (53.1-2), thereby finally coming to the realization that he had borne, like a silent lamb, their punishment" (Jesaja, 126-128; here, 127; translation mine).

${ }^{1080}$ Blenkinsopp, Isaiah 40-55, 353-354. Childs, Isaiah, 416. Childs understands the servant's suffering to be typed according to the innocent sufferer of the Psalter-in particular Psalm 22 (part of the sub-collection Pss 15-24). His suffering depicts "a calling, even an office, into which a servant of God has been summoned" (414). 
death of the 'āšām animal." "1081 Blenkinsopp sees an analogy with the servant, though he is reticent about pushing the analogy too far in order to explicate the nature of the death. ${ }^{1082}$ However we are to understand the means by which this death is efficacious for Israel, "God himself took the initiative in accepting the servant's life as the means of Israel's forgiveness." 1083 Although this "we" group was the murderer of the servant, the ultimate agent of his death was God himself, and the intended beneficiaries of this death were Israel. ${ }^{1084}$ The "we" of Isa 53 recognizes the freedom that the servant has won for it and, "in the experience of encountering the hidden plan of God, [is] itself transformed into the new Israel, which share[s] in the coming redemptive age." ${ }^{1085}$ The concluding verses (w. 11b-12) repeat the perspective by which this poem was opened: The servant will be exaltedindeed his life will be extended. ${ }^{1086}$ More significantly, the raison d'être of his mission to Israel and thereby to the nations is also fulfilled: He will make many to be accounted

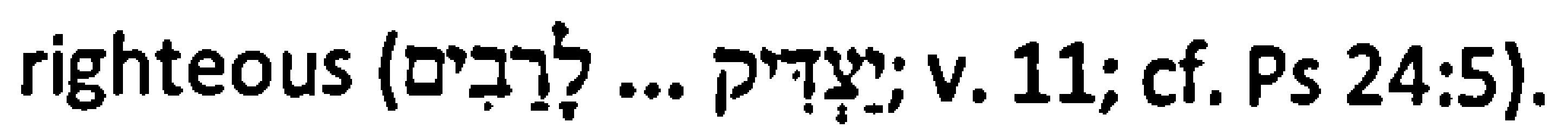

We thus have what may be seen as the reverse movement of 1sa 49:3. ${ }^{1087}$ There, Israel's mission was uniquely transferred to this one individual Israelite. Now, at the climax of that mission, this Israelite has somehow created within Israel a community that is able, through its "justification," to fulfil its original role as witness to the nations, for as righteous they may now "ascend" to Jerusalem. ${ }^{1088}$ These transformed disciples of the servant come to call themselves the "servants" (עבדים), and their destiny becomes the main theme of the

${ }^{1081}$ Blenkinsopp, Isaiah 40-55, 353.

${ }^{1082}$ Childs, too, is reticent about drawing cultic analogies (Isaiah, 418: "there is no contextual preparation in chapter 53 to alert the reader to a cultic interpretation").

${ }^{1083}$ Childs, Isaiah, 418.

${ }^{1084}$ Cf. Beuken, "Trito-Isaiah," 73.

${ }^{1085}$ Childs, Isaiah, 418. Cf. Goldingay, Isaiah, 305: "They (or the prophet) now affirm that this servant is the key to their becoming that sort of people [i.e. that God desires], and that this comes about through his being afflicted as they were [in the exile], but without deserving it."

${ }^{1086}$ Resurrection is not mentioned, though the imagery is provocative indeed (Childs, Isaiah, 419). Blenkinsopp, with his more historicist perspective, avoids this conclusion and attempts to explain the language as follows: "While it is unlikely that the author thought of the survival of death or returning from the dead in a straightforward kind of way, it seems probably that he retained a strong sense of the Servant as an active presence amongst his followers" (Isaiah 40-55, 355).

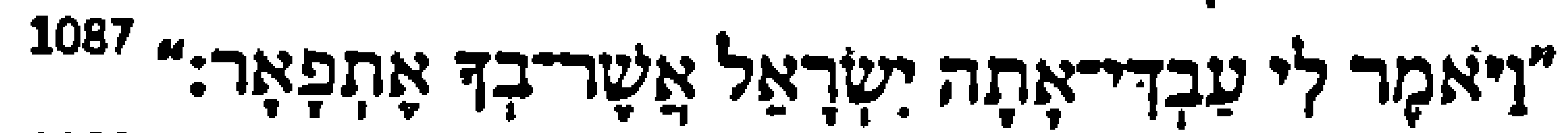

${ }^{1088}$ Given that the effect of the exile was to cleanse Israel (Isa 33:23; 40), there appears to be an analogy between the fruit of the exile and the fruit of the death of the servant for Israel, the latter recapitulating the first. Blenkinsopp claims that "the Servant's project will be continued and carried to fruition by his disciples" (/saiah 40-55, 355). 
final chapters of the book (chaps. 56-66). ${ }^{1089}$ In short, these servants are the "seed" (Iרז) of the servant (cf. 53:10). In Isa 54:3 this seed is promised to both the servant and the personified city of Jerusalem - they are her estranged children to whom the servant has now "transferred" his righteousness. ${ }^{1090}$ In this righteous seed, the promise to both the servant and Zion is fulfilled: They will "be gathered by God on his holy mountain and in his house of prayer"1091 (cf. Isa 62:10-12, which Blenkinsopp considers to be an eschatologized version of the processional liturgy found in, e.g., Ps 24:7-10). ${ }^{1092}$

How does the work of the servant in Isa 53 relate to Psalm 24?

For a start, as we have seen (and in contrast to Isa 33), the vision contained in the third servant song does not represent the fulfilment of Ps 24 ; i.e. the "threshold of heaven" is not yet crossed. Although the suffering of the servant is described in the past tense (qatal

${ }^{1089}$ The seminal essay is by Beuken, "Trito-Isaiah." "The question of the identity of the servants is the centre of Third-Isaiah's interest" (68). "In these generations the promise to the servant is realized: he sees his offspring" (70). The "new order of righteousness will be visible in the offspring of the prophet [of chap. 61], who looks like the Servant [of chap. 53] and is already clothed, as a pledge, with righteousness. Thus it appears that [Trito-Isaiah] concerns himself with the Servant precisely in respect of the question: who are his offspring, in whom does he go on living? The final goal of God's actions is not the servant but his descendants" (73).

${ }^{1090}$ Beuken, "Trito-Isaiah," 68. Both the roots זע ז מק belong to the same semantic field as עב in Isa 56-66 (67-68).

${ }^{1091}$ Beuken, "Trito-Isaiah," 68-69. The concept also undergoes an expansion, "because it appears that foreigners can join themselves to YHWH in order to serve him" (69). Also consonant with Ps 24 is the inner-Israelite division between the seed of the servant and the sinful children of the harlot (e.g. chap. 57; cf. p. 69). Regarding the presence of the temple in chap. 66:1-6, Beuken does not think that it is spiritualized away (cf. Beuken, "Temple").

1092 "If we take in the scene as a whole, we could read it as an eschatologized version of the processional hymns in which the gates of righteousness (in this instance, the temple gates) are addressed directly and through which a righteous people enter with thanksgiving (Pss 24:7-10; 100:4; 118:19-20)" (Blenkinsopp, Isaiah 56-66, 244). My thesis has been that the liturgy has already been eschatologized in the final form of the psalm itself (cf. 7.4.3.). Beuken summarizes the relation of these verses to the destiny of the seed of the servant as follows: "[l]t is conceivable that the topic of 'the seed' passes over into that of 'the people of the holy place' (w. 10-12). In this way the conclusion brings the theme of the righteous progeny further to the point that was announced in the prologue: YHWH gathers his servants in his house (56.6-8). ... We know that righteousness is necessary for admission to the sanctuary (cf. the literary genre of the 'gate liturgy': Pss. 15; 24; Isa. 33.14-16). At the gateways this decision is made, because behind the gates the recovered covenant is celebrated in the praise of $\left.\mathrm{YHWH}_{\text {( }} \mathrm{v} .9\right)$. Therefore the summons of $\mathrm{v} .10$ implicates the righteousness of those addressed, their acceptance by YHWH. These are now 'the people of the holy place'. The visionary drama announced by the prologue is concluded. Now 'the dispersed of Israel' are assembled in the house of $\mathrm{YHWH}$, together with 'the foreigners'. Altogether they are 'the servants of YHWH' (56.6-8)" ("Trito-Isaiah," 74). 
forms), the promise of exaltation, including the promise of "seed,"1093 is described in the future tense (yiqtol forms). As such, we still find ourselves "on the threshold" of consummation, or better, "at the foot of the mountain" (Ps 24:3), for the servant's work is related to the issue of Israel's capacity to ascend mount Zion and not his own. If the ascent of the communal Jacob after the judgement of exile is the means by which Yhwh consummates history, then the "declaring righteous" (hiphil צד, 53:11) of a recalcitrant Israel is Yhwh's means of enabling his once rebellious people (רור, Ps 24:6) to do so. That element within Israel that is obedient to the servant is transformed into the true Jacob and thus capable of returning to a transformed Zion. As such, the obedient, individual, suffering, killed, and then living and exalted servant is God's vehicle for getting his people to Zion, just as in Samuel and in Pss 2, 21-22 it is the Davidic king who, through his righteousness, is used by God to "get his people to Zion" (keeping in mind a certain metaphorical flexibility for the term "Zion," of course; cf. 9.1.3.4.; 9.2.3.2.2.). According to Childs, there is no attempt to explicitly connect the figure of the suffering servant with the messianic Davidic king of Isa 1-39, ${ }^{1094}$ yet at the same time there appears to be an analogy of function. ${ }^{1095}$

When we seek to relate the means by which the suffering servant redeems Israel to the structure of Psalm 24, a surprising inversion of the pattern emerges. The servant is present within both the second and third stanzas (and by ontological analogy he may well be present in stanza I, along the lines of the Christology in John 1:1). He is present within the second stanza ( $v$. 3-6) as the true Jacob, for he realizes what it takes to truly be Jacob. Having taken on the calling of the communal servant (Isa 49:3), he is indeed capable of making the ascent to Jerusalem/Zion. ${ }^{1096}$ The servant is also present in the third stanza, for

${ }^{1093}$ Isa 53:8 has a difficult reference to "his generation" (דורו). Can this be meaningfully connected to Ps 24:6?

${ }^{1094}$ Childs, Introduction, 335: "In light of the consistent pattern of prophecy and fulfilment, it is a remarkable fact that nowhere do the editors seek to identify the servant with the royal figure of First Isaiah (9.1ff.; 11.1ff.). The imagery of the two portrayals is completely different and there is no redactional effort whatever to unite them."

${ }^{1095}$ In an article on the redactional function of references to the "servant" (עבדיס) within the Psalter, Berges argues that, similar to Isaiah, the servants appear towards the end of the book, overtaking the function of the Davidic king ("Knechte," 162). Although, for reasons treated above (see 9.2.3.2.2.), I believe that he over-democratizes the concept of kingship within the Psalter, the move from Davidic king to servants (from Ps 89 onwards) strengthens the presence of a conceptual connection between the servants, the individual servant, and the Davidic king within Isaiah.

${ }^{1096}$ of course, metaphorical flexibility is required here. I am assuming that the language of the servant's "exaltation" is of the same substance as a successful ascent of Zion. Note the common

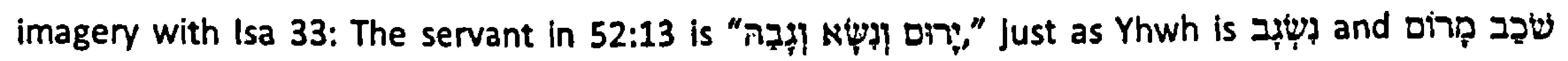


by being the true Jacob he becomes the King of Glory's vehicle by which to get communal Jacob on top of the mountain. The element of surprise is that whereas in Ps 24 the object of Yhwh's violence is anyone who stands in the way of the consummation of Yhwh's history-evil Jerusalem/Babylon (cf. Isa 33)-in Isa 53 the object of this wrath is the true Jacob himself, who now bears the punishment due to his communal counterpart. ${ }^{1097} \mathrm{~A}$ true Jacob emerges out of stanza II to become the object of Yhwh's wrath in stanza III and thereby the vehicle for the appearance of a righteous generation (רוT, v. 6) who may ascend mount Zion alongside him (stanza II).

The theological question may be raised at this point as to how it is that such an innocent death could be redemptive for Israel, and how it is that such a people could become righteous as a result of it. Isa 53 does not provide an explanation-the tone of the confessing "we" is itself one of surprise-and I will refrain from exploring this question here. Within the context of Childs' canonical thesis, these texts must be seen as fragmentary witnesses to a larger theological whole. Even systematic theologians have not yet reached a consensus on the precise nature of the atonement (see, for example, the uncertainty about the significance of the Christus Victor motif $\left.{ }^{1098}\right)$. This description, however, at least brings us closer to answering the question raised in 9.2.3.2.2. concerning the nature of the presence of David within Psalm 24. We saw that the canonical David was portrayed as a figure constituted by his unique role within the divine economy of salvation for Israel (9.1.3.1. 9.2.3.2.2.). Within this economy he was a vehicle of divine agency, yet this divine agency achieved its purposes by means of the free agency of David as one who subordinated himself to Yhwh's will. At times, David is presented as being the ideal Israelite, one who suffered alongside his people (e.g. Pss $17 / / 22$ ) and who followed God's law (Pss $16 ; 18 ; 24: 3-6)$, at times he is presented as the one who fights for his people, winning them redemption (Pss 20; 21; 24:7-10) (cf. 9.2.3.2.2.). Re-read in the light of Isa 53-having been invited to do so by the analogous theological structure between Ps 24 and the book of Isaiah as a whole-we see that the figure of David somehow infuses the entirety of our psalm. It is not a case of either/or-either David is a mere righteous Israelite or David is a

(33:5). Yhwh is thereby located in the same place where the "true Jacob" of 33:14-16 will dwell (

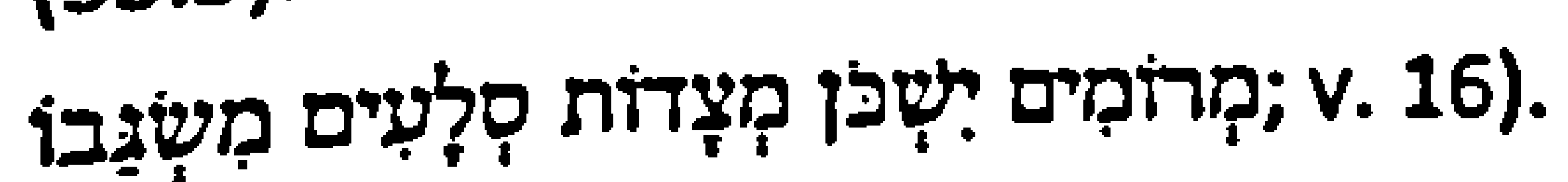

1097 Goldingay sees an analogy between the servant's suffering in Isa 53 and the suffering of the nation in exile, with the only difference being that the nation deserved it (Isaiah, 305).

${ }^{1098}$ Childs, Biblical Theology, 516-518. 
redeemer-it is a case of both/and. Within the mystery of the "new things" (תוֹדฺָุ; Isa 42:9) that Yhwh is doing, the obedience of one typed according to the David of the Psalter is the vehicle by which Yhwh-as one "mighty in battle" (Ps 24:8)-brings at least some of his people towards himself within the heavenly Jerusalem.

\subsection{Summary}

Having stated at the outset of this section that the function of this inquiry into Ps 24's broader canonical context is to enable us to better perceive the inner dynamic of the psalm itself (9.), it is time to summarize what we have seen so far and apply our results to Ps 24. We will start with our treatment of the human witness.

\subsubsection{Verbum}

In our initial analysis of Ps 24 as a discrete entity, we discovered that it appears to be a collage of older liturgical traditions (7.4.). In other words, an author/editor had taken hold of texts and motifs grounded in the lived experience of historical Israel and shaped them in a particular manner. We saw that there is theological continuity between the meaning generated by the final result of this shaping activity (1.3.) and the meanings these traditions and rituals had when enacted at the various stages behind the final form. From a diachronic perspective, for example, we posited a ritual in which the "horizontal" traditions of Israelite history (e.g. Exodus, Conquest, the rise of the Davidic monarchy) had been integrated into a cosmological frame of reference that gave these events a significance that went beyond the immediate concerns of historical Israel. Nothing less than the consummation of Yhwh's creation was being realized through the medium of Israelite history. This ritual-or the memory of it-was then further nuanced in the final form of the text by the insertion of an element of contingency: Present human participation in this event depends upon obedience to the will of God. The particular literary technique by which this new vision was rendered created an implied narrative in the final form, a narrative not unlike the one presupposed in Israel's ritual experience. Within its selfcontained literary context, however, this narrative functions as an abstraction from the particularities of Israel's various traditions. What is being witnessed to is the basic structure or pattern according to which God operates in and for the world. In short, creational order as a sphere for human flourishing constitutes the beginning and end of history (w. 1-2). This order is partially consummated by Yhwh's indwelling of it in the midst of his people (implied in v. 3), a move that makes the stability and fecundity of w. 1-2 available to his people in a special way (cf. 5). Yet the full consummation of this reality requires a response 
of obedience on the part of those with whom he would dwell (w. 3-6). The relationship that consummates creation is covenantal. Given the contingency of the consummation of this reality, it appears that w. 7-10 now function to signal the means by which Yhwh will deal with this contingency. Wickedness is painfully removed-within Israel and withoutand Yhwh enters his paradise with his community of the redeemed Jacob by his side.

We have also seen that Ps 24 went through a further level of theological interpretation. By means of its superscription - or at least by means of a later biographical Davidization of the superscriptions in general-the canonical persona of David was somehow introduced into the scheme of things (9.1.). We turned to the books of Samuel in order to gauge the nature and function of the canonical David and discovered that he played a key role in the realization of a history that shared the basic features of the narrative instantiated in Ps 24. Israel's destiny was set within the context of God's plans for the cosmos. This destiny was to culminate with an arrival at the holy mountain, God's elected location amongst his people within which he would dwell and from which he would bless. The condition for arrival was obedience to his torah. This did not change when Israel elected a king, for he too had to submit to the divine revelation of how to live in a manner that is holy and righteous. Once elected, however, this figure acquired a key role in the fulfilment of Israel's hopes, as David became God's elected vehicle for achieving the "rest" that Israel (and God) sought. We thus find that David acquires a double role in relation to the concerns of Ps 24: He embodies that which it takes for Israel to be itself $(v .6)$ and he is the vehicle by which Israel arrives at its God-given destination (w. 7-10).

Returning to the immediate literary context of Ps 24, we found that the David of Samuel mirrors the David of the sub-collection of Pss 15-24 (9.2.). The outer framework of this collection (Pss 15, 19, and 24) functions to establish the basic structure of the divine economy: Human obedience to divine torah (Ps 15) is the means by which creation life is realized (Ps 19), a reality that is ultimately consummated when Yhwh brings obedient Israel across the threshold of the sanctuary (Ps 24). Within this framework we found once again that the figure of David played a double role: $\mathrm{He}$ is a divinely elected vehicle for the salvation of Israel (Pss 18; 20-21) and he is an ideal member of Israel, even in suffering (e.g. Pss $17 ; 22)$. We saw further that these two dimensions of his identity appear to be simply juxtaposed with each other, leaving a gap for further interpretation. We concluded that this tension between a "royal" and a "democratized" David is found elsewhere in the Bible 
(Samuel; Isaiah; the juxtaposition of Pss 1 and 2) and turned to the relevant sections within Isaiah to seek further illumination.

The book of Isaiah also provides us with a narrative framework that echoes the one found in Ps 24 and the books of Samuel: The Lord offers life to his people on the condition of obedience, a life that is made fully available when God finds his rest amongst his people within Zion. As in the other stories, Yhwh actively intervenes in order to remove the obstacles to his people's realization of this desire. In Ps 24 he conquers evil through subduing the primeval oceans (stanza I), revealing his torah (stanza II), and overcoming his historical enemies (stanza III). In Samuel his righteous wrath can be focussed against those outside of Israel (the Philistines) and those inside (David's own entourage). In Isaiah, a new dimension of divine activity is revealed, for the measures God takes to clear the way for the consummation of creation in Zion go to an even deeper depth. Zion itself is destroyed in an act of cleansing. The fruit of this purifying fire is a people in exile now forgiven their sinsrighteous in the eyes of God-and thus capable of ascending to Jerusalem/Zion as the fulfilment of their own hopes.

In this context, the imperative of Ps 24:6 has not lost its urgency: In light of what Yhwh has done and has now promised to do (stanzas $\mid$ and $I I I=$ exile and restoration; judgement and forgiveness), Israel is called upon to realize its true identity as Jacob and thereby ascend to the mountain of life.

We saw, however, that the destruction of Zion was not the deepest depth to which Yhwh was willing to descend in order to get his Jacob. In the face of Israel's unbelief, a mysterious historical individual appears on the scene, embodying the identity of the nation and bearing in his own flesh, even unto death, the consequences of his people's continued disobedience. The narrative found in Ps 24 is picked up again when we hear about the ultimate fate of this obedient and righteous individual: He experiences restoration and is exalted upon the heights with Yhwh. Yet, as we have seen, the recapitulation of the message of Ps 24 within his own flesh did not serve as the replacement of the community (the $7 \pi$ of v. 6), it functioned to bring it into existence. Somehow, those who confess him and follow his torah (Isa 50:10) are his seed (Iרו), themselves now the redeemed (צדיקים).

Once again, the imperative of v. 6 does not lose its urgency: In light of the torah and the accomplishment of the servant, Israel is called to be the true Jacobl The answer to the "who" question provided in v. 4 is now supplemented-deepened perhaps-by the 
description of the suffering servant in Isa 53:1-12. That is what the true Jacob looks like, both corporately as well as individually.

How is David present in Ps 24? Somehow, the two strands of identity, the "royal" and the "democratic," come together in the servant of Isa 53. The David of the superscription is one of the people, for he embodies within himself Israel's appropriate response to the divine imperative, even when it means that he himself must become the object of the divine wrath displayed in the framing stanzas ( $w$. 1-2; 7-10). Yet precisely in being so, he also fulfils his royal function of bringing his people to their proper rest upon Zion. This, too, is displayed in the framing stanzas.

The effect of not only reading the David of the books of Samuel into Ps 24-as invited to do so by the logic of the superscriptions-but also of infusing that identity with its potential development in Deutero and Trito-Isaiah, is that the structure of Psalm 24 is maintained while intensifying the thematic interconnection of its parts. David is found throughout the psalm. He is the one who fulfils the criteria of v. 4 and thus makes it a reality. Indeed, his life, suffering, and restoration ${ }^{1099}$ provide the full content of the answer to the question of v. 3 , such that he is the torah that is proclaimed in v. 4 . His victory in obedience achieves a victory for Israel, for it provides the means by which Jacob may ascend the mountain ( $w$. 7-10). And yet his victory entailed becoming the object of the divine wrath, so that the King of Glory's killing of the innocent David became the means by which the obstacle to Israel's ascent is removed. And finally, it appears that the achievement of the servant David finds-somehow-its analogue in the mythic time of creation, where the construction of the world itself is the result of a vanquishing of the demonic forces of the ocean. Can one say that in order for God to get his communal Jacob upon Zion he has had to send their royal head and representative-Jonah-like-into the depths of the primeval sea?

Having concluded our analysis of Isaiah we see that much mystery still remains. How are we to proceed? A clue is provided by the ongoing function of v. 6 .

We have seen that at each level of exegesis, regardless of the context in which we situate Ps 24, the implicit imperative of v. 6 does not lose its urgency. In the context of the ongoing accomplishments of God that drive his history of salvation, the community of faith

${ }^{1099}$ The David of Samuel also experiences a restoration, after the rebellion of Absalom. 
must consistently realize its true identity by submitting to the divine imperative. The ever deeper theological embedding of this psalm throughout the canonical process has served to keep the imperative alive by retaining the structure and loosening the psalm's explicit referential context. The final form of Psalm 24 may belong to one of the latest redactional layers of the Psalter, thus explaining its capacity to encompass such broad swathes of Biblical tradition. ${ }^{1100}$ Yet its very canonization for an ongoing community of faith testifies to its continuing kerygmatic function and thus its capacity to encompass newer construals of the content of the divine economy. According to Christian understanding, this community has branched into two primary traditions: Rabbinic Judaism and the Church. Each community now reads its Old Testament/Tanakh through the lens of a broader deposit of tradition: the Talmud and the New Testament. The function of these broader bodies of tradition is not to override the plain sense of the Old Testament witness but to draw out its full implications, now grasped within the context of a broader vision of what is involved in the divine economy. ${ }^{1103}$ For the Church this economy inevitably finds its centre in the historical life, death, and resurrection of the eternal Logos: Jesus the Messiah (cf. $\underline{8.2 .)}$. On Childs' analysis, the Church's traditional claim is not that the Old Testament prepares for the New, but that the Old Testament witnesses directly to the same reality witnessed by the New Testament, albeit in its own distinctive idiom. Having attended to this Old Testament idiom in our two sections entitled Verbum, it is time to return to the res to see whether this pole of the dialectic may provide us with greater clarity concerning the inner coherence of Ps 24.

We start with a review of what we have seen of the res so far.

\subsubsection{Res}

Having rooted a primary source of Ps 24 's tradition-historical trajectory in the experience of God in the pre-exilic temple (7.4.3.), we turned to the systematic theologian Robert Jenson in order to explicate what this reality may, in fact, "look like" (․). Jenson; drawing on the total canonical tradition and Christian tradition concluded that its shape was Trinitarian: The reality beyond the gates is the "kingdom of heaven," a dynamic reality in which the Spirit opens the Father and the Son to each other for a communion of perfect love. We saw that the shape of the reality experience on the other side of the gates-

${ }^{1100}$ Although Psalm 24's liturgical parts come from some of the oldest layers of Israelite tradition (cf. 7.4.).The history of Ps 24, therefore, spans a large chunk of the history of Israel.

${ }^{1101}$ Cf. Seitz, "Old Testament or Hebrew Bible?" in Word, 61-74. 
heaven as a reality within God in se-reflected the canonical shape of our psalm (cf. the analogy between Barth's "Vollgestalt" and Childs" "final form" at the end of 3.6.3.2.). The horizon for the interpretation of the whole is set by half-stanza I: Yhwh's secure establishment of a sphere in which the fullness of life may flourish. Within the reality of God himself, this fullness of life is the telos of the divine movement of the Son to the Father in the Spirit (in obedience). Just as this reality is consummated when the Son "arrives" at the Father, so too does the "Son" of stanza II (Jacob) arrive, in the power of the Spirit (stanza III), across the threshold of the gates to be with his Father (v. 3).

We also noted the Trinitarian movement is not just "immanent," it is also "economic," i.e. the movement of the Son towards the Father in the Spirit opens up pro nobis to include our creaturely dimension of reality. The Son "ascends" to the Father by way of human history. This understanding accords with both our synchronic and diachronic analyses of the psalm. In both cases, we saw that the "mythic" reality present in half-stanza I is realized historically in stanzas II and III. However we interpreted the events in these stanzaswhether ascent is taken literally or metaphorically, liturgically or salvation-historically, or whether the divine wrath is directed against Israel or the nations or both-they represent the recapitulation of half-stanza I in the historical realm. Life-sustaining order is generated by conquering the obstacles that would hinder it in the historical realm. In addition to this, the abiding significance of the imperative in v. 6 continues to implement this reality in ongoing human history-including our own day-for by achieving its perlocutionary effect it removes one more obstacle to the consummation of creation.

In order to complete the dialectic mapped out in 7.1.3. above, we must now pose one final interpretive question to Psalm 24: In what sense does the economic movement of the Trinity enable us to grasp its full kerygmatic substance?

Before responding to this question directly, I will summarize two prior attempts to actualize the psalm's kerygmatic substance for the sake of the post-Biblical church, each taken from a very different tradition and historical period. The examples provided are not of equal weight, however, and their portrayal here is simply heuristic. Their comparison is designed to illustrate how Biblical exegesis of the kind practised above can be fruitfully brought into a two-way relation to dogmatic reflection, in particular the gospel as good news "for us." The first is a sermon on Ps 24:7-10, preached in Advent by the Reformed 
systematic theologian Eberhard Jüngel, sometime before $1968 .{ }^{1102}$ The second is a summary of the early church's construal of what could be called the sensus spiritualis of Ps 24 (dating to the first four centuries A.D.). In conclusion I will indicate the direction that I think that an interpretation of Ps 24 within the full context of the "canon of truth" ought to take.

\section{Res 2: The Divine Economy}

\subsection{Eberhard Jüngel on Psalm 24}

\subsubsection{Jüngel's View of the Res}

The fact that we concentrate our analysis on a homily should not detract from the seriousness of its content. According to Jüngel himself, the sermon is the moment in which the true substance of the Biblical text should come to light. ${ }^{1103}$ His logic is grounded in an appraisal of the historical nature of the text itself. Although it is the product of a long tradition-historical development, this complex history consists in a continual act of confession of a single referent: Jesus Christ in his relation to God. ${ }^{1104}$ This is "die 'homologische Grundsituation' des Textes, in die alle Texte in ihrer jeweils verschiedenen geschichtlichen Situation einstimmen." "1105 Jüngel does not differ here to what has been said of Childs' approach in Part I above (e.g. 3.3.). He does appear, however, to have a different

1102 Jüngel, Predigten, 25-30.

${ }^{1103}$ See also MCGlasson, Proclamation, 8-9: "the preaching of the Word of God is the Word of God. ... What is the point of contact between the glory of the risen Lord and the listening world? The answer is the weekly sermon. ... [T] he voice of Christian preaching is the voice of Christ. ... But what, then, is preached? ... The subject matter of Christian preaching is the truth."

1104 Jüngel, Predigten, 132: "in den Texten bekennen, wie auch immer, doch stets, wer es auch immer sei, Glaubende. Und sie bekennen doch Immer, sel es als den kúplos (Herrn), sei es als den Gottessohn, sel es als den Menschensohn, Jesus Christus In selner Zugöhrigkeit zu Gott, sei es zu Gott als dem Schöpfer, sei es zu Gott als dem Erlöser; sie tun es auch dann, wenn sie von Jesus Christus schweigen, weil sie aus dem Bekenntnis zu Jesus Christus enstanden sind. In der Zusammengehörigkeit von Gott und Jesus Christus bringen die Glaubenden aber Gott als ihren Gott zur Sprache. In jedem Text bekennen sich also: a) Glaubende b) zu Jesus Christus und damit c) zu Gott" (emphasis original).

1105 Jüngel, Predigten, 132. This is part of the historical intentionality of the human tradents of tradition and needs to be taken into account by exegesis: "Welchen Anspruch erheben diese texte? Sie erheben-so können wir sehr allgemein sagen-den Anspruch, als menschliche Worte Gott selbst zur Sprache zu bringen. In den menschlichen Worten der neutestamentlichen Texte ist also mehr zu finden als nur menschliche Meinung. Aber, und das darf nicht verkannt werden, dieses Mehr ist nur in menschlichen Worten und nur als Äußerung menschlicher Melnung zu finden" (emphasis original). 
emphasis when it comes to describing the nature of this theological referent. Rather than focusing on the shape of the divine economy from creation to new creation, he focuses on the existential moment in the believer when he confesses that Christ's death and resurrection has purchased for him reconciliation with God. The substance of the text, then, is what he calls the "eschatologically new situation," i.e. the situation in which we find ourselves reconciled with God in Christ (cf. the different meanings of the word "eschatological" discussed in 3.3.3. above). ${ }^{1106}$ The function of preaching is to bring this theological Sache to the congregation: "Verkündigt werden soll ja nicht der Text, sondern, das, was im Text als Zu-Verkündigendes zur Sprache kommt. Deshalb werden die Texte ausgelegt."1107 How does this more existential perception of the res shape his grasp of the substance of Ps 24 ?

\subsubsection{Jüngel's Sermon on Psalm 24}

The text allocated to Jüngel to preach on is only the final stanza of our psalm: w. 7-10. Jüngel thus takes this section as the starting point for his sermon. His interpretation of these verses, however, is shaped by the larger canonical context of the psalm, both literary as well as theological.

His exposition goes through four stages, each one dealing with either the concept of "gates" or "God." He presents his thoughts in the following order: Gates 1, God 1, Gates 2, God 2.

Gates 1: Jüngel opens with thoughts on the nature of gates in general: They serve both to guarantee and to deny access to a place beyond them. In particular, when the world beyond the gate and the world in front of it are in conflict, the gates remain closed. In this case, they function as a barrier rather than as a means of entrance. In Ps 24 we also have two "worlds" that are about to meet each other, separated for now by gates. One of these worlds is the world represented by the interior of the temple. Drawing on v. 1, Jüngel does not believe that it is the physical space itself that is of significance in the psalm. Rather, it is that which this space represents: the created order. We have come to a similar conclusion in our analysis above (7.3.2.4.3.2.1.). As we will see, however, the "created order" within

1106 Jüngel, Predigten, 134. This reality is grounded in the historical fact of Christ's life (as the only human capable of perfect devotion to God, pp. 133-134), though his accomplishment on the cross creates a redeemed community which transcends history (138). This divine reality is both the source (geschichtliche Ermöglichung) of the text and the object of its witness, and as such is part of the reality of the text itself (die Situation des Textes) which must be interpreted.

1107 Jüngel, Predigten, 130. 
the temple is understood to be the fallen creation that constitutes our present dimension of reality and not the eschatological consummation of creation in the life of God.

In sum, the gate provides access to the profane created order.

God 1: If the world inside the gate is profane, then the world outside it is sacred, for the person seeking to access it is "the LORD of hosts." Jüngel unpacks the significance of this name later in the sermon. For now, in order to build his image of the meeting of two worlds around a gate, Jüngel focuses on the identity of God as creator of the cosmos. This is an identification possibly furnished by w. 1-2. As such, the scene portrayed in Ps 24:7-10 is one in which the creator of the world is standing at the entrance to his own world, desiring to go in. As creator, Jüngel tells us, God has a natural right to enter his world.

Almost as a side-remark, Jüngel points out how "eery" this situation is (gespenstig). God desires to enter a temple devoid of his presence, or metaphorically/allegorically understood, a Godless world. If he stays outside, the world will remain like a "spectre," devoid of its true life. Jüngel, however, does not follow up on the metaphysical questions this situation raises. According to him, the psalm's focus is thoroughly theocentric, which means that it is what is going on in front of the temple that matters.

The nature of activity in front of the gate helps us understand what is special about this particular gate and the meeting of these two worlds. On the one hand, stanza III of our psalm depicts quite a fanfare, as a mighty warrior demands entrance. The potential violence implicit in the scene, however, is softened by Jüngel, who emphasizes the continuity between this stanza and the former one (w. 3-6): God the warrior's means of access parallels that of humanity's means of access. Just as humanity must give an account of itself, so must God ("Auf dem Weg der Menschen zum Heiligtum kommt Gott daher"). ${ }^{1108}$ Both must give an account of who they are, and the answer determines the success of their petition. God, just like humanity, must wait outside, before the doors are opened from the inside. In short, the fighter comes to the gates, but he does not fight his way through them. This testifies to God's meekness and human responsibility to let him in.

Gates 2: In the next stage of Jüngel's sermon, he attempts to penetrate the text to its substance (to use Childs' language), to "get to the heart of the matter" (to use Jüngel's). In order to expand the textual referent to encompass our world and thus draw us into the

${ }^{1108}$ Jüngel, Predigten, 27 (emphasis original). 
world of the Bible, Jüngel refers to his theory concerning the function of gates in general (cf. Gates 1). Working on the assumption that it is the function of the gate that is the key to its true significance, Jüngel lists other barriers or entrances in human life that have a similar function, e.g. national boarders, house doors, safe doors. This process of identifying the presence of doors by virtue of their function leads him to conclude that the "ultimate" gate is the gate of the human heart ("Auch an diese Tür und an sie vor allem klopft der Adventspsalm"). ${ }^{1109}$ This metaphorical gate functions in terms of interpersonal relationships: We can allow other people into our inner world and thus be transformed by them, or we can bar them from access. This is our decision, one under our control. The gates of the temple, then, which are the gates to the created order, become the gates to our hearts, and the gate openers are ultimately we ourselves. God does not force his way in (he limits himself to the path of humanity as found in w. 3-6; cf. God 1), rather he asks and we must decide to open. Jüngel even draws allegorical significance from the command that the gates be "lifted up": "Wer sich Gott öffnet ... der muß sich ihm ganz aufschließen."1110

God 2: Having established the true identity of the world on the other side of the gates as our own interior life, controlled by our will ("the heart"), Jüngel returns to the person outside the gate, the one desiring access to this world. God is identified using two titles, the first being given after the first has proved to be insufficient. Nevertheless, both titles have something to say about the identity of this God. According to the first title, he is not only the Creator of the Universe who has come along the path of his own creation, he is also a mighty warrior, the King of Glory. Jüngel considers the paradox that this warrior does not fight his way into our lives, but rather waits for us to accept him. If this is done, he can become a warrior for us rather than against us. The identity which is most appealing to the gates, and given its elucidation by Jüngel, clearly also the most appealing to the human being who controls the gates, is signified by the title "the LORD of the (heaven/y) hosts." In other words, God is the god of the divine kingdom (Himmel; Gottes Reich) with its power and potential for us. Opening the gates of our hearts to allow him into our world allows us to also participate in his world. This, as far as the requirements of the gates/human heart is concerned, is what really matters.

1109 Jüngel, Predigten, 28 (emphasis mine).

1110 Jüngel, Predigten, 28 (emphasis original). 


\subsubsection{Response to Jüngel's Actualization of Psalm 24}

Jüngel's interpretation is creative and sensitive to the shape of the final form of the text. He attempts to move through the text to its theological subject matter (i.e. God wishes to be a part of my life in the here and now). In order to do this, he struggles to respect the literary context, for all the psalm's stanzas are drawn upon for his interpretation. The first stanza is implicit throughout in Jüngel's emphasis on God's created order, of which he is the rightful King and yet into which he desires to enter peacefully. Stanza II is present in that its parallel structure to stanza III effects Jüngel's interpretation of the latter: God enters the temple along the path trodden by humanity, i.e. he humbles himself and brings himself down to our level. ${ }^{1111}$ Jüngel also situates the psalm in the broader context of Old Testament theology: The temple is seen to represent the cosmos, which Jüngel then interprets to be the unredeemed cosmos. God wishes to enter the world, and ultimately the world of our hearts, in order to redeem it, give it life by virtue of his presence. In this manner, the psalm is understood to be a kind of existential Advent psalm, in line with its position in the German Protestant calendar. ${ }^{1112}$

All in all, there is nothing theologically unorthodox here about Jüngel's theology. ${ }^{1113}$, believe this sermon could be preached in any church of any denomination and it could encourage any congregant. However, in light of my own exegesis of the psalm, there are some problems with his interpretation which skew the witness of the psalm to a degree. It appears that the source of this difficulty is Jüngel's existential interpretation of the res.

I mentioned in 10.1.1. that for Jüngel the "substance" of Scripture is "the eschatological new situation." We saw in 3.3.3. that this word means different things to different scholars. The impression created by Jüngel's language here is that the term primarily refers to a transformation of an individual's subjective perception of life in the here and now as a result of receiving the reconciliation that Christ has achieved for us with God. In light of this, it is understandable that Jüngel interprets the temple as being the human heart: Our human subjectivity is the ultimate target of God's redeeming activity, and so the substance of the text must speak to this dimension of reality. ${ }^{1114}$ This understanding of the res of

\footnotetext{
${ }^{1111}$ It is not clear to me how he reconciles the Lord's coming to the temple along the path of humanity and humanity being the ones who open the gates to the let him in.

${ }^{1112}$ See the lectionary readings for Advent in the Evangelisches Gesangbuch. Psalm 24 is the reading for every Sunday of Advent.

${ }^{1113}$ A similar interpretation was made by Augustine and Athanasius, see 10.2.2. This does not mean, however, that this interpretation does the most justice to the text I See below.

${ }^{1114}$ This is the moment in which Ps 24 "zum Wort Gottes an uns [wird)" (Jüngel, Predigten, 28).
} 
Scripture, however, conflicts with both the content and the form of Psalm 24 and thus blurs its message. Concerning content, our analysis above has revealed that the reality behind the gates of the sanctuary is the opposite of Jüngel's interpretation: It is heaven, i.e. God's dimension of reality, and not the human heart. God enters his own dimension of reality in stanza III and the question is whether humanity of stanza II will enter that "eschatological" reality with him. In the context of our analysis of Ps 24, "eschatology" refers to an objective future reality into which a human may one day enter, a reality which he anticipates in the present and at best experiences only proleptically. It does not refer to the transformation of one's subjectivity in the present, however much experiencing this future may have consequences for one's perception of the present world (cf. 2.1.). By designating the temple as the human heart, Jüngel's sermon short-circuits this cosmological-narrative element and thus misses the primary function of the psalm, which is to challenge Israel to be the true Jacob by virtue of its place within a particular divine economy that encompasses the past and the future.

In terms of form, Jüngel's designation of the temple as the human heart cannot produce a coherent reading of the final form of the psalm. If God is entering the human heart in stanza III, how are we to understand the human ascent in stanza II? Are humanity and God entering two different locations (seeing that humanity obviously cannot enter into its own heart and seeing that a pilgrim would not wish to ascend to a reality that is in need of redemption rather than offering it)? Is the temple in stanza II to be understood literally whereas the temple in stanza III is to be understood metaphorically? Although extending the meaning of the plain text in order to grasp its subject matter and thus actualize it for a later generation is certainly legitimate, it is also the case that the semantic extension has to remain coherent across the board (cf. $\underline{4.5 .2 .)}$.

In sum, according to Ps 24, that which Israel must receive is not God into its heart but a knowledge of his economy into its mind so that it may believe and live correctly in the light of that particular reality. ${ }^{1115}$

1115 Jüngel does step back from his heart metaphor and talk about the need to proclaim the gospel through the "gates" of the secular cities of the world (Predigten, 29). In itself, this is true, of course. But within Ps 24 the gates function to show where the cities themselves should go, not the place into which God enters. Jüngel does talk of Himmelstore on p. 29, but here he uses the term to metaphorically refer to the Lord and his angelic hosts. The meeting, then, is between two "gates," the gate to the human heart and the "gate" of God's reality (which is outside the former gate). 
We turn now to the approach of the Church Fathers.

\subsection{The Church Fathers on Psalm 24}

\subsubsection{The Fathers' View of the Res}

According to Andrew Louth's reading of the Church Fathers, their assumptions concerning the substance of the gospel were less focussed on human subjective response and more on the nature of a fact, a particular reality. ${ }^{1116} \mathrm{He}$ summarizes this reality as follows: "[T]he heart of the Christian faith is not something simply conceptual; it is a fact or, even better, an action, the movement of the Son sent into the world for our sakes to draw us back to the Father. ${ }^{\prime 1117}$ Although this does not exclude the existential dimension of personally appropriating this reality, the Fathers emphasized the structure of the reality itself rather than on our need to personally believe in it. Furthermore, on this analysis, the heart of the gospel is not our personal reconciliation with God in Christ in the here and now but the depiction of a journey towards a destination, i.e. movement of the Son towards the Father, with us in his train. Louth's citation of Dom Gregory Dix brings out this narrative element:

There is but one coming, in the incarnation, in the Spirit, in the Eucharist and in the judgement. And that is the 'coming' of 'One like unto the Son of Man' (who is 'the people of the saints of the Most High', i.e., Christ and the Church) to the Father. This is the end and meaning of human history, the bringing of man, the creature of time, to the Ancient of Days, in eternity. The same eternal fact can touch the process of history at more than one point. ${ }^{1118}$

In this context, the "Old Testament builds up a context, a matrix, in which the mystery of Christ can be incarnated." ${ }^{1119}$ In the New Testament story, this mystery becomes fact. In order to grasp this mystery, the Fathers used allegory, a "way of relating the whole of scripture to that mystery, a way of making a synthetic vision out of the images and events

My reading also has implications for mission. Whereas on Jüngel's reading the passage of God through the gates into a fallen realm implies that we should bring the message of the gospel through the "gates" of the fallen cities etc. of our world, on my reading our primary responsibility is to believe the gospel ourselves and embody it through "ascending" to Zion in obedience. The act of obedient pilgrimage is itself not only an embodiment of the reality of the kingdom, it functions as a witness to the those who observe it. This is similar to the function of Israel in Deutero-Isaiah (see 9.3.3.).

${ }^{1116}$ Louth, Mystery, 74.

${ }^{1117}$ Louth, Mystery, 89.

${ }^{1118}$ Dix, Shape, 262; cited in Louth, Mystery, 89 (emphasis original).

${ }^{1119}$ Louth, Mystery, 120. 
of the Biblical narrative"1120 (cf. 3.6.3.1.). The purpose of this type of exegesis is not primarily, as with Jüngel, to confront the congregation with the decision to accept Christ's forgiveness in the present, it is to encourage us to enter into the dynamic movement witnessed to by the literal sense of the text and to attempt to understand the depths of the mystery discerned there. Louth describes this as a move from fides to intelligentia. ${ }^{1121}$

Already we can see strong elements of continuity with my analysis of Ps 24 . The typical Patristic approach appears to emphasize the objective nature of God's total salvation history, a history with a particular narrative movement involving a beginning, a journey, and an arrival. Although it does not exclude the particular moment of the individual's appropriation of forgiveness that is so central for Jüngel's understanding of the gospel, it relativizes it somewhat by placing it within a broader framework. I will now provide a brief overview of Patristic exegesis of Ps 24 to see whether their approach may in fact bring us closer to the mystery contained therein.

\subsubsection{Patristic Interpretation of Psalm 24}

Within the first four Christian centuries there is a unanimous interpretation of Psalm 24 as a prophecy of Christ's ascension to his Father in the flesh, taking the redeemed righteous in his train. ${ }^{1122}$ The basic pattern is first clearly discernable in the Apocalypse of Peter, the oldest undeniable interpretation of Ps $24 .{ }^{1123}$ During Jesus' transfiguration and the appearance Moses and Elijah (Mt 17), Peter is portrayed as asking Jesus about the location of the other righteous members of Israel's history. By way of an answer he receives a vision of a paradise filled with the righteous individuals who had died before the victory of Christ. The righteous are explicitly identified as the ones spoken of in Ps 24:6. As it turns out, this paradise is only a kind of "pre-heaven," a place where they are kept as prisoners. A dramatic scene then enfolds in which Jesus and the two prophets ascend first into this "First Heaven" and then take the righteous further upwards into the true Heaven, the Second Heaven. This ascension creates "great fear and horror," implying that some kind of celestial resistance needs to be overcome. With the calling out of Ps $24: 7$, "Open wide the

${ }^{1120}$ Louth, Mystery, 121.

${ }^{1121}$ Louth, Mystery, 116. There is of course a broader context within which this act is to be carried out: the liturgy of the church and the act of prayerful contemplation. See chap. 2, "Tradition and the Tacit," in Louth, Mystery.

${ }_{1122}$ Kähler, Te Deum, 62: "Überall in den Zentren theologischer Arbeit ist ein gleichartiges Verständnis des Psalms wirksam." He references Palestine, Alexandria, Carthage, Southern Gaul, Rome, and Asia Minor. See also Heine, Reading, 133-137.

${ }_{1123}$ Cf. Kähler, Te Deum, 53-55. 
Gates, you princes" (cf. the text criticism of vv. 7 and 9 in 7.2.2.), - presumably addressed to the angels guarding the gates-the righteous are brought to their final destiny. ${ }^{1124}$

As mentioned, other interpretations of Ps 24 kept the basic structure found in the Apocalypse of Peter while varying some of the details. Justin, in his so-called First Apology, read Ps 24 in connection with two other major Christian proof texts: Isa 53 and Dan 7:13. The Isaiah passage seems to have furnished him with the answer to the question as to why Jesus was not recognized by the angels at the gates of heaven: He arose in the human form of the suffering servant, without beauty, honour, or glory. ${ }^{125}$ Irenaeus tells us more explicitly why Jesus was not recognized: He ascended in the "flesh" ( $\sigma a p \xi)$, whereas he had descended without it. ${ }^{1126}$ The conclusion of the ascension is witnessed to by $P_{s} 110: 1 .^{1127}$ Tertullian also sees a prophecy of the Ascension, but he does not see a reference to a simultaneous deliverance of the saints from Hades. This is for doctrinal reasons: He is convinced that "Heaven is shut to all [but the martyrs] until the end of the world." 1128 Interestingly, Hippolytus recounts that the Gnostics had a similar interpretation, one which in itself is not necessarily un-Christian. The text they draw upon to explain the confusion of the gatekeepers is Ps 22:6: "But I am a worm and not a man, scorned by mankind and despised by the people."1129

By the time of Athanasius, this standard interpretation had become so established that it could function as a context for the interpretation of other texts without the need to

${ }^{1224}$ The section Kähler refers to is chap. 17, which goes as follows: "And behold, suddenly there came a voice from heaven, saying, 'This is my beloved Son in whom I am well pleased: [he has kept] my commandments.' And then came a great and exceedingly white cloud over our heads and bore away our Lord and Moses and Elijah. And I trembled and was afraid; and we looked up, and the heaven opened and we beheld men in the flesh and they came and greeted our Lord and Moses and Elijah and went to another heaven. And the word of the scripture was fulfilled: This is the generation that seeks him and seeks the face of the God of Jacob.' And great fear and commotion took place in heaven, and the angels pressed one upon another that the word of the scripture might be fulfilled which says, "Open the gates, you princes." Translation by Elliot, Aprocryphal New Testament, 600-609; available online at http://www.21stcenturysaints.com/resources/APOC PETER.pdf (accessed August 2011).

${ }^{1125}$ Kähler, Te Deum, 55-56; Heine, Reading, 133-134.

${ }^{1126}$ Kähler, Te Deum, 57; Heine, Reading, 134-135.

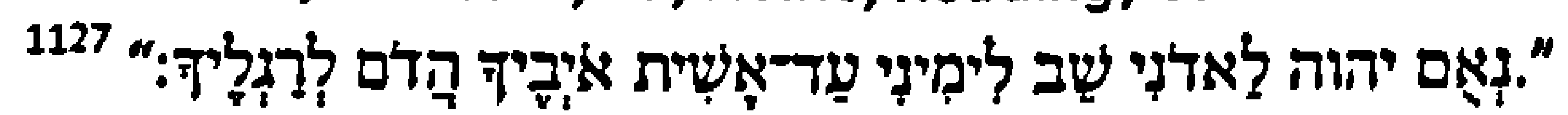

${ }^{1128}$ MacCulloch, Hell, 266; cited in Kähler, Te Deum, 58-59.

${ }^{1129}$ Kähler, Te Deum, 59. Hippolytus provides a brief summary: "He comes to the heavenly gates: angels accompany Him: and the gates of heaven were closed. For He has not yet ascended into heaven. Now first does He appear to the powers of heaven as flesh ascending. Therefore to these powers it is said by the angels, who are the couriers of the Saviour and Lord: 'Lift up your gates, ye princes; and be lifted up, ye everlasting doors: and the King of glory shall come in'" (ANF:5, 170). 
actually quote the psalm. The psalm had become "ein Mittel, Vorgänge, von denen man eigentlich nichts wissen konnte, vorstellbar zu machen, erzählbar zu gestalten." ${ }^{1130}$ In Athanasius' case, it provides him with a warrant for asserting the deity of the exalted and incarnate logos as described in Phil 2:5-11. Gregory of Nyssa even claimed that Ps 24 is a better witness to the work of Christ than the Gospels themselves, for the latter only talk of the work of the earthly Christ. The noble prophet David, on the other hand, gives us access to events that take place within the heavenly sphere. ${ }^{1131}$ The scene that Gregory perceives in Ps 24 is more elaborate than the other interpretations. The first set of questions and answers in w. 7-8 refer to Christ's descent through the gates that separate the earthly from the heavenly spheres. The opening of the gates by the "irdischen Engeln, denen das menschliche Leben anvertraut ist," leads to Jesus' incarnation and his battle with the Devil, "der die menschliche Natur gefangen hatte." ${ }^{1132}$ After his victory over the powers of sin and death Jesus returns to heaven. Jesus is once again unrecognizable by the angels guarding the gates of the upper regions, for his incarnation and the scars of the battle have left him unrecognizable (Greogry, along with many other interpreters, cites Isa 63:2). The question and answer scene is thus repeated in w. 9-10. This time, the title the "Lord of the Powers" is mentioned, because Jesus has consummated his work. The Gospel of Nicodemus is a particularly detailed interpretation of Ps 24 entirely in relation to the Harrowing of Hell. ${ }^{1233}$

Other variations on Ps 24 are also found that retain the structure of a triumphant ascent of Christ, yet interpret the manner in which this happens in different ways. Although Origen follows the typical interpretation of Ps 24 as a prophecy of the Ascension, ${ }^{1134}$ in his commentary on Matthew he also applies it to the story of Jesus' entrance into Jerusalem (Mt 21:1-11). Here he sees a parallel between the questions of the inhabitants-"who is

1130 Kähler, Te Deum, 61.

1131 Kähler, Te Deum, 61: "Ihm kommt der Prophetie, die im 24. Psalm liegt, geradezu der Rang einer Ergänzung der Evangelien zu, ja, der Psalm ist ihnen im Grunde überlegen."

1132 Kähler, Te Deum, 61.

1133 Kähler, Te Deum, 63-64. According to this account, two righteous Jews who had been resurrected from the dead shortly after Jesus' own resurrection give eyewitness reports on how their resurrection took place. In short, Jesus entered Hell and there was a call to open the gates. Satan responded by locking them in fear. The enslaved saints inside cried out again for the doors to be opened. Satan's partner, Inferus, asks "Who is the king of glory?" King David, in his function as prophet, answers with Ps. 24:8 and repeats the demand to open the door. Inferus binds Satan and, so it seems, lets Jesus in. Jesus enters, establishes his Siegeszeichen, which is the cross, and then takes all the saints to Heaven.

${ }^{1134}$ Heine, Reading, 135. 
this?"-and the questions posed in the psalm. ${ }^{1135}$ Ambrose interprets the psalm in a manner similar to Jüngel: It talks of Christ's entrance into the human heart. Finally, Augustine appears to oscillate between a number of referents for the term gates: They are the gates of heaven, the gates set up by the rulers of this world, the gates of our mind. ${ }^{1136}$

\subsubsection{Response to Patristic Interpretation of Psalm 24}

We saw that, according to Louth, the substance of Scripture for the Fathers was "the movement of the Son sent into the world for our sakes to draw us back to the Father" (10.2.1.). The Fathers interpreted Ps 24 as being a prophecy of precisely this movementsome going so far as to see within stanza III a witness to both his descent and his ascent (though see my treatment of the function of stanza II in 7.3.2.4.3.2.1. which also factors a descent into the picture). For the Fathers, the event of the resurrection in the flesh was not just another stage within the life of Christ that could be reported and prophesied about for its own sake, it is the consummation of God's plan of salvation, the "climax of the mystery of Christ." 1137 According to Douglas Farrow, the Feast of the Ascension "was celebrated as the crown of Christian feasts and the ground of the sacraments." ${ }^{1138}$ We thus see that the Fathers accorded Ps 24 the same theological significance in its capacity to witness to the basic economy of God as I have sought to show in my own analysis above (see, e.g., 8.3.).

Beyond the Father's recognition of Ps 24's fundamental theological significance, it is interesting to note how well their interpretation accords with the poetic structure of the final form of the psalm. For a start we have the simultaneous entry of both a community (the righteous; cf. v. 6) and God himself (Christ, the divine Son). The relation of this movement is one in which the second actualizes the first (cf. 7.3.2.4.3.1.). On their own, the righteous were not capable of accessing heaven - whether they were imprisoned in Hades or a "first paradise." It is the work of the Lord that consummates their upward journey by bringing them to the threshold of their final destiny. The nature of the work carried out by

1135 Kähler, Te Deum, 60.

${ }^{1136}$ Kähler just focuses on his moral reinterpretation of the scene (62), but there appears to be more diversity than this. See Schaff's translation in NPNF:8, 61. Augustine was in fact a student of Ambrose, which may explain the similarity in their subjectivization of the temple. Interestingly, Augustine and Ambrose are criticized by Farrow for subjectivizing the Ascension, even while affirming it ontologically (Ascension), see 10.3.

1137 Farrow, Ascension, 9.

${ }^{1138}$ Farrow, Ascension, 9. This stands in stark contrast to its celebration today, he says. "Today it is something of an embarrassment. Both exegetically and theologically the ascension is quickly assimilated to the resurrection. Its festival is commonly passed over as a redundant marker on the road to Pentecost, allowing it little or no impact on the shape of Christian life and thought" (9). 
the Lord is also apposite: He is a victorious warrior-a blood-stained one if read in relation to Isa 63:1-3-now returning from his battle with the forces of evil (cf. the common reference to Ps 110:1). ${ }^{1139}$ There is also the interplay of "mundane" human history and a spiritual dimension hidden from view. The gates are the gates of heaven and thus participate in the heavenly realm (cf. the term עולם in vv. 7 and 9; cf. 7.3.2.2.2.), though the journey to get there is by way of historical Jerusalem (cf. e.g. 7.4.2.1.). The work of salvation goes beyond the incarnation, and thus identification with human Israel (v. 6), for it includes a further descent into Hell, the primordial source of all evil (w. 1-2). Just as the psalm appears to represent a consummation of God's plan for Israel, so does the ascension of Christ represent a consummation of God's plan for humanity. Finally, the Fathers have picked up on the potential canonical link with lsa 53 and made it central to their exegesis. The vehicle of the redemption of the righteous is the divine Son, the human son of David, whose mission is embodied in the suffering of the mysterious servant-the true Jacob.

The biggest criticism of this exegesis concerns the issue of genre (cf. 4.5.2.). If it is the case that the sensus spiritualis must be discerned within the sensus literalis, to what degree can we say that Ps 24 is a "prophecy" of the ascension of Christ? Although there is a diversity and complexity to Patristic interpretation to which my incredibly brief summary has done little justice, the Patristic approach to this question gives the impression that the text functions as a window onto a single sequence of events within the life of Jesus. In light of my treatment of the verbum above, this understanding of the text's function must be rejected. Rather than being a supernatural description by the prophet David of a single event foreordained to take place almost two thousand years later, I have argued that the final form of Ps 24 is the product of a tradition-historical development consisting in a dialectic between authoritative tradition and the experience of God. The result is a schematic portrayal of the basic shape of God's ways in the world, a pattern that can be found repeated in the events of Israel's canonical history. Any connection between Jesus' career and Ps 24, therefore, must be based on an analogy of substance, on the "filling-up" of a mould, and not on a direct correlation between prior prediction and later occurrence (cf. 4.5.2.)..$^{1140}$

1139 In this connection it is interesting to note that Kohlbrügge sees an analogy between $v .2$ and Ps 2:7-9 (Auslegungen, 194). Incidently, he also interprets Ps 24 as a "Schlußstein der fünf vorhergehenden Psalmen" (189).

${ }^{1140}$ Cf. Childs, "Prophecy;" "Witness." 
The strength of the type of exegesis outlined above is that it takes the church's confession of the ontological unity of the two-testamental canon seriously. Christ truly is the substance of Scripture and thus provides the key to its ultimate meaning. The danger is that by rushing too quickly to the referent and not attending to the shape and function of the witness, the prophetic message is replaced by an alternative narrative and, if this narrative is out of touch with the flow of Scripture and tradition in general, with an alternative gospel. ${ }^{1141}$ Having heeded the Father's impulse to relate the narrative of Ps 24 to the narrative of Christ-rather than to the existential moment of our acceptance of Christ (as Jüngel, cf. 10.1.2.)-we conclude our exegesis by reflecting more closely on the nature of Christ's narrative and its possible relation to the canonical shape of Ps 24.

\subsection{Psalm 24 and "Jesus History"}

\subsubsection{Jesus History}

"Jesus history" is the phrase Douglas Farrow uses to describe the peculiar and unique narrative shape that constitutes the identity of Jesus Christ. ${ }^{1142}$ It consists in his birth, life, death, resurrection, ascension, heavenly session, and return -a series of events in a genuine temporal sequence that may not be reduced to one another. In the light of recent interpretation, this warning applies most importantly to the distinction between Christ's resurrection from the dead and his ascent into heaven in the flesh 40 days later. Farrow takes this latter event, reported in Lk 24:50-53 and Acts 1, to be one that took place in our dimension of space and time, one in which Jesus' physical body was literally taken up into the place that Jenson has described as "heaven" and that I have identified as the reality behind the gates of Ps 24 (8.). ${ }^{1143}$ Farrow's response to the complaint that this is impossible to imagine in a post-Copernican world is that the place to which Jesus ascends is entirely different to our reality, constituted by God's own uncreated dimensions of time and space. The ascension entailed Jesus" "elevation beyond any temporal or spatial frame of reference open to us. Not that Jesus has become atemporal or atopic, as if his incarnation had been

${ }^{1141}$ Herein lies strong parallel between allegorical and historical-critical exegesis. See Childs, "Sensus literalis" and section 4.5.1.

${ }_{1142}$ Farrow, Ascension. He appears to be inspired by the work of Hans Frei, especially in Identity.

${ }^{1143}$ Farrow, Ascension, 22. 
reversed; ${ }^{1144}$ but rather that he has been given a time and a place in which and from which to be Lord of every place and time."

More significant for our purposes than the metaphysical explanation of the Ascension is its significance within the context of God's plan. If, as I have said, the eternal innerTrinitarian movement in which the Son is brought to the Father in the Spirit is opened up to include created time and space (8.2.), Christ's ascension into heaven is the moment in which the movement of the economic Trinity is consummated and human existence is enabled-in Jesus and by the Spirit ${ }^{1146}$ - to participate in the life of the kingdom of God. Just as the Son eternally moves from and towards his Father, so does he move from and towards him in our time and space in a literal birth and then ascent, one that took its departure in the vicinity of Jerusalem. ${ }^{1147}$

The Ascension, then, is the climax not just of Jesus-history ${ }^{1148}$ but of the history of Israel and indeed the history of the cosmos. Farrow tries to demonstrate this by embedding the event within its larger Biblical context. The journey motif is central to the message of LukeActs, where Jesus, like David before him, makes his slow, tortuous advance to Jerusalem. This journey is then recapitulated by his disciples, in particular in the travels and trials of Paul. ${ }^{1149}$ Jesus' journey to Jerusalem and the cross, however, is a mirror of his postresurrection journey to the heavenly Jerusalem. That which is achieved on the cross, namely the perfecting of the imago dei, is brought into the presence of God and rendered capable of communion with him. For this reason, Jesus' ascension and not just his resurrection is "undertaken on behalf of God's people and with a view to the realization of their kingdom hopes."

This becomes clear within the context of the larger Biblical narrative. Farrow turns initially to the apocalyptic vision in Dan 7, which he sees as telling the same story as Luke.

${ }^{1144}$ Here Farrow sides with Calvin over against the Lutheran doctrine of Christ's ubiquity.

${ }^{1145}$ Farrow, "Christ Coming," 147. See Ascension for more details. For a recent argument for divine spatiality and temporality see MacDonald, Metaphysics.

${ }^{1146}$ The task of the Spirit in the ascension is "to present Jesus to the Father as beloved son and heir, and to present him to us also, in his heavenly session, as brother and Lord" (Farrow, Ascension, 266).

${ }^{1147}$ Does this echo the glory cloud associated with God's כבוד??

${ }^{1148}$ Farrow argues that the ascension is the hinge connecting Acts and Luke and the key to the new history of the people of God.

${ }^{1149}$ Farrow, Ascension, 22-23, citing Wright, NTPG, 379-380.

${ }^{1150}$ Farrow, Ascension, 23. 
This purely visionary scene, however, portrays what happens on the other side of the glory cloud. ${ }^{1151}$ If Luke 24 provides us with a departure scene, Dan 7 provides us with an arrival scene, albeit here with the whole people of God in view.

[W] hat we see 'from above' is something which at the end of the age will take place in human history, namely, the people of God being exalted over the destructive chaos of the nations ... And that means that we are glimpsing something of the world's own destination, when the human imago dei has been reformed as the priest-king within creation through the perfecting and the vindicating of the saints. ${ }^{1152}$

This journey motif is found elsewhere in Scripture, says Farrow, and is connected with the motif of the cosmic mountain. He briefly summarizes this motif as follows:

The biblical story begins with Eden, of course, the mountain-garden of God from which Adam was forced to descend, at the foot of which was the flaming sword of the guardian cherubim, which would frustrate any attempt to return. The pattern of descent and ascent is furthered (and proleptically fulfilled) in the story of the great flood, during which it is granted to one man, his family and representatives of the animal creation with him, to rise far above even the highest places of our fallen, chaotic world, until he comes to rest on Ararat. Next is the man-made mountain of Babel, provocatively pushed upwards in the very face of the cherubim, a mountain which Yahweh himself stooped to level. Its positive part is Sinai, which God graciously invited Moses to ascend on behalf of his people, on which the seventy elders also 'saw God' in table fellowship. There on Sinai the pattern was laid out for the holy tabernacle, in which the high priest was to ascend by stages into the divine Presence once each year, and from thence descend to bless the people. When this tabernacle ... itself comes to rest on Mount Zion, kingship in Israel is co-opted with it, so that ascent to the Davidic throne likewise comes to hold promise of access to the lost blessings of the mountain-garden of God. ${ }^{1153}$

Jesus' ascent, then, is the typological fulfilment of a journey that has had its starts and stops throughout world history.

Thus in the end Babel proves only a foil for the much more sinister Calvary, where Zion becomes the ironic mountain of death with its man-made trees. Then again, Ararat, Sinai and Zion in turn show themselves foils, not merely for a lost Eden, but for a new cosmic glory-temple on the heights of which man is to dwell as the true image of God, fully permeated and empowered by the overshadowing Spirit. Jesus, enabled by the Spirit, is the builder of this temple

${ }^{1151}$ Farrow, Ascension, 25: "What Daniel envisioned from above ... Luke is now able to chronicle from below."

1152 Farrow, Ascension, 24.

${ }^{1153}$ Farrow, Ascension, 27. He recognizes the the crucifixion was also an enthronement. "Yet on the cross he is still the king in exile. God has another and better throne than the one we devised!" ("Christ Coming," 236, fn. 15). 
and the first embodiment of his image. Through his resurrection and ascension he will realize in the presence of God the fruit of the work he accomplished here with us, when we in our own crude parody of the ascension lifted him to the cross. ${ }^{1154}$

Farrow identifies the arrival scene with the day of Pentecost, proclaimed as a royal coronation in Peter's sermon in Acts 2. The fruit of this coronation is the "pandemonium of Pentecost," patronage marking the occasion of his accession to the throne. ${ }^{1156}$ This is in preparation for the final dénouement of his second advent. The intervening period is likened to "a period of transitional government. ... It is an establishing of the conditions under which, and of the officialdom through which, he is to rule in the kingdom without end." ${ }^{1157}$

The church, as the "community of the new covenant between God and humanity, which is grounded in the self-offering of Christ," ${ }^{1158}$ is born into this situation of "transitional government." This is significant for the question of its own identity, for it exists at the point where two histories diverge: the history of Jesus and the history of the world. On the one hand, the establishment of Christ at the right hand of the Father created the possibility for true ecclesial being. ${ }^{1159}$ On the other hand, the church still participates in a world seemingly untouched by the fruit of Jesus' offering. The church may only remain true to itself to the degree that it remains anchored in Jesus' ongoing history, his past, present, and future acts. For Farrow, this situation is Eucharistic, for it is at this sacrament that the church is not only reminded of its true ontological ground, in the power of the Spirit it may also become united to the living Christ as he already participates in the fullness of the kingdom of heaven. ${ }^{1160}$ Yet it must not be forgotten that Jesus' ascension means a divergence from our still fallen history. The experience of the kingdom in the present can only be proleptic, a foretaste of Christ's still-impending return. ${ }^{1161}$

\subsubsection{Psalm 24 and Jesus History}

In our review of the theological interpretation of Ps 24 by Jüngel and the Church Fathers, we came to the conclusion that the latter approach did better justice to its form

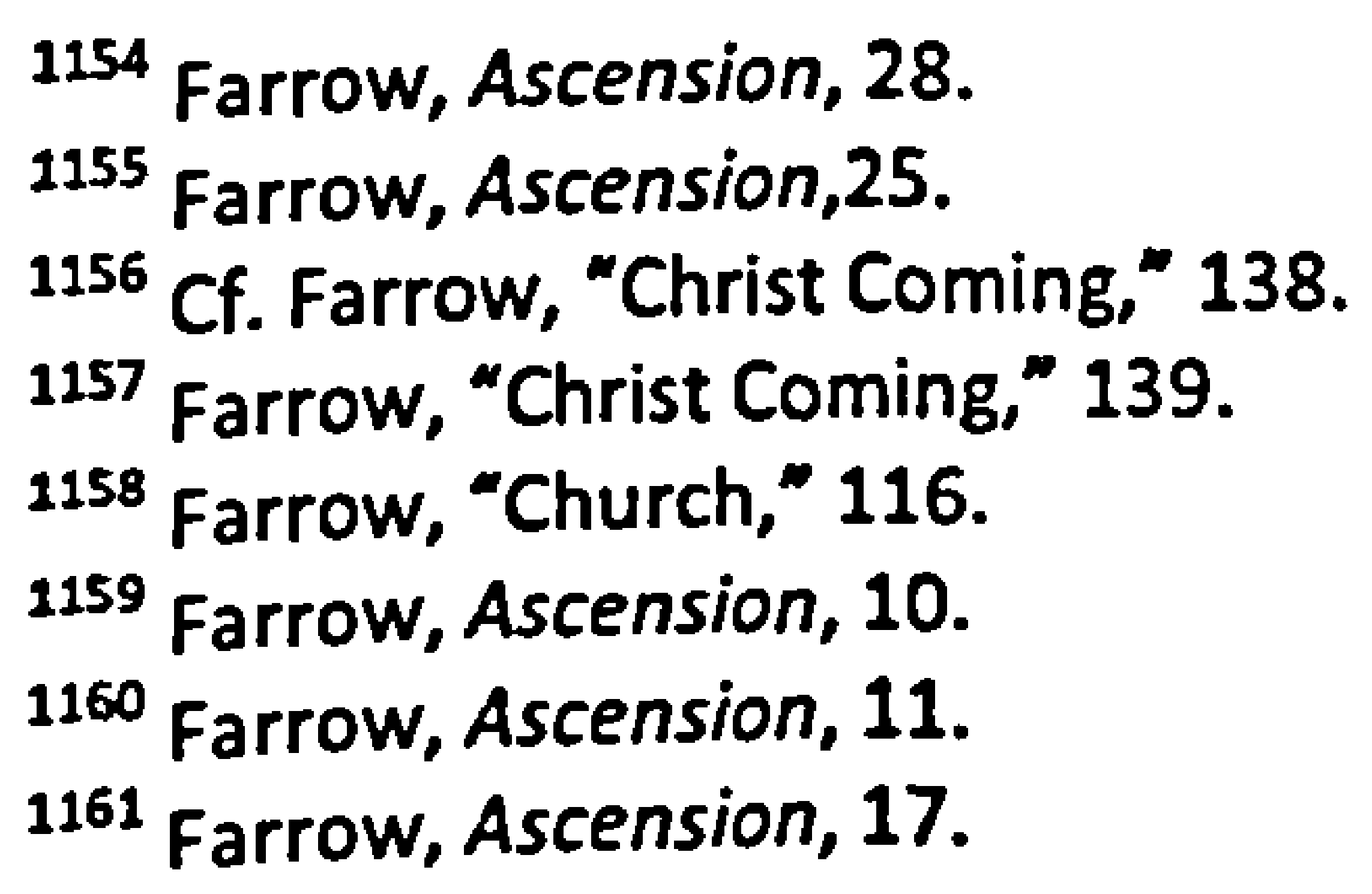


and content. By relating Ps 24 to the ascension of the divine messiah they fixed its meaning in terms of a single event that in itself consummates the basic Biblical pattern that we have seen repeated throughout Scripture: God himself, in the form of his human "son of David," brings his people to their heavenly destination by means of his confrontation with the forces of evil, both by his obedience to the torah and by his direct confrontation with the power of evil on the cross. The Fathers' interpretation of the genre of the psalm, however, as pure future predictive prophecy, such that it simply portrays events that would one day take place, does not accord with the genre of the psalm itself. The result is a kind of rationalization of the psalm which tries to fix its meaning by speculating as to what precisely must have happened to Jesus after the cloud hid him from his disciples' sight. ${ }^{1162}$ This interpretation does not only not do justice to the form of Ps 24 , it threatens to go beyond the plain sense witness of the New Testament concerning the nature of Jesus' mission (cf. Gregory of Nyssa's comments in 10.2.2.). In order to understand this mission more appropriately, we turned to Douglas Farrow's construal. Reading Ps 24 in relation to this more modern interpretation of "Jesus history" has increased the fruitfulness of the connection that the Fathers made between Ps 24 and the Ascension, particularly in the way in which Farrow's construal brings out the significance of the indirect imperative of v. 6: "this is ... Jacob."

As with the Fathers, Farrow's portrayal of the significance of Jesus' ascension has numerous points of contact with the witness of Ps 24 . Both narratives portray a journey of ascent ${ }^{1163}$ that climaxes in the arrival of both humanity and God at the holy city of Jerusalem, cite of the temple, the place of access to "heaven," i.e. that special place where God's life is consummated-for himself and for us (‥). Both stories recognize that this is a journey that should be trod by the community of Israel and both place the success of this journey within the horizon of God's plan for creation. The means of success involves obedience to God's will, for it is disobedience that has tarnished the imago dei. Farrow also hints at the element of battle in this ascension movement (cf. stanza III)-so prominent in the Church Fathers-but unfortunately he does not give it the centrality that Ps 24 would

${ }^{1162}$ Perhaps one can say that here the Church Fathers have made a mistake similar to the historical speculations of historical critics who similarly feel obliged to construct various historical, sociolorical or cultural contexts by which to fix the meaning of the text. See Childs' comments on the relation between allegory and historical criticism in 4.5.1. above.

${ }^{1163}$ On the symbolic meaning of על ע.3.2.4.3.1.3. above. 
require. ${ }^{1164}$ Finally, Farrow picks up on the typological patterning by which Jesus' identity is rendered, a literary technique (though see Minear's comments at the end of 3.6.3.1.) that we have also seen at work in Ps 24 , as its story is brought into relation to other parts of the canon (see especially $\underline{\text { 9.). }}$.

Of particular significance, especially given Childs' theory of Scripture's canonical function (3.3.3.), is the centrality for both Ps 24 and the Farrow's version of the Ascension of the issue of ecclesial identity. We have already seen the significance of this concept for Ps 24 in our exegesis of v. 6 (cf. 7.3.2.2.1.). Its significance for Farrow can be seen in the larger context of his discussion of the Ascension, namely the way in which it grounds ecclesiology. ${ }^{1165}$ The important point of connection is the way both accounts attempt to render ecclesial identity. On a basic level, Ps 24:6 identifies the true Israel in terms of its ethical conduct. Yet at a deeper level, one that is revealed when one probes into the poetic structure of the psalm (7.3.), the grounds for the possibility and success of such conduct have been and are being laid by Yhwh himself. Yhwh provides for Jacob's obedience in the past tense by already having conquered the evil that would overwhelm his created order (stanza 1); Yhwh provides for Jacob's obedience in the present and future tenses by battling to remove the obstacles to Israel's obedience (even in the form of Israel's own, temporary, destruction in exile) and giving them the hope that he will one day bring them to their longed-for destination. In Farrow's framework this pattern can be given a Christological interpretation. Living in the "already but not yet" of Christ's current heavenly session, the battle has already been won in the past through Christ's death and resurrection ${ }^{1166}$ and made effective the moment Christ crossed the heavenly threshold to render Israel fit to stand before God. At the same time, we are living in the period of his absence, dependent upon the power of the Spirit to equip us for the continuing battle against the powers of evil, to conform us to the image of the true Jacob, and thus to prepare us for the day when our flesh too will be exalted to participate in the community of the Father and the Son in the

1164 "Of course the messiah must resist every possible shortcut on his journey. He cannot ascend the heights of the temple directly, as the devil suggests, for the temple itself requires reconstruction, a reconstruction he will accomplish in connection with his own person through bitterconflict with the world, the flesh, and the devil-and especially with those who take it as their task to guard the temple [see John 2:12ff.]" (Farrow, Ascension, 28).

${ }^{1165}$ The full title of his book is Ascension and Ecclesia: On the Significance of the Doctrine of the Ascension for Ecclesiology and Christian Cosmology. According to Farrow's public CV, this book was described by Professor Ellen Charry of Princeton Theological Seminary as "nothing less than a theological breakthrough" (http://people.mcgill.ca/douglas.farrow/).

${ }^{1166}$ This is Kohlbrügge's interpretation of stanza I in Auselgung. 
heavenly Zion. This Christological re-interpretation, however, also finds its impetus within Ps 24, for it echoes the pattern created by its Davidization. Jesus, the true royal son of David, is the one who brings his people to their appointed destination, ruling now from the right hand of the Father. At the same time, he received this right by taking on the form of a servant, descending from the heights above the earth to do battle with the Devil below it. $^{1167}$

Within this Christological context, the implicit imperative of v. 6 still stands for the church today, along with the canonical framework that gives it meaning. We still live within the context of stanza II, at the foot of Mount Zion trying to ascend, still contained within its "unrealized" temporal frame (cf. $\underline{7.3 .2 .4 .3 .2 .}$ ). In order to arrive at the destination of creation, we must realize our true identity and become the true Jacob by putting the ethical conduct demanded by God into practice. We can do this, however, for we are bracketed by divine achievement. Looking to the past, we can celebrate the Davidic victory over the great serpent (w. 1-2), and looking to the future we can look forward to the day when the true David, who is the true Jacob, will bring us in the Spirit to the place where the creational blessings of stanza I are realized in the divine-human communion of stanza II.

\section{Conclusions}

This thesis has sought to contribute to the ongoing discussion about theological hermeneutics by providing a theoretical account of the inner coherence of Brevard Childs' "canonical approach" (Part I) and by exemplifying that approach with a "canonical" interpretation of Psalm 24 (Part II). My starting point was the general observation about the circular nature of interpretation, which requires an understanding of both the particular text at hand as well as its broader "reality," i.e. its context. This applies as much to Luke's portrayal of Jesus' Biblical exegesis on the road to Emmaus as to the kind of historical-critical methodology proposed by John Barton. The difference is a matter of how

${ }^{1167}$ Given that Ps 24 was the ascension text for the early church, it is fascinating that it does not get a single reference in Farrow's entire work, which deals so much with Patristic interpretation. Perhaps he recognized this omission, when he wrote in his dictionary article on the Ascension: "The biblical landscape, in other words, is full of peaks and valleys, of ascents and descents, literally as well as figuratively, historically as well as liturgically. The Prophets and the Psalms (including the songs of ascent) integrate the Edenic aspirations of the people of God with the geography of Zion, the temple liturgy, the spirituality of covenant life, and geopolitics. Psalm 24, for example, becomes a cipher for the whole biblical vision, Dan. 7 for the full sweep of redemption history" (Farrow, "Ascension," 66; emphasis my own). I hope that my thesis substantiates this claim. 
one interprets the nature of both the text as well as its context. The decision one makes at this level influences how one extracts meaning from the text.

With this general observation in mind we turned to Brevard Childs' own construal of these two entities: text and context or verbum and res. We saw that Childs' answer was shaped by the two contexts in which he operated. On the one hand, he was situated within the post-Enlightenment tradition of historical-critical analysis of the Bible. In other words, he sought to attend to the nature of Scripture as the product of historically and culturally particular human tradents. The adequacy of the tools for analysis, then, was determined by their ability to do justice to this dimension of the text. On the other hand, his experience of reality was such that he could not believe that the universe was a closed system operating according to the purely immanent principles of cause and effect. There was another dimension of reality - the reality of God-which breaks into our dimension in acts of salvific self-revelation. In particular, the divine subject of this revelatory activity operates through a historically and culturally particular human community, the people of Israel and the church, into which Childs felt himself adopted and by means of which he could grow in the knowledge of this reality. Given that this community is the tradent of the Biblical tradition that Childs studies, it is logical that he believed that it is the God who reveals himself through this community that constitutes the ultimate "context" of Scripture.

The remainder of Part I consists in an analysis of Childs' understanding of Scripture's form and content as well as the hermeneutical implications he drew from this understanding. I decided to analyse these two entities independently of one another in order to see how they come together. Childs himself did not do this and to my knowledge neither has any study of his work.

My analysis of Scripture's form was divided into two stages. I first looked for elements of continuity amongst all authoritative traditions "across" time, i.e. when considered "synchronically" at one point in time. I concluded that for Childs all the Biblical traditions in all their diversity functioned to point beyond themselves to a particular God and to shape the community of faith in light of that reality. I then looked for elements of continuity within individual traditions "through" time, i.e. throughout their tradition-historical growth, and concluded that they are characterized by dialectic and Sachkritik (criticism according to substance). In other words, the growth of each strand of tradition consisted in an attempt to do better justice to the single divine content (i.e. substance) contained within earlier levels of tradition in light of a growing knowledge of that reality. The result of this theo- 
critical dialectical process is a literary "final form" that does better justice to the one divine reality undergirding the whole. This is why the final form is the authoritative form for the community of faith: the source of that community's life is the one reality of God which is given its fullest authoritative expression in that particular form of the tradition which has definitively theologically critiqued and hermeneutically shaped all previous layers for the sake of later generations of the faithful. The power of the final form lies in its more adequate capacity to render the content of the source of the community's life.

Having outlined Childs' grasp of the human dimension of the tradition, we turned to the nature of its theological content. This is hermeneutically significant because for Childs this divine reality is actively involved in the production of Scripture itself (i.e. he is both the subject and the object of its witness). Thus, the theo-critical tradition-history and the final form into which it eventuated were ultimately seen to be the result of the "coercion" of the Spirit, whereby the human witness was rendered capable of truly witnessing to its divine referent. The same applies to those who received and perhaps reshaped the sacred tradition: In the power of the Spirit they were rendered capable of perceiving the true theological substance contained within the prior witness. The result is that it is not only the case that the human tradents intended to witness to God, in the power of God himself they did in fact achieve this. This provides a further reason for respecting the final form of the text: It is the arena constituted by God himself in order to reveal himself to his human partners. It also has the hermeneutical implication that the exegete is obliged to respect the history of ecclesial interpretation, for if it is the case that the final form of Scripture functions to continually reveal God, then one should expect to be able to identify "family resemblances" in the history of faithful exegesis.

I concluded this section by relating its content to Childs' theory of a multi-level approach to interpretation. The canonical tradition has provided us with a particular shape which is to be interpreted. We must, therefore, respect this shape. This requires an exegesis that draws upon the best modern exegetical tools available for grasping the shape of the final form of the text. Yet the affirmation of the ontological unity of Scripture within the reality of God requires that we go beyond the simple plain sense of the text to grasp the undergirding reality that unites the whole. We should therefore move beyond the individual texts and inquire into how they have been rendered within the broader Biblical tradition, at each step respecting the particular manner of their configuration (e.g. by not subordinating the OT to the NT, given the logic of the form of a two-testamental canon; or 
by respecting the genre of "narrative," even when attempting to identify a unified substance within it). Ultimately, this involves reading the text in light of the reality (i.e. the substance) itself. By moving from text to reality and then back again we participate in the same hermeneutical spiral that constitutes all good interpretation.

In Part I, the concept of "substance" was the axis upon which everything else rotates in my portrayal of Childs' theory. To my knowledge, no other interpretation of Childs' approach has given this concept such a central role. In highlighting its significance and in illustrating the way in which it relates to and unites the various strands of Childs' thought, I hope that Part I will have made a contribution both to our understanding of Childs' "canonical approach" as well as the further practice of theological interpretation. Even if one does not accept every detail of the portrayal, it seems to me that this is the level upon which further theoretical work in this field must operate if genuine progress is to be made in the face of the fragmentation and secularization that has characterized so much Biblical study.

The viability and fruitfulness of Childs' approach was then tested in Part II, where I assumed the truthfulness of his construal and then read Psalm 24 within that context. For a start, this required drawing upon contemporary methodology, as the canonical approach is not a method. We found that on the one hand some recent form-critical and poetic theory continues to affirm the importance of extra-textual information for the historical interpretation of the text. At the same time, there has been a growing appreciation of the text's ability to constitute its own context by means of the poetic function of language. 1 tried to give equal weight to both in my interpretation. I started with a poetic analysis of the psalm in order to see how its form constrains its meaning; 1 then posited a brief tradition-historical thesis in order to show how the poetic form relates to the growth of the psalm over time. We saw that there was strong theological continuity: Synchronically, the text appeared to reflect a basic eschatological narrative whereby God consummates his creation by inhabiting it with his people upon the condition of their obedience and after having violently removed all obstacles to that consummation. The diachronic analysis helped us understand the elliptical nature of this narrative: It has been constructed out of the fragments of temple liturgy. The historical dimension also enabled us to appreciate something of the force of this editorial decision: By drawing upon known cultic experience an echo was created of that experience, even while theo-critically reconfiguring that experience within a more developed theological framework. 
Our synchronic and diachronic analyses were guided by the assumptions outlined in Part I, and the result appears to be a better grasp of the message of the psalm itself. Thus, by looking for a theocentric focus, we saw that the reality of God constituted the horizon for the question of human identity; by looking for its kerygmatic function we saw that the psalm functioned to shape the community of faith in light of this reality. We also followed Childs in assuming both the Trinitarian nature of that identity as well as its presence within other parts of the canon. Concerning the Trinity, we saw that by identifying the historical location of the psalm's genesis within the cult a bridge was provided for thinking about the nature of "heaven" as a reality experienced within the temple. This in turn enabled us to see the deeper theological bonds that united the various parts of the psalm: Not only is the implied narrative a reflection of a typical eschatological pattern, it reflects the dynamic shape of the divine reality itself. In other words "heaven," i.e. that which was encountered in the temple, is the "moment" of the union of the Father with his Son in the Spirit through the Son's obedience. The movement internal to the divine being is played out historically in the history of Israel, such that the content of Psalm 24's witness is given a deeper dimension. Its content is theological in the literal sense of the term.

Concerning the ontological unity of the tradition, we followed canonical pointers internal to Psalm 24 (i.e. its superscription and its canonical shape) to see whether its broader literary context could sharpen our grasp of its content. Its superscription pointed us to the books of Samuel, its canonical shape pointed us beyond these books to the subcollection of Psalms 15-24 and the book of Isaiah. In all three bodies of tradition we found the same basic movement identified in the poetic shape of the psalm as well as the reality experienced within the temple: A human entity, either the people of Israel or King David, ascends to the presence of God in his power and upon the condition of obedience in order to consummate the purpose of the cosmos. These three portions of Scripture also provided us with an angle for answering a question raised by the superscription: What is the relation between David and Psalm 24? The answer was not clear, given the fragmentary nature of the tradition, but the impression created is that Psalm 24 provides us with the context for interpreting the significance of David's life. In other words, he is a figure within the implied narrative, and this in two ways. On the one hand he is the true "Jacob," the one who fulfils the requirements for ascending to Yhwh in "heaven"/Zion. On the other hand, he is the human vehicle for the redemption of Israel and thus the means by which Israel is enabled to ascend to Yhwh in "heaven"/Zion. In particular, Isaiah 53 gives the impression that he embodies these two functions-i.e. as obedient representative of Israel and as redeemer of 
Israel-within the one act of being punished for Israel's sins, thus recapitulating their exile and creating the condition for their final ascent. This interpretation of the presence of David within Psalm 24 functions to bind its parts even more tightly together. The psalm consists of three parts: The first outlines the goal of creation (vv. 1-2); the second outlines the human means of its consummation (vv. 3-6); the third portrays the divine means of its consummation (w. 7-10). A David interpreted as the suffering servant of Isaiah 53 fulfils part 1 by embodying part 2 and fulfilling the function of Yhwh in part 3.

The circle of interpretation was closed in the final chapter. Having set Psalm 24 within its larger literary context we turned once again to an interpretation of the question of the Bible's ultimate substance in order to better understand Psalm 24's inner unity. By factoring in the agency of King David, a potential connection is suggested with Christian confessions of Jesus as the agent of Israel's salvation-a connection already suggested by the Trinitarian shape of the psalm. We first turned to more theological exegetes in tune with the broader rule of faith for interpretive guidance and found the traditional interpretation of the psalm as a prophecy of the Ascension to be suggestive. We then saw that one particular construal of the significance of the Ascension within the divine scheme of things (by Douglas Farrow) illustrated not only a host of thematic and structural parallels, it also managed to connect the narrative dimension of the Psalm-i.e. its portrayal of the divine economy-to its kerygmatic function-i.e. its call to Israel to realize its true identity. In short, obedience to God is the means of consummating God's creation by ascending to God in heaven, but God himself has provided the grounds for the possibility of this obedience. He has overcome the primal powers of evil present in the cosmos (wv. 1-2) and the human heart ( $v$. 3-6) through the crucifixion and resurrection of the obedient son of David (Wv. 1-2; 7-10); he will also return one day to consummate this work in our dimension of time and space (wv. 1-2; 7-10). There is a "meantime," however, namely life within the tension between the "already" and the "not-yet." Christ has already ascended to the Father in heaven to enable our true communion with him, yet being in heaven means that he is currently not with us. Like Jacob in Ps 24 , then, we must learn to inhabit this tension by looking both to the past and to the future. Cognizant of this greater divine reality, we will be able to realize v. 6 by stepping out of the realm of potentiality and entering the realm of actuality, i.e. to truly become like the servant of the Lord.

By its very nature, canonical exegesis functions to both open up and to limit interpretive possibilities. This has been the result of my exegesis of Psalm 24. On the one 
hand, limits have been set on the possible number of meanings that may be extracted from Ps 24. It has a definite shape, the perception of which is strengthened by its repetition both throughout Scripture as well as within certain dogmatic construals of Scripture's substance. On the other hand, Psalm 24's poetic and elliptical nature as well as its canonical configuration within a larger intra-textual matrix function to allow a range of possibilities for actualizing the psalm. A contribution of Part II of this thesis is to illustrate both the limitations and the possibilities that interpretation within the canonical context can offer us. Depending on the situation of its reader(s), for example, one may identify with the figure of Jacob in different ways. Are we to be challenged to become Jacob, out of fear of the judgement promised in $\mathrm{w}$. 7-10 and out of a sense that we are living against the grain of the cosmos, or are we to rejoice that we already are Jacob, looking back in gratefulness of God's achievements in the past (w. 1-2) and forwards in hope to his future intervention (w. 7-10)? Even within the canonical tradition we have seen the multivalency of concepts such as "earth," "holy hill," "Lord of Hosts," "gates," "David." As long as we stick to the canonical witness that this is the basic and unchanging pattern of God's ways with us and that this pattern represents the ultimate shape of the history of the cosmos, these canonical boundaries give the preacher-exegete the freedom to reinterpret their world and challenge their community in a variety of ways in light of the divine reality.

\section{Appendix: Analysis of Childs' Exodus and Isaiah}

\section{Commentaries}

My analysis of Childs' canonical approach in Part $I$ is highly theoretical with few exegetical examples. The purpose of this appendix is to clothe the theory with exegetical flesh. For the sake of consistency, I have decided to limit myself to his two commentaries, Exodus and Isaiah. An analysis of these two commentaries is helpful for seeing the continuities in Childs' approach, for not only do they almost bracket his career, the former was written before the term "canonical approach" was developed whereas the latter was written after the term had already become problematic for Childs (Exodus was written in 1974; Isaiah in 2001). ${ }^{1168}$ There is, however, a difference in terms of scope between the two commentaries. Although they both belong to the same series (Old Testament Library,

1168 "I ... resist the practice of some immediately to characterize my approach as 'canonical,' since the label has only engendered major confusion. Frequently, I have had genuine difficulty in even recognizing those features that have been assumed by reviewers to be constitutive of $\mathrm{my}$ approach" (Childs, Isaiah, xii). 
published by Westminster John Knox Press), Exodus includes an overview of the text's Wirkungsgeschichte as well as constructive theological reflection. Isaiah, on the other hand, is limited to commentary, with the odd excursus or comment touching on broader theological themes. ${ }^{1169}$

In what follows I analyse Childs' commentaries in terms of some of the basic categories operative in section 1. I first look at his statements concerning the nature of the witness itself, i.e. Israel's verbum; I look at Childs' comments on the substance of that witness, i.e. its res.

\section{Verbum}

\section{a. The Profile of the Tradents}

The logic of Childs' canonical approach flows out of a commitment to the reality testified to by the prophets and apostles. He does not start with an a priori commitment to the final form, synchronic exegesis, or a thematic approach to Scripture. Rather, he looks to the historical tradents that gave us this witness and attempts to understand what they were getting at. From that analysis his gaze is directed elsewhere, but only after the tradents have redirected him.

Thus we find in Exodus evidence of a diversity of tradents involved in the production of the text. The "Plagues of Egypt" narrative (Ex 7:8-11:10), for example, consists of Priestly and Jahwist sources with small fragments of the Elohist $(P, J, E)$, supplemented by late glosses. ${ }^{1170}$ Each source has its own narrative account of the plague, drawing on a common body of oral tradition, which originally stood independent of the others. These authors responded to their tradition in different ways, shaping it for the next generation. The Jahwist, for example, "shows tremendous freedom and imagination in fashioning his account," despite the "traditional forces bearing on the writer which had determined in general the conclusion and general structure of the narrative. ${ }^{1171} \mathrm{~J}$ builds in a concession motif, for example, creating a sense of increased tension in which Pharaoh's reneging on a previously granted concession $(8: 28 ; 9: 28)$ turns to an impasse created by the inadequacy of Pharoah's later offer, (10:8-11), climaxing in the final breakdown in communication (10:24-29). In addition to this, the Jahwist skilfully portrays Moses and Pharaoh as

\footnotetext{
${ }^{1169}$ The Wirkungsgeschichte of Isaiah is the subject of a book in its own right: Struggle.

1170 Cf. Exodus, 131, for Childs' suggested source divisions with glosses.

${ }^{1171}$ Childs, Exodus, 135.
} 
competing antagonists-despite the roles which tradition had assigned to them-and creates an interesting tension between the LORD's absolute demands for release and his willingness to negotiate. ${ }^{1172}$ The Elohist, on the other hand, is only preserved in fragmentary form, though as a continuous strand nonetheless. Its movement follows that of the Priestly writer and seems to reflect more the original tradition which was their common source. The plagues come in quick series and have no affect on Pharaoh because of the hardness of his heart. The editorial integration of $E$ with J results in an expansion of J's basic schema, such as the transition from the LORD's executing the plague in J to Moses' being the agent. Again, the $P$ source reflects a variant tradition to that of $\mathrm{J}$. For example, there was a distinction between plagues and miracles which originally served to distinguish the traditions of P and J. In P's schema Moses and the magicians compete in the performing of miraculous signs, yet the signs soon take on the characteristic of plagues, whereas the J source speaks initially of plagues, but these shortly function as signs. $P$ also interprets the function of the hardening of Pharaoh differently to $E$ : Rather than plagues being a result of Pharaoh's hardness, Pharaoh is hardened so that the LORD can multiply his signs. Another difference to $\mathrm{J}$ and $\mathrm{E}$ is that for $\mathrm{P}$ the killing of the first-born does not belong the the plague tradition but to an originally independent Passover tradition. This plague is neither a plague in a sequence nor a sign, rather in P's account it functions to bring about the release of the Israelites, in fulfilment of the promise of 7:3-5. $P$ also links the plague tradition to the crossing of the sea, in contrast to J, for whom the sea tradition belongs to the tradition of the wanderings in the wilderness.

Not only do these authors actualize their sacred traditions in differing ways, the combination creates an actualization of its own. Both the Passover and Reed Sea traditions are brought into closer proximity to the plague tradition and there is a merging of miracles and plagues so that signs function as plagues and plagues serve as signs. In addition to all this, the various glosses evidence further theological reflection on the content of the tradition, actualizing the text for later generations in various ways. In 9:14-16, God's longsuffering does not represent self-restraint rather than impotence. 9:19-21 evidences a didactic interest to distinguish between "god-fearers" and the unbelievers, providing a testimony that the solidarity of judgement against all Egypt could always be relieved by faith in God's word. 10:1b-2 is a theological expansion, Deuteronomic in character:

${ }^{1172}$ Childs, Exodus, 136. 
The author uses the hardening vocabulary of J, but the theology of P. Any clear-cut distinction between sign and plague has also been lost. The expansion reflects the early interest in the actualization of the plague for a later generation. Here the Deuteronomic interest is more didactic than liturgical (cf. Ex.13.14f.; Josh.4.21). The understanding of the plagues as a testimony to God's great power by which to make sport of mighty Pharaoh is at work. ${ }^{1173}$

In this compact summary all the elements that characterize Childs' understanding of Israel's dialogue with tradition and God are present: critical use of authoritative tradition in light of a broader theological purpose with the aim of identifying God's will for later generations.

Again, the various construals of the three sources is not only a response to a common tradition, but a theological response to a theological problem present within that ancient tradition. Childs notes the presence of a "strange atmosphere" of "historical distance" that pervades the whole. ${ }^{1174}$ His search for the original Sitz im Leben leads him through the history of transmission to "a primary, non-derivable stage." Prior to the construals of J, $P$, and $E$ is a level of tradition in which Moses is universally seen to be a man "possessed of power to perform miracles." Yet, despite this power, he was unable to force the king of Egypt to release the Israelites.

In fact, this fundamental failure of the miracles to subdue Pharaoh accounts for the variety of reflections which sought an explanation. Pharaoh's heart was hardened; Pharaoh continued to renege on his promise; the magicians used magic to copy Moses. Only in the plague stories was a tradition retained in which such great miracles, constantly repeated, continued to fail. The fact that ultimately plague $X$ did not accomplish its end, did not remove the difficulty of the earlier one, nor explain the failure. ${ }^{1175} \mathrm{Childs}$ concludes:

the sense of the mystery of Pharaoh's resistance lies at the root of the tradition. Now it is apparent that the essential problem with which we began is not ultimately form-critical in nature, but profoundly theological. The interpreter is still faced with the task of penetrating the mystery of God's power before human pride. ${ }^{1176}$

\footnotetext{
1173 Childs, Exodus, 142.

1174 Childs, Exodus, 142.

1175 Childs, Exodus, 149.

${ }^{1176}$ Childs, Exodus, 149.
} 
Indeed, within the body of the commentary itself (i.e. interpretation of the final form), Childs notes that despite the presence of different sources, in the final form there is no real tension.

Rather, they contribute to the richness of the narrative and vary the pattern of the series to prevent the threat of monotony in recounting the long series. Because the concessions reach an impasse, in the final analysis there is no real conflict in terms of content between the ... approaches to Pharaoh's resistance. ${ }^{1177}$

Israel's witnesses did not only take the form of literary interpreters of tradition. If one digs back even further, Childs believes, there is evidence of cultic rituals and sacred offices (Childs often gives precedence to the oral stage as being of more significance for the current shape of the text than the interweaving of various sources ${ }^{1178}$ ). Perhaps his most complex theory concerns the existence of two forms of the Mosaic office rooted within ancient Israel's cultic institutions, the traditions of which were later combined at an oral stage of development before the prophetic authors of the source documents provided their own additional literary stamp. ${ }^{1379}$ These two religious institutions are deduced from two conflicting narrative sequences. In the first, the people are terrified by the theophany of God at Sinai and request Moses to serve as mediator (20:18-20). God accepts the proposal and mediates the law through him. Then on the basis of the divine commands Moses leads the people in a ceremony in which the covenant is ratified $(24: 3-8)$. The ritual consists in a rehearsal of the law, a commitment by the people, and a rite involving blood manipulation which seals the pact. On the other hand, there is a conflicting story in which God himself legitimates Moses, a decision planned from the outset by God (19:9). Later, Moses alone is given the commandments and on the basis of these laws God makes a covenant with Moses on behalf of Israel (34:27). In this tradition the people do not participate in a covenant ceremony of ratification but are simply informed by Moses of the covenant (34:32). Central to this pattern is that God's direct revelation-face to faceadheres to Moses alone and not to the people.

The stereotyped nature of these stories leads Childs (along with Mowinckel and von Rad) to the conclusion that they do not simply describe a historical event. Rather, they have a cultic stamp and function as aetiologies for the establishment of an ongoing office

${ }^{1177}$ Childs, Exodus, 155. Emphasis mine.

${ }^{1178}$ See Childs' handling of sources vs tradition-history on pp. 7-8; 184-186; 274-284; 321-326.

${ }^{1179}$ Childs, Exodus, 344-360. 
within an institution. Though both offices share prophetic and priestly characteristics, they differ in their institutional locations. ${ }^{1180}$ In short, the first form of the Sinai tradition "had its setting in the covenant renewal festival in which Moses functioned as the prototype of covenant mediator between God and the people."1181 The second sequence also represents an office (see the frequentative tense in 34:34), though this time anchored in the institution of the tent of meeting (ch. 33), which parallels Sinai in its function as the site of divine theophanies. In this office, Moses speaks to God "face to face" and is represented as a "continual vehicle of the will of God," a "continuous medium of revelation,"1182 as well as an intercessor $(34: 7,9)$ and recipient of the divine spirit (Deut 31).

In the later history of tradition, the institution of the tent of meeting declined, to be absorbed by covenant renewal tradition. This dominant form of the tradition has given the overall structure to the present Sinai narrative in Exodus 19-24. This process was only intensified by the author of Deuteronomy, who has completely overshadowed the tent tradition. Nevertheless, the tent tradition has not been completely eliminated. It still enriches the Deuteronomic concept of the office, as now a major feature of Moses' function is his intercession for the people (Deut 9:13-21; 25-29). Finally, in the Priestly theology one can trace another diverging development. The vocabulary of the old tent of meeting tradition has been absorbed into the Jerusalem theology. The tent has now

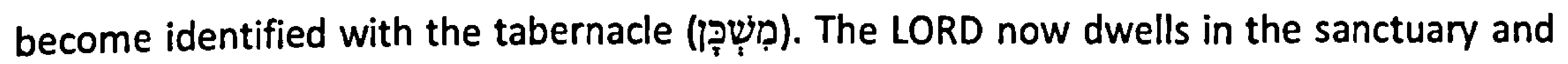
the cloud and glory reflect the permanent divine presence. "Nevertheless, the priestly school retained its sense of continuity with the older tent tradition and continued to afford a channel for preserving traditions of Moses' office which were found in the tent tradition, such as the shining face of Ex.34.29ff."1183

The final set of tradents are the redactors, who have attempted to bring these disparate though interrelated traditions-turned-source documents into a unified narrative. Thus, in the sealing of the covenant narrative (24:1-18), Childs identifies the following signs of harmonization: $:^{1184}$

${ }^{1180}$ Childs, Exodus, 357.

${ }^{1181}$ Childs, Exodus, 355.

1182 Childs, Exodus, 356.

1183 Childs, Exodus, 359.

${ }^{1184}$ Childs, Exouds, 502. 
1. Whereas v. 1a speaks of the ascent of the elders in a way which seems to disregard Moses' special role as mediator, w. $1 \mathrm{~b}-2$ have altered the original impact of the verse so that Moses' unique role is not diminished.

2. Originally there were two different accounts of the covenant ceremony. That described above and one involving a covenant meal. In order to harmonize the two, w. 1-2 and 9-11 have been joined to $v$ v. 3-8, so that the meal now functions as a culmination of a single rite.

3. v. 2 had singled out the special role of Moses. This element is now joined by a literary redactor to $w .3-8,12-14$ in order to produce the effect of different stages in a series of ascents up the mountain. Verse 2 provides a point from which to make a smooth tradition to the command in v. 12.

With the publication of Isaiah twenty seven years later a "paradigm shift" had taken place in critical methodology. ${ }^{1185}$ Within the study of Isaiah, there has been a shift beyond literary and form criticism to redaction criticism, with its focus on the structure of the book as a whole, the force of textualization of the oral tradition into a written corpus, the impact of the historical prophet on the redactors as well as the activity of retrospective reading, whereby earlier material was reinterpreted by later material. ${ }^{1186}$ Childs' commitment to canon as a "quality of the text" obliges him to draw on the latest developments in order to better grasp the peculiar profile of the tradents. Nevertheless, the basic lineaments of his theory remain the same: Israel has testified throughout its history to its God in a dialectical relationship with its diverse sacred traditions, registering its fullest understanding in the final form of the text with the intent of guiding future generations of the faithful.

Thus, there was a historical Isaiah whose preaching has been preserved in the document bearing his name. Childs references the work of H. G. M. Williamson, who claims that nearly all the parts of chap. 1 are derived from a prior written form of the words of Isaiah himself. ${ }^{1187}$ Though he finds the theory speculative, Childs judges that it is helpful in showing the high level of continuity of chap. 1 with the preaching of Isaiah. ${ }^{1188}$ Again, the historical prophet preached in oracles of various genres, such as accusation, invective,

\footnotetext{
1185 Childs, Isaiah, 2.

${ }^{1186}$ Childs, Isaiah, 2-3.

${ }^{1187}$ H.G.M. Williamson, "Relocating."

${ }^{1188}$ Childs, Isaiah, 16.
} 
torah instruction, trial summons, dirge, and promise. ${ }^{1189}$ These oral proclamations were collected into literary compilations which developed as the oracles were added. Within the larger narrative framework of the prophet's proclamation, clear components emerged, namely God's plan for Israel's judgement, signs of a promised faithful remnant, and the ultimate judgement of Assyria. These components were repeated and reinforced throughout chaps. 1-12 within a constantly recurring pattern, even when the relationship remained often fragmentary. Again, these elements existed at the primary level of the tradition, though they appeared in strikingly different ways in the collection (cf. the exegesis of, e.g., chaps. 1, 6, 7). Their development, then, was a matter of dialectic. On the one hand, faithful editors responded to the oracles, which were a major force in determining the shape of the larger composition. ${ }^{1190}$ On the other hand, these expansions and additional commentary emerged within the context of interpreting new communal experiences, a process called Fortschreibung (editorial expansion). This process of expansion and enrichment had an end point with the establishment of a stabilized form. ${ }^{1191}$

Isaiah 33 reflects a similar case. This chapter consists of very different liturgical forms which have been shaped into a unified presentation of Isaiah's vision of the future after the threat from the great enemy has been overcome. Childs is no longer as confident as he was in his Exodus commentary about our ability to reconstruct the Sitz im Leben of these forms. In his opinion, Gunkel's cultic theories are at best a brilliant piece of speculation. ${ }^{1192} \mathrm{He}$ is more confident, however, about our ability to perceive the work of the editors who have reshaped these forms into a literary composition. In short, the classic Isaianic pattern outlined above has been represented by an intertextual reuse of prior prophetic and psalmic tradition. These traditions have been joined into a holistic interpretation with events taken from Israel's continuing experience with God. In the context of the narrative sequence of chapters 28-32, earlier Isaianic oracles are reused to reinterpret the events leading up to the attack on Jerusalem during the reign of King Hezekiah. ${ }^{1193}$ Childs concludes from this that the context for interpretation should be the text's synchronic

1189 In contrast to the majority of interpreters, Childs believes that promise oracles were part of the original message. Cf. Childs, Isaiah, 215: "There is no compelling evidence to suggest that only the message of judgement was primary and that the element of promise was always secondary from a later redaction."

${ }^{1190}$ Childs, Isaiah, 215.

${ }^{1191}$ Childs, Isaiah, 216.

${ }^{1192}$ Gunkel, "Jesaia 33."

${ }^{1193}$ Childs, Isaiah, 245. 
setting within the book, ${ }^{1194}$ though this conclusion is a derivative of the intentionality of the editors and the possible new genre of the text (Spiegeltext) ${ }^{1195}$ rather than an appeal to postmodern epistemology.

The theologicol nature of the tradents' witness can be seen in Childs' exegesis of Isa 31:4-9. Childs notes that there is tension between v. 4 , which compares the LORD to an attacking lion in a thoroughly hostile action, and v. 5, which appears to reverse his relation to Jerusalem by means of a simile of hovering birds that shield against danger. ${ }^{1196}$ Childs notes that

the key to the tension is first given the parable in 28:23-29, which discloses the strangeness of God's purpose with Israel. This theme is then developed further in both chapters 29 and 30, and continued in chapter 31. The major point is that the Isaianic message does not consist of a tension between pessimistic and optimistic opinions of the prophet, or between competing redactional construals or earlier and later periods. Such a developmental trajectory renders an understanding of the true dimensions of the text virtually impossible. Rather, the issue is a complex theological one that emerged already in the prologue of the book (1:2-3). How is such a lack of understanding of God by Israel possible? Increasingly in the reflective style of the sage, chapters 28.33 focus on the folly of Israel in rejecting the merciful intervention of God, which can only result in utter destruction. Yet from the disclosure of God's revelation of his purpose in creation, there remains an unswerving hope of salvation that is fully incomprehensible to human sinfulness, blinded as it is in folly and arrogance. The prophet does not offer a systematic theological tractate, but a profound struggle with a continuing encounter with God that resonate through the entire corpus as a consistent witness. Israel's judgment and Israel's redemption cohere in God's purpose even when it often appears mysterious and incomprehensible to human logic. ${ }^{1997}$

Finally, it is Childs' commitment to the profile of the tradent that stops him from going too far in the direction a canonical approach dedicated to the final form might entail. The genre of the text as prophecy means that one can never exclude questions of history and intentionality from exegesis of the final form, as Childs warns in his response to certain redaction critics who tend to over emphasize the intertextual nature of prophecy:

First, Third Isaiah remains a prophetic collection, both in form and content, which means there is an encounter with actual historical realities, albeit seen

${ }^{1194}$ Childs, Isoiah, 246.

${ }^{1395}$ The phrase is Beuken's, In "Jesaja 33." Childs claims that Beuken's theory rivals Gunkel's in its significance

${ }^{11 \%}$ Childs, isaiah, 233.

${ }^{1197}$ Childs, Isaioh, 233-234. 
in the light of the divine. This dimension dare not be flattened simply into a type of learned scribal activity dealing exclusively with literary texts. Second, not every occurrence of a parallel can be assigned to an intentional reuse. A critical assessment must be made that reckons with the theological substance at stake beyond merely identifying formal parallelism discovered by the perusal of a concordance. ${ }^{1198}$

This brings us to the particularly kerygmatic nature of the witness of the tradents.

\section{b. Form and Function}

A proper understanding of the proclamation of the prophets and apostles consists in grappling with the form and function of their message. This has already been indicated in our treatment of the tradents above: The various forms (cultic mediator, oral tradition, prophetic oracle, literary documents, stabilized Scripture) are united by the kerygmatic function of witnessing to the reality of God for the purpose of instructing future generations. Given that Childs' entire emphasis on the "final form of the text" rests on the theological nature of Israel's traditions throughout its history, it is necessary to highlight its presence in his two commentaries.

Childs points out the presence of an "anachronism" in the story of the manna and quails (16:1-36), in which the jar of manna was to be placed "before the Testimony" (v. 34), even though the Ark hadn't been built yet. He rejects both pre-critical interpretations, which say that this was done by way of anticipation, and critical interpretations, which say it was simply an oversight. Childs interpretation is also not "post-critical," as if he would attempt to bracket out the diachronic dimension. Rather, he attends to the theological intentionality of the redactor, "whose chronological inconsistencies usually reflect definite theological concerns. ${ }^{.1199}$ He concludes,

It is much more likely that also here there is a theological point which caused the writer to override the chronological sequence. A jar of manna which is the sign of God's sustaining mercy is kept alongside the tablets of the law. Indeed, the sign of divine grace preceded the giving of the law of Sinail Still the emphasis of this passage does not fall on establishing the priority of the manna, nor should the chronology be pressed. Rather, the point of the text focuses on the testimony that the manna and the tablets belong together before God. In New Testament terminology, the gospel and the law cannot be separated. ${ }^{1200}$

\footnotetext{
${ }^{1298}$ Childs, Isaiah, 462.

${ }^{1199}$ Childs, Exodus, 291.

${ }^{2200}$ Childs, Exodus, 291-292.
} 
Again, Childs notes that there are many signs which indicate that chapters $32-34$ consist of various traditions structured into a theological framework: Chapter 32 (the golden calf event) recounts the breaking of the covenant; chap. 34 relates its restoration. By joining chap. 34 to chaps. 32 and 33 , the redactor built chap. 34 into the pattern of sin and forgiveness. He did this by introducing the tablet motif of a covenant restoration into J's account (which was originally only a parallel account of the Sinai covenant), ${ }^{1201}$ thus transforming it into the renewal of a broken covenant $(34: 1,4)$. The new composition "offered a profoundly theological interpretation of the meaning of the Sinai covenant which left a decisive stamp on the entire Old Testament." ${ }^{1202}$

The theological nature of the tradition is not only present at the level of the redactor. The Decalogue, for example, was used religiously throughout its various stages of development in various institutions (worship, liturgy, preaching, and teaching). It served as a basis for homily, exhortation, and instruction. The cultic setting gradually receded and there was a move towards internalization in the later stages, opening up "a whole new dimension to be subsumed under the authority of the will of God."1203 In particular, it functioned as both a boundary for the outer limits of the covenant as well as a source of positive instruction for life within the circle of the covenant. ${ }^{1204}$ As later laws were added, in particular the conglomerate represented by the Book of the Covenant, the function was to subsume the diversity "under the aegis of Israel's covenant theology." 1205 For this reason, the tradition has assigned authorship of the whole to Moses $(20: 22 ; 24: 3-4)$.

The theological nature of the witness is a constant theme in Isaiah. Yet true to his commitment to the relationship between form and function, Childs does his best to "do justice to the unique nature of ... prophetic proclamation..1206 For Childs,

Biblical prophecy is not simply a description of a coming historical event made in advance, shortly to be visible to all. Rather, Isaianic prophecy interprets the effects of God's entrance into human history. It embraces a different dimension of reality, which only in part coheres with empirical history. The quality of God's salvific presence is not limited to one specific event in time and space, but embraces the whole of God's announced purpose for creation, which moves towards consummation. The nature of correspondence between

\footnotetext{
1201 Childs, Exodus, 608.

1202 Childs, Exodus, 610.

1203 Childs, Exodus, 399.

${ }^{1204}$ Childs, Exodus, 398.

${ }^{1205}$ Childs, Exodus, 459.

${ }^{1206}$ Childs, Isaiah, 361.
} 
word and event can only be measured in terms of this ongoing divine plan toward ultimate restoration of God's creation. Prophecy thus speaks of a quality of future event. ${ }^{1207}$

Part of this ongoing "divine plan" is the work of the editors, who render the Biblical material in the light of the larger literary collection by attempting "to highlight and intensify the kerygmatic content of the message in light of the whole. ${ }^{\prime 1208}$ In the process, the historical particularity of earlier layers is not lost. Thus, the fall of Babylon in $\mathbf{5 3 9}$ is registered in chap. 46 . Nevertheless,

the object of human pride and arrogance represented by Babylon is also addressed, and this description far transcends the events surrounding sixthcentury Babylon. The confessional affirmation of God's absolute and unique sovereignty, "I am Yahweh, there is no other," is picked up from earlier chapters and continually extended as the measuring rod by which to describe what actually is unfolding according to the ways of God. ${ }^{1209}$

Childs' rejection of both supernaturalism and historicism therefore, is not made on the basis of general theological commitments, but rather on the basis of the profile of the text itself. The account of the angle's slaughter of the Assyrians in 37:36-38 is not in the genre of historical report, contra Young, ${ }^{1210}$ neither is it the case that the sole forces at work in the universe are those of immanent cause and effect, contra Clements. ${ }^{1211}$ Rather, there is a complex balance of both dimensions of reality. The account of the confrontation with the Rabshakeh is fully anchored in the real world of history. Yet when the issue turns theological and Sennacherib mocks God himself, the Biblical writer uses another literary medium to describe the confrontation.

God's action is portrayed apart from all natural causes, without reference to human agencies. ... Rather, sheer evil is smashed by the direct hand of God in the conventional idiom of the malak $Y H W H$... . The biblical writer's point ... is formulated apart from any natural explanations. His is a confession: God indeed brought victory to his people, as he had promised. ${ }^{1212}$

In sum:

${ }^{1207}$ Childs, Isaiah, 361-362.

${ }^{1208}$ Childs, Isaiah, 362.

${ }^{1209}$ Childs, Isaiah, 362.

${ }^{1210}$ Young, Isaiah.

${ }^{1211}$ Clements, Isaiah, 26. Childs critique of attempts to date chap. 29 (Isaiah, 166) can be applied here: "The function of the biblical text is seldom illuminated by a crude hermeneutic of such direct referentiality."

${ }^{1212}$ Childs, Isaiah, 277-278. 
The writer feels constrained to employ a particular style when he shapes this confessional history, a history that embraces both the world of God and that of humankind. However, once the confessional witness to God's faithfulness has been made, the writer returns to the world of human affairs. ${ }^{1213}$

Childs' sensitivity to the role of historical referentiality can be seen in his handling of chaps. 1-11. He notes that in these chapters the role of historical events varies greatly.

In chapter 7 the historical context of the Syro-Ephramite war of 734 is absolutely crucial for its interpretation, and the historical details have been assigned a centrality by the biblical text itself. Again, in chapter 9 the initial background for the messianic light that suddenly breaks forth (v. 1) appears to be the Assyrian conquest of Galilee, but even here very shortly the messianic promise far transcends the initial eighth-century setting. When one comes to chapter 11, the emphasis of v. 1 falls on the new life sprouting form the mutilated house of David, but an exact chronological setting is not given. Rather, the stress lies on the rebirth, which does not emerge from the proud Davidic dynasty but from the ancient, uncorrupted stem of Jesse. For commentators in this case to focus on reconstructing a historical context to provide the key for understanding runs the danger of so concentrating on a level behind the text as to miss the text's own theological witness. ${ }^{1214}$

Finally, Childs' focus on the intentionality of the prophetic witness has implications for the function of intertextuality, a disputed category. ${ }^{1215}$ Sensitivity and skill are required as not only are there different authors at work, but the work of a later author often reinterpreted an older work in light of a fuller understanding of its referent. ${ }^{1216}$ Thus, the primary function of intertextuality for Third Isaiah (chaps. 56-66) consists in signalling continuity with prior tradition. Its function is deictic-that is, pointing, identifying-rather than midrashic. ${ }^{1217}$ At times it is difficult to determine to what extent a resonance is intentional, rather than deriving from the effect on the reader of a complex poetic composition. Nevertheless, where intentionality can be gauged, it can function as a guide for the purpose and function of Third Isaiah within the whole. ${ }^{1218}$ For example, Third Isaiah serves consciously to unite the major themes of both First and Second Isaiah into one literary composition. Yet Third Isaiah does not only establish continuity, there is also reinterpretation of the previous themes in a variety of ways. The expected promise of the

${ }^{1213}$ Childs, Isaiah, 278.

${ }^{1214}$ Childs, Isaiah, 101.

${ }^{1215}$ Childs, Isaiah, 445: "the issue [of intertextuality] involves many problems, and scholars are far from united regarding the significance of the reuse of a passage (e.g. Bloom, Hollander)."

${ }^{1216}$ Childs, Biblical Theology, 84.

${ }^{1217}$ Childs, Isaiah, 445.

${ }^{1218}$ See p. 446 for a list of parallels and their themes. 
new age has been radicalised in terms of its eschatology. In contrast to Second Isaiah (chaps. 40-55), the deliverance from Babylon is not seen as concurrent with the inbreaking of the new age, but as only an illustration, a foretaste, of God's promise, which is increasingly identified with a new creation of heaven and earth (65:17-25). Again, Third Isaiah linked the faithful remnant of First Isaiah (chaps. 1-39) with the "servants" who followed in the footsteps of Second Isaiah's "suffering servant" (Isa 53). Finally, instead of the enemy being simply a part of the "former things" who would disappear with the entrance of the new, their reappearance in Third Isaiah testifies prophetically that they are not to be understood chronologically, but rather ontologically. God's servants will always be under attack from enemies. Evil will persist and refuse to participate in the divine new order. ${ }^{1219}$ Childs' conclusion is significant:

The resulting shape bears a truthful witness to the selfsame divine reality first testified to by the eighth century prophet Isaiah, but then continually unfolded, modified, and enriched by successive generations of prophetic tradents to serve as Israel's authoritative scripture, a prophetic word that stands for ever $(40: 8)$ and accomplishes its divine purpose $(55: 1) .^{1220}$

\section{c. The "Effect" on the Final Form}

This ongoing dialogue with tradition and reality has produced that complex phenomenon known as "the final form of the text." In what does this entity consist? It should be clear that for Childs this is no "flat" phenomenon, consisting of either literary or conceptual uniformity. There is a depth dimension to the final form, as historical criticism has always told us. Yet, contra historicism, the depth of the final form does not only consist in redactional layers and diverse sources. Reality itself attains a depth that comes with the recognition that the mundane can become a vehicle for the divine, or that a truth claim in one context receives a different profile in another. The purpose of this section is to look at just what Childs meant by "the integrity of the final form."

For a start, the final form is the result of a history of which God was the controlling subject, guiding his people to the fullness of revelation. This history has left its mark in the text itself and its analysis can be useful in explaining the irregularities in the final form. Recognition of redactional expansion in the Second Commandment (Exod 20:4-6), for

${ }^{1219}$ Childs, Isaiah, 448.

${ }^{1220}$ Childs, Isaiah 449. See also p. 102: intertextuality "serves as a response by its readers (editors) to the force of the text when it seeks critically to enrich earlier parts of the corpus from later texts as a means of clarifying and deepening a grasp of the substance to which scripture as a whole points." 
example, explains the odd syntax (v.4); the tension between God's repetition of the "Ten Commandments" in 34:28 and the actual content of his speech is due to Deuteronomic expansion; differing sources explains tensions regarding the divine name at the burning bush (3:1-4:17); Moses' odd response to God in 19:9 is a misplaced gloss from 8b; the literary structure of Isa 15:1-16:14 is unclear, causing problems for a coherent interpretation; Isa $35: 16$ is a disturbing gloss due later editorial activity; Isa $40: 19-20$ are secondary expansions that interrupt the logical connection between w. 18 and 21 .

At no point does Childs try to gloss over these tensions in a modern form of midrash. Rather, "The danger of employing modern midrash can be met both by a critical evaluation in the light of the whole intent of the narrative, as well as by a recognition of the historical dimensions of the text." ${ }^{\prime 221}$ Thus, whereas the misplaced gloss of Exod 19:9 can be ignored in light of the movement of the whole (the word to Moses does not call for the people's response), the gloss in Isa 35:16 is hermeneutically significant as it reflects the desire of the editor to urge readers to find confirmation of the prophecy of Edom's destruction by looking elsewhere in scripture. ${ }^{1222}$ The Deuteronomic expansion in Exod 34:28 represented a significant move which impacted the whole of the tradition, namely the distinction of the Ten Commandments from other parts of the law, and thus cannot be eliminated as meaningless. The logical break in Isa 40:19-20, though probably redactional, serves a theological point: The incomparability of God lies as the basis of the Old Testament's rejection of any attempt to represent the God of Israel by means of an image. ${ }^{1223}$

The tradition, then, was never heavily systematized. Nevertheless, guidelines were given for its later appropriation. The question is how one relates the diachronic to the synchronic. Given the nature of the editorial activity outlined above, Childs summarises the consequences as follows: "[M]y concern is to analyze how the coercion of the text from the hearing of the earliest levels of tradition evoked further interpretive activity from its editorial tradents who sought to register the continual effect of the whole on each single text." 1224 In other words, the tradents submitted to a "force" channelled through the totality of their traditions which was registered in the canonical actualized text, eventuating in the final form. The intention was to critically

\footnotetext{
${ }^{1221}$ Childs, Exodus, 374, fn. 9.

${ }^{1222}$ Childs, Isaiah, 257.

${ }^{1223}$ Childs, Isaiah, 310.

${ }^{1224}$ Childs, Isaiah, 63.
} 
enrich earlier parts of the corpus ... as a means of clarifying and deepening a grasp of the substance to which scripture as a whole points. This concern is for the truth of the witness, which is measured by its faithfulness to its theological context rather than by modern criteria of testing the accuracy of a biblical text according to the original sequence of historical events. ${ }^{1225}$

The final form, then, is the site to which these tradents are pushing so that later interpreters can grasp the reality to which they were responding, each in their own, fragmentary way. The final form is the location of the "truer testimony." term "effect" to describe the nature of the meaning thus created. It is authorial in the sense that it participates in the telos of the prophet's witness, yet, given the depth of the content of the witness, its semantic potential exceeds the conscious content of the prophet's communicative intention. Intentionality is important, but its interpretive significance is relativized. The exegete is called to operate in the tension between witness and reality, never reducing one to the other while recognising their inherent connection.

In respect to the Decalogue, for example, Childs says, "Rather than speculate on why this particular selection took place, a more fruitful approach would be to investigate the effect of the selection in its present form."1227 First he notes the "stark simplicity" of the series. The Decalogue is not addressed to an elite, but to everyone. It needs no legal interpretation, but is straightforward and immediately manifest in its meaning. Second, there is a comprehensiveness to the commands, a breadth of selection, which sets the Decalogue apart from other series such as Exod 34 or Lev 19. The selection is also balanced between commands directed primarily to God and those affecting one's fellows. In Childs' final point we see how the history behind the final form informs its interpretation. He notes the lack of a specific historical setting apart from that provided by the tradition in the narrative framework. This does not mean, however, that the Decalogue is a collection of timeless ethical principles:

[T] he understanding of the tradition itself which emerges from the usage leading up to its final form would surely point in a different direction. ... [T] covenant obligations allowed for a variety of applications in the ongoing history of the nation because the law was always seen as the living will of God himself. ${ }^{1228}$

${ }^{1225}$ Childs, Isaiah, 102.

1226 Childs, Exodus, xv.

${ }^{1227}$ Childs, Exodus, 399.

${ }^{1228}$ Childs, Exodus, 400. 
Again, Childs holds that the "effect" of the odd placement of the ratification of the covenant (Exod 24:3-8) between God's command to the seventy elders in w. 1-2 and their obedience in vv. 9-11 is to make the meal an essential part of the one ceremony. "The covenant meal no longer functions as a parallel ceremony by which to seal the covenant, but rather as a joyous confirmation of the new relationship which had already been accomplished in w. 3-8."1229 Verse 9-11 function in their present position in the narrative "as a eucharistic festival ... a new avenue of communion has been opened to his people which is in stark contrast to the burning terror of the theophany in ch. 19."1230 This interpretive move does not remove the tensions which remain from earlier stages of the story, but "if read as a whole and not pressed too hard, a quite coherent picture is achieved." 1231

The deliverance at the Reed Sea (13:17-14:31) is an example where the final form operates as a critical judgement against modern interpretive moves which attempt to separate what has been pieced together. This narrative consists of a $P$ strand, which understood the event in miraculous terms, and a J strand, which saw the LORD working through natural causes. Nevertheless, to say that originally the salvation was "natural" with the miraculous bits added in an attempt to describe the theological meaning of the event goes against the theological witness of the final form. The two strands have been woven together so that the sum is more than the parts:

The biblical writer is aware both of the variety within the tradition and of the two levels of divine activity which combined ordinary and wonderful elements. The writer first brackets the entire episode within the framework of a divine plan which is in mortal conflict with another plan. Then the writer assigns to Moses as the human agent the execution of the wonderful elements. At the same time the direct intervention of God is pictured in terms of 'natural' causes such as the blowing of the east wind, the impeding of chariot wheels, and the panicking of the Egyptian army. ${ }^{2232}$

Despite the theological integrity of this narrative, its theological validity rests on continuity with the earlier witness: "[T]he parts in themselves did not present a story which

${ }^{1229}$ Childs, Exodus, 504.

1230 Childs, Exodus, 507.

1231 Childs, Exodus, 505.

${ }^{1232}$ Childs, Exodus, 228. 
was different in kind from the combined one. Indeed both sources ( $J$ and $P$ ) witnessed to Israel's redemption at the hand of God."1233

Finally, an example of a broader theological vision which overrides the chronological particularities of the narrative is the Song of the Sea (15:1-21). On the one hand, the framework of the song anchors it to a specific moment in history ("At that time Moses sang"). This creates a tension with the content of the song itself, which references events from the future beyond the time of Moses (such as the crossing of the Jordan). Early commentators tried to solve the problem by understanding the preterit tenses as prophetic futures. Modern critical scholars explain the difficulty as a reading back into the Mosaic period of a much later poem. But neither solution does justice to the present context of the Old Testament text.

By taking seriously the synchronistic dimension of Ex 14 and 15 a characteristic theological feature of the Old Testament emerges. God who has acted in Israel's history is the same one who is acting and will act. The chronological tension which continues to disturb modern commentators apparently did not provide a problem for the Old Testament redactor. The epic style allowed the writer to move back and forth from the past to the present without sacrificing the concrete quality of specific historical situations. ${ }^{1234}$

Again, in Childs' Isaiah commentary, a balance needs to be found between the synchronic and the diachronic. ${ }^{1235}$ On the one hand, form-critics have been successful in demonstrating elements of continuity with earlier prophecy, especially in recovering the force of stereotyped elements within the literature. This is the weakness with synchronic approaches, which do not assess properly "the diachronic forces often still at work in shaping stereotyped forms." ${ }^{1236}$ On the other hand, this form-critical approach atomises the text, whereas literary approaches are helpful for "a sense of a holistic reading ... and for closer attention to literary techniques in rendering its unique type of prophetic poetry. ${ }^{1237}$

${ }^{1233}$ Childs, Exodus, 229.

${ }^{1234}$ Childs, Exodus, 249.

${ }^{1235}$ Childs, Isaiah, 440: "I shall argue that both a diachronic and a synchronic dimension are necessary for biblical exegesis. In a word, I deem inadequate the usual diachronic approach of traditional historical criticism that offers a literary and historical reconstruction of the text's allegedly original background as the necessary context for critical interpretation. Likewise, 1 reject a synchronic or structuralist rendering-a position increasingly defended both in liberal and conservative circles-which focuses solely on the text as a self-sufficient literary entity apart from any consideration of the reality behind its written form. Rather, the crucial issue remains in determining how the diachronic and synchronic relate."

${ }^{1236}$ Childs, Isaiah, 306.

1237 Childs, Isaiah, 306. 
One can see Childs wrestling with the tension in his exegesis of chapter 40:12-31. Westermann has helpfully identified w. 27-31 with a disputation genre, the previous verses being rhetorical questions with the flavour of disputation. The historical setting is Israel in exile complaining about its abandonment by God. This form-critical insight must be preserved against synchronic attempts of, say, Muilenburg, who posits instead of the disputation genre "as a literary type a hymnic monologue of self-predication." ${ }^{2238}$ Nevertheless, Westermann's assumption that the sociological setting of the genre determines its present meaning causes him to read it against the canonical grain it has received. Westermann assigns priority to v. 27 as it allows him a means of recovering such a setting: Sixth-century Jews in Babylon complain that they have been abandoned by their God, to which a doxological answer is given. The rest of the text is subordinated to the perspective of Israel's complaint. The final form, however, reverses the order. Its focus is "unremittingly theocentric," rather than focussing on the anthropocentric complaints of Israel. Thus, "the passage begins with a rhetorical style which then provides the response to a complaint; however, it is given voice when the accusations have already been rendered irrational and groundless in the light of God's actual creative and redemptive presence." Westermann's approach helps identify the presence of doubt, which is never eliminated by the final form. "Israel's belief has not been disregarded." Nevertheless, it is now "absorbed within the reality of the everlasting God." 1239

Another example of the relative usefulness of the diachronic, which is nevertheless subordinated to the synchronic, is Childs' treatment of 1 sa $63: 1-6 .{ }^{1240}$ He believes that this oracle purposely brackets chaps. 60-62, which are enclosed by its parallel, 59:15b-20. The most significant implication of this move is the effect it has had on the synchronic reading of the final form of the book. Isaiah 59:20 had spoken of the coming of God to Zion as Redeemer. This theme has been picked up and greatly enlarged in chaps. 60-62, which describe this in terms of the glorification of Jerusalem and its inhabitants. Nevertheless, the crucial function of chap. 63 , which is set forth in a retrospective sequence, is to emphasize that divine judgement must precede the entrance of God's promised kingship. Childs concludes:

\footnotetext{
${ }^{1238}$ Childs, Isaiah, 307.

1239 Childs, Isaiah, 308.

${ }^{1240}$ Childs, Isaiah, 518: "To recognize in the texts signs of growth and tension can greatly aid in hearing the final form in all its subtle complexity."
} 
Although it is helpful to see that in the growth of the book of Third Isaiah the apparently earlier traditions of chapters 60-62 were bracketed with a later editorial framework, far more important than this concentric pattern are the implications for its interpretation. According to the witness of the chapters, the eschatological economy of God unfolds sequentially according to his purpose of judgment that precedes the final redemption of God's elect. ${ }^{1241}$

The complexity of the nature of the final form is in part due to the nature of its subject matter, which consists in the interaction of divine and human reality. Often one historical event is retained in all its particularity, yet at the same time functions paradigmatically to make a theological point. Historical Moab, for example, functions in Isa 25:1-12, "not as a misplaced literary fragment but as a representative symbol of ontological resistance to God's purpose for his creation."1242 Chapters 24-27 have a distinct typological flavour and function as a paradigmatic presentation of life lived in the end time. This is not to say that the material is a systematized abstraction.

The particularity of the presentation remains sharply contoured by means of the imagery of apocalyptic speech and the conventions of liturgical language. Yet there appears to be an intentional distance established from those specific historical events, which are rendered as illustrations of larger patterns. ${ }^{1243}$

The effect of this manner of literary composition is that its coherence does not lie in a linear temporal sequence in which the righteous are sharply removed from the wicked and the new age always succeeds the old. Rather, the chapter is organized in an aspectual, typologizing manner, and a different scenario is unfolded in each chapter even when similar conventions are used that often overlap in context. For example, there is much similarity in the genre and content of 25:1-6 and 26:1-6. Yet in chap. 25 the appropriate response to God's approaching judgment is followed by a portrayal of a "heavenly" festival. In contrast, in chap. 26 the faithful response in prayer to God's judgment of the lofty city (v. 5) is followed by a lengthy reflection of this same community of faith, but under oppression from the wrath of God, which is still felt $(26: 10){ }^{1244}$

Ultimately, salvation is depicted in terms that transcend any one experience. Chapter 25 speaks of a life removed from death, while chapter 26 of the promise of resurrection to life even after the suffering of death.

The final form functions as a critical norm for the modern exegete, such as in its ability to protect against "historicising" the text. For example, Alt's suggestion that the oracle

\footnotetext{
${ }^{1241}$ Childs, Isaiah, 519.

${ }^{242}$ Childs, Isaiah, 183.

${ }^{1243}$ Childs, Isaiah, 189.

${ }^{1244}$ Childs, Isaiah, 189.
} 
found in Isa 8:23-9:6(7) was a succession oracle and as such uses a hyperbolic idiom ${ }^{1245}$ overlooks the function of the text within the larger literary context. "To interpret the text as a historical vestige, moored in misguided hopes from Israel's past, is to misunderstand the canonical forces at work in shaping the prophetic tradition into a corpus of scripture directed to Israel's subsequent generations of faith." ${ }^{1246}$ Instead, Childs sees a different movement:

There is a narrative movement from 7:1-9:6 that portrays the rejection of the promise of God by the house of David and the resulting destruction of the people of God as divine hardening takes effect. Conversely, there emerges the hope of a faithful remnant, adumbrated by Isaiah's own experience of death and rebirth in chapter 6 , and foreshadowed by the sign of Immanuel. This unfolding presentation of the entrance of God's rule in the midst of terrifying disasters culminates in the history of the Syro-Ephraimite crisis with the messianic promise of chapter 9 and anticipates its ultimate expansion in chapter $11 .{ }^{1247}$

This focus on the effect of the combination and redaction of traditions explains Childs' cautious use of reader-response theory as a tool for registering the way in which coherence can be sought by readers working with the final product. Concerning the odd tense in Isa 38:21, which seems to refer to an event before the song of $w$. 10-20, Childs says:

The RSV appears at first to take undue liberty with the Hebrew verb form when rendering the tense as a pluperfect ("Now Isaiah had said ..."), but this translation is attempting to bring out the narrative effect of these verses on the reader of the whole passage. Long's interpretation of 2 Kings 20:8-11, which is also a passage without a smooth literary join, runs parallel to the function of 38:21-22: "Reading this epistle as filling a gap in the earlier narrative we may understand that before his recovery Hezekiah (had) asked for a sign to confirm that he would be healed by Yahweh" (2 Kings, 238). ${ }^{1248}$ Such a reading is not to be dismissed as a conservative apologetic seeking a seamless reconstruction, but a modern literary approach to a difficult text that explores how its coherence would have been sought by later readers who are aware of a larger canonical corpus of parallel texts. ${ }^{1249}$

Focus on the effect that the inscripturating activity had on the final product brings us to a useful bridging point between "witness" and "substance." On the one hand, a commitment to the historical prophets and apostles requires a nuanced understanding of

\footnotetext{
1245 A. Alt, "Jesaja 8."

${ }^{1246}$ Childs, Isaiah, 80.

${ }^{1247}$ Childs, Isaiah, 81.

1248 Long, 2 Kings.

${ }^{1249}$ Childs, Isaiah, 283.
} 
the intertextuality that constitutes the final form. On the other, this new shaping unleashes a new dynamic for accessing the substance of the witness. In the combined voices we perceive more clearly the true history of God which encompasses our present reality.

\section{Res}

\section{a. Force and Sachkritik}

It should be clear by now that Childs does not advocate a commitment to the final form for its own sake. As he says,

The decision is not derived from a higher evaluation of the last level of redaction per se, but rather in the entire critical assessment provided by the final form of the text as to what is normative for Israel's faith involving all the different levels. It is constitutive of canonical shaping to offer this theological Sachkritik on the tradition in its entirety. ${ }^{1250}$

It is the Sachkritik (criticism according to content), then, that gives the final form its substance and validity and calls for such a nuanced reading. Not all its parts carry the same weight or serve a similar role as the tradent of the prophetic message. "The narrative or kerygmatic witness of the final form is often filled with vestiges from earlier stages of composition," which often only bear indirectly on the shape of the whole. ${ }^{1251}$ It is in Childs' understanding of the nature of this criticism and the forces at work in shaping it that we come to the dogmatic presupposition of the canonical approach: God Himself is at work in Israel's history, mediated through experience and tradition. As argued above, we need to interpret Childs' use of such seemingly neutral terms as "religious," "new situation," "response to a force," in the light of their full theological meaning. The "situation" is God's revelation in history and experience, the "force" is the Spirit, "coercing" a response through elected channels, and the "religious activity" is faithful, inspired response within this movement.

This dialectic can be seen in the direction of influence that Childs constantly identifies. The redactor of the final form of the narrative containing the Decalogue "sought to work out the inner logic of this received tradition;" 1252 the redactional structuring of chaps. 3234 "offered a profoundly theological interpretation of the meaning of the Sinai

\footnotetext{
${ }^{1250}$ Childs, Isaiah, 441.

${ }^{1251}$ Childs, Isaiah, 441.

1252 Childs, Exodus, 397.
} 
covenant; $^{\prime 1253}$ the second commandment was shaped in response to a force emanating from the Deuteronomic interpretation of the Sinai event; ${ }^{1254}$ the Sabbath command was not a creation of the Priestly writer but is rather a theological development of an older tradition, in which the Sabbath is grounded in the act of creation. ${ }^{1255}$ We can assume then, that when Childs says that the Jahwist "shows tremendous freedom and imagination in fashioning his account, ${ }^{\prime 256}$ he is not saying that the result is a matter of aesthetic creativity, a fiction for our entertainment or even, to use more post-critical categories, nothing more than a narrative to restructure our vision of reality. Rather, the Jahwist was responding to the work of the Spirit, channelled through elected traditions from the context of a fuller revelation of God, and he is using his indigenous creativity in order to try and communicate this theological reality.

This understanding is expressed far more intensely in Childs' Isaiah commentary. This is not, however, due to a change in Childs' method. Though the language may have changed (he speaks now of "intertextuality" and redactional "retrojection"), the substance is the same. The intensification in Childs' focus is related to the genre of the book of Isaiah itself, which by its prophetic nature constantly interacts with canonical tradition. Thus, Isaiah 4:23

has chosen words and themes from Israel's tradition that provide a resonance for the informed reader. ... [T] he passage reflects a holistic reading of Israel's entire prophetic corpus that combines a wide range of prophetic and priestly promises into one single story. In a word, one sees in chapter 4 every evidence of an interpretation that has been responsive to the coercion of the entire biblical text and is not just an expression of a given political or sociological ideology. 2257

Again, the colon "Holy seed is its stump" (Isa 6:13) is an example of textual extension (Fortschreibung) which, rather than being an "optimistic" gloss stemming from an editor's wishful thinking, is a response to the coercion of the prophetic text. It is an attempt to "pursue and to interpret the full dimensions of the biblical text." 1258

Isaiah does not speak here of a remnant or of a pious group who escaped judgment. All of Israel must perish: "houses without people." The radical

\footnotetext{
${ }^{1253}$ Childs, Exodus, 610.

${ }^{1254}$ Childs, Exodus, 406.

${ }^{1255}$ Childs, Exodus, 416.

${ }^{1256}$ Childs, Exodus, 135.

${ }^{1257}$ Childs, Isaiah, 35.

${ }^{1258}$ Childs, Isaiah, 58.
} 
quality of this imagery resonates with the intensity of 587 [BCE]. There is no continuity from the old to the new. Yet Isaiah has himself emerged from his [metaphorical] "death" [described earlier in chapter 6] and shortly names his son "a remnant-will-return" (7:3). Thus the mystery of the remnant continues, and these ancient readers saw in the stump that remained standing when felled (cf. 11:1) the hope of the new. The force of the entire narrative of chapter 6, particularly in the larger context of chapters 1-12, strove for an exposition of the meaning of $v$. 13 . The tree had been felled, but its stump still stands and in the stump is the holy seed waiting to sprout in God's time. ${ }^{1259}$

Fortschreibung took place as part of a dialectic between tradition and reality. An example of coercion emanating from the reality/experience side of the dialectic is Isa 1:2728 , which retrojects post-exilic conditions into an earlier text:

From the experience of the exile ["experience" being, as we have come to expect, a theologically loaded category], Israel discovered a different dimension of $\mathrm{w}$. 21-26. It was not that the Isaianic text had to be adjusted to fit the social realities of a later time, but exactly the reverse. From the coercion of the biblical text Israel learned how correctly to understand the new postexilic situation. Desolate Israel clung firmly as never before to the promised salvation of Zion and the final destruction of God's enemies. The scribal editor confirmed the promise of Isaiah as true: Zion-as far as it was truly Zion-would surely be redeemed. Moreover, this promised salvation would stem solely from God's justice ... and from his righteousness ..., not from Israel's virtue. Thus, this textual extension confirmed Isaiah's promise as true, and by using the vocabulary of Israel's later (postexilic) experience defined more clearly the implicit Isaianic concept of Zion as a faith reality, distinct from merely a political entity, but still containing the wicked along with the faithful. ${ }^{1260}$

One of Childs' most explicit references to God as the subject of the kerygmatic process

is made in relation to the composition of Isa 1-12:

There was another force at work in the history of composition. As the oracles of Isaiah were collected, treasured, and shaped into a written literature, the developing corpus was constantly being enriched by continual expansion until it finally reached a stabilized form. Often these expansions and additional commentary emerged as a response to the coercion of earlier texts within the context of interpreting new communal experiences. ... The editors who shaped the literary collection had little interest in preserving a historical record of the sequence of prophetic proclamations, but felt free to retroject later oracles into earlier passages in order to bring clarity and deeper understanding to the context of the original oracles. For example, the prophecy in chapters $2-3$ of the judgment of God on proud Israel appears to have picked up vocabulary from the terrifying punishment inflicted on the nation by the exile. Conversely,

${ }^{1259}$ Childs, Isaiah, 58.

${ }^{1260}$ Childs, Isaiah, 22; emphasis mine, in order, once again, to highlight continuity. 
the portrayal of exalted Jerusalem in 2:1-4 or the hope of the return of the diaspora (11:10ff.) uses the language of those who later experienced the fulfilment of earlier promises. The point to emphasize is that the prophetic oracles developed as they were used authoritatively by those who treasured them as scripture, and they continued to address the changing needs of each new generation as the vehicle of divine revelation. Because the major force in the history of growth was the continued impact on the Jewish community of the reality of God mediated through its authoritative writings, it is a fundamental misunderstanding to attribute the development within the prophetic corpus merely to extrabiblical sociological or historical influences. ${ }^{1251}$

Given that it is God who is both the subject and the object of this kerygmatic history, it is time to turn to the last element in Childs' system: the res of the witness.

\section{b. The Res}

As Childs has repeated throughout his career, the unity of Scripture lies it its referent, i.e. it is ontological. ${ }^{1262}$ This is the basis for his rejection of narrow structuralist categories or purely synchronic analysis. The function of the Bible as Scripture "is to point to the substance (res) of its witness, to the content of its message, namely, to the ways of God in the world." ${ }^{1263}$ This leads to a strong thematic focus in Childs' commentaries. ${ }^{1264}$ Thus, the continuity of the "substance" of scripture within the diversity of its proclamation is often expressed as the presence of a single theme. For example, the various stories in Exod 33:123 have been redactionally united to illuminate one issue: God's presence. ${ }^{1265}$ In Isa 1 we have two different idioms, law and wisdom, which bear testimony to the same subject matter: Israel's total alienation from its God to whom it owes its life and well-being. ${ }^{1266}$ in Isa 51:9-16 we have a depiction of three separate events: the drying up of the sea, the passing of the redeemed through the waters, and the return of the Babylonian exiles to Zion. Nevertheless, the events are not depicted along a historical trajectory. Rather, "the occurrences are three moments in the one purpose of God for Israel's salvation. Because the content of God's redemptive intervention, that is, its substance, is the same, the three

${ }^{1261}$ Childs, Isaiah, 216; emphasis mine.

${ }^{1262}$ Cf. Childs, Biblical Theology, 551: "A major thesis of this book is that much of this modern critical rejection of dogmatic theology has been misplaced and that only when one is able to relate the various biblical witnesses to their subject matter, or substance, can one begin to comprehend the nature of the Bible's coherence."

${ }^{2263}$ Childs, Isaiah, 4.

${ }^{1264}$ His Old Testament and Biblical theologies are structured around typical Biblical themes. Nevertheless, note his warning concerning the danger of idealism: the success of a thematic approach "depends on how critically and skilfully it is employed;" in Childs, Biblical Theology, 15-16.

${ }^{1265}$ Childs, Exodus, 585.

${ }^{1266}$ Childs, Isaiah, 17. 
events have been fused together as a unified ontological witness to the one purpose of God concerning his people."1267

The Biblical redactors also tended to use a thematic approach. For example, in Isa 11

an apparent redactional force at work in construing the Isaianic corpus holistically, which would bring together into a larger unity the divers themes of the reign of God, the coming of a promised messianic rule, and the emergence of a faithful remnant. ... Certainly no heavy-handed systematization of the prophetic oracles was attempted, but guidelines were carefully established that signalled points of resonance within the whole. ... In sum, it is a striking characteristic of chapter 11 that all the various themes sounded in the previous chapter are pulled together to provide, as it were, a holistic reading of the entire Isaianic message. ${ }^{1268}$

Again, the significance of Isa 7 in its canonical context is thematic:

Chapter 7 does indeed continue the theme of hardening, but it also introduces other major themes that have been lost in the usual retrospective reading of these chapters. Above all, chapter 7 introduces the messianic hope associated with Immanuel and begins to develop the theme of the remnant, which had only been adumbrated in the earlier chapters (1:9; 4:1ff.; 6:13). In addition, these themes of chapter 7 are further, expanded in an integral way in 8:19:7(6). They continue through chapters 10 and 11 and reach a crescendo in chapter 12 , thus concluding the first major division of Isaiah. ${ }^{1269}$

There is continuity in focus on themes within the history of tradition leading to the final form, as well as within the reception history of the final form. For example, the differing portrayals of Pharaoh's resistance to Moses, though different according to each literary source, do not conflict "in terms of content," as at the end of the day all the concessions reach an impasse. ${ }^{1270}$ Within the larger canon the plague tradition was critically received according to a perception of its theological content. The theme of the mockery of the Egyptians or the separation of Israel from punishment, for example, is not repeated. On the other hand, the theme of God's special act of grace, which was later rejected by Israel, is highlighted in Psalms 78 and 105. Even later in Biblical tradition, the book of Revelation picks up on the theme of the battle between God and Pharoah. There is a change in form,

\footnotetext{
${ }^{1267}$ Childs, Isaiah, 404.

${ }^{1268}$ Childs, Isaiah, 106, 102.

${ }^{1269}$ Childs, Isaiah, 62.

${ }^{1270}$ Childs, Exodus, 155.
} 
however, if not substance. The theme has now become both a cosmological and eschatological battle between God and Satan. ${ }^{1271}$

Another example of the thematic appropriation of a story within the broader canon is the narrative of the manna and quail. This has already been treated in section 4.5 .1 . above.

A similar parallel between the focus on substance within the history of reception within the Old Testament and its appropriation by the New can be seen in Childs' handling of Isa 40. Within Isaiah,

\begin{abstract}
the function of the prologue of chapter 40 was to confirm the truth of the word of God regarding the promise of divine salvation. The temporal sequence relating the promise and the fulfillment was reinterpreted in the light of a fresh understanding of God's purpose. Judgment on Jerusalem was executed by the Babylonians, not the Assyrians, and only after the destruction of Babylon was the new age of salvation to appear. The credibility of the prophecy was not undercut by an adjustment within the historical sequence because the truth of prophecy could only be measured by its faithfulness to the substance of the divine reality of which it spoke. ...
\end{abstract}

When John the Baptist linked the appearance of Jesus with the prophet's call to "prepare the way of the Lord," he was not making a mechanical connection with an ancient prediction of Isaiah. Rather, the reality of God's salvation was manifest in Jesus Christ in such a way that his advent provided a perfect morphological fit according to its redemptive substance with the Old Testament promise. ${ }^{1272}$

Childs identifies a similar movement within the reception of the Isaianic tradition. This has implications for the relative value of identifying exact literary subdivisions in the text. Though identifying such divisions helps against atomizing the text, Childs argues that

in the ancient hearing and reading of scripture, that is, in its canonical reception, the resonance set up from repeated themes played a more important role in interpretation than the modern concerns with establishing exact literary units. Therefore, the decision of whether $66: 1-4$ belongs literarily with chapter 65 (Smith) (273 $^{127}$ or is only closely related (Beuken) ${ }^{1274}$ is not of major importance when interpreting chapters 65 and 66 . The fact that appeals to the repetition of similar themes and to verbal parallels are recognized by [various scholars], even when used to support different subdivisions, would

\footnotetext{
${ }^{1271}$ Childs, Exodus, 169.

1272 Childs, Isaiah, 303.

1273 P.A. Smith, Trito-Isaiah, 128-172.

${ }^{1274}$ Beuken, "Closure."
} 
caution against pressing only one reading to the exclusion of others. ${ }^{1275}$

The themes under consideration are, for Childs, facets of the dynamic reality of God, which is ultimately the only ground for unity in the canon. This has implications for our evaluation of redaction criticism, which is correct to point out the retrojection of later texts into earlier ones, but fails to evaluate correctly the nature of this activity. In relation to Isa 6 , Childs says:

What is here present is not a tendentious reading back of a subsequent political agenda, but is part of a process of canonical shaping that stems from a holistic reading of the larger prophetic corpus. The witness to God continues to grow in richness and understanding. This true subject matter is then often extended to earlier portions of Isaiah without attention to the age of its discovery, but rather only to the truth of its witness when measured according to its theological substance. Thus the portrayal of God's rule in 2:1-4 and again in 4:2-6 resonates with elements of Isaiah's vision of chapter 6 and is grounded in the reality of God's eschatological rule, revealed to the prophet in chapter 6. Likewise, 2:6ff. also reverberates with the imagery of God's glory, but here revealed in terror (2:21). The point to emphasize is that canonical shaping develops from a holistic wrestling with the subject matter of the biblical text, and as comprehension grows through encounter with the living God it begins to infuse the entire book with a truthful witness to the one story of God's salvific purpose with israel. ${ }^{1276}$

It is for this reason that Childs can say that retrojection "enriches" earlier texts. It is possible, for example,

that Isa 11 has been redactionally enriched by bringing into this earlier passage elements from the most fully developed description of the new heavens and earth $(65: 17 f f$.$) . The effect is to interpret the promise of the prophet Isaiah$ with new clarity and profundity by an explicit appeal to new creation. What Isaiah envisioned was not a return to a mythical age of primordial innocence, but the sovereign execution of a new act of creation in which the righteous will of God is embraced and the whole earth now reflects a reverent devotion "as the waters cover the sea."1277

This same reality is also testified to in the New Testament, though now understood more profoundly through the experience of Christ. An example of how the different conceptions of theological reality held by the Synagogue and the church coerced their exegesis is their reception of the Passover tradition:

\footnotetext{
${ }^{1275}$ Childs, Isaiah, 534.

${ }^{1276}$ Childs, Isaiah, 59.

${ }^{1277}$ Childs, Isaiah, 104.
} 
The Christian confession of Jesus Christ as the fulfillment of the Old Testament prophecy effected almost immediately a different understanding of the place of the passover in the church from that of the synagogue. The change in approach reflected itself in a variety of fundamental issues of faith. What had been for Israel an unequivocal and straightforward memorial to the deliverance from Egypt became for the Christian church a mysterious and paradoxical sign within God's redemptive history of both the new and the old, of life and of death, of the future and the past. ...

Judaism had developed a clear tradition on how the ancient passover rite was to be actualized for every new generation of Jews. ... But for the church this direct, unbroken identification of deliverance was no longer possible. The weight of the tradition had been decisively shifted. What Israel thought was the substance of her freedom was only the foreshadowing of the hope. ... Increasingly the sense of a reality hidden within the old form made direct participation in redemption through the passover impossible. ${ }^{1278}$

The attempt to penetrate the text to its substance has continued through the history of interpretation. In regard to the story of the visit of Jethro (Exod 18:1-27), Childs notes that the Greek Fathers and later the Reformers "saw the witness of the text to lie in the relation of God's will as revealed through divine communication to his prophet and God's will as discovered in the wisdom of human experience."1279 Again, a concept of the "substance" of the law directed Calvin's appropriation of the Decalogue: "The Old Testament law when used by the Christian must be directed to the end for which it was given. It must reach to the substance of the precept. It must be expanded to enjoin the opposite of that which is prohibited." ${ }^{1280}$ Or concerning Isa 6, Calvin resisted traditional Christian exegesis which, following John 12 , claimed that Jesus was the real object of the prophetic vision in a flat sense.

Rather, he argued that in Isaiah 6 the prophet speaks of God, the Lord, in an absolute manner. Yet Calvin is quick to add that God never revealed himself to the Old Testament patriarchs apart from his eternal Word, the only begotten Son. Calvin wisely resists Christian interpreters trying to prove from the song of the seraphim that there were three persons in one essence in the Godhead. He prefers using stronger evidence to support the doctrine of the Trinity. Yet at the same time he confesses that it is indeed the triune God who is being worshipped in the Old Testament. His strongest evidence does not derive from isolated proof texts, but rather from a holistic reading of the entire canon of ancient Israel. ${ }^{1281}$

\footnotetext{
${ }^{1278}$ Childs, Exodus, 213.

${ }^{1279}$ Childs, Exodus, 335.

${ }^{1280}$ Childs, Exodus, 434.

${ }^{1281}$ Childs, Isaiah, 60.
} 
Calvin shared the substance of the faith of his forebears, but his more adequate hermeneutic enabled him to perceive it on a more profound basis.

A good example of Childs' preference for a thematic interpretation over one geared towards literary unity is his treatment of the final form of the plague tradition (Exod 7:811:10). Childs agrees with Jacob and Cassuto ${ }^{1282}$ that there may well be a literary pattern behind the present structure of the plagues. Nevertheless, he rejects their synthetic interpretation because "the major themes are not brought into any sharper focus by recognizing this pattern." ${ }^{1283}$ Instead, finds the approach of M. Greenberg more fruitful, ${ }^{1284}$

which delineates the major themes of the entire passage, which analysis is not dependent on recognizing one final literary pattern. He sees the major theme of the plague story to revolve around the revelation by God of his nature to Pharaoh, to the Egyptians, and to all men. Even more important is recognizing how this theme fits into the movement of the book as a whole. The initial revelation of God's name met with human resistance and disbelief which created the tension of the narrative. The plagues function as a demonstration of God's nature which shatters the resistance. ${ }^{1285}$

It is interesting to note how this thematic approach impacts Childs' freedom in using critical tools:

When properly used, this approach has the additional advantage of being able to make use of the more technical analytic work as well. On the one hand, by incorporating the full richness and variety of the individual sources into the themes, one's understanding of the narrative can be enriched rather than impoverished by reductionist generalizations. On the other hand, the interpreting of the sources within the thematic framework of the whole passage prevents the exegesis from becoming unduly fragmented. For example, one can allow for the differences between $J$ and $P$ within the theme of Pharaoh's resistance. Even the tension between signs and plagues could help to sketch the full range of God's method of showing his power. The fact that at times Pharaoh is warned, and at times not, or that Moses can be both flexible and intransigent, provides tremendous possibilities for discovering new combinations and dimensions of the story. ${ }^{1286}$

That a fuller grasp of the "substance" of the text-i.e. the divine reality-by the contemporary interpreter can legitimately alter the meaning of a text can be seen in Childs' treatment of Isa 2:3. What is the meaning of "torah" in this context? Traditional critics

\footnotetext{
1282 Jacob, Buch der Torah; U. Cassuto, Exodus.

${ }^{1283}$ Childs, Exodus, 150.

1284 Greenberg, "Thematic Unity."

${ }^{1285}$ Childs, Exodus, 151.

${ }^{1286}$ Childs, Exodus, 151.
} 
identify it with the teaching of the prophets, independent of the law of Moses (e.g. Isa 8:16; 30:9). G. Sheppard ${ }^{1287}$ has argued that in 2:3 the term has been expanded to include by assumption the revealed Mosaic legislation as the divinely given norm for Israel (e.g. Isa $8: 20 ; 24: 5)$. Childs, however, argues, the semantic extension is not simply in terms of prophetic torah being identified with the Mosaic.

Rather, the subject matter of the prophetic message as divine truth continues to exercise a coercion on Israel such that the Mosaic Torah itself increasingly received its full meaning from the divine reality witnessed to by the prophets. On the one hand, the substance (res) of the prophetic polemic served to check all legalistic moves inherent in law (1 Sam. 15:22ff.). On the other hand, the unswerving appeal to the Mosaic Torah by the prophets (Jer. 7:1ff.; Mal. 4:4) blocked all attempts to mitigate the full force of the divine will that was given a concrete form at Sinai. In a word, both law and prophetic proclamation were expanded in terms of a deepening grasp of God's reality, but neither was subordinated in principle to the other. Of course, it was this understanding of the nature of Hebrew scripture that drove the apostle Paul to identify the divine truth of the entire Old Testament with the one reality made known through God in Jesus Christ (Rom. 10:1ff.). ${ }^{1288}$

For the exegete, then, the two dimensions of the text-its linguistic shape and its content-must be kept in balance. An example of two Biblical scholars who have focussed too exclusively on only one of these poles are Knierim and Eichrodt in their interpretation of the First Commandment. The question is raised: How is one to explain the delineation of God's claim on Israel in negative terms against other gods?

Two basic options have been offered by way of solution. On the one hand, Eichrodt is representative of a group of scholars who argue that the intolerance of Yahweh respecting other gods is an essential part of the Mosaic religion and can be deduced from the covenant itself. His answer attempts to speak to the substance of the issue, but avoids thereby the form-critical question. On the other hand, Knierim's essay ${ }^{1289} \ldots$ is representative of a group of scholars who argue that the particular formulation must be handled apart from the larger theological question. The formulation must have arisen from a concrete situation within the history of tradition. Knierim himself derives the formulation from the covenant at Shechem and the threat of rival deities. His answer is supported by the literary evidence, but it remains a question whether this kind of evidence is adequate for the question which its seeks to answer. In sum, the choice between the two approaches involves a methodological decision which can hardly be reached in relation to only this

\footnotetext{
${ }^{1287}$ G. Sheppard, "Isaiah 1-39,' 93-94.

${ }^{1288}$ Childs, Isaiah, 30.

${ }^{1289}$ R. Knierim, "Erste Gebot," 20-39.
} 
one issue. ${ }^{1290}$

And this final quote brings us to the subject matter of this essay: What is the correct exegetical approach for grappling with the true subject matter of the witness of historical Israel?

\section{Bibliography}

Ackroyd, Peter. "Isaiah I-XII: Presentation of a Prophet." Vetus Testamentum Supplement 29 (1978): 16-48.

Aitken, J.K. The Semantics of Blessing and Cursing in Ancient Hebrew. Louvain-Paris-Dudley, MA.: Peeters, 2007.

Alexander, T. Desmond, and David W. Baker, Dictionary of the Old Testament: Pentateuch. Downer's Grove, IL.: InterVarsity Press, 2003.

Alt, Albrecht. "Jesaja 8, 23-9, 6: Befreiungsnacht und Krönungstag." In Kleine Schriften zur Geschichte des Volkes Israel II, by Albrecht Alt, 206-225. Munich: Beck'sche Verlagsbuchhandlung, 1953.

Alter, Robert. The Art of Biblical Poetry. New York: Basic Books, 1987.

-. The David Story: A Translation and Commentary on 1 and 2 Samuel. New York: Norton, 1999.

-. "The Poetic and Wisdom Books." In The Cambridge Companion to Biblical Interpretation, edited by John Barton, 226-240. Cambridge: Cambridge University Press, 1998.

Andersen, Francis I., and Dean I. Forbes. The Hebrew Bible: Andersen-Forbes Phrase Marker Analysis. Logos Research Systems, Inc. 2005.

Anderson, A.A. 2 Samuel. Dallas: Word, Incorporated, 1989.

-. The Book of Psalms. 1. 1-72. Grand Rapids/London: New Century Bible Commentary, 1972.

${ }^{1290}$ Childs, Exodus, 404. 
Anderson, Bernhard W. "Introduction: Mythpoetic and Theological Dimensions of Biblical Creation Faith." In Creation in the Old Testament, edited by Bernhard W. Anderson, 1-23. London; Philadelphia: SPCK; Fortress Press, 1984.

Anderson, Gary A. "Moses and Jonah in Gethsemane: Representation and Impassibility in their Old Testament Inflections." In Seeking the Identity of Jesus: A Pilgrimage, edited by Berverly Roberts Gaventa and Richard B. Hays, 215-231. Grand Rapids: Wm. B. Eerdmans, 2008.

Arnold, Bill T., and H.G.M. Williamson, Dictionary of the Old Testament: Historical Books. Downers Grove, IL: InterVarsity Press, 2005.

Auffret, Pierre. La sagesse a bati sa maison: Études structures littéraires dans l'Ancien Testament et spécialement dans les psaumes. Fribourg-Göttingen: Vandenhoek \& Ruprecht, 1982.

Auwers, Jean-Marie. La Composition littéraire du psautier: un état de la question. Paris: Gabalda, 2000.

Bächli, Otto. Das Alte Testament in der Kirchlichen Dogmatic von Karl Barth. NeukirchenVluyn: Neukirchener Verlag, 1987.

Baethgen, Friedrich. Die Psalmen. Göttingen: Vandenhoeck \& Ruprecht, 1897.

Baltzer, Klaus. Deutero-Isaiah: A Commentary on Isaiah 40-55. Translated by Peter Machinist. Minneapolis: Fortress Press, 2001.

Barbiero, Gianni. Das Erste Psalmbuch als Einheit: eine synchrone Analyse von 1-41. Frankfurt am Main: Peter Lang, 1999.

Barr, James. "Allegory and Historicism." Journal for the Study of the Old Testament 69 (1996): 105-120.

-. The Concept of Biblical Theology: An Old Testament Perspective. London: SCM Press, 1999.

Barr, James. "The Literal, the Allegorical, and Modern Biblical Scholarship." Journal for the Study of the Old Testament 44 (1989): 3-17.

Barth, Karl. Der Römerbrief. 2nd edition. Zollikon-Zürich: Evangelischer Verlag, 1940. 
—. Die Kirchliche Dogmatik. Vol. III.3. Zürich: Theologischer Verlag Zürich, 1980.

—. Die Kirchliche Dogmatik. Vol. I.2. Zollikon-Zürich: Evangelischer Verlag A.G., 1948.

-. Die Kirchliche Dogmatik. Vol. I.2. Zürich: Theologischer Verlag Zürich, 1980.

-. Dogmatik im Grundriss im Anschluß an das apostolische Glaubensbekenntnis. Stuttgart: W. Kohlhammer Verlag, 1947.

-. Einführung in die evangelische Theologie. Zurich: EVZ-Verlag, 1962.

-. Evangelical Theology: An Introduction. Translated by G. Foley. New York: Holt, Rinehart \& Winston, 1963.

-. The Epistle to the Romans. 6th edition. Translated by Edwyn C. Hoskyns. London: Oxford University Press, 1933, 1968.

-. The Göttingen Dogmatics. Edited by Hannelotte Reiffen. Translated by Geoffrey W. Bromiley. Grand Rapids: Wm. B. Eerdmans Publishing Company, 1991.

Barthélemy, D. Preliminary and Interim Report on the Hebrew Old Testament Text Project. New York: UBS, 1980.

Bartholomew, Craig G. "Uncharted Waters: Philosophy, Theolog and the Crisis in Biblical Interpretation." In Renewing Biblical Interpretation, edited by Craig Bartholomew, Colin Greene and Karl Möller, 1-39. Carlisle; Grand Rapids, MI.: Paternoster Publishing; Zondervan Publishing House, 2000.

Bartholomew, Craig G., and M. W. Goheen. The Drama of Scripture: Finding our Place in the Biblical Story. Grand Rapids, Mi: Baker Academic, 2004.

Barton, John. "Canonical Approaches Ancient and Modern." In The Biblical Canons, edited by Jean-Marie Auwers and Henk J. de Jonge, 199-209. Leuven: Leuven University Press, 2003.

-. "Marcion Revisited." In The Canon Debate, edited by Lee M. MCDonald and James A. Sanders, 341-354. Peabody, Mass.: Hendrickson Publishers, 2002.

-. Reading the Old Testament: Method in Biblical Study. London: Darton, Longman and Todd, 1984. 
-. "Unity and Diversity in the Biblical Canon." In Einhelt der Schrift und die Vielfolt des Kanons, edited by John Barton and Michael Wolter, 1-26. Berlin: W. de Grurter, 2003.

Beckwith, Roger T. The courses of the Levites and the eccentric Psalms scrolls from Qumran." Revue de Qumron 11, no. 4 (1984): 499.524.

Bekin, Pete. The verb in poetry. 25 January 2011. http://balshanul.wordpress.com/2011/01/25/the-verb-in-pociry/ laccessed February 2, 2011).

-. Definiteness, information structure, and the particle sx in BH. 5 November 2009. hitp://balshanut.wordpress.com/2009/11/05/definiteness-information-structureand-the-particle-K07\%90\%07\%AA.in-bh/ (accessed February 2, 2011).

Bergant, Dianne. "The Earth is the Lord's": A Biblical Reflection on Psalm 24:1." Mlission Studies 15, no. 2 (1998): 66-74.

Berges, Ulrich. "Die Knechte Im Psalter: Ein Beltrag zu seiner Kompositionsgeschichte." Biblico 81, no. 2 (2000): 153.178.

-. Jesojo: Der Prophet und dos Buch. Lelpzig: Evangelische Verlagsanstalt, 2010.

-. You are My Witnesses and My Servant." In Prophetic Exllic Gotfungen: The Relevonce of Forced Migrotion Consciousness in the Mojor ond Minor Prophets, edited by John Ahn. Edinburgh: T\&T Clark (lorthcoming).

Berlin, Adele. "Grammatical Aspects of Biblical Parallelism." Hebrew Union College Annuol 50 (1979): $17-43$.

-. "Mrth and Meaning in Psalm 114." In Dlochronle and Synchronic: Reading the Psalms in Real Time: Proceedings of the Boylor Symposlum on the Book of Psolms, edired by Joel S. Burnetl, W. H. Bellinger Jr. and W. Dennis Tueker Jr., 67.80. London: T\& T Clark, 2007.

-. The Dynomics of Biblical Parallelism. Bloomington, IN: Indians University Press, 1992.

Beuken, Willem A.M. "Does Trito-Isalah Reject the Temple? An Intertextual inquiry into isa 66.1.6." In Intertextuality in Biblical Writings: Cssoys in Honour of Bos von lerset. edired by Sipke Draisma, 53.66. Kampen, Netherlands: J.H. Kok, 1989. 
-. "Isaiah Chapters LXV-LXVI: Trito-Isaiah and the Closure of the Book of Isaiah." In Congress Volume, Leuven 1989, 204-221. Leiden: E.J. Brill, 1991.

-. Jesoja 28-39. Translated by Andrea Spans. Freiburg: Herder, 2010.

-."Jesaja 33 als Spiegeltext im Jesajabuch." Ephemerides Theologicae Lovanienses 67 (1991): 5-35.

-. "The Main Theme of Trito-Isaiah: 'The Servants of Yhwh'." Journal for the Study of the Old Testoment 47 (1990): 67-87.

Blenkinsopp, Joseph. Isaiah 1-39. London: Doubleday, 2000.

-. Isaiah 1-39: A New Translation with Introduction and Commentary . London: Doubleday, 2000.

-. Isaiah 40-55: A New Translation with Introduction and Commentary. London: Doubleday, 2002.

-. Isaiah 56-66: A New Translation with Introduciont and Commentary. London: Doubleday, 2003.

Bloch-Smith, Elizabeth. "Who is the King of Glory?" Solomon's Temple and its Symbolism." In Scripture and Other Artifacts: Essays on the Bible and Archaeology in Honour of Philip J. King, edited by M. Coogan, P. J. King and J. C. Exum, 18-31. Lousiville, 1994.

Blum, Erhard. "Formgeschichte-A Misleading Category? Some Critical Remarks." In The Changing Face of Form Criticism for the Twenty-First Century, edited by Marvin A. Sweeney and Ehud Ben Zvi, 32-45. Grand Rapids, MI: William B. Eerdmans Publishing Company, 2003.

Botha, Phil J. "Answers Disguised as Questions: Rhetoric and Reasoning in Psalm 24." Old Testament Essays 22, no. 3 (2009): 535-553.

Botterwerk, G. Johannes, Helmer Ringgren, and Heinz-Josef Fabry, Theologisches Wörterbuch zum Alten Testament. 8 vols. Stuttgart: W. Kohlhammer, 1970-1994.

Braude, William G. The Midrash on Psalms (Midrash Tehillim). New Haven: Yale University Press, 1959. 
Briggs, Charles Augustus. A Critical and Exegetical Commentary on the Book of Psolms. Vol. 1. Edinburgh: T \& T Clark, 1906.

Briggs, Richard S. "Speech-act Theory." Dictionony for the Theologicol Interpretotion of the Bible, edited by Kevin J. Vanhoozer, Craig G. Bartholomew, Daniel s. Treier and N. T. Wright, 763-766. Grand Rapids, MI.; London: SPCK; Baker Academic, 2005.

Brown, Francis, Samuel Rolles Driver, and Charles Augustus Briggs. The Enhonced BrownDriver-Briggs Hebrew and English Lexicon with on oppendix contoining the Biblical Aromoic. Electronic edition. Oak Harbor, WA: Logos Research Systems, 2000 (1906, 1951).

Brown, William P. "Here Comes the Sunl' The Metaphorical Theolosy of Psalms 15-24." In The Composition of the Book of Psolms, edited by Erich Zenger, 259-277. Leuven: Walpole, Mass.: Uitgeverij Peeters, 2010.

Broyles, Craig C. Psolms. Peabody, Mass.: Hendrickson, 1999.

Broyles, Craig C. The Psalms and Cult Symbolism: The Case of the Cherubim-Ark." In Interpreting the Psolms: Issues ond Approoches, edited by David Finth and Philip S. Johnston, 139.158. Downers Grove, Illinois: IVP Academic, 2005.

Bruezsemann, Walter. "The ABC's ol Old Testament Theology in the US." Zeitschrift für die altrestomentliche Wissenschofe 114, no. 3 (2002): $412-432$.

-. Theology of the Old Testoment: Testlmony, Dispute, Advococy. Minneapolis: Fortress Press, 1997.

Brunert, Gunild. Psolm 102 Im Kontext des Vierten Psolmenbuches. Stutlgart: Katholisches Bibelwerk, 1996.

Brunner-Traut, Emma. Frühformen des Erkennens: om Beisplel Agrplens. 2nd edition. Darmstadt: WBG, 1992.

Bulemann, Rudoll. History ond Escholology. Edinburgh: The University Press, 1957.

-. Jesus Christ and Mythology. London: SCM Press, 1960.

-. Theologie des Neuen Testoments. 9th edition. Tubingen: J.C.B. Mohr(Paul Siebeck). 1954. 
Burnett, Richard E. "Historical Criticism." In Dictionary for the Theological Interpretation of the Bible, edited by Kevin J. Vanhoozer, Craig G. Bartholomew, Daniel J. Treier and N. T. Wright, 290-293. Grand Rapids, Ml; London: SPCK; Baker Academic, 2005.

Cabaniss, Allen. The Harrowing of Hell, Psalm 24, and Pliny the Younger: A Note." Vigiliae christionae 7, no. 2 (1953): 65-74.

Campbell, Antony F. 2 Somuel. Grand Rapids, MI.: William B. Eerdmans, 2005.

Caputo, John D. "Heidegger and Theology." In The Cambridge Companion to Heidegger, edited by Charles Guignon, 270-288. Cambridge: Cambridge University Press, 1993.

Carlson, Rolf August. David, the Chosen King: A Traditio-Historical Approach to the Second Book of Samuel. Translated by Stanley Rudman and Eric J. Sharpe. Stockholm: Almqvist \& Wiksell International, 1964.

Carrithers, Michael. Why Humans Have Cultures: Explaining Anthropology and Social Diversity. Oxford: Oxford University Press, 1992.

Carroll, M. Daniel R. The Power of the Future in the Present: Eschatology and Ethics in O'Donovan and Beyond." In A Royal Priesthood? A Dialogue with Oliver O'Donovan, edited by Craig Bartholomew, Jonathan Chaplin, Robert Song and Al Wolters, 116143. Carlisle, UK; Grand Raipds, MI: Paternoster Press; Zondervan, 2002.

Cassuto, Umberto. A Commentary on the Book of Exodus. Jerusalem: Magnes Press, 1968.

Cheyne, Thomas Kelly. The Book of Psalms, Vol. 1. London: Kegan Paul, Trench, Trübner, \& Co., 1904.

Childs, Brevard S. "A Response [to James Mays et al.]." Horizons in Biblical Theology 2 (1980): 199-211.

- "Allegory and Typology Within Biblical Interpretation." Paper presented at St Mary's College, Universtiy of St. Andrews. St Andrews, 2000.

-. "Analysis of a Canonical Forumla: 'It Shall be Recorded for a Future Generation'." In Die hebräische Bibel und ihre zweifoche Nochgeschichte: Festschrift für R. Rendtorff zum 65. Geburtstog, edited by Erhard Blum, Chr. Macholz and E. W. Stegemann, 357-364. Neukirchen-Vluyn: Neukirchener Verlag, 1990. 
-. "Biblical Scholarship in the Seventeenth Century: A Study in Ecumenics." In Longuoge, Theology, and the Bible: Essays in Honour of Jomes Borr, edited by Samuel E. Balentine and John Barton, 325-333. Oxford: Clarendon Press, 1994.

-. Biblical Theology in Crisis. Philadelphia: WestminsterJohn Knox Press, 1974.

-. Biblical Theology of the Old and New Testaments: Theological Reflection on the Christion Bible. Minneapolis: Fortress Press, 1992.

-. "Critical Reflections on James Barr's Understanding of the Llecral and the Allegorical." Journal for the Study of the Old Testoment 46 (1990): 3-9.

-. "Critique of Recent Intertextual Canonical Interpretation." Zeitschrift für die olttestomentliche Wissenschoft 115, no. 2 (2003): 173-184.

-."Death and Dying in Old Testament Theologr." in Love ond Deoth in the Ancient Neor Eost, edired by John H. Marks and Robern M. Good, 89.91. Guilford, Conn.: Four Quarters Publishing Company, 1987.

-. "Does the Old Testament Witness to Jesus Christ?" In Evangclium, Schriftouslegung. Kirche: Festschrift för Peter Stuhlmocher sum 65. Geburtslog, edited by Jostein Adna and Scolt J. Hafemann, 57.64. Goltingen: Vandenhoek \& Ruprecht, 1997.

-. Interpretation in Faith: The Theological Responsibility of an Old Testament Commentary." Interpretotion 18, no. 40 (1962): $432-449$.

-. "Interpreting the Bible Amid Culfural Change." Theology Todoy 54 (1997): 200-211.

-. Introduction to the Old Testoment os Scripture. Philadelphia: Fortress Press, 1979.

-. Isoioh and the Assyrion Crisis. London: SCM, 1967.

-. Isoioh: A Commentory. Louisville: Westminster John Knox, 2001.

-. "Jesus Christ the Lord and the Scriptures of the Church." In The Rule of Foith: Scripture. Conon, and Creed in a Crilical Age, edited by Ephraim Radner and George Sumner. 1-12. Harrisbure, Pa.: Morehouse Publishers, 1998.

-. "Karl Barth as Interpreter of Scripture." Edited by David L. Dickerman. Korl Borth and the Future of Theology: A Memorial Colloquium Held of the Yole Divinity of School Jonuary 18 1969. New Haven: Yale Divinity School Association, 1969. 30.39. 
-. "Karl Barth: The Preacher's Exegete." Paper presented at The Lyman Beecher Lectureship on Preaching, Yale University. New Haven, 1989.

-. Memory and Tradition in Israel. London: SCM, 1962.

-. "Midrash and the Old Testament." In Understanding the Sacred Text, edited by John Reumann, 45-59. Valley Forge, Pa.: Judson Press, 1972.

-. Myth and Reality in the Old Testament. 2nd ed. London: SCM, 1962.

-. "Old Testament in Germany 1920-1940." In Altes Testament, Forschung und Wirkung: Festschrift für Henning Grof Reventlow, edited by Peter Mommer and Winfried Thiel, 233-246. Frankfurt am Main: Peter Lang, 1994.

-. Old Testoment Theology in a Cononical Context. Philadelphia: Fortress Press, 1985.

-. "On Reading the Elijah Narratives." Interpretation: A Journal of Bible and Theology 34, no. 2 (1980): 128-137.

-. "Prophecy and Fulfillment: A Study of Contemporary Hermeneutics." Interpretation: A Journal of Biblle and Theology 12, no. 3 (1958): 257-271.

-. "Psalm 8 in the Context of the Christian Canon." Interpretation: A Journal of Bible and Theology 23, no. 1 (1969): 20-31.

-. "Psalm Titles and Midrashic Exegesis." Journal of Semitic Studies 16, no. 2 (1971): 137150.

-. "Reflections on the Modern Study of the Psalms." In Magnalia Dei: The Mighty Acts of God: Essays on Bible and Archaeology in Memory of G. E. Wright, edited by Frank Moore Cross, Werner E. Lemke and Patrick D. Miller, 377-388. New York: Doubleday, 1976.

-. "Response to Reviewers of Introduction to the OT as Scripture." Journal for the Study of the Old Testament 16 (1980): 52-60.

-. "Retrospective Reading of the Old Testament Prophets." Zeitschrift für die alttestamentliche Wissenschoft 108, no. 3 (1996): 362-377.

-."Review of Michael Fishbane, Biblical Interpretation in Ancient Israel." Journal of Biblical Literature 106, no. 3 (1987): 511-513. 
-. "Speech-act Theory and Biblical Interpretation." Scottish Journol of Theology 58, no. 4 (2005): 375-392.

-. The Almost Forgotten Genesis Commentary of Benno Jacob." In Recht und Ethos im Atten Testoment-Gestolt und Wirkung: Festschrift für Horst Seeboss zum 65. Geburtstog, edited by Stefan Beyerle and Gonter Mayer, 273-280. NeukirchenVuyn: Neukirchener Verlag, 1999.

-. The Book of Exodus: A Critical, Theological Commentary. Louisville: Westminster John KnoxPress, 1974.

-. The Canon in Recent Biblical Studies: Reflections on an Era." In Conon and Biblical Interpretotion, edited by Craig Bartholomew, Scoll Hahn, Robin Parry, Christopher Seitz and AI Wolters, 33-57. Grand Rapids: Zondervan, 2006.

-. "The Canonical Shape of the Prophetic Literature." Interpretotion: A Journal of Bible and Theology 32, no. 1 (1978): 46-55.

-. The Church's Guide for Reading Paul: The Canonical Shoping of the Pauline Corpus. Grand Rapids: Eerdmans, 2008.

-. The Etiological Tale Re-examined." Vetus Testomentum 24, no. 4 (1974): 387-397.

-. "The Genre of Biblical Commentary as Problem and Challenge." In Tehilla le-Moshe: Biblical and Judoic Studies in Honour of Moshe Greenberg. edited by Mordechai Cogan and Barry L. Eichler, 185-192. Winona Lake, Ind.: Eisenbrauns, 1997.

-. The Nature of the Christian Bible: One Book, Two Testaments." In The Rule of Foith: Scripture, Conon, and Creed in a Critical Age, edited by Ephraim Radner and George Sumner, 115-125. Harrisbure, PA: Morchouse Publlshing, 1998.

-. The New Testoment as Conon: An Introduction. Philsdelphla: Foniess Press, 198.4.

-. The Old Testament as Scripture of the Church." Concordia Theological Meanthly 43 (1972): 709-722.

-. The One Gospel in Four Witnesses." In The Rule of Falth: Scriplure, Conon, and Creed in - Critical Age, edited by Ephralm Radner and Georeo Sumner, 51-62. Harrisburs. Pa.: Morehouse Publishers, 1998. 
-. "The Sensus Literalis of Scripture: An Ancient and Modern Problem." In Beiträge zur alttestamentlichen Theologie: Festschrift für Walther Zimmerli zum 70. Geburtstag, edited by Herbert Donner, Robert Hanhart and Rudolf Smend, 80-93. Göttingen: Vandenhoek \& Ruprecht, 1977.

-. "The Struggle for the Righteousness of God in the Psalter." In Christ in Our Place, edited by Trevor Hart and Dan Thimell, 255-264. Allison Park, Pa.: Pickwick Publications, 1989.

-. The Struggle to Understand Isaiah as Christian Scripture. Grand Rapids: Eerdmans, 2004.

-. "Walter Brueggemann's Theology of the Old Testament. Testimony, Dispute, Advocacy." Scottish Journal of Theology 53, no. 2 (2000): 228-233.

-. "Wellhausen in English." Semeia 25 (1985): 83-88.

Childs, Brevard S., and Westminster John Knox. An Interview with Brevard Childs (19232007). Fall 2000. http://www.philosophy-religion.org/bible/childs-interview.htm (accessed December 15, 2010).

Clements, Ronald E. God and the Temple: The Presence of God in Israel's Worship. Philadelphia: Fortress Press, 1965.

-. Isaiah and the Deliverance of Jerusalem: A Study of the Interpretation of Prophecy in the Old Testament. Sheffield: JSOT Press, 1980.

-. Worship and Ethics: A Re-Examination of Psalm 15." In Worship and the Hebrew Bible: Essays in Honour of John T. Willis, edited by M. Patrick Graham, Rick R. Marrs and Steven L. McKenzie, 78-94. Sheffield: Sheffield Academic Press, 1999.

Clifford, RJ. Psalms 1-72. Nashville: Abingdon Old Testament Commentaries, 2002.

Clines, David J.A. "A World Established on Water (Psalm 24): Reader-Response, Deconstruction and Bespoke Interpretation." In The New Literary Criticism of the Hebrew Bible, edited by J. Cheryl Exum and David J.A. Clines, 79-90. Sheffield: JSOT Press, 1993.

-. ed. The Dictionary of Classical Hebrew. 5 vols. Sheffield: Sheffield Academic Press, $1993-$ 2001. 
Cooper, Alan. "Ps 24:7-10: Mythology and Exegesis." Journal of Biblical Uterolure 102, no. 1 (1983): 37-60.

Craigie, Peter C. Psolms 1.50 (Revised Edition). Nashville, Tenn.: Word Biblical Commentary, 2004.

Creach, Jerome F.D. The Destiny of the Righteous in the Psolms. St. Louis, Missourt: Chalice Press, 2008.

-. "The Psalms and the Cult." In Interpreting the Psalms: Issues and Approoches, edited by David Firth and Philip S. Johnston, 119-137. Downers Grove, Illinois: IVP Academic, 2005.

-. The Shape of Book four of the Psalter and the Shape of Second Isaiah." Journal for the Study of the Old Testoment 80 (1998): 63-76.

Crenshaw, James L "Forward: The Book of Psalms and les Interprefers." In The Psolms in Isroel's Worship, by Sigmund Mowinckel, xix-xxxil. Grand Rapids, MI: Wm. B. Eerdmans, 2004.

Cross, Frank Moore. Conoonite Myth and Hebrew Eple. Cambridge: Hanard University, 1973.

Dahood, Mitchell Joseph. Psalms 1, 1-50. Garden Clty, New York: Doubleday, 1966.

Davidson, A.B. Introductory Hebrew Grommar: Hebrew Syntax. 3rd edition. Edinburgh: T \& TClark, 1902.

Davidson, Robert. The Vitolity of Worship. A Commentory on the Book of Psolms. Grand Rapids, MI.: Eerdmans, 1998.

Davis, Ellen F. "Exploding the Limits: Form and Function in Psalm 22." Journal for the Study of the Old Testoment 53 (1992): 93-105.

Day, John. The Ask and the Cherubim in the Psalms." In Psalms and Proyers: Popers feod of the Joint Meeting of the Soclety of Old Testoment study ond Het Oudiestomentische Werkgezelschop in Nederlond en Belgie, Apcldoarn August 2006, edited by Bob Becking and H. G.L. Pecls, 65-77. Leiden: Brill, 2007. 
DeClassé-Walford, Nancy L. "An Intertextual Reading of Psalms 22, 23, adn 24." In The Book of Psolms: Composition and Reception, edited by Peter W. Flint, Patrick D. Miller, Aaron Brunell and Ryan Roberts, 139-152. Leiden; Boston: Brill, 2005.

Delitzsch, Franz. Biblical Commentary on the Psalms. London: Hendrikson Publishers, 1902.

-. Biblischer Kommentar über die Psalmen. Leipzig: Dörfling \& Franke, 1883.

Diem, Hermann. Dogmatics. Translated by H. Knight. Philadelphia: Westminster Press, 1959.

-. Dogmatik: Ihr Weg zwischen Historismus und Existentialismus. 2nd edition. Vol. 2. 2 vols. Munich: Chr. Kaiser Verlag, 1957.

Dix, Dom Gregory. The Shape of the Liturgy. Westminster: Dacre Press, 1945.

Driver, Daniel. Brevard Childs, Biblical Theologion: For the Church's One Bible. Tübingen: Mohr-Siebeck, 2010.

Duhm, Bernhard. Die Psalmen. Freiburg: Mohr, 1899.

Eaton, J.H. Kingship and the Psalms. 2nd edition. Sheffield: JSOT Press, 1986.

Eichrodt, Walther. Theologie des Alten Testaments. 7th edition. Vol. I. Stuttgart: Ehrenfried Klotz Verlag, 1962.

Elliger, Karl. Das Buch der zwölf Kleinen Propheten. Göttingen: Vandenhoek \& Ruprecht, 1975.

Elliot, J. K. Apocryphal New Testament. Oxford: Clarendon Press, 1993.

Erlich, V. Russion Formolism. The Hague: Mouton, 1955.

Evangelisches Gesangbuch: Ausgabe für die Evangelische Landeskirche in Württemberg. Stuttgart: Gesangbuchverlag Stuttgart GmbH, 1996.

Evans, C. Stephen. "Canonicity, Apostolicity, and Biblical Authority: Some Kierkegaardian Reflections." In Conon and Biblical Interpretation, edited by Craig G. Bartholomew, Scott Hahn, Robin Parry, Christopher Seitz and Al Wolters, 146-166. Milton Keynes: Paternoster Press, 2006. 
Farrow, Douglas B. "Ascension." In Dictlonory for Theological Interpretation of the Bible, edited by Craig G. Bartholomew, Daniel J. Treier, N. T. Wright and Kevin J. Vanhoozer, 65-68. London; Grand Rapids, MI: SPCK; Baker Academic, 2005.

- Ascension and Ecclesia: On the Significonce of the Doctrine of the Ascension for Ecclesiology and Christion Cosmology. Grand Rapids, Ml: William B. Eerdmans Publishing Company, 1999.

-. "Church, Doctrine of the." In Dictionory for the Theological Interpretation of the Bible, edited by Kevin J. Vanhoozer, Craig G. Bartholomew, Daniel J. Treier and N. T. Wright, 117-120. London; Grand Rapids, MI: SPCK; Baker Academic, 2005.

-. "Confessing Christ Coming." In Nicene Christionily: The Future for a New Ecumenism. edited by Christopher R. Seitz, 133-148. Grand Rapids, MI: Brazos Press, 2001.

Fishbane, Michael. Biblical Myth and Robbinic Mythmoking. Oxford: Oxford Untverstiy Press, 2003.

Floyd, Michael. Minor Prophets: Port 2. Grand Rapids, Ml: Willlam 8. Eerdmans Publishing Company, 2000.

Fokkelman, Jan P. Mojor Poems of the Hebrew Bible: At the Interfoce of Prosody and Structural Anolysis. Vol. 3. Assen: Van Gorcum, 2003.

-. Reoding Biblical Poetry: An Ineroductory Guide. Translated by Ineke Smit. Louisville: Westminster John Knox Press, 2001.

-. Throne ond City (II Som. 2-8 \& 21-24). Vol. III. IV vols. Assen: Van Gorcum, 1990.

Freedman, David Noel, ed. The Anchor Yale Bible Dictionary, 6 vols. New York: Doubleday. 1992.

Frei, Hans. The Eclipse of Biblical Norrotlve: A Study In Elghtcenth and Ninetecnth Century Hermeneutics. Yale University Press, 1974.

-. The Identity of Jesus Christ: The Hermeneutical Basis of Dogmatic Theology. Philadelphia: Forress Press, 1975.

Furry, Tim. Scripture and History: The Perplexity of Dissoclotion of the Post from the Present. 2008. hilp://limshadyud.blogspot.com/2008/09/rome-paper-part-1.html; 
http://timshadyud.blogspot.com/2008/09/scripture-and-history-part-ii.html. (accessed 2010).

Futato, Mark D. Interpreting the Psalms: An Exegetical Handbook. Grand Rapids, MI: Kregel Publications, 2007.

Galling, Kurt. "Der Beichtspiegel: Eine gattungsgeschichtliche Studie." Zeitschrift für die Alttestamentliche Wissenschaft 47 (1929): 125-130.

Gerok, Karl. Die Psalmen. Vol. 1. 3 vols. Suttgart: Verlag von Carl Krabbe, 1891.

Gerstenberger, Erhard S. "Canon Criticim and the Meaning of 'Sitz im Leben'." In Conon, Theology, and Old Testament Interpretation: Essays in Honour of Brevard S. Childs, edited by Gene M. Tucker, David L. Petersen and Robert R. Wilson, 20-31. Philadelphia: Fortress Press, 1988.

-. Psalms, Part 1: With an Introduction to Cultic Poetry. Grand Rapids, Ml: William B. Eerdmans Publishing Company, 1988.

-. Psolms, Port 2, and Lamentations. Grand Rapids, Ml: William B. Eerdmans Publishing Company, 2001.

-. Theologies in the Old Testament. Translated by John Bowden. Edinburgh: T \& T Clark, 2002.

-. "World Dominion' in Yahweh Kingship Psalms: Down to the Roots of Globalizing Concepts and Strategies." Horizons in Biblical Theology 23 (2001): 192-210.

Gesenius, Friedrich Wilhelm. Gesenius' Hebrew Grammar. 2nd English edition. Edited by E. Kautzsch and Arthur Ernest Cowley. Translated by Arthur Ernest Cowley. Oxford: Clarendon Press, 1910.

Gillingham, Susan. The Zion Tradition and the Editing of the Hebrew Psalter." In Temple and Worship in Biblical Israel: Proceedings of the Oxford Old Testament Seminar, edited by John Day, 308-341. London: T\&T Clark, 2007.

Gillmayr-Bucher, Susanne. "The Psalm Headings: A Canonical Relecture of the Psalms." In Biblical Canons, edited by Jean-Marie Auwers and Henk J. de Jonge, 247-254. Leuven: Leuven University Press, 2003. 
Girard, Marc. Les Psoumes Redécouverts: De lo structure aus sens: 1-50. 2nd edition. Vol. 1. 3 vols. Chicoutimi: Bellarmin, 1996.

Goldingay, John. Isoioh. Peabody; Carlisle: Hendrickson; Patnernoster Press, 2006.

-. Old Testoment Theology. Volume 2: Isroel's Foith. Vol. 2. 3 vols. Downers Grove, Il.: InterVarsity Press, 2006.

-. Psolms. Volume 1: Psalms 1-41. Michigan: Baker Academic, 2006.

-. Psalms. Volume 2: Psalms 42-89. Vol. 2. 3 vols. Grand Rapids, Michigan: Baker Academic, 2007.

-. "Repetition and Variation In the Psalms." Jewish Quorterly Review 68, no. 3 (1978): 146151.

Goulder, Michael. "David and Yahweh in Psalms 23 and 24." Journol for the Study of the Oid Testoment 30, no. 3 (2006): 463-473.

Graetz, H. Kritischer Commentor zu den Psolmen. Breslau, 1882.

Green, Joel. "The (Re-) Turn to Theology." Journal of Theological Interpretotion 1, no. 1 (2007): 1-3.

Greenberg, Moshe. The Thematic Unity of Exodus II-XI." In Founth World Congress of Jewish Studies I, 151-154. Jerusalem: Snow Llon Publications, 1967.

Greene-McCreight, Kathleen. "Rule of Falth." In Dictlonory for the Theological Interpretation of the Bible, edited by Kevin J. Vanhoozer, Craig G. Bartholomew, Daniel J. Treier and Nicholas T. Wright, 703.704. Grand Rapids, MI: SPCX; Baker Academic, 2005.

Gressmann, Hugo. "Die Aulgaben der altiestamentlichen Forschung." Zelischrift für die olttestomentliche Wissenschoft 42 (1924): 1-33.

Groom, Sue. Linguistic Analysis of Biblical Hebrew. Carlisle: Palernosser Press, 2003.

Gunkel, Hermann. Die Psolmen. Gth edition. Golsingen: Vandenhock \& Ruprecht, 1986.

-. "Jesaja 33, eine prophepische Llturgie." Zeltschrlft for die Alftestomentliche UVissenschoft 47 (1924): 177-208. 
-."Psalm 24: An Interpretation." The Biblical World 21, no. 5 (1903): 366-370.

Gunkel, Hermann, and Joachim Begrich. Einleitung in die Psalmen: Die Gattungen der religiósen Lyrik Isroels. 4th edition. Göttingen: Vandenhoeck \& Ruprecht, 1985.

Gunneweg, Antonius H. J. "Altes Testament und existentiale Interpretation." In Sola Scriptura: Aufsätze zu alttestamentlichen Texten und Themen, by Antonius H. J. Gunnewez, edited by Peter Höffken, 66-81. Göttingen: Vandenhoek \& Ruprecht, 1992.

Guretzki, David. Karl Barth on the Filioque. Farnham: Ashgate, 2009.

-. "Review of J. Webster's Holy Scripture: A Dogmatic Sketch." Studies in Religion/Sciences Religieuses 33, no. 2 (2004): 269-270.

Hăgglund, Bengt. "Die Bedeutung der >regula fidei< als Grundlage theologischer Aussagen." Studia Theologica 12, no. 1 (1958): 1-44.

Hallo, William W., and K. Lawson Younger, . The Context of Scripture. Vol. 1. 3 vols. Leiden; New York: Brill, 1997 -

Hammann, Wilhelm. Erklörung von Psalm 24: eine biblisch-theologische Untersuchung. Inougural-Dissertation zur Erlangung der Doktorwürde der philosophischen Fakultät der Universitót Tübingen. Darmstadt: C.F. Winter'sche Buchdruckerei, 1905.

Harner, P. B. "Creation Faith in Deutero-Isaiah." Vetus Testamentum 17 (1967): 298-306.

Hart, David Bently. "The Lively God of Robert Jenson." First Things. October 2005. http://www.firstthings.com/article/2007/01/the-lively-god-of-robert-jenson-4 (accessed August 2011).

Hart, Trevor. "Revelation." In The Cambridge Companion to Karl Barth, edited by John Webster, 37-56. Cambridge: Cambridge University Press, 2000.

Hays, Chrisopher B. "Bard Called the Tune: Whither Theological Exegesis in the Post-Childs Era?" Journal for Theological Interpretation 4, no. 1 (2010): 139-151.

Hays, D. "Jeremiah, the Septuagint, the Dead Sea Scrolls and Inerrancy." In Evangelicals and Scripture: Tradition, Authority and Hermeneutics, edited by V. Bacote, D. L. Okholm and L. C. Miquélez, 133-149. Downers Grove, Il.: InterVarsity Press, 2004. 
Hays, Richard. "Reading the Bible with the Eyes of Fatih: The Practice of Theological Exegesis." Journol of Theological Interpretotion 1, no. 1 (2007): 5-21.

Heine, Ronald E. Reoding the Old Testoment with the Ancient Church: Exploring the Formation of Eorly Christion Thought. Grand Rapids, MI: Baker Academic, 2007.

Hengstenberg. Ernst Wilhelm. Commentory on the Psolms: Volume 1. 4th edition. Edinburgh: T\&T Clark, 1869.

Henneke, Susanne. "Die Kulturtheologie von Kornelis Heiko Miskorte im Spiegel seiner Barthrezeption." Unpublished paper to be held in 2012.

Heppe, Heinrich. Reformed Dogmotics. rev, and reprinted edn. Edited by Ernst Blzer. Grand Rapids: Baker Book House, 1978.

Hermisson, Hans-Jürgen. "Jakob und Zion, Schðpfung und Heil: Zur Einheit der Theologie Deuterojesajas." Zeichen der Zeit 44 (1990): 262-268.

Hirsch, David H.; Aschkenasy, Nehama;. "Translatable Structure, Untranslatable Poem: Psalm 24." Modern Longuoge Studies 12, no. 4 (1982): 21.34.

Hobbins, John F. "Annotated Bibliography: Ancient Hebrew Poctry Studies." Ancient $\begin{array}{lllll}\text { Hebrew } & \text { Poetry } & 9 & \text { August }\end{array}$ http://ancienthebrewpoetry.typepad.com/ancient_hebrew_poctry/files/annotate d_bibliography.pdf (accessed january 2011).

Hobbins; John F. "Regularities in Ancient Hebrew Verse: A New Descripitive Model." Zeitschrift für die Alttestomentliche Wissenschoft 119, no. 4 (2007): 564.585.

Holladay, William Lee. Jeremioh 2: A Commentary on the Book of the Prophet Jeremiah. Chapters 26-52. Vol. 2. 2 vols. Minneapolis: Fortiess Press, 1989.

Hossfeld, Frank-Lothar. "Nachlese zu neucren Studien der Elnzugslisurgie von Ps 15." In Die oltzestomentliche Botschoft als Wegweisung: Festschrift för W. Reinelt, edited by J. Zmijewskl, 135-156. Stutigart: Katholisches Bibelwerk, 1991.

Hossfed, Frank-Lothar, and Erleh Zenger. "Wer darf hinaulzlehn zum Berg JHWHs?" Zur Redaktionsgeschichte und Theologie def Psalmengruppe 15.14." In Bibliseche Theologie und geslleschofilicher Wondel, edited by GeOrg Braulik OSB, Walier GroB and Sean MCEvenue, 166-182. Freiburg: Herder, 1993. 
-. "Neue und Alte Wege der Psalmenexegese: Antworten auf die Fragen von M. Millard und R. Rendtorff." Biblical Interpretation 4, no. 3 (1996): 332-343.

—. Die Psolmen I: Psalm 1-50. Würzburg: Echter Verlag, 1993.

-. Psolms 2: A Commentary on Psolms 51-100. Translated by Linda M. Maloney. Minneapolis, MN: Fortress Press, 2005.

Hunter, Alistair G. Psalms. London: Routledge, 1999.

-. "The Righteous Generation': The Use of DÓR in Psalms 14 and 24." In Reflection and Refraction: Studies in Biblical Historiography in Honour of A. Graeme Auld, edited by Robert Rezetko, Timothy H. Lim and Brian W. Auker, 187-205. Leiden: Brill, 2006.

Jacob, Benno. Das Zweite Buch der Torah. Jerusalem, Microfilm.

Jacquet, L. Les Psaumes et le coeur de l'homme: Introduction et Premier livre du Psaumes (1 d 41). Namur, 1975.

Jakobson, Roman. "Linguistics and Poetics." In Style in Language, edited by T.A. Sebeok, 350-377. Cambridge, Mass.: MIT Press, 1960.

-. Vers une science de l'art poétique." In Selected Writings V: Verse and its Masters and Explorers, by Roman Jakobson, 541-544. The Hague: Mouton, 1966/1971.

Jenson, Robert W. "For Us ... He Was Made Man." In Nicene Christianity: The Future for a New Ecumenism, edited by Christopher R. Seitz, 75-86. Grand Rapids, MI: Brazos Press, 2001.

-. "Once More the Logos Asarkos." International Journal of Systematic Theology 13, no. 2 (2011): 130-133.

-. Systemotic Theology. Volume I. The Triune God. Vol. 1. 2 vols. Oxford: Oxford University Press, 1997.

-. Systemotic Theology. Voume II. The Works of God. Oxford: Oxford University Press, 1999.

-. Toward a Christian Doctrine of Israel." Reflections: Center of Theological Inquiry 3 (2000): 2-23. 
Jeremias, Jörg. "Das Wesen der alttestamentlichen Prophetie." Die theologische Literoturzeitung 131 (2006): 3.14.

Johnson, Ben. The Question of Property in the New Testament." In Christion Ethios and the Question of Property, edited by Bella Hamartl, 50-58. Geneva, Switzerlan: Lutheran World Federation, 1982.

Jonker, L.C. "Revisiting the Psalm Headings: Second Temple Levitical Propagandar" In Psolms and Liturgy, edited by Dirk J. Human and C.J.A. Vos, 102-122. London; New York: Clark, 2004.

Jüngel, Eberhard. Gott als Geheimnis der Welt: Zur Begröndung der Theolagie des Gekreuzigten im Streit zwischen Theismus und Atheismus. Tabingen: J.C.B. Mohr (Paul Siebeck), 1977.

-. Predigten. Mit einem Anhong: Wos hat die Predigt mit dem Text zu tun? Munich: Chr. Kaiser Verla\&, 1968.

- Thesen zur Grundlegung der Christologie." In Unierwegs zur Soche, by Eberhard Jüngel. edited by 3rd revised edition, 234-244. Tubingen: Mohr Sle beck, 2000 (1972).

Jüngling, Hans-Winfried. "Das Buch Jesaja." In Einlelfung In dos Alte Testoment, edited by Erich Zenger U.a., 381-404. Stutigart: Kohlhammer, 2001.

Kăhler, Ernst. Studien zum Te Deum und zur Geschichie des 29 Psolmes In der Alen Kirche. Gollingen: Vandenhoek \& Rupreche, 1958.

Kahler, Martin. Biblische Theologle. Vol. 3, in Reolencyclopdie für protestontische Theologie und Kirche, ediled by Albert Hauck, 192-200. Lelpzig: J.C. Hinrichs, 1897.

Keel, Orhmar. "Altsgyptische und biblische Welibilder, die Anlsnge der vorsolestischen Philosophie und das apxn.Problem in spjten Schrilten." In Das biblische Wefibild und seine altorientalischen Kontexte, edited by Bernd Jsnowskl and B. [60, 34.36; 46-47. Tubingen, 2001.

Keil, Carl Friedrich; Franz Delitzsch. Commentory on the Old Testoment. 10 vols. Peabody, MA: Hendrickson, 2002.

Kidner, Derek. Psolms 1-72. Downers Grove: InterVarsity Press, 1973. 
Kittel, Rudolf. Die Psolmen: Kommentar zum Alten Testament. Leipzig Erlangen, 1922.

-. "Die Zukunft der Alttestamentlichen Wissenschaft." Zeitschrift für die Alttestamentliche Wissenschaft 39 (1921): 84-89.

Klass, Stefan. "Der <Staat Israel> im Spannungsfeld von Politik und Religion. Theologische Wahrnehmungsübungen bei Karl Barth und Friedrich-Wilhelm Marquardt." In Das Gelobte Land: Erez Israel von der Antike bis zu Gegenwart. Quellen und Dorstellungen, edited by Alexandra Pontzen and Axel Stähler, 300-326. Reinbeck bei Hamburg: Rowohlt Taschenbuch Verlag, 2003.

Kleer, M. Der liebliche Sänger der Psalmen Israels. Bodenheim: Philo, 1996.

Klement, Herbert H. II Samuel 21-24: Context, Structure and Meaning in the Samuel Collection. Frankfurt am Main: Peter Lang, 2000.

Knierim, Rolf. "Das Erste Gebot.” Zeitschrift für die alttestamentliche Wissenschaft 77, no. 1 (1965): 20-39.

-. The Task of Old Testament Theology: Substance, Method and Cases. Grand Rapids, MI: Wm. B. Eerdmans, 1995.

Knierim, Rolf, and Gene M. Tucker. "Editor's Forward." In Psalms, Part 1: With an Introduction to Cultic Poetry, by Erhard Gerstenberger, xi-xiv. Grand Rapids, MI: William B. Eerdmans Publishing Company, 1988.

Koch, Klaus. Tempeleinlaßliturgien und Dekaloge." In Studien zur Theologie der alttestamentlichen Überlieferungen, edited by Rolf Rendtorff and Klaus Koch, 45-60. Neukirchen Kreis Moers: Neukirchener Verlag, 1961.

-Was ist Formgeschichte? Neue Wege der Bibelexegese. 2nd edition. Neukirchen-Vluyn: Neukirchener Verlag, 1967.

Koehler, Ludwig. Theologie des Alten Testaments. 3rd Ed. Tübingen: Mohr Siebeck, 1953.

Kohlbrügge, H.F. Auslegungen zu Psalm 20-33. Elberfeld: Verlag der nieder-reformierten Gemeine, 1922. 
Kooij, Andre van der. Zur Frage der Exegese im LxX.Psalter. Ein Beitrag zu Verhăltnisbestimmung zwischen Original und Ubersetzung." In Septuoginto und seine Tocherübersetzungen, 366-380. Goltingen: Vandenhoek \& Ruprecht, 2000.

Körting, Corinna. Zion in den Psolmen. Tübingen: Mohr Slebeck, 2006.

Kraus, Hans-Joachim. A Continental Commentory: Psolms 1.59. Translated by Hilton C. Oswald. Minneapolis, MN: Fortress Press, 1993.

- A Continentol Commentary: Psolms 60-150. Translated by Hilton C Oswald. Minneapolis, MN: Fortress Press, 1993.

-. Biblische Theologische Aufsötze. Neuklichen-Vluyn: Neuklichener Verlog, 1972.

-. Theology of the Psolms. Translated by Keith Crim. Minneapolis, MN: Fortress Press, 1992.

-. Worship in lsroel. Oxford: Oxford University Press, 1966.

Kreuzer, Siegfried, and Dieter Vieweger. Proseminor Altes Testoment: Ein Arbeitsbuch. Stutigart: Verlas W. Kohlhammer, 1999.

Lamparter, H. Dos Buch der Psolmen I: Psolm 1-72. Stuttgart: Calwer Verlag, 1958.

Landy, Francis. "Critical Note: In Defense of Jakobson." Journol of Biblicol Literoture 111, no. 1 (1992): $105-113$.

Lane, W.L. "Form Criticism." In Baker Encyclopedia of the Bible, cdited by Walter E. Elwell and Barry J. Belzel, 812-815. Grand Raplds, MI: Baker Book House, 1988.

LaNeel Tanner, Beth. The Book of Psolms Through the Lens of Intertextuolity. New York: Peter Lang Publishing, 2001.

Lan\&, Bernhard. "Das Verbol des Meineids im Dekalog." Theologische Quortolschrift 161. no. 2 (1981): 97-105.

Leeuwen, Raymond C. Van. "Cosmos, Temple, House: Bullding in Ancient Mesopotamia and Israel." In From the Foundotions to the Crenellotlons: Essoys on Temple Building in the Ancient Neor Eost ond Hebrew Bible, edited by Mark J. Boda and Jamie Novotny. 399-422. Mûnster: Ugarit-Verlag. 2010. 
-. "Form Criticism, Wisdom, and Psalms 111-112." In The Changing Face of Form Criticism for the Twenty-First Century, edited by Marvin A. Sweeney and Ehud Ben Zvi, 65-84. Grand Rapids, MI: William B. Eerdmans Publishing Company, 2003.

Lescow, Theodor. "Textübergreifende Exegese: Zur Lesung von Ps 24-26 auf redaktioneller Sinnebene." Zeitschrift für die Alttestamentliche Wissenschaft 107 (1995): 65-79.

Levenson, Jon D. "The Temple and the World." The Journal of Religion 64, no. 3 (1984): 275-298.

Levinson, Bernard M. "Goethe's Analysis of Exodus 34 and Its Influence on Wellhausen: The Pfropfung of the Documentary Hypothesis." Zeitschrift für die Alttestamentliche Wissenschaft 114 (2002): 212-223.

Lodge, D. Modes of Modern Writing: Metaphor, Metonymy, and the Typology of Modern Literature. Ithaca, New York: E. Arnold, 1977.

Lohfink, Norbert. "Der neue Bund und die Völker." Kirche und Israel 6 (1991): 115-133.

Long, B.O. 2 Kings. Grand Rapids, MI: Eerdmans, 1991.

Longman, Tremper III. "Israelite Genres in their Ancient Near Eastern Context." In The Changing Face of Form Criticism for the Twenty-First Century, edited by Marvin A. Sweeney and Ehud Ben Zvi, 177-198. Grand Rapids, MI: Wm. B. Eerdmans Publishing Co., 2003.

Loretz, Oswald. Ugarit-Texte und Thronbesteigungspsalmen: Die Metamorphose des Regenspenders Baal-Jahwe (Ps 24, 7-10; 29; 47; 93; 95-100 sowie Ps 77, 17-20; 114. Münster: Ugarit-Verlag, 1988.

Lotman, Jurij M. Vorlesungen zu einer strukturalen Poetik: Einführung, Theories des Verses. Translated by Waltraud Hachnow. Munich: Fink, 1972.

Louth, Andrew. Discerning the Mystery: An Essay on the Nature of Theology. Oxford: Clarendon, 1983.

Lucas, Ernest C. Exploring the Old Testament: A Guide to the Psalms \& Wisdom Literature. Downers Grove, IL: InterVarsity Press, 2003. 
Ludwig. Theodore M. The Tradition of Establishing the Earth in Deutero-Isaiah." Journal of Biblical Literature 92 (1973): 345-357.

Lugt, Pieter van der. Contos ond Strophes in Biblicol Hebrew Poetry with Special Reference to the First Book of the Psalter. Leiden: Brill, 2006.

MacCulloch, John Arnott. The Horrowing of Hell: A Comporative Study of on Early Christion Doctrine. Edinburgh: T. \& T. Clark, 1930.

MacDonald, Neil B. Karl Borth and the Strange New World Within the Bibie. Carlisle, UK: Paternoster, 2000.

- Metaphysics and the God of Isroel: Systematlc Theology of the Old and New Testoments. Milton Keynes; Grand Rapids, MI: Paternostcr; Baker Academic, 2006.

Maier, Johann. Dos oltisroelitische Ladehelligtum. Berlin: Topelmann, 1965.

Marion, Jean-luc. "On the Eucharistic Site of Theology." In God Without Being, by Jean-Luc Marion, translated by Thomas A. Carlson, 138-152. Chieago: University of Chicago Press, 1991.

Mays, James Luther. "A Question of Identity: The Threefold Hermeneutic of Psalmody." Asbury Theological Journal 46, no. 1 (1991): 87.94.

-. Psalms. Louisville: Westminster John Knox Press, 1994.

-. "The David of the Psalms." Interpretotion 40, no. 2 (1986): 143.155.

Mazor, Yair. "Psalm 24." Scandinovion Journal of the Old Testament 7 (1993): 303-316.

McCann, J. Clinton. A Theological Introduction to the Book of Psalms: The Psalms os Torah. Nashville: Abingdon Press, 1993.

MeConville, J. Gordon. Deuteronomy. Leicester; Downers Grove, Illinois: Apollos; InterVarsity Press, 2001.

-. "How Can Jacob Stand? He is so Smalli (Amos 7:2): The Prophelle Word and the Reimagining of Istael." In Isrocl's Prophats and Isroct's Post. Essors on the Relotionship of Prophetic Texts and isroclite History in Honour of John H. Hoyes. edited by B.E. Kelle and M. B. Moore, 131-157. New York: TE.T Clark, 2006. 
-. "Prophetic Writings." In Dictionary for the Theological Interpretation of the Bible, edited by Kevin J. Vanhoozer, Craig G. Bartholomew, Daniel J. Treier and Nathaniel T. Wright, 628-632. London; Grand Rapids, MI.: SPCK; Baker Academic, 2005.

McCormack, Bruce. "Forward." In Karl Barth's Theological Exegesis, by Richard E. Burnett, vii-ix. Tübingen: Mohr Siebeck, 2001.

MCGlasson, Paul C. Canon and Proclamation: Sermons for our Times. Grand Rapids, Ml: Eerdmans, 2000.

-. Invitation to Dogmatic Theology: A Cononical Approoch. Grand Rapids, MI: Brazos Press, 2006.

McGrath, Alistair. "Doctrine." In Dictionary for the Theological Interpretation of the Bible, edited by K. J., Bartholomew, C. G., Treier, D. J., \& Wright, N. T. Vanhoozer, 177-180. London; Grand Rapids, MI.: SPCK; Baker Academic, 2005.

McKnight, Scot. "Israel." In Dictionary for the Theological Interpretation of the Bible, edited by Kevin J. Vanhoozer, Craig G. Bartholomew, Daniel J. Treier and N. T. Wright, 344346. Grand Rapids, Ml; London: SPCK; Baker Academic, 2005.

Melugin, Roy F. "Recent Form Criticism Revisited in an Age of Reader Response." In The Changing Face of Form Criticism for the Twenty-First Century, edited by Marvin A. Sweeney and Ehud Ben Zvi, 46-64. Grand Rapids, MI: Wm. B. Eerdmans, 2003.

Metzger, Martin. "Eigentumsdeklaration und Schöpfungsaussage." In "Wenn nicht jetzt, wonn donn": Aufsötzte für Hans-Joachim Kraus zum 65. Geburtstag, edited by Hans Georg Geyer, Johann Michael and Werner Schneider, 37-51. Neukirchen-Vluyn: Neukirchener Verlag, 1983.

Milgrom, Jacob A. Leviticus: A Book of Rituals and Ethics. Minneapolis: Fortress Press, 2004.

Millard, Matthias. Die Komposition des Psalters: Ein Formgeschichtlicher Ansatz. Tubingen: J.C.B. Mohr (Paul Siebeck), 1994.

-. "Repons." Biblical Interpretation 4, no. 3 (1996): 344-345.

-. Von der Psalmenexegese zur Psalterexegese: Anmerkungen zum Neuansatz von FrankLothar Hossfeld und Erich Zenger." Biblical Interpretation 4, no. 3 (1996): 311-327. 
Miller, Patrick D. Israelite Religion and Biblical Theology: Collected Essoys. Sheffield: Sheffield Academic Press, 2000.

-. "Kingship, Torah Obedience, and Prayer: The Theology of Psalms 15-24." In Neve Wege der Psalmenforschung. Festschrift für Walter Beyerlin, edited by Klaus Seybold and Erich Zenger, 127-142. Freiburg im Br: Herder, 1994.

-. The Beginning of the Psalter." In Shope and Shoping of the Psolter, edited by J. Clinton McCann, 83-92. Sheffield: Jsot Press, 1993.

Minear, Paul S. The Bible and the Historion: Breoking the Silence About God in Biblical Studies. Nashville: Abingdon Press, 2002.

Mitchell, David C. "Lord, Remember Davd: G. H. Wilson and the Message of the Psalter." Vetus Testomentum 56, no. 4 (2006): 526-548.

Moberly, R.W.L. "Christ in all the Scriptures? The Challenge of Reading the Old Testament as Christian Seripture." Journol of Theologicol Interpretotlon 1, no. 1 (2007): 79-100.

Moberty, Walter. The Old Testoment of the Old Testoment. Minneapolis: Forticss Press, 1992.

Moller, Hans. "Strophenbau der Psalmen." Zelischrift för die Altestomentliche Wissenschaft 50 (1932): 240.256.

Morgenstern, Julian. The Gates of Righteousness." Hebrew Union College Annuol 6 (1929): 1.37.

Mowinckel, Sigmund. Psolmenstudien. 6 vols. Amsterdam: Schlppers, 1966.

-. The Psolms in Isroel's Worshlp. Two volumes in One. Translated by D. R. Ap.Thomas. Sheffield: JSOT, 1992.

Muntas Andor. "Property in the Old Testament." In Chrlstion Ethics and the Question of Property, edited by Bela Harmatl, 43-49. Geneva, Switzerland: Lutheran World Federation, 1982.

Muraoka, Takamitsu. "Shon Note: The Stotus Constructus of Adjectlves in Biblical Hebrew." Vetus Testamenfum 27, no. 3 (1977): 375.380. 
Murphy, S. Jonathan. "Is the Psalter a Book with a Single Message?" Bibliotheca Sacra 165 (2008): 283-293.

Nasuti, Harry P. Defining the Sacred Songs: Genre, Tradition and the Post-Critical Interpretation of the Psalms. Sheffield: Sheffield Academic Press, 1999.

Nel, Philipp. J. "Parallelism and Recurrence in Biblical Hebrew Poetry: A Theoretical Proposal." Journal of Northwest Semitic Languages, no. 18 (1992): 135-142.

Neusner, Jacob. The Babylonian Talmud: A Translation and Commentary. Peabody, MA: Hendrickson Publishers, 2011.

Niccacci, Alviero. "Analysing Biblical Hebrew Poetry." Journal for the Study of the Old Testament 74 (1997): 77-93.

-. "The Biblical Hebrew Verbal System in Poetry." In Biblical Hebrew in its Northwest Semitic Setting: Typological and Historical Perspectives, edited by Steven E. Fassberg and Avi Hurvitz, 247-268. Jerusalem: The Hebrew University Magnes Press, 2006.

Nogalski, James. "Reading David in the Psalter: A Study in Liturgical Hermeneutics." Horizons in Biblical Theology 23, no. 2 (2001): 168-191.

Noth, Martin. The Lows in the Pentateuch and Other Essays. Translated by D. R. Ap-Thomas. Edinburgh \& London: Oliver \& Boyd, 1966.

Nötscher, F. Die Psalmen: Echter Bibel. Würzburg: Echter Verlag, 1947.

O'Brien, Julia. "Review of Prophecy and Hermeneutics." Review of Biblical Literature. 2008. http://www.bookreviews.org/pdf/6055_6906.pdf (accessed 2009).

Ollenburger, Benjamin C. Zion the City of the Great King: A Theological Symbol of the Jerusalem Cult. Sheffield: Sheffield Academic Press, 1987.

Ostmeyer, Karl-Heinrich. Gebet/Beten (NT). Deutsche Bibelgesellschaft. January 2010. http://uww.bibelwissenschaft.de/nc/wibilex/dasbibellexikon/details/quelle/WIBI/referenz/48891/cache/de5eb60c84735cd885918c dfe6b488e7/ (accessed February 24, 2011). 
Otto, Eckhart. "Kultus und Ethos in Jerusalemer Theologie: Ein Beitrag zur Begründung der Ethik im Alten Testament." Zeitschrift für die Alttestomentliche Wissenschoft 98 (1986): 161-179.

Perdue, Leo G. "'Is There Anyone Left of the House of Saul ... ?' Ambiguity and the Characterization of David in the Succession Narrative." Journal for the Study of the Old Testament 30 (1984): 67-84.

Podella, Thomas. Transformationen kultischer Darstellungen: Toraliturgien in Ps 15 und 24." Scondinavion Journal of the Old Testoment 13, no. 1 (1999): 95-130.

Poliiack, Meira. 'Deutero-Isaiah's Typological Use of Jacob in the Portrayal of Israel's National Renewal." In Creation in Jewish and Christlon Tradition, edited by H. Graf Reventlow and Y. Hoffman, 72-110. Sheffield: Sheffield Academic Press, 2002.

Raabe, Paul R. "Deliberate Ambiguity in the Psalter." Journol of Biblicol Ltteroture 110, no. 2 (1991): 213-227.

Rabbl Abrohom Chaim Feuer; Rabbl Nosson Scherman; Rabbi Meir Zlotowitz. Tehillim/Psalms: A New Translation with a Commentary Anthologized from Tolmudic, Midrashic and Rabbinic Sources. Vol. 1. 2 vols. Brooklyn, New York: Mesorah Publications, 1985.

Rad, Gerhard von. Dos erste Buch Moses, Genes/s. 5th edition. Gottingen: Vandenhoek \& Ruprecht, 1958.

-. Old Testoment Theology. Translated by D.M.G. Stalker. Vol. 1. 2 vols. Edinburgh: Oliver \& Boyd, 1965.

-. Old Testoment Theology. Translated by D.M.G. Stalker. Vol. 2. 2 vols. London: Oliver \& Boyd, 1965.

-. The Problem of the Hexateuch and Other Essays. Translated by E.W. Trueman Dicken. London: Oliver \& Boyd, 1966.

-. Theologie des Aten Testoments. Vol. 1. 2 vols. Munich: Chr. Kaiser, 1958.

Rahlis, Alfred. Psalmi cum Odis. Goltingen: Vondenhoek \& Ruprecht, 1967. 
Rainer Lachmann; Ernst Öffner. "Erster Sonntag nach Trinitatis (Kirchensonntag). Psalm 24:

Die Erde ist des Herrn." In Predigtstudien für das Kirchenjahr 1985: Perikopenreihe -Zweiter Halbband, edited by Peter Krusche, Dietrich Rössler and Roman Roessler, 111-124. Stuttgart: Kreuz Verlag, 1985.

Reifsnyder, Richard W. "Psalm 24." Interpretation 51, no. 3 (1997): 284-288.

Rendtorff, Rolf. "Anfragen an Frank-Lothar Hossfeld und Erich Zenger Aufgrund der Lektüre des Beitrages von Matthias Millard." Biblical Interpretation 4, no. 3 (1996): 329-331.

-. "The Psalms of David: David in the Psalms." In Book of Psalms: Composition and Reception, edited by Peter W. Flint, Patrick D. Miller, Aaron Brunell and Ryan Roberts, 53-64. Leidon; Boston: Brill, 2005.

- Theologie des Alten Testaments: Ein kanonischer Entwurf. Band 2: Thematische Entfaltung. Vol. 2. 2 vols. Neukirchen-Vluyn: Neukirchener Verlag, 2001.

Richter, Wolfgang. Exegese als Literaturwissenschaft: Entwurf einer alttestamentlichen Literaturtheorie und Methodologie. Göttingen: Vandenhoek \& Ruprecht, 1971.

Roberts, Alexander; James Donaldson; A. Cleveland Coxe. The Ante-Nicene Fathers. Vol. V: Translations of the Fathers Down to A.D. 325. Oak Harbor: Logos Research Systems, 1997.

Roberts, Jimmy J. M. "God's Imperial Reign According to the Psalter." Horizons in Biblical Theology 23 (2001): 211-221.

Roberts, Jimmy J. M. "The King of Glory." The Princeton Seminary Bulletin 3, no. 1 (1980): 510.

Robinson, Robert B. "Sing us One of the Songs of Zion: Poetry and Theology in the Hebrew Bible." In The Labour of Reading: Desire, Alienation, and Biblical Interpretation, edited by Fiona C. Black, Roland Boer and Erin Runions, 87-106. Atlanta: Society of Biblical Literature, 1999.

Rogerson, J.W.; McKay, J.W. Psalms 1-50. Cambridge: Cambridge University Press, 1977.

Rosenstock, Bruce. "David's Play: Fertility Rituals and the Glory of God in 2 Samuel 6." Journal for the Study of the Old Testament 31, no. 1 (2006): 63-80. 
Ross, J.P. "Jahweh Sĕbā'ōt in Samuel and Psalms." Vetus Testamentum 17 (1967): 76-92.

Sanders, James A. "The Heart of the Christian Faith for Me." In Three Faiths One God: A Jewish, Christion, Mulsim Encounter, edited by John Hick and Edmund S. Meltzer, 185-186. Albany: State University of New York Press, 1989.

Scalise, Charles. Canonical Hermeneutics: The Theological Basis and Implications of the Thought of Brevard Childs. PhD Dissertation, Southern Baptist Theological Seminary, 1987.

Schaff, Philip. The Nicene and Post-Nicene Fathers, First Series, Vol. VIII: St. Augustin: Expositions on the Book of Psalms. Oak Harbor: Logos Research Systems, 1997.

Schmidt, H. Die Psalmen. Tübingen, 1934.

Schmidt, Werner H. Alttestamentlicher Glaube. 9th edition. Neukirchen-Vluyn: Neukirchener Verlag, 2004.

Schmidt, Werner H.; assisted by Holger Delkurt and Axel Graupner. Die Zehn Gebote im Rahmen Alttestamentiicher Ethik. Darmstadt: Wissenschaftliche Buchgesselschaft, 1993.

Seebass, Horst. David, Saul und das Wesen des biblischen Glaubens. Neukirchen-Vluyn: Neukirchener Verlag, 1980.

Seeligmann, Isac L. "Voraussetzungen der Midraschexegese." Supplements to Vetus Testamentum 1, 1953: 150-181.

Seitz, Christopher R. "You are my Servant, You are the Israel in whom I will be Glorified": The Servant Songs and the Effect of Literary Context In Isalah." Calvin Theological Journal 39, no. 1 (2006): 117-134.

-. "Canonical Approach." In Dictlonary for Theological Interpretation of the Bible, edited by Kevin J. Vanhoozer, Craig G. Bartholomew, Daniel J. Treier and Nathaniel T. Wright, 100-102. London; Grand Rapids, Mi.: SPCK; Baker Academic, 2005.

-. Isaiah 1-39. Louisville: John Knox Press, 1993. 
-. "Our Help is in the Name of the LORD, the Maker of Heaven and Earth: Scripture and Creed in Ecumenical Trust." In Nicene Christianity: The Future for a New Ecumenism, edited by Christopher R. Seitz, 19-34. Grand Rapids, MI: Brazos Press, 2001.

-. Prophecy and Hermeneutics: Toward a New Introduction to the Prophets. Grand Rapids, MI: Baker Academic, 2007.

-. "The Canonical Approach and Theological Interpretation." In Canon and Biblical Interpretation, edited by Craig G. Bartholomew, Scott Hahn, Robin Parry, Christopher R. Seitz and Al Wolters, 58-110. Milton Keynes: Paternoster Press, 2006.

-. "Two Testaments and the Failure of One Tradition-History." In Figured Out: Typology and Providence in Christion Scripture, by Christopher R. Seitz, 35-48. Lousiville: Westminster John Knox Press, 1989.

-. Word Without End: The Old Testament as Abiding Theological Witness. Cambridge: Eerdmans, 1998.

Seremak, Jerzy. Psalm 24 als Text zwischen den Texten. Berlin: Peter Lang, 1998.

Seybold, Klaus. Die Psalmen. Tübingen: JCB Mohr [Paul Siebeck], 1996.

—.Poetik der Psalmen. Stuttgart: W. Kohlhammer, 2003.

Sheppherd, Gerald. "Isaiah 1-39." In Harper's Bible Commentary, edited by James Mays, 93-94. New York: Harper, 1988.

Slotki, Israel Wolf. "The Text and Ancient Form of Recital of Psalm 24 and Psalm 124." Journal of Biblical Literature 51, no. 3 (1932): 214-226.

Smail, Thomas. "The Holy Spirit in the Holy Trinity." In Nicene Christianity: The Future for a New Ecumenism, 149-166. Grand Rapids, MI: Brazos Press, 2001.

Smart, James D. "The Eschatological Interpretation of Psalm 24." Journal of Biblical Literature 53 (1933): 175-180.

Smith, James K.A. The Fall of Interpretation: Philosophical Foundations for a Creational Hermeneutic. Downers Grove, Il.: InterVarsity Press, 2000. 
Smith, Mark S. "Like Deities, Like Temples (Like People)." In Temple and Worship in Biblical Israel: Proceedings of the Oxford Old Testament Seminar, edited by John Day, 3-27. Edinburgh: T\&T Clark, 2007.

Smith, Paul Allen. Rhetoric and Redaction in Trito-isaioh. Leiden: E.J. Brill, 1995.

Sparks, Kenton L. Ancient Texts for the Study of the Hebrew Bible: A Guide to the Background Literature. Peabody: Hendrickson Publishers, 2005.

Spieckermann, Hermann. "Die Ganze Erde ist seiner Herrlichkeit voll": Pantheismus im Alten Testament?" Zeitschrift für Theologle und Kirche 87, no. 4 (1990): 415-436.

-. Heilsgegenwart: Eine Theologie der Psalmen. Göttingen: Vandenhoeck \& Ruprecht, 1989.

Spiegel, Shalom. "A Prophetic Attestation of the Decalogue: Hosea 6:5 with some observations on Psalms 15 and 24." Horvord Theological Review 27, no. 2 (1934): 105-144.

Spurgeon, Charles Haddon. "Climbing the Mountain." Spurgeon's Sermons. Philip R. Johnson. 2001. http://www.spurgeon.org/sermons/0396.htm (accessed August 15, 2011).

-. Psolms. Wheaton, Il.: Crossway Books, 1993.

Stadelmann, Luis IJ. The Hebrew Conception of the World: A Philologlcal and Literary Study. Rome: Pontifical Biblical Institute, 1970.

Stec, D. The Targum of Psalms: Translated, with a Critical Introduction, Apparatus, and Notes. London: T \& T Clark, 2004.

Steingrimmson, Sigurdus Örn. Tor der Gerechtigkeit: Eln literaturwissenschaftliche Untersuchung der sogenonnten Einzugsliturgien im AT: Ps 15; 24, 3.5 und Jes 33, 14-16. St. Ottlien: Eos Verlag Erzabtel St. Ottlien, 1984.

Steins, Georg. "Geschichte, die im Rahmen bleibt: Kanonische Beobachtungen an 1 Sam 2 und 2 Sam 22f." In Der Bibelkanon in der Bibelauslegung: Methodenreflexionen und Beispielexegesen, edited by Egbert Ballhorn and Geort Steins, 198-211. Stuttgart: W. Kohlhammer, 2007. 
-. "Kanon und Anamnese: Auf dem Weg zu einer Neuen Biblischen Theologie." In Der Bibelkanon in der Bibelauslegung: Methodenreflexionen und Beispielexegesen, edited by Egbert Ballhorn and Georg Steins, 110-129. Stuttgart: Kohlhammer, 2007.

-. "Kanonisch-intertextualle Bibellektüre-my way." In Intertextualitöt: Perspektiven ouf ein interdisziplinäres Arbeitsfeld, edited by K. Hermann and S. Hübenthal, 55-60. Aachen: Shaker Verlag, 2007.

Sternberg, Meier. The Poetics of Biblical Narrative: Ideological Literature and the Drama of Reading. Bloomington: Indiana University Press, 1987.

Stuhlmueller, Carol. The Psalms. Wilmington: Old Testament Message, 1983.

Sulzbach, Carla. "When Going on a Heavenly Journey, Travel Light and Dress Appropriately." Journal for the Study of the Pseudepigrapha 19, no. 3 (2010): 163-193.

Sumpter, Philip E. "Brevard Childs as Critical and Faithful Exegete." The Princeton Theological Review 14, no. 38 (2008): 95-116.

Sweeney, Marvin A. "Canonical Criticism: Childs' Approach." In Dictionary of Biblical Criticism and Interpretation, edited by Stanley E. Porter, 46-47. Oxon: Routledge, 2007.

-. Isaiah 1-4 and the Post Exilic Understanding of the Isaianic Tradition. Berlin: Walter de Gruyter, 1988.

Sweeney, Marvin A., and Ehud Ben Zvi, . The Changing Face of Form Criticism for the Twenty-First Century. Grand Rapids, MI: William B. Eerdmans Publishing Company, 2003.

Sykes, Stephen. "Narrative Accounts of Biblical Authority: The Need for a Doctrine of Revelation." Modern Theology 5, no. 4 (1989): 327-342.

Tatu, Silviu. "Nicholas P. Lunn, Word-Order Variation in Biblical Hebrew Poetry: Differentiating Pragmatics and Poetics." Journal for the Study of Religions and Ideologies 6, no. 17 (2007): 145-148.

Terrien, Samuel. The Psalms: Strophic Structure and Theological Commentary. Grand Rapids, MI: Wm. B. Eerdmans, 2003. 
The Digital Korl Borth Librory. Alexander Street Press. n.d. http://solomon.dkbl.alexanderstreet.com/.

Thiselton, Anthony C. "Hermeneutical Circle." In The Theological Dictionary for the Interpretotion of the Bible, edited by Kevin J. Vanhoozer, Craig G. Bartholomew, Daniel J. Treier and N. T. Wright, 281-282. London; Grand Rapids, MI: SPCK; Baker Academic, 2005.

-. New Horizons in Hermeneutics: The Theory and Practice of Transforming Biblical Reading. Grand Rapids, MI: Zondervan, 1992.

-. The Two Horizons: New Testament Hermeneutics and Philosophical Description with Special Reference to Heidegger, Bultmann, Gadomer, and Wittgenstein. Exeter: Paternoster, 1980.

Torrance, Alan. "Does God Suffer? Incarnation and Impassibility." In God in our Place. Festschrift Jomes Torronce, edited by T. Hart, 315-368. Exeter and Allison Park, Pa.: D. Thimmell, 1989.

-. "Trinity." In The Combridge Companion to Karl Barth, edited by John Webster, 72-91. Cambridge: Cambridge University Press, 2000.

Torrance, Thomas F. Karl Borth: An Introduction to His Eorly Theology 1910-1931. Edinburgh: T. \& T. Clark Publishers, 2001.

Tov, Emanuel. Textual Criticism of the Hebrew Bible. 2nd edition. Translated by Emanuel Tov. Minneapolis: Fortress Press, 2001.

Treier, Daniel J. Introducing Theological Interpretation of Scripture: A Christian Practice. Grand Rapids, Ml: Baker Academic, 2008.

-. "Theological Hermeneutics, Contemporary." In Dictlonary for the Theological Interpretotion of the Bible, edited by Kevin J. Vanhoozer, Craig G. Bartholomew, Daniel J. Treier and N. T. Wright, 787-793. Grand Rapids, Ml; London: SPCK; Baker Academic, 2005.

Treves, T. "The Date of Psalm XXIV." Vetus Testamentum 10 (1960): 428-434. 
Tromp, Nicholas J. "Jacob in Psalm 24: Apposition, Aphaeresis or Apostrophe?" In Von Kanaan bis Kerala: FS J.P.M. Van der Ploeg, edited by W C. Delsman, J R T M. Peters and J T. Nelis, 271-282. Kevelaer: Butzon \& Bercker, 1982.

Tucker, W. Dennis Jr. "Rethinking the Nature of Hebrew Poetry." In Psalms 1-50 (Revised Edition), by Peter Craige, 370-414. Nashville, Tenn.: Word Biblical Commentary, 2004.

Turner, Geoffrey. "The Righteousness of God in Psalms and Romans." Scottish Journal of Theology 63, no. 3 (2010): 285-301.

Van der Merwe, Christo H.J.; Naudé, Jackie A.; Kroeze, Jan H. A Biblical Hebrew Reference Grammar. Sheffield: Sheffield Academic Press, 1997.

VanGemeren, Wilem, ed. New International Dictionary of Old Testament Theology and Exegesis. 5 vols. Carlisle: Paternoster Publishing, 1996.

Vanhoozer, Kevin J., Craig G. Bartholomew, Daniel J. Treier, and Nathaniel T. Wright, . Dictionary for the Theological Interpretation of the Bible. London: Grand Rapids, MI; SPCK, 2005.

Volf, Miroslav. After Our Likeness: The Church as the Image of the Trinity. Gram Rapids, MI; Cambridge: William B. Eerdmans Publishing Company, 1998.

Vos, Casparus Johannes Adam. Theopoetry of the Psalms. London: T\&T Clark, 2005.

Vosberg, Lother. Studien zum Reden vom Schöpfer in den Psalmen. Munich: Chr. Kaiser, 1975.

Wagner, J. Ross. "The Septuagint and the 'Search for the Christian Bible'." In Scripture's Doctrine and Theology's Bible: How the New Testament Shapes Christian Thought, edited by Markus Bockmuehl and Alan J. Torrance, 17-28. Grand Rapids, MI: Baker Academic, 2008.

Wallace, Howard N. Psalms. Sheffield: Phoenix Press, 2009.

Waltke, Bruce K. "Aims of OT Textual Criticism." Westminster Theological Journal 51, no. 1 (1989): 93-108. 
Waltke, Bruce K.; O'Connor, M.P. An Introduction to Biblical Hebrew Syntox. Winona Lak, Ind.: Eisenbrauns, 1990.

Watson, Wilfred G.E. Classical Hebrew Poetry: A Guide to its Techniques. Sheffield: JSOT Press, 1984.

Waugh, Linda R. "The Poetic function in the Theory of Roman Jakobson." Poetics Todoy 2, no. 1 a (1980): 57-82.

Weber, Beat. "Die Buchovertüre Psalm 1-3 und ihre Bedeutung für das Verstanndnis des Psalters." Old Testament Essoys 23, no. 3 (2010): 834-845.

-. "Entwurf einer Poetologie der Psalmen." In Lesarten der Bibel: Untersuchungen zu einer Theorie der Exegese des Alten Testoments, edited by Helmut Utzschneider and Erhard Blum, 127-154. Stuttgart: W. Kohlhammer, 2006.

-. Werkbuch Psalmen I: Die Psalmen 1-72. Vol. 1. 2 vols. Stuttgart: Verlag Kohlhammer, 2001.

Webster, John. "Barth, Karl." In Dictionary for the Theological Interpretotion of the Bible, edited by Kevin J. Vanhoozer, Craig G. Bartholomew, Daniel J. Treier and N. T. Wright, 82-84. Grand Rapids, Ml; London: SPCK; Baker Academic, 2005.

-. Holy Scripture: A Dogmotic Sketch. Cambridge: Cambridge University Press, 2004.

Weisur, Artur. Die Psolmen übersetzt und erklärt. 4th edition. Göttingen: Vandenhoek \& Ruprecht, 1955.

Welch, J.W., ed. Chiosmus in Antiquity: Structures, Anolyses, Exegesis. Hildesheim: Gerstenberg, 1981.

Welker, Michael. "Sola Scriptura? The Authority of the Bible in Pluralistic Environments." In A God So Near: Essoys on Old Testoment Theology in Honour of Patrick D. Miller, edited by Brent A. Strawn and Nancy R. Bowen, 375-392. Winona Lake, IN.: Eisenbrauns, 2003.

-. "Wright on the Resurrection." Scottish Journal of Theology 60, no. 4 (2007): 458-475.

Wellhausen, Julius. The Book of Psolms. London: J. Clarke and Company, 1898. 
Wenham, Gordon. "Towards a Canonical Reading of the Psalms." In Canon and Biblical Interpretation, edited by Craig G. Bartholomew, Scott Hahn, Robin Parry, Christopher Seitz and Al Wolters, 333-349. Milton Keynes; Grand Rapids, MI: Paternoster Press; Zondervan, 2006.

Westermann, Claus. Blessing. Philadelphia: Fortress Press, 1978.

—. Das Buch Jesaja: Kapitel 40-66. Göttingen: Vandenhoek \& Ruprecht, 1966.

Wilcox, Peter; Paton-Williams, David. "The Servant Songs in Deutero-Isaiah." Journal for the Study of the Old Testament 42 (1988): 79-102.

Wildberger, Hans. A Continental Commentary: Isaiah 1-12. Translated by Thomas H. Trapp. Minneapolis, MN: Fortress Press, 1991.

Williamson, H.G.M. "Isaiah: A Commentary [Review article]." Theology Today 59, no. 1 (2002): 121-124.

-. "Relocating Isaiah 1:2-9." In Writing and Reading the Scroll of Isaiah, edited by C.C. Broyles and Craig Evans, 263-277. Leiden: E.J. Brill, 1997.

-. The Book Called Isaiah: Deutero-Isaiah's Role in Composition and Redaction. Oxford: Oxford University Press, 1994.

Willis, John T. "Ethics in a Cultic Setting." In Essays in Old Testament Ethics: J. Philip Hyatt, In Memoriam, edited by James L. Crenshaw and John T. Willis, 145-169. New York: Ktav, 1974.

-. "Isaiah 2:2-5 and the Psalms of Zion." In Writing and Reading the Scroll of Isaiah: Studies of an Interpreative Tradition. Volume 1, edited by Craig C. Broyles and Craig A. Evans, 296-316. Leuven: Brill, 1997.

Wilson, Gerald H. The Editing of the Hebrew Psalter. Atlanta: Scholars Press, 1985.

-. The NIV Application Commentary: Psalms-Volume 1. Grand Rapids, MI: Zondervan, 2002.

-. "The Qumran Psalms Scroll (11QPsa) and the Canonical Psalter: Comparision of Editorial Shaping." The Catholic Biblical Quarterly 59 (1997): 448-464.

-. "The Use of Royal Psalms at the 'Seams' of the Hebrew Psalter." Journal for the Study of the Old Testament 35 (1986): 85-94. 
Wolff, Hans Walter. A Continental Commentary: Micah. Minneapolis: Fortress Press, 1990.

-. Hosea: A Commentary on the Book of the Prophet Hosea. Translated by Gary Stansell. Philadelphia: Fortress Press, 1974.

-. Joel and Amos: A Commentary on the Books of the Prophets Joel and Amos. Translated by Waldemar Janzen, S. Dean MCBride Jr. and Charles A. Muenchow. Philadelphia: Fortress Press, 1977.

Wright, Christopher J. H. Old Testoment Ethics for the People of God. Downer's Grove, III.: InterVarsity Press, 2004.

Wright, Nicholas Thomas. The New Testament and the People of God: Christion Origins and the Question of God. Minneapolis: Fortress Press, 1992.

Xun, Chen. Theological Exegesis in the Canonical Context: Brevard Springs Childs's Methodology of Biblical Theology. Oxford: Peter Lang, 2010.

Yona, Shamir. "A Type of Expanded Repetition in Biblical Parallelism." Zeitschrift für die Alttestomentliche Wissenschaft 119, no. 4 (2007): 586-601.

Young, E.J. The Book of Isaiah: The English Text, with Introduction, Exposition and Notes. Vol. 2: Chapters 19 to 39. Grand Rapids, Ml: Eerdmans, 1969.

Zanella, Francesco. "Componential Analysis of Meaning." In Encyclopedia of the Hebrew language and Linguistics. Forthcoming.

Zenger, Erich. "Das Buch der Psalmen." In Einleitung in das Alte Testoment, by Erich Zenger et al., 309-326. Stuttgart: W. Kohlhammer, 2001.

Zimmerli, Walther. "Biblische Theologie I: Altes Testament." In Theologische Realenzyklopädie VI, 426-455. Berlin: Walter de Gruyter, 1980.

-. Old Testament Theology in Outline. Translated by David E. Green. Edinburgh: T \& T Clark, 1978. 